\title{
STUDY MATERIAL
}

\section{PROFESSIONAL PROGRAMME}

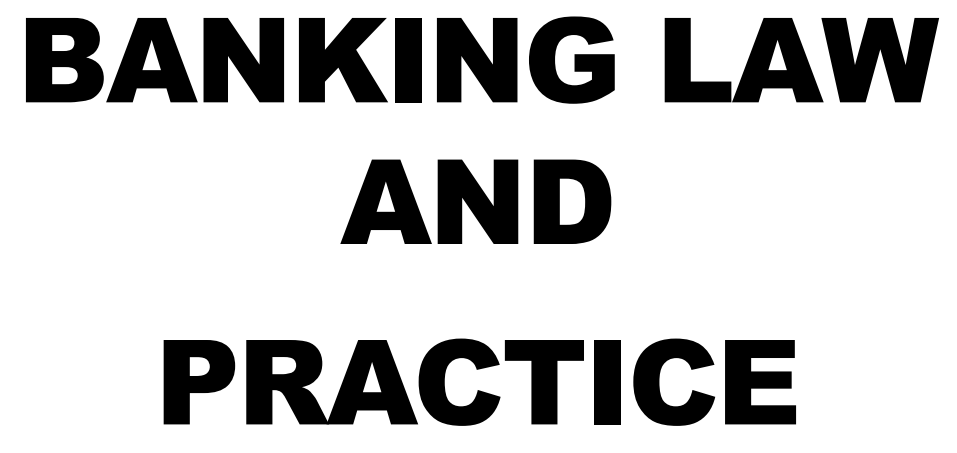

\author{
MODULE 3 \\ ELECTIVE PAPER 9.1
}




\title{
TIMING OF HEADQUARTERS
}

\author{
Monday to Friday \\ Office Timings - 9.00 A.M. to 5.30 P.M.
}

Public Dealing Timings

Without financial transactions - 9.30 A.M. to 5.00 P.M.

With financial transactions -9.30 A.M. to 4.00 P.M.

\author{
Phones \\ 41504444, 45341000 \\ Fax \\ $011-24626727$ \\ Website \\ www.icsi.edu \\ E-mail \\ info@icsi.edu
}




\section{BANKING LAW AND PRACTICE}

Company Secretaries have a pivot role to play in the Banking and Financial Sector. A Company Secretary can work as a compliance officer in a banking and financial institution and play an important role in ensuring compliance to complicated legal, regulatory and supervisory issues all the time, transcending various spheres of banking operations. So, in order to build the capacity of Companies Secretaries to work as a compliance officer in Banks and to provide them a specialized knowledge in Banking laws and practice, a paper on Banking Laws and Practice has been added as an elective paper. The students who want to pursue their career in Banking and financial sector may chose this subject.

The syllabus and content of this paper has been developed in joint association of Indian Institute of Banking and Finance and the syllabus covers most of the aspects from gamut of banking. The objective of including this paper is to give a specialized knowledge of law and practice relating to banking.

An attempt has been made to cover fully the syllabus prescribed for each module/subject and the presentation of topics may not always be in the same sequence as given in the syllabus. Candidates are also expected to take note of all the latest developments relating to the subjects covered in the syllabus by referring to RBI circulars, financial papers, economic journals, latest books and publications in the subjects concerned.

Although due care has been taken in publishing this study material, yet the possibility of errors, omissions and/ or discrepancies cannot be ruled out. This publication is released with an understanding that the Institute shall not be responsible for any errors, omissions and/or discrepancies or any action taken in that behalf.

Should there be any discrepancy, error or omission noted in the study material, the Institute shall be obliged if the same are brought to its notice for issue of corrigendum in the e-bulletin Student Company Secretary. In the event of any doubt, students may write to the Directorate of Academics in the Institute for clarification at academics@icsi.edu.

There is open book examination for this Elective Subject of Professional Programme. This is to inculcate and develop skills of creative thinking, problem solving and decision making amongst students of its professional programme and to assess their analytical ability, real understanding of facts and concepts and mastery to apply, rather than to simply recall, replicate and reproduce concepts and principles in the examination. 


\section{SYLLABUS}

\section{MODULE III, ELECTIVE PAPER 9.1: Banking Law and Practice (100 Marks)}

\section{Level of Knowledge: Expert Knowledge}

Objective: To acquire specialized knowledge of law and practice relating to Banking

\section{Detailed Contents:}

\section{Overview of Banking System}

\section{Regulatory Framework and Compliances}

A. Provisions of RBI Act 1935, Banking Regulation Act 1949, Prevention of Money Laundering Act, 2002.

B. Government and RBl's Powers Opening of New Banks and Branch Licensing Constitution of Board of Directors and their Rights Banks Share Holders and their Rights CRR and SLR Concepts CashCurrency Management Winding up -Amalgamation and Mergers Powers to Control Advances - Selective Credit Control - Monetary and Credit Policy Audit and Inspection Supervision and Control - Board for Financial Supervision - its Scope and Role Disclosure of Accounts and Balance Sheets Submission of Returns to RBI, Corporate Governance.

\section{Legal Aspects of Banking Operations}

Case Laws on Responsibility of Paying and Collecting Banker Indemnities or Guarantees - Scope and Application - Obligations of a Banker - Precautions and Rights - Laws relating to Bill Finance, LC and Deferred Payments - Laws Relating to Securities - Valuation of Securities - Modes of Charging Securities Lien, Pledge, Mortgage, Hypothecation etc. - Registration of Firms/Companies - Creation of Charge and Satisfaction of Charge.

\section{Banking Related Laws}

Law of Limitation - Provisions of Bankers Book Evidence Act -Special Features of Recovery of Debts Due to Banks and Financial Institutions Act, 1993 TDS Banking Cash Transaction Tax Service Tax, Asset Reconstruction Companies, The Securitization and Reconstruction of Financial Assets and Enforcement of Security Interest Act, 2002, The Consumer Protection Act, 1986, Banking Ombudsman Lok Adalats, Lender's Liability Act.

\section{Banker - Customer Relations}

The legal relationship between the Banker and Customer, the Multifarious Transactions between them and the Rights and Duties of the Parties springing out of such relationship Nature of Banking Business Legal Nature of Banker-Customer Relationship and their Mutual Rights and Duties Special Categories of Customers, such as Corporations, Partnership Firms, Hindu Joint Families, Unincorporated Bodies, Trusts, Joint Account Holders, Minors, Nominee Accounts, Liquidator, Mercantile Agents, Non-Resident Indians, Foreigners and the Legal Incidence of Each Different Types of Accounts such as Current Accounts, Savings Bank Account and Fixed Deposits Other Transactions between Banker and Customer such as Safe Deposit Vaults, Financial Advice, Letters of Introduction and Other Services Rendered by Banks Special features of the relationship between banker and customer - Their mutual rights and duties - lien - Power to combine different accounts - Secrecy of account. 


\section{Loans and Advances}

Law, Practice and Policies governing the employment of the funds in the hands of the banker with special reference to the lending banker State Policy on Loans and Advances - Priority sector advances and socioeconomic policies - Financial inclusion - Self- Employment Schemes - Women Entrepreneurs - Small Scale Industries - Agricultural Finance, Export Finance, etc. - Micro Finance - How the banker profitably uses the fund - Call loans and loans repayable at short notice - Loans and advances - Overdrafts - Legal control over bank's deployment of funds.

\section{Securities for Banker's Loans}

The legal issues involved in and the practice governing the different kinds of securities for banker's advances and loans Guarantees, pledge, lien, mortgage, charge - subject matters of collateral security Corporate Securities Documents of title to goods Land and Buildings Book debts Life Policies Factoring; Bill Discounting; Bank Guarantees; Letters of Credit; Commercial Papers.

\section{Financial Analysis of Banks}

Introduction; Role of financial analysis in financial management; Techniques of Financial Analysis; DuPont Model of Financial Analysis; Special issues in Financial Analysis of Banking Industry.

\section{Financial System Contemporary and Emerging Issues: An Overview}

Introduction; Role of Financial System; Capital Flow Through Intermediary Financial Institutions; Direct Capital Flow; Primary Market Products; Primary Market Issue Facilitators; Secondary Market; Economic Importance of Financial Markets.

\section{International Banking Management}

International Banking: An Overview, Legal \& Regulatory Framework, International Banking Operations Management, Risk Management in International Banking, Special Issues: Technology and International Banking; Globalisation and International Banking; Financial Innovations in International Banking.

\section{Electronic Banking and IT in Banks}

IT in Banking: An Introduction. IT Applications in Banking- Computer-Based Information Systems for Banking; Electronic Banking; Electronic Fund Management, Enabling Technologies of Modern Banking- Electronic Commerce and Banking; Supply Chain Management; Customer Relationship Management; Integrated Communication Networks for Banks Security and Control Systems - Cybercrimes and fraud management Planning and Implementation of Information Systems.

\section{Risk Management in Banks}

Risk Management: An Overview, Credit Risk Management, Liquidity and Market Risk Management, Operational Risk Management, Special Issues- Risk Management Organisation; Reporting of Banking Risk; Risk Adjusted Performance Evaluation Basel III.

\section{Ethics and Corporate Governance in Banks}

Ethics and Business, Corporate Governance, Corporate Social Responsibility, Governance in Financial Sector. 


\section{LIST OF RECOMMENDED BOOKS}

\section{MODULE 3}

\section{ELECTIVE PAPER 9.1 : BANKING LAW AND PRACTICE}

The students may refer to the given books and websites for further knowledge and study of the subject :

\section{READINGS}

1. M.L.Tannan, revised by : Banking Law and Practice, Wadhwa \& Company, Nagpur C.R. Datta \& S.K.

Kataria

2. A.B. Srivastava and : Seth's Banking Law, Law Publisher's India (P) Limited K. Elumalai

3. R.K. Gupta

: BANKING Law and Practice in 3 Vols.Modern Law Publications.

4. Prof. Clifford Gomez

: Banking and Finance - Theory, Law and Practice, PHI Learning Private Limited

5. J.M. Holden : The Law and Practice of Banking, Universal Law Publishing. 


\section{ARRANGEMENT OF STUDY LESSONS}

\begin{tabular}{cl}
\hline Study Lesson No. & \\
\hline 1. & Overview of Banking System \\
2. & Regulatory Framework and Compliances \\
3. & Legal Aspects of Banking Operations \\
4. & Banking Related Laws \\
5. & Banker - Customer Relations \\
6. & Loans and Advances \\
7. & Securities for Banker's Loans \\
8. & Financial Analysis of Banks \\
9. & Financial System Contemporary and Emerging Issues: An Overview \\
10. & International Banking Management \\
11. & Electronic Banking and IT in Banks \\
12. & Risk Management in Banks \\
13. & Ethics and Corporate Governance in Banks \\
& Annexures
\end{tabular}




\section{CONTENTS}

FINANCIAL, TREASURY AND FOREX MANAGEMENT

\section{LESSON 1}

OVERVIEW OF BANKING SYSTEM

Indian Banking System - Evolution

Reserve Bank of India as a Central Bank of the Country

State Bank of India and Its associate (Subsidiaries) Banks

Nationalization of Banks

Regional Rural Banks

Local Area Banks

New Private Sector Banks

Different Types of Banks in India

Commercial Banks

Co-Operative Banking System

National Bank for Agriculture and Rural Development (NABARD) 9

Small Industries Development Bank of India (SIDBI) 9

$\begin{array}{lr}\text { National Housing Bank (NHB) } & 10\end{array}$

$\begin{array}{ll}\text { Export Import Bank of India (EXIM Bank) } & 10\end{array}$

$\begin{array}{ll}\text { Functions of Commercial Banks } & 11\end{array}$

$\begin{array}{ll}\text { LESSON ROUND UP } & 12\end{array}$

$\begin{array}{lr}\text { SELF TEST QUESTIONS } & 12\end{array}$

\section{LESSON 2}

REGULATORY FRAMEWORK AND COMPLIANCES

$\begin{array}{ll}\text { Reserve Bank of India Act, } 1934 & 16\end{array}$

Banking Regulation Act, $1949 \quad 16$

$\begin{array}{lr}\text { Setting Up of a New Bank } & 18\end{array}$

$\begin{array}{ll}\text { Branch Licensing } & 19\end{array}$

Branch Authorisation Policy for Commercial Banks 19

$\begin{array}{ll}\text { New Bank Licensing Policy, } 2013 & 20\end{array}$

Banks' Share Holders and their Rights 23

$\begin{array}{ll}\text { Cash Reserve Ratio } & 24\end{array}$

$\begin{array}{ll}\text { Statutory Liquidity Ratio (SLR) } & 26\end{array}$

$\begin{array}{ll}\text { Currency Chests } & 28\end{array}$

$\begin{array}{lr}\text { Currency Printing and Coin Minting } & 28\end{array}$ 
Quantitative/General Credit Control

$\begin{array}{ll}\text { Selective Credit Control } & 30\end{array}$

$\begin{array}{ll}\mathrm{RBI} \text { as a Controller of foreign Exchange } & 31\end{array}$

RBI as Banker to the Government 31

RBI as Lender of the Last Resort $\quad 31$

$\begin{array}{ll}\text { Monetary and Credit Policy } & 32\end{array}$

Audit and Inspection of Banking Company $\quad 32$

Supervision and Control of Banking Companies $\quad 34$

$\begin{array}{ll}\text { Board for Financial Supervision } & 34\end{array}$

Winding Up - Amalgamation and Mergers of Banks 34

Reserve Bank as Liquidator $\quad 35$

Disclosure of Accounts and Balance Sheets of Banks 36

Submission of Returns to RBI $\quad 42$

$\begin{array}{ll}\text { Fraud - Classification and Reporting } & 43\end{array}$

$\begin{array}{ll}\text { Corporate Governance } & 47\end{array}$

$\begin{array}{ll}\text { Effective Corporate Governance Practices } & 48\end{array}$

$\begin{array}{ll}\text { Corporate Governance in Banks } & 48\end{array}$

$\begin{array}{ll}\text { Prevention of Money Laundering Act, } 2002 \text { (PMLA) } & 48\end{array}$

Banking Codes and Standards Board of India (BSCSBI) 50

$\begin{array}{ll}\text { The Banking Ombudsman Scheme } & 51\end{array}$

$\begin{array}{ll}\text { LESSON ROUND UP } & 53\end{array}$

$\begin{array}{ll}\text { SELF TEST QUESTIONS } & 54\end{array}$

\section{LESSON 3}

BANKER - CUSTOMER RELATIONSHIP

$\begin{array}{ll}\text { Meaning of a Banking Company } & 58\end{array}$

$\begin{array}{ll}\text { Relationship as Debtor and Creditor } & 60\end{array}$

$\begin{array}{ll}\text { Banker as Trustee } & 61\end{array}$

Banker as Agent $\quad 62$

$\begin{array}{ll}\text { Obligations of a Banker } & 63\end{array}$

$\begin{array}{ll}\text { Pass Book and Statement of Account } & 67\end{array}$

$\begin{array}{ll}\text { Precautions to Be Taken By the Banker and the Customer } & 69\end{array}$

$\begin{array}{ll}\text { Garnishee Order } & 70\end{array}$

$\begin{array}{ll}\text { Rights of the Attaching Creditor } & 73\end{array}$

$\begin{array}{ll}\text { Rights of a Banker } & 73\end{array}$

$\begin{array}{ll}\text { Exceptions to the Right of General Lien } & 75\end{array}$ 
$\begin{array}{ll}\text { Right to Charge interest and incidental Charges, Etc. } & 78\end{array}$

$\begin{array}{ll}\text { Various Types of Customers } & 79\end{array}$

Closing of a Bank Account - Termination of Banker-Customer Relationship 82

Various Deposit Schemes $\quad 83$

Deposits - General $\quad 83$

$\begin{array}{lr}\text { Demand Deposits } & 84\end{array}$

$\begin{array}{ll}\text { Term Deposits } & 86\end{array}$

Hybrid Deposits or Flexi Deposits Or Multi Option Deposit Scheme (MODS) 88

Tailor-Made Deposit Schemes $\quad 89$

$\begin{array}{lr}\text { Special Schemes for Non-Resident Indians (NRIs) } & 90\end{array}$

'Know Your Customer' (KYC) Guidelines of the RBI 92

$\begin{array}{ll}\text { Customer Identification Procedure } & 93\end{array}$

Customer Identification Requirements 93

$\begin{array}{ll}\text { Specimen Signature } & 95\end{array}$

$\begin{array}{ll}\text { Power of Attorney } & 96\end{array}$

Closing of a Bank Account - Termination of Banker-Customer Relationship 96

$\begin{array}{ll}\text { Insurance of Bank Deposits } & 97\end{array}$

$\begin{array}{ll}\text { Salient Features of Deposit insurance } & 97\end{array}$

$\begin{array}{ll}\text { Nomination } & 98\end{array}$

$\begin{array}{lr}\text { Settlement of Claims } & 98\end{array}$

LESSON ROUND UP $\quad 99$

$\begin{array}{lr}\text { SELF TEST QUESTIONS } & 100\end{array}$

\section{LESSON 4}

\section{LEGAL ASPECTS OF BANKING OPERATIONS}

$\begin{array}{ll}\text { Introduction } & 104\end{array}$

$\begin{array}{ll}\text { Legal aspects of a Cheque } & 104\end{array}$

$\begin{array}{ll}\text { Definition of a Cheque } & 104\end{array}$

$\begin{array}{lr}\text { Different Types of Cheques } & 104\end{array}$

$\begin{array}{lr}\text { Crossing of a Cheque } & 105\end{array}$

$\begin{array}{lr}\text { Cheque Crossed Generally } & 105\end{array}$

$\begin{array}{ll}\text { Cheque Crossed Specially } & 105\end{array}$

Payment of Cheque Crossed Generally Or Specially 105

Cheque Bearing "Not Negotiable" 105

$\begin{array}{lr}\text { Double Crossing } & 106\end{array}$ 
$\begin{array}{lr}\text { Definition of Endorsement } & 106\end{array}$

Legal Provisions Regarding Endorsements 106

$\begin{array}{ll}\text { General Rules Regarding the form of Endorsements } & 107\end{array}$

$\begin{array}{lr}\text { Legal aspects of a Paying Banker } & 108\end{array}$

$\begin{array}{lr}\text { Obligations of a Paying Banker } & 108\end{array}$

$\begin{array}{ll}\text { Protection to Paying Banker } & 109\end{array}$

Liability of Paying Banker When Customer's Signature on Cheque Is forged 110

Payment in Good Faith, Without Negligence of An instrument On Which Alteration Is Not Apparent 111

Payment By Bank Under Mistake - Whether Recoverable 113

Legal aspects of Collection of a Cheque $\quad 113$

Holder for Value $\quad 114$

$\begin{array}{ll}\text { Collecting Banker as An Agent } & 114\end{array}$

$\begin{array}{ll}\text { Statutory Protection to Collecting Bank } & 115\end{array}$

$\begin{array}{ll}\text { Duties of the Collecting Bank } & 115\end{array}$

Negligence of Collecting Bank in Collecting Cheques Payable to Third Parties 119

$\begin{array}{ll}\text { Indemnities and Guarantees } & 119\end{array}$

$\begin{array}{lr}\text { Operations in Deposit Accounts and Complaints of Customers } & 120\end{array}$

Reconciliation of Transactions at ATMs Failure 122

Foreclosure Charges/Prepayment Penalty - Home Loans 122

Banking Hours/Working Hours/Operation 122

Sick/Old/incapacitated Account Holders - Operational Procedure 123

Erroneous Debits Arising On Fraudulent Or Other Transactions 125

Safe Deposit Locker/Safe Custody Article Facility 125

Deceased Depositors - Settlement of Claims - Procedure thereof 125

$\begin{array}{ll}\text { Accounts with Survivor/Nominee Clause } & 125\end{array}$

$\begin{array}{ll}\text { Accounts without the Survivor/Nominee Clause } & 126\end{array}$

$\begin{array}{ll}\text { Settlement of Claims in Respect of Missing Persons } & 126\end{array}$

$\begin{array}{ll}\text { Unclaimed Deposits/inoperative Accounts in Banks } & 127\end{array}$

$\begin{array}{ll}\text { Customer Confidentiality Obligations } & 127\end{array}$

$\begin{array}{ll}\text { Transfer of Account from One Branch to Another } & 127\end{array}$

Co-Ordination With officers of Central Board of Direct Taxes 127

Declaration of Holiday under the Negotiable instruments Act, $1881 \quad 127$

$\begin{array}{ll}\text { Miscellaneous } & 128\end{array}$

$\begin{array}{lr}\text { LESSON ROUND UP } & 128\end{array}$

$\begin{array}{lr}\text { SELF TEST QUESTIONS } & 129\end{array}$ 


\section{LESSON 5}

\section{BANKING RELATED LAWS}

Limitation Act - Important aspects

Period of Limitation for Certain Documents

Revival of Documents

Court Holiday

Bankers' Book Evidence Act, 1891

Tax Laws Applicable in Banking Operators

Recovery of Debts Due to Banks and Financial institutions Act, 1993 (DRT Act) 135

Debt Recovery Tribunals 136

Lok Adalats 136

$\begin{array}{ll}\text { SARFAESI Act - Important aspects } & 137\end{array}$

$\begin{array}{ll}\text { Some Important Terms Covered Under the SARFAESI Act } & 137\end{array}$

$\begin{array}{ll}\text { Securitization } & 138\end{array}$

$\begin{array}{lr}\text { Asset Reconstruction } & 139\end{array}$

$\begin{array}{lr}\text { Enforcement of Security interest } & 139\end{array}$

$\begin{array}{lr}\text { Lenders Liability Act } & 140\end{array}$

$\begin{array}{ll}\text { Banking Ombudsman } & 141\end{array}$

Important Features of Banking Ombudsman 141

The Consumer Protection Act, $1986 \quad 142$

LESSON ROUND UP 143

$\begin{array}{lr}\text { SELF TEST QUESTIONS } & 143\end{array}$

\section{LESSON 6}

\section{LOANS AND ADVANCES}

$\begin{array}{lr}\text { Principles of Lending } & 148\end{array}$

$\begin{array}{lr}\text { Credit Worthiness of Borrowers } & 150\end{array}$

Collection of Credit information $\quad 151$

Cash Credit $\quad 153$

$\begin{array}{lr}\text { Overdrafts } & 154\end{array}$

Bills Finance $\quad 155$

Procedure for assessment of Working Capital 156

$\begin{array}{ll}\text { Term Loans } & 159\end{array}$

Bank Guarantee $\quad 162$

$\begin{array}{lr}\text { Bank Guarantee: Precautions } & 163\end{array}$ 
$\begin{array}{lr}\text { Categories Under Priority Sector } & 167\end{array}$

Description of the Categories Under Priority Sector 169

(a) Agriculture $\quad 169$

(b) Micro and Small Enterprises $\quad 171$

(c) Education $r$

(d) Housing $r$

(e) Export Credit $r$

(f) Others $r$

(g) Weaker Sections $\quad 173$

(h) Investments By Banks in Securitised assets 173

(i) Transfer of assets Through Direct assignment /Outright Purchases 174

(j) Inter Bank Participation Certificates Bought By Banks 174

(k) Bank Loans to MFls for On-Lending 174

$\begin{array}{ll}\text { Non-Achievement of Priority Sector Targets } & 175\end{array}$

Common Guidelines for Priority Sector Loans $\quad 175$

National Rural Livelihood Mission (NRLM) 176

$\begin{array}{ll}\text { Women SHGS and their Federations } & 177\end{array}$

Prime Minister's Employment Generation Programme (PMEGP) 179

Kisan Credit Card Scheme 182

Financing Self Help Groups (SHGS) 185

$\begin{array}{lr}\text { SHGS - Important aspects } & 185\end{array}$

$\begin{array}{lr}\text { Financing Joint Liability Groups (JLGS) } & 186\end{array}$

$\begin{array}{ll}\text { Personal Loans } & 186\end{array}$

$\begin{array}{ll}\text { Consumer Loans } & 187\end{array}$

$\begin{array}{lr}\text { Consortium Finance } & 188\end{array}$

$\begin{array}{lr}\text { Trade Finance } & 188\end{array}$

$\begin{array}{lr}\text { Pre-Shipment Credit - Features and Precautions } & 189\end{array}$

$\begin{array}{lr}\text { Post-Shipment Credit } & 189\end{array}$

$\begin{array}{ll}\text { Import Finance } & 190\end{array}$

LESSON ROUND UP 191

$\begin{array}{lr}\text { SELF TEST QUESTIONS } & 192\end{array}$

\section{LESSON 7}

\section{SECURITIES FOR BANK LOANS}

General Principles of Secured Advances 
Stocks and Shares as a Security for the Loan/Advance 199

$\begin{array}{ll}\text { Debentures as a Security for the Loan/Advance } & 200\end{array}$

$\begin{array}{ll}\text { Goods as a Security for the Loan/Advance } & 201\end{array}$

Life Policies as a Security for the Loan/Advance $\quad 204$

Book Debts as a Security for the Loan/Advance 205

Fixed Deposit as a Security for the Loan/Advance 206

Supply Bills as a Security for the Loan/Advance 206

$\begin{array}{ll}\text { Charge Over Securities } & 208\end{array}$

$\begin{array}{lr}\text { Pledge of Security } & 208\end{array}$

$\begin{array}{lr}\text { Hypothecation Over Securities } & 209\end{array}$

$\begin{array}{ll}\text { Difference between Hypothecation and Pledge } & 211\end{array}$

$\begin{array}{ll}\text { Lien } & 211\end{array}$

$\begin{array}{ll}\text { Assignment } & 212\end{array}$

$\begin{array}{ll}\text { Mortgage } & 212\end{array}$

$\begin{array}{ll}\text { Usufructuary Mortgage } & 214\end{array}$

$\begin{array}{ll}\text { English Mortgage } & 214\end{array}$

Equitable Mortgage Or Mortgage By Deposit of Title Deeds 215

$\begin{array}{ll}\text { Anomalous Mortgage } & 215\end{array}$

$\begin{array}{ll}\text { Priority of Mortgages } & 216\end{array}$

$\begin{array}{ll}\text { Limitation Period in Mortgages } & 217\end{array}$

$\begin{array}{ll}\text { Registration of Charge } & 217\end{array}$

$\begin{array}{ll}\text { Documentation } & 218\end{array}$

$\begin{array}{ll}\text { Precautions to Be Taken While Executing Loan Documents } & 218\end{array}$

$\begin{array}{ll}\text { Execution of Document By Joint Hindu Family } & 221\end{array}$

$\begin{array}{ll}\text { Execution of Document By Limited Liability Company } & 221\end{array}$

Execution of Document By Co-Operative Societies 222

Execution of Document By Clubs/institutions/Schools 222

Execution of Document By Physically Handicapped 222

Execution of Document By Blind Persons $\quad 222$

Execution of Document By Illiterate Borrowers 223

Execution of Document By Pardanashin Women 223

LESSON ROUND UP 223

$\begin{array}{lr}\text { SELF TEST QUESTIONS } & 223\end{array}$ 


\section{LESSON 8}

FINANCIAL ANALYSIS OF BANKS

Types of Analysis

Analysis of Balance Sheet

Analysis of Profit and Loss Account

232

Analysis of Funds Flow/ Cash Flow Statements

234

Techniques Used in Analysis of Financial Statements 234

$\begin{array}{ll}\text { Funds Flow Analysis } & 234\end{array}$

$\begin{array}{ll}\text { Trend Analysis } & 234\end{array}$

Ratio Analysis $\quad 235$

$\begin{array}{ll}\text { Du Pont Model } & 236\end{array}$

Financial Analysis by Bank as a Lender $\quad 237$

Financial Analysis by Bank as a Investor 238

LESSON ROUND UP $\quad 239$

$\begin{array}{lr}\text { SELF TEST QUESTIONS } & 239\end{array}$

\section{LESSON 9}

FINANCIAL SYSTEM CONTEMPORARY AND EMERGING ISSUE : AN OVERVIEW

Capital Market

Primary Market

Various Aspects of the Primary Market Issues

Secondary Market

$\begin{array}{lr}\text { Instruments - Capital Market } & 247\end{array}$

$\begin{array}{ll}\text { Mutual Funds } & 248\end{array}$

$\begin{array}{lr}\text { Stock Exchange } & 250\end{array}$

$\begin{array}{ll}\text { Qualified Institutional Buyers (QIBs) } & 251\end{array}$

$\begin{array}{ll}\text { Foreign Direct investment (FDI) } & 251\end{array}$

$\begin{array}{ll}\text { LESSON ROUND UP } & 251\end{array}$

$\begin{array}{lr}\text { SELF TEST QUESTIONS } & 252\end{array}$

\section{LESSON 10}

INTERNATIONAL BANKING MANAGEMENT

International Banking Overview 
Bank for International Settlement (BIS) 259

$\begin{array}{ll}\text { Basel II } & 260\end{array}$

Legal Issues in international Banking Transactions $\quad 262$

Syndicated Credit - Important Features $\quad 262$

International Laws - Application in international Banking Scenario 263

International Banking Operations Management 265

Risk Management in international Banking 266

FOREX Markets - Features/ Issues $\quad 269$

Special Issues: Technology and international Banking 270

Globalization and international Banking: Important aspects 271

$\begin{array}{ll}\text { Financial Innovations in International Banking } & 271\end{array}$

$\begin{array}{ll}\text { LESSON ROUND UP } & 273\end{array}$

$\begin{array}{lr}\text { SELF TEST QUESTIONS } & 274\end{array}$

\section{LESSON 11}

\section{ELECTRONIC BANKING AND IT IN BANKS}

$\begin{array}{ll}\text { Introduction } & 278\end{array}$

IT and Communication Systems - Important features 278

$\begin{array}{ll}\text { Communication Networks in Banking System } & 278\end{array}$

$\begin{array}{ll}\text { Automated Clearing Systems } & 279\end{array}$

Clearing House Inter-bank Payment System (CHIPS) 279

$\begin{array}{ll}\text { Electronic Fund Management } & 279\end{array}$

$\begin{array}{lr}\text { Electronic Clearing System (ECS) } & 280\end{array}$

$\begin{array}{ll}\text { ECS - Important aspects/ features } & 280\end{array}$

$\begin{array}{ll}\text { Real Time Gross Settlement (RTGS) } & 280\end{array}$

National Electronic Funds Transfer (NEFT) 280

$\begin{array}{ll}\text { Indian Financial System Code (IFSC) } & 281\end{array}$

$\begin{array}{ll}\text { Automated Teller Machines (ATMs) } & 282\end{array}$

$\begin{array}{ll}\text { Internet Banking } & 282\end{array}$

$\begin{array}{lr}\text { Core Banking Solutions (CBS) } & 282\end{array}$

Computerization of Clearing of Cheques 283

Cheque Truncation System (CTS) 283

Internet and Supply Chain Management $\quad 284$

$\begin{array}{ll}\text { International Payment Systems } & 285\end{array}$ 
Role of Central Bank in Payment Mechanism 287

$\begin{array}{ll}\mathrm{RBI} \text { - Payments and settlements System } & 287\end{array}$

$\begin{array}{ll}\text { Digital Certificate and Digital Signature } & 289\end{array}$

$\begin{array}{ll}\text { Cyber Crimes and Fraud Management } & 289\end{array}$

$\begin{array}{ll}\text { Cyber Crimes } & 289\end{array}$

$\begin{array}{lr}\text { Classification of Cyber Crimes } & 290\end{array}$

$\begin{array}{ll}\text { Financial Crimes } & 291\end{array}$

Integrated Communication Network for Banks Security and Control Systems 292

$\begin{array}{ll}\text { Information System Security (ISS) } & 294\end{array}$

Information Technology Act, 2000 \& other Relevant Acts 295

LESSON ROUND UP 295

$\begin{array}{lr}\text { SELF TEST QUESTIONS } & 295\end{array}$

\section{LESSON 12}

RISK MANAGEMENT IN BANKS

$\begin{array}{ll}\text { Risk Management - Important Features } & 301\end{array}$

$\begin{array}{ll}\text { Risk Management Structure } & 302\end{array}$

Risk Management under Basel I 303

Risk Management under Basel II 303

$\begin{array}{ll}\text { Credit Risk Measurement - Basel II Norms } & 304\end{array}$

Liquidity and Market Risk Management $\quad 305$

$\begin{array}{ll}\text { Cross Border Risk } & 307\end{array}$

$\begin{array}{ll}\text { Country Risk Management System (Crms) } & 307\end{array}$

$\begin{array}{ll}\text { Operational Risk } & 308\end{array}$

$\begin{array}{ll}\text { Some Examples of Operational Risks } & 308\end{array}$

$\begin{array}{ll}\text { Legal Risk } & 308\end{array}$

$\begin{array}{ll}\text { Risk Management Under Basel III } & 309\end{array}$

$\begin{array}{ll}\text { Reporting of Banking Risk } & 309\end{array}$

Risk Adjusted Performance Evaluation: Important aspects $\quad 310$

LESSON ROUND UP $\quad 312$

$\begin{array}{lr}\text { SELF TEST QUESTIONS } & 313\end{array}$

LESSON 13

ETHICS AND CORPORATE GOVERNANCE IN BANKS

$\begin{array}{ll}\text { Ethics - An Overview } & 316\end{array}$

$\begin{array}{ll}\text { Ethical and Unethical Issues } & 316\end{array}$ 
$\begin{array}{ll}\text { Business Ethics } & 317\end{array}$

$\begin{array}{ll}\text { Code of Ethics } & 317\end{array}$

$\begin{array}{ll}\text { Ethical aspects in Human Resource Management } & 318\end{array}$

$\begin{array}{ll}\text { Ethical aspects in Marketing Management } & 318\end{array}$

$\begin{array}{ll}\text { Ethical aspect in Financial Management } & 319\end{array}$

$\begin{array}{ll}\text { Desired Ethical Practices and Corporate Governance } & 319\end{array}$

$\begin{array}{ll}\text { Corporate Social Responsibility in the Financial Sector } & 320\end{array}$

Role of the Board of Directors $\quad 321$

Role of Chairman and/or CEO 322

$\begin{array}{ll}\text { Compliance officer } & 322\end{array}$

$\begin{array}{ll}\text { Clause } 49 & 322\end{array}$

$\begin{array}{ll}\text { Audit Committee (AC) } & 322\end{array}$

Auditors and Other internal Audit Reports $\quad 323$

Customer Service Committee $\quad 323$

Special Committee for Monitoring Large Value Frauds 323

IT Strategy Committee $\quad 323$

Remuneration Committee $\quad 323$

$\begin{array}{ll}\text { Nomination Committee } & 323\end{array}$

$\begin{array}{ll}\text { Disclosure New Clause } 41 & 324\end{array}$

Basel Committee Recomendations $\quad 324$

Auditors' Certificate on Corporate Governance $\quad 325$

$\begin{array}{ll}\text { LESSON ROUND UP } & 325\end{array}$

$\begin{array}{ll}\text { SELF TEST QUESTIONS } & 326\end{array}$

ANNEXURES

$\begin{array}{ll}\text { Annexure I } & 329\end{array}$

$\begin{array}{ll}\text { Annexure II } & 339\end{array}$

$\begin{array}{ll}\text { Annexure III } & 349\end{array}$

TEST PAPER

$\begin{array}{lr}\text { Practice Test Paper } & 370\end{array}$ 


\section{Lesson 1}

\section{Overview of Banking System}

\section{LESSON OUTLINE}

- Indian Banking System -Evolution

- Structure of Banks in India

- Different types of Banks in India

- Constituents of the Indian Banking System

- Commercial Banks

- Co-Operative Banking System

- Development Banks

- LESSON ROUND UP

- SELF TEST QUESTIONS

\section{LEARNING OBJECTIVES}

Banks are the important segment in Indian Financial System. An efficient banking system helps the nation's economic development. Various categories of stakeholders of the Society use the banks for their different requirements. Banks are financial intermediaries between the depositors and the borrowers. Apart from accepting deposits and lending money, banks in today's changed global business environment offer many more value added services to their clients. The Reserve Bank of India as the Central Bank of the country plays different roles like the regulator, supervisor and facilitator of the Indian Banking System.

To enable the reader to

- Understand the features of Indian Banking System

- Know the significant contribution of different types of banks

- Appreciate how important banking services for the economy 


\section{INDIAN BANKING SYSTEM - EVOLUTION}

\section{Genesis}

Indian Banking System for the last two centuries has seen many developments. An indigenous banking system was being carried out by the businessmen called Sharoffs, Seths, Sahukars, Mahajans, Chettis, etc. since ancient time. They performed the usual functions of lending moneys to traders and craftsmen and sometimes placed funds at the disposal of kings for financing wars. The indigenous bankers could not, however, develop to any considerable extent the system of obtaining deposits from the public, which today is an important function of a bank.

Modern banking in India originated in the last decades of the 18th century. The first banks were The General Bank of India which started in 1786, and the Bank of Hindustan. Thereafter, three presidency banks namely the Bank of Bengal (this bank was originally started in the year 1806 as Bank of Calcutta and then in the year 1809 became the Bank of Bengal), the Bank of Bombay and the Bank of Madras, were set up. For many years the Presidency banks acted as quasi-central banks. The three banks merged in 1925 to form the Imperial Bank of India. Indian merchants in Calcutta established the Union Bank in 1839, but it failed in 1848 as a consequence of the economic crisis of 1848-49. Bank of Upper India was established in 1863 but failed in 1913. The Allahabad Bank, established in 1865 , is the oldest survived Joint Stock bank in India . Oudh Commercial Bank, established in 1881 in Faizabad, failed in 1958. The next was the Punjab National Bank, established in Lahore in 1895, which is now one of the largest banks in India. The Swadeshi movement inspired local businessmen and political figures to found banks of and for the Indian community during 1906 to 1911. A number of banks established then have survived to the present such as Bank of India, Corporation Bank, Indian Bank, Bank of Baroda, Canara Bank and Central Bank of India. A major landmark in Indian banking history took place in 1934 when a decision was taken to establish 'Reserve Bank of India' which started functioning in 1935. Since then, RBI, as a central bank of the country, has been regulating banking system.

\section{Reserve Bank of India as a Central Bank of the Country}

The Reserve Bank, as the central bank of the country, started their operations as a private shareholder's bank. $\mathrm{RBI}$ replaced the Imperial Bank of India and started issuing the currency notes and acting as the banker to the government. Imperial Bank of India was allowed to act as the agent of the RBI. RBI covered all over the undivided India. In order to have close integration between policies of the Reserve Bank and those of the Government, It was decided to nationalize the Reserve Bank immediately after the independence of the country. From $1^{\text {st }}$ January 1949, the Reserve Bank began functioning as a State-owned and State-controlled Central Bank.. To streamline the functioning of commercial banks, the Government of India enacted the Banking Companies Act, 1949 which was later changed as the Banking Regulation Act 1949. RBI acts as a regulator of banks, banker to the Government and banker's bank. It controls financial system in the country through various measures.

\section{State Bank of India and its Associate (Subsidiaries) Banks - A New Channel of Rural Credit}

In order to serve the economy in general and the rural sector in particular, the All India Rural Credit Survey Committee recommended the creation of a state-partnered and state-sponsored bank by taking over the Imperial Bank of India, and integrating with it, the former state-owned or state-associate banks. An act was accordingly passed in Parliament in May 1955 and the State Bank of India was constituted on 1 July 1955. Later, the State Bank of India (Subsidiary Banks) Act was passed in 1959, enabling the State Bank of India to take over eight former State-associated banks as its subsidiaries (later named Associates). The State Bank of India was thus born with a new sense of social purpose. Associate Banks of State Bank of India viz., State Bank of Hyderabad, State Bank of Mysore, State Bank of Bikaner and Jaipur, State Bank of Travancore, State Bank of Patiala, State Bank of Indore, State Bank of Saurashtra have been working as per the guidance of State Bank of India. Two banks viz. State Bank of Patiala and State Bank 
of Hyderabad are fully owned by State Bank of India and in other Associate Banks, the majority of shareholdings are with the SBI. Out of these associate banks, two banks viz., State Bank of Indore and State Bank of Saurashtra have been merged with the State Bank of India and merger of the remaining five banks is under process. State Bank of India and its Associate Banks were given preferential treatment by RBI over the other commercial banks, by appointing them as an agent of RBI for transacting Central and State Government business as well as setting up of currency chests for the smoother cash management in the country

\section{Nationalization of Banks for implementing Govt. policies}

Indian Banking System witnessed a major revolution in the year 1969 when 14 major commercial banks in the private sector were nationalized on $19^{\text {th }}$ July, 1969. Most of these banks having deposits of above $₹ 50$ crores were promoted in the past by the industrialists. These banks were:

1. Allahabad Bank

2. Bank of Baroda

3. Bank of India

4. Bank of Maharashtra

5. Canara Bank

6. Central Bank of India

7. Dena Bank

8. Indian Bank

9. Indian Overseas Bank

10. Punjab National Bank

11. Syndicate Bank

12. Union Bank of India

13. United Bank of India

14. United Commercial Bank (now known as UCO bank)

The purpose of nationalization was:

(a) to increase the presence of banks across the nation.

(b) to provide banking services to different segments of the Society.

(c) to change the concept of class banking into mass banking, and

(d) to support priority sector lending and growth.

In 1980, another six more commercial banks with deposits of above $₹ 200$ crores were nationalized:

1. Andhra Bank

2. Corporation Bank

3. New Bank of India

4. Punjab and Sind Bank

5. Oriental Bank of Commerce

6. Vijaya Bank 
Later on the New Bank of India was merged with Punjab Nationalized Bank.

The nationalization of banks resulted in rapid branch expansion and the number of commercial bank branches have increased many folds in Metro, Urban, Semi - Urban and Rural Areas. The branch network assisted banks to mobilize deposits and lot of economic activities have been started on account of priority sector lending.

\section{Regional Rural Banks}

In 1975, a new set of banks called the Regional Rural Banks, were setup based on the recommendations of a working group headed by Shri Narasimham, to serve the rural population in addition to the banking services offered by the co-operative banks and commercial banks in rural areas. Inception of regional rural banks (RRBs) can be seen as a unique experiment as well as experience in improving the efficacy of rural credit delivery mechanism in India. With joint shareholding by Central Government, the concerned State Government and the sponsoring bank, an effort was made to integrate commercial banking within the broad policy thrust towards social banking keeping in view the local peculiarities. RRBs were expected to play a vital role in mobilizing the savings of the small and marginal farmers, artisans, agricultural labourers and small entrepreneurs and inculcate banking habit among the rural people. These institutions were also expected to plug the gap created in extending the credit to rural areas by largely urban-oriented commercial banks and the rural cooperatives, which have close contact with rural areas but fall short in terms of funds.

\section{Local area banks}

Local Area Banks with operations in two or three contiguous districts were conceived in the 1996 Union budget to mobilise rural savings and make them available for investments in local areas. They are expected to bridge the gaps in credit availability and enhance the institutional credit framework in rural and semi-urban areas. Although the geographical area of operation of such banks is limited, they are allowed to perform all functions of a scheduled commercial bank. The Raghuram Rajan Committee had envisaged these local area banks as private, wellgoverned, deposit-taking small-finance banks. They were to have higher capital adequacy norms, a strict prohibition on related party transactions, and lower concentration norms to offset chances of higher risk from being geographically constrained. Six entities were given licenses to operate LABs by RBI but only four are functioning. . Of these four banks, Capital Local Area Bank accounted for more than 70 per cent of total assets of all four LABs taken together as on $31^{\text {st }}$ March, 2012.

\section{New Private Sector Banks}

In 1991, the Narasimham committee recommended that banks should increase operational efficiency, strengthen the supervisory control over banks and the new players should be allowed to create a competitive environment. Based on the recommendations, new private banks were allowed to start functioning.

\section{STRUCTURE OF BANKS IN INDIA}

Banks can be classified into scheduled and non- scheduled banks based on certain factors

\section{(a) Scheduled Banks:}

Scheduled Banks in India are the banks which are listed in the Second Schedule of the Reserve Bank of India Act1934. The scheduled banks enjoy several privileges as compared to non- scheduled banks. Scheduled banks are entitled to receive refinance facilities from the Reserve Bank of India. They are also entitled for currency chest facilities. They are entitled to become members of the Clearing House. Besides commercial banks, cooperative banks may also become scheduled banks if they fulfill the criteria stipulated by RBI. 
No. of branches of Scheduled Commercial Banks as on 31stMarch, 2013:

\begin{tabular}{|l|l|l|l|l|l|}
\hline Bank Group & Rural & Semi-urban & Urban & Metropolitan & Total \\
\hline Public Sector Banks & 23286 & 18854 & 14649 & 13632 & 70421 \\
\hline Private Sector Banks & 1937 & 5128 & 3722 & 3797 & 14584 \\
\hline Foreign Banks & 8 & 9 & 65 & 249 & 331 \\
\hline Regional Rural Banks & 12722 & 3228 & 891 & 166 & 17007 \\
\hline Total & $\mathbf{3 7 9 5 3}$ & $\mathbf{2 7 2 1 9}$ & $\mathbf{1 9 3 2 7}$ & $\mathbf{1 7 8 4 4}$ & $\mathbf{1 0 2 3 4 3}$ \\
\hline
\end{tabular}

\section{(b) Non-scheduled banks:}

These are those banks which are not included in the Second Schedule of the Reserve Bank of India. Usually those banks which do not conform to the norms of the Reserve Bank of India within the meaning of the RBI Act or according to specific functions etc. or according to the judgement of the Reserve Bank, are not capable of serving and protecting the interest of depositors are classified as non-scheduled banks.

\section{Different types of Banks in India}

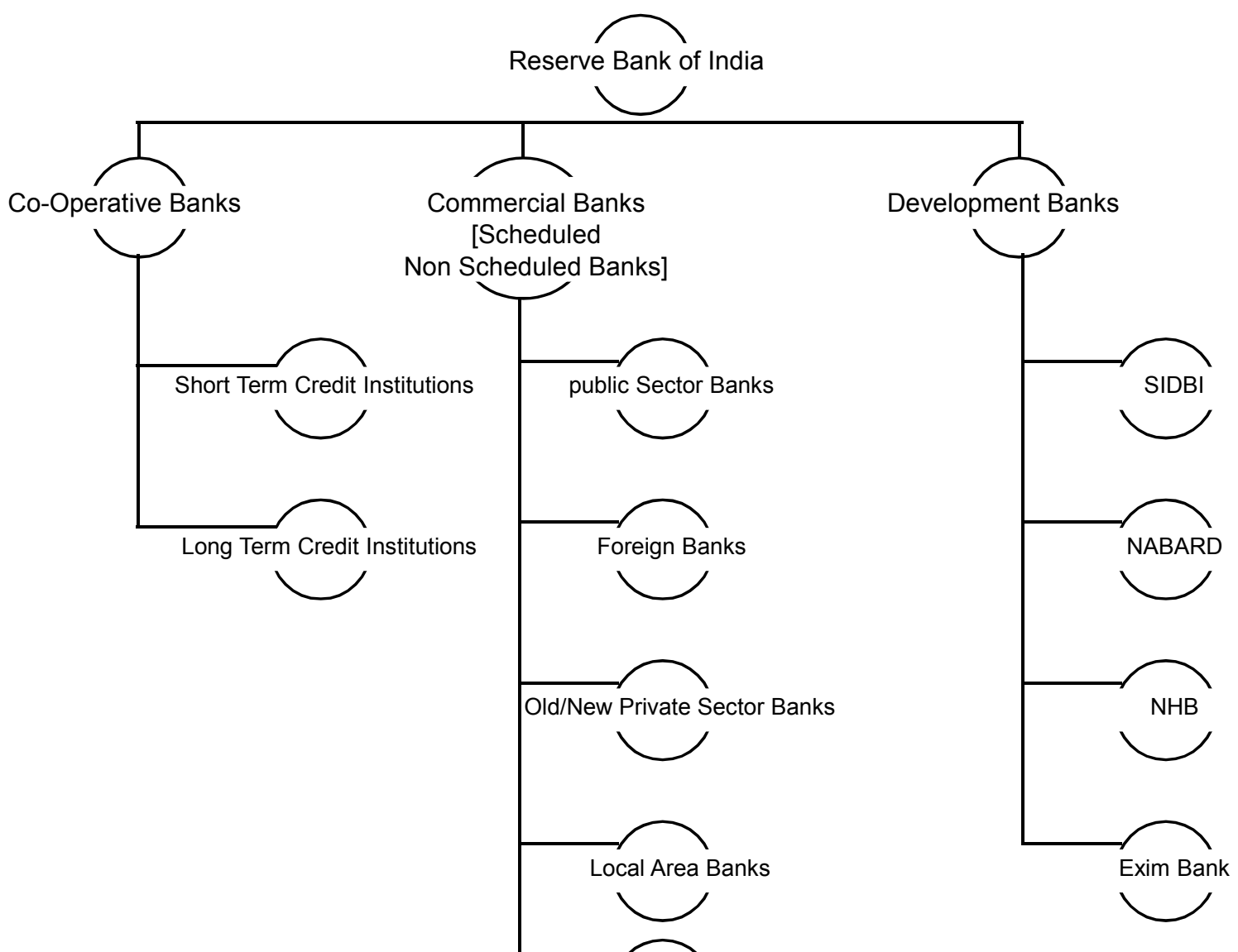

Regional Rural Banks 


\section{Constituents of the Indian Banking System}

The constituents of the Indian Banking System can be broadly listed as under :

(a) Commercial Banks:

(i) Public Sector Banks

(ii) Private Sector Banks

(iii) Foreign Banks

(b) Cooperative Banks:

(i) Short term agricultural institutions

(ii) Long term agricultural credit institutions

(iii) Non-agricultural credit institutions

(c) Development Banks:

(i) National Bank for Agriculture and Rural Development (NABARD)

(ii) Small Industries Development Bank of India (SIDBI)

(iii) EXIM Bank

(iv) National Housing Bank

\section{COMMERCIAL BANKS}

\section{Public Sector Banks}

The term 'public sector banks' by itself connotes a situation where the major/full stake in the banks are held by the Government. Till July,1969, there were only 8 Public Sector Banks (SBI \& its 7 associate banks). When 14 commercial banks (total 20 banks) were nationalized in 1969, 100\% ownership of these banks were held by the Government of India. Subsequently, six more private banks were nationalized in 1980. However, with the changing in time and environment, these banks were allowed to raise capital through IPOs and there by the share holding pattern has changed. By default the minimum $51 \%$ shares would be kept by the Government of India, and the management control of these nationalized banks is only with Central Government. Since all these banks have ownership of Central Government, they can be classified as public sector banks. Apart from the nationalized banks, State Bank of India, and its associate banks, IDBI Bank and Regional Rural Banks are also included in the category of Public Sector banks. The total number of public sector banks as on March, 2013 were 82 as per the following categorization:
(a) State Bank of India and its Associate Banks $\quad-6$
(b) Nationalised Banks $\quad-19$
(c) Regional Rural Banks $\quad-56$
(d) IDBI Bank -1

\section{Private Sector Banks}

The major stakeholders in the private sector banks are individuals and corporate. When banks were nationalized under two tranches (in 1969 and in 1980), all banks were not included. Those non nationalized banks which continue operations even today are classified as Old Generation Private Sector Banks.. like The Jammu \& Kashmir Bank Ltd, The Federal Bank, The Laxmi Vilas Bank etc. In July 1993 on account of banking sector reforms the Reserve Bank of India allowed many new banks to start banking operations. Some of the leading 
banks which were given licenses are: UTI bank (presently called Axis Bank) ICICI Bank, HDFC Bank, Kotak Mahindra Bank, Yes Bank etc., These banks are recognized as New Generation Private Sector Banks. Ten banks were licensed on the basis of guidelines issued in January 1993. The guidelines were revised in January 2001 based on the experience gained from the functioning of these banks, and fresh applications were invited.

Of the 10 licences issued in 1993, four banks merged with other lenders over a period of time. Times Bank merged with HDFC Bank, while Global Trust Bank was amalgamated with the state-owned Oriental Bank of Commerce. Centurion Bank took over Bank of Punjab to become Centurion Bank of Punjab, which merged with HDFC Bank in 2008. On account of these new generation private sector banks, a new competitive environment was created in the Indian Banking System. These banks were having competitive advantages over their counterparts (of the existing old private banks, public sector banks) in their IT support system, innovative products, and pricing of their products. Private sector banks have been rapidly increasing their presence in the recent times and offering a variety of newer services to the customers and posing a stiff competition to the group of public sector banks. Total private sector banks as on $31^{\text {st }}$ March 2013 were 22. Besides these, four Local Area Banks are also categorized as private banks.

\section{Foreign Banks}

The other important segment of the commercial banking is that of foreign banks. Foreign banks have their registered offices outside India, and through their branches they operate in India. Foreign banks are allowed on reciprocal basis. They are allowed to operate through branches or wholly owned subsidiaries. These foreign banks are very active in Treasury (forex) and Trade Finance and Corporate Banking activities. These banks assist their clients in raising External Commercial Borrowings through their branches outside India or foreign correspondents. They are active in loan syndication as well. Foreign banks have to adhere to all local laws as well as guidelines and directives of Indian Regulators such as Reserve Bank of India, Insurance and Regulatory Development Authority, Securities Exchange Board of India. The foreign banks have to comply with the requirements of the Reserve Bank of India in respect to Priority Sector lending, and Capital Adequacy ratio and other norms. Total foreign banks as on $31^{\text {st }}$ March 2013 were 43 having 331 branches. Besides these, 46 foreign banks have their representative offices in India as on $31^{\text {st }}$ March 2013.

\section{CO-OPERATIVE BANKING SYSTEM}

Cooperative banks play an important role in the Indian Financial System, especially at the village level. The growth of Cooperative Movement commenced with the passing of the Act of 1904. A cooperative bank is a cooperative society registered or deemed to have been registered under any State or Central Act. If a cooperative bank is operating in more than one State, the Central Cooperative Societies Act is applicable. In other cases the State laws are applicable. Apart from various other laws like the Banking Laws (Application to Co-operative Societies) Act, 1965 and Banking Regulation (Amendment) and Miscellaneous Provisions Act, 2004, the provisions of the RBI Act, 1934 and the BR Act, 1949 would also be applicable for governing the banking activities.

These cooperative banks cater to the needs of agriculture, retail trade, small and medium industry and selfemployed businessmen usually in urban, semi urban and rural areas. In case of co-operative banks, the shareholders should be members of the co-operative banks. The share linkage to borrowing is a distinctive feature of a co-operative bank. Rural cooperative sector in India plays a vital role in fulfilling the credit requirements of rural agricultural sector of India. At recent times, the rural credit flow through rural cooperative sector has risen substantially in order to keep pace with the growing demand for credit in the rural parts of India. The Cooperative rural Credit Structure in our country are of following types:

\section{Short Term Agricultural Credit institutions}

The short term credit structure consists of the Primary Agricultural Credit Societies at the base level, which are affiliated at the district level into the District Central Cooperative bank and further into the State Cooperative Bank 
at the State level. Being federal structures, the membership of the DCCB comprises all the affiliated PACS and other functional societies and for the SCB, the members are the affiliated DCCBs.

The DCCB being the middle tier of the Cooperative Credit Structure, is functionally positioned to deal with the concerns of both the upper and lower tiers. This very often puts the DCCB in a position of balancing competing concerns. While the SCB may managing District Central Cooperative wish the DCCB to prioritize its task in a particular manner, the PACs may have their own demands on the DCCB. Balancing these competing concerns could often be a dilemma for the DCCBs.

There are 30 State Cooperative Banks. These banks support and guide 372 District Central Cooperative Banks (DCCBs) in India which have 13478 branches as on March, 2013. These DCCBs are providing finance to more than 35 lakhs farmers through about 1.15 lacs Primary Agricultural Cooperative Societies (PACS).

\section{Long Term Agricultural Credit Institutions}

The long term cooperative credit structure consists of the State Cooperative Agriculture \& Rural Development Banks (SCARDBs) and Primary Cooperative Agriculture \& Rural Development Banks (PCARDBs) which are affiliated to the SCARDBs. The total No. of SCARDB's are 19; of which 10 have Federal Structure, 7 have Unitary Structure and 2 have Mixed Structure (i.e. operating through PCARDBs as well as its own branches).Loans are given to members on the mortgages of their land usually up to $50 \%$ of their value in some states or up to 30 times the land revenue payable in other states, duly taking into account their need and repayment capacity. The performance of these banks as on $31^{\text {st }}$ March 2012 has been as under:

$\begin{array}{ll}\text { No. of SCARDBs } & 19 \\ \text { No. of PCARDBs } & 714 \\ \text { No. of Branches of PCARDBs } & 1,056 \\ \text { No. of Branches of Unitary SCARDBs } & 761 \\ \text { Annual Lending } & ₹ 17,603.42 \mathrm{Cr} \\ \text { Total Membership } & 13.65 \text { Million }\end{array}$

\section{Urban Cooperative Banks}

The term Urban Cooperative Banks (UCBs), although not formally defined, refers to the primary cooperative banks located in urban and semi-urban areas. These banks, until 1996, were allowed to lend money only to non-agricultural purposes. This distinction remains today. These banks have traditionally been around communities, localities working out in essence, loans to small borrowers and businesses. Today their scope of operation has expanded considerably. The urban co-operative banks can spread operations to other States and such banks are called as multi state cooperative banks. They are governed by the Banking Regulations Act 1949 and Banking Laws (Cooperative Societies) Act, 1965. The total number of UCBs stood at 1,618 as on $31^{\text {st }}$ March 2012. Scheduled UCBs are banks included in the Second Schedule of the RBI Act, 1934 and include banks that have paid-up capital and reserves of not less than ₹5 lacs and carry out their business in the interest of depositors to the satisfaction of the Reserve Bank.

\section{DEVELOPMENT BANKS}

History of development Banking in India can be traced to the establishment of the Industrial Finance Corporation of India in 1948. Subsequently, with the passing of State Financial Corporation Act,1951, several SFCs came into being. With the introduction of financial sector reforms, many changes have been witnessed in the domain of development banking. There are more than 60 Development Banking Institutions at both Central and State level. We are discussing here below the major four development banks which assist in extending long term lending and 
re-finance facilities to different areas of economy for the economic development pertaining to Small Scale and Medium industries, Agricultural Sector and Housing Sector. These financial institutions plays crucial role in assisting different segments including the rural economic development.

\section{National Bank for Agriculture and Rural Development (NABARD)}

National Bank for Agriculture and Rural Development (NABARD) was established in July 1982 by an Act of Parliament based on the recommendations of CRAFICARD. It is the apex institution concerned with the policy, planning and operations in the field of agriculture and other rural economic activities. NABARD has evolved several refinance and promotional schemes over the years and has been making constant efforts to liberalize, broad base and refine/ rationalize the schemes in response to the field level needs. The refinance provided by NABARD has two basic objectives:

(i) Supplementing the resources of the cooperatives banks and RRBs for meeting the credit needs of its clientele, and

(ii) Ensuring simultaneously the buildup of a sound, efficient, effective and viable cooperative credit structure and RRBs for purveying credit.

NABARD undertakes a number of inter-related activities/services which fall under three broad categories

\section{(a) Credit Dispensation :}

NABARD prepares for each district annually a potential linked credit plan which forms the basis for district credit plans. It participates in finalization of Annual Action Plan at block, district and state levels and monitors implementation of credit plans at above levels. It also provides guidance in evolving the credit discipline to be followed by the credit institutions in financing production, marketing and investment activities of rural farm and non- farm sectors.

\section{(b) Developmental \& Promotional}

The developmental role of NABARD can be broadly classified as:-

- Nurturing and strengthening of - the Rural Financial Institutions (RFIs) like SCBs/SCARDBs, CCBs, RRBs etc. by various institutional strengthening initiatives.

- Fostering the growth of the SHG Bank linkage programme and extending essential support to SHPIs NGOs/VAs/ Development Agencies and client banks.

- Development and promotional initiatives in farm and non-farm sector.

- Extending assistance for Research and Development.

- Acting as a catalyst for Agriculture and rural development in rural areas.

\section{(c) A Supervisory Activities}

As the Apex Development Bank, NABARD shares with the Central Bank of the country (Reserve Bank of India) some of the supervisory functions in respect of Cooperative Banks and RRBs.

\section{Small Industries Development Bank of India (SIDBI)}

Small Industries Development Bank of India (SIDBI) was established in October 1989 and commenced its operation from April 1990 with its Head Office at Lucknow as a development bank. It is the principal and exclusive financial institution for the promotion, financing and development of the Micro, Small and Medium Enterprise (MSME) sector and for co-ordination of the functions of the institutions engaged in similar activities. It is a central government undertaking. The prime aim of SIDBI is to support MSMEs by providing them the valuable factor of production finance. Many institutions and commercial banks supply finance, both long-term and short-term, to small entrepreneurs. SIDBI coordinates the work of all of them. 
SIDBI has evolved a strategy to analyze the problems faced by MSMEs and come out with tailor-made solutions. It has covered around 600 MSME clusters, through a pan-India network of 85 branches, 50 Credit Advisory Centres, and partnerships with cluster-level industry associations as on January 31, 2013. A unique scheme of the credit guarantee for Micro and Small Enterprises called CGTMSE has provided coverage to about 1 million with guarantee covers for an aggregate loan amount of over ₹ 48,000 crore.

\section{Functions of Small Industries Development Bank of India (SIDBI):}

Over the years, the scope of promotional and developmental activities of SIDBI has been enlarged to encompass several new activities. It performs a series of functions in collaboration with voluntary organisations, nongovernmental organisations, consultancy firms and multinational agencies to enhance the overall performance of the small scale sector. The important functions of SIDBI are discussed as follows:

(i) Initiates steps for technology adoption, technology exchange, transfer and up gradation and modernisation of existing units.

(ii) SIDBI participates in the equity type of loans on soft terms, term loan, working capital both in rupee and foreign currencies, venture capital support, and different forms of resource support to banks and other institutions.

(iii) SIDBI facilitates timely flow of credit for both term loans and working capital to MSMEs in collaboration with commercial banks.

(iv) SIDBI enlarges marketing capabilities of the products of MSMEs in both domestic and international markets.

(v) SIDB1 directly discounts and rediscounts bills with a view to encourage bills culture and helping the SSI units to realise their sale proceeds of capital goods / equipments and components etc.

(vi) SIDBI promotes employment oriented industries especially in semi-urban areas to create more employment opportunities so that rural-urban migration of people can be checked.

\section{National Housing Bank (NHB)}

National Housing Bank was set up in July, 1988 as the apex financing institution for the housing sector with the mandate to promote efficient, viable and sound Housing Finance Companies (HFCs). Its functions aim at to augment the flow of institutional credit for the housing sector and regulate HFCs. NHB mobilizes resources and channelizes them to various schemes of housing infrastructure development. It provides refinance for direct housing loans given by commercial banks and non-banking financial institutions. The NHB also provides refinance to Housing Finance Institutions for direct lending for construction/purchase of new housing/dwelling units, public agencies for land development and shelter projects, primary cooperative housing societies, property developers. At present, it is a wholly owned subsidiary of Reserve Bank of India which contributed the entire paid-up capital. RBI has proposed to transfer its entire shareholding to Government of India to avoid conflict of ownership and regulatory role. For this transfer, the central bank will pay RBI, in cash, an amount equal to the face value of the subscribed capital issued by the RBI. The outstanding portfolio of NHB at $₹ 33,083$ crores as on $31^{\text {st }}$ December 2012 is almost equally divided between the commercial banks and the HFCs.

\section{Export Import Bank of India (EXIM Bank)}

Export-Import Bank of India was set up in 1982 by an Act of Parliament for the purpose of financing, facilitating and promoting India's foreign trade. It is the principal financial institution in the country for coordinating the working of institutions engaged in financing exports and imports. Exim Bank is fully owned by the Government of India and the Bank's authorized and paid up capital are ' 10,000 crore and ' 2,300 crore respectively.

Exim Bank lays special emphasis on extension of Lines of Credit (LOCs) to overseas entities, national governments, 
regional financial institutions and commercial banks. Exim Bank also extends Buyer's credit and Supplier's credit to finance and promote country's exports. The Bank also provides financial assistance to export-oriented Indian companies by way of term loans in Indian rupees or foreign currencies for setting up new production facility, expansion/modernization or up gradation of existing facilities and for acquisition of production equipment or technology. Exim Bank helps Indian companies in their globalization efforts through a wide range of products and services offered at all stages of the business cycle, starting from import of technology and export product development to export production, export marketing, pre-shipment and post-shipment and overseas investment.

The Bank has introduced a new lending programme to finance research and development activities of exportoriented companies. R\&D finance by Exim Bank is in the form of term loan to the extent of 80 per cent of the R\&D cost. In order to assist in the creation and enhancement of export capabilities and international competitiveness of Indian companies, the Bank has put in place an Export Marketing Services (EMS) Programme. Through EMS, the Bank proactively assists companies in identification of prospective business partners to facilitating placement of final orders. Under EMS, the Bank also assists in identification of opportunities for setting up plants or projects or for acquisition of companies overseas. The service is provided on a success fee basis.

Exim Bank supplements its financing programmes with a wide range of value-added information, advisory and support services, which enable exporters to evaluate international risks, exploit export opportunities and improve competitiveness, thereby helping them in their globalisation efforts.

\section{FUNCTIONS OF COMMERCIAL BANKS}

Sections $5 \& 6$ of Banking Regulation Act, 1949 contain the functions which a commercial banks can transact. These functions can be divided into two parts:
(a) Major functions
(b) Other functions/ancillary services

\section{(a) Major functions:}

(i) Accepting Deposits

(ii) Granting Advances

\section{(b)Other functions:}

(i) Discounting of bills and cheques

(ii) Collection of bills and cheques

(iii) Remittances

(iv) Safe custody of articles

(v) Safe Deposit Lockers

(vi) Issue of Letter of Credit

(vii) Issue of Guarantees

Besides the above functions, Banks now-a-days associate themselves in the following activities also either by opening separate departments or through separately floated independent subsidiaries:

(i) Investment Counseling

(ii) Investment Banking

(iii) Mutual Fund

(iv) Project Appraisal 
(v) Merchant Banking Services

(vi) Taxation Advisory Services

(vii) Executor Trustee Services

(viii) Credit Card Services

(ix) Forex Consultancy

(x) Transactions of Government Business

(xi) Securities Trading

(xii) Factoring

(xiii) Gold/Silver/Platinum Trading

(xiv) Venture Capital Financing

(xv) Bankassurance - Selling of Life and General Insurance policies as Corporate Agent

\section{LESSON ROUND UP}

- A strong banking system is an indicator for the economic development of any nation. Banks are important segment in Indian Financial System. An efficient and vibrant banking system is the back bone of the financial sector. The major functions of banks are to accept deposits from public and provide lending to the needy sectors. Besides commercial banks, cooperative credit institutions also plays important role in the rural economy of the country. Development banks line NABARD, SIDBI, NHB and EXIM Bank are providing refinance facilities to commercial banks and other financial institutions.

- The Reserve Bank of India as the Central Bank of the country plays different roles like the regulator, supervisor and facilitator of the Indian Banking System.

\section{SELF TEST QUESTIONS}

1. State whether the following statements are 'True' or 'False'
(a) The Reserve Bank was nationalized in the year 1949
(b) In India private sector banks started banking operations after 1991
(c) The minimum government stake in the nationalized banks is $70 \%$
(d) RBI is a banker to the Government

2. TERMINAL QUESTIONS (MCQS):

A. Banks with deposits above —were nationalized on $19^{\text {th }}$ July, 1969 .
(a) ₹ 500 crores
(b) ₹200 crores
(c) ₹ 100 crores
(d) ₹ 50 crores

B. In the $2^{\text {nd }}$ tranche of nationalization, how many banks were nationalized?
(a) 5 banks
(b) 6 banks
(c) 10 banks
(d) 14 banks

C. As regards development banks identify the exception.
(a) IDBI Bank
(b) The Small Industries Development Bank of India 
(c) The National Housing Bank

(d) The National Bank for Agricultural and Rural Development

D. In 1921, three Presidency banks were merged and a new entity was created as

(a) State Bank of India (b) Imperial Bank of India

(c) Central Bank of India (d) Reserve Bank of India

3. Write a short Note on
(a) NABARD
(b) SIDBI
(c) State Bank of India and Its associates

4. What do you mean by Commercial Banks? What are the main functions of Commercial Banks?

5. Write a short note on the evolution of banking system in India. 
14 PP-BL\&P 


\section{Lesson 2}

\section{Regulatory Framework and Compliances}

\section{LESSON OUTLINE}

- An Overview of RBI Act, 1934 And Banking Regulation Act, 1949

- Opening of New Banks and Branch Licensing

- Constitution of Banks' Board of Directors and their Rights

- Banks' Share Holders and their Rights

- CRR and SLR Concepts

- Cash - Currency Management

- Powers to Control Advances

- RBI as a Controller of Foreign Exchange

- RBI as Banker to the Government

- RBI as Lender of the Last Resort

- Monetary and Credit Policy

- Audit and Inspection

- Supervision and Control

- Winding Up - Amalgamation and Mergers

- Disclosure of Accounts and Balance Sheets

- Submission of Returns to RBI

- Fraud - Classification and Reporting

- Corporate Governance

- Prevention of Money Laundering Act, 2002 (PMLA)

- Banking Codes And Standards Board Of India (BSCSBI)

- LESSON ROUND UP

- SELF TEST QUESTIONS

\section{LEARNING OBJECTIVES}

Banking industry in India is mainly governed by the Reserve Bank of India Act,1934 and the Banking Regulation Act,1949. There are other legal frame work like the Companies Act,1956, the Negotiable Instruments Act, 1881 , the Indian Contract Act,1872, the DRT Act,1993, the Law of Limitation, FEMA,1999, etc. which are supplementary to the RBI Act, 1934 and the BR Act, 1949.

Reserve Bank of India and the Government of India have been empowered to exercise control over banks from its opening to winding up.

At the end of the chapter, the reader would be able to:

- Appreciate the role of banks and their regulatory and compliance requirements

- Understand the Government and RBI's Powers to control and regulate banks

- Know the important provisions of RBI Act, 1934, Banking Regulation (BR)Act, 1949 and PML Act, 2002

- Distinguish between the concepts of CRR and SLR

This chapter covers the Regulation and Control on banking in India by the Government of India and the Reserve Bank of India it also highlights the features of various legal frame work like the RBI Act, 1934 and the BR Act,1949 the provisions of which are applicable to banking. Apart from the above Acts, different laws and their provisions have also been discussed. RBI as the central bank of the nation and its role as regulator, supervisor and facilitator have also been covered. The importance of CRR and SLR and other relevant aspects have been discussed. 


\section{AN OVERVIEW OF RBI ACT, 1934 AND BANKING REGULATION ACT 1949}

\section{Reserve Bank of India Act, 1934}

The Reserve Bank of India Act,1934 was enacted to constitute the Reserve Bank of India with an objective to (a) regulate the issue of bank notes (b) for keeping reserves to ensure stability in the monetary system (c) to operate effectively the nation's currency and credit system

The RBI Act covers: (i) the constitution (ii) powers (iii) functions of the Reserve Bank of India. The act does not directly deal with the regulation of the banking system except for few sections like Sec 42 which relates to the maintenance of CRR by banks and Sec 18 which deals with direct discount of bills of exchange and promissory notes as part of rediscounting facilities to regulate the credit to the banking system.

The RBI Act deals with:

(a) incorporation, capital, management and business of the RBI

(b) the functions of the RBI such as issue of bank notes, monetary control, banker to the Central and State Governments and banks, lender of last resort and other functions

(c) general provisions in respect of reserve fund, credit funds, audit and accounts

(d) issuing directives and imposing penalties for violation of the provisions of the Act

\section{Banking Regulation Act, 1949}

The Banking Regulation Act, 1949 is one of the important legal frame works. Initially the Act was passed as Banking Companies Act, 1949 and it was changed to Banking Regulation Act 1949. Along with the Reserve Bank of India Act 1935, Banking Regulation Act 1949 provides a lot of guidelines to banks covering wide range of areas. Some of the important provisions of the Banking Regulation Act 1949 are listed below.

- The term banking is defined as per Sec 5(i) (b), as acceptance of deposits of money from the public for the purpose of lending and/or investment. Such deposits can be repayable on demand or otherwise and withdraw able by means of cheque, drafts, order or otherwise

- Sec 5(i)(c) defines a banking company as any company which handles the business of banking

- Sec 5(i)(f) distinguishes between the demand and time liabilities, as the liabilities which are repayable on demand and time liabilities means which are not demand liabilities

- Sec 5(i)(h) deals with the meaning of secured loans or advances. Secured loan or advance granted on the security of an asset, the market value of such an asset in not at any time less than the amount of such loan or advances. Whereas unsecured loans are recognized as a loan or advance which is not secured

- Sec 6(1) deals with the definition of banking business

- Sec 7 specifies banking companies doing banking business in India should use at least on work bank, banking, banking company in its name

- Banking Regulation Act through a number of sections restricts or prohibits certain activities for a bank. For example:

(i) Trading activities of goods are restricted as per Section 8

(ii) Prohibitions: Banks are prohibited to hold any immovable property subject to certain terms and conditions as per Section 9 . Further, a banking company cannot create a charge upon any unpaid capital of the company as per Section 14. Sec 14(A) stipulates that a banking company also cannot create a floating charge on the undertaking or any property of the company without the prior permission of Reserve Bank of India 
(iii) A bank cannot declare dividend unless all its capitalized expenses are fully written off as per Section 15.

\section{Other important sections of Banking Regulation Act, 1949}

Sections 11 and 12 deals with the Paid up Capital, Reserves and their terms and conditions, Sec 18 specifies the Cash Reserve Ratio to be maintained by Non-scheduled banks and Sec 19 (2) clarifies about the share holding of a banking company. No banking company shall hold shares in any company, (either as pledge, or mortgagee or absolute owners of any amount exceeding $30 \%$ of its own paid up share capital plus reserves (or) $30 \%$ of the paid up share capital of that company whichever is less

Section 24 specifies the requirement of maintenance of Statutory Liquidity Ratio (SLR) as a percentage (as advised by Reserve Bank of India from time to time) of the bank's demand and time liabilities in the form of cash, gold, unencumbered securities

\section{Other compliance requirements}

Section 29 - Every bank needs to publish its balance sheet as on March $31^{\text {st }}$

Section 30(i) - Audit of Balance sheet by qualified auditors

Section 35 gives powers to RBI to undertake inspection of banks

Other various sections deal with important returns which are to be submitted by banks to Reserve Bank of India

- Return of bank's liquid assets and liabilities

(Monthly)

- Return of bank's assets and liabilities in India

(Quarterly)

- Return of unclaimed deposits of 10 years and above

(Yearly)

With changing time and requirements from time to time, various other compliance issues which need to be handled by banks, have been amended/incorporated relating to:

- Nomination facilities

- Time period for preservation of bank books/records

\section{OPENING OF NEW BANKS AND BRANCH LICENSING}

In India, there are various types of banks and they were set up under different Acts passed by the Central and State Governments as under:

\begin{tabular}{|l|l|}
\hline BANKS - CATEGORY & LEGAL FRAME WORK \\
\hline State Bank of India & State Bank of India Act,1955 \\
\hline SBI Associate Banks & State Bank (Subsidiary Banks) Act,1959 \\
\hline Nationalised Banks - 1969 & Banking Companies (Acquisition and Transfer of Undertakings) Act,1970 \\
\hline Nationalised Banks - 1980 & Banking Companies (Acquisition and Transfer of Undertakings) Act, 1980 \\
\hline Regional Rural Banks & Regional Rural Banks Act,1976 \\
\hline Private Sector Banks & Indian Companies Act,1986 \\
\hline Co-operative Banks & $\begin{array}{l}\text { Co-operative Societies Acts (State/Central) and Banking Laws (Applicable } \\
\text { to Cooperative Societies) Act,1965 }\end{array}$ \\
\hline & Banking Laws (Application to Co-operative Societies Act,1965 \\
\hline
\end{tabular}


All the above types of banks are required to follow the relevant laws of RBI Act and Banking Regulation Act besides the provisions of the specific Act under which the said bank has been incorporated.

\section{Setting up of a New Bank}

The Reserve Bank of India has the powers as per the provisions of the BR Act and the RBI Act to issue licenses to new banks to function as banks and also to open new branches from time to time. The Banking Regulation Act.1949 requires a company or entity to obtain a license from the Reserve Bank of India to start the business of banking in India. Further to the licensing, the required permission is also to be obtained for opening and shifting of branches as per the Branch Authorisation Policy declared by RBI from time to time.

Reserve Bank of India would grant the license and the permission subject to certain terms and conditions in each case. It is open to the Reserve Bank of India to consider the findings of the inspection report under Sec 35 of the Banking Regulation Act while disposing of an application for license. Before granting a license under Sec 22, Reserve Bank may have to be satisfied by an inspection of the books of the banking company in respect of the following aspects:

1. Whether the company is or will be able to pay its present and future depositors in full as and when their claims accrue

2. Whether the affairs of the company are being conducted or likely to be conducted in a manner detrimental to the interests of its present and future depositors

3. Whether the company has an adequate capital structure and earning prospects

4. Whether public interest will be served by grant of license to the company

5. Other issues relating to branch expansion, unbanked area and other aspects

In respect of foreign banks, (which are incorporated outside India), application for a license to the Reserve Bank of India to open banks/branches in India, would be considered by RBI on satisfying the following conditions apart from the conditions applicable to domestic banks:

(a) whether carrying on of banking business by the company in India will be in public interest

(b) whether the government or the law of the country in which the company is incorporated discriminates against banking companies registered in India

(c) whether the company complies with provisions of the BR Act as applicable to foreign companies

Section 11 of the Banking Regulation Act stipulates the minimum capital and reserve requirements of a Banking Company, the Reserve Bank of India can stipulate a higher requirement of capital for licensing a company

As per the provisions of the Banking Regulation Act, 1949 Reserve Bank of India can cancel the licenses granted to any banking company on account of any one or more of the following reasons:

(i) the company ceases to carry on banking business in India

(ii) the company fails to comply with any of the conditions imposed under the specific provisions of the Banking Regulation Act

Before cancellation of a license for non-compliance with any of the conditions, the company has to be given an opportunity for taking necessary steps for complying with or fulfilling the conditions. However, in cases, where the Reserve Bank is of the opinion that delay will be prejudiced to the interests of the depositors or the public then Reserve Bank can take appropriate action. A banking company whose license is cancelled can appeal to the Central Government within 30 days from the date of the order of cancellation. 


\section{Branch Licensing}

The opening of branches by banks is governed by the provisions of Section 23 of the Banking Regulation Act, 1949. In terms of these provisions, without the prior approval of the Reserve Bank of India (RBI), banks cannot

- Open a new place of business in India or abroad

- Cannot shift or change, except within the same city, town or village the location of the existing place of business

As regards branch licensing, banks have to refer to the guidelines of the Reserve Bank from time to time, including change of premises, shifting of branches to other locations, etc. As regards Regional Rural Banks, the application for permission have to be routed through the National Bank for Agriculture and Rural Development and based on the comments of NABARD, RBI would act accordingly. The Branch Authorisation Policy for commercial banks as on $1^{\text {st }}$ July, 2013 is as under:

\section{Branch Authorisation Policy for Commercial Banks}

(i) For the purpose of branch authorisation policy, a "branch" means a full-fledged branch, including a specialized branch, a satellite or mobile office, an Extension Counter, an off-site ATM (Automated Teller Machine), administrative office, controlling office, service branch (back office or processing centre) and credit card centre. A call centre will not be treated as a branch.

(ii) Domestic scheduled commercial banks (other than RRBs) are permitted to open branches, Administrative offices, Central Processing Centres (CPCs) and Service branches in Tier 2 to Tier 6 centres (with population up to 99,999 as per Census 2001 and in rural, semi-urban and urban centres in North Eastern States and Sikkim, and to open mobile branches in Tier 3 to Tier 6 centres (with population up to 49,999 as per Census 2001)and in rural, semi-urban and urban centres in North Eastern States and Sikkim without permission from Reserve Bank of India in each case, subject to reporting. Since the concept of mobile branches was mooted for rural areas, the general permission granted for operationalising mobile branches in Tier 3 to Tier 6 centres has not been extended to the operationalisation of mobile branches in Tier 2 centres.

(iii) With a view to further increasing operational flexibility of banks, domestic scheduled commercial banks (other than RRBs) are permitted to open offices exclusively performing administrative and controlling functions (Regional Offices/Zonal Offices) in Tier 1 Centres without the need to obtain prior permission in each case, subject to reporting.

(iv) Opening of branches/Central Processing Centres (CPCs)/Service branches by domestic scheduled commercial banks (other than RRBs) in Tier 1 centres (centres with population of 1,00,000 and above as per 2001 Census) will continue to require prior permission of the Reserve Bank of India, except in the case of North Eastern States and Sikkim, where the general permission would cover Tier-1 centres also.

(v) Domestic Scheduled Commercial Banks, while preparing their Annual Branch Expansion Plan (ABEP), should allocate at least 25 percent of the total number of branches proposed to be opened during a year in unbanked rural (Tier 5 and Tier 6 ) centres. An unbanked rural centre would mean a rural (Tier 5 and Tier 6 ) centre that does not have a brick and mortar structure of any scheduled commercial bank for customer based banking transactions.

(vi) In view of the requirement for opening at least 25 per cent of the branches under ABEP in unbanked rural centres, it would now not be mandatory to open at least one third of the total number of branches proposed to be opened in Tier 2 to Tier 6 centres in under-banked districts of under-banked States. However, as there is a continuing need for opening more branches in under-banked districts of under-banked States for ensuring more uniform spatial distribution, banks would be provided incentive for opening such branches. Accordingly, for each branch proposed to be opened in Tier 2 to Tier 6 centres of under- 
banked districts of under-banked States, excluding such of the rural branches proposed to be opened in unbanked rural centres that may be located in the under-banked districts of under-banked States in compliance with the requirement as indicated in sub para viii) above, authorisation will be given for opening of a branch in a Tier 1 centre. This will be in addition to the authorisation given for branches in Tier 1 centres based on the considerations stated above.

(vii) Banks may consider front-loading (prioritizing) the opening of branches in unbanked rural centres over a 3 year cycle co-terminus with their Financial Inclusion Plan (2013-16). Credit will be given for the branches opened in unbanked rural centres in excess of the required 25 percent of the ABEP for the year which will be carried forward for achieving the criteria in the subsequent ABEP/year of the Financial Inclusion Plan (FIP).

\section{NEW BANK LICENSING POLICY, 2013}

Over the last two decades, the Reserve Bank of India (RBI) gave license to twelve banks in the private sector. This happened in two phases. Ten banks were licensed on the basis of guidelines issued in January 1993. The guidelines were revised in January 2001 based on the experience gained from the functioning of these banks, and fresh applications were invited. The applications received in response to this invitation were vetted by a High Level Advisory Committee constituted by the RBI, and two more licences were issued, to two entities, viz., Kotak Mahindra Bank and Yes Bank. While preparing these guidelines, the Reserve Bank recognized the need for an explicit policy on banking structure in India keeping in view the recommendations of the Narasimham Committee, Raghuram Rajan Committee and other viewpoints.

\section{Guidelines and important aspects}

\section{(A) Eligible Promoters}

(i) Entities/groups in the private sector that are 'owned and controlled by residents' [as defined in Department of Industrial Policy and Promotion (DIPP)] and entities in public sector, are eligible to promote a bank through a wholly-owned Non-Operative Financial Holding Company (NOFHC).

(ii) Promoters/Promoter Groups with an existing non-banking financial company (NBFC) are eligible to apply for a bank licence.

\section{(B) 'Fit and Proper' criteria}

Promoters/Promoter Groups should be 'fit and proper' in order to be eligible to promote banks through a wholly owned NOFHC. RBI would assess the 'fit and proper' status of the applicants on the basis of following criteria

(a) Promoters/Promoter Groups should have a past record of sound credentials and integrity

(b) Promoters/Promoter Groups should be financially sound and have a successful track record of running their business for at least 10 years.

RBI may, inter alia, seek feedback on applicant Groups on these or any other relevant aspects from other regulators, and enforcement and investigative agencies like Income Tax, CBI, Enforcement Directorate, etc. as deemed appropriate.

\section{(C) Corporate structure of the NOFHC}

(i) Promoter/Promoter Group will be permitted to set up a bank only through a wholly-owned Non-Operative Financial Holding Company (NOFHC).

(ii) The NOFHC should hold the bank as well as all the other financial services entities of the Group regulated by RBI or other financial sector regulators. Only non-financial services companies/entities and nonoperative financial holding company in the Group and individuals belonging to Promoter Group will be allowed to hold shares in the NOFHC. Financial services entities whose shares are held by the NOFHC cannot be shareholders of the NOFHC. 
(iii) The general principle is that no financial services entity held by the NOFHC would be allowed to engage in any activity that a bank is permitted to undertake departmentally. In this context:

(iv) The NOFHC should not be permitted to set up any new financial services entity for at least three years from the date of commencement of business of the NOFHC. However, this would not preclude the bank from having a subsidiary or joint venture or associate, where it is legally required or specifically permitted by RBI.

(v) Only those regulated financial sector entities in which a Promoter Group has significant influence or control will be held under the NOFHC.

(vi) The Promoter/Promoter Group entities/individuals associated with Promoter Group should hold equity investment, in the bank and other financial entities held by it, only through the NOFHC.

(vi) Shares of the NOFHC should not be transferred to any entity outside the Promoter Group. Any change in shareholding (by the Promoter Group) with in the NOFHC as a result of which a shareholder acquires 5 per cent or more of the voting equity capital of the NOFHC should be with the prior approval of RBI.

\section{(D) Minimum voting equity capital requirements for banks and shareholding by NOFHC}

(i) The initial minimum paid-up voting equity capital for a bank should be ₹5 billion (₹.500 crores). Any additional voting equity capital to be brought in will depend on the business plan of the Promoters.

(ii) The NOFHC should hold a minimum of 40 per cent of the paid-up voting equity capital of the bank which should be locked in for a period of five years from the date of commencement of business of the bank.

(iii) Shareholding by NOFHC in the bank in excess of 40 per cent of the total paid-up voting equity capital should be brought down to 40 per cent within three years from the date of commencement of business of the bank.

(iv) The shareholding by NOFHC should be brought down to 20 per cent of the paid-up voting equity capital of the bank within a period of 10 years, and to 15 per cent within 12 years from the date of commencement of business of the bank.

(v) The capital requirements for the regulated financial services entities held by the NOFHC should be as prescribed by the respective sectoral regulators. The bank should be required to maintain a minimum capital adequacy ratio of 13 per cent of its risk weighted assets (RWA) for a minimum period of 3 years after the commencement of its operations subject to any higher percentage as may be prescribed by $\mathrm{RBI}$ from time to time. On a consolidated basis, the NOFHC and the entities held by it should maintain a minimum capital adequacy of 13 per cent of its consolidated RWA for a minimum period of 3 years.

(vi) The bank should get its shares listed on the stock exchanges within three years of the commencement of business by the bank.

\section{(E) Regulatory framework}

(i) The NOFHC will be registered as a non-banking financial company (NBFC) with the RBI and will be governed by a separate set of directions issued by RBI.

(iii) The financial entities held by the NOFHC will be governed by the applicable Statutes and regulations prescribed by the respective financial sector regulators.

\section{(F) Foreign shareholding in the bank}

Where foreign shareholding in private sector banks is allowed up to a ceiling of 74 per cent of the paid-up voting equity capital, the aggregate non-resident shareholding from FDI, NRIs and FIls in the new private sector banks should not exceed 49 per cent of the paid-up voting equity capital for the first 5 years from the date of licensing of the bank. No non-resident shareholder, directly or indirectly, individually or in groups, or through subsidiary, associate 
or joint venture will be permitted to hold 5 per cent or more of the paid-up voting equity capital of the bank for a period of 5 years from the date of commencement of business of the bank. After the expiry of 5 years from the date of commencement of business of the bank, the aggregate foreign shareholding would be as per the extant FDI policy.

\section{(G) Corporate governance of NOFHC}

The NOFHC should comply with the corporate governance guidelines as issued by RBI from time to time.

\section{(H) Prudential Norms for the NOFHC}

The prudential norms will be applied to NOFHC both on stand-alone as well as on a consolidated basis. Some of the major prudential norms are as under:

\section{(I) NOFHC on a stand-alone basis}

(a) Prudential norms for classification, valuation and operation of investment portfolio.

(b) Prudential norms on Income Recognition, Asset Classification and Provisioning pertaining to Advances.

(c) The NOFHC for the purpose of its liquidity management can make investments in bank deposits, money market instruments, government securities and actively traded bonds and debentures.

(d) The NOFHC should closely monitor its liquidity position and interest rate risk. For this purpose, the NOFHC should prepare a structural liquidity statement (STL) and interest rate sensitivity statement (IRS).

(f) The NOFHC may have a leverage up to 1.25 times of its paid-up equity capital and free reserves. The actual leverage assumed within this limit should be based on the ability of the NOFHC to service its borrowings from its dividend income.

\section{(ii) NOFHC on a consolidated basis}

(a) NOFHC should maintain capital adequacy and other requirements on a consolidated basis based on the prudential guidelines on Capital Adequacy and Market Discipline - New Capital Adequacy Framework (NCAF) issued under Basel II framework and Guidelines on Implementation of Basel III Capital Regulations in India, when implemented.

(b) The NOFHC should prepare consolidated financial statements and other consolidated prudential reports in terms of the Guidelines for consolidated accounting and other quantitative methods and in terms of Scope of Prudential Consolidation indicated under Basel III Capital Regulations.

(c) The consolidated NOFHC should adhere to the instructions on disclosure in Financial Statements Notes to Accounts

(d) The consolidated NOFHC should prepare a structural liquidity statement (STL), interest rate sensitivity statement (IRS).

\section{(I) Exposure norms}

Exposure norms are to be observed as per the guidelines of the Reserve Bank of India from time to time.

\section{(J) Business Plan for the bank}

(a) Applicants for new bank licenses will be required to furnish their business plans for the banks along with their applications. The business plan will have to address how the bank proposes to achieve financial inclusion.

(b) The business plan submitted by the applicant should be realistic and viable. In case of deviation from the stated business plan after issue of licence, RBI may consider restricting the bank's expansion, effecting change in management and imposing other penal measures as may be necessary. 


\section{(K) Other conditions for the bank}

(i) The Board of the bank should have a majority of independent Directors.

(ii) Any acquisition of shares which will take the aggregate holding of an individual/entity/group to the equivalent of 5 per cent or more of the paid-up voting equity capital of the bank, will require prior approval of RBI.

(iii) No single entity or group of related entities, other than the NOFHC, should have shareholding or control, directly or indirectly, in excess of 10 per cent of the paid-up voting equity capital of the bank.

(iv) The bank should comply with the priority sector lending targets and sub-targets as applicable to the existing domestic banks. For this purpose, the bank should build its priority sector lending portfolio from the commencement of its operations.

(v) The bank should open at least 25 per cent of its branches in unbanked rural centres (population up to 9,999 as per the latest census) to avoid over concentration of their branches in metropolitan areas and cities which are already having adequate banking presence.

(vii) The bank should operate on Core Banking Solutions (CBS) from the beginning with all modern infrastructural facilities.

(viii) The bank should have a high powered Customer Grievances Cell to handle customer complaints.

\section{(J) Procedure for RBI decisions}

Reserve Bank of India would consider many factors before issuing the licenses for the new private sector banks. At the first stage, the applications will be screened by RBI to ensure prima facie eligibility of the applicants. RBI may apply additional criteria to determine the suitability of applications, in addition to the 'fit and proper' criteria prescribed by it. Thereafter, the applications will be referred to a High Level Advisory Committee to be set up by $\mathrm{RBI}$.

The High Level Advisory Committee will comprise eminent persons with experience in banking, financial sector and other relevant areas. The constitution of the committee will be announced shortly. The High Level Advisory Committee will set up its own procedures for screening the application.

The Committee will submit its recommendations to RBI for consideration. The decision to issue an in-principle approval for setting up of a bank will be taken by RBI. RBI's decision in this regard will be final. The validity period of in-principal approval for setting up of a bank is 18 months.

\section{CONSTITUTION OF BANKS' BOARD OF DIRECTORS AND THEIR RIGHTS}

As per the relevant provisions of the Banking Regulation Act, at least fifty one percent of the total number of directors should be persons, who have special knowledge or practical experience, with respect of accountancy, agriculture and rural economy, banking, economics, finance, law, etc., The varied exposure and experience of different directors would be useful to the banking company.

The directors of the banking company should not have a substantial interest. As per the provisions of the Banking Regulation Act, the term "substantial interest" would mean that the total shareholding of the said banking company by an individual or his or his spouse or minor child (singly) should not exceed Rs Five lakhs or ten per cent of the paid up capital of the banking company.

The directors of a banking company should not hold office for more than eight years continuously. The board of the bank is constituted as per the provisions of the BR Act.

\section{BANKS' SHARE HOLDERS AND THEIR RIGHTS}

As per the Banking Regulation Act, there is no specified limit on the number of shares to be held by a shareholder 


\section{PP-BL\&P}

in a banking company. While there is no restriction on the holding of number of shares, as far as the voting rights is concerned, but no shareholder can exercise voting rights in respect of the shares held by him/her in excess of ten per cent of the total voting rights of all the shareholders of the banking company. However this provision does not in any way affect the transfer of shares or the registration of such share transfers.

The Reserve Bank of India has directed banking companies that whenever they receive more than the prescribed percentage of share transfer to one shareholder/party, the Board of the bank should refer to the Reserve Bank. Without the Reserve Bank's acknowledgement/instructions, the Bank's Board cannot transfer such shares to a shareholder/party. This is to ensure that the controlling interest in a banking company is not changed without the knowledge and approval of the Reserve Bank.

\section{Other Issues}

According to the directives of the Reserve Bank of India, the details of the Bank's top executives including the CEO, Chairman and Managing Director and others needs to be furnished to the Reserve Bank of India. Also, information regarding the share holding pattern, direct or indirect holding and other relevant details should be furnished.

As regards payment of dividends to the shareholders, banks are required to be guided by the Banking Regulation Act and the directives of the Reserve Bank of India. While declaring dividends banks should consider the NPA levels and other applicable requirements as per the Reserve Bank directives.

\section{CASH RESERVE RATIO (CRR) AND STATUTORY LIQUIDITY RATIO (SLR) CONCEPTS}

\section{Cash Reserve Ratio}

Cash Reserve Ratio (CRR) is the mandatory reserves to be maintained with Reserve Bank of India. Every scheduled Bank is required to keep certain percentage of their demand and time liabilities, as cash balances with the Reserve Bank of India from time to time as per Section 42 of the Reserve Bank of India Act,. There is no maximum ceiling or floor rate in respect of CRR. The non-scheduled banks are required to maintain the cash reserve as per Section 18 of the Banking Regulation Act.

\section{Computation of DTL:}

Liabilities of a bank may be in the form of demand or time deposits or borrowings or other miscellaneous items of liabilities. As defined under Section 42 of the RBI Act, 1934, liabilities of a bank may be towards the banking system or towards others in the form of demand and time deposits or borrowings or other miscellaneous items of liabilities.

\section{Demand Liabilities:}

Demand Liabilities of a bank are liabilities which are payable on demand. Some of the important items are: (i)current deposits (ii) demand liabilities portion of savings bank deposits (iii) margins held against letters of credit/guarantees (iv) balances in overdue fixed deposits ( $v$ ) cash certificates and cumulative/recurring deposits (vi) outstanding Telegraphic Transfers (TTs), Mail Transfers (MTs), Demand Drafts (DDs) (vii) unclaimed deposits (viii) credit balances in the Cash Credit account and (ix) deposits held as security for advances which are payable on demand.

Money at Call and Short Notice from outside the Banking System should be shown against liability to others.

\section{Time Liabilities:}

Time Liabilities of a bank are those which are payable otherwise than on demand. These include:

(i) fixed deposits

(ii) cash certificates 
(iii) cumulative and recurring deposits, time liabilities portion of savings bank deposits, staff security deposits, margin held against letters of credit, if not payable on demand, deposits held as securities for advances which are not payable on demand and Gold deposits.

\section{Other Demand and Time Liabilities (ODTL)}

ODTL include interest accrued on deposits, bills payable, unpaid dividends, suspense account balances representing amounts due to other banks or public, net credit balances in branch adjustment account, any amounts due to the banking system which are not in the nature of deposits or borrowing. Such liabilities may arise due to items like (i) collection of bills on behalf of other banks, (ii) interest due to other banks and so on. If a bank cannot segregate the liabilities to the banking system, from the total of ODTL, the entire ODTL may be shown against item II (c) 'Other Demand and Time Liabilities' of the return in Form 'A' and average CRR maintained on it by all SCBs.

Cash collaterals received under collateralized derivative transactions should be included in the bank's DTL/NDTL for the purpose of reserve requirements as these are in the nature of 'outside liabilities'.

\section{Assets with the Banking System:}

Assets with the banking system include balances with banks in current account, balances with banks and notified financial institutions in other accounts, funds made available to banking system by way of loans or deposits repayable at call or short notice of a fortnight or less and loans other than money at call and short notice made available to the banking system. Any other amounts due from banking system which cannot be classified under any of the above items are also to be taken as assets with the banking system.

\section{Borrowings from abroad by banks in India:}

Loans/borrowings from abroad by banks in India will be considered as 'liabilities to others' and will be subject to reserve requirements.

\section{Arrangements with Correspondent Banks for Remittance Facilities:}

When a bank accepts funds from a client under its remittance facilities scheme, it becomes a liability (liability to others) in its books. It should be shown as ' Liability to others in India' and the same should also be taken into account for computation of DTL for CRR/SLR purpose.

\section{Liabilities not to be included for DTL/NDTL computation:}

The following items will not form part of liabilities for the purpose of CRR and SLR:

(a) Paid up capital, reserves, any credit balance in the Profit \& Loss Account of the bank, amount of any loan taken from the RBI and the amount of refinance taken from Exim Bank, NHB, NABARD, SIDBI

(b) Net income tax provision

(c) Amount received from DICGC towards claims and held by banks pending adjustments thereof

(d) Amount received from ECGC by invoking the guarantee

(e) Amount received from insurance company on ad-hoc settlement of claims pending judgment of the Court

(f) Other items as approved by RBI

\section{Exempted Categories:}

SCBs are exempted from maintaining CRR on the following liabilities:

- Liabilities to the banking system in India as computed under Clause (d) of the explanation to Section 42(1) of the RBI Act, 1934; 
- Demand and Time Liabilities in respect of their Offshore Banking Units (OBU) and

- SCBs are not required to include inter-bank term deposits/term borrowing liabilities of original maturities of 15 days and above and up to one year in "Liabilities to the Banking System" (item 1 of Form A return). Similarly banks should exclude their inter-bank assets of term deposits and term lending of original maturity of 15 days and above and up to one year in "Assets with the Banking System" (item III of Form A return) for the purpose of maintenance of CRR. The interest accrued on these deposits is also exempted from reserve requirements.

\section{Procedure for Computation of CRR:}

In order to improve cash management by banks, as a measure of simplification, a lag of one fortnight in the maintenance of stipulated CRR by banks is provided.

\section{Maintenance of CRR on Daily Basis:}

With a view to providing flexibility to banks in choosing an optimum strategy of holding reserves depending upon their intra fortnight cash flows, all SCBs are required to maintain minimum CRR balances up to 70 per cent of the average daily required reserves for a reporting fortnight on all days of the fortnight ( Reserve Bank of India has increased the requirement of minimum daily CRR balance maintenance to 99 per cent effective from the first day of the fortnight beginning July 27,2013 ).

As present, no Interest is paid on Eligible Cash Balances maintained by SCBs with RBI under CRR:

\section{Fortnightly Return in Form A (CRR):}

Under Section 42 (2) of the RBI Act, 1934, all SCBs are required to submit to Reserve Bank a provisional Return in Form ' $A$ ' within 7 days from the expiry of the relevant fortnight and the final Form ' $A$ ' return is required to be submitted to RBI within 20 days from expiry of the relevant fortnight.

As regards the SB accounts, the calculation of the proportion of demand liabilities and time liabilities by SCBs in respect of their savings bank deposits on the basis of the position as at the close of business on 30th September and 31st March every year. The average of the minimum balances maintained in each of the month during the half year period should be treated by the bank as the amount representing the "time liability" portion of the savings bank deposits. When such an amount is deducted from the average of the actual balances maintained during the half year period, the difference would represent the "demand liability" portion. The proportions of demand and time liabilities so obtained for each half year should be applied for arriving at demand and time liabilities components of savings bank deposits for all reporting fortnights during the next half year.

\section{Penalties:}

Penal interest will be charged as under in cases of default in maintenance of CRR by SCBs as per the directives of the Reserve Bank of India.

\section{Statutory Liquidity Ratio (SLR)}

Statutory Liquidity Ratio (SLR): SLR is also the mandatory reserves to be maintained by banks held in the form of prescribed securities. This is also based on certain percentage of their demand and time liabilities of a bank.

As per Section 24 of the Banking Regulation Act, every banking company in India is required to maintain in India, in cash, gold or unencumbered approved securities an amount which should not at close of business on any day be less than the percentage prescribed by RBI of the total of its demand and time liabilities in India. This is known as "Statutory Liquidity Ratio".

Consequent upon amendment to the Section 24 of the Banking Regulation Act, 1949 through the Banking Regulation (Amendment) Act, 2007 , the Reserve Bank can prescribe the SLR for SCBs in specified assets. The value of such assets of a SCB should not be less than such percentage not exceeding 40 per cent of its total DTL in India 
as on the last Friday of the second preceding fortnight as the Reserve Bank may, by notification in the Official Gazette, specify from time to time.

Reserve Bank has specified that every SCB should maintain in India assets as detailed below, the value of which should not, at the close of business on any day, be less than the percentage as specified by RBI of the total net demand and time liabilities as on the last Friday of the second preceding fortnight as prescribed valued in accordance with the method of valuation specified by the Reserve Bank of India from time to time:

(a) Cash or Gold valued at a price not exceeding the current market price, or

(b) Investment in the following instruments which will be referred to as "Statutory Liquidity Ratio (SLR) securities":

(i) Dated securities issued (as directed by the Reserve Bank from time to time)

(ii) Treasury Bills of the Government of India

(iii) Any other instrument as may be notified by the Reserve Bank of India, provided that the securities (including margin) referred to above, if acquired under the Reserve Bank- Liquidity Adjustment Facility $(\mathrm{LAF})$, should not be treated as an eligible asset for this. Encumbered SLR securities should not be included for the purpose of computing the percentage specified above. In computing the amount for the above purpose, the following will be accounted for "cash maintained in India":

(i) The deposit required under sub-section (2) of Section 11 of the Banking Regulation Act, 1949 to be made with the Reserve Bank by a banking company incorporated outside India;

(ii) Any balances maintained by a scheduled bank with the Reserve Bank in excess of the balance required to be maintained by it under Section 42 of the Reserve Bank of India Act, 1934 (2 of 1934);

(iii) Net balances in current accounts with other scheduled commercial banks in India.

\section{Procedure for Computation of SLR:}

The procedure to compute total NDTL for the purpose of SLR under Section 24 (2) (B) of B.R. Act 1949 is broadly similar to the procedure followed for CRR. . SCBs are required to include inter-bank term deposits/term borrowing liabilities of all maturities in 'Liabilities to the Banking System'. Similarly, banks should include their inter-bank assets of term deposits and term lending of all maturities in 'Assets with the Banking System' for computation of NDTL for SLR purpose.

\section{Classification and Valuation of Approved Securities for SLR:}

As regards classification and valuation of approved securities, banks may be guided by the instructions stipulated by RBI from time to time on Prudential Norms for classification, valuation and operation of investment portfolio by banks.

\section{Penalties:}

If a banking company fails to maintain the required amount of SLR, it should be liable to pay to RBI in respect of that default, as per the directives of the Reserve Bank of India from time to time.

\section{Return in Form VIII (SLR):}

(i) Banks should submit to the Reserve Bank before 20th day of every month, a return in Form VIII showing the amounts of SLR held on alternate Fridays during immediate preceding month with particulars of their DTL in India held on such Fridays or if any such Friday is a Public Holiday under the Negotiable Instruments Act, 1881, at the close of business on preceding working day.

(ii) Banks should also submit a statement as annexure to Form VIII return giving daily position of (a) assets 
held for the purpose of compliance with SLR, (b) the excess cash balances maintained by them with RBI in the prescribed format, and (c) the mode of valuation of securities.

\section{Correctness of Computation of DTL to be certified by Statutory Auditors:}

The Statutory Auditors should verify and certify that all items of outside liabilities, as per the bank's books had been duly compiled by the bank and correctly reflected under DTL/NDTL in the fortnightly/monthly statutory returns submitted to Reserve Bank for the financial year.

\section{CASH - CURRENCY MANAGEMENT}

The currency ( bank notes) of our country is issued by the Reserve Bank of India. The Reserve Bank has the sole right to issue and management of currency in India under Section 22 of the RBI Act. RBI may issue notes of different denominations as decided by the Central Government, based on the recommendations made by the Central Board of the bank from time to time. Such notes should be legal tender at any place in India.

The Reserve Bank handles the currency management function through its Department of Currency Management in Mumbai. The aggregate value of gold coins, bullion and foreign securities held by RBI should not be below the prescribed limit at any time. The Reserve Bank currency management is handled through two departments viz., the Issue Department and the Banking Department. The issue department should ensure that the aggregate value of the currency notes and bank notes in circulation from time to time should be equivalent to the eligible assets( gold coins, bullion and foreign securities) held by RBI

\section{Currency Chests}

The Reserve Bank of India has made adequate arrangements for the issue of currency notes and distribution of coins and currency notes across India. One of the distribution channel used by the Reserve Bank is Currency Chests. Reserve Bank has authorized selected branches of banks to establish currency chests. In these currency chests, bank notes and coins are stocked/stored on behalf of the Reserve Bank. Currency chests which are managed by banks, store soiled and re-issuable notes and also fresh currency notes. The banks review the currency notes (which are in their view not fit for circulation and forward them to RBI for further action. After reexamining them, RBI if necessary, re circulate them, other wise arranges to destroy them, as per their procedures. The issue department co-ordinates with printing presses and mints for its regular supply of notes and coins. It also ensures that notes/coins are distributed through different channels such as Reserve Bank counters, banks, post offices, co-operative banks.

\section{Currency Printing and Coin Minting}

The Government of India on the advice of the Reserve Bank of India decides on the various denominations for printing the notes. The Reserve Bank coordinates with the Government in designing the bank notes. Printing of currency notes are handled by the Security Printing and Minting Corporation of India Limited (SPMCIL) and The Bharatiya Reserve Bank Note Mudran Pvt Ltd (BRBNMPL) in their different printing presses setup at Nashik, Devas, Mysore. SPMCIL has mints for coin production at Mumbai, Noida, Hyderabad. The Reserve Bank acts as agent for the Central Government for issue, distribution, withdrawing of the coins.

Reserve Bank of India's concern is on the level of forged notes penetrated into the circulation. The Reserve Bank has been regularly educating the public, banks and others through press releases and display of "Know Your Bank Note". Reserve Bank from time to time circulate information on the security features of the currency notes. Banks are advised to install the required ultra violet machines and counterfeit note detecting machines. Reserve Bank provides training to banks and government treasury offices and issues detailed guidelines on how to detect and take further necessary steps including impounding of such notes. 


\section{POWERS TO CONTROL ADVANCES}

The core business of a banking company is to lend money in the form of loans and advances. Lending may be for short term or medium term or long term. Lending money can be on secured or unsecured basis to different kinds of borrowers for various purposes.

RBI has to facilitate the flow of an adequate volume of bank credit to industry, agriculture and trade to meet their genuine needs. At the same time, to keep inflationary pressures under check, it has to restrain undue credit expansion and also ensure that credit is not diverted for undesirable purposes. As the central monetary authority, the Reserve Bank's chief function is to ensure the availability of credit to the extent that is appropriate to sustain the tempo of development and promote the maintenance of internal price stability. The Reserve Bank is empowered under the Banking Regulation Act to issue directions to control loans and advances by banking companies. Reserve Bank at its discretion may issue directions to all banking companies or to any particular banking company, The Reserve Bank may determine the policy in respect of banks' loans and advances and issue directions from time to time.

The instruments of credit control are of two types as under:

(a) General or Quantitative

(b) Selective or Qualitative

\section{Quantitative/General Credit Control}

Under the General Credit Control, the instruments often employed by RBI are discussed below:

\section{Bank Rate Policy}

The Bank rate has been defined in Section 49 of RBI Act as " the standard rate at which it (RBI) is prepared to buy or rediscount bills of exchange or other commercial paper eligible to purchase under this Act. By varying the rate, the $\mathrm{RBI}$ can to a certain extent regulate the commercial bank credit and the general credit situation of the country. The impact of this tool has not been very great because of the fact that RBI does not have a mechanism to control the unorganized sector.

\section{Reserve Requirements}

The Reserve Bank of India is vested with the powers to vary the CRR and SLR as explained above. By varying reserve requirements, the $\mathrm{RBI}$ restricts/frees the flow of funds by way of credit to different sectors of the economy. When SLR or CRR is increased by RBI, It reduces commercial banks' capacity to create credit and thus helps to check inflationary pressures

\section{Open Market Operations}

Open market operations are a flexible instrument of credit control by means of which the Reserve Bank on its own initiative alters the liquidity position of the bank by dealing directly in the market instead of using its influence indirectly by varying the cost of credit. Open market operations can be carried out by purchases and sales, by Central Bank, of a variety of assets such as government securities (G-sec), commercial bills of exchange, Foreign exchange, gold and even company shares. In practice, however, RBI confines to the purchase and sale purchase of government securities including treasury bills. When the RBI purchases government securities from the banks, the latest deposits with it tend to increase adding to the cash reserves of banks and hence their capacity to expand credit increase. Conversely, when the RBI sells securities to the banks, their deposits with RBI would get reduced, contracting the credit base. The net result would be a contraction of credit and a reduction in money supply. 


\section{Repo Rate and Reverse Repo Rate:}

Repos: The RBI introduced repurchase auctions (Repos) since December,1992 with regards to dated Central Government securities. When banking systems experiences liquidity shortages and the rate of interest is increasing, the RBI will purchase Government securities from Banks, payment is made to banks and it improves liquidity and expands credit.

Reverse Repos : Since November, 1996 RBI introduced Reverse Repos to sell Govt. securities through auction at fixed cut-off rates of interest. It provides short term avenues to banks to park their surplus funds, where there is considerable liquidity and call rate has a tendency to decline. These two rates are, now-a- days, commonly applied for reducing money supply or increasing it.

\section{Moral Suasion}

Moral Suasion indicates the advice and exhortations given by the Reserve Bank to the banks and other players in the financial system, with a view to regulate and control the flow of credit, generally, or to any one particular segment of the economy. This may be attempted through periodical discussions/communications. With a substantial share of banking business being in the public sector, this tool has proved effective.

\section{Direct Action}

This technique indicates the denial of the Reserve Bank to extend facilities to the banks which do not follow sound banking principles or where the Reserve Bank feels the capital structure of the bank is very weak. This is not attempted frequently but is used in rare cases involving continual and wilful violations of policies of the Reserve Bank/Govt. of India.

\section{Selective Credit Control}

Under the Selective Credit Control, the authority of the Reserve Bank is exercised by virtue of the provisions of Section 21 and 35 A of Banking Regulation Act. The Reserve Bank may give directions to banks generally or to any bank or a group of banks in particular on different aspects of granting credit, namely, -

(a) the purposes for which advances may or may not be made

(b) the margins to be maintained in respect of secured advances

(c) the maximum amount of advances or other financial accommodation which may be made by a bank to or the maximum amount of guarantees which may be given by a bank on behalf of any one company, firm, association of persons or individuals, having regard to the bank's financial position such as paid-up capital, reserves nd deposits and other relevant considerations, and

(d) the rate of interest and other terms of conditions subject to which advances or other financial accommodation may be granted or guarantees may be given.

While the first two instruments control the quantum of credit, the third instrument works as a leverage on the cost of credit. Selective Credit Control is imposed to manage the balance between the supply and demand of the essential commodities. The main purpose of the Selective Credit Control is to restrict the speculative hoarding of essential commodities using bank credit.

Some of the main restrictions on loans and advances are:

(i) As per the provisions of the Banking Regulation Act, no banking company in India can grant loans or advances against the security of its own shares

(ii) No banking company can hold shares in a company (a) as pledge or mortgagee in excess of the limit of 30 per cent of the Paid up capital of that company or 30 percent of the Bank's Paid-up capital and 
Reserves, whichever is less. No banking company can commit to grant or grant loans or advances to or on behalf of any of its directors

(iii) Further restrictions on the loans and advance to the director as a partner, guarantor of any loans and advances

(iv) No banking company can grant loans against (a) Fixed Deposits of other Banks (b) Certificate of Deposits

The restrictions on different types of loans and advance may be imposed from time to time by the Reserve Bank of India according to the requirement of the situation as well.

\section{RBI AS A CONTROLLER OF FOREIGN EXCHANGE}

RBI has got the powers under Foreign Exchange Management Act, 1999 (FEMA) to prohibit, restrict and regulate the following:

(a) transfer or issue of any foreign security by a resident of India and by a person residing outside India

(b) transfer or issue of any security or foreign security by any branch, office or agency in India owned by a person outside India

(c) any borrowing or lending in foreign exchange

(d) any borrowing or lending in rupees between a resident in India and a person outside India

(e) deposits between residents in India and residents outside India

(f) export, import or holding of currency or currency notes

(g) transfer of immovable property outside India other than a lease not exceeding five years by a person resident in India

(h) acquisition or transfer of immovable property in India other than a lease by a person resident outside India

(i) giving guarantee or surety in respect of any debt obligation or other viability incurred by person resident in India to a person outside India and vice-versa.

The Reserve Bank does not deal in foreign exchange directly with the public. It gives license to certain Scheduled Commercial Banks and other entities to deal in foreign exchange and those are known as authorized dealers (ADs) in foreign exchange.

\section{RBI AS BANKER TO THE GOVERNMENT}

In terms of Section 20 and 21, the RBI has the obligation to transact the banking business of the Central Government. Accordingly, it is required to accept money for account of the Government, to make payments on its behalf up to the amount outstanding in the credit of the Government, and also to carry out the Government's exchange, remittance and other banking operations including the management of the public debt. It acts as an advisor to the Government. RBI performs similar functions on behalf of State Governments by virtue of agreements entered into with them under Section 21A. RBI has entrusted the work of payment and receipts on behalf of Government to its agents like State Bank of India and its Associate Banks. Some other commercial banks are also doing some Government transactions as an agents of RBI.

\section{RBI AS LENDER OF THE LAST RESORT}

Under the RBI Act, the scheduled banks are eligible to certain financial facilities from the RBI. The facilities which are provided by RBI for the financial needs of banks are laid down in Section 17 of RBI Act. The facility is generally provided in the form of rediscount of eligible bills and loans and advances against eligible securities. 
Section 18(1)(3) provides for short term loans against any other securities which the RBI may consider sufficient.

\section{Marginal Standing Facility}

To borrow funds through this window, banks have to pay interest at a rate $100 \mathrm{bps}$ higher than the repo rate. Banks are allowed to use MSF only after exhausting the excess statutory liquidity ratio (SLR) of their net demand and time liabilities. Banks keep excess SLR to pledge securities for funds from the central bank or the overnight market to meet their product needs.

\section{MONETARY AND CREDIT POLICY}

As part of the Monetary Management, the Reserve Bank of India announces their policies on a regular basis, which is called as Monetary and Credit Policy

Monetary Policy statement consists of two parts. Part A cover Monetary Policy and is divided into four sections viz., -

1. Overview of global and domestic macroeconomic developments

2. Outlook and projections for growth, inflation and monetary aggregates

3. Stance of monetary policy and 4.monetary measures.

Part B deals with the developmental and regulatory policies consisting five sections viz.,

(a) Financial Stability

(b) Financial Markets

(c) Credit Delivery and Financial Inclusion

(d) Regulatory and Supervisory Measures and

(e) Institutional Developments

The various aspects of global economy and domestic economy and the significant events which took place in the past year, are covered. Further the outlook for the future in respect of global and domestic economies are discussed. The policy also highlights the important risks like inflation risk, current account deficit and the monetary measures to manage such and other risks are covered. Added to these, the issues and policy measures relating to financial stability, financial markets, control measures through regulations and supervision are also covered. The Policy also indicates the quarterly review period. Various initiatives taken by the Reserve Bank of India as Regulator and Supervisor in the Indian Banking Scenario are also highlighted. It also includes the credit delivery and other issues relating to priority sector lending. The IT initiatives and the related issues are also discussed.

The Monetary policy outlines the various measures taken and expected to be taken by the Reserve Bank of India in their role as the Monetary Management.

\section{AUDIT AND INSPECTION OF BANKING COMPANY}

\section{Audit}

The balance sheet and the profit and loss account of a banking company have to be audited as stipulated under Section 30 of the Banking Regulation Act. Every banking company's account needs to be verified and certified by the Statutory Auditors as per the provisions of legal frame work.

The powers, functions and duties of the auditors and other terms and conditions as applicable to auditors under the provisions of the Companies Act are applicable to auditors of the banking companies as well. The audit of 
banking companies books of accounts calls for additional details and certificates to be provided by the auditors. They include:

Whether or not;

- information and explanation, required by the auditor were found to be satisfactory;

- the transaction of the company, as observed by the auditor were within the powers of the company;

- profit and loss account shows a true picture of the profit or loss for the period for which the books have been audited and any other observations to be brought to the notice of the shareholders;

Special responsibility is cast on the bank auditor in certifying the bank's balance sheet and profit and loss account, since that reflects the sound financial position of the banking company.

Apart from the balance sheet audit, Reserve Bank of India is empowered by the provisions of the Banking Regulation Act to conduct/order a special audit of the accounts of any banking company. The special audit may be conducted or ordered to be conducted , in the opinion of the Reserve Bank of India that the special audit is necessary;

(i) in the public interest and/or

(ii) in the interest of the banking company and/or (iii) in the interest of the depositors. The Reserve Bank of India's directions can order the bank to appoint the same auditor or another auditor to conduct the special audit. The special audit report should be submitted to the Reserve Bank of India with a copy to the banking company. The cost of the audit is to be borne by the banking company.

\section{Inspection}

As per Sec 35 of the Banking Regulation Act, the Reserve Bank of India is empowered to conduct an inspection of any banking company. After conducting the inspection of the books, accounts and records of the banking company a copy of the inspection report to be furnished to the banking company. The banking company, its directors and officials are required to produce the books, accounts and records as required by the $\mathrm{RBI}$ inspectors, also the required statements and/or information within the stipulated time as specified by the inspectors.

\section{Government's role:}

The Central Government may direct the Reserve Bank to conduct inspection of any banking company. In such cases, a copy of the report of inspection needs to be forwarded to the Central Government. On review of the inspection report, the Central Government can take appropriate action. In the opinion of the Central Government if the affairs of the banking company is not being carried out in the interests of the banking company, public and or depositors, the Central Government may (i) prohibit the banking company to accept fresh deposits (ii) direct the Reserve Bank to apply for winding up of the banking company under the provisions of the Banking Regulation Act. Before taking action, the Government has to give an opportunity to the banking company to explain their stand. Based on the response, the Government can initiate appropriate action as required.

\section{Scrutiny:}

Apart from inspecting the books and accounts of the company, the Reserve Bank can conduct scrutiny of the affairs and the books of accounts of any banking company. Like in the case of inspection, the Reserve Bank can handle the scrutiny as required. 


\section{SUPERVISION AND CONTROL}

\section{Board for Financial Supervision}

To have better supervision and control, a separate board was constituted namely "The Board for Financial Supervision" as per the provisions of the Reserve Bank of India. The Board has the jurisdiction over the banking companies, Nationalised banks, State Bank of India and its subsidiaries. The members of the Board are: Governor of the Reserve Bank of India as the chairperson, Deputy Governors of the Reserve Bank of India, and one of the deputy governors should be nominated by the Governor as the full time vice chairman, Four directors from the Central Board of the Reserve Bank nominated by the Governor as members.

Functions and Powers: The Board performs the functions and exercises the powers of supervision and inspection under the Reserve Bank of India Act, in respect to different banking companies. The Board is assisted by the department of supervision. The Board has to report to the Central Board on half yearly basis. The Board meets on a monthly basis, with at least one meeting in a month. The Board has powers to constitute sub committees, like the executive committee. The vice chairman of the Board is the ex-officio chairman of the committee.

Apart from the above, the Governor may constitute an advisory committee to offer advice from time to time to the Board. The council will have at least five members who have special knowledge in different areas like accountancy, law, banking, economics, finance and management. The Governor presides over the meetings and the other members of the council are the vice chairman and other members.

\section{WINDING UP - AMALGAMATION AND MERGERS OF BANKS}

A banking company may be amalgamated with another banking company as per BR Act. The banking companies have to prepare a scheme of amalgamation, the draft copy of the scheme of amalgamation covering terms and conditions needs to be placed separately by the companies to their shareholders. Each shareholder needs to be given notice, The scheme of amalgamation should be approved by a resolution passed by majority of members representing two-thirds in value of the shareholders of each company present in person or by proxy. A shareholder, who votes against the scheme of amalgamation and gives necessary notice, may claim the value of his shares from the banking company, in case the scheme is sanctioned by the Reserve Bank. Once the scheme is sanctioned by the Reserve Bank then the assets and liabilities of the amalgamated company pass on to the other company with which it is to be amalgamated. The order of the sanction of amalgamation by Reserve Bank will be the conclusive proof of amalgamation.

In case the Central Government orders amalgamation of two companies, such amalgamation would take place after consultation with the Reserve Bank

Under Sec 45 of the Banking Regulation Act the Reserve Bank can apply to the Central Government for an order of moratorium in respect of any company, on account of certain valid reasons. After considering various aspects, the Central Government may think it fit and proper to impose the moratorium. The period of moratorium can be extended from time to time for a maximum period of six months. During the period of moratorium, the banking company would not be allowed to make any payments to the depositors or discharge any liabilities or obligations to any other creditors unless otherwise directed by the Central Government in the order of moratorium or at any time thereafter.

\section{Scheme of Amalgamation}

During the period of moratorium, the Reserve Bank may prepare a scheme of reconstruction or amalgamation. Such a scheme may be prepared by the Reserve Bank due to any one or more of the following aspects: 1 . In the public interest 2 . In the interests of the depositors 3. To secure proper management of the banking company 4 . In the interest of the banking system of the country. As per the various provisions, the scheme of amalgamation would be worked out and implemented. A copy of the draft of the scheme should be sent to the government and 
also to the banking company (transferee bank) and others concerned with the amalgamation. The Government may sanction with modifications as it may consider necessary, after that the scheme should come into effect from the date of the sanction.

Once the scheme is sanctioned by the Central Government, it would be binding on the banking company, transferee bank and the members, depositor and other creditors and others as per the sanction. The sanction by the Central Government is the conclusive proof that the amalgamation or reconstruction has been carried out with the accordance with the provisions of the relevant sections of the Act. Consequent to amalgamation, the transferee bank should carry on the business as required by the law.

The Central Government may order moratorium on the banking companies on the application of the Reserve Bank. The Reserve Bank may also apply to High Court for winding up of a banking company when the banking company is not able to pay its debts and also in certain other circumstances. The High Court would decide the case based on the merits of the case a moratorium order would be passed. After passing the order the court may appoint a special officer to take over the custody and control of the assets, books, etc of the banking company in the interests of the depositors and customers. During the period of moratorium, the Reserve Bank is not satisfied with the functioning of the bank, and in its opinion the affairs of the banking company is being conducted not in the interests of the depositors and customers, Reserve Bank may apply to the High Court for winding up of the company.

\section{Winding up by High Court}

The High Court may order winding up of a banking company on account of (a) The banking company is unable to pay its debts (b) An application of winding up had been made by the Reserve Bank under the provisions of the Banking Regulation Act (Sec37 and 38)

The RBI is to make an application for winding up (under Sec 38 of BR Act) and under Sec 35 (4) if directed by the Central Government. Central Government may give such direction, based on the report of inspection or scrutiny made by the Reserve Bank, and on account of the situation that the affairs of the bank are being conducted to the detriment of the interests of the depositors. However before giving such direction, the banking company would be given an opportunity to make a representation in connection with the inspection/scrutiny report.

In the following circumstances, the Reserve Bank of India can apply for winding up of a banking company.

- Non- compliance with the requirements of Sec 11 regarding minimum paid up capital and reserves.

- Prohibition to accept fresh deposits under Sec 35(4) of the Banking Regulation Act or Sec 42 (3A)(b) of the Reserve Bank of India Act

- Failure to comply with the requirements of the applicable provisions of the Banking Regulation Act and the Reserve Bank of India Act

\section{Official Liquidator:}

Sec 38A of the Banking Regulation Act provides for appointment of an official liquidator attached to the High Court by the Central Government, to conduct the winding up proceedings of a banking company.

\section{Reserve Bank as Liquidator}

If Reserve Bank of India applies to the High Court, the Reserve Bank, State Bank or any other bank as notified by the Central Government or an individual may also be appointed as the official liquidator. Within the stipulated time, the liquidator is required to make a preliminary report regarding the availability of the assets to make preferential payments as per the provisions of the Companies Act and for discharging liabilities to depositors and other creditors. Within the stipulated time, the liquidator is required to give notice calling for claims for preferential payment and other claims from every secured and unsecured creditors. However, depositors need not make claims. The claims of every depositor of a banking company is deemed to have been filed for the amount as 
reflected in the books of the banking standing in his/her credit.

\section{Voluntary Winding Up:}

Voluntary winding up would be permitted only when the Reserve Bank has certified that the banking company will not be able to pay in full all its debts as they accrue.

\section{DISCLOSURE OF ACCOUNTS AND BALANCE SHEETS OF BANKS}

There are various types of users of the financial statements of banks like shareholders, investors, creditors, credit rating agencies, management students and others who need information about the financial position and performance of the banks. The financial statements are required to provide the information about the financial position and performance of the bank in making economic decisions by the users. The important information sought by these users are, about bank's Liquidity and solvency and the risks related to the assets and liabilities recognized on its balance sheet and to its off balance sheet items This useful information can be provided by way of 'Notes' to the financial statements, being supplementary information for market discipline. Market discipline has been given due importance under Basel II framework on capital adequacy by recognizing it as one of its three Pillars. To cover the full and complete disclosure, some very useful information is better provided, or can only be provided, by notes to the financial statements. Hence notes become an integral part of the financials of banks. The users can make use of these notes and supplementary information to arrive at a meaningful decision.

\section{Presentation}

Summary of Significant Accounting Policies' and 'Notes to Accounts' may be shown under Schedule 17 and Schedule 18 respectively, to maintain uniformity.

\section{Minimum Disclosures:}

While complying with the requirements of Minimum Disclosures, banks should ensure to furnish all the required information in 'Notes to Accounts'. In addition to the minimum disclosures, banks are also encouraged to make more comprehensive disclosures to assist in understanding of the financial position and performance of the bank, that the disclosure as furnished is intended only to supplement, and not to replace, other disclosure requirements under relevant legislation or accounting and financial reporting standards..

\section{Summary of Significant Accounting Policies:}

Banks should disclose the accounting policies regarding key areas of operations at one place (under Schedule 17) along with Notes to Accounts in their financial statements. The list includes - Basis of Accounting, Transactions involving Foreign Exchange, Investments - Classification, Valuation, etc, Advances and Provisions thereon, Fixed Assets and Depreciation, Revenue Recognition, Employee Benefits, Provision for Taxation, Net Profit, etc.

\section{Disclosure Requirements}

In order to encourage market discipline, Reserve Bank has over the years developed a set of disclosure requirements which allow the market participants to assess key pieces of information on capital adequacy, risk exposures, risk assessment processes and key business parameters which provide a consistent and understandable disclosure framework that enhances comparability. Banks are also required to comply with the Accounting Standard 1 (AS 1) on Disclosure of Accounting Policies issued by the Institute of Chartered Accountants of India (ICAI). The enhanced disclosures have been achieved through revision of Balance Sheet and Profit \& Loss Account of banks and enlarging the scope of disclosures to be made in "Notes to Accounts".

\section{Additional/Supplementary Information}

In addition to the 16 detailed prescribed schedules to the balance sheet, banks are required to furnish the following information in the "Notes to Accounts": Such furnished (Information should cover the current year and the previous year) 
"Notes to Accounts" may contain the supplementary information such as:-

(a) Capital (Current \& Previous year) with breakup including CRAR - Tier I/II capital (\%), \% of shareholding of GOI, amount of subordinated debt raised as Tier II capital. Also it should show the total amount of subordinated debt through borrowings from Head Office for inclusion in Tier II capital., etc.

(b) Investments: Total amount should be mentioned in crores, with the total amount of investments, showing the gross value and net value of investments in India and Abroad. The details should also cover the movement of provisions held towards depreciation on investments.

Under investments a separate note should cover on Repo Transactions (in face value terms- Amount in crores), covering the details relating to minimum and maximum outstanding during the year, daily average outstanding during the year and also outstanding as on March 31. Non-SLR Investment Portfolio would consist of (i) Issuer composition of Non SLR investments. Sale and Transfers to/from HTM Category

\section{Sale and Transfers to/from HTM Category}

If the value of sales and transfers of securities to/from Hold To Maturity (HTM) category exceeds 5 percent of the book value of investments held in HTM category at the beginning of the year, the bank should disclose the market value of the investments held in the HTM category and indicate the provision not made for the excess of book value over the market value. This disclosure is to be made in 'Notes to Accounts' in banks' audited Annual Financial Statements. The 5 percent threshold referred to above will exclude the one time transfer of securities to/ from HTM category with the approval of Board of Directors permitted to be undertaken by banks at the beginning of the accounting year and sales to the Reserve Bank of India under per-announced OMO auctions.

The changes in guidelines regarding HTM/HFT and AFS securities are very dynamic and reflect the market developments and regulatory concerns. The students may do well to note the changes/developments in the area by referring to RBI website.

\section{Derivatives: Forward Rate Agreement/Interest Rate Swap}

Important aspects of the disclosures would include the details relating to:

(a) The notional principal of swap agreements

(b) Losses which would be incurred if counterparties failed to fulfill their obligations under the agreements (c) Collateral required by the bank upon entering into swaps

(d) Nature and terms of the swaps including information on credit and market risk and the accounting policies adopted for recording the swaps

(e) Examples of concentration could be exposures to particular industries or swaps with highly geared companies

(f) If the swaps are linked to specific assets, liabilities, or commitments, the fair value would be the estimated amount that the bank would receive or pay to terminate the swap agreements as on the balance sheet date. For a trading swap the fair value would be its mark to market value

(g) Concentration of credit risk arising from the swaps

(h) The fair value of the swap book

\section{Exchange Traded Interest Rate Derivatives:}

As regards Exchange Traded Interest Rate Derivatives, details would include the notional principal amount undertaken:

(i) during the year (instrument-wise), 
(ii) outstanding as on $31^{\text {st }}$ March (instrument-wise),

(iii) outstanding and not "highly effective" (instrument-wise),

(iv) Mark-to-market value of exchange traded interest rate derivatives outstanding and not "highly effective" (instrument-wise)

\section{Qualitative Disclosure}

Banks should discuss their risk management policies pertaining to derivatives with a specific reference to the extent to which derivatives are used, the associated risks and business purposes served. This discussion also includes

(a) the structure and organization for management of risk in derivatives trading,

(b) the scope and nature of risk measurement, risk reporting and risk monitoring systems,

(c) policies for hedging and/or mitigating risk and strategies and processes for monitoring the continuing effectiveness of hedges/mitigants, and accounting policy for recording hedge and non-hedge transactions; recognition of income, premiums and discounts; valuation of outstanding contracts; provisioning, collateral and credit risk mitigation

\section{Quantitative Disclosures}

Apart from qualitative disclosures, banks should also include the qualitative disclosures. The details for both

- Currency Derivatives

- Interest rate derivatives

Information required to be furnished are:

- Derivatives (Notional Principal Amount) showing separate details such as for hedging and for trading

- Marked to Market Positions - a) Asset (+) b) Liability (-)

- Credit Exposure

- Likely impact of one percentage change in interest rate (100*PV01) (a) on hedging derivatives (b) on trading derivatives

- Maximum and Minimum of 100*PV01 observed during the year (a) on hedging (b) on trading

\section{Asset Quality:}

Banks' performances are considered good based on the quality of assets held by banks. With the changing scenario and due to number of risks associated with banks like Credit, Market and Operational risks, banks are concentrating to ensure better quality assets are held by them. Hence, the disclosure needs to cover various aspects of asset quality consisting of :

(a) Non-Performing Assets, covering various details like Net NPAs, movement of NPAs (Gross)/(Net) and relevant details provisioning to different types of NPAs including Write-off/write-back of excess provisions, etc., Details of Non-Performing financial assets purchased, sold, are also required to be furnished.

(b) Particulars of Accounts Restructured:

The details under different types of assets such as (i) Standard advances (ii) Sub-standard advances restructured(iii) Doubtful advances restructured (iv) TOTAL with details of number of borrowers, amount outstanding, sacrifice

(c) Banks disclose the total amount outstanding in all the accounts/facilities of borrowers whose accounts 
have been restructured along with the restructured part or facility. This means even if only one of the facilities/accounts of a borrower has been restructured, the bank should also disclose the entire outstanding amount pertaining to all the facilities/accounts of that particular borrower.

(d) Details of financial assets sold to Securitization/Reconstruction Company for Asset Reconstruction. Banks which purchased non-performing financial assets from other banks are required to make the following disclosures in the Notes to Accounts to their Balance sheets. Similarly banks which sold non-performing financial assets furnish details of such assets sold.

(e) Provisions on Standard Assets:

Provisions towards Standard Assets need not be netted from gross advances but shown separately as 'Provisions against Standard Assets', under 'Other Liabilities and Provisions - Others' in Schedule No. 5 of the balance sheet.

\section{(f) Other Details:}

Business Ratios: (i) Interest Income as a percentage to Working Funds (ii) Non-interest income as a percentage to Working Funds (iii) Operating Profit as a percentage to Working Funds (iv) Return on Assets (v) Business (Deposits plus advances) per employee (vi) Profit per employee

\section{Asset Liability Management:}

As part of Asset Liability Management, the maturity pattern of certain items of assets and liabilities such as deposits, advances, investments, borrowings, foreign current assets, and foreign currency liabilities.

Banks are required to disclose the information based on the maturity pattern covering daily, monthly and yearly basis such as Day 1; 2 to 7 days; 8 to 14 days; 15 to 28 days; 29 days to 3 months ; Over 3 months and up to 6 months; Over 6 months and up to 1 year; Over 1 year up to 3 years; Over 3 years and up to 5 years; Over 5 years, showing the amount in crores.

\section{Exposures}

\section{Breakup of Exposures:}

Banks should also furnish details of exposures to certain sectors like Real Estate Sector, by giving details on account of

(a) Direct Exposure for (i) Residential mortgages (ii) Commercial Real Estate (iii) Investments in mortgaged based securities (MBS)

(b) Indirect Exposure covering fund based and non-fund based exposures on National Housing Bank (NHB) and Housing Finance Companies (HFCs)

\section{Exposure to Capital Market}

Capital Market exposure details should be disclosed for the current and previous year in crores. The details would include:

(i) direct investment in equity shares, convertible bonds. convertible debentures and units of equity- oriented mutual funds the corpus of which is not exclusively invested in corporate debt

(ii) details of advances against shares, debentures, bonds or other securities on clean basis to individuals to invest in shares (including IPOs) and other capital market instruments

(iii) details of advances for any other purposes wherein securities in shares or debentures or bonds are held as primary security

(iv) loans and advances to stock brokers (v) loans sanctioned to corporates against the security of shares. 
debentures, bonds etc for meeting the promoter's the quota in anticipation of raising resources (vi) bridge loans to companies against expected equity flows, issues (vii) financing to stockbrokers for margin trading (viii) all exposures to Venture Capital Funds (both registered and unregistered

Country exposures should be furnished as risk category wise country exposure . The risks are to be categorized as : (a) insignificant (b) low (c) moderate (d) high (e) very high (f) restricted (g) Off-credit

In case banks have not yet moved over to the internal rating system, they may use the seven category classification followed by the Export Credit Guarantee Corporation of India Ltd (ECGC) for the purpose of classification and making provisions for country risk exposures. Banks may on request obtain the details on quarterly basis from ECGC

The details should also include the net exposure and provision held as at Mach current year as well as the previous year.

Apart from the above category of exposures, banks are required to disclose details relating to

Single Borrower Limit (SGL)/Group Borrower Limit (GBL) exceeded by the bank, and Unsecured Advances are to be furnished.

Miscellaneous items would include Amount of Provisions made for Income Tax during the year, and Disclosure of Penalties imposed by RBI, etc.

Disclosure Requirements as per Accounting Standards where RBI has issued guidelines in respect of disclosure items for "Notes to Accounts"

(a) AS-5 - relating to Net Profit or Loss for the period, prior period items and changes in accounting policies.

(b) AS -9-Revenue Recognition giving the reasons for postponement of revenue recognition.]

(c) AS - 15 - Employee Benefits

(d) AS - 17 - Segment Reporting such as Treasury, Corporate/wholesale Banking, Retails Banking, 'Other Banking Operations' and Domestic and International segments, etc.

(e) AS - 18 - Related Party Disclosures

(f) AS - 21 - Consolidated Financial Statements (CFS)

(g) AS - 22 - Accounting for Tax \& Income - Adoption of AS - 22 entails creation of Deferred Tax Assets (DTA) and Deferred Tax Liabilities (DTL) which have a bearing on the computation of capital adequacy ratio and banks' ability to declare dividends. DTA represents unabsorbed depreciation and carry forward losses which can set-off against Assets future taxable income which is considered as timing difference. DTA has an effect of decreasing future income tax payments which indicates that they are prepaid income taxes and meet the definition of assets. It is created by credit to opening balance of Revenue Reserves on the first day of application of AS - 22 or P \& L Account for the current year. DTA should be deducted from Tier I capital.

Deferred Tax Liability (DTL) is created by debit to opening balance of Revenue Reserves on the first day of application of AS-22 or P \& L Account for the current year and will not be eligible for inclusion in Tier I and Tier II capital for capital adequacy purpose. DTL have an effect of increasing the future year's income tax payments which indicates that they are accrued taxes and meet the definition of liabilities.

(h) AS - 23-Accounting for investments in Associates in Consolidated Financial Statements. It relates to the effects of the investments in associates on the financial position and operating results of a group

(i) AS - 24-Discontinuing Operations - resulted in shedding of liability and realization of the assets by the bank, etc. 
(j) AS - 25 - Interim Financial Reporting - Half yearly reporting.

(k) Other Accounting Standards: Banks are required to comply with the disclosure norms stipulated under the various Accounting Standards issued by ICAI.

\section{Additional Disclosures}

(a) Provisions and contingencies - Banks are required to disclose in the "Notes to Accounts" the information on all Provisions and Contingencies giving Provision for depreciation on Investment, Provision towards NPA, Provision towards Standard Assets, Provision made towards Income Tax, and Other Provision and contingencies.

(b) Floating Provisions - comprehensive disclosures on floating provisions.

(c) Draw Down from Reserves - Details of draw down of reserves are to be disclosed.

(d) Complaints - Brief details on Customer Complaints and Awards passed by the Banking Ombudsman.

(e) Letters of Comfort (LOC) issued by banks - Details of all the Letters of Comfort (LoCs) issued during the year, including their assessed financial impact, etc.

(f) Provision Coverage Ratio (PCR) - ratio of provisioning to gross non-performing assets

(g) Bancassurance Business - Details of fees/remuneration received, etc.

\section{Concentration of Deposits, Advances, Exposures, and NPAs}

(a) Concentration of deposits - Total deposits of 20 large depositors and percentage of the deposits to total deposits of the bank.

(b) Concentration of Advances - Total advances to 20 largest borrowers and percentage of the advance to total advances of the bank.

(c) Concentration of Exposures - Total Exposure to 20 largest borrowers/customers and percentage of the exposures to total exposure of the bank on borrowers/customers.

(d) Concentration of NPAs - Total exposure to top 4 NPA accounts.

01. Sector-wise NPAs - Details of sector-wise NPAs such as Agriculture \& Allied Activities, Industry (Micro \& Small, Medium and Large), Services, and Personal Loans.

02. Movement of NPAs - Additions, Recoveries, Up gradation, Write-offs, etc. from Gross NPAs and the final position as on the date of the Financial Statement.

03 Overseas Assets, NPAs, and Revenue -Giving the Total assets, Total NPAs, and Total Revenue.

(e) Off-balance sheet SPVs sponsored - (consolidated) giving Domestic and Overseas SPVs sponsored.

(f) Unamortized Pension and Gratuity Liabilities - Appropriate disclosures of the accounting policy followed in regard to amortization of pension and gratuity expenditure may be made in the Notes to Accounts to the financial statements.

(g) Disclosure of Remuneration - Composition \& mandate of Remuneration Committee, meetings, details of staff received variable remuneration awards, etc.

(h) Disclosures relating to Securitisation - Giving the total outstanding amount of securitized assets as per books of the SPVs sponsored by the bank and total amount of exposures retained by the bank as on the date of balance sheet to comply with the Minimum Retention Requirements (MRR), etc.

(i) Credit Default Swaps (CDS) - Banks using a proprietary model for pricing CDS, should disclose both the proprietary model price and the standard model price in terms of extant guidelines in the Notes to the 
Accounts and should also include an explanation of the rationale behind using a particular model over another.

(The prescribed formats in respect of certain disclosures are given in RBI Circular)

\section{SUBMISSION OF RETURNS TO RBI}

Each banking company has to prepare and furnish returns to the Reserve Bank under various provisions of the Banking Regulation Act and the Reserve Bank of India Act. The returns which are to be submitted to RBI are discussed below:

\section{Return of Liquid Assets}

Every banking company has to submit a return of its liquid assets as per the provisions of the Banking Regulation Act. The return should contain particular of assets and the demand and time liabilities as at the close of business of each alternate Friday. In case such Friday is a holiday then as at the close of business of the preceding working day. The Reserve Bank is also empowered to require a banking company to furnish returns showing particulars of assets and demand and time liabilities as at the close of each day of the month.

\section{Monthly Returns}

Every month, a banking company has to submit a monthly return to the Reserve Bank as per the provisions of the Banking Regulation Act,1949. This return is prepared as on the last Friday of the previous month, and the return should be submitted before the end of the month succeeding to which it relates. Reserve Bank can call for information and statements at any time relating to the business or affairs of the banking company.

\section{Accounts and Balance Sheet}

The annual accounts and balance sheet have to be submitted to the Reserve Bank within three months from the end of the period for which they relate.

\section{Return of Assets in India}

A banking company has to submit to Reserve Bank under the Banking Regulations Act, a quarterly return regarding its assets in India. The return is to be submitted within one month of the end of the quarter.

\section{Return of Unclaimed Deposits}

Under Sec 26 of the Banking Regulation Act a banking company has to submit within thirty days of the close of each calendar year a return on unclaimed deposits (not operated for ten years)

\section{Return of CRR of Non Scheduled Banks}

Every banking company ( non- scheduled bank) has to furnish a return to the Reserve Bank of India under Sec 18 (i) of the Banking Regulation Act in respect of cash reserve.

\section{Fortnightly Return in Form A (CRR)}

Under Section 42 (2) of the RBI Act, 1934, all SCBs are required to submit to Reserve Bank a provisional Return in Form ' $A$ ' within 7 days from the expiry of the relevant fortnight and the final report to be submitted to RBI within 20 days from expiry of the relevant fortnight. Based on the recommendation of the Working Group on Money Supply: Analytics and Methodology of Compilation, all SCBs in India are required to submit this report. Memorandum to form 'A' return giving details about paid-up capital, reserves, time deposits comprising short-term (of contractual maturity of one year or less) and long-term (of contractual maturity of more than one year),certificates of deposits, NDTL, total CRR requirement etc., Annexure $A$ to Form ' $A$ ' return showing all foreign currency liabilities and assets and Annexure $B$ to Form ' $A$ ' return giving details about investment in approved securities, investment in 
non-approved securities, memo items such as subscription to shares/debentures/bonds in primary market and subscriptions through private placement. For reporting in Form ' $A$ ' return, banks should convert their overseas foreign currency assets and bank credit in India in foreign currency in four major currencies viz., US dollar, GBP, Japanese Yen and Euro into rupees at RBI Reference Rates announced on its website from time to time.

\section{Return in Form VIII (SLR)}

(i) Banks should submit to the Reserve Bank before 20th day of every month, a return in Form VIII showing the amounts of SLR held on alternate Fridays during immediate preceding month with particulars of their DTL in India held on such Fridays or if any such Friday is a Public Holiday under the Negotiable Instruments Act, 1881, at the close of business on preceding working day.

(ii) Banks should also submit a statement as annexure to Form VIII return giving daily position of; (a) assets held for the purpose of compliance with SLR, (b) the excess cash balances maintained by them with RBI in the prescribed format, and (c) the mode of valuation of securities.

\section{Report on NRE Deposits}

NRD-CSR software package being used by the banks for submission of detailed monthly data on non-resident deposits to the Reserve Bank, has been replaced by eXtensible Business Reporting Language (XBRL) platform to provide validations for processing requirement in respect of existing NRD schemes, improve data quality, enhance the security-level in data submission, and enable banks to use various features of XBRL-based data submission, and tracking.

\section{Priority Sector Lending -Revised Reporting System}

Disbursement to be reported in the monthly and yearly reporting formats is defined as under:

(i) Cash credit/over draft account and running accounts of similar nature: Debit summation minus interest and other charges or sanctioned limit, whichever is lower for the particular period under consideration (monthly/quarterly/half yearly/yearly).

(ii) Term Loans: Debit summation minus interest and other charges for the particular period under consideration (monthly/quarterly/half yearly/yearly).

\section{FRAUD - CLASSIFICATION AND REPORTING}

\section{Classification of Frauds}

Frauds are classified, mainly on the basis of the provisions of Indian Penal Code (IPC), as under:-

(a) Misappropriation and criminal breach of trust.

(b) Fraudulent encashment through forged instruments, manipulation of books of account or through fictitious accounts and conversion of property.

(c) Unauthorized credit facilities extended for reward or for illegal gratification.

(d) Negligence and cash shortages.

(e) Cheating and forgery.

(f) Irregularities in foreign exchange transactions.

(g) Any other type of fraud not coming under the specific heads as above.

- Cases of 'negligence and cash shortages' and 'irregularities in foreign exchange transactions' ( $\&$ f) are to be reported as fraud if the intention to cheat/defraud is suspected/proved.

Cases such as:- 
(i) Cases of cash shortage more than ₹ 10,000 , and

(ii) Cases of cash shortage more than ₹ 5,000 if detected by management/auditor/inspecting officer and not reported on the day of occurrence by the persons handling cash. where fraudulent intention is not suspected/proved at the time of detection will be treated as fraud.

- Frauds involving forged instruments have be reported only by the paying banker whereas collection of a genuine instrument fraudulently by a person who is not the true owner, the collecting bank, which is defrauded, will have to file fraud report with the RBI.

- Collection of an instrument where the amount has been credited before realization and subsequently the instrument is found to be fake/forged and returned by the paying bank, the collecting bank is required to report the transaction as fraud with the $\mathrm{RBI}$ as they are at loss by parting the amount.

- Collection of an altered/fake cheque involving two or more branches of the same bank, the branch where the altered/fake cheque has been encashed is required to report the fraud to its H.O. for further reporting to RBI by the H.O.

- An altered/fake cheque having been paid/encashed involving two or more branches of a bank under Core Banking Solution (CBS), the branch which released the payment is required to report the fraud to its H.O. for further reporting to RBI.

- Cases of theft, burglary, dacoity and robbery are not treated as fraud.

- Banks (other than foreign banks) having overseas branches/offices are required to report all frauds perpetrated at such branches/offices to RBI.

\section{Reporting of Fraud to RBI}

Banks need not furnish FMR-1 return in respect of individual fraud cases involving amount below ₹ 1.00 Lakh to $\mathrm{RBI}$. However, banks should furnish the statistical data in respect of such frauds to RBI in a quarterly statement.

\section{(a) Frauds involving amounts of $₹ 1.00$ lakh and above but less than $₹ 25.00$ lakh}

Frauds including subsidiaries and affiliates/joint ventures perpetrated through misrepresentation, breach of trust, manipulation of books of account, fraudulent encashment of instruments like cheques, drafts and bills of exchange, unauthorized handling of securities charged to the bank, misfeasance, embezzlement, misappropriation of funds, conversion of property, cheating, shortages, irregularities, etc.

Cases under criminal proceedings initiated by central investigating agencies suo-moto and/or where RBI has directed to treat as frauds.

Banks are required to send Soft copy of the reports (FMR-1/B) to the Central Office of the Department of Banking Supervision (DBS) within three weeks of detection of fraud, etc.

The cases of individual frauds involving amounts of ₹ 1.00 lakh and above but less than ₹25.00 lakh should be reported to the Regional Office of Urban Banks Department of Reserve Bank of India, under whose jurisdiction the Head Office of the bank falls, in the format given in FMR-1, within three weeks from the date of detection.

\section{(b) Frauds involving amounts of ₹ $\mathbf{2 5 . 0 0 ~ l a k h ~ a n d ~ a b o v e ~}$}

The cases of individual frauds involving amounts of ₹ 25.00 lakh and above should be reported to Central Frauds Monitoring Cell, Department of Banking Supervision, Reserve Bank of India, in the format given in FMR-1, within three weeks from the date of detection. Separate FMR-1 should be furnished in respect of each, case without clubbing. A copy of FMR-1 should also be submitted to the Regional Office of Urban Banks Department of Reserve Bank of India under whose jurisdiction the Head Office of the bank falls.

Banks may report the fraud by means of D.O. letter giving the details such as amount involved, nature of fraud, 
modus operandi in brief, name of the branch/office, parties involved, etc. addressed to the Principal Chief General Manager of the Department of Banking Supervision, Reserve Bank of India, Central Office, within a week of such fraud coming to the notice of the bank'sHead Office.

\section{Frauds committed by unscrupulous borrowers}

Such frauds include:-

- Fraudulent discount of instruments or kite flying in clearing effects.

- Fraudulent removal of pledged stocks/disposing of hypothecated stocks without the bank's knowledge/ inflating the value of stocks in the stock statements and drawing excess bank finance.

- Diversion of funds outside the borrowing units, lack of interest or criminal neglect on the part of borrowers, their partners, etc. leading to the unit becoming sick as also due to laxity in effective supervision over the operations in borrowal accounts on the part of the bank functionaries rendering the advance difficult to recover.

- In respect of frauds in borrowal accounts additional information as prescribed under Part B of FMR - 1 should also be furnished.

Banks are supposed to exercise due diligence while appraising the credit needs of unscrupulous borrowers, borrower companies, partnership/proprietorship concerns and their directors, partners and proprietors, etc. as also their associates who have defrauded the banks.

Besides the borrower fraudsters, other third parties such as builders, vehicle/tractor dealers, warehouse/cold storage owners, etc. and professionals are also to be held accountable if they have played a vital role in credit sanction/disbursement or facilitated the perpetration frauds. Banks are required to report to Indian Banks Association (IBA) the details of such third parties involved in frauds.

\section{Cases of attempted fraud}

The practice of reporting attempted fraud, where likely loss would have been ₹25 lakhs or more to Fraud Monitoring Cell, Reserve Bank of India, Central Office has been discontinued. However, the bank should continue to place the individual cases of attempted fraud involving ₹25 lakhs or more before the Audit Committee of its Board. The report containing attempted frauds which is to be placed before the Audit Committee of the Board should cover the following

(a) The modus of operandi of attempted fraud (b) How the attempt did not materialize into a fraud or how the attempt failed/or was foiled.(c) The measures taken by the bank to strengthen the existing systems and controls (d) New systems and controls put in place in the area where fraud was attempted,

In addition, yearly consolidated review of such cases detected during the year containing information such as area of operations where such attempts were made, effectiveness of new process and procedures put in place during the year, trend of such cases during the last three years, need for further change in process and procedures, if any, etc. as on March 31 every year may be placed before the Audit Committee of the Board starting from the year ending March 31, 2013 within three months from the end of the relative year.

\section{Quarterly Returns}

Report on frauds outstanding

- Banks are required to submit its Quarterly Report (FMR-2) on frauds outstanding to Central Office, RBI, within 15 days of the end of the quarter it relates (soft copy).

- The Report is to be accompanied by a certificate to the effect that all individual fraud cases of ₹1 Lakh and above reported to the RBI (FMR-1) during the quarter have also been put up to the bank's Board and have been incorporated in the Report. 


\section{Closure of fraud cases}

- Fraud cases closed during the quarter are required to be reported by banks in quarterly return to the Central Office, RBI, and R.O., RBI, along with reasons for the closure where no further action was called for.

- Cases closed/reported with prior approval of R.O., RBI, should also fulfill:-

(a) $\mathrm{CBI} /$ Police/Court have finally disposed of;

(b) Staff accountability has been examined/completed;

(c) The amount of fraud has been recovered or written off.

(d) Insurance claim wherever applicable has been settled.

(e) Bank has reviewed the systems and procedures taken steps to avoid recurrence and the fact of which has been certified by the Board.

Banks should also pursue vigorously with $\mathrm{CBI}$ for final disposal of pending fraud cases especially where the banks have completed staff side action, etc.

\section{Progress Reports on Frauds (FMR-3)}

Banks are required to submit case-wise quarterly progress reports on frauds involving ₹ 1.00 lakh and above (including cases where there are no developments) in the format given in FMR - 3 to the Central Office of RBI, as well as the concerned Regional Office of the RBI within 15 days of the end of the quarter to which they relate.

\section{Reporting to the Board}

Banks need to ensure that all frauds of ₹ 1.00 Lakh and above are reported to their Boards promptly on their detection. Such reports should, among others, contain the failure on the part of the concerned branch officials and controlling authorities and consider initiation of appropriate action against the officials responsible for the fraud.

\section{Quarterly Review of Frauds}

- Information relating to frauds are to be placed before the Audit Committee of the Board of Directors on quarterly basis ending March, June and September with statistical analysis.

- Banks are required to constitute a Special Committee consisting of CMD of public sector banks and MD in respect of SBI/its associates for monitoring and follow up of cases of frauds involving amounts of ₹ 1.00 crore and above exclusively. The main function of the committee would be to monitor and review all the frauds of $₹ 1.00$ crore and above and to put in place, among others, measures as may be considered to prevent recurrence of frauds such as strengthening of internal controls etc.

\section{Annual Review of Frauds}

Banks are required to conduct an annual review of the frauds and place a note before the Board of Directors/ Local Advisory Board for information. The review would take into account, among others, whether the systems in the bank are adequate to detect frauds once they have taken place within the shortest possible time.

\section{Guidelines for Reporting Frauds to Police/CBI Private Sector Banks/Foreign banks (operating in India)}

While reporting the frauds, banks are required to ensure that, besides the necessity of recovering the amount expeditiously, the guilty persons do not get unpunished.

Cases that are required to be referred to State Police include:-

(i) Cases of fraud involving an amount of ₹ 1.00 lakh and above committed by outsiders on their own and/ or with the connivance of bank staff/officers. 
(ii) Cases of fraud involving amount exceeding ₹ 10,000/-committed by bank employees.

(iii) Fraud cases involving amounts of Rs 1.00 crore and above should also be reported to the Serious Fraud Investigation Office (SFIO), GOI, in FMR-1.

\section{Public Sector Banks}

All frauds below ₹ 300 Lakh are to be reported to the Local Police.

\section{Cases to be referred to $C B I$}

(a) Cases of fraud involving amount of $₹ 3.00$ crore and above upto 15.00 crore:-

- Where staff involvement is prima facie evident - CBI (Anti Corruption Branch).

- Where staff involvement is prima facie not evident- CBI (Economic Offences Wing)

(b) All cases involving more than ₹ 15.00 crore - Banking Security and Fraud Cell of the respective centres, which is specialized cell of the Economic Offences Wing of the CBI for major bank fraud cases.

Cases to be referred to Local Police

\begin{tabular}{|l|l|}
\hline Fraud involving & Compliant to be filed with \\
\hline $\begin{array}{l}\text { ₹ } 1.00 \text { Lakh and above involving outsiders } \\
\text { (Private parties and bank staff }\end{array}$ & $\begin{array}{l}\text { Regional Head of the bank to State CID/Economic Offences } \\
\text { Wing of State concerned }\end{array}$ \\
\hline Below ₹ 1.00 Lakh but above ₹ 10,000/- & Local Police Station by the branch \\
\hline Below ₹ 10,000/- involving bank officials & $\begin{array}{l}\text { Reported to Regional Head of the bank to decide on further } \\
\text { course of action. }\end{array}$ \\
\hline $\begin{array}{l}\text { Fraudulent encashment of DD/TTs/Pay } \\
\text { orders/Cheques/DWs, etc. }\end{array}$ & Local Police concerned \\
\hline $\begin{array}{l}\text { Frauds involving forged instruments } \\
\text { Collection of genuine instrument, but } \\
\text { collected frequently by a person who is } \\
\text { not the owner }\end{array}$ & Paying banker to Local Police \\
\hline $\begin{array}{l}\text { Payment of uncleared instrument which } \\
\text { found to be fake/forged and returned by } \\
\text { the paying bank }\end{array}$ & Collecting Bank to Local Police \\
\hline $\begin{array}{l}\text { Collection/payment of altered/fake cheque } \\
\text { involving } 2 \text { or more branches of the same } \\
\text { bank }\end{array}$ & Police \\
\hline
\end{tabular}

\section{Reporting Cases of Theft, Burglary, Dacoity, and Bank Robberies}

Occurrence of any bank robberies, dacoities, thefts and burglaries are required to be reported immediately by Fax/e-mail to RBI, Department of Banking Supervision, Central Office and Regional Office, Security Adviser, and Ministry of Finance of Economic Affairs (Banking Division), GOI, with details of modus operandi and other information as required in FMR-4. Banks are also required to submit a quarterly consolidated statement (FMR-4) to RBI Central Office/RO within 15 days of the end of the quarter it relates. In case of no theft, burglary, dacoity, and bank robberies during a quarter, a NIL report is required to be submitted to RBI.

\section{CORPORATE GOVERNANCE}

Corporate Governance is an integral part of the management control system which reflects the corporate's strategy 
in maintaining the image and reputation of the company. In today's global competition, banks have to be careful in ensuring their integrity in dealing with the financial aspects of their clients. In this respect, a dynamic corporate governance practices are needed..

Corporate Governance means to ensure that the transparency, accountability in the interests of the stakeholders such as the shareholders, employees, clients and others. Over the years eve since the Cadbury Committee in 1992 came out with set of guidelines on the topic of Corporate Governance, many more committees have highlighted the need for a changing corporate governance practices with the changing time and business environment.

\section{Effective Corporate Governance Practices}

The objectives are:-

(j) To promote transparent and efficient markets which are consistent with the rule of Law.(ii) To protect and facilitate the exercise of shareholders' rights (iii) Timely and accurate disclosures to be made on all important issues relating to the corporation covering the financial situation, performance ,ownership and governance of the company

\section{Corporate Governance in Banks}

Over the years, the Reserve Bank of India as Supervisor of Banking companies in India has been playing significant role in ensuring the sound corporate governance practices which are followed by the banking companies. RBl's various guidelines in mergers and acquisitions, pattern of shareholding, restrictions on various issues, are some of the examples of RBI's role in the corporate governance practices of banks in India

Laundering means acquiring, owning, possessing or transferring any proceeds ( of money) of crime or knowingly entering into any transaction related to proceeds of the crime either directly or indirectly or concealing or aiding in the concealment of the proceeds or gains of crime, within or outside India. It is a process for conversion of money obtained illegally to appear to have originated from legitimate sources. Invariably, there are three stages through which money laundering takes place.

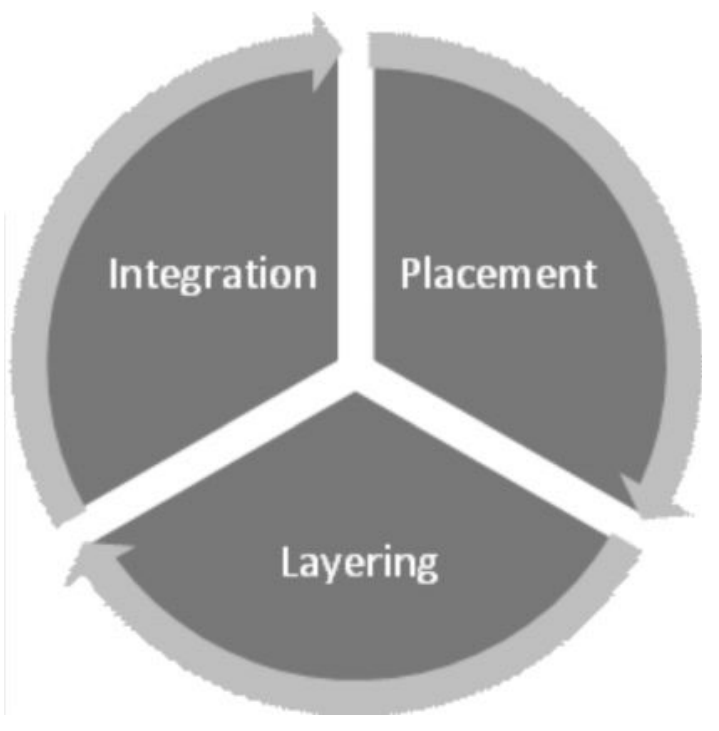

(a) The first step is called the placement, when the cash is deposited in the domestic banks or is used to buy goods such as precious metals, work of art, etc.

(b) The second step is called the layering. Once the funds are entered into the financial system (banks), the funds are converted by transfers to different destinations. This stage is called as layering. At different 
locations bank accounts are opened and the funds are transferred as quickly as possible (some time breaking into series of small transactions to escape from the limits set up by banks for cash transactions)

(c) The last stage is called the integration. In this stage, the launderer attempts to justify that the money obtained through illegal activities is legitimate. Through different methods attempts are made at this stage, like using front offices of the companies, using the tax haven and off shore units, using these funds as security for loans raised, etc.

The Prevention of Money laundering Act, 2002 (PMLA) aimed at combating money laundering in India with three main objective to prevent and control money laundering to confiscate and seize the property obtained from laundered money, and to deal with any other issue connected with money laundering in India. The Act provides that whosoever directly or indirectly attempts to indulge or knowingly assists or knowingly is a party or is actually involved in any process or activity connected with the proceeds of crime and projective it as untainted property should be guilty offences of money laundering. For the purpose of money laundering the PMLA identifies certain offences under the Indian Penal Code, the Narcotic Drugs and Psychotropic Substances Act, the Arms Act, the Wild Life (Protection) Act, the Immoral Traffic (Prevention) Act and the Prevention of Corruption Act, the proceeds of which would be covered under this Act.

To combat the menace of aforesaid offences of money laundering the Government is entrusting the work relating to investigation, attachment of property/proceeds of crime relating to the scheduled offences under the Act and filling of complaints etc. to the Directorate of Enforcement, which currently deals with offences under the Foreign Exchange Management Act.

\section{Role of banks}

All banks (including RRBs and Co-operative banks) are covered under the above Act. The money launderers may open deposit accounts with banks in fake names and banks will be required to be vigilant for not becoming a party to such transactions. With a view to preventing banks from being used, intentionally or unintentionally, by criminal elements for money laundering or terrorist financing, it is clarified that whenever there is suspicion of money laundering or terrorist financing or when other factors give rise to a belief that the customer does not, in fact, pose a low risk, banks should carry out full scale customer due diligence (CDD) before opening an account.

Similarly, they have to observe the norms regarding record keeping, reporting, account opening and monitoring transactions. The Act has made various provisions regarding money laundering transactions which include maintenance of record of all transactions relating to money laundering. Records relating to such transactions should be preserved for 10 years from date of cessation of transactions between the client and the banking company.

Govt. has set up Financial Intelligence Unit (FIU-IND) to track and curb money laundering offences. Banks, financial institutions, stock brokers, etc. are to report non-cash transactions (cheques/drafts) totaling to over ₹1 crore a month and cash transactions of ₹ 10 lakh a month, to Financial Intelligence Unit.

Non-adherence of the provision of the Act will be an offence and these offences are cognizable/non-bailable. Punishment would be rigorous imprisonment for not less than 3 years but up to 7 years and fine as per the gravity of the offence. Enforcement Directorate has been made the designated authority to track cases of money laundering.

As per the Act, banking companies, financial institutions and intermediaries should maintain record of transactions, identity of clients etc. A director appointed by the Central Government has the right to call for records and impose penalties in case of failure on the part of the banking companies and other financial intermediaries. Central Government in consultation with the Reserve Bank has framed rules regarding the maintenance of records, retention period of records, verification of the identity of client ( $\mathrm{KYC}$ norms) and submitting the details and information to the director when called upon to do so. 
To ensure compliance under the PMLA, banking companies should strictly comply with the KYC norms without any deviation. KYC norms are applicable for both the new and existing client accounts. One of the objective of KYC norms is the clear identity of the customer. The identity does not end with obtaining the required identity proof like, verification and retaining copies of PAN card, Passport, AADHAR card, and other relevant documents as specified. Further to obtaining the required application forms, the photo identity and address proof documents, banks are required to ensure that all the relevant details like status of the customer, and relevant documentary verification to confirm the status, declaration about the multiple bank account details, source of income, source of funds, and expected income and activities in the accounts etc., are obtained and bank records are updated with these details. Banks should also accordingly set up internal control checking systems, whereby the system can identify and caution the bank officials about unusual transactions, at the time of input stage to enable the officials to take appropriate action. Banks should be very careful to avoid incidents of Money Laundering at the entry level itself. This precautionary action on the part of bank officials and the inbuilt warning system in the computers of banking companies, would go a long way to control the menace of Money Laundering. Banking companies should also ensure that as part of effective control system, that all the employees at all levels should be informed and trained to practice anti money laundering to safe-guard not only the customers funds, but also to be proactive to avoid incidents of money laundering. The internal auditors, external auditors including the Statutory Auditors and the Reserve Bank of India inspectors should include the verification of the Anti- Money Laundering procedures as part of their audit and inspection of banking companies. They should ensure that all the required guidelines and directives in respect of Anti Money Laundering including the adherence to the KYC norms, monitoring of accounts, maintenance of records, reporting of high volume transactions, suspicious transactions, filing of required returns to the authorities and proper control mechanism are adhered to. The executives should ensure monitoring and controlling of such incidents. Further the computer systems should be upgraded with the required checking and cautioning of suspicious and un authorized transactions at the input stage.

\section{BANKING CODES AND STANDARDS BOARD OF INDIA (BSCSBI)}

The Banking Codes and Standards Board of India has been registered as a separate society under the Societies Registration Act, 1860. It functions as an independent and autonomous body, to monitor and assess the compliance with codes and minimum standards of service to individual customers to which the banks agree to. The Code is a voluntary initiative by a bank and is also a unilateral commitment by the bank to its individual customers to deal with them in a transparent and fair manner in its day to day operations. RBI derives supervisory comfort in case of banks which are members of the Board. Members of public can contact the BCSBI either on its website or at its postal address. Website address: www.bcsbi.org.in

The main function of the Board is to ensure adherence to the "Code of Bank's Commitment to Customers". The Code is voluntary and sets minimum standards of banking practices for banks to follow when they are dealing with individual customers in their day-to-day operations. The Code is not only meant to provide protection to the individual customers but is also expected to generate awareness in the common man about his rights as a consumer of banking services.

Banks are required to register themselves with $\mathrm{BCSBI}$ as members and have the Code adopted by their respective boards. Thereafter, the banks will have to enter into a covenant with $\mathrm{BCSBI}$, binding them to monitoring by $\mathrm{BSCBI}$ as far as implementation of the code is concerned.

Any Scheduled Commercial Bank is eligible to become member of BCSBI. The Code represents each member bank's commitment to minimum standards of service to individual customers in relation to products and services offered by the bank, e.g.

Deposit accounts

Safe deposit lockers

Settlement of accounts of deceased account holders 
Foreign exchange services

Remittances within India

Loans and advances and guarantees

Credit cards

Internet banking

In these areas the Code, inter alia, dwells upon

Interest rates

Tariff schedule

Terms and conditions governing relationship between the bank and the customer

Compensation for loss, if any, to the customer due the acts of omission or commission on the part of the bank

Privacy and confidentiality of the information relating to the customer

Norms governing advertisements, marketing and sales by banks

Every Member bank is required to:

Have a Help desk/Helpline at the branch

Have a Code Compliance officer at each Controlling office above the level of the branch.

Display at each branch name and contact number of Code Compliance Officer.

Display Name and address of the Banking Ombudsman

In case a customer is not provided services as promised in the Code, he can first approach the help desk of the branch/bank. In case the issue is not resolved, the Code Compliance Officer of the bank may be approached by the complainant. In case the issue is still not resolved to the satisfaction of the customer he should take it up with the Banking Ombudsman .

\section{THE BANKING OMBUDSMAN SCHEME}

The Banking Ombudsman Scheme enables an expeditious and inexpensive forum to bank customers for resolution of complaints relating to certain services rendered by banks. The Banking Ombudsman Scheme is introduced under Section 35 A of the Banking Regulation Act, 1949 by RBI with effect from 1995.

The Banking Ombudsman is a senior official appointed by the Reserve Bank of India to redress customer complaints against deficiency in certain banking services. As on date, fifteen Banking Ombudsmen have been appointed with their offices located mostly in state capitals. The addresses and contact details of the Banking Ombudsman offices have been provided in the annex.All Scheduled Commercial Banks, Regional Rural Banks and Scheduled Primary Co-operative Banks are covered under the Scheme.

\section{Grounds of Complaints}

The Banking Ombudsman can receive and consider any complaint relating to the following deficiency in banking services (including internet banking):

- non-payment or inordinate delay in the payment or collection of cheques, drafts, bills etc.;

- non-acceptance, without sufficient cause, of small denomination notes tendered for any purpose, and for charging of commission in respect thereof;

- non-acceptance, without sufficient cause, of coins tendered and for charging of commission in respect 
thereof;

- non-payment or delay in payment of inward remittances ;

- failure to issue or delay in issue of drafts, pay orders or bankers' cheques;

- non-adherence to prescribed working hours ;

- failure to provide or delay in providing a banking facility (other than loans and advances) promised in writing by a bank or its direct selling agents;

- delays, non-credit of proceeds to parties accounts, non-payment of deposit or non-observance of the Reserve Bank directives, if any, applicable to rate of interest on deposits in any savings, current or other account maintained with a bank ;

- complaints from Non-Resident Indians having accounts in India in relation to their remittances from abroad, deposits and other bank-related matters;

- refusal to open deposit accounts without any valid reason for refusal;

- levying of charges without adequate prior notice to the customer;

- non-adherence by the bank or its subsidiaries to the instructions of Reserve Bank on ATM/Debit card operations or credit card operations;

- non-disbursement or delay in disbursement of pension (to the extent the grievance can be attributed to the action on the part of the bank concerned, but not with regard to its employees);

- refusal to accept or delay in accepting payment towards taxes, as required by Reserve Bank/Government;

- refusal to issue or delay in issuing, or failure to service or delay in servicing or redemption of Government securities;

- forced closure of deposit accounts without due notice or without sufficient reason;

- refusal to close or delay in closing the accounts;

- non-adherence to the fair practices code as adopted by the bank or non-adherence to the provisions of the Code of Bank s Commitments to Customers issued by Banking Codes and Standards Board of India and as adopted by the bank ;

- non-observance of Reserve Bank guidelines on engagement of recovery agents by banks; and

- any other matter relating to the violation of the directives issued by the Reserve Bank in relation to banking or other services.

A customer can also lodge a complaint on the following grounds of deficiency in service with respect to loans and advances

- non-observance of Reserve Bank Directives on interest rates;

- delays in sanction, disbursement or non-observance of prescribed time schedule for disposal of loan applications;

- non-acceptance of application for loans without furnishing valid reasons to the applicant; and

- non-adherence to the provisions of the fair practices code for lenders as adopted by the bank or Code of Bank's Commitment to Customers, as the case may be;

- non-observance of any other direction or instruction of the Reserve Bank as may be specified by the Reserve Bank for this purpose from time to time. 
- The Banking Ombudsman may also deal with such other matter as may be specified by the Reserve Bank from time to time.

There is no cost involved in filing complaints with Banking Ombudsman. The Banking Ombudsman does not charge any fee for filing and resolving customers' complaints.

\section{Miscellaneous provisions}

The amount, if any, to be paid by the bank to the complainant by way of compensation for any loss suffered by the complainant is limited to the amount arising directly out of the act or omission of the bank or Rs 10 lakhs, whichever is lower.

The Banking Ombudsman may award compensation not exceeding Rs 1 lakh to the complainant only in the case of complaints relating to credit card operations for mental agony and harassment. The Banking Ombudsman will take into account the loss of the complainant s time, expenses incurred by the complainant, harassment and mental anguish suffered by the complainant while passing such award.

\section{LESSON ROUND UP}

- The Reserve Bank of India Act,1934 was enacted to constitute the Reserve Bank of India with an objective to (a) regulate the issue of bank notes (b) for keeping reserves to ensure stability in the monetary system (c) to operate effectively the nation's currency and credit system.

- The term banking is defined as per Sec 5(i) (b), as acceptance of deposits of money from the public for the purpose of lending and/ or investment. Banking Regulation Act through a number of sections restricts or prohibits certain activities for a bank. For example: Trading activities of goods are restricted as per Section 8

- Banks are prohibited to hold The Banking Regulation Act.1949 requires a company or entity to obtain a license from the Reserve Bank of India to start the business of banking in India.

- Section 11 of the Banking Regulation Act stipulates the minimum capital and reserve requirements of a Banking Company.

- The opening of branches by banks is governed by the provisions of Section 23 of the Banking Regulation Act, 1949.

- Promoters/ Promoter Groups should be 'fit and proper' in order to be eligible to promote banks through a wholly owned NOFHC

- The NOFHC will be registered as a non-banking financial company (NBFC) with the RBI and will be governed by a separate set of directions issued by RBI.

- As per the relevant provisions of the Banking Regulation Act, at least fifty one percent of the total number of directors should be persons, who have special knowledge or practical experience, with respect of accountancy, agriculture and rural economy, banking, economics, finance, law, etc.,

- Cash Reserve Ratio (CRR) is the mandatory reserves to be maintained with Reserve Bank of India.

- Open market operations are a flexible instrument of credit control by means of which the Reserve Bank on its own initiative alters the liquidity position of the bank by dealing directly in the market instead of using its influence indirectly by varying the cost of credit.

- A banking company may be amalgamated with another banking company as per BR Act.

- There are various types of users of the financial statements of banks like shareholders, investors, 


\section{PP-BL\&P}

creditors, credit rating agencies, management students and others who need information about the financial position and performance of the banks.

- The Banking Ombudsman Scheme enables an expeditious and inexpensive forum to bank customers for resolution of complaints relating to certain services rendered by banks.

\section{SELF TEST QUESTIONS}

1. State whether the following statements are 'True' or 'False'
(a) Amalgamation between banking companies should be approved by the Central Government.
(b) Non scheduled banks need not maintain reserves
(c) Layering is a term associated with money laundering
(d) RBI have powers to issue coins
(e) Non adherence of KYC norms can create opportunity for money laundering

2. Choose the correct alternative.

A. Public Sector Banks are classified as banks
(a) Body corporate constituted under special statute
(b) Banking company registered under the Companies Act,1956
(c) Reserve Bank of India Act,1934
(d) State Bank of India Act,1955

B. As regards currency chest, identify the correct statement

(a) The notes and coins held in the currency chest of Reserve Bank of India belongs to Reserve Bank of India

(b) The notes and coins held in the currency chest of State Bank of India belongs to State Bank of India

(c) The notes and coins held in the currency chest of Central Bank of India belongs to Central Bank of India

(d) The notes and coins held in the currency chest of Union Bank of India belongs to Union Bank of India

C. In case of winding up of a banking company, the official liquidator need not give notice calling for claims except:
(a) secured creditors
(b) preferential payments
(c) depositors
(d) unsecured creditors

3. Explain how RBI controls foreign exchange.

4. Write a short note on the role of
(a) $\mathrm{RBI}$ as Banker to the Government
(b) RBI as Lender of the Last Resort 
(c) Monetary and Credit Policy

(d) Currency chests

(e) Selective Credit Control

(f) Minimum Disclosures

5. How is good governance ensured in banking companies? Write about the corporate governance in banks.

6. What are the returns to be submitted to RBI BY BANKS?

7. Briefly explain the types of frauds and reporting of frauds to RBI.

8. What do you mean by " money laundering"? What is the role of RBI in PREVENTION OF MONEY LAUNDERING?

9. Distinguish between the features of the Reserve Bank of India Act, 1934 and the Banking Regulation Act, 1949.

10. What are the various steps involved in case of amalgamation of two banks? 
56 PP-BL\&P 


\section{Lesson 3}

\section{Banker - Customer Relationship}

\section{LESSON OUTLINE}

- Introduction

- Meaning of a banking company

- Who is a customer?

- Relationship as debtor and creditor

- Banker as trustee

- Bailee/ bailor

- Lesser/ lessee

- Banker as agent

- Obligations of a banker

- Pass book and statement of account

- Garnishee order and attachment order

- Rights of a banker

- Various types of customers

- Closing of a bank account - termination of banker-customer relationship

- Various deposit schemes

- Other aspects of deposit accounts

- Closing of a bank account - termination of banker-customer relationship

- Insurance of bank deposits

- Nomination

- Lesson round up

- Self test Questions

\section{LEARNING OBJECTIVES}

The objectives include:

(a) Providing knowledge of various legal provisions affecting bankers

(b) Awareness about legal cases decided on the subject

(c) Precautions which a bank should undertake to avoid legal liability

(d) Understanding the rights and liabilities of a customer and a bank in regard to various situations in their relationship. 


\section{INTRODUCTION}

The relationship between a banker and his customer depends upon the nature of service provided by a banker. Accepting deposits and lending and/or investing are the core banking businesses of a bank. In addition to its primary functions, it deals with various customers by providing other services like safe custody services, safe deposit lockers, and assisting the clients by collecting their cheques and other instruments as an agent and trustees for them. So, based on the above a banker customer relationship can be classified as under:

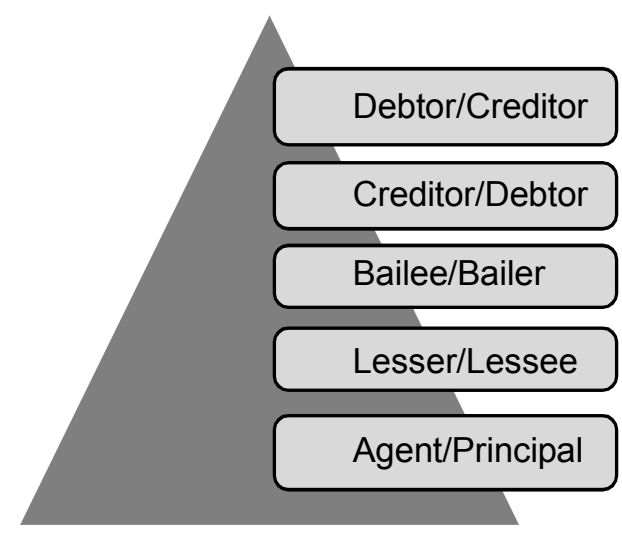

From the above diagram it can be seen that different types of relationship exists between a banker and customer.

\section{MEANING OF A BANKING COMPANY}

A banking company is defined as a company which transacts the business of banking in India . Section 5 (b) of The Banking Regulation Act, 1949 defines the term banking as "accepting for the purpose of lending or investment of deposits of money from the public, repayable on demand or otherwise and withdrawable by cheque, draft, order or otherwise.

Section -7 of this Act makes it essential for every company carrying on the business of banking in India to use as part of its name at least one of the words - bank, banker, banking or banking company. Section 49A of the Act prohibits any institution other than a banking company to accept deposit money from public withdrawable by cheque. The essence of banking business is the function of accepting deposits from public with the facility of withdrawal of money by cheque. In other words, the combination of the functions of acceptance of public deposits and withdrawal of the money by cheques by any institution cannot be performed without the approval of Reserve Bank.

\section{Features of Banking}

The following are the basic characteristics to capture the essential features of Banking:

(i) Dealing in money: The banks accept deposits from the public and advance the same as loans to the needy people. The deposits may be of different types - current, fixed, savings, etc. accounts. The deposits are accepted on various terms and conditions.

(ii) Deposits must be withdrawable: The deposits (other than fixed deposits) made by the public can be withdrawable by cheques, draft or otherwise, i.e., the bank issue and pay cheques. The deposits are usually withdrawable on demand. 
(iii) Dealing with credit: The banks are the institutions that can create credit i.e., creation of additional money for lending. Thus, "creation of credit" is the unique feature of banking.

(iv) Commercial in nature: Since all the banking functions are carried on with the aim of making profit, it is regarded as a commercial institution.

(v) Nature of agent: Besides the basic function of accepting deposits and lending money as loans, bank possesses the character of an agent because of its various agency services.

\section{WHO IS A CUSTOMER?}

The term 'customer' of a bank is not defined by law. Ordinarily, a person who has an account in a bank is considered is customer. Banking experts and the legal judgments in the past, however, used to qualify this statement by laying emphasis on the period for which such account had actually been maintained with the bank. In Sir John Paget's view "to constitute a customer there must be some recognizable course or habit of dealing in the nature of regular banking business." This definition of a customer of a bank lays emphasis on the duration of the dealings between the banker and the customer and is, therefore, called the 'duration theory'. According to this viewpoint a person does not become a customer of the banker on the opening of an account; he must have been accustomed to deal with the banker before he is designated as a customer. The above-mentioned emphasis on the duration of the bank account is now discarded. According to Dr. Hart, "a customer is one who has an account with a banker or for whom a banker habitually undertakes to act as such." Supporting this viewpoint, the Kerala High Court observed in the case of Central Bank of India Ltd. Bombay vs. V.Gopinathan Nair and others (A.I.R., 1979, Kerala 74) : "Broadly speaking, a customer is a person who has the habit of resorting to the same place or person to do business. So far as banking transactions are concerned he is a person whose money has been accepted on the footing that banker will honour up to the amount standing to his credit, irrespective of his connection being of short or long standing."

For the purpose of KYC policy, a 'Customer' is defined as :

- a person or entity that maintains an account and/or has a business relationship with the bank;

- one on whose behalf the account is maintained (i.e. the beneficial owner);

- beneficiaries of transactions conducted by professional intermediaries, such as Stock Brokers, Chartered Accountants, Solicitors etc. as permitted under the law, and

- any person or entity connected with a financial transaction which can pose significant reputational or other risks to the bank, say, a wire transfer or issue of a high value demand draft as a single transaction.

Thus, a person who has a bank account in his name and for whom the banker undertakes to provide the facilities as a banker, is considered to be a customer. It is not essential that the account must have been operated upon for some time. Even a single deposit in the account will be sufficient to designate a person as customer of the banker. Though emphasis is not being laid on the habit of dealing with the banker in the past but such habit may be expected to be developed and continued in figure. In other words, a customer is expected to have regular dealings with his banker in future.

An important consideration which determines a person's status as a customer is the nature of his dealings with a banker. It is evident from the above that his dealings with the banker must be relating to the business of banking. A banker performs a number of agency functions and tenders various public utility services besides performing essential functions as a banker. A person who does not deal with the banker in regard to the essentials functions of the banker, i.e.. accepting of deposits and lending of money, but avails of any of the services rendered by the banker, is not called a customer of the banker. For example, any person without a bank account in his name may remit money through a bank draft, encash a cheque received by him from others or deposit his valuables in the Safe Deposit Vaults in the bank or deposit cash in the bank to be credited to the account of the Life Insurance 
Corporation or any joint stock company issuing new shares. But he will not be called a customer of the banker as his dealing with the banker is not in regard to the essential functions of the banker. Such dealings are considered as casual dealings and are not in the nature of banking business.

Thus, to constitute a customer the following essential requisites must be fulfilled:

(i) a bank account - savings, current or fixed deposit - must be opened in his name by making necessary deposit of money, and

(ii) the dealing between the banker and the customer must be of the nature of banking business.

A customer of a banker need not necessarily be a person. A firm, joint stock company, a society or any separate legal entity may be a customer. Explanation to Section 45-Z of the Banking Regulation Act, 1949, clarifies that section "customer" includes a Government department and a corporation incorporated by or under any law.

Since the banker-customer relationship is contractual, a bank follows that any person who is competent to contract can open a deposit account with a bank branch of his/her choice and convenience. For entering into a valid contract, a person needs to fulfill the basic requirements of being a major (18 years of age or above) and possessing sound mental health (i.e. not being a lunatic). A person who fulfils these basic requirements, as also other requirements of the banks as mentioned below, can open a bank account. However, minors (below 18 years of age) can also open savings account with certain restrictions. Though any person may apply for opening an account in his name but the banker reserves the right to do so on being satisfied about the identity of the customer.

By opening an account with the banker, a customer enters into relationship with a banker. The special features of this relationship impose several obligations on the banker. He should, therefore, be careful in opening an account in his name but the banker reserves the right to do so on being satisfied about the identity of the customer. Prior to the introduction of "Know Your Customer (KYC)" guidelines by the RBI, it was the practice amongst banks to get a new customer introduced by a person who has already one satisfactory bank account with the Bank or by a staff member who knows him properly. Most of the banks preferred introduction to be given by a current account holder. Different practices of various banks were causing confusion and sometimes loss to the bank on not opening "properly" introduced account when any fraud took place in the account. A new customer was also facing difficulty in opening an account if he was a new resident of that area. To overcome all these problems and streamline the system of knowing a customer, RBI has directed all banks to adopt KYC guidelines.

\section{RELATIONSHIP AS DEBTOR AND CREDITOR}

On the opening of an account the banker assumes the position of a debtor. He is not a depository or trustee of the customer's money because the money over to the banker becomes a debt due from him to the customer. A banker does not accept the depositors' money on such condition. The money deposited by the customer with the banker is, in legal terms, lent by the customer to the banker, who makes use of the same according to his discretion. The creditor has the right to demand back his money from the banker, and the banker is under and obligation to repay the debt as and when he is required to do so. But it is not necessary that the repayment is made in terms of the same currency notes and coins. The payment, of course, must be made in terms of legal tender currency of the country.

A depositor remains a creditor of his banker so long as his account carries a credit balance. But he does not get any charge over the assets of his debtor/banker and remains an unsecured creditor of the banker. Since the introduction of deposit insurance in India in 1962, the element of risk to the depositor is minimized as the Deposit Insurance and Credit Guarantee Corporation undertakes to insure the deposits up to a specified amount. 
Banker's relationship with the customer is reversed as soon as the customer's account is overdrawn. Banker becomes creditor of the customer who has taken a loan from the banker and continues in that capacity till the loan is repaid. As the loans and advances granted by a banker are usually secured by the tangible assets of the borrower, the banker becomes a secured creditor of his customer.

Though the relationship between a banker and his customer is mainly that of a debtor and a creditor, this relationship differs from similar relationship arising out of ordinary commercial debts in following respects:

(i) The creditor must demand payment. In case of ordinary commercial debt, the debtor pays the amount on the specified date or earlier or whenever demanded by the creditor as per the terms of the contract. But in case of deposit in the bank, the debtor/ banker is not required to repay the amount on his own accord. It is essential that the depositor (creditor) must make a demand for the payment of the deposit in the proper manner. This difference is due to the fact that a banker is not an ordinary debtor; he accepts the deposits with an additional obligation to honour his customer's cheques. If he returns the deposited amount on his own accord by closing the account, some of the cheques issued by the depositor might be dishonoured and his reputation might be adversely affected. Moreover, according to the statutory definition of banking, the deposits are repayable on demand or otherwise. The depositor makes the deposit for his convenience, apart from his motives to earn an income (except current account). Demand by the creditor is, therefore, essential for the refund of the deposited money. Thus the deposit made by a customer with his banker differs substantially from an ordinary debt.

(ii) Proper place and time of demand. The demand by the creditor must be made at the proper place and in proper time as prescribed by a bank. For example, in case of bank drafts, travellers' cheques, etc., the branch receiving the money undertakes to repay it at a specified branch or at any branch of the bank.

(iii) Demand must be made in proper manner. According to the statutory definition of banking, deposits are withdrawable by cheque, draft, order or otherwise. It means that the demand for the refund of money deposited must be made through a cheque or an order as per the common usage amongst the bankers. In other words, the demand should not be made verbally or through a telephonic message or in any such manner.

\section{BANKER AS TRUSTEE}

Ordinarily, a banker is a debtor of his customer in respect of the deposits made by the latter, but in certain circumstances he acts as a trustee also. A trustee holds money or assets and performs certain functions for the benefit of some other person called the beneficiary. For example, if the customer deposits securities or other valuables with the banker for safe custody, the latter acts as a trustee of his customer. The customer continues to be the owner of the valuables deposited with the banker. The legal position of the banker as a trustee, therefore, differs from that of a debtor of his customer. In the former case the money or documents held by him are not treated as his own and are not available for distribution amongst his general creditors in case of liquidation.

The position of a banker as a trustee or as a debtor is determined according to the circumstances to the each case. If he does something in the ordinary course of his business, without any specific direction from the customer, he acts as a debtor (or creditor). In case of money or bills, etc., deposited with the bank for specific purpose, the bankers' position will be determined by ascertaining whether the amount was actually debited or credited to the customer's account or not. For example, in case of a cheque sent for collection from another banker, the banker acts as a trustee till the cheques is realized and credited to his customer's account and thereafter he will be the debtor for the same account. If the collecting banks fails before the payment of the cheque is actually received by it from the paying bank, the money so realized after the failure of the bank will belong to the customer and will not be available for distribution amongst the general creditors of the bank. 


\section{PP-BL\&P}

On the other hand, if a customer instructs his bank to purchase certain securities out of his deposit with the latter, but the bank fails before making such purchase, the bank will continue to be a debtor of his customer (and not a trustee) in respect of amount which was not withdrawn from or debited to his account to carry out his specific instruction.

The relationship between the banker and his customer as a trustee and beneficiary depends upon the specific instructions given by the latter to the farmer regarding the purpose of use of the money or documents entrusted to the banker. In New Bank of India Ltd. vs. Pearey Lal ( A.I.R. 1962, Supreme court 1003), the Supreme Court observed in the absence of other evidence a person paying into a bank, whether he is a constituent of the bank or not, may be presumed to have paid the money to be held as banker ordinarily held the money of their constituent. If no specific instructions are given at the time of payment or thereafter and even if the money is held in a Suspense Account the bank does not thereby become a trustee for the amount paid.

In case the borrower transfers to the banker certain shares in a company as a collateral security and the transfer is duly registered in the books of the issuing company, no trust is created in respect of such shares and the banks' position remains that of a pledge rather than as trustee. Pronouncing the above verdict, in New Bank of India vs. Union of India (1981) 51 Company Case p. 378, the Delhi High Court observed that a trustee is generally not entitled to dispose of or appropriate trust property for his benefit. "In the present case the banker was entitled to dispose of the shares and utilize the amount thereof for adjustment to the loan amount if the debtor defaults. The banker's obligation to transfer back the shares can arise only when the debtor clears dues of the bank was not considered as trustee.

\section{BANKER AS A BAILOR / BAILEE}

Section 148 of Indian Contract Act,1872, defines bailment, bailor, and bailee. A bailment is the delivery of goods by one person to another for some purpose upon a contract. As per the contract, the goods should when the purpose is accomplished, be returned or disposed off as per the directions of the person delivering the goods. The person delivering the goods is called the bailer and the person to whom the goods are delivered is called the bailee.

Banks secure their loans and advances by obtaining tangible securities. In certain cases banks hold the physical possession of secured goods (pledge) - cash credit against inventories; valuables - gold jewels (gold loans); bonds and shares (loans against shares and financial instruments) In such loans and advances, the collateral securities are held by banks and the relationship between banks and customers are that of bailee (bank) and bailer.(borrowing customer)

\section{BANKER AS A LESSER / LESSEE}

Section 105 of 'Transfer \& Property Act' deals with lease, lesser, lessee. In case of safe deposit locker accounts, the banker and customer relationship of lesser/lessee is applicable. Banks lease the safe deposit lockers (bank's immovable property) to the clients on hire basis. Banks allow their locker account holders the right to enjoy (make use of ) the property for a specific period against payment of rent.

\section{BANKER AS AGENT}

A banker acts as an agent of his customer and performs a number of agency functions for the convenience of his customers. For example, he buys or sells securities on behalf of his customer, collects cheques on his behalf and makes payment of various dues of his customers, e.g.. insurance premium, etc. The range of such agency functions has become much wider and the banks are now rendering large number of agency services of diverse nature. For example, some banks have established Tax Services Departments to take up the tax problems of their customers. 


\section{OBLIGATIONS OF A BANKER}

Though the primary relationship between a banker and his customer is that of a debtor and creditor or vice versa, the special features of this relationship, impose the following additional obligations on the banker:

\section{Obligations to honour the cheques}

The deposits accepted by a banker are his liabilities repayable on demand or otherwise. The banker is, therefore, under a statutory obligation to honour his customer's cheques in the usual course. Section 31 of the Negotiable Instruments Act, 1881, lays down that:

"The drawee of a cheque having sufficient funds of the drawer in his hands, properly applicable to the payment must compensate the drawer for any loss or damage caused by such default."

\section{Obligation to maintain Secrecy of Account}

The account of the customer in the books of the banker records all of his financial dealings with the latter and the depicts the true state of his financial position. If any of these facts is made known to others, the customer's reputation may suffer and he may incur losses also. The banker is, therefore, under an obligation to take utmost care in keeping secrecy about the accounts of his customers. By keeping secrecy is meant that the account books of the bank will not be thrown open to the public or Government officials and the banker will take all necessary precautions to ensure that the state of affairs of a customer's account is not made known to others by any means. The banker is thus under an obligation not to disclose-deliberately or intentionally—any information regarding his customer's accounts to a third party and also to take all necessary precautions and care to ensure that no such information leaks out of the account books.

The nationalized banks in India are also required to fulfill this obligation. Section 13 of the Banking Companies (Acquisition and Transfer of Undertakings) Act, 1970, specially requires them to "observe, except as otherwise required by law, the practices and usages customary amongst bankers and in particular not to divulge any information relating to the affairs of the constituents except in circumstances in which they are, in accordance with law or practices and usages or appropriate for them to divulge such information."

Thus, the general rule about the secrecy of customer's accounts may be dispensed with in the following circumstances:

I. When the law requires such disclosure to be made; and

II. When practices and usages amongst the bankers permit such disclosure.

A banker will be justified in disclosing information about his customer's account on reasonable and proper occasions only as stated below:

(a) Disclosure of Information required by Law. A banker is under statutory obligation to disclose the information relating to his customer's account when the law specially requires him to do so. The banker would, therefore, be justified in disclosing information to meet statutory requirements:

(i) Under the Income- Tax Act, 1961. According to Section 131, the income tax authorities possess the same powers as are vested in a Court under the Code of Civil Procedure, 1908, for enforcing the attendance of any person including any offer of banking company or any offer thereof, to furnish information in relation to such points or matters, as in the opinion of the income-tax authorities will be useful for or relevant to any proceedings under the Act. The income -tax authorities are thus authorized to call for necessary information from the banker for the purpose of assessment of the bank customers.

Section 285 of the Income- tax Act, 1961, requires the banks to furnish to the Income-tax Officers the names and addresses of all persons to whom they have paid interest exceeding ₹ 400 mentioning the actual amount of interest paid by them. 
(ii) Under the Companies Act, 1956. When the Central Government appoints an Inspector or to investigate the affairs of any joint stock company under Section 235 or 237 of the Companies Act, 1956, it shall be the duty of all officers and other employees and agents (including the bankers ) of the company to-

(a) produce all books and papers of, or relating to, the company, which are in their custody or power, and

(b) otherwise to give the Inspector all assistance in connection with investigation which they are reasonably able to give (Section 240 ).

Thus the banker is under an obligation to disclose all information regarding the company but no of any other customer for the purpose of such investigation (Section 251).

(iii) By order of the Court under the Banker's Books Evidence Act, 1891. When the court orders the banker to disclose information relating to a customer's account, the banker is bound to do so. In order to avoid the inconvenience likely to be caused to the bankers from attending the Courts and producing their account books as evidence, the Banker's Books Evidence Act, 1891, provides that certified copies of the entries in the banker's book are to be treated as sufficient evidence and production of the books in the Courts cannot be forced upon the bankers. According to Section 4 of the Act, " a certified copy of any entry in a banker's book shall in all legal proceedings be received as prima facie evidence of the matters, transitions and accounts therein recorded in every case where, and to the same extent, as the original entry itself is now by law admissible, but not further or otherwise." Thus if a banker is not a party to a suit, certified copy of the entries in his book will be sufficient evidence. The Court is also empowered to allow any party to legal proceedings to inspect or copy from the books of the banker for the purpose of such proceedings.

(iv) Under the Reserve Bank of IndiaAct,1934. The Reserve Bank of India collects credit information from the banking companies and also furnishes consolidated credit information from the banking company. Every banking company is under a statutory obligation under Section 45-B of the Reserve Bank. The Act, however, provides that the Credit information supplied by the Reserve Bank to the banking companies shall be kept confidential. After the enactment of the Reserve Bank of India (Amendment) Act, 1974, the banks are granted statutory protection to exchange freely credit information mutually among themselves.

(v) Under the Banking Regulation Act, 1949. Under Section 26, every banking company is requires to submit a return annually of all such accounts in India which have not been operated upon for 10 years. Banks are required to give particulars of the deposits standing to the credit of each such account.

(vi) Under the Gift Tax Act, 1958. Section 36 of the Gifts Tax Act, 1958, confers on the Gift Tax authorities powers similar to those conferred on Income- Tax authorities under Section 131 of the Income Tax Act [discussed above (i).]

(vii) Disclosure to Police. Under Section 94 (3) of the Criminal Procedure Code, the banker is not exempted from producing the account books before the police. The police officers conducting an investigation may also inspect the banker's books for the purpose of such investigations (section 5. Banker's Books Evidence Act).

(viii) Under the Foreign Exchange Management Act, 1999, under section 10. Banking companies dealing in foreign exchange business are designated as 'authorized persons' in foreign exchange. Section 36, 37 and 38 of this Act empowers the officer of the Directorate of Enforcement and the Reserve Bank to investigate any contravention under the Act.. 
(ix) Under the Industrial Development Bank of India Act, 1964. After the insertion of sub-section 1A in Section 29 of this Act in 1975, the Industrial Development Bank of India is authorized to collect from or furnish to the Central Government, the State Bank, any subsidiary bank, nationalized bank or other scheduled bank, State Co-operative Bank, State Financial Corporation credit information or other information as it may consider useful for the purpose of efficient discharge of its functions. The term 'credit information' shall have the same meaning as under the Reserve Bank of India Act, 1934.

(b) Disclosure permitted by the Banker's Practices and Usages. The practices and usages customary amongst bankers permit the disclosure of certain information under the following circumstances:

(i) With Express or Implied Consent of the Customer. The banker will be will be justified in disclosing any information relating to his customer's account with the latter's consent. In fact the implied term of the contract between the banker and his customer is that the former enters into a qualified obligation with the latter to abstain from disclosing information as to his affairs without his consent (Tourniers vs. National Provincial and Union Bank of India). The consent of the customer may be expressed or implied. Express consent exists in case the customer directs the banker in writing to intimate the balance in his account or any other information to his agent, employee or consultant. The banker would be justified in furnishing to such person only the required information and no more. It is to be noted that the banker must be very careful in disclosing the required information to the customer or his authorized representative. For example, if an oral enquiry is made at the counter, the bank employee should not speak in louder voice so as to be heard by other customers. Similarly, the pass-book must be sent tot the customer through the messenger in a closed cover. A banker generally does not disclose such information to the customer over the telephone unless he can recognize the voice of his customer; otherwise he bears the risk inherent in such disclosure.

In certain circumstances, the implied consent of the customer permits the banker to disclose necessary information. For example, if the banker sanctions a loan to a customer on the guarantee of a third person and the latter asks the banker certain questions relating to the customer's account. The banker is authorized to do so because by furnishing the name of the guarantor, the customer is presumed to have given his implied consent for such disclosure. The banker should give the relevant information correctly and in good faith.

Similarly, if the customer furnishes the name of the banker to a third party for the purpose of a trade reference, not only an express consent of the customer exists for the discloser of relevant information but the banker is directed to do so, the non - compliance of which will adversely affect the reputation of the customer.

Implied consent should not be taken for granted in all cases even where the customer and the enquirer happen to be very closely related. For example, the banker should not disclose the state of a lady's account to her husband without the express consent of the customer.

(ii) The banker may disclose the state of his customer's account in order to legally protect his own interest. For example, if the banker has to recover the dues from the customer or the guarantor, disclosure of necessary facts to the guarantor or the solicitor becomes necessary and is quite justified.

(iii) Banker's Reference. Banker follows the practice of making necessary enquires about the customers, their sureties or the acceptors of the bills from other bankers. This is an established practice amongst the bankers and is justified on the ground that an implied consent of the customer is presumed to exist. By custom and practice necessary information or opinion about the customer is furnished by the banker confidentially. However, the banker should be very careful in replying to such enquiries.

Precautions to be taken by the banker. The banker should observe the following precautions while giving replies about the status and financial standing of a customer: 
(i) The banker should disclose his opinion based on the exact position of the customer as is evident from his account. He should not take into account any rumour about his customer's creditworthiness. $\mathrm{He}$ is also not expected to make further enquiries in order to furnish the information. The basis of his opinion should be the record of the customer's dealings with banker.

(ii) He should give a general statement of the customer's account or his financial position without disclosing the actual figures. In expressing his general opinion he should be very cautious-he should neither speak too low about the customer nor too high. In the former case he injures the reputation of the customer ; in the latter, he might mislead the enquirer. In case unsatisfactory opinion is to be given, the banker should give his opinion in general terms so that it does not amount to a derogatory remark. It should give a caution to the enquirer who should derive his own conclusions by inference and make further enquiries, if he feels the necessity.

(iii) He should furnish the required information honestly without bias or prejudice and should not misrepresent a fact deliberately. In such cases he incurs liability not only to his own customer but also to the enquirer.

(c) Duty to the public to disclose : Banker may justifiably disclose any information relating to his customer's account when it is his duty to the public to disclose such information. In practice this qualification has remained vague and placed the banks in difficult situations. The Banking Commission, therefore, recommended a statutory provision clarifying the circumstances when banks should disclose in public interest information specific cases cited below:

(i) when a bank asked for information by a government official concerning the commission of a crime and the bank has reasonable cause to believe that a crime has been committed and that the information in the bank's possession may lead to the apprehension of the culprit,

(ii) where the bank considers that the customer's is involved in activities prejudicial to the interests of the country.

(iii) where the bank's books reveal that the customer is contravening the provisions of any law, and

(iv)where sizable funds are received from foreign countries by a constituent.

Risks of Unwarranted and Unjustifiable Disclosure. The obligation of the banker to keep secrecy of his customer's accounts - except in circumstances noted above - continue even after the account is closed. If a banker discloses information unjustifiably, he shall be liable to his customer and the third party as follows:

(a) Liabilities to the customer. The customer may sue the banker for the damages suffered by him as a result of such disclosure. Substantial amount may be claimed if the customer has suffered material damages. Such damages may be suffered as a result of unjustifiable disclosure of any information or extremely unfavourable opinion about the customer being expressed by the banker.

(b) Liabilities to third parties. The banker is responsible to the third parties also to whom such information is given, if -

(i) the banker furnishes such information with the knowledge that it is false, and

(ii) Such party relies on the information and suffers losses.

Such third party may require the banker to compensate him for the losses suffered by him for relying on such information. But the banker shall be liable only if it is proved that it furnished the wrong or exaggerated information deliberately and intentionally. Thus he will be liable to the third party on the charge of fraud but not for innocent misrepresentation. Mere negligence on his part will not make him liable to a third party.

The general principles in this regard are as follows: 
(1) A banker answering a reference from another banker on behalf of the latter's constituent owes a duty of honesty to the said constituent.

(2) If a banker gives a reference in the form of a brief expression of opinion in regard to creditworthiness, it does not accept and there is not expected of it any higher duty than that of giving an honest answer.

(3) If the banker stipulates in its reply that it is without responsibility, it cannot be held liable for negligence in respect of the reference.

\section{PASS BOOK AND STATEMENT OF ACCOUNT}

Though the Pass Book contains true and authenticated record of the customer's account with the banker, no unanimous view prevails regarding the validity of the entries in the Pass Book. The banker may incur errors in recording entries in the Pass Book. The question, therefore, arises whether the Pass Book constitutes a conclusive proof of the accuracy of the entries made therein.

According to Sir John Paget, "The proper function which the Pass Book ought to fulfill is to constitute a conclusive and unquestionable record of transactions between the banker and the customer and it should be recognized as such. After full opportunity of examination on the part of the customer all entries, at least to his debt, ought to be subsequently final and not liable to be subsequently reopened at any rate to the detriment of the banker".

In fact this view point rests on the presumption that the customer is under an obligation to verify the entries made in the Pass Book periodically and if detects any mistake, he ought to bring it to the notice of the banker within a reasonable period. If he does not do so and remains silent after the receipt of the Pass Book, customer's concurrence with the correctness of the entries is taken for granted. In some of the legal judgements, especially in Morgan vs. United States Mortgage and Trust Co. and Devaynes vs. Noble (1816) it was held that negligence or omission on the part of the customer to examine the correctness of the entries in the Pass Book is a fault on his part and thus renders as an evidence of settled and accepted account. The implied obligations on the customer to examine the Pass Book have not been supported in many other judicial decisions in England and India. For reference, we may cite the cases of Keptigalla Rubber Estate Co. vs. National Bank of India (1909) and Chatterton vs. London and Country Bank. In the absence of such obligation on the customer, the entries in the Pass Book cannot be treated as a conclusive proof of their accuracy and as settled account,. The customer is competent to point out the mistakes or omissions in the Pass Book at any time he happens to know about them. Thus the entries in the Pass Book do not form the conclusive evidence of their correctness accuracy. The entries erroneously made or wrongly omitted may be either advantageous to the customer or the banker. Both the parties may, therefore, indicate the mistakes or omissions therein and get them rectified. The legal position in this regard is as follows:

\section{Effect of Entries to the Advantage of the Customer}

The account of a customer may sometimes wrongly show a credit balance, which is larger than the correct balance because of the duplication of credit entries or incorrectly entering higher amounts for such entries or due to omission of any debit entry. The legal position of the banker and his customer shall be as follows:

(i) The Pass Book is written by the banker and hence the entries therein may form an evidence against the banker. The customer is rightly entitled to believe them as correct and to act on the basis of such entries. If the Pass Book shows a higher balance and the customer withdraws such balance treating it as his own and subsequently spends it away. the banker shall not be entitled to recover such amount wrongly paid to the customer. But the customer shall have to prove that (a) he acted in such manner relying on the correctness of the balance shown in the Pass Book and had no knowledge of the mistakes therein, and (b) he altered his position by spending the same,. This benefit has been to the customer in various judgements because of the presumption that normally a person spends what he presumes to belong to him and if the banker permits him to withdraw excess money on the above presumption, it would be great 
prejudice to him, if he is called to pay them back. ' Skyring vs. Greenwood (1825) and Holt vs. Markham (1923)

(ii) There are some exceptions to the above mentioned principle of estoppel. If the customer regularly maintains his account books and the bank regularly sends him the Pass Book (or statement in lieu of the Pass Book) the customer cannot act on the basis of the above presumption. Though it is not obligatory for him to check the Pass Book (or the statements), but in such circumstances, it is difficult to establish that he was ignorant about the mistakes in the Pass Book, because he regularly maintained the account books. In such circumstances, a constructive notice of the mistake is supposed to have been given to him.

The decision of the Madras High Court in Oakley Bowden and Co. vs. The Indian Bank Ltd. (A.I.R., 1964, Madras 202) says that "generally speaking, a bank owes a duty to its customer to maintain proper and accurate accounts of credits and debits. If a bank makes wrong credit entries without knowing the fact at the time the entries were made and intimates to its customers the credit entries and the customer acting upon the intimation of credit entries, alters his position to his prejudice, the bank, therefore, will be stopped from contending that the credit entries were wrongly made and that the amounts covered by them should be refunded to it by the customer. Such an intimation by the bank is obviously a representation made to the customer, which the customer is at liberty, in fact, entitled, to act upon. Once it is acted upon by the customer bonafide, of course, it will then be too late for the bank to realize from the credit entries they made mistakenly and seek to have recompensed by means of adjustment in the accounts or recovery of the amounts from the customer." The Court observed that if the Company had even cursorily scrutinized the periodic statements received by it from its two customers, it would have detected that two of the credit entries were in fact only duplicate entries. The Court held that the Company was negligent in scrutinizing the accounts and that it had constructive notice of the duplicate entries and, therefore, it could not raise the plea of estoppel against the bank. It was held that the bank could recover the amounts in question.

In S. Kotrabasappa vs. Indian Bank (1990) 69 Company Case 683, the Karnataka High Court held that the customer who has taken unfair advantage of a mistaken credit made by the bank is bound to return or repay the amount according to Section 72 of the Indian Contract Act which states that "A person to whom money has been paid or anything delivered by mistake or under coercion, must repay or return it."

\section{Effect of the Customer Signing Confirmation Slips}

The Pass Book itself is not a conclusive proof of a settled account. Banks nowadays periodically issue to the customers confirmation slips, which gave the balance in the account as on a given date. By putting his signature on the confirmation slip, the customer accepts and confirms such balance. The legal effect of a customer's signing the confirmation slip was considered by the Kerala High Court in Essa Ismail vs. Indian Bank Ltd. (1963). The Court observed that "unless there is evidence to show that the practice or the custom indicated a stated or settled account, the customer is not precluded from questioning the debit entries in a Pass Book but, when confirmation slips are sent and signed by the customer, he will be bound by the debits made." In this case, the confirmation slips were signed by the customer or his authorized agent. Hence the same were binding on him and his heirs and could not be challenged by them.

(iii) The banker is entitled to point out the customer any mistake or omission and to rectify it as soon as he knows about it. On receipt of such information the customer is not entitled to withdraw the excess amount wrongly credited to his account. But the banker should not dishonour the cheques drawn and issued by the customer before the notice of such wrong entry is served on him. If he does, he will be liable for the consequences of their wrongful dishonour.

\section{Effect of Wrong Entries in Favour of the Banker}

When a credit entry has been totally omitted or its figure has been wrongly stated or any debit entry has been erroneously made in the account of the customer. Such entries are favourable to the banker and against the customer. The customer is entitled to get the mistake rectified as soon as he happens to detect it. This right of he 
customer does not lapse even if he returns the Pass Book without raising objection regarding any entry or he remains silent after the receipt of the Pass Book because, as already noted, the customer is not bound to examine the Pass Book periodically and regularly. $\mathrm{He}$ is entitled to recover the amount wrongly debited to, or omitted to be credited to his account. The right of the customer to get the mistake rectified is, however, subject to one limitation. If the customer comes to know about the forgery in the cheque and he does not inform the bank, it will constitute negligence on his part. The customer will, therefore, not be entitled to recover the amount paid by the banker on the forged cheque.

The most important point to note is that the negligence on the part of the customer should have been actually proved. In Canara Bank vs. Canara Sales Corporation and Others (AIR 1987 SC 1603) the Supreme Court held that after reasonable opportunity was given to the customer to examine the Bank's statements; its debit entries should be deemed to be final and should not be open for reconstruction to the detriment of the Bank. The Supreme Court rejected the appeal and held that the bank can escape liability only if it can establish knowledge to the customer of the forgery in the cheques. Inaction for continuously long period cannot by itself afford a satisfactory ground for the bank to escape the liability. The Court further held that there was no duty for a customer to inform the Bank of fraud committed on him of which he was unaware. Nor can inaction for a reasonably long time in not discovering fraud or irregularity be made a defense to defeat a customer in an action for loss.

It is pertinent to note in this connection that the current accounts rules of the banks usually lay such obligation on the customer. For example,

"On a Pass Book or Statement of Account being received by a customer, the entries should be carefully examined and any error or omission should immediately be brought to the notice of the bank; otherwise, the return of the Pass Book or rendering of the Statement of Account to the customer will be treated as settlement of the account and acknowledgement of its correctness to date. The Bank will not be responsible for any loss arising from the neglect of these precautions." (Bank of Baroda Current Account Rule)

Similarly, the State Bank of India requires that-

"The entries should be carefully examined by the constituent, and, if any errors or omissions are discovered, the attention of the Bank must be drawn to them immediately. The Bank will not be responsible for any loss arising from neglect of this precaution."

It is thus apparent that the current account rules, which form the basis of agreement between the banker and the customer, impose a duty on the customer to carefully examine the entries. If he is negligent in performing this duty and thereby some loss is caused, the banker shall not be liable for the same.

\section{Effect of False Entry in the Pass Book}

The liability of a banker to his customer in case his employee commits an act of embezzlement and makes false entries in the Pass Book was considered by the Supreme Court in State Bank of India vs. Shyama Devi (A.I.R. 1978 S.C. 1263). The Supreme Court laid down the legal principle which governs liability of an employer for the loss caused to a customer through the misdemeanor or negligence of an employee as follows: "The employer is not liable for the act of the servant if the cause of the loss or damage arose without his actual fault or privity or without the fault or neglect of his agent or servant in the course of his employment.

\section{Precautions to be taken by the Banker and the Customer}

1. The Pass Book must be sent by the customer to the bank periodically and regularly for recording the necessary entries, so that mistakes, if any, may be detected by the customer soon thereafter. Reserve Bank has advised the banks to issue a simple receipt to the tenderer of savings bank Pass Book if it is retained by the Bank for updating.

2. The Pass Book must be initialed by the accountant or other responsible officer of the Bank, who must 
ascertain the accuracy of the balance on the date of recording the entries, otherwise the customer will be entitled to act upon the same, if it is wrongly stated.

3. The customer must tally the entries with his own record-either the account books or he counterfoils of pay-in-slips and cheques, etc. If any accuracy is found, the customer must inform the bank immediately to get the mistake rectified.

4. While sending the Pass Book to the customer, the banker should take steps to ensure the secrecy of its contents. The Pass Book must be sent in a closed cover.

GARNISHEE ORDER AND ATTACHMENT ORDER

\section{Garnishee Order}

The obligation of a banker to honour his customer's cheques is extinguished on receipt of an order of the Court, known as the Garnishee order, issued under Order 21, Rule 46 of the code of Civil Procedure, 1908. If a debtor fails to pay the debt owed by to his creditor, the latter may apply to the Court for the issue of a Garnishee Order on the banker of his debtor. Such order attaches the debts not secured by a negotiable instrument, by prohibiting the creditor the creditor from recovering the debt and the debtor from the making payment thereof. The account of the customer with the banker, thus, becomes suspended and the banker is under an obligation not to make any payment from the account concerned after the receipt of the Garnishee Order. The creditor at whose request the order is issued is called the judgement- creditor, the debtor whose money is frozen is called judgement- debtor and the banker who is the debtor of the judgement debtor is called the Garnishee.

The Garnishee Order is issued in two parts. First, the Court directs the banker to stop payment out of the account of the judgement- debtor. Such order, called Order Nisi, also seeks explanation from the banker as to why the funds in the said account should not be utilized for the judgement- creditor's claim. The banker is prohibited from paying the amount due to his customer on the date of receipt of the Order Nisi. He should, therefore, immediately inform the customer so that dishonour of any cheque issued by him may be avoided. After the banker files his explanation, if any, the Court may issue the financial order, called Order Absolute where the entire balance in the account or a specified amount is attached to be handed over to the judgement- creditor. On receipt of such an order to the banker is bound to pay the garnished funds to the judgement- creditor. Thereafter, the banker liabilities towards his customer are discharged to that extent. The suspended account may be revived after payment has been made to the judgementcreditor as per the directions of the Court. The following points are to be noted in this connection:

II. The amount attached by the order. A garnishee order may attach either the amount of the judgement debtor with the banker irrespective of the amount which the judgement- debtor owes to the creditor or a specified amount only which is sufficient to meet the creditor' claim from the judgement-debtor. In the first case, the entire in the account of the customer in the bank is garnished or attached and if banker pays any amount out of the same which is in excess of the amount of the debt of the creditor plus cost of the legal proceedings, he will render himself liable for such payment. For example, the entire to the credit of $X$, the principal debtor, ₹ 10,000 is attached by the Court while the debt owed by him to his creditor $Y$ is only $₹ 6,000$. If the banker honours the cheque of the customer $X$ to the extent of ₹ 5,000 and thus reducing the balance to ₹ 5,000 he will be liable for defying the order of the Court. On the other hand, if he dishonours all cheques, subsequent to the receipt of the Garnishee Order, he will not be liable to the customer for dishonouring his cheques.

It is to be noted that the Garnishee Order does not apply to the amount of the cheque marked by a bank as a good for payment because the banker undertakes upon himself the liability to pay the amount of the cheque. On the other hand, if the judgement debtor gives to the bank a notice to withdraw, it does not amount withdrawal, but merely his intention to withdraw. The Garnishee Order will be applicable to such funds. In the second case, only the amount specified in the order is attached and the amount is excess of that may be paid to the customer by the banker. 
For example, $X$ is customer of SBI and his current account shows a credit balance of $₹ 10,000$. He is indebted to $Y$ for ₹ 5,000. the latter applies to the Court for the issue of a Garnishee Order specifies the amount (₹ 5,000) which is being attached, the banker will be justified in making payment after this amount, i.e., the balance in the customer's account should not be reduced below $₹ 5,000$. Usually in such cases, the attached amount is transferred to a suspense account and the account of the customer is permitted to be operated upon with the remaining balance.

III. The order of the Court restrains the banker from paying the debts due or accruing due. The word 'accruing due' mean the debts which are not payable but for the payment of which an obligation exists. If the account is overdrawn, the banker owes no money to the customer and hence the Court Order ceases to be effective. A bank is not a garnishee with respect to the unutilized portion of the overdraft or cash credit facility sanctioned to its customer and such utilized portion of cash credit or overdraft facility cannot be said to be an amount due from the bank of its customer. The above decision was given by the Karnataka High Court in Canara Bank vs. Regional Provident Fund Commissioner. In his case the Regional Provident Fund Commissioner wanted to recover the arrears of provident fund contribution from the defaulters' bankers out of the utilized portion of the cash credit facility. Rejecting this claim, the High Court held that the bank cannot be termed as a Garnishee of such unutilized portion of cash credit, as the banker's position is that of creditor. For example, PNB allows it as customer to overdraw to the extent of ₹ 5,000 . The customer has actually drawn ( $₹ 3,000$ ) cannot be attached by a Garnishee Order as this is not a debt due from the banker. It merely indicates the extent to which the customer may be the debtor of the bank.

The banker, of course, has the right to set off any debt owed by the customer before the amount to which the Garnishee Order applies is determined. But it is essential that debt due from the customer is actual and not merely contingent. For example, if there is an unsecured loan account in the name of the judgement-debtor with a balance of ₹ 5,000 at the time of receipt of Garnishee Order, such account can be set off against the credit balance in the other account. But if the debt due from the judgement- debtor is not actual, i.e., has not actually become due, but is merely contingent, such set off is not permissible. For example, if $A$, the judgement- debtor, has discounted a bill of exchange with the bank, there is contingent liability of $A$ towards the bank, if the acceptor does not honour the bill on the due date. Similarly, if A has guaranteed a loan taken from the bank by $B$, his liability as surety does not arise until and unless $B$ actually makes default in repaying the amount of the loan.

The banker is also entitled to combine two accounts in the name of the customer in the same right. If one account shows a debit balance and the other a credit one, net balance is arrived at by deducting the former from the latter.

IV. The Garnishee Order attachés the balance standing to the credit of the principal debtor at the time the order is served on the banker. The following points are to be noted in this connection:

(a) The Garnishee Order does not apply to: (1) the amounts of cheques, drafts, bills, etc.., sent for collection by the customer, which remain uncleared at the time of the receipt of the order, (2) the sale proceeds of the customer's securities, e.g., stocks and shares in the process of sale, which have not been received by the banker. In such cases, the banker acts as the agent for the customer for the collection of the cheques or for the sale of the securities and the amounts in respect of the same are not debts due by the banker to the customer, until they are actually received by the banker and credited to the customer's account. But if the amount of such uncleared cheque, etc., is credited to the customer's account, the position of the banker changes and the garnishee order is applicable to the amount of such uncleared cheques. Similarly, if one branch of a bank sends its customer's cheque for realization to its another branch and the latter collects the same from the paying banker before the receipt of the Garnishee Order by the first branch, the amount so realized shall also be subject to Garnishee Order, even though the required advice about realization of cheque is received after the receipt of the Garnishee Order. Giving this judgement in Gerald C.S. Lobo vs. Canara Bank (1997) 71 Comp. Cases 290, the Karnataka high Court held that the branch which collects money on behalf of another branch is to be treated as agent of the latter and consequently the moment a cheque sent for collection by the other 
branch has been realized by the former, the realization must be treated as having accrued to the principal branch.

(b) The Garnishee Order cannot attach the amounts deposited into the customer's account after the Garnishee Order has been served on the banker. A Garnishee Order applies to the current balance at the time the order is served, it has no prospective operation. Bankers usually open a new account on the name of customer for such purpose.

(c) The Garnishee Order is not effective in the payments already made by the banker before the order is served upon him. But if a cheque is presented to the banker for payment and its actual payment has not yet been made by the banker and in the meanwhile a Garnishee Order is served upon him, the latter must stop payment of the said cheque, even if it is passed for payment for payment. Similarly, if a customer asks the banker to transfer an amount from his account and the banker has already made necessary entries of such transfer in his books, but before the intimation could be sent to the other account-holder, a Garnishee Order is received by the banker, it shall be applicable to the amount so transferred by mere book entries, because such transfer has no effect without proper communication to the person concerned.

(d) In case of cheques presented to the paying banker through the clearing house, the effectiveness of the Garnishee Order depends upon the fact whether time for returning the dishonoured cheques to the collecting banker has expired or not. Every drawee bank is given specified time within which it has to return the unpaid cheques, if any, to the collecting bank. If such time has not expired and in the meanwhile the bank receives a Garnishee Order, it may return the cheque dishonoured. But if the order is received after such time over, the payment is deemed to have been made by the paying banker and the order shall not be applicable to such amount.

(e) The Garnishee Order is not applicable to:

(i) Money held abroad by the judgement- debtor ; and

(ii) Securities held in the safe custody of the banker,

(f) The Garnishee Order may be served on the Head Office of the bank concerned and it will be treated as sufficient notice to all of its branches. However, the Head Office is given reasonable time to intimate all concerned branches. If the branch office makes payment out of the customer's account before the receipt of such intimation, the banker will not be held responsible for such payment.

\section{Application of the Garnishee Order to Various Types of Account}

\section{(a) Joint Accounts :}

A joint account is opened in the names of two or more persons. If only one of them is a judgement-debtor, the joint account cannot be attached. But, if both or all the joint account- holders are joint judgement- debtors in any legal proceedings, the joint account can be attached. For example, if $A$ owes a debt of $₹ 1,000$ to $B$ in his personal capacity, the latter cannot pray for the attachment of a joint account in the names of $A$ and $C$. But if $A$ and $C$ are jointly responsible for the debt, their joint account may be attached. But the reverse is possible, i.e., in the case of a debt jointly taken by two or more joint judgement-holders, their individuals accounts with the banks may be attached because each one of them is jointly and severally liable for the loans jointly taken by them.

\section{(b) Partnership Account:}

In case of debt taken by a partnership firm, the personal accounts of the partners can also be attached in addition to the account in the name of the firm because the liability of partners is both joint and several. But the reverse is not possible. If a partner is a judgement-debtor, only his individual account may be attached and not that of the firm or those of other partners. 


\section{(c) Trust Accounts:}

A trustee hold the funds or property of some else for the benefit of the beneficiary. An account opened in the personal name of the Trustee, in his capacity as such, cannot be utilized for paying his personal liabilities. The banker should, therefore, inform the court that the account is a Trust account and in the meanwhile stop payments from the account and instruct the Trustee.

\section{Rights of the Attaching Creditor}

When the garnishee deposits the attached amount in the Court, the attaching creditor ( or judgement- creditor) becomes a secured creditor. In Rikhabchand Mohanlal Surana vs. The Sholapur Spinning and Weaving Co. Ltd. (76 Bombay Law Reporter 748) the High Court held that -

"While the attachment is only by a prohibitory order then the attaching creditor has no rights in the property attached, but once the property or moneys come into the possession of the Court for the attaching creditor. The Court does not hold the money for the debtor more so when the garnishee obtains complete discharge by making payment in Court."

\section{Attachment Order Issued by Income- Tax Authorities}

The credit balance in the account of a customer of a banker may be attached by the Income-Tax authorities, if the former defaults in making payment of the tax due from him. Section 226 (3) of the Indian Income- Tax Act, 1961, authorizes the Income- Tax Act, 1961, authorities the Income Tax Officer "to require by notice in writing any person from whom money is due or may become due the assessee or any person who holds or may subsequently hold money for a or account of the assessee, to pay to the Income-Tax Officer an amount equal to or less than the amount of such arrears." Thus, the order of the Income-Tax Officer may attach (i) any debts due and payable, (ii) debts due but not payable on the date of the receipt of the notice, and (iii) any amount received subsequently. Balances lying in a joint account may also be attached even though the notice is issued on a single account. The share of the joint holders in such account shall be presumed, until contrary in proved, to be equal. Thus the amount to the credit of a joint account may be attached pro rata irrespective of the fact that the joint account is payable to 'either or survivor' or otherwise.

This section makes it obligatory for every person to whom such notice is issued to comply with such notice. In case of a banking company, it shall not be necessary for any pass book or deposit receipt or any other document to be produced for the purpose of any entry, endorsement, etc., before payment is made. After making payment as required under this section, the banker shall be fully discharged from his liability to the assessee to the extent of the discharged from his liability to the assessee to the extent of the amount so paid. But if he fails to make payment, he shall be deemed to be an assessee in default in respect of the amount specified in the notice and further proceedings may be taken against him for the realization of such amount. The banker should, therefore, comply with such order. His obligation towards his customer is reduced to that extent.

\section{RIGHTS OF A BANKER}

\section{Right of Appropriation}

In case of his usual business, a banker receives payments from his customer. If the latter has more than one account or has taken more than one loan from the banker, the question of the appropriation of the money subsequently deposited by him naturally arises. Section 59 to 61 of the Indian Contract Act, 1872 contains provisions regarding the right of appropriation of payments in such cases. According to Section 59 such right of appropriation is vested in the debtor, who makes a payment to his creditor to whom he owes several debts. He can appropriate the payment by (i). an express intimation or (ii) under circumstances implying that the payment is to be applied to the discharge of some particular debt. If the creditor accepts such payment, it must be applied accordingly. For example, A owes B several debts, including ₹ 1,000 upon a promissory note which falls due on 1st December, 1986. He owes $B$ no other debt of that amount. On 1-12-1986 A pays B $₹ 1,000$. The payment is to be applied to the discharge of the promissory note. 


\section{PP-BL\&P}

If the debtor does not intimate or there is no other circumstances indicating to which debt the payment is to be applied, the right of appropriation is vested in the creditor. He may apply it as his discretion to any lawful debt actually due and payable to him from the debtor (Section 60) Further, where neither party makes any appropriation, the payment shall be applied in discharge of each proportionately (Section 61).

In M/s. Kharavela Industries Pvt. Ltd. v. Orissa State Financial Corporation and Others [AIR 1985 Orissa 153 (A)], the question arose whether the payment made by the debtor was to be adjusted first towards the principal or interest in the absence of any stipulation regarding appropriation of payments in the loan agreement. The Court held that in case of a debt due with interest, any payment made by the debtor is in the first instance to be applied towards satisfaction of interest and thereafter toward the principal unless there is an agreement to the contrary.

In case a customer has a single account and he deposits and withdraws money from it frequently, the order in which the credit entry will set off the debit entry is the chronological order, as decided in the famous Clayton's Case. Thus the first item on the debit side will be the item to be discharged or reduced by a subsequent item on the credit side. The credit entries in the account adjust or set-off the debit entries in the chronological order. The rule derived from the Clayton's case is of great practical significance to the bankers. In a case of death, retirement or insolvency of a partner of a firm, the then existing debt due from the firm is adjusted or set-off by subsequent credit made in the account. The banker thus loses his right to claim such debt from the assets of the deceases, retired or insolvent partner and may ultimately suffer the loss if the debt cannot be recovered from the remaining partners. Therefore, to avoid the operation of the rule given in the Clayton's case the banker closes the old account of the firm and opens a new one in the name of the reconstituted firm. Thus the liability of the deceased, retired or insolvent partner, as the case may be, at the time of his death, retirement or insolvency is determined and he may be held liable for the same. Subsequent deposits made by surviving/ solvent partners will not be applicable to discharge the same.

\section{Right of General Lien}

One of the important rights enjoyed by a banker is the right of general lien. Lien means the right of the creditor to retain the goods and securities owned by the debtor until the debt due from him is repaid. It confers upon the creditor the right to retain the security of the debtor and not the right to sell it. Such right can be exercised by the creditor in respect of goods and securities entrusted to him by the debtor with the intention to be retained by him as security for a debt due by him (debtor).

Lien may be either (i) a general lien or, (ii) a particular lien. A particular lien can be exercised by a craftsman or a person who has spent his time, labour and money on the goods retained. In such cases goods are retained for a particular debt only. For example, a tailor has the right to retain the clothes made by him for his customer until his tailoring charges area paid by the customer. So is the case with public carriers and the repair shops.

A general lien, on the other hand, is applicable in respect of all amounts due from the debtor to the creditor. Section 171 of the Indian Contract Act, 1872, confers the right of general lien on the bankers as follows:

"Bankers... may, in the absence of a contract to the contrary, retain as a security for a general balance of account, any goods bailed to them."

\section{Special Features of a Banker's Right of General Lien}

(i) The banker possesses the right of general lien on all goods and securities entrusted to him in his capacity as a banker and in the absence of a contract inconsistent with the right of lien. Thus, he cannot exercise his right of general lien if -

(a) the goods and securities have been entrusted to the banker as a trustee or an agent of the customer; and

(b) a contract - express or implied - exists between the customer and the banker which is inconsistent with the banker's right of general lien. In other words, if the goods or securities are entrusted for some specific purpose, the banker cannot have a lien over them. These exceptional cases are discussed later on. 
(ii) A banker's lien is tantamount to an implied pledge: As noted above the right of lien does not confer on the creditor the right of sale but only the right to retain the goods till the loan is repaid. In case of pledge ${ }^{8}$ the creditor enjoys the right of sale. A banker's right of lien is more than a general lien. It confers upon him the power to sell the goods and securities in case of default by the customer. Such right of lien thus resembles a pledge and is usually called an ' implied pledge'. The banker thus enjoys the privileges of a pledge and can dispose of the securities after giving proper notice to the customer.

(iii) The right of lien is conferred upon the banker by the Indian Contract Act: No separate agreement or contract is, therefore, necessary for this purpose. However, to be on the safe side, the banker takes a letter of lien from the customer mentioning that the goods are entrusted to the banker as security for a loan-existing or future-taken from the banker and that the latter can exercise his right of lien over them. The banker is also authorized to sell the goods in case of default on the part of the customer. The latter thus spells out the object of entrusting the goods to the banker so that the same may not be denied by the customer later on.

(iv). The right of lien can be exercised on goods or other securities standing in the name of the borrower and not jointly with others. For example, in case the securities are held in the joint names of two or more persons the banker cannot exercise his right of general lien in respect of a debt due from a single person.

(v) The banker can exercise his right of lien on the securities remaining in his possession after the loan, for which they are lodged, is repaid by the customer, if no contract to contrary exists. In such cases it is an implied presumption that the customer has re-offered the same securities as a cover for any other advance outstanding on that date or taken subsequently. The banker is also entitled to exercise the right of general lien in respect of a customer's obligation as a surety and to retain the security offered by him for a loan obtained by him for his personal use and which has been repaid. In Stephen Manager North Malabar Gramin Bank vs. ChandraMohan and State of Kerala, the loan agreement authorized the bank to treat the ornaments not only as a security for that loan transaction, but also for any other transaction or liability existing or to be incurred in future. As the liability of the surety is joint and several with that of the principal debtor, such liability also came within the ambit of the above provision of the agreement.

Section 171 of the Contract Act entitles a banker to retain the goods bailed to him for any other debt due to him, i.e., any debt taken prior to the debt for which the goods were entrusted as security.

But in a lien there should be a right of possession because, lien is a right of one man to retain that which is in his possession belonging to another. Possession of the goods by the person claiming right of lien, is anterior to the exercise of that right and for which possession whether actual or conductive is a must. (Syndicate Bank Vs. Davander Karkare (A.I.R. 1994 Karnataka 1)

\section{Exceptions to the Right of General Lien}

As already noted the right of lien can be exercised by a banker on the commodities entrusted to him in his capacity as a banker and without any contract contrary to such right. Thus the right of lien cannot be exercised in the following circumstances:

(a) Safe custody deposits. When a customer deposits his valuables - securities, ornaments, documents, etc. - with the banker for safe custody, he entrusts them to the banker $s$ a bailee or trustee with the purpose to ensure their safety from theft, fire, etc. A contract inconsistent with the right of lien is presumed to exist. For example, if he directs the banker to collect the proceeds of a bill of exchange on its maturity and utilize the same for honouring a bill of exchange on his behalf, the amount so realized will not be subject to the right of general lien.

Similarly, if a customer hands over to the banker some shares with the instruction to sell them at or above a certain price and the same are lying unsold with the banker, the latter cannot exercise his right of lien on the same, because the shares have been entrusted for a specific purpose and hence a contract inconsistent with the right of lien comes into existence. 
But if no specific purpose is mentioned by the customer, the banker can have lien on bills or cheques sent for collection or dividend warrants, etc. If the security comes into the possession of the banker in the ordinary course of business, he can exercise his right of general lien.

(c) Right of General Lien becomes that of Particular Lien. Banker's right of general lien is displaced by circumstances which show an implied agreement inconsistent with the right of general lien. In Vijay Kumar v. M/s. Jullundur Body Builders, Delhi, and Others (A.I.R. 1981, Delhi 126), the Syndicate Bank furnished a bank guarantee for ₹ 90,000 on behalf of its customer. The customer deposited with it as security two fixed deposit receipts, duly discharged, with a covering letter stating that the said deposits would remain with the bank so long on any amount was due to the Bank from the customer. Bank made an entry on the reverse of Receipt as "Lien to BG 11/80." When the bank guarantee was discharged, the bank claimed its right of general lien on the fixed deposit receipt, which was opposed on the ground that the entry on the reverse of the letter resulted in the right of a particular lien, i.e., only in respect of bank guarantee.

The Delhi High Court rejected the claim of the bank and held that the letter of the customer was on the usual printed form while" the words written by the officer of the bank on the reverse of the deposit receipt were specific and explicit. They are the controlling words, which unambiguously tell us what was in the minds of the parties of the time. Thus the written word which prevail over the printed "word". The right of the banker was deemed that of particular lien rather than of general lien.

(d) Securities left with the banker negligently. The banker does not possess the right of lien on the documents or valuables left in his possession by the customer by mistake or by negligence.

(e) The banker cannot exercise his right of lien over the securities lodged with him for securing a loan, before such loan is actually granted to him.

(f) Securities held in Trust. The banker cannot exercise his right of general lien over the securities deposited by the customer as a trustee in respect of his personal loan. But if the banker is unaware of the fact that the negotiable securities do not belong to the customer, his right of general lien is not affected.

(g) Banker possesses right of set-off and not lien on money deposited. The banker's right of lien extends over goods and securities handed over to the banker. Money deposited in the bank and the credit balance in the accounts does not fall in the category of goods and securities. The banker may, therefore, exercise his right of set -off rather the right of lien in respect of the money deposited with him. The Madras High Court expressed this view clearly as follows:

The lien under Section 171 can be exercised only over the property of someone else and not own property. Thus when goods are deposited with or securities are placed in the custody of a bank, it would be correct to speak of right of the bank over the securities or the goods as a lien because the ownership of the goods or securities would continue to remain in the customer. But when moneys are deposited in a bank as a fixed deposit, the ownership of the moneys passes to the bank and the right of the bank over the money lodged with it would not be really lien at all. It would be more correct speak of it as a right to set-off or adjustment." (Brahammaya vs. K.P. Thangavelu Nadar, AIR (1956), Madras 570)

\section{Right of set- off}

The right of set-off is a statutory right which enables a debtor to take into account a debt owed to him by a creditor, before the latter could recover the debt due to him from the debtor. In other words, the mutual claims of debtor and creditor are adjusted together and only the remainder amount is payable by the debtor. A banker, like other debtors, possesses this right of set-off which enables him to combine two accounts in the name of the same customer and to adjust the debit balance in one account with the credit balance in the other. For example, A has taken an overdraft from his banker to the extent of ₹ 5,000 and he has a credit balance of ₹ 2,000 in his savings bank account, the banker can combine both of these accounts and claim the remainder amount of ₹ 3,000 only. This right of set-off can be exercised by the banker if there is no agreement-express or implied-contrary to this right and after a notice is served on the customer intimating the latter about the former's intention to exercise the 
right of set-off. To be on the safer side, the banker takes a letter of set-off from the customer authorizing the banker to exercise the right of set-off without giving him any notice. The right of set-off can be exercised subject to the fulfillment of the following conditions:

(i) The accounts must be in the same name and in the same right. The first and the most important condition for the application of the right of set-off is that the accounts with the banker must not only be in the same name but also in the same right. By the words 'the same right' meant that the capacity of the accountholder in both or call the accounts must be the same, i.e., the funds available in one account are held by him in the same right or capacity in which a debit balance stands in another account. The underlying principle involved in this rule is that funds belonging to someone else, but standing in the same name of the account - holder, should not be made available to satisfy his personal debts. The following examples, make this point clear:

(a) In case of a sole trader the account in his personal name and that in the firm's name are deemed to be in the same right and hence the right of set-off can be exercised in case either of the two accounts is having debit balance.

(b) In case the partners of a firm have their individual accounts as well as the account of the firm with the same bank, the latter cannot set-off the debt due from the firm against the personal accounts of the partners. But if the partners have specially undertaken to be jointly and severally liable for the firm's debt due to the banker, the latter can set-off such amount of debt against the credit balances in the personal accounts of the partners.

(c) An account in the name of a person in his capacity as a guardian for a minor is not be treated in the same right as his own account with the banker.

(d) The funds held in Trust account are deemed to be in different rights. If a customer opens a separate account with definite instructions as regards the purpose of such account, the latter should not be deemed to be in the same right. The case of Barclays Bank Ltd. v. Quistclose Investment Limited may be cited as an illustration. Rolls Rozer Ltd .borrowed an amount from Quistclose Investment Ltd. with the specific purpose of paying the dividend to the shareholders and deposited the same in a separate account 'Ordinary Dividend No. 4 Account with Barclays Bank Ltd. and the latter was also informed about the purpose of this deposit. The company went into liquidation before the intended dividend could be paid and the banker combined all the accounts of the company, including the above one. Quistclose Investment Ltd., the creditors of the company, claimed the repayment of the balance in the above account which the bank refused. It was finally decided that by opening an account for the specific purpose of paying the dividend a trust arose in favour of the shareholders. If the latter could not get the funds, the benefit was to go to the Quistclose Investment Ltd. and to the bank. The banker was thus not entitled to set-off the debit balance in the company's account against the credit balance in the above account against the credit balance in the above account. The balance held in the clients' account of an advocate is not deemed to be held in the same capacity in which the amount is held in his personal account.

(e) In case of a joint account, a debt due from one of the joint account- holders in his individual capacity cannot be set-off against an amount due to him by the bank in the joint account. But the position may appear to be different if the joint account is payable to ' former or survivor'. Such an account is deemed to be primarily payable to the former and only after his death to the survivor. Thus the former's debt can be set-off against the balance in the joint account.

(ii) The right can be exercised in respect of debts due and not in respect of future debts or contingent debts. For example, a banker can set-off a credit balance in the account of customer towards the payment of a bill which is already due but not in respect of a bill which will mature in future. If a loan given to a customer is repayable on demand or at a future date, the debt becomes due only when the banker makes a demand or on the specified date and not earlier. 
(iii) The amount of debts must be certain. It is essential that the amount of debts due from both the parties to each other must be certain. If liability of any one of them is not determined exactly, the right of setoff cannot be exercised. For example, if $A$ stands as guarantor for a loan of ₹ 50,000 given by a bank to $B$, his liability as guarantor will arise only after $B$ defaults in making payment. The banker cannot setoff the credit balance in his account till his liability as a guarantor is determined. For this purpose it is essential that the banker must first demand payment from his debtor. If the latter defaults in making payment of his payment of his debt, only then the liability of the guarantor arises and the banker can exercise his right of set-off against the credit balance in the account of the guarantor. The banker cannot exercise this right as and when he realizes that the amount of debt has becomes sticky, i.e., irrecoverable.

(iv) The right may be exercised in the absence of an agreement to the contrary. If there is agreementexpress or implied-inconsistent with the right of set-off, the banker cannot exercise such right. If there is an express contract between the customer and the banker creating a lien on security, it would exclude operation of the statutory general lien under Section 171 of the Indian Contract Act, 1872. In Krishna Kishore Karv. Untitled Commercial Bank and Another (AIR 1982 Calcutta 62), the UCO Bank, on the request of its customer K.K. Kar, issued guarantee for ₹ 2 lakhs in favour of the suppliers of coal guaranteeing payment for coal supplied to him. The customer executed a counter- guarantee in favour of the Bank and also paid margin money ₹ 1.83 lakhs to the Bank. After fulfilling its obligations under the guarantee, the Bank adjusted ₹ 76,527 due from the customer under different accounts against the margin money deposited by the customer in exercise of its lien (or alternatively the right of set-off). The High Court held that the bank was not entitled to appropriate or adjust its claims under Section 171 of the Contract Act in view of the existence of the counter- guarantee, which constituted a contract contrary to the right of general lien.

(v) The Banker may exercise this right at his discretion. For the purpose of exercising this right of all branches of a bank constitute one entity and the bank can combine two or more accounts in the name of the same customer at more than one branch. The customer, however, cannot compel or pursue the banker to exercise the right and to pay the credit balance at any other branch.

(vi) The banker has right to exercise this right before the garnishee order is made effective. In case a banker receives a garnishee order in respect of the funds belonging to his customer, he has the right first to exercise his right of set-off and thereafter to surrender only the remainder amount to the judgementcreditor.

\section{Right to charge Interest and Incidental Charges, etc.}

As a creditor, a banker has the implied right to charge interest on the advances granted to the customer. Bankers usually follow the practice of debiting the customer's account periodically with the amount of interest due from the customer. The agreement between the banker and the customer may, on the other hand, stipulate that interest may be charged at compound rate also. In Konakolla Venkata Satyanarayana \& Others vs. State Bank of India (AIR, 1975 A.P. 113) the agreement provided that "interest.... shall be calculated on the daily balance of such amount and shall be charged to such account on the last working day of each month." For several years the customer availed the overdraft facilities and periodical statements of accounts were being sent to the customer showing that interest was being charged and debited at compound rate and no objection was raised at any time. The High Court, therefore, held that there was no doubt that the customer had agreed to the compound rate of interest being charged and debited to his account. The customer need not pat the amount of interest in cash. After making a debit entry in the account of the customer, the amount of interest is also deemed as a debt due from the customer to the banker and interest accrues on the same in the next period. The same practice is followed in allowing interest on the savings accounts. Banks also charge incidental charges on the current accounts to meet the incidental expenses on such accounts. 


\section{VARIOUS TYPES OF CUSTOMERS}

\section{Individuals}

Accounts of individuals form a major chunk of the deposit accounts in the personal segment of most banks. Individuals who are major and of sound mind can open a bank account.

\section{(a) Minors:}

In case of minor, a banker would open a joint account with the natural guardian. However to encourage the habit of savings, banks open minor accounts in the name of a minor and allows single operations by the minor himself/ herself. Such accounts are opened subject to certain conditions like (i) the minor should be of some minimum age say 12 or 13 years or above (ii) should be literate (iii) No overdraft is allowed in such accounts (iv) Two minors cannot open a joint account. (v) The father is the natural guardian for opening a minor account, but RBI has authorized mother also to sign as a guardian (except in case of Muslim minors)

\section{(b) Joint Account Holders:}

A joint account is an account by two or more persons. At the time of opening the account all the persons should sign the account opening documents. Operating instructions may vary, depending upon the total number of account holders. In case of two persons it may be (i) jointly by both account holders (ii) either or survivor (iii) former or survivor In case no specific instructions is given, then the operations will be by all the account holders jointly, The instructions for operations in the account would come to an end in cases of insanity, insolvency, death of any of the joint holders and operations in the account will be stopped.

\section{(c) Illiterate Persons}

Illiterate persons who cannot sign are allowed to open only a savings account (without cheque facility) or fixed deposit account. They are generally not permitted to open a current account. The following additional requirements need to be met while opening accounts for such persons:

- The depositor's thumb impression (in lieu of signature) is obtained on the account opening form in the presence of preferably two persons who are known to the bank and who have to certify that they know the depositor.

- The depositor's photograph is affixed to the ledger account and also to the savings passbook for identification.

Withdrawals can be made from the account when the passbook is furnished, the thumb impression is verified and a proper identification of the account holder is obtained

\section{Hindu Undivided Family (HUF)}

HUF is a unique entity recognized under the Hindu customary law as comprising of a 'Karta' (senior-most male member of the joint family), his sons and grandsons or even great grandsons in a lineal descending order, who are 'coparceners' (who have an undivided share in the estate of the HUF). The right to manage the HUF and its business vests only in the Karta and he acts on behalf of all the coparceners such that his actions are binding on each of them to the extent of their shares in the HUF property. The Karta and other coparceners may possess self-acquired properties other than the HUF property but these cannot be clubbed together for the HUF dues.

HUF business is quite distinct from partnership business which is governed by Indian Partnership Act, 1932. In partnership, all partners are individually and collectively liable to outsiders for the dues of the partnership and all their individual assets, apart from the assets of the partnership, would be liable for attachment for partnership dues. Contrarily, in HUF business, the individual properties of the coparceners are spared from attachment for HUF dues. 
The following special requirements are to be fulfilled by the banks for opening and conducting HUF accounts:

- The account is opened in the name of the Karta or in the name of the HUF business.

- A declaration signed by Karta and all coparceners, affirms the composition of the HUF, its Karta and names and relationship of all the coparceners, including minor sons and their date of birth.

- The account is operated only by the Karta or the authorized coparceners.

- In determining the security of the family property for purposes of borrowing, the self-acquired properties of the coparceners are excluded.

- On the death of a coparcener, his share may be handed over to his wife, daughters and other female relatives as per the Hindu Succession Act, 1956.

The Hindu Succession Act, 1956 has been amended in 2005. The Amendment Act confers equal rights to daughters in the Mitakshara Coparcenary property. With this amendment the female coparcener can also act as Karta of the HUF. When any HUF property is to be mortgaged to the Bank as a security of loan, all the major coparceners (including female coparceners) will have to execute the documents

\section{Firms}

The concept of 'Firm' indicates either a sole proprietary firm or a partner- ship firm. A sole proprietary firm is wholly owned by a single person, whereas a partnership firm has two or more partners. The sole-proprietary firm's account can be opened in the owner's name or in the firm's name. A partnership is defined under section 4 of the Indian Partnership Act, 1932, as the relationship between persons who have agreed to share the profits of business carried on by all or any of them acting for all. It can be created by an oral as well as written agreement among the partners. The Partner- ship Act does not provide for the compulsory registration of a firm. While an unregistered firm cannot sue others for any cause relating to the firm's business, it can be sued by the outsiders irrespective of its registration. In view of the features of a partnership firm, bankers have to ensure that the following requirements are complied with while opening its account:

- The account is opened in the name of the firm and the account opening form is signed by all the partners of the firm.

- Partnership deed executed by all the partners (whether registered or not) is recorded in the bank's books, with suitable notes on ledger heading, along with relevant clauses that affect the operation of the account.

- Partnership letter signed by all the partners is obtained to ensure their several and joint liabilities. The letter governs the operation of the account and is to be adhered to accordingly.

The following precautions should be taken in the conduct of a partnership account:

- The account has to be signed 'for and on behalf of the firm' by all the authorized partners and not in an individual name.

- A cheque payable to the firm cannot be endorsed by a partner in his name and credited to his personal account.

- In case the firm is to furnish a guarantee to the bank, all the partners have to sign the document.

- If a partner (who has furnished his individual property as a security for the loan granted to the firm) dies, no further borrowings would be permitted in the account until an alternative for the deceased partner is arranged for, as the rule in Clayton's case operates. 


\section{Companies}

A company is a legal entity, distinct from its shareholders or managers, as it can sue and be sued in its own name. It is a perpetual entity until dissolved. Its operations are governed by the provisions of the Companies Act, 1956. A company can be of three types:

- Private Limited company: Having 2 to 51 shareholders.

- Public company: Having 7 or more shareholders.

- Government company: Having at least 51per cent shareholdings of Government (Central or State).

The following requirements are to be met while opening an account in the name of a company:

- The account opening form meant for company accounts should be filled and specimen signatures of the authorized directors of the company should be obtained.

- Certified up-to-date copies of the Memorandum and Articles of Association should be obtained. The powers of the directors need to be perused and recorded to guard against 'ultra vires' acts of the company and of the directors in future.

- Certificate of Incorporation (in original) should be perused and its copy retained on record.

- In the case of Public company, certificate of commencement of business should be obtained and a copy of the same should be recorded. A list of directors duly signed by the Chairman should also be obtained.

- Certified copy of the resolution of the Board of Directors of the company regarding the opening, execution of the documents and conduct of the account should be obtained and recorded.

\section{Trusts}

A trust is a relationship where a person (trustee) holds property for the benefit of another person (beneficiary) or some object in such a way that the real benefit of the property accrues to the beneficiary or serves the object of the trust. A trust is generally created by a trust deed and all concerned matters are governed by the Indian Trusts Act, 1882 .

The trust deed is carefully examined and its relevant provisions, noted. A banker should exercise extreme care while conducting the trust accounts, to avoid committing breach of trust:

- A trustee cannot delegate his powers to other trustees, nor can all trustees by common consent delegate their powers to outsiders.

- The funds in the name of the trust cannot be used for crediting in the trustee's account, nor for liquidating the debts standing in the name of the trustee.

- The trustee cannot raise loan without the permission of the court, unless permitted by the trust deed.

\section{Clubs}

Account of a proprietary club can be opened like an individual account. However, clubs that are collectively owned by several members and are not registered under Societies Registration Act, 1860, or under any other Act, are treated like an unregistered firm. While opening and conducting the account of such clubs, the following requirements are to be met:

- Certified copy of the rules of the club is to be submitted.

- Resolution of the managing committee or general body, appointing the bank as their banker and specifying the mode of operation of the account has to be submitted,

- The person operating the club account should not credit the cheques drawn favouring the club, to his personal account. 


\section{Local Authorities}

Municipal Corporation, Panchayat Boards are local authorities created by specific Acts of the state legislature. Their constitution, functions, powers, etc. are governed by those Acts. Bankers should ensure that accounts of such bodies are opened and conducted strictly as per the provisions of the relevant Act and regulations framed there under. The precautions applicable for company or trust accounts are also applicable in the case of these accounts, in order to guard against ultra vires acts by the officers of the local authority operating the account.

\section{Co-operative societies}

Co-operative societies are required to open accounts only with these banks which are recognized for this purpose (under the Co-operative Society Act). The following documents should be obtained while opening their account:

- Certificate of registration of the society under the Co-operative Society Act.

- Certified copy of the bye-laws of the society.

- Resolution of the managing committee of the society prescribing the conditions for the conduct of the account.

- List of the members of the managing committee with the copy of the resolution electing them as the committee members.

\section{CLOSING OF A BANK ACCOUNT - TERMINATION OF BANKER-CUSTOMER RELATIONSHIP}

Banker-customer relationship is a contractual relationship between two parties and it may be terminated by either party on voluntary basis or involuntarily by the process of law. These two modes of termination are described below.

1. Voluntary Termination: The customer has a right to close his demand deposit account because of change of residence or dissatisfaction with the service of the banker or for any other reason, and the banker is bound to comply with this request. The banker also may decide to close an account, due to an unsatisfactory conduct of the account or because it finds the customer undesirable for certain reasons. However, a banker can close an account only after giving a reasonable notice to the customer. However, such cases of closure of an account at the instance of the banker are quite rare, since the cost of securing and opening a new account is much higher than the cost of closing an account. If a customer directs the banker in writing to close his account, the banker is bound to comply with such direction. The latter need not ask the reasons for the former's direction. The account must be closed with immediate effect and the customer be required to return the unused cheques.

2. If the Bank desires to close the account: If an account remains un-operated for a very long period, the banker may request the customer to withdraw the money. Such step is taken on the presumptions that the customer no longer needs the account. If the customer could not be traced after reasonable effort, the banker usually transfers the balance to an "Unclaimed Deposit Account", and the account is closed. The balance is paid to the customers as and when he is traced.

The banker is also competent to terminate his relationship with the customer, if he finds that the latter is no more a desirable customer. The banker takes this extreme step in circumstances when the customer is guilty of conducting his account in an unsatisfactory manner, i.e. if the customer is convicted for forging cheques or bills or if he issues cheques without sufficient funds or does not fulfil his commitment to pay back the loans or overdrafts, etc. The banker should take the following steps for closing such an account.

(a) The banker should give to the customer due notice of his intention to close the account and request 
him to withdraw the balance standing to his credit. This notice should give sufficient time to the customer to make alternative arrangements. The banker should not, on his own, close the account without such notice or transfer the same to any other branch.

(b) If the customer does not close the account on receipt of the aforesaid notice, the banker should give another notice intimating the exact date by which the account be closed otherwise the banker himself will close the account. During this notice period the banker can safely refuse to accept further credits from the customer and can also refuse to issue fresh cheque book to him. Such steps will not make him liable to the customer and will be in consonance with the intention of the notice to close account by a specified date.

The banker should, however, not refuse to honour the cheques issued by the customer, so long as his account has a credit balance that will suffice to pay the cheque. If the banker dishonours any cheque without sufficient reasons, he will be held liable to pay damages to his customer under Section 31 of the Negotiable Instruments Act, 1881. In case of default by the customer to close the account, the banker should close the account and send the money by draft to the customer. He will not be liable for dishonouring cheques presented for payment subsequently.

3. Termination by Law: The relationship of a banker-customer can also be terminated by the process of law and by the occurrence of the following events:

(a) Death of customer: On receiving notice or information of the death of a customer, the bank stops all debit transactions in the account. However, credits to the account can be permitted. The balance in the account is given to the legal representative of the deceased after obtaining the letters of administration, or succession certificate, or indemnity bond as per the prescribed procedure, and only then, the account is closed.

(b) Bankruptcy of customer: An individual customer may be declared bankrupt, or a company may be wound up under the provisions of law. In such an event, no drawings would be permitted in the account of the individual/company. The balance is given to the Receiver or Liquidator or the Official Assignee and the account is closed thereafter.

(c) Garnishee Order: After receiving a garnishee order from a court or attachment order from income tax authority, the account can be closed as one of the options after taking the required steps.

(d) Insanity of the customer: A lunatic/person of unsound mind is not competent to contract under Section 11 of the Indian Contract Act, 1872. Since banker-customer relationship is contractual, the bank will not honour cheques and can close the account after receiving notice about the insanity of the customer and receiving a confirmation about it through medical reports.

\section{VARIOUS DEPOSIT SCHEMES}

\section{Deposits - General}

Deposits of banks are classified into three categories:

(1) Demand deposits are repayable on customers' demand. These comprise of:

- Current account deposits

- Savings bank deposits

- Call deposits

(2) Term deposits are repayable on maturity dates as agreed between the customers and the banker. These comprise of: 
- Fixed deposits

- Recurring deposits

(3) Hybrid deposits or flexi deposits combine the features of demand and term deposits. These deposits have been lately introduced in by some banks to better meet customers' financial needs and convenience and are known by different names in different banks.

The demand and time deposits of a bank constitute its demand and time liabilities that the bank reports every week (on every Friday) to the RBI.

\section{Demand Deposits}

\section{(a) Current account:}

A current account is a running and active account that may be operated upon any number of times during a working day. There is no restriction on the number and the amount of withdrawals from a current account. Current accounts can be opened by individuals, business entities (firms, company), institutions, Government bodies / departments, societies, liquidators, receivers, trusts, etc. The other main features of current account are as under:

- Current accounts are non-interest bearing and banks are not allowed to pay any interest or brokerage to the current account holders.

- Overdraft facility for a short period or on a regular basis up to specified limits - are permitted in current accounts. Regular overdraft facility is granted as per prior arrangements made by the account holder with the bank. In such cases, the bank would honour cheques drawn in excess of the credit balance but not exceeding the overdraft limit. Prescribed interest is charged on overdraft portion of drawings.

- Cheques/ bills collection and purchase facilities may also be granted to the current account holders.

- The account holder periodically receives statement of accounts from the Bank.

- Normally, banks levy charges for handling such account in the shape of "Ledger Folio charges". Some banks make no charge for maintenance of current account provided the balance maintained is sufficient to compensate the Bank for the work involved.

- Third party cheques and cheques with endorsements may be deposited in the current account for collection and credit.

\section{(b) Current Deposits Premium Scheme:}

This is a deposit product which combines Current \& Short deposit account with 'sweep-in' and 'sweep-out' facility to take care of withdrawals, if any. Besides containing all features of a current account, the product is aimed at offering current account customers convenient opportunity to earn extra returns on surplus funds lying in account which may not normally be utilized in the near future or are likely to remain unutilized. The automated nature of facility for "Sweep In or Sweep Out" of more than a specified limit of balance to be maintained and creating fixed deposits for desired period, would save lot of operational hassles and add-on value in such accounts. Thus, with this facility the customer shall be able to deploy his funds which in ordinary current account were not attracting any interest.

Sweep out from current to short deposits may be automatically when balance in the account is more than a specified limit or weekly or on specific days which may be on 1 st $\& 16$ th of every month or once within a month as prescribed by an individual bank.

\section{(c) Savings Account}

Savings bank accounts are meant for individuals and a group of persons like Clubs, Trusts, Associations, Self Help Groups (SHGs) to keep their savings for meeting their future monetary needs and intend to earn income 
from their savings. Banks give interest on these accounts with a view to encourage saving habits. Everyone wants to save for something in the future and their savings should be safe and accessible anytime, anyplace to help meet their needs. This account helps an individual to plan and save for his future financial requirements. In this account savings are completely liquid.

Main features of savings bank accounts are as follows:

- Withdrawals are permitted to the account-holder on demand, on presentation of cheques or withdrawal form/letter. However, cash withdrawals in excess of the specified amount per transaction/day (the amount varies from bank to bank) require prior notice to the bank branch.

- Banks put certain restrictions on the number of withdrawals per month/quarter, amount of withdrawal per day, minimum balance to be maintained in the account on all days, etc. A fee/penalty is levied if these are violated. These rules differ from bank to bank, as decided by their Boards. The rationale of these restrictions is that the Savings Bank account should not be used like a current account since it is primarily intended for attracting and accumulating savings.

- The Bank pays interest on the products of balances outstanding on daily basis. Rate of interest is decided by bank from time to time.

- No overdraft in excess of the credit balance in savings bank account is permitted as there cannot be any debit balance in savings account.

- Most banks provide a passbook to the account-holder wherein date-wise debit credit transactions and credit balances are shown as per the customer's ledger account maintained by the Bank.

- Cheque Book Facility Accounts in which withdrawals are permitted by cheques drawn in favour of self or other parties. The payees of the cheque can receive payment in cash at the drawee bank branch or through their bank account via clearing or collection. The account holder may also withdraw cash by submitting a withdrawal form along with Pass Book, if issued.

- Non-cheque Book Facility accounts where account holders are permitted to withdraw only at the drawee bank branch by submitting a withdrawal form or a letter accompanied with the account passbook requesting permission for withdrawal. In such cases third parties cannot receive payments.

- Almost all banks which provide ATM facility, give ATM cards to their accounts holder, so that they avail withdrawal facility 24 hours and all days at any place.

\section{(d) Basic Savings Bank Deposit Account}

With a view to making the basic banking facilities available in a more uniform manner across banking system, RBI has modified the guidelines on opening of basic banking 'no-frills' accounts'. Such accounts are now known as "Basic Savings Bank Deposit" Account which offers the minimum common facilities as under:-

- The account should be considered as a normal banking service available to all;

- No requirement of minimum balance;

- Facilitate deposit and withdrawal of cash at bank branch as well as ATMs;

- Receipt/credit of money through electronic payment channels or by means of cheques/ collection of cheques drawn by Central/State Government Agencies and departments;

- Account holders are permitted a maximum of four withdrawals in a month including ATM withdrawals;

- Facility of ATM card or ATM-cum Debit Card

- Facilities are free of charge and no charge would be levied for non-operation/activation of in-operative 'Basic Savings Bank Deposit Account'; 
- Holders of 'Basic Savings Bank Deposit Account' are not eligible for opening of any other savings bank accounts and existing such accounts should be closed down within a period of 30 days from the date of opening of 'Basic Savings Bank Deposit Account'.

- Existing 'no frills' accounts can be converted to 'Basic Savings Bank Deposit Account'

\section{(e) Premium or Savings Bank Plus Account:}

Premium Savings Account provides an enriched version of Savings Bank account consisting of various concessions and add-ons. It is suitable for High Net worth Individual/ Mass Affluent customers. The account will be linked to Multi Option Deposit (MOD) account, for auto sweep, for issue of Term Deposits and unitized break-up facilities. Any surplus funds in the account exceeding the threshold limit, for a minimum amount of ₹10,000/- and in multiple of ₹1000/- in any one instance, are transferred as Term Deposit and earns interest as applicable to Term Deposits. The account is useful to those persons who have surplus funds for an uncertain period and by keeping the fund in this Savings Bank account, they may get interest of term deposit. This account provides a customer the convenience of a Savings Bank Account along with higher return of Term Deposit.

\section{(f) Deposit at Call Accounts:}

Call deposits or deposit at call accounts are maintained by fellow banks with another bank which are payable on demand only. Some banks have put restriction of giving advance notice of a week or less than that when depositor requires payment of call deposits. These accounts may or may not fetch interest, as per the rules framed by the $\mathrm{RBI}$ or Indian Banks Association (IBA) from time- to-time.

\section{Term Deposits}

\section{(a) Recurring Deposits or Cumulative Deposits :}

In Recurring Deposits accounts, a certain amount of savings are required to be compulsorily deposited at specified intervals for a specific period. These are intended to inculcate regular and compulsory savings habit among the low/middle income group of people for meeting their specific future needs e.g. higher education or marriage of children, purchase of vehicles etc. The main features of these deposits are:

- The customer deposits a fixed sum in the account at pre-fixed frequency (generally monthly/quarterly) for a specific period (12 months to 120 months).

- The interest rate payable on recurring deposit is normally the applicable rate of fixed deposits for the same period.

- The total amount deposited is repaid along with interest on the date of maturity.

- The depositor can take advance against the deposits up to $75 \%$ of the balance in the account as on the date of advance or have the deposits pre-paid before the maturity, for meeting emergent expenses. In the case of pre-mature withdrawals, the rate of interest would be lower than the contracted rate and some penalty would also be charged. Similarly, interest is charged on advance against the deposits, which is normally one or two per cent higher than the applicable rate of interest on deposits.

\section{(b) Monthly-Plus Deposit Scheme / Recurring Deposit Premium account}

It is a recurring deposit scheme with flexibility of "Step-up and Step-down" options of monthly instalments. The scheme is available to individuals, institutions, corporate, proprietorship or partnership firms, trusts, HUF, etc. Under the scheme, the customer selects the "core amount" at the time of opening the account and deposits the same initially. Minimum core amount may be ₹100 and maximum ₹1,00,000. Period of deposit will be pre-decided by the customer himself. The depositor can deposit instalment in excess of the minimum core amount (but not exceeding ten times of the core amount) in the multiples of ₹100 in any month. Like stepping up the instalment amount, a customer can also reduce the same (Step-down) in any subsequent months but no below the core 
amount. The interest on this scheme will be as per the term deposit rate applicable for the fixed period. Interest will be calculated on the monthly product basis, for the minimum balance between the $10^{\text {th }}$ and the last day of the month and will be credited quarterly.

\section{(c) Fixed Deposits}

Fixed deposits are repayable on the fixed maturity date along with the principal and agreed interest rate for the period and no operations are allowed to be performed by the customer against the deposit, as is permitted in demand deposits. The depositor foregoes liquidity on the deposit and the bank can freely deploy such funds for loans/advances and earn interest.

Hence, banks pay higher interest rates on fixed deposits as compared to savings bank deposits from which he can withdraw, requiring banks to keep some portion of deposits always at the disposal of the depositors. Another reason for banks paying higher interest on fixed deposits is that the administrative cost in the maintenance of these accounts is very small as compared to savings bank accounts where several transactions take place in cash, transfer or clearing, thus increasing the administrative cost. Main Features of Fixed Deposits are as follows:

- Fixed deposits are accepted for specific periods at specified interest rates as mutually agreed between the depositor and the banker at the time of opening the account. Since the interest rate on the deposit is contractual, it cannot be altered even if the interest rate fluctuates - upward or downward - during the period of the deposit.

- The interest rates on fixed deposits, which were earlier regulated by the RBI, have been deregulated and banks offer varying interest rates for different maturities as decided by their boards. The maturitywise interest rates in a bank will, however, be uniform for all customers subject to two exceptions high value deposits above certain cut-off value and deposits of senior citizens (above the specified age normally 60 years); these may be offered higher interest rate as per specified Basis Points. However, specific directions are issued by the bank's board with regard to the differential rate and the authority vested to allow such differential rate of interest, to prevent discrimination and misuse at branch level.

- Minimum period of fixed deposit is 7 days, as per the directive of the RBI. The maximum term and band of term maturities are deter- mined by each bank along with the respective interest rates for each band.

- Adeposit receipt is issued by the bank branch accepting the fixed deposit- mentioning the depositor's name, principal amount, maturity period and interest rate, dates of the deposit and its maturity etc. The deposit receipt is not a negotiable instrument, nor is it transferable, like a cheque. However, a term deposit receipt evidences contract for the deposit on the specified terms.

- On maturity of a deposit, the principal and interest can be renewed for another term at an interest rate prevalent at that time and a fresh deposit receipt is issued to the customer, evidencing a fresh contract. Alternatively, the deposit can be paid up by obtaining the discharge of the depositor on the reverse of the receipt.

- Many banks prepay fixed deposits, at their discretion, to accommodate customers' request for meeting emergent expenses. In such cases, interest is paid for the period actually elapsed and at a rate generally1 per cent lower than that applicable to the period elapsed. Banks also may grant overdraft/ loan against the security of their fixed deposits to meet emergent liquidity requirements of the customers. The interest on such facility will be 1 per cent -2 per cent higher than the interest rate on the fixed deposit.

\section{(d) Special Term Deposits}

Special Term Deposit carries all features of Fixed Deposit. In addition to these, interest gets compounded every 
quarter resulting higher returns to the depositors. Now-a-days, $80 \%$ of the term deposits in banks is under this scheme.

\section{Higher Interest payable to Senior Citizens:}

Persons who have attained the age of 60 years are "Senior Citizens" in regard to the payment of higher interest not exceeding $1 \%$ over and above the normal rates of term deposits. Each bank has prepared its own scheme of term deposits for senior citizens.

\section{(e) Certificate of Deposit:}

Banks also offer deposits to attract funds from corporate companies and banks and other institutions. One such important deposit product offered by banks is called as Certificate of Deposit (CD). Special features of a Certificate of Deposit (CD):

1. Certificate of Deposit is issued at a discount to mature for the face value at maturity

2. Minimum amount for a $C D$ is $₹ 100,000.00$ ( $₹$ One lakh only) and multiples thereof

3. Minimum and maximum period a $C D$ with banks are 7 days and 365 days respectively

4. CDs differs from Banks' Fixed Deposits (FDs) in respect of (i) prepayment and (ii) loans. While banks allows the fixed deposit holder the facility to withdraw before maturity (prepayment) and if required allows the fixed deposit holder to avail of a loan, both of them are not permissible in case of certificate of deposits. i.e., In case of Certificate of Deposits prepayment of CDs and loans against CDs are not allowed.

\section{Hybrid Deposits or Flexi Deposits or MULTI OPTION DEPOSIT SCHEME (MODS)}

These deposits are a combination of demand and fixed deposits, invented for meeting customer's financial needs in a flexible manner. Many banks had introduced this new deposit product some years ago to attract the bulk deposits from individuals with high net- worth. The increasing competition and computerization of banking has facilitated the proliferation of this product in several other banks in the recent past. Banks have given their own brand names to such deposits e.g. Quantum Deposit Scheme of ICICI Bank, Multi Option Deposit Scheme (MODS) of SBI.

The flexi deposits show a fusion of demand and fixed deposits as reflected from the following features of the product:

- Only one savings/current account (Current Premium account or Savings Bank Premium a/c as already discussed above) is opened and the term deposits issued under the scheme are recorded only on the bank's books as no term deposit receipts are issued to the customer. However, the term deposits issuance and payment particulars would be reflected in the statement of the savings/current account for customer's information/record.

- Once the quantum of deposits in savings/current account crosses a pre-agreed level, such surplus amount is automatically transferred to the term deposit account of a pre-determined maturity (usually one- year) in the customer's name for increasing the interest earning.

- In the event of a shortfall in the current/savings account, the cheques drawn on the account are honoured by automatically transferring back the required amount to the savings/current account from the fixed deposit account (reverse sweep). In such a case, the term deposit is broken and the amount of the reverse sweep earns lower interest rate due to the pre-mature payment of that portion of the term deposit. However, the remaining amount of the term deposit continues to earn the original interest rate.

Main Advantages of Flexi-Deposits to a Customer Are: 
- Advantage of Convenience: The customer opens only one account (savings or current) under the scheme and need not come to the bank branch each time for opening term deposit accounts or for pre- paying/ breaking term deposit for meeting the shortfall in the savings /current account.

- Advantage of Higher Interest Earning: The customer earns higher interest on his surplus funds than is possible when he opens two separate accounts: savings and term deposits.

- Withdrawals through ATMs can also be conveniently made.

\section{Exclusive Features:}

- Complete Liquidity.

- Convenience of Overdraft.

- Earns a higher rate of interest on deposit, without the dilemma of locking it for a long period.

- At the time of need for funds, withdrawals can be made in units of '1,000/- from the Deposits by issuing a cheque from Savings Bank Account or through overdraft facility from Current account.

- Flexibility in period of Term Deposit from 1 year to 5 years.

\section{Tailor-made Deposit Schemes}

Almost all banks have designed different schemes with different names which have a combination of two or three deposit schemes as mentioned above. These schemes are prepared as per the requirements of a particular customer. For example: One person approaches the bank and says that yesterday he has been blessed with a girl/boy baby and he wants to save for his/her educational and marriage expenses. Looking to the amount required for education and marriage after a certain period as per the normal age of marriage, the Bank will suggest him a scheme of Recurring Deposit plus Special Term Deposit. A few schemes are enumerated below:

\section{(a) Advantage Deposit}

Advantage Deposit is a combination of fixed deposit and mutual fund investment, offering you the safety of a fixed deposit and the returns of an equity fund. Advantage Deposit counters equity-market fluctuations through Systematic Investment Plans

- Combination of a Fixed Deposit (with monthly interest payout) and Systematic Investment Plan (SIP) of a Mutual Fund.

- Re-investment of monthly interest payout of Fixed Deposit into systematic investment plan of Mutual Fund.

- Automatic debits to account through Standing Instruction / ECS debit mandate

\section{(b) Child Education Plan}

"Child Education Plan", is a unique way to save for child's future.

To fulfill child's dream \& aspirations, begin by making small investments in a Recurring Deposit for a short tenure and receive regular payouts for the rest of the tenure in child's school/college life.

If a child is in kindergarten, a person can invest regularly for the next 5 years and this investment plan will take care of his primary education.

If a child is in secondary school, just invest ₹ 3,500 (per month) for the first 6 years, in a plan of 10 years' tenure. Get an annual payout of more than ₹1 lac (depending upon the prevailing interest rates) for the next 4 years and fulfill the dream of seeing the child graduate from a great college. 


\section{Eligibility}

Child Education Plan can be opened for only minors (1 day to 18 years) under a Guardian (natural / court appointed). The minor needs to have a Savings Account with a bank

\section{(c) Insurance-linked Deposit Schemes}

Some banks have designed certain schemes which provide personal accidental insurance to the savings bank depositors free of cost or at a nominal rate under group insurance scheme. These marketing strategies are adopted for a limited period during a special deposit mobilization campaign so as to have an edge over in the competitive position. This gives an attraction to the new depositors and a few people tend to shift their accounts from one bank to another. For example : HDFC is giving free personal accidental insurance to its depositors with certain conditions. One Regional Rural Bank is providing free accidental insurance to a new depositor during the first year and, thereafter, the bank charges ₹5 for ₹50000 personal accident insurance. Recently, Standard Chartered Bank launched a savings account with cricket as the theme. Account-holders will score 'runs' for the transactions, which can then be redeemed for gifts such as tickets for cricket matches played in India, autographed cricketing merchandise or sporting equipment from Nike.

\section{(d) Deposit Schemes for a particular type of Segment clients:}

Banks have special deposit schemes for senior citizens, school going children and women. Some banks pay more interest if the term deposit is in the name of a woman. Some concessions in regard to minimum balance requirements and service charges are given to a particular segment client like salaried persons, army personnel.

\section{Special Schemes for Non-Resident Indians (NRIs)}

Non-resident deposits are mobilized from the persons of Indian nationality, or Indian origin living abroad (NRIs) and Overseas' Corporate Bodies (OCBs) predominantly owned by such persons.

\section{Non-Resident Indians (NRIs) These fall into two categories:}

(a) Indian citizens who stay abroad for employment/business/ vacation or for any other purpose in the circumstances indicating an intention to stay abroad for an uncertain period. Income TaxAct has prescribed minimum residence period abroad in a year or block of years for determining income tax liability of such persons in India.

(b) Persons of Indian Origin (PIOs) other than Pakistan or Bangladesh, who had held Indian Passport at any time, or whose parents or grand- parents were citizens of India, or the person is a spouse of an Indian citizen.

2. Overseas Corporate Bodies (OCBs): These refer to a company, partnership firm, society or other corporate body owned directly or indirectly to the extent of at least 60 per cent by NRIs.

NRIs can maintain the following types of accounts with banks in India, which are designated as Authorized Dealers (ADs) by the RBI.

(NRI accounts are exempt from income tax, wealth tax, gift tax. Loans against the security of these deposits can also be granted by banks in India.)

\section{(a) Ordinary Non-Resident (NRO)}

NRIs can open Non-Resident Ordinary (NRO) deposit accounts for collecting their funds from local bona fide transactions. NRO accounts being Rupee accounts, the exchange rate risk on such deposits is borne by the depositors themselves. When a resident becomes a NRI, his existing Rupee accounts are designated as NRO. Such accounts also serve the requirements of foreign nationals resident in India. NRO accounts can be maintained as current, saving, recurring or term deposits. While the principal of NRO deposits is non-repatriable, current income and interest earning is repatriable. Further NRI/PIO may remit an amount, not exceeding US \$1 million per financial year, out of the balances held in NRO accounts/ sale proceeds of assets /the assets in India 
acquired by him by way of inheritance/legacy, on production of documentary evidence in support of acquisition, inheritance or legacy of assets by the remitter, and an undertaking by the remitter and certificate by a Chartered Accountant in the formats prescribed by the Central Board of Direct Taxes vide their Circular No. 10/2002 dated October 9, 2002.

\section{(b) Non-Resident (External) (NRE) Accounts}

The Non-Resident (External) Rupee Account NR(E)RA scheme, also known as the NRE scheme, was introduced in 1970. Any NRI can open an NRE account with funds remitted to India through a bank abroad. This is a repatriable account and transfer from another NRE account or $F C N R(B)$ account is also permitted. A NRE rupee account may be opened as current, savings or term deposit. Local payments can be freely made from NRE accounts. Since this account is maintained in Rupees, the depositor is exposed to exchange risk. NRIs / PIOs have the option to credit the current income to their Non-Resident (External) Rupee accounts, provided the authorized dealer is satisfied that the credit represents current income of the non-resident account holders and income tax thereon has been deducted / provided for.

\section{(c) FCNR (B) Scheme}

Non-Resident Indians can open accounts under this scheme. The account should be opened by the non-resident account holder himself and not by the holder of power of attorney in India.

- These deposits can be maintained in any fully convertible currency.

- These accounts can only be maintained in the form of term deposits for maturities of minimum 1 year to maximum 5 years.

- These deposits can be opened with funds remitted from abroad in convertible foreign currency through normal banking channel, which are of repatriable nature in terms of general or special permission granted by Reserve Bank of India.

- These accounts can be maintained with branches, of banks which are authorized for handling foreign exchange business/nominated for accepting $\operatorname{FCNR}(B)$ deposits..

- Funds for opening accounts under Global Foreign Currency Deposit Scheme or for credit to such accounts should be received from: -

- Remittance from outside India or

- Traveller Cheques/Currency Notes tendered on visit to India. International Postal Orders cannot be accepted for opening or credit to FCNR accounts.

- Transfer of funds from existing NRE/FCNR accounts.

- Rupee balances in the existing NRE accounts can also be converted into one of the designated currencies at the prevailing TT selling rate of that currency for opening of account or for credit to such accounts.

\section{Advantages of FCNR (B) Deposits}

- Principal along with interest freely repatriable in the currency of the choice of the depositor.

- No Exchange Risk as the deposit is maintained in foreign currency.

Loans/overdrafts in rupees can be availed by NRI depositors or 3rd parties against the security of these deposits. However, loans in foreign currency against FCNR (B) deposits in India can be availed outside India through correspondent Banks.

- No Wealth Tax \& Income Tax is applicable on these deposits.

- Gifts made to close resident relatives are free from Gift Tax. 
- Facility for automatic renewal of deposits on maturity and safe custody of Deposit Receipt is also available.

\section{Payment of Interest}

Interest on FCNR (B) deposits is being paid on the basis of 360 days to a year. However, depositor is eligible to earn interest applicable for a period of one year if the deposit has completed a period of 365 days.

For deposits up to one year, interest at the applicable rate will be paid without any compounding effect. In respect of deposits for more than one year, interest can be paid at intervals of 180 days each and thereafter for remaining actual number of days. However, depositor will have the option to receive the interest on maturity with compounding effect in case of deposits of over one year.

\section{No bank should:}

(i) accept or renew a deposit over five years;

(ii) discriminate in the matter of rate of interest paid on the deposits, between one deposit and another accepted on the same date and for the same maturity, whether such deposits are accepted at the same office or at different offices of the bank, except on the size group basis. The permission to offer varying rates of interest based on size of the deposits will be subject to the following conditions:

(a) Banks should, at their discretion, decide the currency-wise minimum quantum on which differential rates of interest may be offered. For term deposits below the prescribed quantum with the same maturity, the same rate should apply.

(b) The differential rates of interest so offered should be subject to the overall ceiling prescribed.

(c) Interest rates paid by the bank should be as per the schedule and not subject to negotiation between the depositor and the bank.

(iii) pay brokerage, commission or incentives on deposits mobilized under FCNR(B) Scheme in any form to any individual, firm, company, association, institution or any other person.

(iv) employ/ engage any individual, firm, company, association, institution or any other person for collection of deposit or for selling any other deposit linked products on payment of remuneration or fees or commission in any form or manner.

(v) accept interest-free deposit or pay compensation indirectly.

\section{Other aspects of deposit accounts}

(a) A person who wants to open a deposit account has to fill up and sign the prescribed account opening application form and furnish:

- acceptable proof of his/her identity and residential address,

- his/her photographs, and

- initial deposit not less than the prescribed minimum balance prescribed by the bank.

\section{'KNOW YOUR CUSTOMER' (KYC) GUIDELINES OF THE RBI}

KYC establishes the identity and residential address of the customers by specified documentary evidences. One of the main objectives of KYC procedure is to prevent misuse of the banking system for money laundering and financing of terrorist activities. The 'KYC' guidelines also reinforce the existing practices of some banks and make them compulsory, to be adhered to by all the banks with regard to all their customers who maintain domestic or non-resident rupee or foreign currency accounts with them. All religious trust accounts and non-religious trust accounts are also subjected to KYC procedure. RBI had advised banks that : 
(a) No account is opened in anonymous or fictitious/benami name (s)

(b) Bank will not open an account or close an existing account if the bank is unable to verify the identity or obtain documents required by it due to non-cooperation of the customer

\section{Customer Identification Procedure}

Customer identification means identifying the customer and verifying his/her identity by using reliable, independent source documents, data or information. Banks need to obtain sufficient information necessary to establish, to their satisfaction, the identity of each new customer, whether regular or occasional, and the purpose of the intended nature of banking relationship. Being satisfied means that the bank must be able to satisfy the competent authorities that due diligence was observed based on the risk profile of the customer in compliance with the extant guidelines in place. Such risk based approach is considered necessary to avoid disproportionate cost to banks and a burdensome regime for the customers. Besides risk perception, the nature of information/documents required would also depend on the type of customer (individual, corporate etc.). For customers that are natural persons, the banks should obtain sufficient identification data to verify the identity of the customer, his address/ location, and also his recent photograph. For customers that are legal persons or entities, the bank should (i) verify the legal status of the legal person/entity through proper and relevant documents; (ii) verify that any person purporting to act on behalf of the legal person/entity is so authorized and identify and verify the identity of that person; (iii) understand the ownership and control structure of the customer and determine who are the natural persons who ultimately control the legal person.

\section{Customer Identification Requirements}

\section{(i) Trust/Nominee or Fiduciary Accounts}

There exists the possibility that trust/nominee or fiduciary accounts can be used to circumvent the customer identification procedures. Banks should determine whether the customer is acting on behalf of another person as trustee/nominee or any other intermediary. If so, banks should insist on receipt of satisfactory evidence of the identity of the intermediaries and of the persons on whose behalf they are acting, as also obtain details of the nature of the trust or other arrangements in place. While opening an account for a trust, banks should take reasonable precautions to verify the identity of the trustees and the settlers of trust (including any person settling assets into the trust), grantors, protectors, beneficiaries and signatories. Beneficiaries should be identified when they are defined. In the case of a 'foundation', steps should be taken to verify the founder managers/ directors and the beneficiaries, if defined.

\section{(ii) Accounts of companies and firms}

Banks need to be vigilant against business entities being used by individuals as a 'front' for maintaining accounts with banks. Banks should examine the control structure of the entity, determine the source of funds and identify the natural persons who have a controlling interest and who comprise the management. These requirements may be moderated according to the risk perception e.g. in the case of a public company it will not be necessary to identify all the shareholders.

\section{(iii) Client accounts opened by professional intermediaries}

When the bank has knowledge or reason to believe that the client account opened by a professional intermediary is on behalf of a single client, that client must be identified. Banks may hold 'pooled' accounts managed by professional intermediaries on behalf of entities like mutual funds, pension funds or other types of funds. Banks also maintain 'pooled' accounts managed by lawyers/chartered accountants or stockbrokers for funds held 'on deposit' or 'in escrow' for a range of clients. Where funds held by the intermediaries are not co-mingled at the bank and there are 'sub-accounts', each of them attributable to a beneficial owner, all the beneficial owners must be identified. Where such funds are co-mingled at the bank, the bank should still look through to the beneficial owners. Where the banks rely on the 'customer due diligence' (CDD) done by an intermediary, they should satisfy 


\section{PP-BL\&P}

themselves that the intermediary is regulated and supervised and has adequate systems in place to comply with the KYC requirements. It should be understood that the ultimate responsibility for knowing the customer lies with the bank.

\section{(iv) Accounts of Politically Exposed Persons (PEPs) resident outside India}

Politically exposed persons are individuals who are or have been entrusted with prominent public functions in a foreign country, e.g., Heads of States or of Governments, senior politicians, senior government/judicial/military officers, senior executives of state-owned corporations, important political party officials, etc. Banks should gather sufficient information on any person/customer of this category intending to establish a relationship and check all the information available on the person in the public domain. Banks should verify the identity of the person and seek information about the sources of funds before accepting the PEP as a customer. The decision to open an account for a PEP should be taken at a senior level which should be clearly spelt out in Customer Acceptance Policy. Banks should also subject such accounts to enhanced monitoring on an ongoing basis. The above norms may also be applied to the accounts of the family members or close relatives of PEPs.

\section{(v) Accounts of non-face-to-face customers}

With the introduction of telephone and electronic banking, increasingly accounts are being opened by banks for customers without the need for the customer to visit the bank branch. In the case of non-face-to-face customers, apart from applying the usual customer identification procedures, there must be specific and adequate procedures to mitigate the higher risk involved. Certification of all the documents presented should be insisted upon and, if necessary, additional documents may be called for. In such cases, banks may also require the first payment to be effected through the customer's account with another bank which, in turn, adheres to similar KYC standards. In the case of cross-border customers, there is the additional difficulty of matching the customer with the documentation and the bank may have to rely on third party certification/introduction. In such cases, it must be ensured that the third party is a regulated and supervised entity and has adequate KYC systems in place.

\section{(vi) Basic Savings Bank Deposit Accounts (No-Frills Savings Bank accounts)}

(i) Persons those belonging to low income group both in urban and rural areas are not able to produce such documents to satisfy the bank about their identity and address. This may lead to their inability to access the banking services and result in their financial exclusion. Accordingly, the KYC procedure also provides for opening accounts for those persons who intend to keep balances not exceeding Rupees Fifty Thousand (₹ 50,000/-) in all their accounts taken together and the total credit in all the accounts taken together is not expected to exceed Rupees One Lakh (₹ 1,00,000/-) in a year. In such cases, if a person who wants to open an account and is not able to produce documents mentioned as mentioned in the chart below, banks should open an account for him, subject to:

Introduction from another account holder who has been subjected to full KYC procedure. The introducer's account with the bank should be at least six months old and should show satisfactory transactions. Photograph of the customer who proposes to open the account and also his address need to be certified by the introducer,

\section{or}

any other evidence as to the identity and address of the customer to the satisfaction of the bank.

(ii) While opening accounts as described above, the customer should be made aware that if any point of time, the balances in all his/her accounts with the bank (taken together) exceeds Rupees Fifty Thousand (₹ 50,000/-) or total credit in the account exceeds Rupees One Lakh (₹ 1,00,000/-) in a year, no further transactions will be permitted until the full KYC procedure is completed. In order not to inconvenience the customer, the bank must notify the customer when the balance reaches Rupees Forty Thousand (₹ $40,000 /-$ ) or the total credit in a year reaches Rupees Eighty thousand (₹ $80,000 /-$ ) that appropriate documents for conducting the KYC must be submitted otherwise operations in the account will be stopped. 


\section{List of documents to be obtained by banks for opening an account}

Features to be verified and documents that may be obtained from customers Features Documents

\begin{tabular}{|c|c|c|}
\hline $\begin{array}{l}\text { Accounts of individuals } \\
\text { - Legal name and any other names used } \\
\text { - Correct permanent address }\end{array}$ & (iv) & $\begin{array}{l}\text { Driving licence (v) Identity card (subject to the bank's } \\
\text { satisfaction) (vi) Letter from a recognized public authority or } \\
\text { public servant verifying the identity and residence of the } \\
\text { customer to the satisfaction of bank (i) Telephone bill (ii) Bank } \\
\text { account statement (iii) Letter from any recognized public } \\
\text { authority (iv) Electricity bill (v) Ration card (vi) Letter from } \\
\text { employer (subject to satisfaction of the bank) (any one } \\
\text { document which provides customer information to the } \\
\text { satisfaction of the bank will suffice) }\end{array}$ \\
\hline $\begin{array}{l}\text { Accounts of companies } \\
\text { - Name of the company } \\
\text { - Principal place of business } \\
\text { - Mailing address of the company } \\
\text { - Telephone/Fax Number }\end{array}$ & (i) & $\begin{array}{l}\text { Certificate of incorporation and Memorandum \& Articles of } \\
\text { Association (ii) Resolution of the Board of Directors to open } \\
\text { an account and identification of those who have authority to } \\
\text { operate the account (iii) Power of Attorney granted to its } \\
\text { managers, officers or employees to transact business on its } \\
\text { behalf (iv) Copy of PAN allotment letter (v) Copy of the } \\
\text { telephone bill }\end{array}$ \\
\hline $\begin{array}{l}\text { Accounts of partnership firms } \\
\text { - Legal name } \\
\text { - Address } \\
\text { - Names of all partners and their addresses } \\
\text { - Telephone numbers of the firm and } \\
\text { partners }\end{array}$ & (i) & $\begin{array}{l}\text { Registration certificate, if registered (ii) Partnership deed (iii) } \\
\text { Power of Attorney granted to a partner or an employee of the } \\
\text { firm to transact business on its behalf (iv) Any officially valid } \\
\text { document identifying the partners and the persons holding } \\
\text { the Power of Attorney and their addresses (v) Telephone bill } \\
\text { in the name of firm/partners }\end{array}$ \\
\hline $\begin{array}{l}\text { Accounts of trusts } \& \text { foundations } \\
\text { - Names of trustees, settlers, beneficiaries } \\
\text { and signatories } \\
\text { - Names and addresses of the founder, } \\
\text { the managers/directors and the } \\
\text { beneficiaries } \\
\text { - Telephone/fax numbers }\end{array}$ & (i) & $\begin{array}{l}\text { Certificate of registration, if registered (ii) Power of Attorney } \\
\text { granted to transact business on its behalf (iii) Any officially } \\
\text { valid document to identify the trustees, settlors, beneficiaries } \\
\text { and those holding Power of Attorney, founders/managers/ } \\
\text { directors and their addresses (iv) Resolution of the managing } \\
\text { body of the foundation/association (v) Telephone bill }\end{array}$ \\
\hline
\end{tabular}

Some close relatives, e.g. wife, son, daughter and daughter and parents etc. who live with their husband, father/ mother and son, as the case may be, are finding it difficult to open account in some banks as the utility bills required for address verification are not in their name. In such cases, banks can obtain an identity document and a utility bill of the relative with whom the prospective customer is living along with a declaration from the relative that the said person (prospective customer) wanting to open an account is a relative and is staying with him/her. Banks can use any supplementary evidence such as a letter received through post for further verification of the address.

\section{Specimen signature}

Specimen signature of the customer is obtained on the account opening form in the presence of the bank staff and it is attested by an authorized bank officer on the form itself. A customer is recognized mainly by his/her signature on the cheques/vouchers and these are compared with the specimen signature on record to verify the genuineness of the customer's signature. 


\section{Power of Attorney}

A power of Attorney is a document duly stamped as per Stamp Act and given by a customer to his banker, authorizing his attorney or agent named therein to operate the account. The banker should ensure that the document:

- gives specific authority to the named person to operate the named account on behalf of the customer,

- is properly stamped and notarized,

- is valid and not time barred,

- does not contain conditions or limitations on the authority of the attorney,

- binds the principal for all the transactions done by the attorney.

The Power of Attorney is then registered in the branch's documents and the attorney's signature is recorded in the account for its operation.

A 'Mandate', which is a simpler and a general purpose version of the Power of attorney, is a simple authority given in writing to the banker by a customer, authorizing a named person to operate the account temporarily for a specified period.

\section{CLOSING OF A BANK ACCOUNT - TERMINATION OF BANKER-CUSTOMER RELATIONSHIP}

Banker-customer relationship is a contractual relationship between two parties and it may be terminated by either party on voluntary basis or involuntarily by the process of law. These two modes of termination are described below.

A. Voluntary Termination: The customer has a right to close his demand deposit account because of change of residence or dissatisfaction with the service of the banker or for any other reason, and the banker is bound to comply with this request. The banker also may decide to close an account, due to an unsatisfactory conduct of the account or because it finds the customer undesirable for certain reasons. However, a banker can close an account only after giving a reasonable notice to the customer. However, such cases of closure of an account at the instance of the banker are quite rare, since the cost of securing and opening a new account is much higher than the cost of closing an account. If a customer directs the banker in writing to close his account, the banker is bound to comply with such direction. The latter need not ask the reasons for the former's direction. The account must be closed with immediate effect and the customer be required to return the unused cheques.

B. If the Bank desires to close the account: If an account remains un-operated for a very long period, the banker may request the customer to withdraw the money. Such step is taken on the presumptions that the customer no longer needs the account. If the customer could not be traced after reasonable effort, the banker usually transfers the balance to an "Unclaimed Deposit Account", and the account is closed. The balance is paid to the customers as and when he is traced.

The banker is also competent to terminate his relationship with the customer, if he finds that the latter is no more a desirable customer. The banker takes this extreme step in circumstances when the customer is guilty of conducting his account in an unsatisfactory manner, i.e. if the customer is convicted for forging cheques or bills or if he issues cheques without sufficient funds or does not fulfill his commitment to pay back the loans or overdrafts, etc. The banker should take the following steps for closing such an account:

(a) The banker should give to the customer due notice of his intention to close the account and request him to withdraw the balance standing to his credit. This notice should give sufficient time to the customer to make alternative arrangements. The banker should not, on his own, close the account without such notice or transfer the same to any other branch. 
(b) If the customer does not close the account on receipt of the aforesaid notice, the banker should give another notice intimating the exact date by which the account be closed otherwise the banker himself will close the account. During this notice period the banker can safely refuse to accept further credits from the customer and can also refuse to issue fresh cheque book to him. Such steps will not make him liable to the customer and will be in consonance with the intention of the notice to close account by a specified date.

The banker should, however, not refuse to honour the cheques issued by the customer, so long as his account has a credit balance that will suffice to pay the cheque. If the banker dishonours any cheque without sufficient reasons, he will be held liable to pay damages to his customer under Section 31 of the Negotiable Instruments Act, 1881. In case of default by the customer to close the account, the banker should close the account and send the money by draft to the customer. He will not be liable for dishonouring cheques presented for payment subsequently.

C. Termination by Law: The relationship of a banker-customer can also be terminated by the process of law and by the occurrence of the following events:

(a) Death of customer: On receiving notice or information of the death of a customer, the bank stops all debit transactions in the account. However, credits to the account can be permitted. The balance in the account is given to the legal representative of the deceased after obtaining the letters of administration, or succession certificate, or indemnity bond as per the prescribed procedure, and only then, the account is closed.

(b) Bankruptcy of customer: An individual customer may be declared bankrupt, or a company may be wound up under the provisions of law. In such an event, no drawings would be permitted in the account of the individual/company. The balance is given to the Receiver or Liquidator or the Official Assignee and the account is closed thereafter.

(c) Garnishee Order: We have already discussed in paragraph 3.4.3. that after receiving a garnishee order from a court or attachment order from income tax authority, the account can be closed as one of the options after taking the required steps.

(d) Insanity of the customer: A lunatic/person of unsound mind is not competent to contract under Section 11 of the Indian Contract Act, 1872. Since banker-customer relationship is contractual, the bank will not honour cheques and can close the account after receiving notice about the insanity of the customer and receiving a confirmation about it through medical reports.

\section{INSURANCE OF BANK DEPOSITS}

An important feature of Indian banking is that deposits of the public with the banks are insured up to the limit of ₹ 1 lakh in each account. After the failure of the Palai Central Bank, a scheduled bank of South India in 1960, the Government and the Reserve Bank felt the necessity of insuring the deposits in the banks so that public confidence in the banking institutions was not shaken whenever any bank failed to operate or was merged with another bank. The Deposit Insurance Corporation of India was established by an Act of Parliament to insure the deposits in the banks and the scheme of deposit insurance was introduced with effect from January 1, 1962. The Corporation was renamed as Deposit Insurance and Credit Guarantee Corporation with effect from July 15, 1978.

\section{Salient Features of Deposit Insurance}

(i) The scheme of deposit insurance applies since its inception to all commercial banks in India, scheduled and non-scheduled. The de- posit insurance cover has been extended to co-operative banks also in 21 States and 3 Union Territories. The Regional Rural Banks have also been included in this scheme. All these banks are called insured banks. 
(ii) The insurance cover is extended to all deposits with the insured banks except the deposits of the Central and State Governments, foreign Governments and the commercial banks.

(iii) The deposits with the insured banks are insured up to a special limit only. The insurance cover is available in respect of all unpaid balances due to a depositor held in a bank in the same capacity and in the same right up to ₹ 1 lakh. This means that every account of a depositor in every insured bank is insured to the extent of ₹ 1 lakh. The accounts with credit balance up to ₹ 1 lakh each are called fully protected accounts.

(iv) The Corporation reimburses the depositors in case the insured bank fails or is amalgamated with another bank and defaults in paying fully the balances due to the depositors in cash or by crediting the same to the full extent in the books of the transferee banks. The difference between the amount so paid or credited and the limit of insurance cover per account is paid by the Corporation. For example, if bank $X$, on its merger with bank $\mathrm{Y}$, gives a credit equal to $75 \%$ of the deposit, a depositor having a credit balance of $₹ 10,000$ will get credit of $₹ 7,500$. The balance of $₹ 2,500$ will be reimbursed to him by the Corporation.

(v) The rate of insurance premium is 5 paise per annum for every hundred rupees of assessable deposits. It is payable by the insured banks and not by the depositors at half-yearly intervals. Assessable deposits are those deposits to which the cover of insurance is ex- tended under (ii) above. Premium is thus payable on total assessable deposits whereas the 'insured deposits' are those which are below the limit of insurance cover, i.e., ₹ 1 lakh in each account.

(vi) The Corporation maintains two funds : (a) Deposit Insurance Fund, and (b) General Fund. The income from insurance premia is credited to the Deposit Insurance Fund and is invested in the Central Government securities. Income from such investments is credited to and the insurance losses are debited to the Revenue Account of the Fund. The General Fund meets all other expenses of the Corporation.

\section{NOMINATION}

While opening accounts and accepting deposits, bankers need to ensure certain procedures and precautions. For example KYC norms. Similarly, at the time of repayment of deposits banks should be careful and repay the amount as per banks' policies and the guidelines of the RBI.

As per the Banking Regulation Act, 1949, a depositor of a bank (including cooperative banks) may nominate one person as nominee of the depositor/s. The nomination is to be made in a prescribed manner. In the event of the death of the depositor, the deposit may be returned to the nominee. The nominee, is entitled to receive the deposit in case of the death of the depositor. A minor can also be nominated as nominee. However in case a minor is appointed as nominee, banks should request that a person be appointed to receive the deposit on behalf of the minor. Commercial banks are governed by the provisions of Banking Companies (Nomination) Rules 1985, and for Co-operative banks provisions of Co-operative Banks (Nomination) Rules 1985 are applicable. Banks get valid discharge if they make payment to the nominee. Depositors should avail the facility of nomination and nominate a person.

Nomination facility is also available in case of articles kept in safe deposit lockers and also in safe custody with banks. As per the provisions of the Banking Regulation Act,1949, any person who keeps any article in safe deposit locker and/or in safe custody, may nominate one person as his nominee to receive the article in the event of the death of that person. The nomination is to be made in a prescribed manner. In the event of the death of the bank's customer, the nominee is entitled to receive the articles kept in safe custody or remove the contents of locker, and the bank gets a valid discharge.

\section{Settlement of claims}

A banker should be careful while making payment of deposit amount, when he receives a claim. When a depositor dies, a claim would be received by the banker either from the nominee or legal heirs of the depositor. 


\section{Settlement of claims from a nominee}

Banks obtain nominations from the depositors in a prescribed manner and should register the nomination in their records. A proper acknowledgment is to be given to the depositor. Once the banker gets a claim from the nominee of the depositor, the banker should verify and satisfy himself

(i) whether the claim is received from the person whose name is recorded as nominee in bank's records, and

(ii) the deposit amount may be paid to the nominee after proper verification of the necessary documents like claim form, the death certificate of the depositor, proper identity of the nominee

(iii) the banker should get an acknowledgement from the nominee. The nominee should acknowledge the receipt of the amount of the deposit, including interest if any, duly signed by the nominee on a revenue stamp. The acknowledgement should clearly state that the nominee has received the deposit amount, as nominee of the depositor. Obtaining the acknowledgement and stamped receipt (as mentioned above) serves as a valid discharge of the bank.

As regards safe deposit lockers and custody accounts, the claims can be settled by the bank after proper verification of bank's records and other relevant documents like claim forms, death certificate of the bank's customer and identity of the nominee.

In case no nomination is available, then banks should follow their legal department's advise and bank's policy and procedures, to settle the claims. Important documents to be obtained are: claim forms, death certificate of the depositor, succession certificate if applicable, proper identification of legal heirs, proper acknowledgment of repayment of deposit/s from the legal heirs.

\section{Payment of balance without succession certificate}

Banks' open and deal with various accounts of different types of customers like individuals, minors, Non Resident Indians, partnership firms, companies, co-operative societies, associations, institutions, government departments, etc., While opening and maintaining accounts of these category of customers, banks should follow the regulator's guidelines and also the applicable legal frame work.

\section{LESSON ROUND UP}

- The relationship between a banker and his customer depends upon the nature of service provided by a banker.

- On the opening of an account the banker assumes the position of a debtor.

- He is not a depository or trustee of the customer's money because the money over to the banker becomes a debt due from him to the customer.

- A banker acts as an agent of his customer and performs a number of agency functions for the convenience of his customers. For example, he buys or sells securities on behalf of his customer, collects cheques on his behalf and makes payment of various dues of his customers, e.g.. insurance premium, etc.

- A banker has the statutory obligation to honour his customer's cheques unless there is valid reason for refusing payment of the same.

- Though the Pass Book contains true and authenticated record of the customer's account with the banker, no unanimous view prevails regarding the validity of the entries in the Pass Book. 
- The Garnishee Order attachés the balance standing to the credit of the principal debtor at the time the order is served on the banker.

- The right of set-off is a statutory right which enables a debtor to take into account a debt owed to him by a creditor, before the latter could recover the debt due to him from the debtor.

- As a creditor, a banker has the implied right to charge interest on the advances granted to the customer.

- Banks mainly deals with two types of customers (i) deposit customers (ii) borrowing customers.

- Depending upon the situation, bank open and maintain various accounts.

- On account of changing scenario, and banks' role as financial intermediaries, technological innovations in IT and communication sector, and increasing e banking scenario banks are exposed to various risks like credit, liquidity, legal, financial, forex and reputation as well as cross border risks.

- In view of the above banks' as custodian of public money should be careful in establishing and maintaining the customer relationship.

- Therefore, banks' are required to ensure KYC Norms and similar norms, Regulators' guidelines and applicable legal framework provisions are strictly followed.

- While opening accounts, banks should be careful in following the rules and procedures.

- Adherence to the KYC Norms help banks to clearly identify the customers.

- Nomination facility enables the banker to repay the deposit amount to the nominee, in case of death of the depositor.

- As discussed, banks should be careful in opening different type of accounts and dealing with various customers.

- It is in the interest of banks, that not only at the time of establishing the customer relationship, but also ensure that necessary care and diligence is exercised, during the operations in the accounts.

- These precautions would assist banks in establishing a good customer relationship.

\section{SELF TEST QUESTIONS}

1. State true or false.

(a) A government company is one in which minimum $51 \%$ share is held by the government

(b) A limited company can give operating instructions as "either or survivor:

(c) NRE account cannot be opened in EURO currency

(d) KYC norms are applicable only to new customers

(e) A fixed deposit receipt is neither a negotiable nor transferable instrument

(f) Karta is term associated with HUF accounts

2. Choose the correct alternative:

A. Memorandum and Articles of Association is applicable to

(a) Public Limited Company

(b) Private Limited Company

(c) Public Trust 
(d) Both a and b

B. FCNR account cannot be opened in
(a) US Dollars
(b) Indian Rupees
(c) Japanese Yen
(d) Canadian Dollars

C. As regards nomination, identify the exception
(a) Savings Bank accounts
(b) Home loans
(c) Safe Custody
(d) Safe Deposit Locker

D. Which of the following statement is true?

(a) Banks can open accounts in the name of associations

(b) Banks cannot open minor accounts

(c) Banks cannot allow loans against fixed deposits

(d) Banks can allow interest for current accounts

3. What are the obligations and the rights of a banker?

4. Explain the relationship of a banker and customer in following cases:

- As debtor and creditor

- Banker as trustee

- Bailee/ bailor

- Lesser/ lessee

- Banker as agent

5. Explain various types of customers and various deposit schemes.

6. Write Short notes on :
(a) Payment in due course
(b) Usance Bill of Exchange
(c) Special crossing

7. How can a banker protect the interests of the bank while handling cheques,

(i) as a collecting banker and

(ii) as a paying banker?

8. Why banks obtain more than one loan document?

9. What precautions banks should take in case of discounting of bills?

10. Highlight the features of cheque. 
102 PP-BL\&P 


\section{Lesson 4}

\section{Legal Aspects of Banking Operations}

\section{LESSON OUTLINE}

- Legal Aspects of a Cheque

- Legal Aspects of a Paying Banker

- Legal Aspects of Collection of a Cheque

- Indemnities

- Guarantees

- Operations In Deposit Accounts

- Complaints Of Customers

- Lesson Round Up

- Self Test Questions

\section{LEARNING OBJECTIVES}

Banks maintain operating accounts like Savings Bank, Current, Overdraft and Cash Credit accounts which are operated by the cheques drawn by the account holders on their bankers. While handling these cheques, a banker may act as a paying banker (when cheques are drawn on him) or collecting banker (when cheques are deposited with him). Banks are under statutory obligation to honour a cheque and make payment if it is in order as per relevant laws. As a collecting banker, he should collect the cheques only for his customer and as per the provisions of the legal frame work the Negotiable Instruments Act, 1881. Legal aspects in banking operations such as indemnities and guarantees are important in banker's point of view. The objectives of this chapter are -

- To understand the important aspects of the role of a banker as paying and collecting banker

- To know about the legal aspects of banking operations and the precautions taken by banks

- To understand the legal aspect of Indemnities and Guarantees 


\section{LEGAL ASPECTS OF A CHEQUE}

\section{Definition of a Cheque}

A cheque is defined in Sec 6 of $\mathrm{NI}$ Act as under :-

(i) A cheque is a bill of exchange drawn on a specified banker

(ii) Payable on demand

(iii) Drawn on a specified banker

(iv) Electronic image of a truncated cheque is recognized under law. The Information Technology Act, 2002 recognizes (a) digital signatures and (b) electronic transfer as well

A cheque is nothing but a bill of exchange with special features (i) It is always payable on demand ( $A$ bill of exchange can be payable on demand/at sight and/or after a specific term called as usance bill) (ii) always drawn on a specified banker i.e., the drawee of a cheque is the banker on whom the cheque is drawn. The banker with whom the customer holds his/her account. This drawee bank is called the paying bank. The parties to a cheque are:

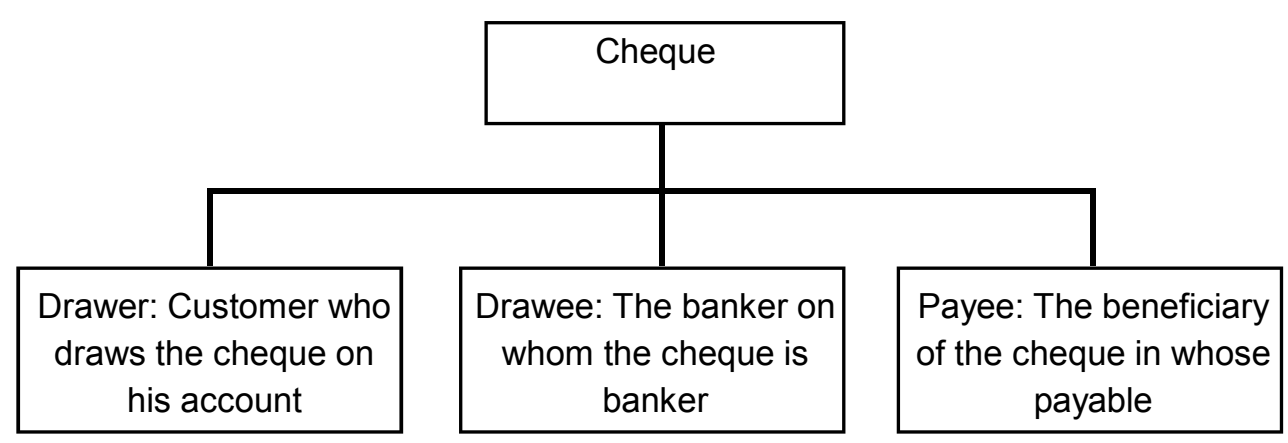

Apart from the above three parties, others involved in payment and collection of cheques are :

Endorser: The person who transfers his right to another person

Endorsee: The person to whom the right is transferred

\section{Different types of cheques}

\section{(1) Open Cheque:}

A cheque is classified as 'Open' when cash payment is allowed across the counter of the bank.

\section{(2) Bearer Cheque:}

A cheque which is payable to any person who holds and presents it for payment at the bank counter is called a 'Bearer cheque'. A bearer cheque can be transferred by mere delivery without any endorsement.

\section{(3) Order Cheque:}

An order cheque is a cheque which is payable to a particular person. In case of order cheque, the word 'bearer' might have been cancelled and the word 'order' is written. The payee can transfer an order cheque by endorsement to another person by signing his name on the back of the cheque 


\section{CROSSING OF A CHEQUE}

Crossing is an 'instruction' given to the paying banker to pay the amount of the cheque through a banker only and not directly to the person presenting it at the counter. A cheque bearing such an instruction is called a 'crossed cheque'; others without such crossing are 'open cheques' which may be encashed at the counter of the paying banker as well. The crossing on a cheque is intended to ensure that its payment is made to the right payee.

Section 123 to 131 of the Negotiable Instruments Act contain provisions relating to crossing. According to Section 131-A, these Sections are also applicable in case of drafts. Thus not only cheques but bank drafts also may be crossed.

\section{Cheque crossed generally}

Where a cheque bears across its face an addition of the words "and company" or any abbreviation thereof, between two parallel transverse lines, or of two parallel transverse lines simply, either with or without the words "not negotiable", that addition shall be deemed a crossing, and the cheque shall be deemed to be crossed generally. [section 123]

\section{Cheque crossed specially}

Where a cheque bears across its face an addition of the name of a banker, either with or without the words "not negotiable", that addition shall be deemed a crossing, and the cheque shall be deemed to be crossed specially, and to be crossed to that banker. [section 124].

\section{Payment of cheque crossed generally or specially}

Where a cheque is crossed generally, the banker on whom it is drawn shall not pay it otherwise than to a banker. Where a cheque is crossed specially, the banker on whom it is drawn shall not pay it otherwise than to the banker to whom it is crossed, or his agent for collection. [section 126].

\section{Cheque bearing "not negotiable"}

A person taking a cheque crossed generally or specially, bearing in either case the words "not negotiable", shall not have, and shall not be capable of giving, a better title to the cheque than that which the person form whom he took it had. [section 130]. Thus, mere writing words 'Not negotiable' does not mean that the cheque is not transferable. It is still transferable, but the transferee cannot get title better than what transferor had.

"Account Payee" crossing : N.I. Act does not recognize "Account Payee" crossing, but this is prevalent as per practice of banks in India. In view of this, RBI has directed banks that:

(1) Crediting the proceeds of account payee cheques to parties other than that clearly delineated in the instructions of the issuers of the cheques is unauthorized and should not be done in any circumstances.

(2) If any bank credits the account of a constituent who is not the payee named in the cheque without proper mandate of the drawer, it would do so at its own risk and would be responsible for the unauthorized payment. Reserve Bank has also warned that banks which indulge in any deviation from the above instructions would invite severe penal action.

(3) In case of an 'account payee' cheque where a bank is a payee, the payee bank should always ensure that there are clear instructions for disposal of proceeds of the cheques from the drawer of the cheque. If there are no such instructions, the cheque should be returned to the drawer.

(4) However, with a view to mitigating the difficulties faced by the members of co-operative credit societies in 
collection of account payee cheques, relaxation has been extended in respect of co-operative credit societies. Banks may consider collecting account payee cheques drawn for an amount not exceeding $₹ 50,000 /$ - to the account of their customers who are co-operative credit societies, if the payees of such cheques are the constituents of such co-operative credit societies.

\section{Double Crossing}

A cheque bearing a special crossing is to be collected through the banker specified therein. It cannot, therefore, be crossed specially again to another banker, i.e., cheque cannot have two special crossings, as the very purpose of the first special crossing is frustrated by the second one.

However, there is one exception to this rule for a specific purpose. If a banker, to whom the cheque is originally specially crossed submits it to another banker for collection as its agent, in such a case the latter crossing must specify that it is acting as agent for the first banker to whom the cheque is specially crossed.

\section{ENDORSEMENT}

\section{Definition of Endorsement}

Section 15 defines endorsement as follows:

"When the maker or holder of a negotiable instrument signs the same, otherwise than as such maker, for the purpose of negotiation, on the back or face thereof or on a slip of paper annexed thereto or so signs for the same purpose a stamped paper intended to be completed as a negotiable instrument, he is said to have endorsed the same and is called endorser.

Thus, an endorsement consists of the signature of the maker (or drawer) of a negotiable instrument or any holder thereof but it is essential that the intention of signing the instrument must be negotiation, otherwise it will not constitute an endorsement. The person who signs the instrument for the purpose of negotiation is called the 'endorser' and the person in whose favour instrument is transferred is called the 'endorsee'. The endorser may sign either on the face or on the back of the negotiable instrument but according to the common usage, endorsements are usually made on the back of the instrument. If the space on the back is insufficient for this purpose, a piece of paper, known as 'allonge' may be attached thereto for the purpose of recording the endorsements.

\section{Legal Provisions regarding Endorsements}

The following provisions are contained in the Act as regards endorsements:

(1) Effect of Endorsements. The endorsement of a negotiable instrument followed by delivery transfers the endorsed property therein with the right of further negotiation (Section 50 ). Thus the endorsee acquires property or interest in the instrument as its holder. He can also negotiate it further. (His right can, of course, be restricted by the endorser in case of a restrictive endorsement.)

Section 50 also permits that an instrument may also be endorsed so as to constitute the endorsee an agent of the endorser.-

(1) to endorse the instrument further, or

(2) to receive its amount for the endorser or for some other specified person.

The examples of such endorsements are as follows:

(i) Pay C for my use.

(ii) Pay $\mathrm{C}$ or order for the account 
Where a negotiable instrument is endorsed for any of the above purposes, the endorse becomes its holder and property therein is passed on the endorsee. In Kunju Pillai and Others vs. Periasami (1969 II. M.I.J. 148) the High Court held that a holder of a negotiable instrument, who secures the same by endorsement, does not lose the right of his action by reason of the death of the original payee. In Mothireddy vs. Pothireddy (A.I.R. 1963, A.P. 313) the Andhra Pradesh High Court also held that "the right based on the endorsement having made for a specific purpose, namely, collection of the amount, will be valid till that purpose is served." The ordinary law regarding agency does not, therefore, apply in such cases.

(2) Endorser. "Every sole maker, drawer, payee or endorsee or all of several join makers, payees or endorses of a negotiable instrument may endorse and negotiate the same." This is subject to the condition that the right to negotiate has not been restricted or excluded (Section 51). Thus in case the instrument is held jointly by a number of persons, endorsements by all of them is essential. One cannot represent the other.

The absence of the words "or order" in the instrument or endorsement thereon does not restrict further negotiation. For example a bill is drawn payable to $A$ or order. A endorses it to $B$ but the endorsement does not contain the words "or order" or any equivalent words. B may further negotiate the instrument.

It is, however, essential that the maker or drawer or drawer of an instrument must have lawful possession over it, i.e., he must be its holder in order to enable him to endorse o negotiate it. A payee or an endorsee of the instrument must be its holder for eth same purpose.

(3) Time. A negotiable instrument may be negotiated until its payment has been made by the banker, drawee or acceptor at or after maturity but not thereafter (Section 60).

(4) Endorsement for a part of the amount. The instrument must be endorsed for its entire amount. Section 56 provides that "no writing on a negotiable instrument is valid for the purpose of negotiable if such writing purports to transfer only a part of the amount appearing to be due on the instrument." Thus an endorsement for a part of the amount of the instrument is invalid.

But in case an instrument has been partly paid, it may be negotiated for the balance of the amount provided a note to that effect is given on the instrument (Section 56).

If the endorser intends to transfer the document to two or more endorsees separately, it will not constitute a valid endorsement.

(5) The legal representative of a deceased person cannot negotiate by delivery only, a promissory note, bill of exchange or cheque payable to order and endorsed by the deceased but not delivered (Section 57). If the endorser dies after endorsing the instrument payable to order but without delivering the same to the endorsee, such endorsement shall not be valid and his legal representative cannot complete its negotiation by mere delivery thereof.

(6) Unless contrary is proved it is presumed under Section 118 that "the endorsements appearing upon a negotiation instrument were made in the order in which they appear thereon." It means that the endorsement which appears on an instrument first is presumed to have been made earlier to the second one.

\section{General Rules regarding the Form of Endorsements}

An endorsement must be regular and valid in order to be effective. The appropriateness or otherwise of a particular form of endorsement depends upon the practice amongst the bankers. The following rules are usually followed in this regard.

1. Signature of the endorser. The signature on the document for the purpose of endorsement must be that of the endorser or any other person who is duly authorized to endorse on his behalf. If a cheque is payable to two persons, both of them should sign their names in their own handwriting. If the endorser signs in block letters, it will not be considered a regular endorsement. 
2. Spelling. The endorser should spell his name in the same way as his name appears on the cheque or bill as its payee or endorsee. If his name is mis-spelt or his designation has been given incorrectly, he should sign the instrument in the same manner as given in the instrument. Thereafter, he may also put his proper signature in the same handwriting, if he likes to do so. For example, if the payee's name is wrongly spelt as 'Virendra Perkash' instead of 'Virendra Prakash' regular endorsement will be as follows:

Virendra Prakash

Merely writing the correct name will not be regular endorsement.

3. No addition or omission of initial of the name. An initial name should neither be an added nor omitted from the name of the payee or endorsee as given in the cheque. For example, a cheque is payable to S.C. Gupta should not be endorsed as S. Gupta or vice versa. Similarly, a cheque payable to Harish Saxena should not be endorsed as $\mathrm{H}$. Saxena because it will be doubtful for the paying banker to ascertain that $\mathrm{H}$. Saxena is Harish Saxena and nobody else. It is possible that some Hari Saxena has signed on the cheque as $\mathrm{H}$. Saxena.

4. Prefixes and suffixes to be excluded. The prefixes and suffixes to the names of the payee or endorsee need not be included in the endorsement. For example, the words "Mr., Messrs, Mrs., Miss, Shri, Shrimati, Lala, Babu, General, Dr., Major, etc." need not be given by the endorser otherwise the endorsement will not be regular. However, an endorser may indicate has title or rank, etc., after his signature. For example, a cheque payable to Mojor Raja Ram or Dr. Laxmi Chandra may be endorsed as 'Raja Ram, Major' or Laxmi Chandra, M.D.' A cheque payable to Padmashri Vishnu Kant may be endorsed as Vishnu Kant, Padmashri.

\section{LEGAL ASPECTS OF A PAYING BANKER}

The Negotiable Instruments Act, 1881 deals with negotiable instruments like promissory notes, bills of exchanges, cheques and similar payment instruments such as demand drafts, dividend warrants, etc. A banker in his capacity as a banker deals with the above mentioned negotiable instruments on different occasions. The NI Act lays down the law relating to payment of a customer's cheque by a banker and also the protection available to a banker. The relationship between a banker and customer, being debtor-creditor relationship the banker is bound to pay the cheques drawn by his customer. This duty on the part of the banker, to honour his customers' mandate, is laid down in Section 31 of the Negotiable Instruments Act.

Sections 10, 85, 85A, 89 and 128 of the Negotiable Instruments Act, 1881 grants protection to a paying banker. We shall in detail, examine individually these Sections and with the help of case laws apply the provisions of these Sections to a given set of facts.

\section{Obligations of a Paying Banker}

The customer who has deposited money with a bank being a creditor has the right to ask back the money from the banker who is a debtor. The duty on the part of the banker to pay has been laid down in Section 31 of the Negotiable Instruments Act, 1881 in the following terms:

\section{Section 31}

"The drawee of a cheque having sufficient funds of the drawer in his hands properly applicable to the payment of such cheque must pay the cheque when duly required to do so, and, in default of such payment, must compensate the drawer for any loss or damage caused by such default."

1. Section 31 applies only to Bankers

This is because as per Section 6 of the Negotiable Instruments Act, 1881 "cheque" has been defined as 
"a Bill of Exchange drawn on a specified banker and not expressed to be payable otherwise than on demand".

2. Sufficient funds: The banker should have sufficient funds of the drawer, i.e. there should be sufficient credit balance in the customer's account.

3. Properly available: The funds available in the customer's account, should also be properly available to the payment of the cheque. The funds may not be available to pay the cheque if:

(a) the banker has exercised his right of set off for amounts due from the customer;

(b) there is an order passed by a Court, competent authority or other lawful authority restraining the bank from making payment.

4. When duly required to do so: The banker is duty bound to pay the cheque only when he is duly required to do so. This means that the cheque must be properly drawn and signed by the drawer.

5. Compensate the drawer: In case the banker refuses payment wrongfully, then he is liable only to the drawer of the cheque and not to any endorsee or holder, except when

(a) the bank is wound up, in which case the holder becomes a creditor entitled to make a claim;

(b) the banker pays a cheque disregarding the crossing, the true owner can hold the banker liable.

6. Loss or damage caused by default: A banker is liable to the drawer for any loss or damage which may have occurred to the drawer due to the wrongful dishonour of the customer's cheque.

\section{Protection to paying banker}

(a) For a paying banker to claim protection under the Negotiable Instruments Act, one of the criteria he has to satisfy is that the payment is in due course. As to what is payment in due course has been stated in Section 10 which reads as follows:

"Payment in due course" means payment in accordance with the apparent tenor of the instrument in good faith and without negligence to any person in possession thereof under circumstances which does not afford a reasonable ground for believing that he is not entitled to, receive payment of the amount therein mentioned.

From the above definition it can be seen that payment in due course requires the payment to be made:

- in accordance with the apparent tenor of the instrument;

- in good faith;

- without negligence;

- to the person in possession of the instrument; and

- while making payment the banker should not have reasons to believe' that the person in possession of the instrument is not entitled to receive payment of the amount mentioned in the instrument.

(b) Section 85 of the Negotiable Instruments Act, 1881 grants protection to a banker on his making payment on a cheque. Though this principle may sound as a simple logic it is to be noted that the protection granted as per Section 85 is not absolute.

Section 85 of the Negotiable Instruments Act, 1881 reads as follows:

\section{Section 85}

1. Where a cheque payable to order purports to be endorsed by or on behalf of the payee, the drawee is discharged by payment in due course. 
2. Where a cheque is originally expressed to be payable to bearer, the drawee is discharged by payment in due course to the bearer thereof, notwithstanding any endorsement whether in full or in blank appearing thereon, and notwithstanding that any such endorsement purports to restrict or exclude further negotiation.

(c) Section 89 of the Negotiable Instruments Act states the effect of making payment on instrument on which alteration is not apparent and reads as follows:

\section{Section 89}

"Payment of instrument on which alteration is not apparent: Where a promissory note, bill of exchange or cheque has been materially altered but does not appear to have been so altered, or where a cheque is presented for payment which does not at the time of presentation appear to be crossed or to have had a crossing which has been obliterated, payment thereof by a person or banker liable to pay, and paying the sum according to the apparent tenor thereof at the time of payment and otherwise in due course, shall discharge such person or banker from all liability thereon; and such payment shall not be questioned by reason of the instrument having been altered or the cheque crossed."

Leading cases on payment of cheques by a bank

\section{Liability of Paying Banker when Customer's Signature on Cheque is Forged}

(a) Section 128: Where the banker on whom a crossed cheque is drawn has paid the same in due course, the banker paying the cheque, and in case such cheque has come to the hands of the payee the drawer thereof, shall respectively be entitled to the same rights, and be placed in the same position in all respects, as they would respectively be entitled to and placed in if the amount of the cheque has been paid to and received by the true owner thereof.

1. In Canara Bank vs Canara Sales Corporation and Others [(1987) 2 Supreme Court Cases 666] the Supreme Court state that when the customer's signature on the cheque is forged, there is no mandate to the bank to pay. As such a banker is not entitled to debit the customer's account on such forged cheque. Since the relationship between the customer and the bank is that of a creditor and debtor, the bank had no authority to make payment of a cheque containing a forged signature. The bank would be acting against the law in debiting the customer with the amount of the forged cheque as there would be no mandate on the bank to pay. The Supreme Court pointed out that the document in the cheque form on which the customer's name as drawer was forged was a mere nullity. The bank would succeed only when it would establish adoption or estoppel. In deciding the case the Supreme Court relied on its earlier judgement in Bihta Co-operative Development and Cane Marketing Union Ltd. vs bank of Bihar (AIR 1967 Supreme Court 389).

2. In Bihta Co-operative Development and Cane Marketing Union Ltd. vs bank of Bihar, the Supreme Court held that "one of the signatures was forged so there was no mandate by the customer at all to the banker and the question of negligence of the customer in between the signature and the presentation of the cheque never arose. Therefore, in a joint account if one of the signatures is forged then there is no mandate and banker cannot make payment.

\section{Payment to Be in Due Course for Bank to Seek Protection}

1. In the case of "Bank of Bihar vs Mahabir Lal (AIR 1964 Supreme Court 397)" Supreme Court held that a banker can seek protection under Section 85 only where payment has been made to the holder, his servant or agent, i.e. payment must be made in due course. Payment to a person who had nothing to do with the firm or a payment to an agent of the Bank would not be a payment to the firm. In this case The bank instead of handing over cash to the firms partner, to be paid over to the wholesalers, entrusted it with one of the bank's employees (Potdar) who accompanied the partner to the wholesalers. However, before the money could be paid to the wholesalers the Potdar absconded. 
2. The Calcutta High Court had occasion to consider as to whether a Bank had made payment in due course or not in the case of Bhutoria Trading Company (BTC) vs Allahabad Bank (AIR 1977 Cal. 363) The Court held that:

"The Expression payment" in due course has been defined in Section 10 of the Negotiable Instruments Act to mean payment in accordance with the apparent tenor of the instrument in good faith and without negligence to any person in possession thereof, under circumstances which do not afford reasonable ground for believing that he is not entitled to receive payment of the amount therein mentioned. It can hardly be questioned that the payment by the defendant bank of the cheque in question has been made by the defendant bank in accordance with its apparent tenor. The cheque is an uncrossed cheque payable to the plaintiff or order. The cheque was endorsed by the plaintiff through its Manager. The fact that Jethmall is the Manager is borne out by the seal of the Company which is unquestionably an authentic seal. The seal of the Manager is also equally authentic. That the payment was made in good faith has not been disputed for all practical purposes. There is not a grain of evidence before the Court from which it remotely appears that the payment was not made in good faith. Now that the entire evidence is before the Court, the question of onus to prove good faith loses much of its importance. No negligence has been proved against the bank. The defendant bank insisted on identification of Jethmall and Jethmall was in fact identified by Kishanlal Maheswari, a constituent of the bank, the defendant NO.3. The defendant bank therefore took all reasonable precautions even though the circumstances in which the cheque was presented for payment did not afford any reasonable ground for believing that Jethmall was not entitled to receive payment of the amount mentioned therein. The plaintiff having failed to prove the trade practice which he alleged and the bank having paid the cheque, in accordance with the apparent tenor of the instrument, in good faith, and without negligence, to Jethmall who was in possession thereof the defendant is entitled to succeed. There were no circumstances which afforded any reasonable ground for believing that he was not entitled to receive payment of the cheque. It must be held that the bank made the payment in due course. The learned Judge, in our opinion has rightly pointed out that payment in due course is necessarily payment in the ordinary course.

3. Whether payment made by a bank was payment in due course would depend on the facts of a given case. In Madras Provincial Co-operative Bank Ltd. vs Official Liquidator, South Indian Match Factory Ltd. (AIR 1945 Mad 30) the court held that payment to a liquidator against the cheque presented across the counter was not a payment in due course and the bank was not entitled to seek protection under Section 85 of the Negotiable Instruments Act. The Court held that under Section 244A of the Indian Companies Act, 1913, an official liquidator was required to open an account with a bank and pay therein moneys received by him in the course of the liquidation. Rule 66 of the Rules framed by the Madras High Court under the Act required that all bills and other securities payable to the company or to the liquidator should, unless the judge otherwise directs, shall as soon as they came into the hands of the liquidator, be deposited by him in the bank. From the cheque itself the Bank had notice that it was payable to the liquidator in his official capacity. That the bank realized this in full was shown by the fact that it called for the order of his appointment. Bankers knew or must have deemed to have known that this money could only be collected by the payee through his own bank and, therefore, it was most improper on his part to ask for payment over the drawee's counter.

\section{Payment in Good Faith, Without Negligence of an instrument on which Alteration is not Apparent}

1. The effect of Sections 10 and 89, and Section 31 was considered by the Supreme Court in Bank of Maharashtra vs M/s Automotive Engineering Co. (1993) 2 SCC 97. The question which arose for consideration in this appeal was whether the paying bank was bound to keep an ultraviolet ray lamp and to scrutinize the cheque under the said lamp even if no infirmity on the face of the said cheque on visual scrutiny was found. The Supreme Court held that: 
(i) Section 89 of the Negotiable Instruments Act gives protection to the paying banker of a cheque which has been materially altered but does not appear to have been so altered, if payment was made according to the apparent tenor thereof at the time of payment and otherwise in due course.

(ii) Section 10 of the said Act defines payment in due course to mean payment in accordance with the apparent tenor of the instrument in good faith and without negligence to any person in possession thereof under circumstances which do not afford a reasonable ground for believing that he is not entitled to receive payment of the amount therein mentioned.

(iii) Section 31 of the said Act obliges the drawee bank having sufficient funds of the drawer in its hands properly applicable to the payment of such cheque, to make payment of the cheque when duly required to do so.

(iv) On analyzing the evidence, the Courts below had held that on visual examination no sign of forgery or tampering with the writings on the cheque could be detected. It was found that the agent of the appellant bank had verified the serial number and signature on the cheque and had compared the signature on the cheque with the specimen signature of the respondent and on scrutiny of the cheque visually no defects could be detected by him. There was sufficient funds of the drawer with the appellant bank, which had no occasion to doubt about the genuineness of the cheque from the apparent tenor of the instrument. There was no evidence to hold that the payment was not made in good faith. Simply because the ultraviolet ray lamp was not kept in the branch and the said cheque was not subjected to such lamp, would not be sufficient to hold the appellant bank guilty of negligence more so when it has not been established on evidence that the other branches of the appellant bank or the other commercial banks had been following a practice of scrutinizing each and every cheque or cheques involving a particular amount under such lamp by way of extra precaution.

(v) In such circumstances, it is not correct legal proposition that the bank, in order to get absolved from the liability of negligence, was under an obligation to verify the cheque for further scrutiny under advanced technology or for that matter under ultraviolet ray lamp apart from visual scrutiny even though the cost of such scrutiny was only nominal and it might be desirable to keep such lamp at the branch to take aid in appropriate case.

(vi) The Courts below were not justified in holding that the bank had failed to take reasonable care in passing the cheque for payment without subjecting it for further scrutiny under ultraviolet ray lamp because the branch was in the industrial area where such forgery was rampant and other branches of the appellant bank were provided with such lamp.

2. The protection granted to a banker under Section 89 had come up for consideration before the Calcutta High Court in Brahma Shumshere Jung Bahadur vs Chartered Bank of India, Australia and China (AIR 1956 Cal. 399). The court held that since no alteration or obliteration was visible at the time of payment, the payment was made according to the apparent tenor at the cheque. Further since drawer had on other occasions also issued cheque signed by him and written by others, the bank suspicion could not have aroused. The Court also held that the words "liable to pay" appearing in the third paragraph of Section 89 included a liability to pay under an overdraft agreement as much as it applied to an ordinary deposit account. As regards exceeding the overdraft limit, the Court held that no definite limit was fixed at any time and it fluctuated according to the securities deposited.

3. In the case of Tanjore Permanent Bank vs S.R. Rangachari (AIR 1959 Madras 119) the High Court was called upon to decide a case in which cheque was materially altered and the bank sought protection under Section 89. The Court held that since the material alteration on both the cheques were visible and since they were not authenticated by the drawers initials, the payment made by the bank was not according 
to the apparent tenor of the instrument and as such the bank cannot claim protection under Section 89 of the Negotiable Instruments Act. The Court in coming to the above conclusion relied on the following paragraph of Bhashyam and Adiga's Negotiable Instruments Act:

The bank has also to see whether there are any alterations in the cheque and whether they have been properly authenticated. Therefore, where an alteration in a cheque is initialed not by all the drawers but only some of them, the bank will be paying the amount on the said cheque at its own risk. In this connection it is necessary to notice that under Section 89 protection is afforded to the bank paying a cheque where the alteration is not apparent.

It is to be noted as per Section 89 the bank can seek protection only if there is material alteration in the cheque and does not appear to have been altered. This, however, does not protect a banker in case the signature of the customer is forged. As stated earlier a forged cheque is no mandate of the customer and as such the bank cannot make payment on a cheque where the signature of the customer is forged. The question whether a signature is forged or not depends on the evidence and the court in coming to a conclusion that the signature is forged would look into the facts and circumstances that led to the payment of the cheque.

4. In Bareilly Bank Ltd. vs Naval Kishore (AIR 1964 All 78) $\mathrm{N}$ opened an account with the bank by making a cash deposit of $₹ 19,900$. $N$ was issued a cheque book containing 25 cheques. 17 months after the opening of the account $\mathrm{N}$ drew a cheque for the first time for ₹ 5,900 which was dishonoured by the bank. On enquiries $N$ was informed that 11 months back three cheques aggregating $₹ 19,500$ were paid by the bank and the present balance in the account was a mere ₹ 437. $\mathrm{N}$ denied issuing of the cheques and sued the bank. In evidence it came out that 3 cheques used to withdraw the amounts were not from the cheque book issued to $\mathrm{N}$ and were from a different cheque book. Though bank was not in a position to explain this lapse, they made an attempt to counter the contentions of $\mathrm{N}$ by producing his specimen signature which appeared to be similar to the ones on the cheques. $\mathrm{N}$ however denied that the specimen signature was his and the Court concluded that the alleged specimen signature were totally different from N's regular signature. Evidence also was led to show that the bank's own employees were involved in the forgery since the ledger page of N's account showed that certain erasures and scorings were made and the signature of $\mathrm{N}$ missing in the cheque book issue register. Therefore the court refused to accept the bank's contention.

\section{Payment by Bank under mistake - whether Recoverable}

The question whether a bank paying a forged cheque can recover the same from the payee was considered by the Calcutta High Court in United Bank of India vs AT Ali Hussain \& Co. (AIR 1978 Calcutta 169). The High Court held that so long as the status quo is maintained and the payee has not changed his position to his detriment, he must repay the money back to the payer. If, however, there has been a change in the position of the payee who, acting in good faith, parts with money to another without any benefit to himself before the mistake is detected, he cannot be held liable. Equity disfavours unjust enrichment. When there is no question of unjust enrichment of the payee by reaping the benefit of an accidental windfall he should not be made to suffer, for he would be as innocent as the payer who paid the money acting under a mistake.

\section{LEGAL ASPECTS OF COLLECTION OF A CHEQUE}

Collection of cheques, bills of exchange and other instruments on behalf of a customer is an indispensable service rendered by a banker to his customer. When a customer of a banker receives a cheque drawn on any other banker he has two options before him - (i) either to receive its payment personally or through his agent at the drawee bank, or (ii) to send it to his banker for the purpose of collection from the drawee bank. In the latter case the banker, deputed to collect the amount of the cheque from another banker, is called the "collecting 


\section{PP-BL\&P}

banker'. He presents the cheque for encashment to the drawee banker and on its realization credits the account of the customer with the amount so realized.

A banker is under no legal obligation to collect his customer's cheques but collection of cheques has now become an important function of a banker with the growth of banking habit and with wider use of crossed cheques, which are invariably to be collected through a banker only. While collecting his customer's cheques, a banker acts either

(i) as a holder for value, or

(ii) as an agent of the customer.

The legal position of the collecting banker, therefore, depends upon the capacity in which he collects the cheques. If the collecting banker pays to the customer the amount of the cheque or credits such amount to his account and allows him to draw on it, before the amount of the cheque is actually realized from the drawee banker, the collecting banker is deemed to be its 'holder for value'. He takes an undertaking from the customer to the effect that the latter will reimburse the former in case of dishonour of the cheque.

\section{Banker as a holder for value}

A banker becomes its holder for value by giving its value to the customer in any of the following ways:

(a) by lending further on the strength of the cheque;

(b) by paying over the amount of the cheque or part of it in cash or in account before it is cleared;

(c) by agreeing either then or earlier, or as a course of business, that customer may draw before the cheque is cleared;

(d) by accepting the cheque in avowed reduction of an existing overdraft; and

(e) by giving cash over the counter for the cheque at the time it is paid in for collection.

In any of these circumstances the banker becomes the holder for value and also the holder in due course. He bears the liability and possesses the rights enjoyed by the holder for value. If the last but one endorsement is proved to be forged, he will be liable to the true owner of the cheque. But he shall have the right to recover the money from the last endorser, i.e., his own customer, if the customer is unable to pay, the banker himself will bear the loss. If the cheque sent for collections returned dishonoured, the collecting banker can sue all the previous parties after giving them notice of dishonour. It is, however, essential that the amount of the cheque is paid to the customer in good faith.

\section{Collecting Banker as an Agent}

A collecting banker acts as an agent of the customer if he credits the latter's account with the amount of the cheque after the amount is actually realized from the drawee banker. Thereafter the customer is entitled to draw the amount of the cheque. The banker thus acts as an agent of the customer and charges from him a commission for collecting the amount from outstation banks.

As an agent of his customer, the collecting banker does not possess title to the cheque better than that of the customer. If the customer has no title thereto, or his title is defective, the collecting banker cannot have good title to the cheque. In case the cheque collected by him did not belong to his customer, he will be held liable for conversion of money, i.e., illegally interfering with the rights of true owner of the cheque.

\section{Conversion by the Collecting Banker}

Sometimes a banker is charged for having wrongfully converted cheques to which his customer had no title or had defective title. Conversion means wrongful or unlawful interference (i.e., using, selling, occupying or holding) with another person's property which is not consistent with the owner's right of possession. Negotiable instruments 
are included in the term 'property' and hence a banker may be charged for conversion if he collects cheques for a customer who has no title or defective title to the instrument. The basic principle is that rightful owner of the goods can recover the same from anyone who takes it without his authority and in whose hands it can be traced. When the banker acts as an agent of his customer for the collection of his cheques, he cannot escape this liability. However, the right of the true owner is a restricted one and cannot be exercised in case the goods reach the hands of one who (i) receives it in good faith, (ii) for value, and (iii) without the knowledge that the other party had no authority thereon. Except these circumstances, the true owner of the goods (including the negotiable instrument) can file a suit for conversion.

\section{Statutory Protection to Collecting Bank}

Section 131 of the Negotiable Instruments Act grants protection to a collecting banker and reads as follows:

\section{Section 131}

Non-liability of a banker receiving payment of cheque: A banker who has in good faith and without negligence received payment for a customer of a cheque crossed generally or specially to himself shall not, in case the title to the cheque proves defective, incur any liability to the true owner of the cheque by reason only of having received such payment.

Explanation: A banker receives payment of a crossed cheque for a customer within the meaning of this section notwithstanding that he credits his customer's account with the amount of the cheque before receiving payment thereof.

The provisions of the above section has been applied to drafts as per Section 131 A of the Negotiable Instruments Act.

Conditions for protection: Though Section 131 grants protection to a collecting banker, the protection is not unconditional. For the collecting banker to claim the protection under Section 131 he has to comply with certain conditions and they are:

1. The collecting banker should have acted in good faith.

2. He should have acted without negligence.

3. He should receive payment for a customer.

4. The cheque should be crossed generally or specially to himself.

\section{DUTIES OF THE COLLECTING BANK}

Section 131 of the Negotiable Instruments Act which affords protection to the collecting bank requires amongst other conditions, that the bank should not have been negligent. To show that the bank has not been negligent the bank will have to prove that it has taken all precautions that would be required of a prudent banker in collecting a cheque. Over the years based on practice and judicial pronouncements, these precautions have been laid down as duties imposed on bankers, the non-compliance of which can make the bank liable on the grounds of negligence. We shall now individually examine these duties.

\section{Duty to open the account with references and sufficient documentary proof}

The duty to open an account only after the new account holder has been properly introduced to is too well grained into today's banker's mind that it would be impossible to find an account without introduction. The necessity to obtain introduction of a good customer is to keep off crooks and fraudsters who may open accounts to collect forged cheques or other instruments. As an added precaution RBI has insisted that while opening accounts photograph of the customer and sufficient documentary proofs for constitution and address be obtained. 


\section{PP-BL\&P}

In this regard the English Decision Ladbroke vs Todd (1914) 30 TLR 433 can be referred to. In this case a thief stole a cheque in transit and collected the same through a banker where he had opened an account without reference and by posing himself as the payee whose signature the thief forged. After the cheque was collected the thief withdrew the amount. The bank was held liable to make good the amount since it acted negligently while opening the account in as much as it had not obtained any reference.

In Syndicate Bank vs Jaishree Industries and Others AIR 1994 Karnataka 315, the Appellant opened an account in the name of "M/s Axle Conductor Industries Ltd. by the Proprietor, R.K. Vyas". The introduction was given by one Nanjunde Gowda, who was having a small shop at the address given by the account holder. The address of the account holder, given by the account holder, was just opposite the Appellant Bank. In the account opening form the name of the account holder was given as "M/ Axle Conductor Industries by the Proprietor R.K. Vyas". No information was sought or inquiry held as to the incorporation of the account holder nor was the Memorandum of Association, Resolution, etc., scrutinized. On 3 January 1979, partners of Firm "A" purchased a draft for ₹ 2,51,125 from State Bank of India, Ahmednagar, in favour of M/s Axle Conductor Industries Ltd. The draft was deposited in the account with the Appellant on 5 October 1979 and the amount was collected by the Appellant and credited to the account on 9 October 1979. On 10 October 1979, the monies were withdrawn from the account. The partners of "A" filed a suit against the Appellant and State Bank of India for recovery of ₹ 2,51,125 wrongly collected by Appellant and paid by State Bank of India.

The High Court held that there was failure to follow the proper procedure for opening account in the name of a limited company, that the account was opened as if it was a proprietary concern, the staff of the Appellant Bank did not bestow sufficient care even to notice the word "Ltd." on several occasions, such as, at the time of opening of the account or withdrawal of amounts from the account. The High Court felt that having accepted the application as if it was an application by a proprietary concern, strangely the Appellant Bank allowed the account to operate in the name of the limited concern. There was, therefore, lack of care on the part of the Appellant Bank in the entire transaction.

The conditions to be satisfied for claiming protection under Section 131 of the Negotiable Instruments Act are: (a) that the banker should act in good faith and without negligence in receiving payment, i.e. in the process of collection, (b) that the banker should receive payment for a customer, i.e. act as mere agent in the collection of the cheque, and not on his account as holder, (c) that the person for whom the banker acts must be his customer, and (d) that the cheque should be one crossed generally or specially to himself.

The High Court stated that if the draft was drawn in favour of a fictitious person, it could not be said that the ownership stood transferred to a non-existent person for the purpose of examining the question whether the bank as a collecting banker acted negligently or not. The ownership would pass to the true owner. The High Court did not consider it necessary to decide as to what extent a person obtaining a draft in favour of a fictitious person would lose the ownership in favour of a bona fide "holder in due course".

In view of the aforesaid, the Appellant Bank was held to have acted without taking any care, and was found negligent throughout and was not entitled to the protection under Section 131 of the Negotiable Instruments Act.

In Indian Bank vs Catholic Syrian Bank AIR 1981 Mad 129, the Madras High Court had occasion to consider negligence of collecting banker which had opened an account after proper introduction.

Briefly the facts were that one $D$ had opened an account with Salem branch of bank A. A customer of that branch had taken $D$ to the said branch and had informed the Manager that $D$ was a man from Indore and that he wanted to open a bank account to enable him to purchase carpets from Salem. Although bank A had claimed that the customer, who had introduced D, was a well-known customer of bank $A$ and was a leading merchant of Salem and had a large volume of business, it was found in the evidence recorded by the Court, that these claims were not true. The introducer had an account and also had some fixed deposits with bank $A$. The transactions were for paltry amount and the amount standing to the credit of the introducer at the relevant time, was only ₹ 192.57 . 
On 12 June 1969, M obtained a demand draft for ₹ 20 from the branch at Singanallur of the bank B. The draft was drawn on the branch office of bank $B$ in favour of $D$ and company. By means of clever forgery, the draft was altered for $₹ 29,000$ drawn in favour of $D$. The draft was presented by $D$ on 13 June 1969 for credit to his account opened with Salem branch of bank $A$ and the amount was collected by bank $A$ from bank $B$ and credited to the account of $D$.

On 14 June 1969, the Salem branch of bank B came to know from its Singanallur branch that the draft was issued for ₹ 20 and was drawn in favour of $D$ and company, payable at Cochin and that no draft for a sum of ₹ 29,000 had been issued. At once the Salem branch of bank A was contacted and was informed of the fraud, but unfortunately by then, bank $A$ had already paid a large part of the draft amount to $D$ under a self cheque.

Bank B (Paying banker) filed the suit against bank A (collecting banker) for recovery of ₹ 29,000 on the ground that the collecting banker had been negligent while opening an account in the name of $D$ and by reasons of its negligence and want of good faith, the forged draft got to be wrongly converted.

The High Court observed that the collecting banker had opened the account, in the name of $D$ on a mere introduction of one of its account holders, knowing fully well that the said account holder was not a well-known leading merchant and had no large business with it at the relevant time. Further the collecting banker had not independently questioned $D$ about his business and his credit worthiness before allowing him to open an account. When $D$ stated that he had come from Indore, the Manager of the collecting banker did not even care to find out his permanent address, more so when in the application for opening account filed by $\mathrm{D}$, the address given was of that of the introducer. Moreover, when D told the Manager of collecting banker that he had not till then opened any account although he had come from Indore to Salem to do business, the collecting banker, before opening the account, should have been more alert.

\section{Duty to confirm the reference where the referee is not known or has given reference in absentia}

Though as a matter of practice bankers in India require introduction by an existing customer of the bank, this may not always be possible especially when the branch is newly opened. In such cases the customers are required to get references from known persons in the locality or from the existing bankers. In such case the banker is required to make enquiries with the referee to confirm that the person whose account is newly opened is a genuine person.

In Harding vs London Joint Stock Bank [1914] 3 Legal Decision Affecting Bankers 81, an account was opened for a new customer after complying with the necessary formalities. The account was not opened by deposit of cash as is the usual practice but was by paying in a third party cheque. The bankers in the case made enquiries with the customer who thereupon produced a forged letter issued by his employer giving him power to deal with the cheque. It was thereafter found that the cheque was stolen by the customer and credited to his account. The bank was held negligent for failure to make necessary enquiries from the employer as to whether the customer who was an employee had in fact the necessary power to deal with the cheque.

\section{Duty to ensure crossing and special crossing}

It is the duty of the banker to ensure that the cheque is crossed specifically to himself and if the cheque is crossed to some other banker they should refuse to collect it. Similarly where the cheque is crossed to a specific account then crediting the same to another account without necessary enquiries would make him liable on the grounds of negligence. In case of "non-negotiable" crossing a banker cannot be held negligent merely because of collection of such instruments. In the case of Crumpling vs London Joint Stock Bank Ltd. [1911-13] All England Rep 647 it was held that a non-negotiable crossing is only one of the factors amongst others to be considered to decide about the bankers negligence and that the mere taking of a non-negotiable cheque cannot be held to be evidence of negligence on the part of the bankers. 


\section{Duty to verify the instruments or any apparent defect in the instruments}

Sometimes the instrument which is presented for collection would convey to the banker a warning that a customer who has presented the instrument for collection is either committing a breach of trust or is misappropriating the money belonging to some other. In case the banker does not heed the warning which is required of a prudent banker then he could be held liable on the grounds of negligence as can be seen from the following cases:

(a) In Underwood Ltd. vs Bank of Liverpool Martin Ltd. [1924] 1 KB 775, the Managing Director of a company paid into his private account large number of cheques which were to be paid into the company's account and the bank was held negligent since it did not make enquiries as to whether the Managing Director was in fact entitled to the amounts represented by these cheques.

(b) In Savory Company vs Llyods Bank [1932] 2 KB 122, the cheques which were payable to the employer was collected by the employee in a private account opened by him and the bank was held liable for negligence. In this case two dishonest clerks of a Stock Broker stole bearer cheques belonging to their employer which were collected in an account maintained by one of the clerks and in another account in his wife's name. It was held that the bank had been negligent in opening the clerks account inasmuch as they had not obtained his employer's name while opening the account and that in the case of his wife's account the bank was negligent in as much as it had not obtained the husband's occupation and his employer's name while opening the account.

(c) In the case of Australia and New Zealand Bank vs Ateliers de Constructions Electriques de Cherleroi [1967] 1 AC 86 PC, an agent paid his principal's cheque into his personal account and the bank was charged with conversion. However, the bank defended the same on the grounds that there was implied authority from the principal to his agent to use his private account for such purpose. Though the banker was negligent in dealing with the cheques without specific authority the bank escaped liability since it was found that the principal had in fact authorized his agent to use his private account.

(d) In Morrison vs London County and Westminster Bank Ltd. [1914-5] All ER Rep 853, the Manager of the plaintiff was permitted to draw cheques per pro his employer and he drew some cheques payable to himself which he collected into his private account. The bank was held negligent for collecting such cheques without making necessary enquiries even though there was a clear indication that the Manager was signing as an agent of the firm.

\section{Duty to take into account the state of customer's account}

The collecting banker is required to take into account the status of the customer and also the various transactions that have taken place in the customer's account so as to know the circumstances and the standard of living of the customer. If for example, a person is an employee and the nature of his employment is that of a clerk his salary would be known to the bank and any substantial credits by way of collection of cheques would be suspected and it would be the duty of the banker to take necessary precautions while collecting such cheques.

In Nu-Stilo Footwear Ltd. vs Lloyds Bank Ltd. [1956] 7 Legal Decisions Affecting Bankers P. 121, the plaintiffs who were manufacturer of ladies footwear were defrauded by their Secretary and Works Accountant who converted 9 cheques payable to the plaintiffs into his account. The Secretary opened the accounts in the defendant bank in a false name and as reference gave his real name. The bank thereupon called the reference and got a satisfactory reply which included the fact that the account holder had recently come down from Oxford and intended setting up a business of his own. The Secretary thereupon presented 9 cheques totally aggregating to $£ 4855$. Since these cheques were drawn on the plaintiffs they sued the defendant bank who had collected the cheques. The Court held that the collecting bank was negligent in as much as the collecting bank did not take necessary precautions because the amounts collected were inconsistent with the business of the account holder and therefore necessary enquires should have been made by the bank. 


\section{Negligence of collecting bank in collecting cheques payable to third parties}

The collecting bank has to make necessary enquiries before any third party cheques are collected on behalf of its customer. In Ross vs London County Westminster and Parrs Bank Ltd. [1919] 1 KB 678, cheques payable to "the Officer in charge, Estate Office, Canadian Overseas Military Force" were used by an individual to pay off his debts. There was an instruction in all the cheques that it was negotiable by the concerned officer. However, it was held that the fact that the cheques were drawn in favour of the Officer in charge should have put the banker on enquiry and since no such enquiry was made by the banker the bank is liable on the grounds of negligence.

\section{INDEMNITIES AND GUARANTEES}

\section{Indemnities}

In day to day banking operations, a banker comes across instances where he has to protect his interest in case of certain transactions. A customer may request a banker to issue a duplicate draft or fixed deposit receipt. In such cases, to protect against any possible loss, the banker should issue the duplicate draft and/or fixed deposit receipt against an indemnity.

Section 124 of the Indian Contract Act,1872 defines indemnity as, "A contract by which one party promises to save the other from loss caused to him by the conduct of the promisor himself, or by the conduct of any other person, is called a ' Contract of Indemnity'.

Indemnity is applicable where there is a loss. The contract of insurance is based on the principles of indemnity. The life insurance companies agree to cover the loss of life, whereas the general insurance companies wish to cover the loss to the property or asset, covered under respective insurance policies.

The two parties involved in the contract of indemnity are (i) "indemnifier", the person who gives the undertaking or promise and (ii) the "indemnified " to whom such a promise is given.

While issuing a duplicate fixed deposit receipt, the bank obtains an indemnity (usually in their standard form) and the indemnifier (customer) need to give all details regarding the original receipt. The indemnity will have clauses to protect the bank's interest. The indemnifier will undertake not to use the original and surrender the same to the bank, in case he is able to locate the original. He further undertakes to cover the loss, if any, that will be incurred by the bank on account of issuing such duplicate fixed deposit receipt.

\section{Guarantees}

Banks grant loans and advances (fund based) and provide other credit facilities (non fund based) such as, bank guarantee and letters of credit. Non fund based limits are granted by banks to facilitate the customers to carry on with the trading and business activities more comfortably. Bankers can earn front end fees and these non fund based items become contingent liabilities for banks.

A contract of guarantee is covered under the Indian Contract Act,1872. Sec 126 defines a guarantee as contract to perform the promise or discharge a liability of a third person in case of his default. The contract of guarantee may be oral or in writing. Banks, however insist on written guarantees.

There are 3 parties to the contract of guarantee. They are called Surety, Principal Debtor and the Creditor. These parties are also called as the guarantor, borrower and the beneficiary.

Banks deal with two types of guarantees: (i) Accepted by the bank, and (ii) Issued by the bank

\section{(1) Guarantees accepted by the Bank:}

At the time of lending money, banks accept securities. In addition to the tangible assets a borrower arranges to furnish a personal security given by surety (guarantor). This is called third party guarantee, who undertakes to pay the money to the bank inclusive of interest and other charges, if any, in case the principal borrower fails to repay 
or if the borrower commits default. Banks also obtain Corporate guarantees issued by companies who execute corporate guarantee as authorized by the Board of Directors' resolution.

As per Sec 128 of the Contract Act,1872, the surety's liability is co-extensive with that of the principal debtor.

For example, Bank MNC has sanctioned a term loan of Rs 10 lakhs to $P$ on the personal guarantees of $Q$ and $S$. In this case Bank MNC is the creditor. $P$ is the borrower or the principal debtor. Both $Q \& S$ are the sureties or guarantors. In case P commits a default, in repaying the debt to the Bank MNC ( as per the terms and conditions of bank's sanction letter) then both Q\&S (as sureties/guarantors) are liable to pay the dues to the bank.

\section{(2) Guarantees issued by the Bank:}

A Bank Guarantee is a commitment given by a banker to a third party, assuring her/ him to honour the claim against the guarantee in the event of the non- performance by the bank's customer. A Bank Guarantee is a legal contract which can be imposed by law. The banker as guarantor assures the third party (beneficiary) to pay him a certain sum of money on behalf of his customer, in case the customer fails to fulfill his commitment to the beneficiary.

\section{OPERATIONS IN DEPOSIT ACCOUNTS AND COMPLAINTS OF CUSTOMERS}

RBI has issued certain guidelines for banking operations and redressal of customer complaints. These guidelines have been summarized below:

\section{Savings bank account}

- The Savings Bank Rules must be made available to account holders while opening the accounts.

- Photographs of all depositors/account holders whether resident or non-resident should be obtained in respect of all types of deposit accounts including fixed, recurring, cumulative, etc. except:-

(i) Banks, Local Authorities and Govt. Departments (excl. public sector undertakings or quasi Government bodies);

(ii) Accounts of Staff members (single/joint)

- Banks need not insist for the presence of account holder for making cash withdrawal of 'self' or bearer cheques unless circumstance so warrants.

- Photographs cannot be a substitute for specimen signatures.

- Only one set of photographs need be obtained and separate photographs need not be obtained for each category of deposit.

- Photographs of the 'Pardanishin' women need to be obtained

- For additional accounts, fresh photographs need not be insisted upon.

- While opening the accounts, the account holders should be informed in transparent manner the requirement of minimum balance and other charges, etc. Revision in charges also needs to be advised from to time.

- Banks may purchase cheques, drafts, etc. deposited in the account for clearing in case of suspension of clearing operations temporally or apprehension of prolonging the suspension. This facility is extended to customers upon examining the credit worthiness, integrity, past dealing, occupation, etc. so as to guard themselves from the possibilities of such instrument being dishonored subsequently.

- Savings Bank Pass Books must be provided invariably to all customers. In case of account statement, the same should be mailed to the customers regularly. These facilities should be provided at Bank's cost. Updating the pass book periodically should also be arranged by the banks. 
- Banks may avoid the usage of inscrutable entries in pass books/statement of account and ensure that brief, intelligible particulars are invariably entered in pass books / statement of account with a view to avoiding inconvenience to depositors.

- Banks are required to ensure that full address / telephone number of the branch is invariably mentioned in the Pass Books / Statement of Accounts issued to account holders.

- All cheque forms should be printed in Hindi and English irrespective of the language the customer uses including regional language.

- Cheques bearing date in Hindi as per the National Calendar (Saka Samvat) can be accepted by banks for payment, if otherwise in order. Banks can, however, ascertain the Gregorian calendar date corresponding to the National Saka calendar in order to avoid payment of stale cheques.

- Banks are required to make available the Magnetic Ink Character Recognition (MICR) code and Indian Financial System Code (IFSC), besides cheque leaf, in all passbook/ statement of account holders

\section{Term Deposit Account}

- Banks are required to issue term deposit receipt indicating therein full details, such as, date of issue, period of deposit, due date, applicable rate of interest, etc.

- Term Deposit Receipts can be freely transferable from one office of bank to another.

- In order to extend better service, banks should ensure sending of intimation of impending due date of maturity well in advance to their depositors. Change in rate of interest should be advised well in advance to the customers.

- Deposits repayable in less than three months or where the terminal quarter is incomplete, interest should be paid proportionately for the actual number of days reckoning the year at 365 days or 366 days in case of leap year.

- Banks may allow premature withdrawal of Term Deposits at the request of the depositor and interest on the deposit for the period that it has remained with the bank will be paid at the rate applicable Banks have the freedom to fix penal interest on such withdrawal. No interest need be paid where premature withdrawal takes place before completion of the minimum period prescribed.

- Bank can permit addition/deletion of name/s of joint account holders. However, the period and aggregate amount of the deposit should not undergo any change. Banks may also allow splitting of joint deposit, in the name of each of the joint account holders provided that the period and the aggregate amount of the deposit do not undergo any change.

- Banks may renew the frozen accounts upon obtaining suitable request letter for renewal. No renewal receipt be issued but suitable noting may be done in the deposit account. Renewal of the deposit may be advised to the concerned Enforcement Authority by registered post/Speed Post/Courier. Overdue interest may be paid as per the policy adopted by the banks.

- Banks are required to ensure that their branches invariably accept cash over the counters from all their customers who desire to deposit cash at the counters. No product can be designed which is not in tune with the basic tenets of banking i.e. acceptance of cash.

- Notwithstanding the legal provisions, opening of fixed/recurring and savings bank accounts be permitted in the name of minor with mother as guardian provided bank take adequate safeguards in allowing operations in the accounts by ensuring that such accounts are not allowed to be overdrawn and that they always remain in credit. 


\section{Current Accounts}

- Banks while opening current account must obtain a declaration to the effect that the account holder is not enjoying any credit facilities with any other bank. Banks must scrupulously ensure that their branches do not open current accounts of entities which enjoy credit facilities (fund based or nonfund based) from the banking system without specifically obtaining a No-Objection Certificate from the lending bank(s).

- Bank may open account of prospective customer in case no response is received from its existing bankers upon waiting for a fortnight. The situation may be reviewed with reference to the information provided by the prospective customer as well as taking needed due diligence on the customer.

- For corporate entities enjoying credit facilities from more than one bank, the banks should exercise due diligence and inform the consortium leader, if under consortium, and the concerned banks, if under multiple banking arrangement.

\section{Reconciliation of transactions at ATMs failure}

- Banks are required to resolve complaints within 7 working days from the date of receipt of the complaint.

- Failure to re-credit the amount with the timeframe should entail payment of compensation to the customer @100/- per day by the issuing bank.

- For compensation, suitable application is to be made within 30 days of date of the transaction.

- All disputes regarding ATM failed transactions should be settled by the issuing bank and the acquiring bank through the ATM System Provider only. No bilateral settlement arrangement outside the dispute resolution mechanism available with the system provider is permissible.

- Non-adherence to the provision attract penalty under the Payment and Settlement System Act 2007.

- Banks are required to display prominently at the ATM locations that complaints should be lodged at the branches where customers maintain accounts to which the ATM is linked along with telephone numbers of help desk/contact persons of ATM owning bank, etc.

- Each bank should ensure that the process flow is modified to provide for the pin validation for every transaction including balance enquiry facilitated through ATM. Failure to this attract penalty.

- Banks are required to have in place a system of online alerts for all types of transactions irrespective of the amount involving usage of cards at various channels.

\section{Levy of Service Charges}

Banks should ensure that the service charges fixed are reasonable and they are not out of line with the cost of providing such services. Customers with low volume of transactions are not penalized.

\section{Foreclosure charges/prepayment penalty - Home Loans}

Banks are not permitted to levy/charge prepayment charges/penalties on Home Loans on floating interest rates, with immediate effect

\section{BANKING HOURS/WORKING HOURS/OPERATION}

- Banks are required to function for public transactions at least for 4 hours on week days and 2 hours on Saturdays in the larger interest of public and trading community. Extension counters, satellite offices, one man offices or other special class of branches may remain open for such shorter hours as may be considered necessary. 
- Banks may fix, after due notice to customers, whatever business hours are convenient i.e. double shift, weekly holiday other than Sunday, or functioning Sundays also (7 days working) etc.

- The banks' branches in rural areas can fix the business hours (i.e., number of hours, as well as timings) and the weekly holidays to suit local requirements subject to the guidelines.

- Commencement of employees' working hours 15 minutes before commencement of business hours could be made operative by banks at branches in metropolitan and urban centres.

- Banks are required to extend business hours for banking transactions other than cash till one hour before close of working hours. Banks can have evening counters at the premises of existing branches in metropolitan/urban centres for providing facilities to the public beyond normal business hours to bring about improvement in customer service and the transactions should be merged with the main accounts of the branch where it is set up.

- All branches except very small branches should have "Enquiry" or "May I help You" counters either exclusively or combined with other duties located near the entry point of the banking hall. Time norms should also be displayed prominently in the banking hall.

- All Branch branches are required to display the various products and services they provide along with various key aspects such as service charges, interest rates, time norms for various banking transactions and grievance redressal mechanism, etc. grouped in 4 heads viz. "Customer Service Information", "Service Charges", "Grievance redressal" and "Others" as indicators in the Notice Boards as per the format provided by RBI. This would enhance the quality of customer service in banks and level of customer satisfaction.

- Further, in addition to the above Board, the banks should also display details such as 'Name of the bank / branch, Working Days, Working Hours and Weekly Off-days' outside the branch premises.

- Banks are further required to make available the detailed information in their Web-site in such a manner that customers are able to easily access the same from the Home Page of the site, besides in booklet form in the touch screen by placing them in the information kiosks or Scroll Bars, or Tag Boards. Website should contain the minimum information such as Policy/Guidelines, Complaints, Opening of accounts/ forms, Loans and Advances, Branches, etc.

\section{Sick/old/incapacitated account holders - Operational Procedure}

In case the old/sick/ incapacitated account holder can put his thumb or toe impression, the same may be accepted for withdrawal of money. It should be identified by two independent witnesses known to the bank, one of whom should be a responsible bank official.

- Where the customer cannot put even his/her thumb impression and also not able to present in the bank, a mark can be obtained on the cheque/withdrawal form which should be identified by two independent witnesses, one of whom should be a responsible bank official.

- Person to whom the payment is to be made may be indicated by the customer in both the above cases and he should be identified by two independent witnesses. The person should be asked to furnish his signature to the bank.

- As per the opinion obtained by IBA, a toe impression or any mark by a customer who lost both the hands can be taken for acceptance.

- Banks are required to take necessary steps to provide all existing ATMs / future ATMs with ramps so that wheel chair users / persons with disabilities can easily access them and also make arrangements in such a way that the height of the ATM does not create an impediment in its use by a wheelchair user.

- Banks are required to ensure that all the banking facilities such as cheque book facility including third 
party cheques, ATM facility, Net banking facility, locker facility, retail loans, credit cards etc., are invariably offered to the visually challenged without any discrimination.

- Banks are required to make at least one third of new ATMs installed as talking ATMs with Braille keypads and place them strategically in consultation with other banks to ensure that at least one talking ATM with Braille keypad is generally available in each locality for catering to needs of visually impaired persons.

- In respect of disabled persons with autism, cerebral palsy, mental retardation and multiple disabilities Banks can rely upon the Guardianship Certificate issued either by the District Court under Mental Health Act or by the Local Level Committees under the above Act for the purposes of opening / operating bank accounts.

\section{Remittance}

- Remittance (DD/MT/TT, etc.) of ₹ 50000/- and above should be by debit to customer's account or against cheques only. DDs of ₹ $20,000 /$ and above are to be issued with "Account Payee" crossing only.

- ADD is uniformly valid for a period of three months and procedure for revalidation after three months should be simplified.

- Duplicate Draft in lieu of lost for amount up to and including ₹ 5000/- can be issued against suitable indemnity without waiting drawing advice within a fortnight from the date of receipt of the request. Delay beyond the period, penal provision to be invoked.

- Banks may ensure that both drop box facility and the facility for acknowledgement of cheques are made available at collection centres (branches) and no branch should refuse to give acknowledge of cheques if tendered at the counters. Banks should display on the drop box itself that "Customers can also tender the cheques at the counter and obtain acknowledgement on the pay-in-slips".

- Banks may place per transaction limits based on their risk perception in respect of Mobile transactions with the approval of their respective Boards.

- Banks need not make payment of cheques/drafts/pay orders/ banker's cheques bearing that date or any subsequent date, if they are presented beyond the period of three months from the date of such instrument (w.e.f. 01.04.12)

- For loss of cheque in transit or in clearing process or at the paying bank's branch, the banks are required to reimburse the accountholder related expenses for obtaining duplicate instruments and also interest for reasonable delays occurred in obtaining the same. The onus rests with the collecting banker and not the account holder.

\section{GENERAL}

\section{Complaints}

- Banks are required to provide Complaints/suggestion box at each office besides maintaining Complaint Book/Register with perforated copies in each set. A copy of the complaint is also to be forwarded to Controlling Office along with remark of the Branch Manager within a time frame.

- Complaint form along with name of the nodal officer for complaint redressal be provided in the Homepage of Website to facilitate submission by customers. Complaints received are to be reviewed by Board for taking corrective steps wherever required. The details are to be disclosed in the financial results giving the number of complaints received, redressed, Awards by Ombudsman, etc.

- Banks are also required to put in place a proper Grievance Redressal Mechanism and examine on an on-going basis whether it is found effective in achieving improvement in customer service in different areas. 


\section{Erroneous Debits arising on fraudulent or other transactions}

- While opening and allowing operation in deposit accounts, banks should remain vigilant to avoid lapses to safeguard against unscrupulous persons opening accounts mainly to use them as conduit for fraudulently encashing payment instruments, etc.

- In such cases, banks should compensate the customer upon completion of departmental action or police interrogation as part of their approved Customer Relation Policy.

\section{Safe Deposit Locker/Safe Custody Article Facility}

- Banks have to refrain from restrictive practices such as linking the lockers facility with placement of fixed or any other deposit beyond what is specifically permitted. Banks may obtain Fixed Deposits to cover 3 years rent and charges of breaking open the locker to take care of an eventuality that the locker-hirer neither operates the locker nor pays rent.

- Bank branches are required to maintain a wait list for the purpose of allotment of lockers and ensure transparency in allotment of the lockers. A copy of the Agreement may be passed on to the locker-hirer at the time of allotment of the locker.

- Banks may carry out customer due diligence for both new and existing customers at least to the levels prescribed for customers classified as medium risk. If the customer is classified in a higher risk category, customer due diligence as per KYC norms applicable to such higher risk category should be carried out.

- Where the lockers have remained non-operated for more than three years for medium risk category or one year for a higher risk category, banks should immediately contact the locker-hirer and advise him to either operate the locker or surrender it. This exercise should be carried out even if the locker hirer is paying the rent regularly.

- Nomination facility is available to locker hirer which would provide for nomination and release of contents of safety lockers/safe custody article to the nominee and protection against notice of claim of other persons (Sec. $45 Z C$ to 45 ZF of B.R. Act 1949)

- Nomination facility can be made available in respect of deposits held in the name of individuals (single/ Joint accounts) including sole proprietorship concerns and Safe Deposit Locker/Safe Custody. Nomination should be made only in favour of individuals and a nominee cannot be an Association, Trust, Society or any other Organization or any office-bearer thereof in his official capacity

- There cannot be more than one nominee in respect of a joint deposit account. In the case of a joint deposit account the nominee's right arises only after the death of all the depositors.

- Banks may allow variation/cancellation of a subsisting nomination by all the surviving depositor(s) acting together. This is also applicable to deposits having operating instructions "either or survivor".

- Banks are required to acknowledge in writing to the depositor(s)/ locker hirers (s) the filing of the relevant duly completed Form of nomination, cancellation and / or variation of the nomination.

- Banks may introduce the practice of recording on the face of the passbook the position regarding availment of nomination facility with the legend "Nomination Registered". This may be done in the case of term deposit receipts also.

\section{DECEASED DEPOSITORS - SETTLEMENT OF CLAIMS - PROCEDURE THEREOF}

\section{Accounts with survivor/nominee clause}

In case there exists a valid nomination and the deposit account is opened with the survivorship clause ("either or survivor" or "anyone or survivor" or "former or survivor" or "latter or survivor"), bank can make payment of the 
balance in the deposit account to the survivor(s)/nominee of a deceased deposit account holder which is considered as a valid discharge of the bank's liability provided:-

(a) The bank has exercised due care and caution in establishing the identity of the survivor(s)/ nominee and fact of death of the account holder through appropriate documentary evidence; there is no order from the competent court restraining the bank from making the payment from the account of the deceased; and

(b) Survivor(s)/nominee has been advised in clear terms that he would be receiving the payment from the bank as a trustee of the legal heirs of the deceased depositor.

Banks may desist from insisting production of succession certificate, letter of administration or probate, etc., or obtain any bond of indemnity or surety from the survivor(s)/nominee, irrespective of the amount standing to the credit of the deceased account holder.

\section{Accounts without the survivor/nominee clause}

- In deceased deposit accounts without the survivor/nominee clause, banks may fix some minimum threshold limit for settlement of claim without insisting on production of any documents other than indemnity.

- Premature termination of Term deposit accounts would not attract any penalty and such clause may be incorporated in the opening form itself.

- Any claim on the balances lying in deceased depositors received from survivor(s) / nominee(s) should be settled within a period not exceeding 15 days from the date of receipt of the claim subject to the production of proof of death of the depositor and suitable identification of the claim(s), to the bank's satisfaction.

\section{Access to Safe Deposit Locker/Safe Custody articles (with survivor/nominee clause)}

- In the event of death of sole locker hirer, banks may give access to the locker with liberty to remove the contents of the locker to the nominee and in case of the locker hired jointly with operational instruction to operate under joint signatures and nomination exists, bank may give access to the locker with liberty to remove the articles jointly to the survivor(s)/nominee.

- In the case of the locker was hired jointly with survivorship clause and the hirers instructed that the access of the locker should be given over to "either or survivor", "anyone or survivor" or "former or survivor" or according to any other survivorship clause, banks may follow the mandate in the event of the death of one or more of the locker-hirers.

\section{Access to Safe Deposit Locker/Safe Custody articles (without survivor/nominee clause)}

- Banks are required to evolve a customer-friendly procedure drawn up in consultation with their legal advisers for giving access to legal heir(s) / legal representative of the deceased locker hirer. Similar procedure should be followed for the articles under safe custody of the bank.

- Banks are also required to prepare an inventory before returning articles left in safe custody/before permitting removal of the contents of the safe deposit locker. Banks are not required to open sealed/ closed packets left with them in Safe Custody or found in locker while releasing them to the nominee and surviving locker heirs/depositor of safe custody article. Banks are required to put in their website the entire procedure for improvement in customer service.

\section{Settlement of claims in respect of missing persons}

Banks are required to formulate a policy which would enable them to settle the claims of a missing person after considering the legal opinion and taking into account the facts and circumstances of each case (claims are to be settled as per provisions u/s 107/108 of Indian Evidence Act 1872).

In order to avoid inconvenience and undue hardship to the common person, banks may, keeping in view their risk 
management systems, fix a threshold limit, up to which claims in respect of missing persons could be settled without insisting on production of any documentation other than (i) FIR and the non-traceable report issued by police authorities and (ii) letter of indemnity.

\section{Unclaimed deposits/Inoperative Accounts in banks}

- A savings as well as current account should be treated as inoperative / dormant if there are no transactions in the account for over a period of two years.

- If credits by way of interest on Fixed Deposit account is being received in the Savings Bank accounts as per the mandate of the customer, the same can be treated as a customer induced transaction and the account can be treated as an operative account. It will become inoperative only after 2 years from the date of the last credit entry of the interest on Fixed Deposit account.

- Banks need to ascertain the whereabouts of the account holder(s) by letters, telephone calls, or contacting legal heirs, or contacting the introducers or employers as available record or any other means suited to them in case of no operations (credits other than periodic interest or debiting service charges) for more than one year.

- Periodical interest should continue to be credited in the inoperative accounts and proceeds of FDR unpaid, the amount left unclaimed should attract Savings Bank rate of interest. Inoperative accounts should get audited periodically. There should not be any charge on activation of an inoperative account.

\section{Customer Confidentiality Obligations}

Banks are not supposed to divulge any information about the account to third parties except where:-

(a) disclosure is under compulsion of law

(b) there is duty to the public to disclose

(c) interest of bank requires disclosure and

(d) the disclosure is made with the express or implied consent of the customer.

The information collected from the customer for the purpose of opening of account is to be treated as confidential and not divulge any details thereof for cross selling or any other purposes.

\section{Transfer of account from one branch to another}

Instructions from customer for transfer of his account to another office should be carried out immediately by transferring the account opening form, specimen signature, standing instructions, etc. under advice to the customer.

\section{Co-ordination with officers of Central Board of Direct Taxes}

Banks should maintain greater co-ordination between the Income-Tax department and extend necessary help/ co-ordination to tax officials whenever required.

\section{Declaration of Holiday under the Negotiable Instruments Act, 1881}

- In terms of Section 25 of the Negotiable Instruments Act, 1881, the expression "public holiday" includes Sunday and any other day declared by the Central Government by notification in the Official Gazette to be a public holiday.

- This power has been delegated to State Govt. by Central Govt. subject to the condition that the Central Government may itself exercise the said function, should it deem fit to do so and this implies that when Central Government itself has notified a day as "public holiday" under Section 25 of the Negotiable Instruments Act, 1881, there is no need for banks to wait for the State Government notification. 


\section{Miscellaneous}

- In predominantly residential areas banks may keep their branches open for business on Sundays by suitably adjusting the holidays and banks should keep rural branches open on weekly market day.

- Banks are required to accept standing instructions in Savings and Current accounts and the same can be enlarged to include payments on account of taxes, bills, rents, school/college fees, etc.

- Branch Manger may be permitted to allow clean overdraft for small amounts to customers whose dealings have been satisfactory.

- All transactions, including payment of interest on deposits/charging of interest on advances, should be rounded off to the nearest rupee

- In order to keep a watch on the progress achieved by the bank in the implementation of the recommendations of various working groups/Committees on customer service, banks may examine the recommendations which have relevance in the present day banking and continue to implement them.

- Banks should follow various provisions of the Code of Bank's Commitment to Customers, implementation of which is monitored by the Banking Codes and Standards Board of India (BCSBI), etc.

\section{LESSON ROUND UP}

- One of the important aspects of credit management is to ensure that the bank is holding all required legal documents.

- Valid legal documents would help the bank to initiate legal course of action against the defaulter/s. Legal documents like hypothecation agreement, deed of pledge, mortgage deed gives the bank the right of charge over the securities.

- Therefore, it is important that necessary care is taken by the branch manager/credit officers and others responsible for handling documentation are fully aware of the bank's requirements in obtaining not only the required documents, but also all these documents are stamped/executed properly to enable the banks to recover the loan dues through legal action.

- A cheque is nothing but a bill of exchange with special features A cheque is classified as 'Open' when cash payment is allowed across the counter of the bank.

- A cheque which is payable to any person who holds and presents it for payment at the bank counter is called a 'Bearer cheque'.

- An order cheque is a cheque which is payable to a particular person. Crossing is an 'instruction' given to the paying banker to pay the amount of the cheque through a banker only and not directly to the person presenting it at the counter.

- Thus, an endorsement consists of the signature of the maker (or drawer) of a negotiable instrument or any holder thereof but it is essential that the intention of signing the instrument must be negotiation, otherwise it will not constitute an endorsement.

- An endorsement must be regular and valid in order to be effective.

- The Negotiable Instruments Act,1881 deals with negotiable instruments like promissory notes, bills of exchanges, cheques and similar payment instruments such as demand drafts, dividend warrants, etc.

- When a customer of a banker receives a cheque drawn on any other banker he has two options before 
him - (i) either to receive its payment personally or through his agent at the drawee bank, or (ii) to send it to his banker for the purpose of collection from the drawee bank.

- A banker is under no legal obligation to collect his customer's cheques but collection of cheques has now become an important function of a banker with the growth of banking habit and with wider use of crossed cheques, which are invariably to be collected through a banker only.

- A collecting banker acts as an agent of the customer if he credits the latter's account with the amount of the cheque after the amount is actually realized from the drawee banker.

- A contract by which one party promises to save the other from loss caused to him by the conduct of the promisor himself, or by the conduct of any other person, is called a ' Contract of Indemnity A contract of guarantee is covered under the Indian Contract Act, 1872.

- Sec 126 defines a guarantee as contract to perform the promise or discharge a liability of a third person in case of his default. In case the old/sick/ incapacitated account holder can put his thumb or toe impression, the same may be accepted for withdrawal of money.

\section{SELF TEST QUESTIONS}

1. What are the different types of cheque? Explain how is the crossing of cheque done?

2. What do you mean by endorsements? Explain the legal requirements of endorsements.

3. What are the legal aspects of collection of cheque?

4. Describe the obligations of a Paying Banker.

5. Write a brief note on indemnities and guarantees.

6. What are the various rights and duties of a banker and customer?

7. Write short notes on
(a) Right of set-off
(b) CASA deposits
(c) FCNR deposits

8 Discuss in brief the importance of nomination for bank accounts.

9. Highlight the features of flexi deposits.

10. What precautions banks should take while opening accounts for different types of customers? 
130 PP-BL\&P 


\section{Lesson 5}

\section{Banking Related Laws}

\section{LESSON OUTLINE}

- Limitation Act, 1963

- Bankers' Book Evidence Act, 1891

- Tax laws

- Recovery of Debts Due to Banks and Financial Institutions Act, 1993 (DRT Act):

- Lok Adalats

- SARFAESI Act, 2002

- Lenders Liability Act

- Banking Ombudsman

- The Consumer Protection Act,1986

- Lesson Round Up

- Self Test Questions

\section{LEARNING OBJECTIVES}

One of the important law relating to banking is the Law of Limitation and this law prompts the lending banker to remain vigilant in taking legal course of action against the borrower in case the loan defaults. When a claim of the bank is required to be proved in the Courts of Law, banks can produce a certified copy of the extracts of original documents, records of the bank as an evidence, as per the provisions of the Bankers' Book Evidence Act,1891. Bank as a business unit (entity) needs to comply with various tax laws. Banks need to pay corporate tax as per rates applicable to companies. Apart from these, whenever banks avail of services of professionals, contractors etc., it needs to deduct and pay applicable tax at source (TDS) and any special tax as per the Income Tax Act, 1961. DRT Act 1993 deals with debt recovery of above Rs 10 lakhs which is applicable to cases pertaining to banks and co-operative banks including Regional Rural Banks. The Act was enacted for expeditious adjudication and recovery of debts. SARFAESI Act, 2002 has facilitated sale of hypothecated property without the intervention of courts. Objectives of this chapter are enable the reader to:

- Appreciate the features and importance of different banking related laws

- Understand the significance of various legal framework and their contribution to banking

- Know about the provisions of different laws assist banks to handle their operations

- Understand the importance of limitation period for loan documents 


\section{LIMITATION ACT, 1963}

\section{Limitation Act - Important Aspects}

The Limitation Act, 1963 specifies certain period prescribed within which any suit appeal or application can be made. The 'prescribed period' means the period of limitation computed in accordance with the provisions of the Limitation Act. A banker is allowed to take legal action by filing a suit, prefer an appeal and apply for recovery only when the documents are within the period of limitation. On the other hand, if the documents expired or are time barred, the banker cannot take any legal course of action to recover the dues. Therefore, banks should be careful to ensure that all legal loan documents held are valid and not time barred. In other words, it is the responsibility of lenders to ensure that all loan documents are properly executed and they are all within the required limitation period as per the limitation act. This is one of the crucial aspect in credit management of banks.

\section{Period of limitation for certain documents}

Period of limitation and the time from which the period begins to run is shown below:

\begin{tabular}{|l|l|}
\hline NATURE OF DOCUMENTS & LIMITATION PERIOD \\
\hline A Demand Promissory Note & Three years from the date of DP Note. \\
\hline $\begin{array}{l}\text { A Bill of exchange payable at sight or } \\
\text { upon presentation }\end{array}$ & Three years when the bill is presented \\
\hline An Usance Bill of exchange & Three years from the due date \\
\hline Money payable for money lent & Three years from the loan was made. \\
\hline A guarantee & Three years from the date of invocation of the guarantee \\
\hline $\begin{array}{l}\text { A mortgage - enforcement of } \\
\text { payment of money }\end{array}$ & Twelve years from the date the money sued becomes due \\
\hline A mortgage - foreclosure & $\begin{array}{l}\text { Twelve years from the money secured by the mortgage becomes } \\
\text { due }\end{array}$ \\
\hline $\begin{array}{l}\text { A mortgage - possession of } \\
\text { Immovable property }\end{array}$ & \begin{tabular}{l} 
Thirty years when the mortgagee becomes entitled to possession \\
\hline
\end{tabular}
\end{tabular}

\section{Revival of Documents}

Banks are expected to hold valid legal documents as per the provisions of the limitation act. If the limitation period expires, then the bank should arrange to obtain fresh set of documents. Such situations are to be discouraged. In certain situations, the limitation period can be exceeded. A limitation period can be extended in the following manners:

1. Acknowledgement of debt: As per Section 18 of Limitation Act, obtaining acknowledgement of debt in writing across the requisite revenue stamp from the borrower before expiration of the prescribed period of limitation, can extend limitation period.

2. Part payment: When part re- payment of the loan is made by the borrower himself or his duly authorized 
agent, before expiry of the documents (Sec 19 of Limitation Act). Evidence of such payments should be in the handwriting or under the signature of the borrower or his authorized agent.

3. Fresh set of documents: When the bank obtains the fresh set of documents before the expiry of the original document, fresh period of limitation will start from the date of execution of the fresh documents. A time-barred debt can be revived under Sec 25 (3) of the Indian Contract Act only by a fresh promise in writing and signed by the borrower or his authorized agent, generally or specially authorized in that behalf. A promissory note/ fresh documents executed for the old or a barred debt will give rise to a fresh cause of action and a fresh limitation period will be available from the date of execution of such documents.

\section{Court Holiday}

In case, if the court is closed on the prescribed period of any suit, appeal or application falls on a date, then the suit appeal or application may be instituted, preferred or made, on the day when the court reopens. ( Sec 4 of the limitation act)

\section{Limitation Period - Precautions to be taken by bank:}

1. Banks should preserve all the relevant loan documents in a secured place

2. The documents should be under dual control of authorized persons

3. Banks should not allow any document to become time barred as per the provisions of Law of Limitation

4. Banks internal control and monitoring system should be very effective in the sense that the renewal of documents should be done well in advance

\section{BANKERS' BOOK EVIDENCE ACT, 1891}

(a) The Act extends to the whole of India except the State of Jammu \& Kashmir

(b) 'Bank' and 'banker' means

(i) any company or corporation carrying on business of banking

(ii) any partnership or individual to whose books, provision of this Act are made applicable

(iii) any post office saving bank or money order office

(c) 'Bankers' books include all books like ledgers, day book, cash book and all other records used in the ordinary business of a bank. The records can be maintained in any form such manual records, printed computer printouts, it can be in written form or stored in a micro-film, magnetic tape or any other form of mechanical or electronic data. Such record can be either on site or at any off site location including a back-up or disaster recovery site

(d) Court means the person or persons before whom a legal proceeding is held and the 'judge' refers to a judge of a High Court

(e) Legal proceeding refers to different types of inquiries proceedings and investigation. Legal proceedings means (i) any proceeding or inquiry in which evidence is or may be given (ii) an arbitration (iii) any investigation or inquiry under Code of Criminal Procdure,1973 or under any other law as applicable for collection of evidence, conducted by a police officer as well

(f) A certified true copy of the bank records. 


\section{Important aspects of Bankers' Book Evidence Act, 1891}

1. If the records are maintained in written form, a copy of any entry along with a certificate certifying at the foot of such copy clearly indicating that;

(i) it is a true copy of such entry/entries

(ii) the extract is taken from one of the ordinary books of the bank

(iii) such entry was made in the ordinary course of business

(iv) such record is still in the custody of the bank

(v) if the copy was obtained by a mechanical or other process a certificate is required for the authenticity of the information/data

Please note that each certificate mentioned above should bear date and should be signed by the principal accountant or manager of the bank with his name and official designation/ title

2. If the records are maintained in the electronic form (computer printouts, floppy, disc, tapes etc.,) a copy of print out and a certificate as mentioned for the manual records

3. If the records are maintained in mechanical form (i) a printout of any entry in the books of a bank stored in a mechanical or electronic form, it should contain a certificate covering all aspects discussed for manual records

Further in case the books of the bank are not written in the handwritten form, then the copies in the form computer printout, such copy must accompany:

(a) a certificate by the principal accountant or the manager stating that it is a printout of such entry or a copy of such printout

(b) In addition to the above another certificate by a person who is in charge of computer furnishing a brief description of the computer system and other particulars like (i) the safety features adopted by the bank to protect the date integrity; (ii) prevention of unauthorized entry into the system, (iii) checks and balancing system of verification of authenticity of input and output,(iv) if the data is retrieved and transformed, details of control system, and (v) in case of micro film and similar manner in which the data are stored, then the details of the arrangement for the storage and custody of such storage systems and practices.

In short, the certificate should be certified by the person in charge of the computer system certifying about the integrity, accuracy and security of the computer system and the data/ records.

A certificate of any entry in a banker's book should in all legal proceedings be received prima facie evidence of the existence of such entry, and should be admissible as if original is produced. On production of certified copy, no further evidence is required. Court can order inspection of books of accounts.

\section{TAX LAWS APPLICABLE IN BANKING OPERATIONS}

Like any other business units, companies, banks and financial institutions are required to ensure that all the applicable provisions of the various tax laws (Income Tax Act, Finance Act etc) to deduct and pay income tax, professional tax, service tax etc. As an employer as well as the beneficiary of different services, banks are required to adhere to the applicable tax provisions.

Apart from the role of employer and beneficiary of services, banks are expected to pay tax on the interest payable to the customers as per the directives of authorities like TDS on interest payable on fixed deposits, NRO deposits, etc. Apart from the above, income on investments made by the bank and dealing in securities by banks, also attract provisions of TDS. 
In view of the above banks should ensure that:

(i) calculation of taxes and recovery of such taxes are correctly handled.

(ii) deducted taxes are paid within the prescribed due date to the concerned authorities without fail. This is one of the crucial compliance requirement and for noncompliance or wrong calculation/ information, banks may face action as well as penalty.

(iii) Further, banks are required to keep proper records of tax collection and remittance.

(iv) In addition to the above, banks are required to report the details to the authorities within a specific time frame. The reporting requirement would also include quarterly reporting as well as submission of half yearly and/or annual statements.

(v) At the time of payment of salary to employees banks should deduct applicable tax at source and arrange to issue the necessary certificates for TDS on form 16 to employees. For other deductions like payment to contractors etc., TDS on form 16A should be issued to the service providers. These TDS (16 and 16A forms ) would serve (i) as evidence of tax deducted at source (ii) as a record (iii) enable the employees and service providers/professionals to claim refund of tax.

\section{RECOVERY OF DEBTS DUE TO BANKS AND FINANCIAL INSTITUTIONS ACT, 1993 (DRT ACT)}

Recovery of the dues of loans from the borrowers through courts was a major issue for the banks and financial institutions due to huge back log of cases and the time involved. The Act came into operation from $24^{\text {th }}$ June 1993.

Important highlights of DRT Act 1993:

1. This Act constituted the special 'Debt Recovery Tribunals' for speedy recovery

2. This Act is applicable for the debt due to any bank or financial institution or a consortium of them, for the recovery of debt above 'Ten lakhs

3. This Act is applicable to the whole of India except the State of Jammu \& Kashmir

4. The term 'debt' covers the following types of debts of the banks and financial institutions

(a) any liability inclusive of interest, whether secured or unsecured

(b) any liability payable under a decree or order of any Civil Court or any arbitration award or Otherwise or

(c) any liability payable under a mortgage and subsisting on and legally recoverable on the date of application

Some examples of interpretation of the term 'debt' by different courts

(a) In the case of United Bank of India vs DRT (1999) 4 SCC 69, the Supreme Court held that if the bank had alleged in the suit that the amounts were due to it from respondents as the liability of the respondents had arisen during the course of their business activity and the same was still subsisting, it is sufficient to bring such amount within the scope of definition of debt under the DRT Act and is recoverable under that Act

(b) In G.V. films vs UTI (2000) 100 Compo Cases 257 (Mad) (HC), it was held that payment made by the bank by mistake is a debt

(c) In the case of Bank of India vs Vijay Ramniklal AIR 1997 Guj.75. it was held that, if an Employee commits 
fraud and misappropriation of money, the amount recoverable from him is not a debt within the meaning of DRT Act.

\section{Debt Recovery Tribunals}

Debt recovery tribunals (DRTs) have been established by the Central Government. The Central Government decides the jurisdiction and also appoints one member as presiding officer, who should be at least a district Judge.

DRT - other important aspects:

(a) When DRT has jurisdiction in such matters the Civil Courts are debarred from handling any case.

(b) The Tribunal and Appellate Tribunal function from the appointed day, which is declared in notification. Their duties, powers and jurisdiction are well defined. From the date of establishing the Tribunal, i.e., the appointed day, no court or other authority should have any jurisdiction, powers or authority to deal with in any way in recovery cases above Rupees ten lakh. High Courts and Supreme Courts, however, have jurisdiction under Constitution Articles 226 and 227.

\section{Recovery Procedure:}

Bank has to file an application for recovery of loan taking into consideration the jurisdiction and cause of action. Other bank or financial institution can also jointly apply. Application can be filed with fees, documents and evidence. The Limitation Act is also applicable on the DRT cases, therefore, the application must be filed by the bank or the financial institution within limitation period from cause of action. In case when the defendant against whom the DRT has passed recovery order, wants to prefer appeal to the Appellate Tribunal, he is required to deposit $75 \%$ or the prescribed percent of the amount as decided by the Tribunal. Without such payment an appeal cannot be filed.

The tribunal issues Recovery Certificate to the applicant. Recovery officers attached to the tribunal, have adequate powers for recovery under the Act. On receiving the recovery certificate, the recovery officer has to proceed for the recovery by attachment and sale of movable and immovable property. Defendant is debarred from disputing the correctness of the amount given in recovery certificate. Orders of recovery officer are applicable within thirty days to the Tribunal.

\section{Special features of DRT:}

The provisions of this Act have overriding effect when there is inconsistency with any other law or in any instrument by virtue of any other law for the time being in force.

\section{Case laws:}

DRT is a special Act for recovery of debt due to banks and financial institutions. DRT has overriding effect over the provisions of Companies Act,1956, hence leave of the company court is not required even if the company is under winding up proceedings (Allahabad Bank vs Canara Bank AIR 2000 SC 1535)

Money realized under DRT Act and distribution between bank and other secured creditors, in cases where winding up proceedings are pending in company court, priority of secured creditors is subject to provisions of 529 A of Companies Act (as per the said section, priority of secured creditors and workman over other dues and distribution inter se between secured creditors and workmen should be pari-pasu).

\section{LOK ADALATS}

Lok Adalats are organized under the Legal Services Authorities Act, 1987. They are intended to bring about a compromise or settlement in respect of any dispute or potential dispute. Lok Adalats derive jurisdiction by consent or when the court is satisfied that the dispute between the parties could be settled at Lok Adalats. It should be 
guided by the principles of justice, equity, fair play and other legal principles. In case of settlement, the Award should be binding on the parties to the dispute. No appeal should lie in any court against the Award. Currently, Lok Adalats organised by civil courts to effect a compromise between disputing parties in matters pending before any court can handle cases up to a ceiling of ' 20 lakh.

\section{SARFAESI ACT, 2002}

The objective of enactment of the SARFAESI ACT was to regulate securitization and reconstruction of financial assets and the enforcement of security interest and for the matters connected therewith or incidental thereto.

\section{SARFAESI Act - Important Aspects}

1. This Act is popularly called as Securitization Act

2. This Act empowers the banks and financial institutions to recover their dues in Non- Performing Asset (NPA) accounts, without the intervention of a court

3. This Act also empowers the banks and financial institutions to issue notice for recovery from the defaulting borrowers and guarantors, calling upon them to discharge the dues in full within 60 days

4. In case the borrower and/or guarantor fails to comply with the 60 days' notice issued by the bank or financial institution in repayment of full dues, then the bank and/or financial institution can:

(a) Take the possession or the management of secured assets of the borrower, and also can transfer the same by way of lease, assignment or sale for realizing the secured assets without the intervention of a court/DRT

(b) Appoint any person to manage the secured assets which have been taken over by the secured creditor (bank)

(c) Also instruct at any time by a notice in writing to a person (i) who holds secured assets of the borrower (ii) from whom any money due or becoming due to the borrower (iii) to pay such money to the secured creditor (bank)

\section{Some important terms covered under the SARFAESI Act}

\section{(1) Bank:}

All the banking companies, Nationalised banks, the State Bank of India and its subsidiary banks, Regional Rural Banks, co-operative banks etc.

\section{(2) Borrower:}

(i) any person who has availed financial assistance from a bank and/or financial institution (ii) any person who has given guarantee (iii) any person who has created any mortgage or pledge as a security for the financial assistance granted by any bank or financial institution (iv) any person who becomes the borrower of a securitization company or reconstruction company, because the company has acquired any interest or right of any bank or financial institution, on account of financial assistance granted to a borrower

\section{(3) Central Registry:}

The register office set up by the Central Government for the purpose of registration of all the transactions of asset securitization, reconstruction and transactions of creation of security interests. The registration system will operate on a priority of registration basis, i.e., 'first come first served basis' the first person who registers gets priority over the persons who registers at a later date. 


\section{(4) Financial assistance:}

Whenever any bank or financial institution allows a borrower;

(i) to avail of a loan or advance (ii) makes subscription of debenture or bonds (iii) issues a letter of credit (iv) issues letter of credit ( $v$ ) extends any other credit facility, it is called financial assistance.

The Act covers;

- Any financial assistance which is due (principle debt or any other amount payable)

- The right of security enforcement is for a default committed by the borrower, and the creditor is a secured creditor. In other words, any unsecured creditor has no right under this Act

- The debt should be classified by the bank as Non- Performing Asset

\section{(5) Financial Asset:}

Financial asset means debt or receivables and includes:

(a) any debt or receivable secured by mortgage of or charge in immovable property or

(b) a claim to any debt or receivables or part thereof whether secured or unsecured or

(c) any charges like a mortgage, hypothecation or pledge of moveable property or

(d) any right or interest in the security, whether full or part, securing debt

(e) any beneficial interest in any movable or immovable property or in debt, receivables whether is existing, future, accruing, conditional or contingent or

(f) any other financial assistance

The Act is applicable only in case of a Non Performing Asset (NPA) of a borrower classified by a bank or financial institution as sub-standard, doubtful or a loss asset as per the RBl's guidelines.

The term 'hypothecation' is defined under this Act as a charge in or upon any movable property (existing or future) created by a borrower in favour of a secured creditor.

Reconstruction company formed for the purpose of asset reconstruction and registered under the Companies Act, 1956 is called Reconstruction company.

The Act covers three important aspects viz., (i) Securitization (ii) Reconstruction of Financial assets and (iii) Enforcement of security interest

\section{Securitization}

Securitization is the process of acquisition of financial asset by the securitization or reconstruction company from the lender (bank or financial institution) The reconstruction or securitization company may be raising funds for acquisition of financial asset from the qualified institutional buyers by issue of security receipts representing undivided interest in the financial assets or otherwise.

\section{Security Receipt:}

A receipt or another security issued by a securitization company or reconstruction company to any qualified institutional buyer. The receipt is an evidence of purchase or acquisition by the holder thereof of an undivided right, title or interest in the financial asset involved in securitization is called the security receipt. The security receipts are transferable in the market. SARFAESI Act made the loans secured by mortgage or other charges transferable. 


\section{Asset Reconstruction}

An asset reconstruction company's role is to takeover loans or advances from the bank or financial institution for the purpose of recovery. In other words any securitization company or reconstruction company acquires any right or interest of any bank or financial institution, in any financial assistance for the purpose of realization of such financial assistance it is called as asset reconstruction.

On acquisition of a financial asset, the securitization or reconstruction company becomes the owner of the financial asset and steps into the shoes of the lender bank or financial institution. This acquisition can also said to be, as a sale of asset without recourse to the bank or financial institution. The regulatory authority for all securitization or reconstruction companies is the Reserve Bank of India. It is a company registered under the Companies Act, 1956 for the purpose of securitization and it also requires a registration from the RBI as per the SARFAESI Act.

\section{Enforcement of Security Interest}

The 'Enforcement of security interest' is important for recovery of the bank's bad loans. The special feature of the Act is that the security interest can be enforced without intervention of the courts, subject to certain procedures to be followed, like 60 days notice has to be served by the bank on the borrower with a request to discharge the loan liability. In case If borrower fails to discharge the liability, secured creditor can take possession of secured asset or other actions as per the provisions of the Act.

\section{Security Interest:}

Any right, title and interest of any kind of the property created in favour of any secured creditor is called as security interest. It includes any secured creditor is called as security interest. Whenever any lender takes any security from the borrower the lender gets interest in that security.

While taking possession of the asset various precautions are required to be taken and if required the help of the Chief Metropolitan Magistrate or District Magistrate can be taken.

\section{Special features:}

Under certain circumstances properties cannot be attached, such as, (i) any security interest securing repayment of any financial assistance not exceeding '1 lakh. (ii) Security interest not registered under this Act. (iii) Any security interest created in agricultural land.(iv) A pledge of movables as per Sec 172 of the Indian Contract Act.

No civil court has any jurisdiction under this Act. The Indian Limitation Act, 1963 is applicable to this Act.

\section{Central Registry}

The Central registry is set up for registration of securitization and reconstruction transaction and creation of security interest. Registration under other Acts like;

(a) Registration Act, 1908 (b) Companies Act, 1986 (c) Patents Act, 1970 (d) Motor Vehicles Act, 1988. The registration under the SARFAESI Act is in addition to the respective registrations required in the above mentioned acts and/or any other Act.

The following items require registration under the SARFAESI Act:

1. Securitization of financial assets

2. Reconstruction of financial assets

3. Creation of security interests

The central registry record can be kept fully or partly on electronic form

Filing of details of securitization, reconstruction, creation of security interests is to be filed with the central registrar. The details in the prescribed form should be filed within thirty days after the date of transaction or the creation of 


\section{PP-BL\&P}

security, by the securitization company, or the reconstruction company or the secured creditor. The prescribed fees are applicable for registration. The delay if any can be condoned by the central registrar for a period of next thirty days after the first thirty days prescribed subject to payment of fees as required. In case of modification of details registered with the central registrar, the modification also needs to be filed before the central registrar by the securitization company, or the reconstruction company or the secured creditor. The time period for modification is also like that of registration, i.e., the modification will have to be filed within thirty days in the prescribed forms with prescribed fees. The delay if any can be condoned by the central registrar for a period of next thirty days after the first thirty days prescribed subject to payment of fees as required.

The security interest registered with the central registrar is required to be satisfied on the payment of full amount by the borrower. The securitization company, or the reconstruction company or the secured creditor as the case may should report the satisfaction, within thirty days of payment in full or satisfaction of the charge. On receipt of the satisfaction charge the central registrar is required to cause a notice to be issued to the securitization company, or the reconstruction company or the secured creditor, calling upon to show cause within a period of fourteen days as to why the payment or satisfaction should not be recorded as intimated. If no cause is shown as required then the central registrar has to order that the memorandum of satisfaction should be entered in the central register. If any cause is shown accordingly a noting is recorded in the central register and should inform to the borrower accordingly.

\section{Taking possession of property mortgaged / hypothecated to banks}

In a recent case Supreme Court has observed that we are governed by rule of law in the country and the recovery of loans or seizure of vehicles could be done only through legal means. In this connection it may be mentioned that the Securitisation and Reconstruction of Financial Assets and Enforcement of Security Interest Act, 2002 (SARFAESI Act) and the Security Interest (Enforcement) Rules, 2002 framed there under have laid down well defined procedures not only for enforcing security interest but also for auctioning the movable and immovable property after enforcing the security interest. It is, therefore, desirable that banks rely only on legal remedies available under the relevant statutes which allow the banks to enforce the security interest without intervention of the Courts.

Where banks have incorporated a re-possession clause in the contract with the borrower and rely on such repossession clause for enforcing their rights, they should ensure that such repossession clause is legally valid, is clearly brought to the notice of the borrower at the time of execution of the contract, and the contract contains terms and conditions regarding (a) notice period to be given to the customers before taking possession (b) the procedure which the bank would follow for taking possession of the property and (c) the procedure which the bank would follow for sale / auction of property. This is expected to ensure that there is adequate upfront transparency and the bank is effectively addressing its legal and reputation risks.

\section{LENDERS LIABILITY ACT}

In India, the SARFAESI Act. was enacted in 2002. On the basis of the recommendations of the working group on Lenders' Liability Laws constituted by the Government of India, Reserve Bank of India had finalized a set of codes of conduct called 'the Fair Practice Code for Lenders' and advised banks to adopt the guidelines. All the banks have formulated their own set of Fair Practice Codes as per the guidelines and implemented it from $1^{\text {st }}$ November, 2003.

Some of the important features of Lenders Liability Act are:

Banks and financial institutions should give acknowledgment for receipt of all loan applications. The loan applications should scrutinize the loan applications within a reasonable period of time. Loan applications in respect of priority sector and advances up to ' 2 lakhs should be comprehensive.

Lenders should ensure that the credit proposal is properly appraised after assessing the creditworthiness of the applicants. They should not use margin and security stipulation as a substitute for the due diligence on 
credit worthiness and other terms and conditions. The lender should inform to the borrower the sanction of credit limit in writing along with the terms and conditions thereof and keep the borrower's acceptance of the credit limits and terms and condition on record. Duly signed acceptance letter should form part of the collateral security. In case of consortium advances, the participating lenders should evolve procedures to complete appraisal of proposals in the time-bound manner to the extent feasible and communicate their decision on financing or otherwise within a reasonable time. Lenders should ensure timely disbursement of loans sanctioned in conformity with the terms and conditions governing such sanction. Post disbursement supervision by lenders, particularly in respect of loans up to ' 2 lakhs, should be constructive with a view to taking care of any 'lenderrelated; genuine difficulty that the borrower may face, Lenders should release all securities on receiving payment of loan or realization of loan, subject to any legitimate right of lien for any other claim lenders may have against the borrowers. Lenders should not interfere in the affairs of the borrowers except for what is allowed as per the terms and conditions of the loan sanction documents. In the matter of recovery of loans, lenders should not resort to undue harassment

Apart from the Fair Practices Code, banks should also have proper system for grievance redressal system, Apart from the above code, banks have set up codes for Bankers' Fair Practices Code, Fair Practices Code for Credit Card Operations, Model Code for Collection of Dues and Repossession of Security etc.,

\section{BANKING OMBUDSMAN}

Banking Ombudsman Service is a grievance redressal system. This service is available for complaints against a bank's deficiency of service. A bank's customer can submit complaint against the deficiency in the service of the bank's branch and bank as applicable, and if he does not receive a satisfactory response from the bank, he can approach Banking Ombudsman for further action. Banking Ombudsman is appointed by RBI under Banking Ombudsman Scheme, 2006. RBI as per Sec 35 A of the Banking Regulation Act, 1949 introduced the Banking Ombudsman Scheme with effect from 1995.

\section{Important features of Banking Ombudsman}

The Banking Ombudsman is a senior official appointed by the Reserve Bank of India to redress customer complaints against deficiency in certain banking services. All Scheduled Commercial Banks, Regional Rural Banks and Scheduled Primary Co-operative Banks are covered under the Scheme.

Some of the deficiency in banking services including internet banking, covered under the Banking Ombudsman Scheme are:

- deficiency in customer service like non-acceptance, without sufficient cause, of small denomination notes tendered for any purpose, and for charging of commission in respect thereof;

- delayed or non- payment of inward remittance, delay in issuance of drafts,

- non-adherence to prescribed working hours;

- refusal to open deposit accounts without any valid reason for refusal;

- levying of charges without adequate prior notice to the customer;

- forced closure of deposit accounts without due notice or without sufficient reason;

- refusal to close or delay in closing the accounts; etc.,

- non-adherence to the fair practices code as adopted by the bank or non-adherence to the provisions of the Code of Bank's Commitments to Customers issued by Banking Codes and Standards Board of India and as adopted by the bank ;

- non-observance of Reserve Bank guidelines on engagement of recovery agents by banks; and any other matter relating to the violation of the directives issued by the Reserve Bank in relation to banking or other 
services.

As regards loans and advances, a customer can also lodge a complaint on the following grounds of deficiency in service with respect to loans and advances:-

- Non-observance of Reserve Bank Directives on interest rates; delays in sanction, disbursement or nonobservance of prescribed time schedule for disposal of loan applications;

- non-acceptance of application for loans without furnishing valid reasons to the applicant; non-adherence to the provisions of the fair practices code for lenders as adopted by the bank or Code of Bank's Commitment to Customers, as the case may be.,

One can file a complaint before the Banking Ombudsman if the reply is not received from the bank within a period of one month after the bank concerned has received one's representation, or the bank rejects the complaint, or if the complainant is not satisfied with the reply given by the bank.

However a complaint will not be considered by the Ombudsman in the following situations:

(i) The person has not approached his bank for redressal of his grievance first

(ii) The subject matter of the complaint is pending for disposal or has already been dealt with at any other forum like court of law, consumer court etc.

(iii) The institution complained against is not covered under the scheme

(iv) The subject matter of the complaint is not within the ambit of the Banking Ombudsman

A person can file a complaint with the Banking Ombudsman simply by writing on a plain paper. A person can also file it on-line or by sending an email to the Banking Ombudsman. For complaints relating to credit cards and other types of services with centralized operations, complaints may be filed before the Banking Ombudsman within whose territorial jurisdiction the billing address of the customer is located.

The complaint can also be filed by one's authorized representative (other than an advocate).

The amount, if any, to be paid by the bank to the complainant by way of compensation for any loss suffered by the complainant is limited to the amount arising directly out of the act or omission of the bank or ' 10 lakhs, whichever is lower

The Banking Ombudsman may award compensation not exceeding ' 1 lakh to the complainant only in the case of complaints relating to credit card operations for mental agony and harassment. The Banking Ombudsman will take into account the loss of the complainant's time, expenses incurred by the complainant, harassment and mental anguish suffered by the complainant while passing such award.

The Banking Ombudsman may reject a complaint at any stage if it appears to him that a complaint made to him is: (i) not on the grounds of complaint referred to above compensation sought from the Banking Ombudsman is beyond ' 10 lakh (ii) in the opinion of the Banking Ombudsman there is no loss or damage or inconvenience caused to the complainant.

If one is aggrieved by the decision, he/she may, within 30 days of the date of receipt of the award, appeal against the award before the appellate authority. The appellate authority may, if he/ she is satisfied that the applicant had sufficient cause for not making an application for appeal within time, also allow a further period not exceeding 30 days.

\section{THE CONSUMER PROTECTION ACT, 1986}

To protect the interests of the consumers, the Consumer Protection Act was enacted. The Act extends to the whole of India except the State of Jammu and Kashmir. The Act covers all goods and services, except goods for resale or for commercial purpose and services rendered free of charge and a contract of personal service. 
Complaints (i.e., any allegation should be in writing made by a complainant to obtain any relief provided by or under this Act)

The complaint may be made by the complainant which includes a consumer or any voluntary consumer association registered under the Companies Act,1956 or any other law or the Central or State Government or one or more consumers, having the same interest and in case of death of a consumer his/ her legal heirs or representative.

The Act is for speedy disposal of the redressal of consumer disputes.

Consumer councils are established to promote and protect the rights of consumers. The Central Council has the jurisdiction for the entire country, followed by the State Council for each state and District Council for each district.

The Councils at the State level is headed by the chairman of the council, i.e., the Minister-in-Charge of the Consumer Affairs in the State Government.

The consumers' complaints are dealt by District Forum, State and National Commission. District forum and State Commission are established by the State Governments, and the National Commission established by Central Government. District Forum has powers to deal with cases up to ' 20 lakhs. The State Commission deals with complaints exceeding value of ' 20 lakh and below ' One crore and appeals against the orders of any District forum within the State. The cases exceeding ' One crore would be handled by the Central Commission. They also deal with appeals against the order of any State Commission.

Complaints should be in a prescribed manner, with full details, evidence and applicable fee. Supporting affidavit is required. Admissibility of complaint is to be decided within twenty one days.

Similarly, other procedures and requirements as per the Act which are in force, would be applicable.

\section{LESSON ROUND UP}

- As regards the Limitation Act,1963, banks can take legal course of action to recover bank dues if the documents are valid and within limitation period.

- In some cases the limitation period can be extended if certain actions are taken within in a specified time frame (before expiration of documents). Bankers Book Evidence Act, is applicable to throughout India except the State of Jammu \& Kashmir.

- It allows certified copies of bank records and books of accounts as an evidence in the Courts of Law. DRTs and Lok Adalats have made recovery of bank's dues very easy.

- How without the intervention of the Court banks can recover the money due to them on account of NonPerforming Assets under the SARFAESI ACT,2002 ?

- The Act covers three important aspects viz., Securitization, Reconstruction of Financial assets and Enforcement of security interest.

- The SARFAESI ACT is not a substitute for registration applicable in any other act. The 'Enforcement of security interest' is important for recovery of the bank's bad loans.

- The special feature of the Act is that the security interest can be enforced without intervention of the courts, subject to certain procedures to be followed, like 60 days' notice has to be served by the bank on the borrower with a request to discharge the loan liability.

\section{SELF TEST QUESTIONS}

1. State whether the following statements are 'True' or 'False'

1. Banks should take legal action within the limitation period 
2. Banking Ombudsman is not applicable to foreign banks in India

3. Lending banker can extend the period limitation

4. Micro film of a ledger is treated as part of bank record

5. A banker allows his customer funds against clearing. This is not a debt as per DRT Act

6. The SARFAESI Act is a substitution to Indian Companies Act

7. A complaint cannot be filed by a representative to the Banking Ombudsman

2. Choose the correct alternative.

A. Bank record means, it covers the

(a) records kept at the branches

(b) records kept at off site premises

(c) records kept at (back up) recovery center

(d) records kept at branches, off site premises including recovery centers

B. The debt recoverable through DRT can be
(a) secured
(b) unsecured
(c) either $a$ or $b$
(d) neither a nor b

C. Lok Adalats are organized under:
(a) The Lok Adalats Act
(b) The SARFAESI Act
(c) The DRT Act
(d) The Legal Services Authorities Act

D. The limitation period for a Sight Bill of Exchange is

(a) Three years after the date of Sight Bill of Exchange

(b) Twelve years after the date of Demand Bill of Exchange

(c) Sight Bill of Exchange is payable on demand therefore no limitation period is applicable

(d) Three years from the date of presentation made to the drawee

E. In which case the provisions of the SARFAESI ACT is applicable

(a) BankA has extended a cc limit to the customer, and the account is in credit as of 31st March,2013

(b) Bank B has granted a clean overdraft to one of the clients and the operations in the account as of 31st March,2013 are satisfactory

(c) As of 31st March,2013 Bank M converted hypothecation charge to a pledge charge for an working capital line of credit

(d) Bank Y has classified an asset as non- performing asset as of 31st March,2013 
F. As per the SARFAESI ACT, the term borrower includes the guarantor

(a) True

(b) Yes but subject to certain conditions

(c) No

(d) Only when the principal debtor fails to reply to the notice within stipulated time

G. As regards registration identify the exception
(a) SARFAESI Act
(b) The Banking Regulation Act
(c) Patents Act
(d) Motor Vehicles Act

H. Who cannot file a complaint to Banking Ombudsman?
(a) a bank customer
(b) joint account holders of a bank
(c) a representative of a bank customer
(d) an advocate of a bank customer

3. Explain important provisions of SARFAESI Act, 2002.

4. Explain the grievance redressal system available for complaints against a bank's deficiency of service.

5. As regards the Bankers' Book Evidence Act, 1891 briefly highlight the procedures banks, should follow in respect of manual and electronic records.

6. Discuss in brief the important aspects of the Limitation Act,1963

7. Write short notes on:
(a) Financial asset
(b) Banking Ombudsman 
146 PP-BL\&P 


\section{Lesson 6}

\section{Loans and Advances}

\section{LESSON OUTLINE}

- Principles of Lending Credit Worthiness of Borrowers

- Types of Credit Facilities

- Non-Fund Based Facilities

- Priority Sector Advances:

- Credit-Linked Government Sponsored Schemes :

- Kisan Credit Card Scheme

- Financing Self Help Groups (Shgs):

- Financing Joint Liability Groups (Jlgs):

- Retail Finance Consortium Finance:

- Trade Finance:

- Export - Import Finance:

- Lesson Round Up

- Self Test Questions

\section{LEARNING OBJECTIVES}

Banks' main source of funds is deposits. These deposits are repayable on demand or after a specific time. Hence, banks should deploy such funds very carefully. Generally, banks use their funds for (i) loan assets and (ii) investments. While deploying funds as loans and advances, banks should ensure that certain lending principles are followed by them. Banks should give importance to the principles of lending based on the following concepts: Safety, Liquidity, Purpose, Diversity, Security and Profitability. Banks should also ensure that a good credit monitoring system is in place both at pre-sanction and post-sanction levels.

After going through this chapter, the reader would be able to:

- Understand various types of credit facilities granted by banks

- Legal frame work and regulatory applications in lending by banks

- Importance of priority sector lending to Agriculture, SMEs, Women Entrepreneurs, etc.

- Deployment of funds to various loans and advances 


\section{PRINCIPLES OF LENDING}

The business of lending, which is main business of the banks, carry certain inherent risks and bank cannot take more than calculated risk whenever it wants to lend. Hence, lending activity has to necessarily adhere to certain principles. Lending principles can be conveniently divided into two areas (i) activity, and (ii) individual.

\section{(i) Activity:}

(a) Principle of Safety of Funds

(b) Principle of Profitability

(c) Principle of Liquidity

(d) Principle of Purpose

(e) Principle of Risk Spread

(f) Principle of Security

\section{(ii) Individual :}

(a) Process of Lending

(b) 5 'C's of the borrower = Character, Capacity, Capital, Collateral, Conditions

Sources of information available to assess the borrower

- Loan application

- Market reports

- Operation in the account

- Report from other Bankers

- Financial statements, IT returns etc.

- Personal interview

- Unit inspection prior to sanction

(c) Security Appraisal

Primary \& collateral security should be 'MASTDAY'

M - Marketability

A - Easy to ascertain its title, value, quantity and quality.

$S$ - Stability of value.

$\mathrm{T}-$ Transferability of title.

D - Durability - not perishable.

A -Absence of contingent liability. I.e. the bank may not have to spend more money on the security to make it marketable or even to maintain it.

$Y$ - Yield. The security should provide some on-going income to the borrower/ bank to cover interest \& or partial repayment. 
The traditional principles of bank lending have been followed with certain modifications. The concept of security has undergone a radical change and profitability has been subordinated to social purpose in respect of certain types of lending. Let us now discuss the principles of lending in details:

\section{Safety}

As the bank lends the funds entrusted to it by the depositors, the first and foremost principle of lending is to ensure the safety of the funds lent. By safety is meant that the borrower is in a position to repay the loan, along with interest, according to the terms of the loan contract. The repayment of the loan depends upon the borrower's (a) capacity to pay, and (2) willingness to pay. The former depends upon his tangible assets and the success of his business; if he is successful in his efforts, he earns profits and can repay the loan promptly. Otherwise, the loan is recovered out of the sale proceeds of his tangible assets. The willingness to pay depends upon the honesty and character of the borrower. The banker should, therefore, taken utmost care in ensuring that the enterprise or business for which a loan is sought is a sound one and the borrower is capable of carrying it out successfully. He should be a person of integrity, good character and reputation. In addition to the above, the banker generally relies on the security of tangible assets owned by the borrower to ensure the safety of his funds.

\section{Liquidity}

Banks are essentially intermediaries for short term funds. Therefore, they lend funds for short periods and mainly for working capital purposes. The loans are, therefore, largely payable on demand. The banker must ensure that the borrower is able to repay the loan on demand or within a short period. This depends upon the nature of assets owned by the borrower and pledged to the banker. For example, goods and commodities are easily marketable while fixed assets like land and buildings and specialized types of plant and equipment can be liquidated after a time interval. Thus, the banker regards liquidity as important as safety of the funds and grants loans on the security of assets which are easily marketable without much loss.

\section{Profitability}

Commercial banks are profit-earning institutions; the nationalized banks are no exception to this. They must employ their funds profitably so as to earn sufficient income out of which to pay interest to the depositors, salaries to the staff and to meet various other establishment expenses and distribute dividends to the shareholders (the Government in case of nationalized banks). The rates of interest charged by banks were in the past primarily dependent on the directives issued by the Reserve Bank. Now banks are free to determine their own rates of interest on advances.. The variations in the rates of interest charged from different customers depend upon the degree of risk involved in lending to them. A customer with high reputation is charged the lower rate of interest as compared to an ordinary customer. The sound principle of lending is not to sacrifice safety or liquidity for the sake of higher profitability. That is to say that the banks should not grant advances to unsound parties with doubtful repaying capacity, even if they are ready to pay a very high rate of interest. Such advances ultimately prove to be irrecoverable to the detriment of the interests of the bank and its depositors.

\section{Purpose of the Loan}

While lending his funds, the banker enquires from the borrower the purpose for which he seeks the loan. Banks do not grant loans for each and every purpose-they ensure the safety and liquidity of their funds by granting loans for productive purposes only, viz., for meeting working capital needs of a business enterprise. Loans are not advanced for speculative and unproductive purposes like social functions and ceremonies or for pleasure trips or for the repayment of a prior loan. Loans for capital expenditure for establishing business are of long-term nature and the banks grant such term loans also. After the nationalization of major banks loans for initial expenditure to start small trades, businesses, industries, etc., are also given by the banks. 


\section{Principle of Diversification of Risks}

This is also a cardinal principle of sound lending. A prudent banker always tries to select the borrower very carefully and takes tangible assets as securities to safeguard his interests. Tangible assets are no doubt valuable and the banker feels safe while granting advances on the security of such assets, yet some risk is always involved therein. An industry or trade may face recessionary conditions and the price of the goods and commodities may sharply fall. Natural calamities like floods and earthquakes, and political disturbances in certain parts of the country may ruin even a prosperous business. To safeguard his interest against such unforeseen contingencies, the banker follows the principle of diversification of risks based on the famous maxim "do not keep all the eggs in one basket." It means that the banker should not grant advances to a few big firms only or to concentrate them in a few industries or in a few cities or regions of the country only. The advances, on the other hand, should be over a reasonably wide area, distributed amongst a good number of customers belonging to different trades and industries. The banker, thus, diversifies the risk involved in lending. If a big customer meets misfortune, or certain trades or industries are affected adversely, the overall position of the bank will not be in jeopardy.

\section{Bank Credit, National Policy and Objectives}

Banking institutions are amongst the commanding heights of an economy. They must serve the national policy and objectives. Twenty major banks in India were nationalized "to serve better the needs of development of the economy in conformity with the national policy and objectives." Necessary changes in the banking policies and practices were urgently necessitated in the wake of nationalization to serve wider social purpose of established democratic socialism in the country.

Significant changes have taken place in the concept of security observed by the bankers in their attitude towards the hitherto weaker and neglected sections of society during the last two decades. Banks have been directed to finance on a large scale agriculturists, small industrialists, professional persons and transporters, etc. Banks have also been asked to help in the implementation of the 20-Point Programme and have been directed to ensure that banks' advances within the priority sectors are given increasingly to the weaker and underprivileged sections at concessional rate of interest. Security of funds lent is not sought exclusively in the tangible assets of the borrower but also in his technical competence, managerial ability, honesty and integrity. Loans are being given in large numbers for the setting up of small businesses and for starting practice by professional persons. It is to be noted that bank credit has to act as an important instrument for achieving wider social purpose, national policies and objectives. However, the basic principles of sound lending are fundamental and are observed even by the nationalized banks. The ways in which the basic principles are followed, of course, may be modified to suit the needs of the times.

Public Sector Banks are also required, under Section 8 of the Banking Companies (Acquisition and Transfer of Undertakings) Act, 1970 in the discharge of their functions, to be guided by such directions in regard to matters of policy involving public interest as the Central Government give. The Central Government and the Reserve Bank have issued a number of directions in this regard, highlighting the social purpose which they have to sub serve.

\section{CREDIT WORTHINESS OF BORROWERS}

The business of sanctioning unsecured advances is comparatively more risky and needs special care and attention on the part of the banker. In the absence of a charge over any specific asset, the safety of advance depends upon the honesty and integrity of the borrower as much as upon the worth of his tangible assets. The banker has, therefore, to make proper enquiries not only about the borrower's capacity to pay but also about his willingness to pay the amount. Though such enquiry is also necessary in case of a secured advance but its urgency is greater in case of an unsecured advance for obvious reasons. 
The creditworthiness of a person means that he deserves a certain amount of credit, which may safely be granted to him. Such creditworthiness is judged by the banker on the basis of his (1) character, (2) capacity, and (3) capital.

1. Character: In assessing the creditworthiness of a person, the first consideration is that of the character of the person concerned. The word character implies and includes a number of personal characteristics of a person, e.g., his honesty, integrity, regularity and promptness in fulfilling his promises and repaying his dues, sense of responsibility, good habits and the reputation and goodwill which he enjoys in the eyes of others. If a person possesses all these qualities, without any doubt or suspicion in the minds of others, he possesses an excellent character and will be considered creditworthy by the banker.

2. Capacity: The success of an enterprise largely depends upon the ability, competence and experience of the entrepreneur. If the borrower possesses necessary technical skill, managerial ability and experience to run a particular industry or trade, success of such unit may be taken for granted (barring some unforeseen circumstances) and the banker will consider him a deserving case for granting an advance. The significance of this factor is now growing as the banks are willing to grant unsecured loans to technicians and competent persons on the basis of soundness of their business projects, irrespective of their own capital.

3. Capital: The importance attached by the banker to the adequacy of capital of the borrower is not without significance. Banks are the repositories of the public money and lend the borrowed money. The banker, therefore, does not lend money to an entrepreneur who does not have adequate funds of his own. In case of failure of the business enterprise, the banker will be able to realize his money if the borrower's own capital is sufficient.

Though all the above-mentioned factors are important and taken into account by the banker at the time of assessing the creditworthiness of the borrower, their relative importance differs from banker to banker and from borrower to borrower. The consideration of security is now undergoing a change. Greater emphasis is being laid on the ability and competence of the borrower and soundness of his project. However, persons of doubtful integrity and without good character are not granted unsecured advances. Further, creditworthiness is a relative term. A person may be considered, on the basis of the above, creditworthy for a certain amount only and not more.

\section{Collection of Credit Information}

For the purpose of assessing the creditworthiness of a borrower, a banker has to collect the above-mentioned information from a number of sources. In foreign countries specialized agencies collect all information relating to the status and financial standing of businessmen and supply the same to the bankers. Seyd and Company in England and Dun and Bradstreet in the U.S.A. are examples of such credit agencies. In the absence of such specialized credit agencies in India, the task of a banker becomes difficult. Every bank maintains a Credit Investigation Department at its head office and main offices in larger cities to collect information regarding the financial position of its borrowers. At other centres, credit investigation is performed by branch managers. The credit information is collected through the following sources:

1. Credit Information Bureau: The Reserve Bank of India has established within itself a Credit Information Bureau which collects credit information from the banks under Section 45-C (1) of the Reserve Bank of India Act, 1934. Banks are required to furnish such credit information in respect of credit limits of ₹ 5 lakhs and over in case of secured advances and ₹ 1 lakh and over in case of unsecured advances. They mention the nature of facility, security and charge along with outstanding balance. After consolidating such information in respect of each customer, the Reserve Bank supplies to the applicant-banks information relating to the total limits sanctioned to and the number of banks dealing with a party. Thus, the banks can 
find out if any of their customers is having excessive borrowings from the banking system at any particular time. Such information can be secured only in respect of big customers and that too relating to the last Fridays of March, June, September and December every year. Hence, the Bureau is of limited assistance to the banks.

2. Borrower: Much information may be secured from the borrower directly. The loan application form seeks basic information about the borrower and his business. The banker may examine his account books and note his past dealings with other banks or parties. His pass books with other banks can show his dealings and the business undertaken in the past. A personal interview with the borrower will also enable the banker to get a clear picture of his state of affairs.

3. Bazar Reports: Banks try to find out the creditworthiness of the party by making enquiries from the brokers, traders and businessmen in the same trade or industry. Their individual opinions may differ but a balanced opinion may be formed about the borrower on the basis of the feelings expressed by a number of such persons.

4. Exchange of credit information amongst banks: It is the practice and customary usage amongst banks to exchange credit information relating to the constituents in their mutual interest. But the credit reports exchanged by banks are brief and superficial. They are in general and guarded terms. Banks are reluctant to exchange meaningful credit information because they apprehend that legal protection available to them will be lost if more facts are divulged to the enquiring banks. A study Group appointed to permit banks to exchange meaningful credit information on their constituents." The Study Group, therefore, suggested that:

(i) there should be free and frank exchange of credit information amongst the banks; and

(ii) there should be qualitative change in the contents of credit reports, which should highlight the management practices of the customers, their behavioural pattern with their buyers, sellers and with the bank instead of concentrating entirely on the worth of assets and financial strength. Similarly, the customer's ability, business acumen and integrity and willingness to honour commitments should also be covered in the Credit Reports.

(iii) A central agency, to be called 'Credit Information Trust,' i.e., CREDIT is established for organized collection, collation, storage and exchange of credit information amongst the banks.

The Reserve Bank of India (Amendment) Act, 1974 inserted a clause which provides statutory protection to banks to exchange freely credit information, mutually amongst themselves. The scope of the term 'credit information', has also been widened so as to include information relating to the means, antecedents, history of financial transactions and the creditworthiness of the borrowers.

5. Balance Sheet and Profit and Loss Account. An analysis of the Balance Sheet and Profit and Loss Account of the borrower for the last few years will reveal his true financial position. These statements should be certified by competent accountants.

\section{TYPES OF CREDIT FACILITIES}

The business of lending is carried on by banks offering various credit facilities to its customers. Basically various credit facilities offered by banks are generally repayable on demand. A bank should ensure proper recovery of funds lent by him and acquaint itself with the nature of legal remedies available to it and also law affecting the credit facilities provided by it.

Credit facilities broadly may be classified as under:

(a) Fund Based Credit Facilities

Fund based credit facilities involve outflow of funds meaning thereby the money of the banker is lent to 
the customer. They can be generally of following types:

(i) Cash credits/overdrafts

(ii) Demand Loans/Term loans

(iii) Bill finance

(b) Non-Fund Based Credit Facilities

In this type of credit facility the banks funds are not lent to the customer and they include:

(a) Bank Guarantees

(b) Letter of Credit

\section{CASH CREDIT}

Cash credit is the main method of lending by banks in India and accounts for about 70 per cent of total bank credit. Under the system, the banker specifies a limit, called the cash credit limit, for each customer, up to which the customer is permitted to borrow against the security of tangible assets or guarantees. Cash credit is a flexible system of lending under which the borrower has the option to withdraw the funds as and when required and to the extent of his needs. Under this arrangement the banker specifies a limit of loan for the customer (known as cash credit limit) up to which the customer is allowed to draw. The cash credit limit is based on the borrower's need and as agreed with the bank. Against the limit of cash credit, the borrower is permitted to withdraw as and when he needs money subject to the limit sanctioned. It is normally sanctioned for a period of one year and secured by the security of some tangible assets or personal guarantee. If the account is running satisfactorily, the limit of cash credit may be renewed by the bank at the end of year. The interest is calculated and charged to the customer's account. Cash credit, is one of the types of bank lending against security by way of pledge or /hypothecation of goods. 'Pledge' means bailment of goods as security for payment of debt. Its primary purpose is to put the goods pledged in the possession of the lender. It ensures recovery of loan in case of failure of the borrower to repay the borrowed amount. In 'Hypothecation', goods remain in the possession of the borrower, who binds himself under the agreement to give possession of goods to the banker whenever the banker requires him to do so. So hypothecation is a device to create a charge over the asset under circumstances in which transfer of possession is either inconvenient or impracticable.

Other features of cash credit arrangements are as follows:

(1) The banker fixes the cash credit limit after taking into account several features of working of the borrowing concern such as production, sales, inventory levels, past utilization of such limits; etc. The banks are thus inclined to relate the limits to the security offered by their customers.

(2) The advances sanctioned under the cash credit arrangement are technically repayable on demand and there is no specific date of repayment, but in practice they 'roll over' a period of time. Cash accruals arising from the sales are adjusted in a cash credit account from time to time but it is found that on a larger number of accounts no credit balance emerges or debit balance fully wiped out over a period of years as the withdrawals are in excess of receipts.

(3) Under the cash credit arrangement, a banker keeps adequate cash balances so as to meet the demand of his customers as and when it arises. But the customer is charged interest only on the actual amount utilized by him. To neutralize the loss of interest on the idle funds kept by the banks within the credit limits sanctioned, a commitment charge on the unutilized limits may be charged by the banks.

(4) The Reserve Bank has advised the banks to evolve their own guidelines to ensure credit discipline and levy a commitment charge. Thus the commitment charge depends upon the discretion of individual banks. 


\section{Advantages of Cash Credit System}

1. Flexibility: The borrowers need not keep their surplus funds idle with themselves, they can recycle the funds quite efficiently and can minimize interest charges by depositing all cash accruals in the bank account and thus ensures lesser cost of funds to the borrowers and better turnover of funds for the banks.

2. Operative convenience: Banks have to maintain one account for all the transactions of a customer. The repetitive documentation can be avoided.

\section{Weakness of the System}

1. Fixation of Credit Limits: The cash limits are prescribed once in a year. Hence it gives rise to the practice of fixing large limits than is required for most part of the year. The borrowers misutilise the unutilized gap in times of credit restraint.

2. Bank's inability to verify the end-use of funds: Under this system the stress is on security aspect. Hence there is no conscious effort on the part of banks to verify the end-use of funds. Funds are diverted, without banker's knowledge, to unapproved purposes.

3. Lack of proper management of funds: Under this system the level of advances in a bank is determined not by how much the banker can lend at a particular time but by the borrower's decision to borrow at the time. The system, therefore, does not encourage proper management of funds by banks.

These weaknesses of the cash credit system were highlighted by a number of committees appointed for this purpose in India. Guidelines have been issued by the Reserve Bank for reforming the cash credit system on the basis of recommendations of the Tandon Committee and the Chore Committee.

\section{Overdrafts}

When a customer is maintaining a current account, a facility is allowed by the bank to draw more than the credit balance in the account; such facility is called an 'overdraft' facility. At the request and requirement of customers temporary overdrafts are also allowed. However, against certain securities, regular overdraft limits are sanctioned. Salient features of this type of account are as under

(i) All rules applicable to current account are applicable to overdraft accounts mutatis mutandis.

(ii) Overdraft is a running account and hence debits and credits are freely allowed.

(iii) Interest is applied on daily product basis and debited to the account on monthly basis. In case of temporary overdraft, interest should be applied as and when temporary overdraft is adjusted or at the end of the month, whichever is earlier.

(iv) Overdrafts are generally granted against the security of government securities, shares \& debentures, National Savings Certificates, LIC policies and bank's own deposits etc. and also on unsecured basis.

(v) When a current account holder is permitted by the banker to draw more than what stands to his credit, such an advance is called an overdraft. The banker may take some collateral security or may grant such advance on the personal security of the borrower. The customer is permitted to withdraw the amount as and when he needs it and to repay it by means of deposit in his account as and when it is feasible for him. Interest is charged on the exact amount overdrawn by the customer and for the period of its actual utilization.

(vi) Generally an overdraft facility is given by a bank on the basis of a written application and a promissory note signed by the customer. In such cases an express contract comes into existence. In some cases, in the absence of an express contract to grant overdraft, such an agreement can be inferred from the course of business. For example, if an account-holder, even without any express grant of an overdraft 
facility, overdraws on his account and his cheque is duly honoured by the bank, the transaction amounts to a loan. In Bank of Maharashtra vs. M/s. United Construction Co. and Others (AIR 1985 Bombay 432), the High Court concluded that there was an implied agreement for grant of overdraft or loan facility.

(vii) Banks should, therefore, obtain a letter and a promissory note incorporating the terms and conditions of the facility including the rate of interest chargeable in respect of the overdraft facility. This is to be complied with even when the overdraft facility might be temporary in nature.

Overdraft facility is more or less similar to 'cash credit' facility. Overdraft facility is the result of an agreement with the bank by which a current account holder is allowed to draw over and above the credit balance in his/her account. It is a short-period facility. This facility is made available to current account holders who operate their account through cheques. The customer is permitted to withdraw the amount of overdraft allowed as and when he/she needs it and to repay it through deposits in the account as and when it is convenient to him/her.

Overdraft facility is generally granted by a bank on the basis of a written request by the customer. Sometimes the bank also insists on either a promissory note from the borrower or personal security of the borrower to ensure safety of amount withdrawn by the customer. The interest rate on overdraft is higher than is charged on loan.

\section{Bills Finance}

In order to ease the pressures on cash flow and facilitate smooth running of business, Bank provides Bill finance facility to its corporate / non corporate clients. Bill finance facility plugs in the mismatches in the cash flow and relieves the corporates from worries on commitments. Besides the fund based bill finance, we also provide agency services for collection of documentary bills/cheques. Under bills finance mechanism a seller of goods draws a bill of exchange (draft) on buyer (drawee), as per payment terms for the goods supplied. Such bills can be routed through the banker of the seller to the banker of the buyer for effective control.

\section{(i) Clean \& Documentary bill :}

(a) When documents to title to goods are not enclosed with the bill, such a bill is called Clean Bill. When documents to title to goods along with other documents are attached to the bill, such a bill is called 'Documentary Bill'.

(b) Documents, the due possession of which give title to the goods covered by them such as RR/MTR, bill of lading, delivery orders etc. are called documents to title to goods.

(c) Cheques and drafts are also examples of clean bills.

\section{(ii) Demand \& Usance bill :}

When the bill of exchange either clean or documentary is made payable on demand or sight, such a bill is called Demand Bill. The buyer is expected to pay the amount of such bill immediately at sight. If such a demand bill is a documentary bill, then the documents including document to title to goods are delivered to the buyer only against payment of the bill. (Documents against Payment-D/P Bills).

When a bill, either clean or documentary is drawn payable after certain period or on a specified date, the bill is called Usance Bill. Such bill is presented to the buyer once for Acceptance, when he accepts to pay the bill on due date and on due date the bill is presented again for Payment. In case of documentary usance bill, the documents are delivered to the buyer (drawee/acceptor) against his acceptance of bill (Documents against acceptance - DA Bills).

\section{Finance against bills of exchange: Difference between Bills Purchase and Bills Discounting}

Banks consider working capital finance to meet the post- sale requirements of borrowers through Bill finance either by 'Purchasing' bills or 'Discounting' them.

(a) Bill Purchase facility is extended against clean demand bills like cheques / drafts/bills of exchange/ 
hundies \& demand documentary bills, whereby the bank lends money to the payee of the cheque/ draft and to the drawer of the bills by purchasing the same against tendering of such bills by the payee/ drawer. The bank in turn sends the bills for collection, preferably to its own branch at the place of drawee or to its correspondent bank or to the buyers (drawee's) bank.

(b) Bills Discounting facility is extended against usance bills: In such cases, the seller tenders the usance bill drawn by him usually along with documents to title to goods, to his banker who discounts the bill i.e. levies discount charges for the unexpired portion of the duration of the bill and credits the balance amount to the seller's account. Thereafter the drawer's bank sends the bill to collecting bank at the centre of drawee either to its own branch or drawee's bank, with instructions to release the documents to title against acceptance and thereafter, to recover the bill amount on due date. Sometimes the accepted usance bills are also tendered and discounted by the bank.

Apart from sanctioning loans and advances, discounting of bills of exchange by bank is another way of making funds available to the customers. Bills of exchange are negotiable instruments which enable debtors to discharge their obligations to the creditors. Such Bills of exchange arise out of commercial transactions both in inland trade and foreign trade. When the seller of goods has to realize his dues from the buyer at a distant place immediately or after the lapse of the agreed period of time, the bill of exchange facilitates this task with the help of the banking institution. Banks invest a good percentage of their funds in discounting bills of exchange. These bills may be payable on demand or after a stated period.

In discounting a bill, the bank pays the amount to the customer in advance, i.e. before the due date. For this purpose, the bank charges discount on the bill at a specified rate. The bill so discounted, is retained by the bank till its due date and is presented to the drawee on the date of maturity. In case the bill is dishonoured on due date the amount due on bill together with interest and other charges is debited by the bank to the customers

\section{Procedure for Assessment of Working Capital}

The term "Working Capital" means, the funds required by a company, enterprise to carry on with daily operations. The features of Working Capital (WC) are:

(a) WC is the short term funds required to meet the daily operating expenses.

(b) WC = Current Assets - Current Liabilities.

(c) Managing the short term fund requirements through the firm's short term assets and short liabilities is known as "Working Capital Management".

(d) One of the main objective of Working Capital Management is to convert Cash to Cash (C to $\mathbf{C})$ in a cyclical form called as "working capital cycle".

\section{Working Capital Cycle}

The Working Capital Cycle operates in the following manner:

1. A borrowing company, avails of working capital finance from the bank. The bank after necessary credit appraisal, grants the working capital finance. The company withdraws funds (cash). The borrower converts the cash into raw material, raw material is used in the manufacturing activities, and gets converted into semi- finished and finished goods depending upon the production schedule. The finished goods are sold invariably on credit sales basis. Bills of exchange are drawn by the seller of the goods on the buyer, which becomes the bills receivable for the seller. On the due date when the bills are paid by the drawee (buyer), the seller repays the working capital loan amount to the bank.

2. The Working Capital Cycle covers two important financing functions viz., Inventory financing and receivables financing. The items consisting of cash- raw materials- semi finished goods-finished goods 
is called as Inventory, and the other items of the cycle, consisting of Bills receivables is called Receivables. In view of the above, it can be recognized that the Working Capital Management is the management of Inventory and Receivables. Efficient management of both inventory and receivables enables the firm to ensure that (Cash to Cash) if properly handled could result in effective cost management and increase in profitability for the firm.

3. Generally, the length of the working capital cycle depends upon:

(i) the stocks of raw material to be held

(ii) the period of time for converting the raw materials to semi- finished and finished goods

(iii) the credit period extended to the purchasers (debtors). The longer the working capital cycle, the funds requirement of the firm would be more

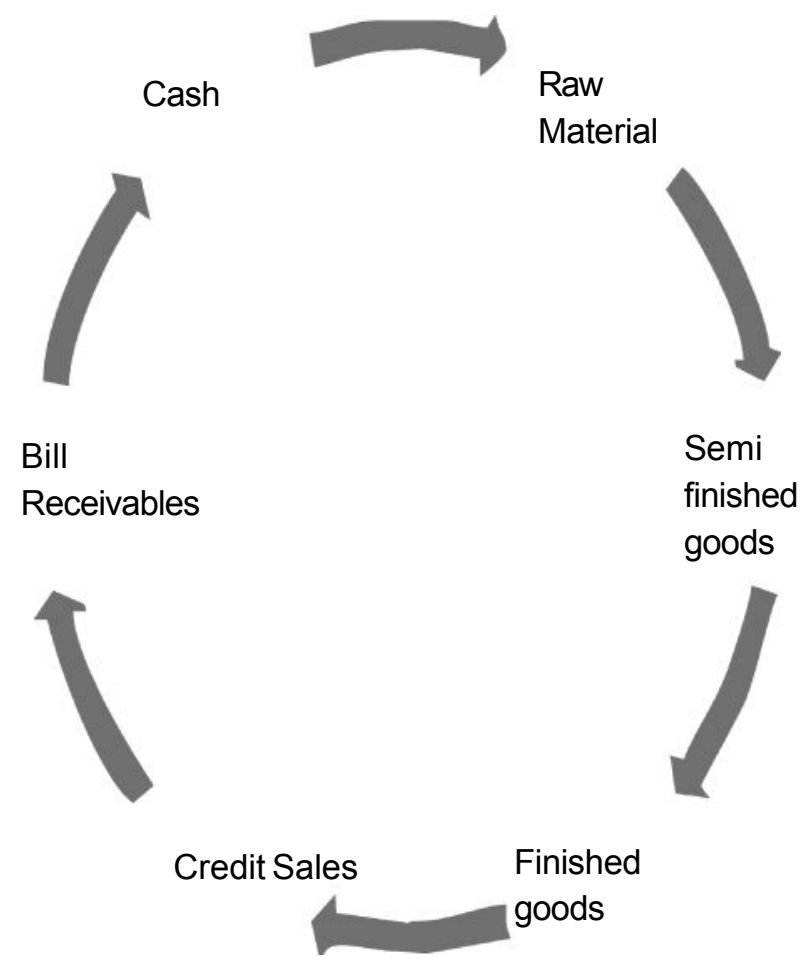

Broadly, working capital is classified into:

Gross Working Capital and Net Working Capital

Gross Working Capital:

The total current assets are referred as the gross working capital. It is also known as the qualitative or circulating capital.

\section{Current Assets:}

(i) Short term Assets (maturing within a year) which are used in the ordinary course of business (ii) Such assets can be converted into cash within a particular period (maximum period is one year)

\section{Current Liabilities:}

(i) Short term Liabilities (maturing within a year) which are used in the ordinary course of business (ii) Such liabilities are payable within a particular period (maximum period is one year) (iii) Usually the payment of current liabilities are made out of the current assets or revenue of the firm. 


\section{Net Working Capital:}

It represents the excess of current assets over the current liabilities.

Banks should be able to assess the adequate working capital required by the firm/company. Because excess working capital means that the firm is having idle funds, which does not earn profit for the firm. It also blocks the bank's funds which could have been lent to another needy borrowing company/firm. However, if the working capital is inadequate, it indicates that the firm is not having sufficient funds for its operations, which can result in lower production

\section{Permanent and Temporary Working Capital:}

Permanent working capital is the minimum investment kept in the form of inventory of raw materials, work-inprogress, finished goods, and book debts to ensure continuous operation of a firm.

\section{Temporary Working Capital:}

When a firm maintains additional current asset over and above the permanent working capital to cover the cyclical (seasonal) demands, it is called temporary working capital.

For example, a garment exporter may require additional funds to meet his exports to US and European markets for their festival season (Christmas, New Year). He approaches his bank for additional WC, and if the bank allows the exporter to avail of additional funds, then it is called temporary or seasonal WC

\section{Working Capital - Bank Finance:}

Banks grant working capital finance to their clients based on certain norms. The steps involved are

Level of Turnover of the firm: This is one of the important step involved in deciding the working capital limit. In respect of existing firms, the past performance is used for deciding the limit. However, in case of new firms, the assessment is based on the availability of raw materials, production capacity, industry norm, etc., are taken into consideration to fix the working capital limit.

Banks are now free to decide the method of calculating the working capital requirements based on the bank's own policy, generally banks use any of the following methods:

\section{Method I:}

In this method, the firm is required to contribute at least $25 \%$ of the working capital gap. The working capital gap = total current assets minus total current liabilities excluding bank finance.

\section{Method II:}

In this method, the firm has to bring in at least $25 \%$ of the total current assets.

\section{Method III:}

In this method, the firm is required to bring in $100 \%$ of those current assets called as "core assets" and at least $25 \%$ of the remaining current assets.

In the case of Method II, the current ratio should be at least 1.33 and in the first case, it could be less and in the third method it may be more.

Working capital management calls for skills good planning and strategy. A good working capital management would depend upon many factors, such as,

(i) Size of business (ii) Seasonal demand for funds (iii) Production Cycle Process (iv) Availability or non- availability of raw materials $(v)$ inventory and receivables management policies (vi) Turnover of inventory (vii) Efficient receivable management

Working Capital finance is granted by banks in the form of cash credit (CC) and overdraft (OD). Cash Credit is 
given against hypothecation/ pledge of stocks/ movable assets for various purposes. While granting cash credit limit, the bank requires the borrower to contribute the margin say $25 \%$ of the value of assets (pledged/hypothecated). Bank allows the customer to drawdown subject to margin which is called the drawing power. If the limit is ₹100 lakhs and with the margin of $25 \%$ the drawing power subject to the security (stock/value of assets pledged/ hypothecated) would by ₹ 75 lakhs or less. In case of OD accounts also the drawdown of funds would be subject to margin and drawing power of the borrower. Banks should follow all the required guidelines of closely monitoring the operations in the $\mathrm{CC}$ accounts. Banks should also take necessary precautions in ensuring regular inspections of stocks and also the value of stocks are regularly valued at market price (mark to market concept) to avoid any risks. Banks stocks and assets should have insurance cover and all terms and conditions of the credit needs to be complied with.

Invariably, CC is given against movable goods/assets, and the $\mathrm{OD}$ is given against financial securities like bills of exchange, fixed deposit receipts, shares and tradable market instruments, and book debts. In the case of OD also, all applicable credit norms needs to be observed by banks without any deviation. Based on the nature of securities, they are either hypothecated, pledged, assigned, to banks or kept under lien with banks.

\section{TERM LOANS}

The loan is disbursed by way of single debit/stage-wise debits (wherever sanction so accorded) to the account. The amount may be allowed to be repaid in lump sum or in suitable installments, as per terms of sanction. Loan is categorized Demand Loan if the repayment period of the loan is less than three years, in case the repayment of the loan is three years and above the loan be considered as Term Loan.

Under the loan system, credit is given for a definite purpose and for a predetermined period. Normally, these loans are repayable in installments. Funds are required for single non-repetitive transactions and are withdrawn only once. If the borrower needs funds again or wants renewal of an existing loan, a fresh request is made to the bank. Thus, a borrower is required to negotiate every time he is taking a new loan or renewing an existing loan. Banker is at liberty to grant or refuse such a request depending upon his own cash resources and the credit policy of the central bank.

\section{Advantages of Loan System}

1. Financial Discipline on the borrower: As the time of repayment of the loan or its installments is fixed in advance, this system ensures a greater degree of self-discipline on the borrower as compared to the cash credit system.

2. Periodic Review of Loan Account: Whenever any loan is granted or its renewal is sanctioned, the banker gets as opportunity of automatically reviewing the loan account. Unsatisfactory loan accounts may be discontinued at the discretion of the banker.

3. Profitably: The system is comparatively simple. Interest accrues to the bank on the entire amount lent to a customer.

\section{Drawbacks}

1. Inflexibility: Every time a loan is required, it is to be negotiated with the banker. To avoid it, borrowers may borrow in excess of their exact requirements to provide for any contingency.

2. Banks have no control over the use of funds borrowed by the customer. However, banks insist on hypothecation of the asset/ vehicle purchased with loan amount.

3. Though the loans are for fixed periods, but in practice the roll over, i.e., they are renewed frequently.

4. Loan documentation is more comprehensive as compared to cash credit system. 


\section{Types of Term Loans:}

Term loans are granted by banks to borrowers for purchase of fixed assets like land and building, factory premises, embedded machinery etc., to enable their manufacturing activities, and their business expansion, if the amounts are repayable after a specific period of time, they are all called as term finance. On the basis of the period for which the funds are required by the borrowers, these loans are classified as short, medium and long term loans.

Banks have been given freedom to fix their own interest rate for loans and advances. As per bank's lending and interest rate policies applicable interest and other charges would be applicable to CC, OD, Term loan accounts. Each bank should decide "base rate" of interest on advances as per RBI directives.

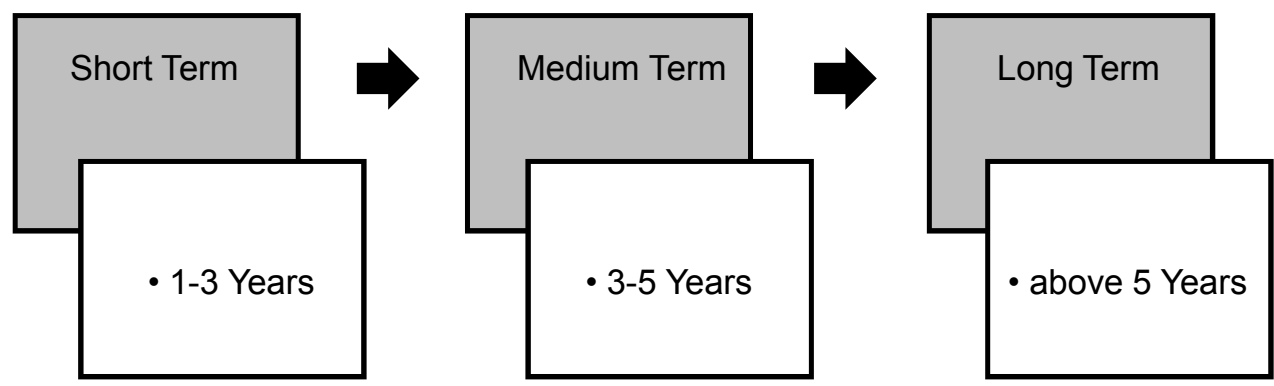

Loans which are repayable within $1-3$ years are classified as Short term, 3-5 years are classified as Medium Term and above 5 years are classified as long term.

\section{Term Loans - Important aspects:}

1. Term loans are given to the manufacturing, trading and service sector units which require funds for purchasing various items of fixed assets, such as, land and building, plant and machinery, electrical installation and other preliminary and pre-operative expenses.

2. Repayment of term loans would depend upon the firm's capacity to produce goods or services by using the fixed assets as financed by banks.

3. Like any other loan, a term loan is sanctioned by the bank, after evaluation of credit proposal (application). The bank before granting terms loans needs to carry out a clear due diligence as to the borrower's requirement, capacity and other aspects.

4. While considering a term loan proposal, the bank need to verify the financial status, economic viability and the firm's production capacity.

5. After proper verification and satisfaction of various requirements, banks can grant a term loan, on certain terms and conditions, covenants, including repayment terms.

6. Term loans like any other credit facility needs to cover Six $C$ concepts and the banks should follow bank's lending policy, exposure norms and the RBI's guidelines and directives

7. All required valid collateral security, duly executed should be one of the pre conditions for the loan amount to be disbursed.

8. The assets created out of the bank loan, are charged depending upon the nature of security (hypothecation, mortgage, etc.,

9. At the time of fixing the limit and quantum of finance, a banker is required to make assessment of actual cost of assets to be acquired, margin to be contributed, sources of repayment, etc.

A legal case decided by High Court in respect of term loans is given below:

(i) Acceleration of Repayment: P.K. Achuthan vs State Bank of Travancore 1974 K.L.T. 806 (FB) 
A question that came for decision in this case was whether a provision in hypothecation bonds to the effect that on a default of borrower in paying any of the instalments, the lender would be entitled to recover the whole of the debt due, inclusive future instalments in one lump sum. The Kerala High Court held that where contract provides for repayment of money in instalments and also contains a stipulation that on default being committed in paying any of the instalments, the whole sum shall become payable, then the lender would be entitled to recover the whole sum inclusive of future instalments.

\section{Bridge Loans}

Bridge loans are essentially short term loans which are granted to industrial undertakings to meet their urgent and essential needs during the period when formalities for availing of the term loans sanctioned by financial institutions are being fulfilled or necessary steps are being taken to raise the funds from the capital market. These loans are granted by banks or by financial institutions themselves and are automatically repaid out of amount of the term loan or the funds raised in the capital market.

In April, 1995, Reserve Bank of India banned bridge loans granted by banks and financial institutions to all companies. But in October, 1995, Reserve Bank of permitted the banks to sanction bridge loans/interim finance against commitment made by a financial institutions or another bank where the lending institution faces temporary liquidity constraint subject to the following conditions:

(i) The prior consent of the other bank/financial institution which has sanctioned a term loan must be obtained.

(ii) The term lending bank/financial institution must give a commitment to remit the amount of the term loan to the bank concerned.

(iii) The period of such bridge loan should not exceed four months.

(iv) No extension of time for repayment of bridge loan will be allowed.

(v) To ensure that bridge loan sanctioned is utilized for the purpose for which the term loan has been sanctioned.

In November, 1997, Reserve Bank permitted the banks to grant bridge loans to companies (other than nonbanking finance companies) against public issue of equity in India or abroad. The guidelines for sanction of such loans are to be laid down by each bank and should include the following aspects:

(i) Security to be obtained for the loan.

(ii) The quantum of outstanding bridge loan (or the limit sanctioned, whichever is higher) during the year.

(iii) Compliance with individual/group exposure norms.

(iv) Ensuring end use of bridge loan.

(v) The maximum period of the bridge loan to be one year.

\section{Composite Loans}

When a loan is granted both for buying capital assets and for working capital purposes, it is called a composite loan. Such loans are usually granted to small borrowers, such as artisans, farmers, small industries, etc.

\section{Consumption Loans}

Though normally banks provide loans for productive purposes only but as an exception loans are also granted on a limited scale to meet the medical needs or the educational expenses or expenses relating to marriages and other social ceremonies etc. of the needy persons. Such loans are called consumption loans.

\section{NON-FUND BASED FACILITIES}

In the business of lending, a banker also extends non-fund based facilities. Non-fund based facilities do not 
involve immediate outflow of funds. The banker undertakes a risk to pay the amounts on happening of a contingency. Non-based facilities can be of following types among other:

(a) Bank Guarantees

(b) Letter of Credit

(c) Underwriting and credit guarantee

\section{BANK GUARANTEE}

As part of Non-fund based facilities, banks issue guarantees on behalf of their clients. A Bank Guarantee is a commitment given by a banker to a third party, assuring her/ him to honour the claim against the guarantee in the event of the non- performance by the bank's customer. A Bank Guarantee is a legal contract which can be imposed by law. The banker as guarantor assures the third party (beneficiary) to pay him a certain sum of money on behalf of his customer, in case the customer fails to fulfill his commitment to the beneficiary.

\section{Types of Guarantee}

Banks issue different types of guarantees, on behalf of their customers, as illustrated below:

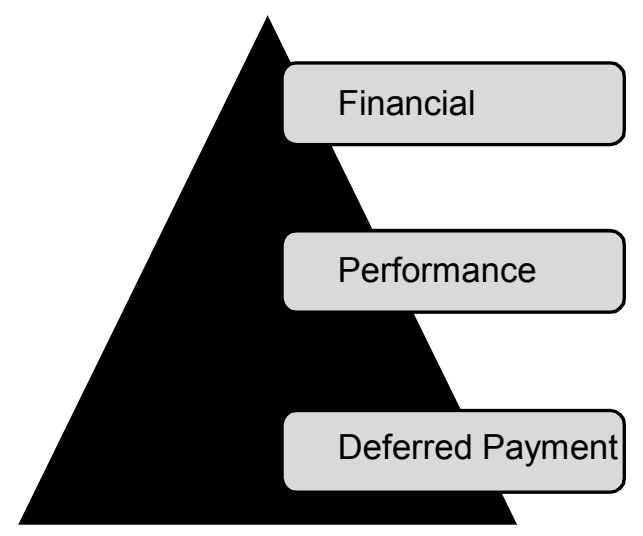

\section{(1) Financial Guarantee:}

The banker issues guarantee in favour of a government department against caution deposit or earnest money to be deposited by bank's client. At the request of his customer, in lieu of a caution deposit/ earnest money, the banker issues a guarantee in favour of the government department. This is an example of a Financial Guarantee. This type of guarantee helps the bank's customer to bid for the contract without depositing actual money. In case, the contractor does not take up the awarded contract, then the government department would invoke the guarantee and claim the money from the bank.

\section{(2) Performance Guarantee:}

Performance Guarantees are issued by banks on behalf of their clients.

For example:

$X Y Z$ Ltd, the Indian engineering company undertakes an overseas project. The project is to construct highways in one of the African nations. $X Y Z \mathrm{Ltd}$, required to furnish a bank guarantee. Since the company has undertaken an overseas project, the company is called as project exporter. XYZ Ltd approaches his banker to issue a bank guarantee in favour of the African nation to whom the company is going to construct the highways. XYS's bank issues a bank guarantee and it will be a performance guarantee. Bank as guarantor guarantees the beneficiary that in case the project exporter (XYZ company) does not perform to the satisfaction of the beneficiary, then within the validity period (including the claim period if any) of the guarantee, the beneficiary can invoke the 
guarantee and the banker has to honour his commitment and pay the amount mentioned in the guarantee. There are three parties in a guarantee:
(a) (Applicant)
(b) (Beneficiary) and
(c) the Banker (guarantor)

\section{(3) Deferred Payment Guarantee:}

Under this guarantee, the banker guarantees payments of installments spread over a period of time.

For example:

A purchases a machinery on a long-term credit basis and agrees to pay in installments on specified dates over a period of time. In terms of the contract of sale, B (the seller) draws Bills of Exchange on the customer for different maturities. These bills are accepted by $A$. The banker (guarantor) guarantees payment of these bills of exchange on the due date. In the event of default by A, the banker need to honour the claim to the seller (beneficiary).

Bank Guarantee - Some Important Features:

- Bank's obligation to pay is primary

- Banker's commitment to honour the claim is primary, even if there is any dispute between the beneficiary and the debtor

- Banker needs to honour the claim, irrespective of the customer's balance in the bank account

- Except in case of frauds, in other cases, the banker cannot refuse payments, when a claim is received within a stipulated time. Courts also have refused to grant injunctions against banks from making payment under the guarantee, except in cases of frauds

\section{Bank Guarantee: Precautions}

The liability of the bank under a guarantee depends on:

(i) the amount of the guarantee and (ii) the period of the guarantee

These two are important factors to be clearly mentioned in the guarantee issued by the banker, otherwise the bank's liability could be unlimited. The bank should obtain a counter guarantee from the customer on whose behalf guarantee is issued. At the time of issuing the guarantee, the amount to be paid under the guarantee should clearly state whether the amount is inclusive of all interest charges, taxes and other levies to avoid disputes regarding the liability of the bank.

On invocation (claim made by the beneficiary), the bank is liable to pay the entire amount of the guarantee unless in case of a fraud. The bank should specifically indicate the period for which the guarantee is valid. The guarantee should also indicate the claim period, usually beyond the validity period.

Further in case of invocation, the banker is required to ensure that: (a) invocation is made within the validity period (b) the amount is not more than the guaranteed amount (c) the person invoking has powers to invoke the guarantee

\section{LETTERS OF CREDIT}

A Letter of Credit is issued by a bank at the request of its customer (importer) in favour of the beneficiary (exporter). It is an undertaking/ commitment by the bank, advising/informing the beneficiary that the documents under a LC would be honoured, if the beneficiary (exporter) submits all the required documents as per the terms and conditions of the LC. 


\section{Importance of letter of credit in trade activities}

The trade can be classified into Inland and International. Due to the geographical proximities of the importers and the exporters, banks are involved in LC transactions to avoid default in payment (credit risks). To facilitate trade and also to enable the exporter and importer to receive and pay for the goods sold and bought, letter of credit is used as a tool. Letter of credit mechanism that the payment and receipts (across the globe) are carried out in an effective manner

\section{Letters of Credit - Parties}

1. Applicant (importer) requests the bank to issue the LC

2. Issuing bank (importer's bank which issues the LC [also known as Opening banker of LC])

3. Beneficiary (exporter)

Different types of banks:

- Opening bank (a bank which issues the LC at the request of its customer [importer])

- Advising bank (the issuing banker's correspondent who advices the LC to beneficiary's banker and/ or beneficiary)

- Negotiating bank (the exporter's bank, which handles the documents submitted by the exporter. The bank also finances the exporter against the documents submitted under a LC)

- Confirming bank (the bank that confirms the credit)

- Reimbursing bank (reimburses the LC amount to the negotiating/ confirming bank)

\section{Types of LC's}

(a) Sight Credit - Under this LC, documents are payable at sight/ upon presentation

(b) Acceptance Credit/ Time Credit - The Bills of Exchange which are drawn, payable after a period, are called usance bills. Under acceptance credit usance bills are accepted upon presentation and eventually honoured on due dates.

(c) Revocable and Irrevocable Credit -A revocable LC is a credit, the terms and conditions of the credit can be amended/ cancelled by the Issuing bank, without prior notice to the beneficiaries. An irrevocable credit is a credit, the terms and conditions of which can neither be amended nor cancelled without the consent of the beneficiary. Hence, the opening bank is bound by the commitments given in the LC.

(d) Confirmed Credit - Only Irrevocable LC can be confirmed. A confirmed LC is one when a banker other than the Issuing bank, adds its own confirmation to the credit. In case of confirmed LCs, the beneficiary's bank would submit the documents to the confirming banker.

(e) Back-to-Back credit - In a back to back credit, the exporter (the beneficiary) requests his banker to issue a LC in favour of his supplier to procure raw materials, goods on the basis of the export LC received by him. This type of LC is known as Back-to-Back credit.

Example: An Indian exporter receives an export LC from his overseas client in Netherlands. The Indian exporter approaches his banker with a request to issue a $L C$ in favour of his local supplier of raw materials. The bank issues a LC backed by the export LC.

(f) Transferable Credit - While a LC is not a negotiable instrument, the Bills of Exchange drawn under it are negotiable. A Transferable Credit is one in which a beneficiary can transfer his rights to third parties. Such LC should clearly indicate that it is a 'Transferable' LC 
(g) "Red Clause" Credit \& "Green Clause" Credit - In a LC a special clause allows the beneficiary (exporter) to avail of a pre-shipment advance (a type of export finance granted to an exporter, prior to the export of goods). This special clause used to be printed (highlighted in red colour, hence it is called "Red Clause" Credit. The issuing bank undertakes to repay such advances, even if shipment does not take place.

In case of a 'Green clause' credit, the exporter is entitled for an advance for storage (warehouse) facilities of goods. The advance would be granted only when the goods to be shipped have been warehoused, and against an undertaking by the exporter that the transportation documents would be delivered by an agreement date.

(h) Standby LC: In certain countries there are restrictions to issue guarantees, as a substitute these countries use standby credit. In case the guaranteed service is not provided, the beneficiary can claim under the terms of the standby credit. In case of Standby LCs, the documents required are proof of non- performance or a simple claim form.

\section{Documents handled under Letters of Credit}

Documents play a crucial role in trade transactions. Documents are integral part of LCs. The banks involved in LC transactions deal only with documents and on the evidence of the correct and proper documents only the paying banks (opening bank/confirming bank) need to make payment. In view of these factors, banks have to be careful while handling documents/ LCs.

At various stages, different banks (Negotiating bank \{beneficiary's bank\}, confirming bank, opening bank) have to verify whether all the required documents are submitted strictly as per the terms and conditions of credit. The important documents handled under LCs are broadly classified as

\section{(a) Bill of Exchange:}

Bill of exchange, is drawn by the beneficiary (exporter) on the LC issuing bank. When the bill of exchange is not drawn under a LC, the drawer of the bill of exchange (exporter), draws the bill of exchange on the drawee (importer). In such a case, the exporter takes credit risk on the importer, whereas, when the Bill of Exchange is drawn under LC, the credit risk for the exporter is not on the importer but on the LC issuing bank. Banks should be careful in ensuring that the Bill of Exchange is drawn strictly as per the terms and conditions of the credit. Some others important aspects are:

(i) It should be drawn by the beneficiary on the opening bank (ii) It should clearly indicate the amount and other details (iii) Depending upon the LC terms a Bill of Exchange may be drawn as a sight bill or an usance bill (iv) It should clearly indicate the LC number.

\section{(b) Commercial Invoice:}

This is another important document. Commercial invoice is prepared by the beneficiary, which contains (i) relevant details about goods in terms of value, quantity, weights (gross/net), importer's name and address, LC number (ii) Commercial invoice should exactly reflect the description of the goods as mentioned in LC. (iii) Another important requirement is that the commercial invoice should indicate the terms of sale contract (Inco terms) like FOB, C\&F, CIF, etc (iv) Other required details like shipping marks, and any specific detail as per the LC terms should also be covered.

\section{(c) Transport Documents:}

When goods are shipped from one port to another port the transport document issued is called the bill of lading. Goods can be transported by means of airways, roadways and railways depending upon the situations. In case goods are transported by means of water ways, the document is called bill of lading, by airways it is known as airway bills and by roadways called as lorry receipt and by railways it is known as railway receipt. In case of a single transaction, when different modes are used to transport the goods from the beneficiary's country to the importer's destination, a single transport document can be used viz., Multi model transport document. 
For ease of reference the most commonly used document i.e., Bill of Lading is discussed here.

(d) Bill of Lading (B/ L):

The $B / L$ is the shipment document, evidencing the movement of goods from the port of acceptance (in exporter's country) to the port of destination (in importer's country). It is a receipt, signed and issued by the shipping company or authorized agent. It should be issued in sets (as per the terms of credit).

\section{Other important features:}

As per the terms and conditions of the credit, a bill of lading should clearly indicate:

(i) the description of goods shipped, as indicated in the invoice

(ii) conditions of goods "Clean" or otherwise (not in good condition/ shortage/damaged)

(iii) drawn to the order of the shipper, blank endorsed or in favour of the opening bank

(iv) the gross and net weight

(v) Freight payable or prepaid

(vi) Port of acceptance and port of destination

Insurance Policy/ Certificate: This document is classified as a document to cover risk.

(a) It must be issued by the insurance company or their authorized agents

(b) It should be issued in the same currency in which the LC has been issued

(c) It should be issued to cover "All Risks"

(d) The date of issuance of the policy/ certificate should be on or before the date of issuance of the shipment, and should clearly indicate that the cover is available from the date of shipment

(e) Unless otherwise specified, it should be issued for an amount of $110 \%$ of CIF value of goods

(f) The description of the goods in the policy/certificate should be as per the terms of the credit

(g) The other important details like the port of shipment, port of destination etc needs to be clearly indicated

\section{Other documents:}

As per the terms of LC, all required documents have to be submitted by the beneficiary. Documents like Certificate of Origin (issued by the Chamber of Commerce), indicates the origin of goods. The origin of goods should not be from any prohibited nations.

Packing list, required certificates, etc. should be drawn as per the terms and conditions of the credit.

\section{Uniform Customs and Practice for Documentary Credit (UCPDC 600)}

International Chamber of Commerce (ICC), arranges to issue uniform guidelines to handle documents under Letters of Credit. These guidelines are used by various parties involved in letters of credit transactions like, exporters, importers, their bankers, shipping and insurance companies. These guidelines gives clarity for the persons to draw and handle various documents. The latest guidelines is called as UCPDC 600 and it came into effect in July 2007. Banks, which are involved in LC transactions need to be familiarized with UCPDC 600.

\section{PRIORITY SECTOR ADVANCES}

National Credit Council meeting held in July 1968 emphasized that commercial banks should increase their involvement in the financing of priority sectors, viz., agriculture and small scale industries. Nationalization of banks ushered in new concept in bank's lending and added a dimension of social banking to business of lending by banks. Initially there was no specific target fixed in respect of priority sector lending. In the recommendations of the Working Group on the 
Modalities of Implementation of Priority Sector Lending and the Twenty Point Economic Programme by Banks (Chairman: Dr. K. S. Krishnaswamy), all commercial banks were advised to achieve the target of priority sector lending at 40 percent of aggregate bank advances by 1985. Sub-targets were also specified for lending to agriculture and the weaker sections within the priority sector. Since then, there have been several changes in the scope of priority sector lending and the targets and sub-targets applicable to various bank groups. The guidelines were revised by RBI in the year 2007 based on the recommendations made in September 2005 by the Internal Working Group of the RBI (Chairman: Shri C. S. Murthy). The Sub-Committee of the Central Board of the Reserve Bank (Chairman: Shri Y. H. Malegam) constituted to study issues and concerns in the Micro Finance institutions (MFI) sector, inter alia, had recommended review of the guidelines on priority sector lending. Accordingly, Reserve Bank of India in August 2011 set up a Committee to re-examine the existing classification and suggest revised guidelines with regard to Priority Sector lending classification and related issues (Chairman: M V Nair). The recommendations of the committee were examined by $\mathrm{RBI}$ and revised guidelines have been issued w.e.f. ${ }^{1 \text { t }}$ July,2012. Some modifications have been made in the Agricultural and MSME category of advances w.e.f. ${ }^{\text {st }}$ April 2013.

\section{Categories under priority sector}

(i) Agriculture

(ii) Micro and Small Enterprises

(iii) Education

(iv) Housing

(v) Export Credit

(vi) Others

The eligible activities under the above categories are mentioned in paragraph 6.4.3

\section{Targets /Sub-targets for Priority sector}

(i) The targets and sub-targets set under priority sector lending for domestic and foreign banks operating in India are furnished below:

\begin{tabular}{|l|l|l|}
\hline Categories & $\begin{array}{l}\text { Domestic commercial banks / Foreign banks } \\
\text { with } 20 \text { and above branches }\end{array}$ & $\begin{array}{l}\text { Foreign banks with less than } \\
\mathbf{2 0} \text { branches }\end{array}$ \\
\hline Total Priority Sector & $\begin{array}{l}40 \text { percent of Adjusted Net Bank Credit [ANBC } \\
\text { defined in sub paragraph (iii) below] or credit } \\
\text { equivalent amount of Off-Balance Sheet } \\
\text { Exposure, whichever is higher. }\end{array}$ & $\begin{array}{l}32 \text { percent of ANBC or credit } \\
\text { equivalent amount of Off- } \\
\text { Balance Sheet Exposure, } \\
\text { whichever is higher. }\end{array}$ \\
\hline Total agriculture & $\begin{array}{l}18 \text { percent of ANBC or credit equivalent amount } \\
\text { of Off-Balance Sheet Exposure, whichever is } \\
\text { higher. Of this, indirect lending in excess of 4.5\% } \\
\text { of ANBC or credit equivalent amount of Off- } \\
\text { Balance Sheet Exposure, whichever is higher, } \\
\text { will not be reckoned for computing achievement } \\
\text { under 18 percent target. However, all agricultural } \\
\text { loans under the categories 'direct' and 'indirect' } \\
\text { will be reckoned in computing achievement under } \\
\text { the overall priority sector target of } 40 \text { percent of } \\
\text { ANBC or credit equivalent amount of Off-Balance } \\
\text { Sheet Exposure, whichever is higher. }\end{array}$ & \\
\hline
\end{tabular}




\begin{tabular}{|c|c|c|}
\hline $\begin{array}{l}\text { Micro \& Small } \\
\text { Enterprises (MSE) }\end{array}$ & $\begin{array}{l}\text { (i) Advances to micro and small enterprises sector } \\
\text { will be reckoned in computing achievement under } \\
\text { the overall priority sector target of } 40 \text { percent of } \\
\text { ANBC or credit equivalent amount of Off-Balance } \\
\text { Sheet Exposure, whichever is higher.(ii) } 40 \text { percent } \\
\text { of total advances to micro and small enterprises } \\
\text { sector should go to Micro (manufacturing) } \\
\text { enterprises having investment in plant and } \\
\text { machinery up to ₹10 lakh and micro (service) } \\
\text { enterprises having investment in equipment up to } \\
\text { ₹ } 4 \text { lakh;(iii) } 20 \text { percent of total advances to } \\
\text { micro and small enterprises sector should go to } \\
\text { Micro (manufacturing) enterprises with investment } \\
\text { in plant and machinery above ₹10 lakh and up } \\
\text { to ₹25 lakh, and micro (service) enterprises } \\
\text { with investment in equipment above ₹4 lakh } \\
\text { and up to ₹10 lakh }\end{array}$ & $\begin{array}{l}\text { No specific target. Forms part } \\
\text { of total priority sector target. }\end{array}$ \\
\hline Export Credit & $\begin{array}{l}\text { Export credit is not a separate category. Export } \\
\text { credit to eligible activities under agriculture and } \\
\text { MSE will be reckoned for priority sector lending } \\
\text { under respective categories. }\end{array}$ & $\begin{array}{l}\text { No specific target. Forms part } \\
\text { of total priority sector target. }\end{array}$ \\
\hline $\begin{array}{l}\text { Advances to Weaker } \\
\text { Sections }\end{array}$ & $\begin{array}{l}10 \text { percent of ANBC or credit equivalent amount } \\
\text { of Off-Balance Sheet Exposure, whichever is } \\
\text { higher. }\end{array}$ & $\begin{array}{l}\text { No specific target in the total } \\
\text { priority sector target. }\end{array}$ \\
\hline
\end{tabular}

(ii) For foreign banks with 20 and above branches, priority sector targets and sub-targets have to be achieved within a maximum period of five years starting from April 1, 2013 and ending on March 31, 2018 as per the action plans submitted by them as approved by RBI. Any subsequent reference to these banks in the circular, will be in accordance to the approved plans.

(iii) The current year's targets for priority sectors and sub-targets will be computed based on Adjusted Net Bank Credit (ANBC) or credit equivalent of Off-Balance Sheet Exposures of preceding March 31st. The outstanding priority sector loans as on March 31st of the current year will be reckoned for achievement of priority sector targets and sub-targets. For the purpose of priority sector lending, ANBC denotes the outstanding Bank Credit in India [(As prescribed in item No.VI of Form 'A' (Special Return as on March 31st) under Section 42 (2) of the RBI Act, 1934] minus bills rediscounted with RBI and other approved Financial Institutions plus permitted non SLR bonds/debentures in Held to Maturity (HTM) category plus other investments eligible to be treated as part of priority sector lending (eg. investments in securitized assets). Deposits placed by banks with NABARD/SIDBI/ $\mathrm{NHB}$, as the case may be, in lieu of non-achievement of priority sector lending targets/sub-targets, though shown under Schedule 8 - 'Investments' in the Balance Sheet at item I (vi) - 'Others', will not be reckoned for ANBC computation. For the purpose of calculation of credit equivalent of off-balance sheet exposures, banks may be guided by the master circular on exposure norms issued by our Department of Banking Operations and Development.

\section{Computation of Adjusted Net Bank Credit}

Bank Credit in India (As prescribed in item No.VI of Form 'A' (Special Return as on March 31 st) under Section 42 (2) of the RBI Act, 1934. I

Bills Rediscounted with RBI and other approved Financial Institutions 
Bonds/debentures in Non-SLR categories under HTM category + other investments eligible to be treated as priority sector.

IV

III+IV

ANBC

${ }^{*}$ For the purpose of priority sector only. Banks should not deduct / net any amount like provisions, accrued interest, etc. from NBC.

It has been observed that some banks are subtracting prudential write off at Corporate/Head Office level while reporting Bank Credit as above. In such cases it must be ensured that bank credit to priority sector and all other sub-sectors so written off should also be subtracted category wise from priority sector and sub-target achievement.

All types of loans, investments or any other item which are treated as eligible for classifications under priority sector target/sub-target achievement should also form part of Adjusted Net Bank Credit.

(iv) The targets for Micro Enterprises within the Micro and Small Enterprises segment (MSE) will be computed with reference to the outstanding credit to MSE as on preceding March 31st.

\section{DESCRIPTION OF THE CATEGORIES UNDER PRIORITY SECTOR}

\section{A. Agriculture}

\section{(a) Direct Agriculture}

Loans to individual farmers [including Self Help Groups (SHGs) or Joint Liability Groups (JLGs), i.e. groups of individual farmers, provided banks maintain disaggregated data on such loans], directly engaged in Agriculture and Allied Activities, viz., dairy, fishery, animal husbandry, poultry, bee-keeping and sericulture (up to cocoon stage).

(i) Short-term loans to farmers for raising crops, i.e. for crop loans.

This will include traditional/non-traditional plantations, horticulture and allied activities.

(ii) Medium \& long-term loans to farmers for agriculture and allied activities (e.g. purchase of agricultural implements and machinery, loans for irrigation and other developmental activities undertaken in the farm, and development loans for allied activities).

(iii) Loans to farmers for pre and post-harvest activities, viz., spraying, weeding, harvesting, sorting, grading and transporting of their own farm produce.

(iv) Loans to farmers up to ₹50 lakh against pledge/hypothecation of agricultural produce (including warehouse receipts) for a period not exceeding 12 months, irrespective of whether the farmers were given crop loans for raising the produce or not.

(v) Loans to small and marginal farmers for purchase of land for agricultural purposes.

(vi) Loans to distressed farmers indebted to non-institutional lenders.

(vii) Bank loans to Primary Agricultural Credit Societies (PACS), Farmers' Service Societies (FSS) and Largesized Adivasi Multi Purpose Societies (LAMPS) ceded to or managed/ controlled by such banks for on lending to farmers for agricultural and allied activities.

(viii) Loans to farmers under Kisan Credit Card Scheme.

(ix) Export credit to farmers for exporting their own farm produce.

Loans to corporates including farmers' producer companies of individual farmers, partnership firms and cooperatives of farmers directly engaged in Agriculture and Allied Activities, viz., dairy, fishery, animal husbandry, 
poultry, bee-keeping and sericulture (up to cocoon stage) up to an aggregate limit of ₹2 crore per borrower for the following activities:

(i) Short-term loans to farmers for raising crops, i.e. for crop loans.

This will include traditional/non-traditional plantations, horticulture and allied activities.

(ii) Medium \& long-term loans to farmers for agriculture and allied activities (e.g. purchase of agricultural implements and machinery, loans for irrigation and other developmental activities undertaken in the farm, and development loans for allied activities).

(iii) Loans to farmers for pre and post-harvest activities, viz., spraying, weeding, harvesting, grading and sorting.

(iv) Export credit for exporting their own farm produce.

\section{(b) Indirect agriculture}

1. Loans to corporates including farmers' producer companies of individual farmers, partnership firms and co-operatives of farmers directly engaged in Agriculture and Allied Activities, viz., dairy, fishery, animal husbandry, poultry, bee-keeping and sericulture (up to cocoon stage)

(i) If the aggregate loan limit per borrower is more than ₹2 crore, the entire loan should be treated as indirect finance to agriculture.

(ii) Loans up to ₹ 50 lakh against pledge/hypothecation of agricultural produce (including warehouse receipts) for a period not exceeding 12 months, irrespective of whether the farmers were given crop loans for raising the produce or not.

2. Bank loans to Primary Agricultural Credit Societies (PACS), Farmers' Service Societies (FSS) and Largesized Adivasi Multi- Purpose Societies (LAMPS)

3. Other indirect agriculture loans

(i) Loans up to ₹ 5 crore per borrower to dealers /sellers of fertilizers, pesticides, seeds, cattle feed, poultry feed, agricultural implements and other inputs.

(ii) Loans for setting up of Agriclinics and Agribusiness Centres.

(iii) Loans up to ₹ 5 crore to cooperative societies of farmers for disposing of the produce of members.

(iv) Loans to Custom Service Units managed by individuals, institutions or organizations who maintain a fleet of tractors, bulldozers, well-boring equipment, threshers, combines, etc., and undertake farm work for farmers on contract basis.

(v) Loans for construction and running of storage facilities (warehouse, market yards, godowns and silos), including cold storage units designed to store agriculture produce/products, irrespective of their location.

If the storage unit is a micro or small enterprise, such loans will be classified under loans to Micro and Small Enterprises sector.

(vi) Loans to MFIs for on-lending to farmers for agricultural and allied activities as per the conditions specified.

(vii) Loans sanctioned to NGOs, which are SHG Promoting Institutions, for on-lending to members of SHGs under SHG-Bank Linkage Programme for agricultural and allied activities. The all- inclusive interest charged by the NGO/SHG promoting entity should not exceed the Base Rate of the lending bank plus eight percent per annum. 
(viii) Loans sanctioned to RRBs for on-lending to agriculture and allied activities.

\section{B. Micro and Small Enterprises}

The limits for investment in plant and machinery/equipment for manufacturing / service enterprise, as notified by Ministry of Micro Small and Medium Enterprises, vide, S.O.1642(E) dated September 9, 2006 are as under:-

\begin{tabular}{|l|l|}
\hline Manufacturing sector & \\
\hline Enterprises & Investment in plant and machinery \\
\hline Micro Enterprises & Do not exceed twenty five lakh rupees \\
\hline Small Enterprises & More than twenty five lakh rupees but does not exceed five crore rupees \\
\hline Service Sector Enterprises & Investment in equipment \\
\hline Micro Enterprises & Does not exceed ten lakh rupees \\
\hline Small Enterprises & More than ten lakh rupees but does not exceed two crore rupees \\
\hline
\end{tabular}

Bank loans to micro and small enterprises both manufacturing and service are eligible to be classified under priority sector as per the following:

\section{(a) Direct Finance}

\section{Manufacturing Enterprises}

The Micro and Small enterprises engaged in the manufacture or production of goods to any industry specified in the first schedule to the Industries (Development and regulation) Act, 1951 and as notified by the Government from time to time. The manufacturing enterprises are defined in terms of investment in plant and machinery.

\section{Loans for food and agro processing}

Loans for food and agro processing will be classified under Micro and Small Enterprises, provided the units satisfy investments criteria prescribed for Micro and Small Enterprises, as provided in MSMED Act, 2006.

\section{Service Enterprises}

Bank loans up to ₹5 crore per unit to Micro and Small Enterprises engaged in providing or rendering of services and defined in terms of investment in equipment under MSMED Act, 2006.

3. Export credit to MSE units (both manufacturing and services) for exporting of goods/services produced/rendered by them.

\section{Khadi and Village Industries Sector (KVI)}

All loans sanctioned to units in the KVI sector, irrespective of their size of operations, location and amount of original investment in plant and machinery. Such loans will be eligible for classification under the sub-target of 60 percent prescribed for micro enterprises within the micro and small enterprises segment under priority sector.

\section{(b) Indirect Finance}

(i) Loans to persons involved in assisting the decentralized sector in the supply of inputs to and marketing of outputs of artisans, village and cottage industries.

(ii) Loans to cooperatives of producers in the decentralized sector viz. artisans village and cottage industries.

(iii) Loans sanctioned by banks to MFIs for on-lending to MSE 


\section{Education}

Loans to individuals for educational purposes including vocational courses up to ₹10 lakh for studies in India and ₹20 lakh for studies abroad.

\section{Housing}

(i) Loans to individuals up to ₹ 25 lakh in metropolitan centres with population above ten lakh and ' 15 lakh in other centres for purchase/construction of a dwelling unit per family excluding loans sanctioned to bank's own employees.

(ii) Loans for repairs to the damaged dwelling units of families up to ₹2 lakh in rural and semi- urban areas and up to ₹5 lakh in urban and metropolitan areas.

(iii) Bank loans to any governmental agency for construction of dwelling units or for slum clearance and rehabilitation of slum dwellers subject to a ceiling of ₹10 lakh per dwelling unit.

(iv) The loans sanctioned by banks for housing projects exclusively for the purpose of construction of houses only to economically weaker sections and low income groups, the total cost of which do not exceed ₹10 lakh per dwelling unit. For the purpose of identifying the economically weaker sections and low income groups, the family income limit of ₹ 1,20,000 per annum, irrespective of the location, is prescribed.

(v) Bank loans to Housing Finance Companies (HFCs), approved by NHB for their refinance, for on-lending for the purpose of purchase/construction/reconstruction of individual dwelling units or for slum clearance and rehabilitation of slum dwellers, subject to an aggregate loan limit of ₹10 lakh per borrower, provided the all- inclusive interest rate charged to the ultimate borrower is not exceeding lowest lending rate of the lending bank for housing loans plus two percent per annum.

The eligibility under priority sector loans to HFCs is restricted to five percent of the individual bank's total priority sector lending, on an ongoing basis. The maturity of bank loans should be co-terminus with average maturity of loans extended by HFCs. Banks should maintain necessary borrower-wise details of the underlying portfolio.

\section{E. Export Credit}

Export Credit extended by foreign banks with less than 20 branches will be reckoned for priority sector target achievement.

As regards the domestic banks and foreign banks with 20 and above branches, export credit is not a separate category under priority sector. Export credit will count towards the respective categories of priority sector, i.e. Agriculture and MSE sector.

\section{F. Others}

1. Loans, not exceeding $₹ 50,000$ per borrower provided directly by banks to individuals and their SHG/ JLG, provided the borrower's household annual income in rural areas does not exceed ₹ 60,000/- and for non-rural areas it should not exceed ₹ 1,20,000/-.

2. Loans to distressed persons not exceeding ₹50,000 per borrower to prepay their debt to non-institutional lenders.

3. Loans outstanding under loans for general purposes under General Credit Cards (GCC). If the loans under GCC are sanctioned to Micro and Small Enterprises, such loans should be classified under respective categories of Micro and Small Enterprises.

4. Overdrafts, up to ₹50,000 (per account), granted against basic banking / savings accounts provided the borrowers household annual income in rural areas does not exceed ₹ 60,000/- and for non-rural areas it should not exceed ₹1,20,000/-. 
5. Loans sanctioned to State Sponsored Organizations for Scheduled Castes/ Scheduled Tribes for the specific purpose of purchase and supply of inputs to and/or the marketing of the outputs of the beneficiaries of these organizations.

6. Loans sanctioned by banks directly to individuals for setting up off-grid solar and other off-grid renewable energy solutions for households.

\section{G. Weaker Sections}

Priority sector loans to the following borrowers will be considered under Weaker Sections category:-

(a) Small and marginal farmers;

(b) Artisans, village and cottage industries where individual credit limits do not exceed ₹ 50,000;

(c) Beneficiaries of Swarnjayanti Gram Swarozgar Yojana (SGSY), now National Rural Livelihood Mission (NRLM);

(d) Scheduled Castes and Scheduled Tribes;

(e) Beneficiaries of Differential Rate of Interest (DRI) scheme;

(f) Beneficiaries under Swarna Jayanti Shahari Rozgar Yojana (SJSRY);

(g) Beneficiaries under the Scheme for Rehabilitation of Manual Scavengers (SRMS);

(h) Loans to Self Help Groups;

(i) Loans to distressed farmers indebted to non-institutional lenders;

(j) Loans to distressed persons other than farmers not exceeding ₹50,000 per borrower to prepay their debt to non-institutional lenders;

(k) Loans to individual women beneficiaries up to ₹50,000 per borrower;

(I) Loans sanctioned to persons from minority communities as may be notified by Government of India from time to time. In States, where one of the minority communities notified is, in fact, in majority, item (I) will cover only the other notified minorities. These States/Union Territories are Jammu \& Kashmir, Punjab, Meghalaya, Mizoram, Nagaland and Lakshadweep.

\section{H. Investments by banks in securitised assets}

(i) Investments by banks in securitised assets, representing loans to various categories of priority sector, except 'others' category, are eligible for classification under respective categories of priority sector (direct or indirect) depending on the underlying assets provided:

(a) the securitised assets are originated by banks and financial institutions and are eligible to be classified as priority sector advances prior to securitisation and fulfill the Reserve Bank of India guidelines on securitisation.

(b) the all-inclusive interest charged to the ultimate borrower by the originating entity should not exceed the Base Rate of the investing bank plus 8 percent per annum.

The investments in securitised assets originated by MFIs, which comply with the guidelines in Paragraph VIII of this circular are exempted from this interest cap as there are separate caps on margin and interest rate.

(ii) Investments made by banks in securitised assets originated by NBFCs, where the underlying assets are loans against gold jewellery, are not eligible for priority sector status. 


\section{(I) Transfer of Assets through Direct Assignment /Outright purchases}

(i) Assignments/Outright purchases of pool of assets by banks representing loans under various categories of priority sector, except the 'others' category, will be eligible for classification under respective categories of priority sector (direct or indirect) provided:

(a) The assets are originated by banks and financial institutions and are eligible to be classified as priority sector advances prior to the purchase and fulfill the Reserve Bank of India guidelines on outright purchase/assignment.

(b) the eligible loan assets so purchased should not be disposed of other than by way of repayment.

(c) the all-inclusive interest charged to the ultimate borrower by the originating entity should not exceed the Base Rate of the purchasing bank plus 8 percent per annum.

The assignments/Outright purchases of eligible priority sector loans from MFIs, which comply with the guidelines in Paragraph VIII of this circular are exempted from this interest rate cap as there are separate caps on margin and interest rate.

(ii) When the banks undertake outright purchase of loan assets from banks/ financial institutions to be classified under priority sector, they must report the nominal amount actually disbursed to end priority sector borrowers and not the premium embedded amount paid to the sellers.

(iii) Purchase/ assignment/investment transactions undertaken by banks with NBFCs, where the underlying assets are loans against gold jewellery, are not eligible for priority sector status.

\section{J. Inter Bank Participation Certificates bought by Banks}

Inter Bank Participation Certificates (IBPCs) bought by banks, on a risk sharing basis, shall be eligible for classification under respective categories of priority sector, provided the underlying assets are eligible to be categorized under the respective categories of priority sector and the banks fulfill the Reserve Bank guidelines on IBPCs.

\section{K. Bank loans to MFls for on-lending}

(a) Bank credit to MFIs extended on, or after, April 1, 2011 for on-lending to individuals and also to members of SHGs / JLGs will be eligible for categorization as priority sector advance under respective categories. viz., agriculture, micro and small enterprise, and 'others', as indirect finance, provided not less than $85 \%$ of total assets of MFI (other than cash, balances with banks and financial institutions, government securities and money market instruments) are in the nature of "qualifying assets". In addition, aggregate amount of loan, extended for income generating activity, is not less than $70 \%$ of the total loans given by MFIs.

(b) A "qualifying asset" shall mean a loan disbursed by MFI, which satisfies the following criteria:

(i) The loan is to be extended to a borrower whose household annual income in rural areas does not exceed ₹60,000/- while for non-rural areas it should not exceed ₹1,20,000/-.

(ii) Loan does not exceed ₹35,000/- in the first cycle and ₹50,000/- in the subsequent cycles.

(iii) Total indebtedness of the borrower does not exceed ₹50,000/-.

(iv) Tenure of loan is not less than 24 months when loan amount exceeds ₹15,000/- with right to borrower of prepayment without penalty.

(v) The loan is without collateral.

(vi) Loan is repayable by weekly, fortnightly or monthly installments at the choice of the borrower.

(c) Further, the banks have to ensure that MFIs comply with the following caps on margin and interest rate as also other 'pricing guidelines', to be eligible to classify these loans as priority sector loans. 
(i) Margin cap at $12 \%$ for all MFls. The interest cost is to be calculated on average fortnightly balances of outstanding borrowings and interest income is to be calculated on average fortnightly balances of outstanding loan portfolio of qualifying assets.

(ii) Interest cap on individual loans at $26 \%$ per annum for all MFIs to be calculated on a reducing balance basis.

(iii) Only three components are to be included in pricing of loans viz., (a) a processing fee not exceeding $1 \%$ of the gross loan amount, (b) the interest charge and (c) the insurance premium.

(iv) The processing fee is not to be included in the margin cap or the interest cap of $26 \%$.

(v) Only the actual cost of insurance i.e. actual cost of group insurance for life, health and livestock for borrower and spouse can be recovered; administrative charges may be recovered as per IRDA guidelines.

(vi) There should not be any penalty for delayed payment.

(vii) No Security Deposit/ Margin are to be taken.

(d) The banks should obtain from MFI, at the end of each quarter, a Chartered Accountant's Certificate stating, inter-alia, that (i) $85 \%$ of total assets of the MFI are in the nature of "qualifying assets", (ii) the aggregate amount of loan, extended for income generation activity, is not less than $70 \%$ of the total loans given by the MFIs, and (iii) pricing guidelines are followed.

\section{Non-achievement of priority sector targets}

All scheduled commercial banks having shortfall in lending to priority sector target/sub shall be allocated amounts for contribution to the Rural Infrastructure Development Fund (RIDF) established with NABARD and other Funds with NABARD/NHB/SIDBI/other Financial Institutions, as decided by the Reserve Bank from time to time.

For the purpose of allocation of RIDF and other Funds, as decided by Reserve Bank from time to time, the achievement levels of priority sector lending as on the March 31st will be taken into account. The deposits under the various Funds will be called upon by NABARD or such other Financial Institutions as per the terms and conditions of the scheme.

The interest rates on banks' contribution to RIDF or any other Funds, periods of deposits, etc. shall be fixed by Reserve Bank of India from time to time and will be communicated to the concerned banks every year by the Reserve Bank at the time of allocation of funds.

The misclassifications reported by the Reserve Bank's Department of Banking Supervision would be adjusted/ reduced from the achievement of that year, to which the amount of declassification/ misclassification pertains, for allocation to various funds in subsequent years.

Non-achievement of priority sector targets and sub-targets will be taken into account while granting regulatory clearances/approvals for various purposes.

\section{Common guidelines for priority sector loans}

Banks should comply with the following common guidelines for all categories of advances under the priority sector.

\section{(a) Rate of interest}

The rates of interest on various categories of priority sector loans will be as per DBOD directives issued from time to time.

\section{(b) Service charges}

No loan related and adhoc service charges/inspection charges should be levied on priority sector loans up to ₹ 25,000 . 


\section{(c) Receipt, Sanction/Rejection/Disbursement Register}

A register/ electronic record should be maintained by the bank, wherein the date of receipt, sanction/rejection/ disbursement with reasons thereof, etc., should be recorded. The register/electronic record should be made available to all inspecting agencies.

\section{(d) Issue of Acknowledgement of Loan Applications}

Banks should provide acknowledgement for loan applications received under priority sector loans. Bank Boards should prescribe a time limit within which the bank communicates its decision in writing to the applicants.

\section{(e) Definitions}

(i) On-lending: Loans sanctioned by banks to eligible intermediaries for onward lending only for creation of priority sector assets. The average maturity of priority sector assets thus created should be co-terminus with maturity of the bank loan.

(ii) Small and Marginal Farmers: Farmers with landholding of up to 1 hectare is considered as Marginal Farmers. Farmers with a landholding of more than 1 hectare but less than 2 hectares are considered as Small Farmers. For the purpose of priority sector loans 'small and marginal farmers' include landless agricultural labourers, tenant farmers, oral lessees and share-croppers, whose share of landholding is within above limits prescribed for "Small and Marginal Farmer".

\section{(f) Other aspects}

(i) Contingent liabilities/off-balance sheet items do not form part of priority sector target achievement. Banks should declassify such accounts with retrospective effect, where a contingent liability/off-balance sheet item is treated as a part of priority sector target achievement.

(ii) Off-balance sheet interbank exposures are excluded for computing Credit Equivalent of Off -Balance Sheet Exposures for the priority sector targets.

(iii) The term "all inclusive interest" includes interest (effective annual interest), processing fees and service charges.

(iv) Banks should ensure that loans extended under priority sector are for approved purposes and the end use is continuously monitored. The banks should put in place proper internal controls and systems in this regard.

\section{CREDIT-LINKED GOVERNMENT SPONSORED SCHEMES}

All commercial banks in India have been directed by Government of India and Reserve Bank of India to actively participate in the Government Sponsored Credit-linked schemes and targets are also allotted to different banks on the basis of the number of branches operating in the area and the scope of lending. Besides, various State Government sponsored schemes, the Central Government has launched the following major two schemes:

\section{National Rural Livelihood Mission (NRLM)}

The Ministry of Rural Development, Government of India has launched National Rural Livelihood Mission (NRLM) by replacing the existing Swarnajayanti Gram Swarozgar Yojana (SGSY), effective from April 1, 2013. NRLM is the flagship program of Govt. of India for promoting poverty reduction through building strong institutions of the poor, particularly women, and enabling these institutions to access a range of financial services and livelihoods services. A women's self- help group, coming together on the basis of mutual affinity is the primary building block of the NRLM community institutional design. NRLM focuses on building, nurturing and strengthening the institutions of the poor women, including the SHGs and their Federations at village and higher levels. In addition NRLM will promote livelihoods institutions of rural poor. The mission will provide a continuous hand-holding support to the institutions of poor for a period of $5-7$ years till they come out of abject poverty 
Main features of the scheme:

(a) NRLM is promoting a major shift from purely 'allocation based' strategy to a 'demand driven' strategy wherein states have the flexibility to develop their own plans for capacity building of women SHGs and Federations, infrastructure and marketing, and policy for financial assistance for the SHGs.

(b) NRLM will identify the target group of poor through a 'participatory identification of the poor' process. This will ensure that the voiceless, poorest of poor are not ignored. In fact under NRLM, the first preference is given to the poorest of poor households.

(c) NRLM will promote the formation of women SHGs on the basis of affinity. It is definitely possible that members who come together on the basis of affinity could be having a common activity.

(d) The NRLM has taken a saturation approach and will ensure all the poor in a village are covered and a woman from each poor family is motivated to join the SHG.

(e) All SHGs in a village come together to form a federation at the village level. The village federation is a very important support structure for the members and their SHGs. The cluster federation is the next level of federation. A cluster consists of a group of villages within a block. The exact configuration will vary from State to State, but typically a cluster consists of $25-40$ villages. The Village federations and the Cluster federations are the two critical support structures for the SHG s and their members in their long journey out of poverty.

(f) NRLM will provide continuous hand-holding support to SHGs, and their federations. Under NRLM this support will be provided to a great extent by capacitating the SHG federations and by building a cadre of community professionals from among the poor women. The federations and the community professionals will be imparted the necessary skills by the mission.

(g) The objective of NRLM is to ensure that SHG s are enabled to access repeat finance from Banks, till they attain sustainable livelihoods and decent living standards. This was missing in SGSY, where the emphasis was on one time support.

\section{Women SHGs and their Federations}

Women SHGs under NRLM consist of 10-15 persons. In case of special SHGs i.e. groups in the difficult areas, groups with disabled persons, and groups formed in remote tribal areas, this number may be a minimum of 5 persons. NRLM will promote affinity based women Self -help groups. Only for groups to be formed with Persons with disabilities, and other special categories like elders, transgender, NRLM will have both men and women in the self-help groups. SHG is an informal group and registration under any Societies Act, State cooperative Act or a partnership firm is not mandatory. However Federations of SHGs formed at village level, cluster level, and at higher levels are to be registered under appropriate acts prevailing in their States.

\section{Financial Assistance to the SHGs:}

NRLM would provide a Revolving Fund (RF) support to SHGs in existence for a minimum period of 3/6 months and follow the norms of good SHGs, i.e they follow 'Panchasutra' - regular meetings, regular savings, regular internal lending, regular recoveries and maintenance of proper books of accounts. Only such SHGs that have not received any $R F$ earlier will be provided with $R F$, as corpus, with a minimum of $₹ 10,000$ and up to a maximum of ₹ 15,000 per SHG. The purpose of RF is to strengthen their institutional and financial management capacity and build a good credit history within the group.

\section{Interest Subvention:}

No Capital Subsidy will be sanctioned to any SHG from the date of implementation of NRLM. NRLM has a provision for interest subvention, to cover the difference between the Lending Rate of the banks and $7 \%$, on all credit from the banks/ financial institutions availed by women SHGs, for a maximum of ₹ $3,00,000$ per SHG. This will be available across the country in two ways: 
(i) In 150 identified districts, banks will lend to all the women SHGs @7\% up to an aggregated loan amount of ₹ $3,00,000 /-$. The SHGs will also get additional interest subvention of $3 \%$ on prompt payment, reducing the effective rate of interest to $4 \%$.

(ii) In the remaining districts also, NRLM compliant women SHGs will be registered with SRLMs. These SHGs are eligible for interest subvention to the extent of difference between the lending rates and $7 \%$ for the loan up to ₹ 3 lakhs, subjected to the norms prescribed by the respective SRLMs. This part of the scheme will be operationalized by SRLMs.

\section{Community Investment support Fund (CIF)}

CIF will be provided to the SHGs in the intensive blocks, routed through the Village level/ Cluster level Federations, to be maintained in perpetuity by the Federations. The CIF will be used, by the Federations, to advance loans to the SHGs and/or to undertake the common/collective socio-economic activities.

\section{Role of banks}

(a) Opening of Savings accounts: The role of banks would commence with opening of accounts for all the Women SHGs, SHGs with members of Disability and the Federations of the SHGs. The 'Know Your Customer' (KYC) norms as specified from time to time by Reserve Bank of India are applicable for identification of the customers.

(b) Lending Norms: The eligibility criteria for the SHGs to avail loans will be as under:

- SHG should be in active existence at least since the last 6 months as per the books of account of SHGs and not from the date of opening of S/B account.

- SHG should be practicing 'Panchasutras' i.e. Regular meetings; Regular savings; Regular interloaning; Timely repayment; and Up-to-date books of accounts;

- Qualified as per grading norms fixed by NABARD. As and when the Federations of the SHGs come to existence, the grading exercise can be done by the Federations to support the Banks.

- The existing defunct SHGs are also eligible for credit if they are revived and continue to be active for a minimum period of 3 months.

(c) Loan amount: Emphasis is laid on the multiple doses of assistance under NRLM. This would mean assisting an SHG over a period of time, through repeat doses of credit, to enable them to access higher amounts of credit for taking up sustainable livelihoods and improve on the quality of life. The amount of various doses of credit should be as follows:

- First dose: 4-8 times to the proposed corpus during the year or ₹ 50, 000 whichever is higher.

- Second dose: 5-10 times of existing corpus and proposed saving during the next twelve months or ₹ 1 lakhs, whichever is higher.

- Third dose: Minimum of ₹ 2 lakhs, based on the Micro credit plan prepared by the SHGs and appraised by the Federations/Support agency and the previous credit history

- Fourth dose onwards: Loan amount can be between ₹ 5-10 lakhs for fourth dose and/or higher in subsequent doses. The loan amount will be based on the Micro Credit Plans of the SHGs and their members.

The loans may be used for meeting social needs, high cost debt swapping and taking up sustainable livelihoods by the individual members within the SHGs or to finance any viable common activity started by the SHGs.

(Corpus is inclusive of revolving funds, if any, received by that SHG, its own savings and funds from other sources in case of promotion by other institutes/NGOs.) 


\section{(d) Type of facility and repayment:}

SHGs can avail either Term loan or a CCL loan or both based on the need. In case of need, additional loan can be sanctioned even though the previous loan is outstanding.

Repayment schedule could be as follows:

- The first dose of loan will be repaid in 6-12 instalments

- Second dose of loan will be repaid in 12-24 months.

- Third dose will be sanctioned based on the micro credit plans, the repayment has to be either monthly/ quarterly /half yearly based on the cash flow and it has to be between 2 to 5 Years.

- Fourth dose onwards: repayment has to be either monthly/quarterly/half yearly based on the cash flow and it has to be between 3 to 6 Years

\section{(e) Security and Margin:}

No collateral and no margin will be charged up to ₹ 10.00 lakhs limit to the SHGs. No lien should be marked against savings bank account of SHGs and no deposits should be insisted while sanctioning loans.

\section{Prime Minister's Employment Generation Programme (PMEGP)}

Government of India has launched credit linked subsidy programme called Prime Minister's Employment Generation Programme (PMEGP) by merging the two schemes that were in operation till 31.03.2008 namely Prime Minister's Rojgar Yojana (PMRY) and Rural Employment Generation Programme (REGP) for generation of employment opportunities through establishment of micro enterprises in rural as well as urban areas. PMEGP is a central sector scheme and is administered by the Ministry of Micro, Small and Medium Enterprises (MoMSME). The Scheme is implemented by Khadi and Village Industries Commission (KVIC), a statutory organization under the administrative control of the Ministry of MSME as the single nodal agency at the National level. At the State level, the Scheme is implemented through State KVIC Directorates, State Khadi and Village Industries Boards (KVIBs) and District Industries Centres (DICs) and banks. The Government subsidy under the Scheme is routed by KVIC through the identified Banks for eventual distribution to the beneficiaries / entrepreneurs in their Bank accounts. The Implementing Agencies, namely KVIC, KVIBs and DICs associate reputed Non- Government Organization (NGOs)/reputed autonomous institutions/Self Help Groups (SHGs)/ National Small Industries Corporation (NSIC) / Udyami Mitras empanelled under Rajiv Gandhi Udyami Mitra Yojana (RGUMY), Panchayati Raj institutions and other relevant bodies in the implementation of the Scheme, especially in the area of identification of beneficiaries, of area specific viable projects, and providing training in entrepreneurship development.

\section{(a) Objectives}

(i) To generate employment opportunities in rural as well as urban areas of the country through setting up of new self-employment ventures/projects/micro enterprises.

(ii) To bring together widely dispersed traditional artisans/ rural and urban unemployed youth and give them self-employment opportunities to the extent possible, at their place.

(iii) To provide continuous and sustainable employment to a large segment of traditional and prospective artisans and rural and urban unemployed youth in the country, so as to help arrest migration of rural youth to urban areas.

(iv) To increase the wage earning capacity of artisans and contribute to increase in the growth rate of rural and urban employment. 


\section{(b) Eligibility Conditions of Beneficiaries}

(i) Any individual, above 18 years of age

(ii) There will be no income ceiling for assistance for setting up projects under PMEGP.

(iii) For setting up of project costing above ₹10 lakh in the manufacturing sector and above ₹ 5 lakh in the business /service sector, the beneficiaries should possess at least VIII standard pass educational qualification.

(iv) Assistance under the Scheme is available only for new projects sanctioned specifically under the PMEGP.

(v) Self Help Groups (including those belonging to BPL provided that they have not availed benefits under any other Scheme) are also eligible for assistance under PMEGP.

(vi) Institutions registered under Societies Registration Act, 1860;

(vii) Production Co-operative Societies, and

(viii) Charitable Trusts.

(ix) Existing Units (under PMRY, REGP or any other scheme of Government of India or State Government) and the units that have already availed Government Subsidy under any other scheme of Government of India or State Government are not eligible.

\section{(c) Other eligibility conditions}

(i) A certified copy of the caste/community certificate or relevant document issued by the competent authority in the case of other special categories, is required to be produced by the beneficiary to the concerned branch of the Banks along with the Margin Money (subsidy) Claim.

(ii) A certified copy of the bye-laws of the institutions is required to be appended to the Margin Money (subsidy) Claim, wherever necessary.

(iii) Project cost will include Capital Expenditure and one cycle of Working Capital. Projects without Capital Expenditure are not eligible for financing under the Scheme. Projects costing more than ₹5 lakh, which do not require working capital, need clearance from the Regional Office or Controller of the Bank's Branch and the claims are required to be submitted with such certified copy of approval from Regional Office or Controller, as the case may be.

(iv) Cost of the land should not be included in the Project cost. Cost of the ready built as well as long lease or rental Work-shed/Workshop can be included in the project cost subject to restricting such cost of ready built as well as long lease or rental work shed/workshop to be included in the project cost calculated for a maximum period of 3 years only.

(v) PMEGP is applicable to all new viable micro enterprises, including Village Industries projects except activities indicated in the negative list of Village Industries. Existing/old units are not eligible.

(vi) The Institutions/Production Co-operative Societies/Trusts specifically registered as such and SC/ ST/ $\mathrm{OBC} /$ Women/ Physically Handicapped / Ex-Servicemen and Minority Institutions with necessary provisions in the bye-laws to that effect are eligible for Margin Money (subsidy) for the special categories. However, for Institutions /Production Cooperative Societies/Trusts not registered as belonging to special categories, will be eligible for Margin Money (Subsidy) for general category.

(vii) Only one person from one family is eligible for obtaining financial assistance for setting up of projects under PMEGP. The 'family' includes self and spouse. 


\section{(d) Quantum and Nature of Financial Assistance}

(i) The maximum cost of the project/unit admissible under manufacturing sector is ₹ 25 lakh.

(ii) The maximum cost of the project/unit admissible under business/service sector is ₹ 10 lakh.

(iii) The balance amount of the total project cost will be provided by Banks as term loan

The Central Government provides capital subsidy ranging between $10 \%$ to $35 \%$ to different categories of borrowers and depending upon the location of the unit.

\section{(e) Identification of beneficiaries:}

The identification of beneficiaries is done at the district level by a Task Force consisting of representatives from KVIC/ State KVIB and State DICs and Banks. The Task force is headed by the District Magistrate / Deputy Commissioner / Collector concerned. The Bankers are involved right from the beginning to ensure that bunching of applications is avoided. However, the applicants, who have already undergone training of at least 2 weeks under Entrepreneurship Development Programme (EDP) / Skill Development Programme (SDP) / Entrepreneurship cum Skill Development Programme (ESDP) or Vocational Training (VT) will be allowed to submit applications directly to Banks. However, the Banks will refer the application to the Task Force for its consideration. Exaggeration in the cost of the project with a view only to availing higher amount of subsidy should not be allowed. KVIC will devise a score card in consultation with SBI and RBI, and forward it to the District Level Task Force and other State/District functionaries. This score board will form the basis for the selection of beneficiaries. This score card will also be displayed on the websites of KVIC and Ministry. The selection process should be through a transparent, objective and fair process and Panchayati Raj Institutions should be involved in the process of selection (Para 11 (i)(b) of the guidelines refers).

\section{(f) Bank Finance}

A Bank sanctions $90 \%$ of the project cost in case of General Category of beneficiary/institution and $95 \%$ in case of special category of the beneficiary/institution, and disburse full amount suitably for setting up of the project. Bank will finance Capital Expenditure in the form of Term Loan and Working Capital in the form of cash credit. Project can also be financed by the Bank in the form of Composite Loan consisting of Capital Expenditure and Working Capital. The amount of Bank Credit will be ranging between $60-75 \%$ of the total project cost after deducting $15-35 \%$ of margin money (subsidy) and owner's contribution of $10 \%$ from beneficiaries belonging to general category and $5 \%$ from beneficiaries belonging to special categories. This scheme will thus require enhanced allocations and sanction of loans from participating banks. This is expected to be achieved as Reserve Bank of India (RBI) has already issued guidelines to the Public Sector Banks to ensure $20 \%$ year to year growth in credit to MSME Sector. SIDBI is also strengthening its credit operations to micro enterprises so as to cover 50 lakh additional beneficiaries over five years beginning 2006-07, and is recognized as a participating financial institution under PMEGP besides other scheduled/ Commercial Banks. Though Banks will claim Margin Money (subsidy) on the basis of projections of Capital Expenditure in the project report and sanction thereof, Margin Money (subsidy) on the actual availment of Capital Expenditure only will be retained and excess, if any, will be refunded to KVIC, immediately after the project is ready for commencement of production.

Working Capital component should be utilized in such a way that at one point of stage it touches $100 \%$ limit of Cash Credit within three years of lock in period of Margin Money and not less than $75 \%$ utilization of the sanctioned limit. If it does not touch aforesaid limit, proportionate amount of the Margin Money (subsidy) is to be recovered by the Bank/Financial Institution and refunded to the KVIC at the end of the third year.

\section{Rate of interest and repayment schedule}

Normal rate of interest shall be charged. Repayment schedule may range between 3 to 7 years after an initial moratorium as may be prescribed by the concerned bank/financial institution. It has been observed that banks have been routinely insisting on credit guarantee coverage irrespective of the merits of the proposal. This approach needs to be discouraged. 
$\mathrm{RBI}$ will issue necessary guidelines to the Banks to accord priority in sanctioning projects under PMEGP. RBI will also issue suitable guidelines as to which RRBs and other banks will be excluded from implementing the Scheme.

\section{KISAN CREDIT CARD SCHEME}

Kisan Credit Card Scheme aims at providing adequate and timely credit support from the banking system under a single window to the farmers for their cultivation \& other needs as indicated below:

(a) To meet the short term credit requirements for cultivation of crops

(b) Post harvest expenses

(c) Produce Marketing loan

(d) Consumption requirements of farmer household

(e) Working capital for maintenance of farm assets and activities allied to agriculture, like dairy animals, inland fishery etc.

(f) Investment credit requirement for agriculture and allied activities like pump sets, sprayers, dairy animals etc.

Note: The aggregate of components a. to e. above will form the short term credit limit portion and the aggregate of components under $f$ will form the long term credit limit portion.

\section{Eligibility}

(i) All Farmers - Individuals / Joint borrowers who are owner cultivators

(ii) Tenant Farmers, Oral Lessees \& Share Croppers

(iii) SHGs or Joint Liability Groups of Farmers including tenant farmers, share croppers etc.

\section{Fixation of credit limit/Loan amount}

The credit limit under the Kisan Credit Card may be fixed as under:

(a) All farmers other than marginal farmers:

The short term limit to be arrived for the first year:

For farmers raising single crop in a year:

Scale of finance for the crop (as decided by District Level Technical Committee) $x$ Extent of area cultivated $+10 \%$ of limit towards post-harvest / household / consumption requirements $+20 \%$ of limit towards repairs and maintenance expenses of farm assets + crop insurance, PAIS \& asset insurance.

Limit for second \& subsequent year :First year limit for crop cultivation purpose arrived at as above plus $10 \%$ of the limit towards cost escalation / increase in scale of finance for every successive year ( $2 \mathrm{nd}, 3 \mathrm{rd}$, 4th and 5 th year) and estimated Term loan component for the tenure of Kisan Credit Card, i.e., five years.

For farmers raising more than one crop in a year:

The limit is to be fixed as above depending upon the crops cultivated as per proposed cropping pattern for the first year and an additional $10 \%$ of the limit towards cost escalation / increase in scale of finance for every successive year (2nd, 3rd, 4th and 5th year). It is assumed that the farmer adopts the same cropping pattern for the remaining four years also. In case the cropping pattern adopted by the farmer is changed in the subsequent year, the limit may be reworked. 
Term loans for investments towards land development, minor irrigation, purchase of farm equipments and allied agricultural activities.

The banks may fix the quantum of credit for term and working capital limit for agricultural and allied activities, etc., based on the unit cost of the asset/s proposed to be acquired by the farmer, the allied activities already being undertaken on the farm, the bank's judgment on repayment capacity vis-a-vis total loan burden devolving on the farmer, including existing loan obligations.

The long term loan limit is based on the proposed investments during the five year period and the bank's perception on the repaying capacity of the farmer

Maximum Permissible Limit: The short term loan limit arrived for the 5th year plus the estimated long term loan requirement will be the Maximum Permissible Limit (MPL) and treated as the Kisan Credit Card Limit.

Fixation of Sub-limits for other than Marginal Farmers:

(i) Short term loans and term loans are governed by different interest rates. Besides, at present, short term crop loans are covered under Interest Subvention Scheme/ Prompt Repayment Incentive scheme. Further, repayment schedule and norms are different for short term and term loans. Hence, in order to have operational and accounting convenience, the card limit is to be bifurcated into separate sub limits for short term cash credit limit cum savings account and term loans.

(ii) Drawing limit for short term cash credit should be fixed based on the cropping pattern and the amounts for crop production, repairs and maintenance of farm assets and consumption may be allowed to be drawn as per the convenience of the farmer. In case the revision of scale of finance for any year by the district level committee exceeds the notional hike of $10 \%$ contemplated while fixing the five year limit, a revised drawable limit may be fixed and the farmer be advised about the same. In case such revisions require the card limit itself to be enhanced (4th or 5th year), the same may be done and the farmer be so advised. For term loans, installments may be allowed to be withdrawn based on the nature of investment and repayment schedule drawn as per the economic life of the proposed investments. It is to be ensured that at any point of time the total liability should be within the drawing limit of the concerned year.

(iii) Wherever the card limit/liability so arrived warrants additional security, the banks may take suitable collateral as per their policy.

\section{(b) For Marginal Farmers:}

A flexible limit of ₹ 10,000 to ₹50,000 be provided (as Flexi KCC) based on the land holding and crops grown including post harvest warehouse storage related credit needs and other farm expenses, consumption needs, etc., plus small term loan investments like purchase of farm equipments, establishing mini dairy/backyard poultry as per assessment of Branch Manager without relating it to the value of land. The composite KCC limit is to be fixed for a period of five years on this basis. Wherever higher limit is required due to change in cropping pattern and/or scale of finance, the limit may be arrived at as per the estimated requirements.

\section{Disbursement}

The short term component of the KCC limit is in the nature of revolving cash credit facility. There should be no restriction in number of debits and credits. However, each installment of the drawable limit drawn in a particular year will have to be repaid within 12 months. The drawing limit for the current season/year could be allowed to be drawn using any of the following delivery channels.
(a) Operations through branch
(b) Operations using Cheque facility
(c) Withdrawal through ATM / Debit cards 
(d) Operations through Business Correspondents and ultra thin branches

(e) Operation through PoS available in Sugar Mills/ Contract farming companies, etc., especially for tie-up advances

(f) Operations through PoS available with input dealers

(g) Mobile based transfer transactions at agricultural input dealers and mandies.

Note: (e), (f) \& (g) to be introduced as early as possible so as to reduce transaction costs of both the bank as well as the farmer.

The long term loan for investment purposes may be drawn as per installment fixed.

\section{Aggregate Card Limit}

As the $\mathrm{CC}$ limit and the term loan limit are two distinct components of the aggregate card limit bearing different rates of interest and repayment periods, until a composite card could be issued with appropriate software to separately account transactions in either sub limits, two separate electronic cards may be issued.

\section{Validity / Renewal}

(i) Banks may determine the validity period of $\mathrm{KCC}$ and its periodic review.

(ii) The review may result in continuation of the facility, enhancement of the limit or cancellation of the limit / withdrawal of the facility, depending upon increase in cropping area / pattern and performance of the borrower.

(iii) When the bank has granted extension and/or re-schedulement of the period of repayment on account of natural calamities affecting the farmer, the period for reckoning the status of operations as satisfactory or otherwise would get extended together with the extended amount of limit. When the proposed extension is beyond one crop season, the aggregate of debits for which extension is granted is to be transferred to a separate term loan account with stipulation for repayment in installments.

\section{Rate of Interest (ROI)}

Rate of Interest will be linked to Base Rate and is left to the discretion of the banks.

\section{Repayment Period}

Each withdrawal under the short term sub-limit as estimated under (a) to (e) of Para 3 above ,be allowed to be liquidated in 12 months without the need to bring the debit balance in the account to zero at any point of time. No withdrawal in the account should remain outstanding for more than 12 months.

The term loan component will be normally repayable within a period of 5 years depending on the type of activity/ investment as per the existing guidelines applicable for investment credit.

Financing banks at their discretion may provide longer repayment period for term loan depending on the type of investment.

\section{Margin}

To be decided by banks.

\section{Security}

Security will be applicable as per RBI guidelines prescribed from time to time. Present Security requirement may be as under: 
(i) Hypothecation of crops up to card limit of ₹ 1.00 lakh as per the extant RBI guidelines.

(ii) With tie-up for recovery: Banks may consider sanctioning loans on hypothecation of crops up to card limit of ₹3.00 lakh without insisting on collateral security.

(iii) Collateral security may be obtained at the discretion of Bank for loan limits above ₹1.00 lakh in case of non tie-up and above ₹3.00 lakh in case of tie-up advances.

(iv) In States where banks have the facility of on-line creation of charge on the land records, the same shall be ensured.

\section{Processing fee}

It may be decided by banks.

\section{Other Conditions}

- In case the farmer applies for loan against the warehouse receipt of his produce; the banks would consider such requests as per the established procedure and guidelines. However, when such loans are sanctioned, these should be linked with the crop loan account, if any and the crop loan outstanding in the account could be settled at the stage of disbursal of the pledge loan, if the farmer desires.

- The National Payments Corporation of India (NPCl) will design the card of the KCC to be adopted by all the banks with their branding.

- All new KCC must be issued as per the revised guidelines of the KCC Scheme .Further, at the time of renewal of existing KCC; farmers must be issued smart card cu

\section{FINANCING SELF HELP GROUPS (SHGS)}

SHG is "a voluntary association of poor formed with the common goal of social and economic empowerment".

In micro financing, a SHG is mainly used as a medium(channel) of credit delivery. It is an voluntary association formed by the members as a group with the objective of eradication of poverty of the members. The members of SHG agree to save regularly to create a common savings called as group corpus. The SHGs encourages the savings habit among group members. The SHG mobilizes the resources of the individual members with a common goal for the overall economic development. The SHG assist banks, financial institutions, in the recovery of loans. SHGs empower women in the developmental activities

\section{SHGs - important aspects}

Generally the number of members in a SHG is 10 to 20 . In certain exceptional areas like, hills, deserts and areas with less population, and in case of economically weaker and/or physically disabled persons, the number of members may be 5 to 20 . Only one member from a family can be the member of a SHG. The desirable requirement is that all the members of a SHG should belong to the families below the poverty line. The main objective of a SHG is to promote the common savings, hence all members need to contribute regularly to the common savings (corpus) of the group. No interest is payable to the members for the savings. The members should not be encouraged to adjust their savings amount against their loan due to the SHG. Every SHG needs to have a SB account (preferably with a bank in their service area). To open an account the SHG needs to pass a resolution in the group meeting and signed by all the members. A copy of the resolution should be submitted to the bank, while opening the bank account. Operations in Bank account: The SHG should authorize at least three members, any two of them, to jointly operate the bank account. The bank account should be in the name of the group and not in the names of individual members. The SHG should clearly decide the terms and conditions of the functioning of the SHG regarding lending to the members (viz., the interest, the loan amount, repayment period etc.) 


\section{FINANCING JOINT LIABILITY GROUPS (JLGS)}

A JLG is group formed basically consisting of tenant farmers and small farmers cultivating land, without having proper title of such land and rural entrepreneurs practicing non-farm activities.

\section{JLG - some important features}

Members residing in the same village/ area, agree to function as a join liability group. One of the important requirement is that each member should have trust among the members to accept the joint liability for individual and group loans. One person from a family can become a member of a JLG. The members should be practicing agricultural activity at least for a continuous period of not less than one year, within the area of operations of the bank branch. Such members should not be a defaulter to any other formal financial institution

Joint Liability Group - Banks give two types of loans to JLGs (i) individual loans (ii) group finance.

Model I: Banks can give individual loans, and all members would jointly execute one inter-se document (i.e., every member is jointly and severally liable for repayment of all loans taken by all individuals in the group. In this case, banks need to assess the proposal based on the individual member's activities and credit absorption capacity. Banks should also ensure that there is a mutual agreement and consensus among all members in respect of the amount of individual loan amount that would be created.

Model II: Banks can finance the JLG on group basis, in this case 4 to 10 individuals would form a group and function as one borrowing unit. The group would be sanctioned one loan, which could be a combined loan requirement of all its members. In case of crop loan, the bank would assess the loan amount based on crop/s to be cultivated and the available area to each member of the JLG. All members would jointly execute the document and takes the responsibility of the debt liability jointly and severally. In both models the group would give a mutual guarantee offered by the JLG members for the group and/or individual loan.

NABARD plays an active role in promoting the JLGs.

(a) NABARD provides, grant assistance to banks and other institutions who promote and nurture JLGs. Such grant assistance is given at different stages.

(b) NABARD provides $100 \%$ refinance assistance to all banks for lending to JLGs under investment credit, in similar lines to that of SHG-Bank Linkage Program.

(c) NABARD would also support banks for their capacity building programs in promoting the concept of financing JLGs by assisting banks in their publicity measures.

\section{RETAIL FINANCE}

Banks assist their clients to tide over their financial needs by extending retail loans. Personal loans, consumer loans comes under the category of retail finance.

\section{Personal Loans}

Banks under the category retail finance, are extending two important loans viz., Personal Loans and Consumer Loans. Usually banks give personal loans without any tangible security. Invariably such loans are given to salaried persons based on their regular source of income i.e., salary.

\section{Purpose:}

To cover travel, marriage or educational and medical expenses. Some banks extend loans to celebrate functions/ festivals as well.

\section{Eligibility:}

Different banks follow different systems, however depending upon the bank's policy the terms and conditions 
may vary. Regular and permanent employees of Central, State Governments, employees of reputed corporate companies, industrial establishment both in Private and Public Sector, with a specific minimum number of years of service.

\section{Loan amount:}

The loan amount is calculated based on how many times of the gross/net salary.(Banks generally verify the proof of employment and salary certificate, to work out the eligible loan amount) The net take home pay would also be considered while arriving at the loan amount. Some banks insist that a minimum of 35 to 40 percent of the gross salary should be the minimum take home pay after the proposed EMI for the loan.

\section{Security:}

While no tangible security like fixed assets is required, some banks require a personal guarantee.

\section{Loan Documents:}

(i) Bank's loan sanction letter (ii) Demand Promissory Note (iii) Loan agreement (as per bank's standard format) (iv) Proof of employment and salary certificate, some banks obtain bank pass book to verify the salary credits (v) Guarantee agreement, if the loan is guaranteed.

\section{Other terms:}

As per bank's policy the other terms and conditions are decided like, interest rate, tenor of the loan, repayment amount, EMI, pre- payment, processing charges etc.,

\section{Consumer Loans}

Consumer loans are either granted by banks by way of term loans and/or finance companies by way of hire purchase. These loans are given to customers to assist them to obtain consumer durables of their choice and requirement, with easy terms. If the goods are purchased through the hire purchase, then the title of the goods passes to the buyer at the end of the term after the last installment is paid.

\section{Purpose:}

Consumer loans, another category of retail finance are granted to enable the customers to buy consumer durables and white goods like refrigerators, TV, PCs. Laptops washing machines, music system, kitchen appliances ,etc.

\section{Eligibility:}

Generally persons who have regular source of income like, salaried persons, professionals, pensioners, self employed small businessmen farmers and village artisans and other individuals.

\section{Loan Amount:}

(i) The loan amount would be decided based on the cost of the goods to be purchased and the margin (which needs to be provided by the borrower) (ii) The minimum take home pay of 30 to 35 percent (after the application of the EMI of the proposed loan) is also considered. (iii) 10 to 20 percent margin is obtained.

\section{Security:}

The consumer goods to be purchased out of the loan amount, are to be hypothecated to the bank

Loan Documents: (i) Bank's loan sanction letter (ii) Demand Promissory Note (iii) Hypothecation agreement (as per bank's standard format) (iv) Proof of employment and salary certificate, some banks obtain bank pass book to verify the salary credits (v) Salaried persons: Proof of employment and salary certificate for three to six months for the individual and his spouse (spouse's income is also taken to work out higher loan eligibility) (vi) Professionals, Self employed, businessmen, IT Returns, Form 16/ 16A (vii) Quotations of the goods/ articles from reputed dealer 


\section{Other conditions:}

As per bank's policy the other terms and conditions are decided like, interest rate, tenor of the loan, repayment amount, EMI, pre payment, processing charges etc.,

\section{CONSORTIUM FINANCE}

Generally banks finance their clients based on their lending policy. Sometimes a single banker may not be able to finance a customer. In such situations, more than one bank joinly grant loans and advances and other credit facilities to a borrower, such type of financing is called as consortium finance.

Banks lend under consortium finance on account of:

- Regulatory requirements

- Restrictions on single and group borrower's limits

- As part of risk management and diversification policy of banks

- At the request of a borrower

When two or more banks join together to finance a borrower it is called Consortium Financing. In case of consortium finance, based on a formal agreement between member banks of the consortium and the group would have identified a banker as ' Lead Bank'.

The functions of lead bank as leader of the group, would include:

(a) arranging meetings between the member banks

(b) active involvement in credit appraisal, to obtain legal documents, to ensure proper charges are created on assets and also to monitor the account

\section{TRADE FINANCE}

Banks play a vital role in providing financial assistance and also comfort levels to the traders through their financing called as "Trade Finance". Trade finance is granted in the form of fund based finance and non- fund based finance to enable the traders in their trading activities. The borrower may be a manufacturer/ trader or trader a who require working capital and term finance for his production and managing his cash flows. Apart from these type of loans, wherein the banker allows the borrower to draw down actual funds, banks also extend credit facility in the form of non -fund based facilities, called non fund based limits like letters of credit, bank guarantees.

Trade finance is granted to the domestic traders as well as traders who are handling EXIM trade (export and import). If the bank extends finance mainly in rupee funds to assist his borrower to sell or buy goods and services within India, it is classified as inland trade finance. On the other hand if a banker assists his borrower to handle international trade activities of export and import the banker is extending credit called overseas trade finance.

Banks also extend trade finance in the form of bills finance for their clients.

\section{EXPORT - IMPORT FINANCE}

An Indian exporter is extended credit facilities (fund based/non fund based) by his banker in the form of;

\section{Pre-shipment Credit and Post-shipment Credit}

Both are categorized under fund based limits. Both put together can be equated to "working capital finance" granted to an exporter.

Pre-shipment credit, also called as packing credit is extended to the exporter to assist him (if he is a manufacturer and exporter) in his procurement of raw material and converting the raw materials to finished and exportable 
goods. With the assistance of bank finance an exporter is able to produce the goods and keep it ready for export. In other words, bank is financing against the inventory of the exporter in the form of inventory financing. It is called as "pre-shipment credit" because the production activities take place before shipment of exportable goods.

\section{Pre-shipment Credit - features and precautions}

1. The status of the borrower as an exporter should be established by the banker. Every exporter is given an exporter's code by the Govt. authorities.

2. Export finance is granted at concessional rate of interest, to encourage exports. Hence banks should be guided by the Bank's policy, exposure norms and the Regulator's guidelines and directives in extending export credit.

3. Banks should also be guided by the provisions of 'FEMA,1999' since export receivables would result in inflow of foreign currency. Export and import of goods and services are treated as current account transactions, as such banks should be careful in reporting requirements of export and import financial transactions in the prescribed formats and frequencies

4. As far as foreign banks operating in India export credit is also eligible to be included in the target/sub targets of Priority Sector lending.

5. Pre-shipment credit is extended to an exporter invariably against export letter of credit issued in favour of the exporter. Banks should ensure all the required credentials, export caution lists, etc. before extending export credit. Banks should be satisfied with the terms and conditions of letter of credit and if need be satisfied with the applicable provisions of UCPDC 600 as well.

6. Banks should extend pre shipment credit based on the type of letter credit, and only for fob value and not for any other value like $\mathrm{c} \& \mathrm{f}$ or $\mathrm{c}$ i $\mathrm{f}$ value of the Ic. Sufficient margin needs to be kept on the fob value and allow the exporter export credit accordingly.

7. Once goods are exported the pre-shipment credit exposure should be squared off against post shipment credit - discounting of export bills.

\section{Post-shipment Credit}

Similarly, once goods are exported, the status changes to "post-shipment credit' since the banker is financing against receivables by either purchasing or discounting the export bills. Invariably, the exporter is granted, both pre-shipment and post-shipment facilities. This is due to the following reasons:

A banker would grant an export credit as under:

$\begin{array}{lll}\text { Pre-shipment credit } & - & ₹ 1,000,000 \\ \text { Post-shipment credit } & - & ₹ 1,000,000 \\ \text { Overall export credit } & - & ₹ 1,000,000\end{array}$

Why should a banker grant an export credit in the above mentioned manner?

(i) The pre-shipment credit and post-shipment credit are linked and granted for the same goods

(ii) By fixing the over all limit equivalent to both pre-shipment credit and post-shipment credit, the bank indicates to the exporter that at any given point in time, the exporter can have a maximum exposure of $₹$ $1,000,000$ as export credit and (i) the o/s of $₹ 1,000,000$ in pre-shipment and nil o/s in post-shipment or (ii) nil o/s in pre-shipment and o/s ₹ 1,000,000 in post-shipment or (iii) the total o/s in both pre-shipment and post-shipment should not exceed ₹ 1,000,000

(iii) Once the goods are exported (i.e. shipped, based on the export documents submitted by the exporter, 
banks would adjust the pre-shipment credit by extending post-shipment credit by negotiating the export bills.

(iv) Through this methodology banks would have better control on the export credit exposure

Banks are also at an advantageous position in getting additional:

(a) Forex business and they can extend forward exchange covers

(b) Increase in fee based as well as income in the form of discount/exchange while handling export bills.

(c) Banks can also have better reporting of export transactions.

Exporters are extended the non- fund based limits in the form of bank guarantees issued on behalf of the exporters.

\section{Import Finance}

Banks extend credit and other facilities to an import customer in his import activities as part of trade finance. Banks generally grant non fund based limits like letters of credit for an import customer. On the due date bank as per their commitment as opening banker of letter of credit would pay against documents received from exporter's banker, and recover the amount from the importer. In case the importer does not have sufficient balance in his account then the banker would grant an import loan, as part of fund based import finance

While dealing with importer and granting import finance, banks should take necessary precautions.

1. Bank should follow the bank's loan policy, exposure norms, the RBl's guidelines and FEMA,1999 provisions

2. In most of the cases only letter of credit limits are granted, though it is a non- funded limit, banks should carry out all the required due diligence, careful credit evaluation, ensuring all the required procedures are followed to avoid any NPA situation once the non funded limit is converted into fund based import finance

3. Like in the case of an exporter, the importer's status needs to be verified and his credentials also to be ensured to safe guard bank's position

4. Close monitoring of funding status in importer's account is a must to enable the banker to pay on the due date against letter of credit. Banks can also obtain sufficient margin, lien on bank's fixed deposits to ensure the funds are available on the due dates

5. Banks should follow the reporting requirements

6. All other precautions are to be taken to cover the risks as well

Apart from the above, banks can also extend foreign exchange forward covers for their export and import clients. They can offer derivative products also as per their bank's policies. However, in all these cases, banks should follow the bank's credit and risk management policies coupled with following the legal and regulatory requirements.

If both the credit facilities are given, it would be easier for the banks to monitor the exposure of the export credit. Banks have responsibility of reporting the realization of export proceeds.

\section{Legal control over bank's deployment of funds}

To avoid excessive concentration of credit amongst few borrowers and to keep the risk potential within limits, the Reserve Bank of India has prescribed credit exposure norms to be followed by banks. Exposure norms mean the ceiling limits within which a bank may grant loans and advances and non-fund based facilities to a single borrower or a group of borrowers. Exposure shall include credit exposure (funded and non-funded credit limits) and investment exposure (including underwriting and similar commitments).

\section{Ceilings for Individual and Group Borrowers}

- The exposure ceiling limits would be 15 percent of capital funds in case of a single borrower and 40 
percent of capital funds in the case of a borrower group. The capital funds for the purpose will comprise of Tier I and Tier II capital as defined under capital adequacy standards. Capital funds for the purpose will comprise Tier I and Tier II capital as defined under capital adequacy standards and as per the published accounts as on March 31 of the previous year.

- Credit exposure to a single borrower may exceed the exposure norm of 15 percent of the bank's capital funds by an additional 5 percent (i.e. up to 20 percent) provided the additional credit exposure is on account of extension of credit to infrastructure projects. Credit exposure to borrowers belonging to a group may exceed the exposure norm of 40 percent of the bank's capital funds by an additional 10 percent (i.e., up to 50 percent), provided the additional credit exposure is on account of extension of credit to infrastructure projects.

- In addition to the exposure permitted above, banks may, in exceptional circumstances, with the approval of their Boards, consider enhancement of the exposure to a borrower (single as well as group) up to a further 5 percent of capital funds subject to the borrower consenting to the banks making appropriate disclosures in their Annual Reports.

- The bank should make appropriate disclosures in the 'Notes on account' to the annual financial statements in respect of the exposures where the bank had exceeded the prudential exposure limits during the year.

\section{Limits on Banks' Exposure to Capital Markets}

- Statutory limit on shareholding in companies

In terms of Section 19(2) of the Banking Regulation Act, 1949, no banking company shall hold shares in any company, whether as pledgee, mortgagee or absolute owner, of an amount exceeding 30 percent of the paid-up share capital of that company or 30 percent of its own paid-up share capital and reserves, whichever is less, except as provided in sub-section (1) of Section 19 of the Act. This is an aggregate holding limit for each company. While granting any advance against shares, underwriting any issue of shares, or acquiring any shares on investment account or even in lieu of debt of any company, these statutory provisions should be strictly observed.

\section{LESSON ROUND UP}

- Loans and advances are the important segment of the deployment of funds of a bank.

- The major activity of the banker as a lending banker calls for many precautions to be exercised by the banker in dealing with different types of borrowers and extending them various credit facilities.

- Banker as a trustee of public funds is required to be careful in deploying the funds which have been accepted as deposits from depositors.

- Lending principles can be conveniently divided into two areas (i) activity, and (ii) individual.

- As the bank lends the funds entrusted to it by the depositors, the first and foremost principle of lending is to ensure the safety of the funds lent.

- The banker must ensure that the borrower is able to repay the loan on demand or within a short period.

- The sound principle of lending is not to sacrifice safety or liquidity for the sake of higher profitability.

- To safeguard his interest against such unforeseen contingencies, the banker follows the principle of diversification of risks based on the famous maxim "do not keep all the eggs in one basket."

- Twenty major banks in India were nationalized "to serve better the needs of development of the economy in conformity with the national policy and objectives." 
- The creditworthiness of a person means that he deserves a certain amount of credit, which may safely be granted to him.

- The Reserve Bank of India has established within itself a Credit Information Bureau which collects credit information from the banks under Section 45-C (1) of the Reserve Bank of India Act, 1934.

- The Reserve Bank of India (Amendment) Act, 1974 inserted a clause which provides statutory protection to banks to exchange freely credit information, mutually amongst themselves.

- Cash credit is the main method of lending by banks in India and accounts for about 70 per cent of total bank credit. Under the system, the banker specifies a limit, called the cash credit limit, for each customer, up to which the customer is permitted to borrow against the security of tangible assets or guarantees.

- When a customer is maintaining a current account, a facility is allowed by the bank to draw more than the credit balance in the account; such facility is called an 'overdraft' facility.

- Bill finance facility plugs in the mismatches in the cash flow and relieves the corporates from worries on commitments. Besides the fund based bill finance, we also provide agency services for collection of documentary bills/cheques.

- When a bill, either clean or documentary is drawn payable after certain period or on a specified date, the bill is called Usance Bill.

- The members are from a homogeneous group who join together to resolve their common problems.

- The group members are encouraged to a common savings and lend such saved funds to their members.

- The SHG aims at improving the living conditions of their members through their savings.

- Whereas, the JOINT LIABILITY GROUP (JLG) is a group of tenant farmers, gets finance based on the joint liability of the members.

- The finance helps them to live in a better conditions.

- NABARD provides $100 \%$ refinance assistance to all banks for lending to JLGs under investment credit, in similar lines to that of SHG-Bank Linkage Programme.

- NABARD also support banks for their capacity building programs in promoting the concept of financing JLGs.

\section{SELF TEST QUESTIONS}

1. State whether the following statements are 'True' or 'False'

(a) Bank lending to priority sector includes SMEs

(b) Pre-shipment credit is granted against the CIF value of a letter of credit

(c) KYC norms are applicable only to deposit accounts and not loan accounts

(d) Banks earn non-interest income in case of letters of credit and bank guarantees

(e) Members of JLG is tenant farmers

(f) Export finance given by a foreign bank is considered as part of priority sector lending

(g) A Kisan credit card holder is eligible for a crop loan

(h) A loan to a SHG is an example of micro credit

(i) A letter of credit is an example of a negotiable instrument 
(j) Banks should diversify their lending

2. Chose the correct alternative.

A. A banker grants CC limit of $₹ 100,000$ against hypothecation of stocks with $25 \%$ margin. If the borrower wants to avail of the full limit of $₹ 100,000$ he should hypothecate -worth of stocks?
(a) ₹ 75,000
(b) ₹100,000
(c) ₹ 125,000
(d) ₹135,000

B. Identify the exception to the principle of lending?
(a) safety
(b) security
(c) fee income
(d) diversity

C. The issuer of a confirmed letter of credit is:
(a) importer's banker
(b) exporter's banker
(c) confirming banker
(d) reimbursing banker

D. Priority Sector loans are granted with certain conditions as to the type, loan amount, category of borrowers, etc., In this regard, identify the exception
(a) Educational Loan
(b) Housing loan
(c) Loans to SHG
(d) Working Capital loan to a CA firm

E. Exposure to a group of borrowers of a bank should not
(a) exceed $15 \%$ of bank's capital funds
(b) exceed $40 \%$ of bank's capital funds
(c) exceed $15 \%$ of bank's total credit
(d) exceed $40 \%$ of bank's total credit

F. When a guarantee is invoked who is primarily responsible to honour?
(a) the beneficiary
(b) the guarantor
(c) the applicant
(d) the guarantor and the applicant

G. Which of the following is not a term loan?
(a) Housing loan
(b) Educational loan
(b) Overdraft against book debts
(d) Consumer loan

3. Explain the lending principles of the bank based on the activities of the bank.

4. What are the Non-based credit facilities provided by the bank?

5. Why banks should be careful, while granting fund based and non fund based credit facilities to various customers?

6. What are the various types of letters of credit? Who are the different bankers involved in letter of credit transactions?

7. What are the Documents handled under Letters of Credit/ Explain.

8. Distinguish between (i) pre-shipment finance and (ii) post-shipment finance

9. Write short notes on:

(a) Financing joint liability groups (JLGS) 
194 PP-BL\&P

(b) Financing self help groups (SHGS)

(c) Kisan credit card scheme

(d) Credit-linked government sponsored schemes

(e) Post shipment credit

(f) Retail Finance

(g) Performance guarantee

(h) Commercial invoice 


\section{Lesson 7}

\section{Securities for Bank Loans}

\section{LESSON OUTLINE}

- Principles Of Lending

- General Principles of Secured Advances

- Various Kinds of Securities :

- Land/Real Estate

- Stocks and Shares

- Debentures

- Goods

- Life Policies

- Book Debts

- Fixed Deposit

- Supply Bills

- Charge Over Securities :

- Pledge

- Hypothecation

- Lien:

- Assignment

- Mortgage

- Registration of Charge

- Documentation

- Lesson Round Up

- Self Test Questions

\section{LEARNING OBJECTIVES}

Banks are required to be careful in handling various loans and advances, otherwise banks may be exposed to various risks. Non observance of proper control, monitoring, and checking might result in the bank's financial loss and sometimes even affects the reputation as well. In this regard understanding the importance of legal terms i.e., Charges like lien, set off, mortgage, pledge, hypothecation and assignment are important. Banks lend money to the borrowers against various kinds of securities. Banks should ensure that they obtain securities to protect the bank in case of default by the borrower. To protect the interests of the banks, the securities obtained by banks should have marketable value and also such security can be legally enforceable.

After reading this chapter the reader would be able to:

- understand the importance of securities in bank's loans and advances

- differentiate between various types of securities

- also know about the features of different types of charges on securities 


\section{GENERAL PRINCIPLES OF SECURED ADVANCES}

While granting advances on the basis of securities offered by customers, a banker should observe the following basic principles:

(a) Adequacy of Margin: The word 'margin' has special meaning and significance in the banking business. In banking terminology, 'margin' means the difference between the market value of the security and the amount of the advance granted against it. For example, if a banker sanctions an advance of ₹ 70 against the security of goods worth $₹ 100$, the difference between the two ( $₹ 100-₹ 70=₹ 30$ ) is called margin. A banker always keeps an adequate margin because of the following reasons:

(i) The market value of the securities is liable to fluctuations in future with the result that the banker's secured loans may turn into partly secured ones.

(ii) The liability of the borrower towards the banker increases gradually as interest accrues and other charges become payable by him. For example, if a loan of ₹ 100 is sanctioned by a banker today, the liability of the borrower at a future date, say, a year after, would be increased by the amount of interest accrued and other charges payable by him. Hence, a banker keeps adequate margin to cover not only the present debt but also the additions to the debt.

Factors Determining Margin: The quantum of margin is not uniform in case of all commodities or in case of all customers. The following factors determine the margin:

(i) The amount of margin depends upon the likely fluctuations in the prices of the various commodities. For example, if a commodity enjoys steady demand and is an item of essential consumption, lower margin is fixed. But the prices of articles of luxury are likely to fluctuate widely. Hence, the banker should be very cautious in accepting the same and should require a very high margin.

(ii) In case of shares of industrial concerns the financial position and reputation of the issuing undertaking is also taken into account. Shares of sound industrial concerns are treated as good as Government securities and a lower margin is required.

(iii) Margins are fixed keeping in view the credit and reputation of the borrower concern, i.e. a lower margin may be fixed for the borrower having first class reputation against the security of the same commodity.

(iv) The margin, determined at the time of sanctioning an advance, may be raised or reduced subsequently according to the variation in the prices of the securities.

(v) In case of commodities which are subject to selective credit control of the Reserve Bank, margins are usually prescribed by the Reserve Bank from time to time. It is essential for the banks to keep such margins.

(b) Marketability of Securities: Advances are usually granted for short periods by the commercial banks because their deposit resources (except term deposits) are either repayable on demand or at short notice. If the customer defaults in making payment, the banker has to liquidate the security. It is, therefore, essential that the security offered by a borrower may be disposed of without loss of time and money. A banker should be very cautious in accepting assets which are not marketable.

It is proverbially said "a banker lends his umbrella when the sky is clear and demands it back as soon as it rains". This is true because in a wider sense he is the trustee of the people's savings. He cannot act as a philanthropist in granting aid to the people who are likely to get ruined. Liquidity of the security is, therefore, a prime consideration. 
(c) Documentation: Documentation means that necessary documents, e.g. agreement of pledge or mortgage, etc., are prepared and signed by the borrower at the time of securing a loan from the bank. Though it is not necessary under the law to have such agreements in writing and mere deposit of goods or securities will be sufficient to constitute a charge over them, but it is highly desirable to get the documents signed by the borrower. These documents contain all the terms and conditions on which a loan is sanctioned by the banker and hence, any misunderstanding or dispute later on may easily be avoided.

(d) Realisation of the Advance: If the borrower defaults in making payment on the specified date, the banker may realize his debt from the sale proceeds of the securities pledged to him. As noted in previous chapter, a pledgee may sell the securities by giving proper notice to the pledger of his intention to sell the securities. In case of loans repayable on demand a reasonable period is to be permitted by the banker for such repayment. This period may be a shorter one if there is urgency of selling the commodities immediately in view of the falling trend in their prices. If a banker is unable to recover his full dues from the security he shall file a suit for its recovery within the period of three years from the date of the sanction of the advance. In case of term loans repayable after a fixed period, the period of limitation (i.e. 3 years) shall be counted from the expiry of that fixed period.

\section{VARIOUS KINDS OF SECURITIES}

\section{Land/Real Estate as a Security for the Loan/Advance}

Bankers in the olden days were very much averse to accept land and building as a security, but this prejudice has over a period of time changed and land and building as a security has become an acceptable collateral in most advances, more particularly to corporate customers. The advantages and disadvantages of this form of security cannot be universally applied to all lands and it depends on the nature of the land offered. We shall now discuss both the advantages and disadvantages.

\section{Advantages}

(i) The advantage that land has over other types of securities is that its value generally increases with time. With every fall in the value of money, the value of land goes up and due to its scant availability in developing areas its value is bound to increase.

(ii) It cannot be shifted, a fact which sometimes is also a disadvantage.

\section{Disadvantages}

\section{(i) Valuation is at times difficult}

The value of a building depends on several factors such as location, size of property, state of repair, amenities, etc., and in the case of factories and industrial buildings, the machinery, nature of industry, etc. This makes the valuation very difficult. Buildings and the materials used in the buildings are not alike. In fact, buildings must be valued on a conservative basis because of limited market in the event of sale.

\section{(ii) Ascertaining the title of the owner}

The banker cannot obtain a proper title unless the borrower himself has title to the property to be mortgaged. In India, the laws of succession particularly those relating to Hindus and Muslims being very complicated, it is difficult to ascertain whether a person has a perfect title to the property or not. The banker would therefore have to consult solicitors and obtain their opinion before accepting it as a security, which in many cases delays lending. Title verification, must also be done to know whether the property was encumbered. This has to be done by verifying record with the Registrar's office, which involves expense and time. In the case of agricultural land, with 
the introduction of land ceiling legislation, legislation protecting the tenants' rights, absence of up-to-date and proper land records, it has become less valuable as a security. Added to this there have been a number of legislations in different states giving debt relief to the farmers and prohibiting transfer of land to persons other than agriculturist.

(iii) Difficult to realize the security

Land is not easily and quickly realizable, due to the lack of ready market. It may take months to sell and sometimes if the market is not favourable, it may fetch a lower price than what was anticipated.

(iv) Creating a charge is costly

The security can be charged either by way of legal mortgage or by way of an equitable mortgage. An equitable mortgage may be created by a simple deposit of title deeds with or without a memorandum. Although equitable mortgage is less expensive, a banker always prefers legal mortgage to an equitable mortgage. Since the remedies under a legal mortgage are better than those under an equitable mortgage. However, completing a legal mortgage involves expenses including stamp duty and lot of formalities.

(v) Difficulty on account of Rent Control Act

In the case of buildings, which come within the purview of the Rent Control Act, it would be difficult to sell the building, particularly when a tenant has been occupying it for a long time.

\section{Precautions to be taken by the banker}

(i) Financial soundness of borrower

The banker should place more reliance on the financial soundness of the borrower.

\section{(ii) Borrower's title}

The banker should get a solicitor to verify the title to the property and the right of the borrower to mortgage.

\section{(iii) Enquiry regarding prior charges}

The borrower should produce a certificate from the Registrar's office listing the charges over the property over a period of time (generally 30 years) that the property is free from encumbrances. This is commonly understood as non-encumbrance certificate. If any prior charges exist the banker's right will be subject to such prior charges.

\section{(iv) Freehold or leasehold}

A freeholder is the absolute owner of his land and is able to deal with it as he likes. A leasehold property is one, which is taken on lease for a period and a leaseholder derives a legal status for a term of years from the freeholder and is free to deal with the land when acting within the terms of the lease and within the law during that period. When the lease expires, the land reverts to the freeholder. In the case of leasehold property, the unexpired period of the lease is an important consideration. The longer the unexpired period of the lease, greater is the value of the security. The bank should also ensure that there are no onerous covenants such as the necessity of taking the freeholder's consent before mortgaging the property. The banker should also obtain the last ground receipt to ensure that the lease is active.

\section{(v) Valuation of the property}

Valuation can be done in anyone of the following ways:

(a) By utilizing the services of recognized valuers who would be engineers or architects. 
(b) Making enquiries with local real estate agents.

(c) By local authorities.

(d) Latest sale transaction of neighbouring properties.

(e) Calculations based on the annual rental value.

\section{(vi) Registration}

Where the principal money secured is $₹ 100$ or more, a mortgage charge is required to be registered unless the charge is an equitable mortgage.

(vii) Documentations

The mortgage deed must be drafted carefully considering all the legal stipulations. It should be witnessed by at least two persons In case of simple mortgage it attracts ad-valorem stamp duty.

\section{(viii) Verification of Tax Receipts}

The banker should request the borrower to produce latest tax receipts since any arrears of tax constitute a preferential charge on property.

(ix) Insurance of the property

To avoid loss of security by fire, natural calamities, it is prudent that in the case of buildings the banker insist on the insurance of the property for its full value at the borrower's expense.

\section{Stocks and Shares as a Security for the Laon/Advance}

\section{Shares}

These may be classified into preference shares (which enjoy preference both with regards the payment of dividend and repayment of capital) and equity shares, i.e., shares which are not preference shares.

\section{Advantages}

(i) Value of the security can be ascertained without any difficulty.

(ii) In normal times, stocks and shares enjoy stability of value and are not subject to wide fluctuations.

(iii) Stocks and shares require very little formalities, for taking them as security.

(iv) It is easier compared to real estate to ascertain the title, more so with the advent of depositories.

(v) Creating a charge of this is less expensive than real estate.

(vi) They yield income by way of dividends, which can be appropriated towards the loan account.

(vii) Being a tangible form of securities they are more reliable.

(viii) The release of such securities involves very little expense and formality.

\section{Disadvantages}

(i) Being easy to realize, they are fraud prone and as such they must be properly secured.

(ii) In the case of partly paid shares, the following demerits are there:

(a) The banker may have to pay the calls.

(b) Partly paid shares are subject to violent price fluctuations. 
(c) They are not easily realizable because of the restricted market for such shares.

\section{Precautions while taking stocks and shares as security}

Banker must take the following precautions while advancing against stocks and shares:

(i) In the case of partly paid shares (a) the banker should never register them in his name.

(b) He must ensure that pending calls are paid.

(c) Sufficient margin should be taken to avoid any future loss or change in the value of the security.

(d) The banker should verify share certificate and ensure that the calls, are paid properly and entered in the space provided for the same.

\section{Other precautions}

(i) Update the list of shares which the particular bank is willing to lend against on a regular basis.

(ii) Updating the amount that can be lent against a particular share which is called the card limit at regular intervals

(iii) Yearly review of the portfolio or more frequent review depending upon the volatility in the capital market.

\section{Debentures as a Security for the Loan/Advance}

Debenture is a document issued by a company acknowledging its indebtedness to the bearer or a registered holder. A fixed rate of interest is payable at stated periods on such debentures. In the case of mortgage debentures, a charge is created on the assets of the company issuing such debentures in favour of a trustee who is responsible to take care of the interest of individual investors.

\section{Advantages}

(i) Easy to sell.

(ii) Not subject to violent price fluctuations.

(iii) They can be transferred at minimum cost.

(iv) Bearer debentures are fully negotiable.

(v) They rank in priority to shares and mostly secured by a charge on the company's property.

\section{Disadvantages}

(i) If interest is not paid regularly on the debentures it would affect its price and marketability.

(ii) If the charge on property of company is not registered, the subsequent charges will get a priority.

(iii) Debentures may be issued by companies having no power to borrow money.

\section{Precautions to be taken while taking debentures as security}

(i) The nature of the debentures must be ascertained, i.e., whether they are unsecured or secured, the later, being preferred.

(ii) The borrowing powers of the company issuing the debentures must be ascertained, and to verify that the same has not been exceeded.

(iii) Deposit of the debentures plus a memorandum of deposit is necessary. 
(iv) The nature and value of the assets charged must be examined frequently.

(v) The banker must find out whether there are any un-cancelled redeemed debentures.

\section{Goods as a Security for the Loan/Advance}

Though, earlier, bankers were not forthcoming to advance against goods or documents of title to goods, now more and more secured advances of the scheduled banks in India are against goods.

\section{Merits of this Security}

(i) Goods have a ready market and as such can be easily sold unlike other kinds of security.

(ii) Valuation of the goods can be easily done.

(iii) The banker gets a tangible form of security compared to unsecured advances, which in case of default by the borrower, can be realized by sale of pledged goods.

(iv) Advances against goods are normally given for short periods and therefore the risk of the banker is considerably reduced.

(v) Barring a few states where the stamp duty is heavy, creating a charge on the security is less costly and involves minimum formalities.

(vi) Banker acquires a good title to the goods when dealing with customers of repute and standing.

\section{Demerits of this Security}

(i) Certain goods are liable to perish or deteriorate in quality over a period of time, thus resulting in reduction of the value of the banker's security.

(ii) There are possible risks of fraud or dishonesty on the part of the borrower. For example, when 10,000 tins of cashew nuts are shown in the godown as security for an advance, it is not possible for the banker to verify the quality and quantity in every tin. It is not even possible to verify whether all the 10,000 tins contain cashew nuts. A fraudulent borrower may not store the full stocks as declared in the godown.

(iii) The value of the security in certain cases more particularly electronic consumer goods are subject to wide fluctuations. Therefore, the valuation of such goods is difficult. Even in the case of necessaries, there being several varieties, unless the banker has expert knowledge, the valuation may be misleading. Disposing of large quantities of goods within a short time may be difficult and may not fetch the expected/ declared price.

(iv) The banker may find it difficult to store the goods.

(v) Transporting the goods from the borrower's premises to the banker's premises and thereafter to the market in case of sale is a considerably costly and time-consuming affair.

(vi) When the banker releases goods for sale on the execution of trust receipts, the money realized by the sale of such goods may not be deposited with the banker, and the borrowers may default to the bankers.

(vii) If the goods are warehoused, the warehouse keeper enjoys a lien over the goods for any unpaid charges. The banker therefore, has to ensure periodically that all charges are duly paid.

\section{Valuation of Goods}

(i) Advances are given based on the stocks and their value declared in monthly stock/statements. The stock/goods are to be inspected at regular intervals and prices verified and tallied with purchase invoices. 
(ii) By visiting factory/godown by officials and valuers like cost accountants

(iii) Follow up of account ensuring payment to creditors for stock and collection of debtors thus avoiding diversion/misuse of funds.

\section{Precautions to be taken}

(i) Advances against goods should be restricted to genuine traders and not to speculators.

(ii) Loans must be given for short periods, since the quality and thereby the value of the security is likely to diminish.

(iii) The banker must have a working knowledge and gather information of the different types of goods regarding their character, price movements, storage value, etc.

(iv) The banker should confirm the state of goods.

(v) The goods should be insured against loss by theft or fire.

(vi) The banker should verify and confirm the title of the borrower to the goods by inspecting the invoices or cash memos.

(vii) The banker as a Pawnee is liable, if reasonable care is not taken of the goods pledged. He should therefore, take proper care for their storage and also take reasonable steps to protect them from damage and pilferage.

(viii) The price of the goods must be accurately ascertained.

(ix) Necessary margin must be taken by the banker to protect him against fluctuations in the price of goods.

(x) The banker must obtain absolute or constructive possession of the goods.

(xi) In the case of hypothecated goods, the bank should obtain from the borrower a written undertaking that the goods are not charged to any bank or creditor and will not be so charged as long as the borrower is indebted to the bank. The banker should obtain at regular periods certificates regarding the quantity and valuation of the goods, which should be physically verified by the banker.

\section{Documents of Title to Goods}

\section{What are Documents of Title to Goods?}

As per the Section 2(4) of the Sale of Goods Act, 1930, a document of title to goods is 'a document used in the ordinary course of business as a proof of possession or control of goods authorizing or purporting to authorize either, by endorsement or delivery, the possessor of the documents, to transfer or receive the goods thereby represented.' Thus, the essential requisites of a document of title to goods are:

(i) The mere possession of the documents creates a right either by virtue of law or trade usage, to possess the goods represented by the documents.

(ii) Goods represented by the documents can be transferred by endorsement and/or delivery of the documents.

(iii) The transferee of the documents can take delivery of the goods in his own right.

(iv) Although they appear to be negotiable instruments, documents of title to goods are not negotiable instruments. The title of bona fide transferee for value can be affected by defects in the title of transferor. They may be called quasi-negotiable instruments.

Examples of documents of title to goods are bills of lading, dock warrant, warehouse-keeper's certificate, railway receipts, delivery orders, etc. Documents of title to goods must be distinguished from other documents like the 
warehouse-keeper's non-transferable receipts, which are mere acknowledgement of the goods. Documents of title to goods are preferred by bankers because under Section 52(2)(e) of the Presidency Towns Insolvency Act, 1909, and Section 28(3) of the Provincial Insolvency Act, 1920, possession of goods represented by such instruments duly endorsed in his favour are taken out of the order and disposition of the insolvent. The significance of this is that in case the borrower becomes insolvent, the Official Receiver or Official Assignee as the case may be, cannot include such goods in the assets of the insolvent.

\section{Merits of this Security}

(i) By mere pledge of the instruments the goods are pledged and serve as a good security.

(ii) The person in possession of the document can transfer the goods by endorsement and/or delivery. The transferee thereafter is entitled to take delivery of the goods in his own right.

(iii) The documents are easily transferable, and the formalities involved are less compared to mortgage or assignment.

\section{Demerits of this Security}

\section{(i) Possibility for fraud and dishonesty}

Since the bill of lading or a railway receipt or a warehouse-keeper's certificate does not certify or guarantee the correctness of the contents of the bags or packages, the banker will have no remedy against the carrier or warehouse-keeper, if they turn out to be containing worthless goods.

\section{(ii) Forged and altered documents}

The documents might be forged ones, or even if genuine, the quantity may be altered.

\section{(iii) Not Negotiable documents}

The document being "Not Negotiable", the transferee of such documents will not get a better title than that of the transferor. Therefore, if the person who pledged the documents has a defective title, the banker will not acquire a better title.

\section{(iv) Unpaid vendor's right of stoppage in transit:}

Under the Sale of Goods Act, 1930, an unpaid vendor has the 'right of stoppage in transit' and he is entitled to direct the carrier that the goods need not be delivered, if not already done. If this right is exercised by the unpaid vendor, the banker cannot obtain the goods and his security is of no value.

(v) In the case of lost documents, delivery of the goods is allowed on the execution of an indemnity bond, this option may be misused by the borrower by selling the goods to some other customer who may take delivery of the goods declaring that he had lost/misplace the document and indemnifying the carrier. To avoid such a contingency, the banker can give notice to the carrier regarding his interest and the pledge.

\section{Precautions to be taken by the banker}

(i) The documents must be examined thoroughly to ensure that they are genuine and of recent origin. In the case of bills of lading, they are prepared generally in triplicate and as such all the copies must be obtained by the banker. Otherwise, the carrier is released from his obligation by delivering the goods on the presentation of any one copy containing ostensibly regular endorsements.

(ii) The banker should ensure that the documents do not contain any onerous clauses or prejudicial remarks about the condition of goods received.

(iii) Banker should ensure that the goods are adequately covered by insurance for full value against risks of theft, fire, damage in transit, etc., and in the case of goods shipped by sea, all the marine risks should be covered. 
(iv) Banker should ensure to get consignee copy and banks name being entered as consignee, so that endorsement/transfer of title is specific.

\section{Trust Receipt}

Whenever the bank releases documents of title to goods to the borrower without payment being made, then a 'Letter of Trust' should be taken. So also in the case of goods hypothecated to the bank. The reasons are as follows:

(i) The borrower on sale of the goods has to hold proceeds in trust for the banker.

(ii) The goods taken under such trust receipts or the sale proceeds thereof, are not available to the official receiver in case the borrower becomes insolvent.

\section{A Trust letter incorporates the following clauses}

(i) Borrower's recognition, of bank's rights in the goods as security and in case of sale, the proceeds, thereof.

(ii) Borrower's, undertaking to hold the goods or sale proceeds thereof, in trust for the banker.

(iii) Borrower's undertaking, to ensure proper storage and insurance, at his cost.

(iv) Borrower's undertaking to direct the buyer to pay the monies directly to the banker, if so required by the banker.

(v) Borrower's undertaking to return unsold goods on banker's request or dispose of the same as directed by the banker.

\section{Life Policies as a Security for the Loan/Advance}

\section{Purpose of Life Policy}

A life policy is taken for two purposes:

(i) It is a source of income for the dependents of the assured in case of his death.

(ii) It is an ideal form of saving since along with income tax deduction on the premium, paid loans can be raised on the policies in times of need.

\section{Advantages}

(i) Life insurance business being highly regulated and permitted only to companies having sound financial health, the banker need not doubt the realisation of the policies, which will be done without any difficulty, if the policy and the claim are in order.

(ii) The assignment of the policy in favour of the banker requires very little formalities and the banker obtains a perfect title.

(iii) The longer the period for which the policy has been in force, the greater the surrender value. It is also useful as an additional security because, in the event of the borrower's death, the debt is easily liquidated from the proceeds of the policy.

(iv) The security can be realized immediately on the borrower's default of payment by surrendering the policy to the insurance company.

(v) The policy is a tangible security and is in the custody of the bank. The banker only has to ensure that regular payment of premiums is made.

\section{Disadvantages}

(i) If the premium is not paid regularly, the policy lapses and reviving the policy is complicated. 
(ii) Insurance contracts being contracts of utmost good faith, any misrepresentation or non-disclosure of any particulars by the assured would make the policy void and enable the insurer to avoid the contract.

(iii) The person (proposer) who has obtained the policy must have an insurable interest in the life of the assured or the contract is void.

(iv) The policy may contain special clauses, which may restrict the liability of the insurer.

(v) When the banker accepts a policy coming under Married Women Property Act he must ensure that all the parties sign in the bank's form of assignment.

(vi) There is facility to obtain the duplicate policy if the original is lost. This can be misused by persons by obtaining duplicate policies. Banker should therefore, verify that no duplicate policy has been issued and there are no encumbrances on the policy.

\section{Precautions}

(i) The policy must be assigned in favour of the bank and should be sent directly to the insurance company for registration and ensured that only authorized office of Insurance Company has noted assignment.

(ii) The bank should see that the age of the assured is admitted.

(iii) The banker should ensure the regular payment of premium.

\section{Book Debts as a Security for the Loan/Advance}

Borrowers can take advances by assigning book debts in favour of the bank. Section 130 of the Transfer of Property Act, permits assignment of actionable claim and the procedure to be followed is:

(i) The assignment must be in writing and signed by the transferor or his duly authorised agent

(ii) Notice of the assignment in writing must be given to the debtor; and

(iii) The assignment may be absolute or by way of charge

\section{Legal Implication of assignment}

(i) The assignee can sue in his/ their own name and can give a valid discharge

(ii) The debtor can exercise any right of set off against the assignee, which but for such transfer, he could have exercised against assignor

(iii) As an actionable claim includes future debts, there can be a valid assignment of future debts as well

\section{Precautions to be taken}

(i) The value of the security depends on the solvency of the debtor and his right of set off, if any. The banker must enquire into both aspects

(ii) The instrument of assignment must be in writing and duly signed in the presence of the banker, signed by the assignor or his duly authorized agent

(iii) The banker must serve notices of assignment on debtors, who must be asked to acknowledge its receipt and confirm:

(a) The amount of the debt

(b) His right of set off, if any, and

(c) Whether he has received notice of prior assignments, if any

(iv) An undertaking from the borrower should be taken that the amount of debts collected directly if any by him will be passed on to the banker, towards the loan account and operations in account be controlled to ensure this compliance 
(v) Where the book debts are as assigned by a joint stock company, the charge must be registered with the Registrar of Joint Stock Companies.

\section{Fixed Deposit as a Security for the Loan/Advance}

When money deposited by a customer is not repayable on demand and is payable on the expiry of a specified period from the date of deposit such a deposit is called a 'Fixed Deposit'. The banker evidences a deposit by issuing a receipt known as fixed deposit receipt. Interest, is paid at regular intervals at a specified rate on such deposits. Banks usually permit depositors to borrow against the deposit. This security is certainly the most valuable, as the money represented by the receipt is already with the bank and there is no problem of valuation or enquiring the title, or the problem of storage and costs associated with storage.

\section{Precautions}

(i) The banker should grant the advance only to the person in whose name the money is deposited. Banker should not advance against fixed deposit receipts of other banks. This is because the banker who has received the deposit will have a general lien over such monies. Even if the lending bank gives notice to the bank, which has received the deposit, the latter may even refuse to register the lien in favour of the lending bank.

(ii) If, the deposit is in joint names the request for loan must come from all of them.

(iii) When the deposit receipt is taken as security, the banker should ensure that all the depositors duly discharge it on the back of the instrument, after affixing the appropriate revenue stamp. In addition to this, the banker should obtain a letter of appropriation which authorizes the banker to appropriate the amount of the deposit on maturity or earlier towards the loan amount.

(iv) After granting the advance, the banker must note his lien in the fixed deposit register to avoid payment by mistake and the lien, must also be noted on the receipt itself.

(v) Advance should preferably not be made against fixed deposit receipt in the name of a minor, unless a declaration is taken from guardian, that loan will be utilized for benefit of the minor.

(vi) Where the money is being advanced against the fixed deposit receipt issued by another branch, the FDR duly discharged must be sent to the branch, where such money is deposited, for the following purposes:

(a) To verify the specimen signature of the depositor

(b) To ensure that no prior lien exists on the fixed deposit receipt

(c) To mark lien on the FDR and the FDR register, in favour of branch advancing money.

(vii) Sometimes, a person may approach for advances by offering the fixed deposit receipts held by third parties as security. In such a case, the fixed deposit receipt must be duly discharged, by the third party, i.e., FD holder and he should declare in writing the bank's right to hold the deposit receipt as security, and also to adjust the deposit amount towards the loan account on maturity or on default in repayment of instalment if any.

\section{Supply Bills as a Security for the Loan/Advance}

Supply bills arise in relation to transactions with the Government and public sector undertakings. A party might have taken a contract for execution, and he is entitled to progressive payments based on work done, for which he has to submit bills in accordance with the terms and conditions of the contract. Similarly, parties who have accepted tenders for supply of goods over a period are entitled to payments on the supply of goods, for which they submit bills in accordance with the terms of the contract. These bills are known as supply bills. 


\section{Procedure followed in respect of supply bills}

(i) The supplier delivers the goods supported by a delivery challan and produces the documents. The appropriate authority of the government department inspects these goods and accepts for payment on due date and the supplier obtains an inspection note. In the case of contracts, an engineer's certificate regarding work done is obtained.

(ii) The supplier or the contractor as the case may be, prepares the bill for obtaining payment. Government departments take quite some time to verify the bills and pass them for payment. Therefore, the supplier or contractor submits these bills together with the accepted delivery challan and inspection note or the engineer's certificates to the appropriate Government department through the banker and requests the banker to advance against such bills.

These bills do not enjoy the status of negotiable instruments. They are in the nature of debts and are assigned, in favour of the banker for payment, after affixing a revenue stamp for having received the amount. The bank should also obtain a letter from the supplier or contractor, requesting the appropriate department to make the payment directly to the banker.

\section{Risks involved in advancing against supply bills}

(i) Although the advance is self-liquidating in nature, in certain cases it can take quite some time before the advance is realized because of administrative and other Governmental procedures.

(ii) It is virtually a clean advance and the bank may not realize the full amount, because of the possibility of counter claim or the right of set off by the Government, as the charge is only by way of assignment.

(iii) Sometimes, the Government may not pass the bills for full payment because of the unsatisfactory quality of goods or defective work done by the contractor or delays in the completion of work.

\section{Precautions to be taken by the banker}

(i) Advances against supply bills should be made only to borrowers who have sufficient experience in Government business and Government regulations.

(ii) The contract between the supplier and the Government department should be scrutinized by the banker, to know the volume of transaction, period of supply, rates agreed upon and various other terms and conditions. The Government will not pass the bills unless there is faithful adherence to the terms and conditions by the supplier.

(iii) The banker should obtain a power of attorney from the supplier authorizing him to receive the money. The same should be registered with the appropriate Government department.

(iv) The banker should obtain the inspection note or the engineer's certificates along with the bills. There should be no adverse remarks in the inspection report regarding the quality and quantity of goods supplied.

(v) There are two types of bills that are submitted by the suppliers. They are:

(a) Interim bills against which Government pays eighty to eighty five per cent of the amount.

(b) Final Bills for the balance of twenty to fifteen per cent which will be paid only after complete verification of goods at the point of destination. Because of the delay involved in the settlement of final bills, banks should prefer the interim bills for advancing and final bills only for collection. Keep sufficient margin, to cover advance with interest thereon from proceeds to be received.

(vi) Banker must reserve the right of demanding the repayment of advance, if the bills remain unpaid for a specified period. The banker, in other words, treats the bills as only items for collection and the advances are recovered. 
When land/building is offered as a security, it is charged to the bank by a mortgage. Mortgages are of six kinds, though as a banker you would be dealing in only three of them. The law, relating to mortgages is dealt with in the Transfer of Property Act, 1882, and more particularly Sections 58 to 99 and 102 to 104 . We shall now study these provisions and see how they affect us, as bankers in our business of lending.

\section{CHARGE OVER SECURITIES}

Charging a security means that the borrower gives the lending bank a right to:

(i) transfer the title from the borrower to the bank

(ii) take possession of the securities

(iii) recover the dues through legal course

Creation of charge on securities is done as per the nature of the security as under:

1. Hypothecation (for movable stocks such as, goods, plant and machinery)

2 Pledge (for movable stocks)

3. Mortgage (in respect of immovable property)

4. Assignment of debts (life like insurance policy/book debts)

5. Lien on deposits with the bank

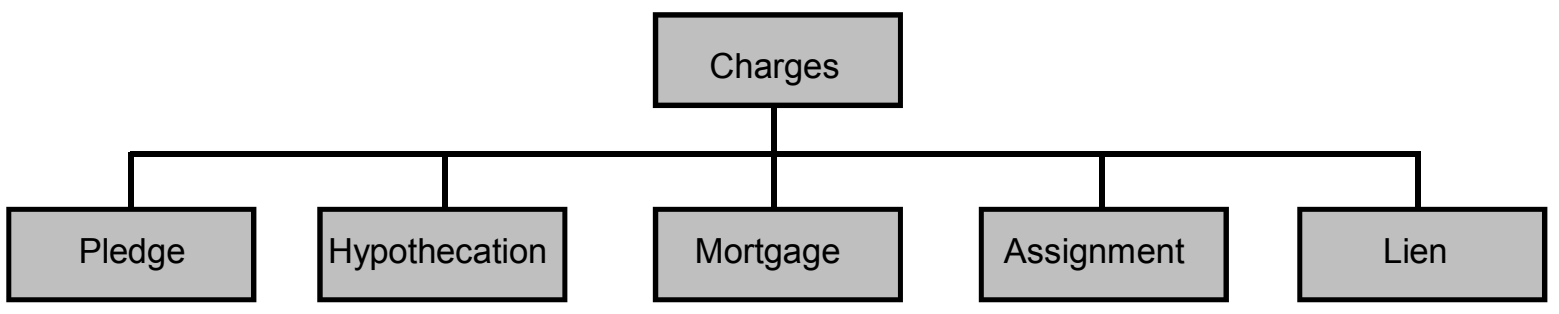

\section{Pledge of Security}

Pledge means bailment of goods for the purpose of providing security for payment of debt or performance of promise. Section 172 of Indian Contract Act, 1872 defines pledge.

\section{Valid Pledge - Important requirements}

There should be delivery of goods (bailment). The bailment (delivery of goods) must be by or on behalf of the debtor. The bailment (delivery of goods) must be for the purpose of providing security for the payment of a debt or performance of a promise.

For example, an agriculturist is sanctioned a gold loan by his banker. The borrower delivers his gold ornaments to the bank as a security for the gold loan. The borrower pledges gold ornaments to raise the loan. In this case, the agriculturist has created a valid pledge. (1) there is bailment of gold (delivery of gold)

(2) The bailment of gold is made by the debtor (borrower)

(3) The bailment of gold is provided as a security to the gold loan (debt)

\section{Pledge - important features}

(i) The person, whose goods are bailed is called pawnor or pledger, and to whom the goods are pledged as pawnee or pledgee.

(ii) Ownership of the property is retained by the pledger, which is subject only to the qualified interest which passes to the pledgee by the bailment. 
(iii) The essential feature of a pledge is the actual or constructive delivery of the goods to the pledgee. By constructive delivery it is meant that there will be no physical transfer of goods from the custody of the pledger/ pawnor to the pledge/ pawnee. All that is required is that the goods must be placed in the possession of the pawnee or of any person authorized to hold them on his behalf.

(iv) The delivery of the goods may be 'physical' when goods are actually transferred and 'symbolic' as in the case of delivery of the key or 'constructive' as in the case of attornment.

(v) Pledge can be created only in the case of existing goods (and not on future goods) which are in the possession of the pledger himself.

(vi) Since the possession of goods is the important feature of pledge and therefore, pledge is lost when possession of the goods is lost.

(vii) An agreement of pledge also known as deed of pledge may be implied from the nature of the transaction or the circumstances of the case

(viii) To protect the interests of the concerned parties the agreement in writing should clearly indicate the terms and conditions.

A valid pledge can be created by (i) the owner of the goods (ii) a mercantile agent, subject to the following terms and conditions are satisfied (iii) the seller of goods, who continues to hold the goods even after sale, can create a valid pledge. The pledgee must act in good faith and without notice of the previous sale.

\section{The Rights of Pledgee are as follows:}

1. Right of Retainer: As per Section 173 of the Indian Contract Act, the pawnee or pledge is entitled to the good pledged not only for non-payment of debt or non- performance of promise, but also for the interest on the debt and for all expense incurred for preservation of the goods pledged.

2. Right against Third Parties: A pledge has the same remedies against third persons, as the owner himself would have, if he is deprived of his goods.

3. No Right to Retain in case of Other Debts: In the absence of a contract to the contrary, the pledge cannot retain goods for a debt or a promise, other than the promise or debt for which the said goods are pledged.

4. Other rights: In case the Pledger makes default, then the Pledgee has three important rights:

(i) He may sue the pawnor upon the debt or promise

(ii) He may retain the pledged goods as collateral security; or

(iii) He may sell it after giving the pledger reasonable notice of the sale

\section{Pledge - Precautions required:}

(i) Banks, as pledgee should ensure that the pledger has good title to the goods/assets

(ii) Bank verifies and satisfies that the contract of pledge (deed of pledge) is complete in all respects, and it covers all important clauses to protect the interest of the bank.

(iii) Bank carryout regular inspection of goods pledged to ensure the quality, quantity, value, and insurance of such goods are as required and as per the stock statements.

(iv) Bank takes reasonable care of the goods (like a man of ordinary prudence would under similar circumstances take) to protect the value of the goods and prevent any loss

\section{Hypothecation over Securities}

\section{What is "Hypothecation"?:}


The term "Hypothecation' means a charge created on any movable asset/property, for a loan borrowed by the owner of goods/movable assets (existing or future) without transferring, either the property or the possession to the lender.

The Securitization and Reconstruction of Financial Assets and Enforcement of Security Interest Act,2002 (SARFAESI Act) defines hypothecation thus:

"hypothecation means a charge in or upon any movable property, existing or future, created by a borrower in favour of a secured creditor without delivery of possession of the movable property to such creditor, as a security for financial assistance and includes floating charge and crystallisation of such charge into fixed charge on movable property"

\section{Hypothecation - important features:}

1. The charge hypothecation is applicable to movable assets.

2. The ownership and possession are held by the borrower of the assets (security).

3. The document (hypothecation agreement) provides for a covenant, whereby the borrower agrees to give possession of the goods (movable assets) when called upon to do so by the creditor. Upon taking over the possession of goods, the charge is treated as pledge.

\section{Other important aspects of Hypothecation:}

Banks should exercise precautions while handling lending against hypothecation for the following reasons:

(a) The possession of the goods/assets are held by the borrower, hence, it is always difficult for the creditor (lender) to have control over such goods.

(b) The borrower may sell the hypothecated stocks, and pay other creditors.

(c) The possibility of raising double finance against the same stock cannot be ruled out. For example the borrower may hypothecate the same stocks to another bank, the goods may be latter pledged to another creditor.

(d) In case of default, the realization of assets may be difficult and costly.

\section{Hypothecation - Precautions required:}

In view of the above difficulties, banks are required to take certain precautions in respect of goods and assets hypothecated, to protect the interest of the banks.

1. Banks should ensure that the borrower enjoys hypothecation facility with only one bank and not with multiple banks. An undertaking to this effect in writing should be taken by the bank to avoid any risk.

2. Banks should display boards in the show room, shops where hypothecated goods are displayed/stored, indicating that such goods are hypothecated to bank.

3. Banks should ensure that

(i) periodical stock statements are submitted by the borrower.

(ii) stock statements should contain relevant, and correct details as regards to quantity, quality and price.

(iii) Regular inspections are carried out to verify the facts mentioned in the stock statements

(v) In case of any discrepancy, depreciation in the value of stock, appropriate action should be taken by the bank immediately by calling for additional securities and increase in the margin. 
4. If the borrower is a limited company, the hypothecation charge must be registered with the Registrar of Companies (ROC) within a period of 30 days of its creation. This is very important, otherwise, the charge will be void against the liquidator and/or any creditor of the company.

\section{Difference between Hypothecation and Pledge}

\begin{tabular}{|l|l|}
\hline \multicolumn{1}{|c|}{ HYPOTHECATION } & \multicolumn{1}{c|}{ PLEDGE } \\
\hline A Applicable to movable goods/assets & Applicable to movable goods/assets \\
\hline B Ownership remains with the borrower & Ownership remains with the borrower \\
\hline C Possession remains with the borrower & Possession is held by the lender \\
\hline D Defined under SARFAESI Act & Defined under Indian Contract Act \\
\hline E Legal document is hypothecationAgreement & Legal document is deed of pledge \\
\hline $\begin{array}{l}\text { F In case the borrower is a Limited Company } \\
\text { registration of charge with ROC is a must }\end{array}$ & $\begin{array}{l}\text { In case the borrower is a Limited Company, } \\
\text { registration of charge with ROC is not applicable }\end{array}$ \\
\hline
\end{tabular}

\section{Lien}

Section 171 of the Indian Contract Act,1872 gives to the banker an absolute right of general lien on all goods and securities received by the banker. The banker has general lien on all deposits. If the deposit receipt is given as a security for raising a loan or discharging an obligation then the lien on such deposit receipt, is a particular lien, and it would exist till the debt is cleared or the obligation is fulfilled.

\section{Lien - Important aspects:}

General lien covers the entire amount due to the bank from the borrower/ debtor.

\section{Banker's General Lien:}

This is applicable in the following situations:

- when a banker receives goods and securities for a purpose

- lien is applicable for the goods and/or securities which are belonging to a person who has delivered them to the banker

- there is no contract to the contrary and the debt is not barred by limitation

A banker's lien is also called as an implied pledge. A banker has the right to retain and if necessary can also sell the goods and/or securities charged in his favour. As pledgee, a banker can sell the goods/securities pledged to him.

A banker cannot exercise his right of lien in following situations:

1. In case when goods and securities are not obtained by him in the ordinary course of business:

2. In case of Safe Custody, when a banker accepts goods/securities of a customer to be kept in safe custody. In this case the relationship of banker and customer is that of the bailee and bailer. Here the banker acts as a trustee and not as a lender/creditor.

3. When the goods or security are left inadvertently or through oversight in the bank premises, the banker cannot exercise his right of lien on them.

4. When money is deposited by a customer with a request to transfer to another branch, the banker cannot exercise the right of lien. This is applicable even the applicant for the transfer of funds is a borrower as well. 
5. The banker cannot have the right of lien and right of set off at the same time.

\section{Assignment}

Assignment is a type of charge on certain securities offered to a creditor. It is transfer of right, for a property or debt. Two persons are involved, the person who transfer his right is called the assignor and the beneficiary is called assignee. For example when a bank gives loan to a borrower against his book debts (future receivables), two parties involved are (i) the borrower (debtor) and the banker (creditor). The borrower/debtor, who is called the assignor, transfers his rights of receiving the funds from his customers.. The banker (lender/creditor) to whom the rights are transferred is called as the assignee.

\section{Assignment - important features:}

1. Section 130 of the Transfer of Property Act, states that the transfer of an actionable claim can be effected only by the execution of an instrument in writing signed by the transferor or by his duly authorized agent.

2. An actionable claim is defined as a claim to any debt other than a debt secured by $\{(i)$ mortgage of immovable property or (ii) hypothecation or (iii) pledge of movable property or (iv) any beneficial interest in any movable property\} not in the possession of the claimant.

3. A borrower may assign any of the following items to secure a loan viz., (i) book debts (ii) life insurance policies (iii) money due from Government department.

4. An assignment can be absolute or by way of security

5. An assignment may be a legal or equitable assignment

6. As regards of book debts, the assignor informs his debtor, in writing, about the details of the assignee's full communication details like name address e mail and telephone numbers etc., to enable him to pay the amount to the assignee directly until further instructions from his client.

(i) In the case of a life insurance policy, is assigned by an endorsement on the back of the policy or by a special deed of assignment. Notice of such assignment must be given to the insurer by the assignor or assignee, to enable the life insurance company to register the assignment in the records of the company records and act as per instructions.

\section{Mortgage}

Section 58(a) of the Transfer of Property Act, 1882 defines a mortgage as follows:

'A mortgage is the transfer of interest in specific immoveable property, for the purpose of securing the payment of money advanced or to be advanced by way of loan, on existing or future debt or the performance of an engagement which may give rise to a pecuniary liability.'

The transferor is called the 'mortgagor' and the transferee a 'mortgagee' the principal money and interest of which payment is secured is called mortgage money and the instrument by which the transfer is effected is called the 'mortgage deed'.

\section{(a) Ingredients of Mortgage}

From the above definition of mortgage, the following are the requirements of a mortgage:

(i) There should be transfer of interest in the property by the mortgagor (the owner or lessor).

(ii) The transfer should be to secure the money paid or to be paid by way of loan.

\section{(b) Mortgage of Land - Various Types}

The Transfer of Property Act contemplates six different kinds of mortgages. They are: 
(i) Simple mortgage

(ii) Mortgage by conditional sale

(iii) Usufructuary mortgage

(iv) English mortgage

(v) Mortgage by deposit of title deeds (Equitable mortgage)

(vi) Anomalous mortgage

\section{Simple mortgage}

According to Section 58(b) of the Transfer of Property Act, a simple mortgage is a transaction whereby, 'without delivering possession of the mortgaged property, the mortgagor binds himself personally to pay the mortgage money and agrees, expressly or impliedly, that in the event of his failing to pay according to his contract, the mortgagee shall have a right to cause the mortgaged property to be sold by a decree of the Court in a suit and the proceeds of the sale to be applied so far as may be necessary in payment of the mortgage money.

\section{Features of simple mortgage}

(i) The mortgagee has no power to sell the property without the intervention of the court In case there is shortfall in the amount recovered even after sale of the mortgaged property the mortgagor continues to be personally liable for the shortfall.

(ii) The mortgagee has no right to get any payments out of the rents and produce of the mortgaged property

(iii) The mortgagee is not put in possession of the property

(iv) Registration is mandatory if the principal amount secured is ₹ 100 and above

\section{Mortgage by way of conditional sale}

As per Section 58(c) of the Transfer of Property Act, a mortgage by way of a conditional sale of the property, is a transaction whereby, the mortgagor ostensibly sells the mortgaged property on the condition that:

(a) on default of payment of the mortgage money on a certain date, the sale shall become absolute, or

(b) on such payment being made the sale shall become void; or

(c) on such payment being made, the buyer shall transfer the property to the seller.

No such transaction shall be deemed to be a mortgage of conditional sale, unless the condition is embodied in the document, which effects or purports to effect the sale.

\section{Essential features of Mortgage by way of conditional sale}

(i) The sale is ostensible and not real.

(ii) If the money is not repaid on the agreed date, the ostensible sale will become absolute upon the mortgagor applying to the Court and getting a decree in his favour. The mortgagor in such a case loses his right to redeem his property.

(iii) The mortgagee can sue for foreclosure, but not for sale of the property. Foreclosure, means the loss of the right possessed by the mortgagor to redeem the mortgaged property.

(iv) There is no personal covenant for repayment of the debt and therefore bankers do not prefer this type of mortgage. The mortgagee cannot look to the other properties of the mortgagor in case the mortgaged property proves insufficient. 


\section{Usufructuary mortgage}

According to Section 58(d) of the Transfer of Property Act, 'a Usufructuary mortgage is a transaction in which

(a) the mortgagor delivers possession expressly, or by implication and binds himself to deliver possession of the mortgaged property to the mortgagee, and

(b) authorizes the mortgagee, to retain such possession until payment of the mortgage money and to receive the rents and profits accruing from the property or any part of such rents and profits and to appropriate the same in lieu of interest, or in payment of the mortgage money, or partly in lieu of interest and partly in payment of the mortgage money.

\section{Essential features of Usufructuary mortgage}

(i) The mortgagee is put in possession of the mortgaged property. Here, by possession it is meant, the legal possession and not the physical possession. For example, the mortgagor may continue to enjoy the physical possession as the lessee of the mortgagee or the mortgagor may be the caretaker of the property directing the tenants to pay rent to the mortgagee. However, the deed must contain a clause providing for the delivery of the property to the mortgagee and authorizing him to retain such possession.

(ii) The mortgagee has the right to receive the rents and profits accruing from the property. Such rents and profits or part thereof, may be appropriated in lieu, of interest or in payment of the mortgage money or partly for both.

(iii) Unless there is a personal covenant for the repayment of the mortgage money, there is no personal liability for the mortgagor. Therefore, the mortgagee cannot sue the mortgagor for repayment of the mortgage debt; nor can he sue mortgagor for the sale or foreclosure of the mortgaged property.

(iv) There is no time limit specified and the mortgagee remains in possession of the property until the debt is repaid. The only remedy for the mortgagee is to remain in possession of the mortgaged property and pay themselves out of the rents and or profits of the mortgaged property. If the mortgagor fails to sue for redemption within thirty years, the mortgagee becomes the absolute owner of the property.

Bankers do not prefer this form of mortgage for the following reasons:

(i) There is no personal covenant to repay the debt.

(ii) As the mortgaged money can be recovered only by the appropriation of rents and/or profits, it will take a very long time to recover money through this process.

\section{English Mortgage}

According to Section 58(e) of the Transfer of Property Act, an 'English Mortgage' is a transaction in which, the mortgagor binds himself 'to repay the mortgage money on a certain date and transfers the mortgaged property absolutely to the mortgagee, but subject to the provision that he will retransfer it to the mortgagor upon payment of the mortgage money as agreed'.

\section{Essential features of English Mortgage}

(i) It provides for a personal covenant to pay on a specified date notwithstanding the absolute transfer of the property to the mortgagee.

(ii) There is an absolute transfer of the property in favour of the mortgagee.

However, such absolute transfer is subject to a provision that the property shall be re-conveyed to the mortgagor in the event of the repayment of mortgage money.

(iii) The mortgagee can sue the mortgagor for the recovery of the money and can obtain a decree for sale. 


\section{Equitable mortgage or mortgage by deposit of title deeds}

According to Section 58(f) of the Transfer of Property Act, 'Where a person in any of the following towns, namely, the towns of Kolkata, Chennai and Mumbai and in any other town which the State Government concerned may, by notification in the official Gazette, specify in this behalf, delivers to a creditor or his agent documents of title to immoveable property, with intent to create a security thereon, the transaction is called a mortgage by deposit of title deeds,'.

\section{Documents of title}

Documents of title or title deed in case of mortgage by deposit of title deeds, shall be documents or instruments which relate to ownership of the mortgagor over the property. In other words, by virtue of a document or instrument, if a person has a right to peaceful possession and enjoyment of the immoveable property, then such a document or instrument is called the title deed. In the case of Syndicate Bank vs Modern Tile and City Works (1980 KL T 550); it was explained by the learned Judges that documents of title or deed means the legal instrument which proves the right of a person in a particular property.

\section{Essential features of equitable mortgage}

(i) Such a mortgage can be affected only in the towns notified by the State Government. However, the territorial restriction refers to the place where the title deeds are delivered and not to the situation of the property mortgaged.

(ii) To create this mortgage, there must be three ingredients i.e., a debt, a deposit of title deeds and an intention that the deeds shall be act as security for the debt.

\section{Anomalous mortgage}

According to Section 58(g) of the Transfer of Property Act, 'a mortgage which is not a simple mortgage, a mortgage by conditional sale and usufructuary mortgage and English mortgage or a mortgage by deposit of title deeds within the meaning of this Section, is called an "Anomalous Mortgage."

\section{Essential features Anomalous mortgage}

(i) It must be a mortgage as defined by Section 58 of the Transfer of Property Act.

(ii) It is negatively defined and should not be anyone of the mortgages listed above.

(iii) Anomalous mortgages are usually a combination of two mortgages. Examples of such mortgages are:

(a) a simple and usufructuary mortgage, and

(b) an usufructuary mortgage accompanied by conditional sale. There may be other forms, molded by custom and local usage.

(c) Merits and Demerits of an Equitable Mortgage

\section{Merits}

(i) The borrower saves the stamp duty on the mortgage deed and the registration charges. It involves minimum formalities.

(ii) It involves less time and can be conveniently created.

It can be done without much publicity and therefore, the customer's position is not exposed to public gaze.

\section{Demerits}

(i) In case of default, the remedy is to obtain a decree for sale of the property. Since, this involves going to the Court, it is expensive and time consuming. This shortcoming can be overcome by inserting a covenant by which the mortgagee is given the power of sale. In that case, the mortgage deed must be properly 
stamped and registered and the mortgage loses the advantage of being simple in procedure and less expensive.

(ii) Where the borrower is holding the title deeds in his capacity as a trustee and equitable mortgage of the same is effected, the claim of the beneficiary, under trust will prevail over any equitable mortgage. Therefore, the banker has to make a proper scrutiny of the title deeds before accepting them as a security.

(iii) The borrower may create a subsequent legal mortgage in favour of another party. However, this possibility is not there, if the equitable mortgagee holds the original title deeds. In India, there is no difference between the two types of mortgages. According to Section 48 of the Registration Act, 1908, a mortgage by deposit of title deeds prevails against any subsequent mortgage relating to the same property. Similarly, the title of the equitable mortgagee, is not defeated by any subsequent sale without notice. However, to avoid any risk of this type, the equitable mortgage should be accepted only after obtaining the original title deeds.

The law in England is slightly different. As between equitable mortgage and legal (simple) mortgage, the latter prevails even though it is effected subsequently. The law, regarding this is, as between law and equity, law prevails. As between the equities, the prior in time prevails.

Pledge requires only a limited interest in the property and ownership remains with the right of pledger. The Pawnee has 'special property' in the goods pledged and can sell the same in the event of default by the pledger of course, after giving reasonable notice.Pawnee has no right of foreclosure. He can only sell the property to realize his dues. Here the legal ownership passes to mortgagee, of course, subject to the mortgagor to redeem the property. The mortgagee as a rule takes decree of a Court of Law before having recourse against the property mortgaged.In certain cases, the mortgagee can foreclose the property.

\section{Priority of Mortgages}

Indian Law of priorities is provided in Section 48 of the Transfer of Property Act. The rule is based on maxim 'he has a better title who was first in point of time.' It lays the general rule regarding priority of rights created by transfer by a person at different times in or over the same immoveable property and provides that, as between such rights, each later created right is subject to the rights previously created. We may further see, as how the rule of priorities operate in respect of different instruments creating mortgages.

(a) Priority among registered instruments

Section 47 of the Registration Act, 1908 provides that a registered document operates, not from the date of its registration, but from the time of its execution. Thus, a document executed earlier, though registered later than another, has priority over the documents executed later.

(b) Priority between registered and unregistered instruments

Let us now deal with the exceptions to the rule, that priority is determined by order of time, which either have been created by statute or owe their origin to the ancient rule of Hindu Law, which required delivery of possession in the case of a security of land. There are also some exceptions recognized in the Indian system founded upon those general principles of justice and equity, which in the absence of any express enactment, Indian judges are bound to administer, and which, have been mostly borrowed, from the English Law.

The first exception is that contained in Section 50 of the Registration Act, which under certain circumstances allows a registered mortgage priority over unregistered mortgage. However, it may be noted that prior mortgage by deposit of title deeds is not affected by subsequent registered mortgage as the same need not be registered. This, is provided in Section 48 of Indian Registration Act. 


\section{Limitation Period in Mortgages}

Article 62 of the Indian Limitation Act, 1963 provides limitation period for filing of suit for recovery of mortgaged debt and sale of mortgaged property in the event of non-payment of the mortgaged debt. Article 63(a) of the said Act provides a limitation period, in case of foreclosure of the mortgaged property. The limitation period for filing a suit for sale of mortgaged property is TWELVE YEARS, from the date the mortgage debt becomes due. The limitation period for filing suit, for foreclosure is THIRTY YEARS, from the date the money secured by mortgage becomes due.

\section{Enforcement of Mortgage - Some Important Aspects}

We will now learn some important aspects as to enforcement of mortgage. It may be noted that a banker, secures monies advanced by creating one of various types mortgages mentioned above. Popular types of mortgages obtained by a banker are:

(i) Mortgage by deposit of title deeds

(ii) Simple mortgage and in some cases

(iii) English mortgage.

Enforcement of all these types of mortgages is by way of filing a suit for sale of mortgaged properties. The procedure for filing a suit for a sale is provided for in the Code of Civil Procedure, 1908. The Section 16(c) of the Civil Procedure provides that a suit for sale of mortgaged property shall be filed in the Court within whose jurisdiction the mortgaged property is situated. Order 34 of the Code provides for various things to be adhered to while filing suit for sale of mortgaged property. When a suit for sale is filed, the Court after hearing the parties passes a preliminary decree. Through the preliminary decree it directs the mortgagor to pay the mortgage debt within a certain period and in the event of his failure to pay the money due under the mortgage, the Court orders for sale of mortgaged properties by passing a final decree. After passing of the final decree, the mortgagee with the help of the Court gets the mortgaged property sold in execution of the mortgage decree.

\section{REGISTRATION OF CHARGE}

Registration of Charges are covered under Sec125 and other relevant sections of the Indian Companies Act,1956. It covers the following charges:

(i) A charge for the purpose of securing debentures

(ii) A charge on uncalled capital of the company

(iii) A charge on any immovable property, wherever situated, or any interest therein

(iv) A charge on any book debts of a company

(v) A charge not being a pledge, on any movable property of the company

(vi) A floating charge on the undertaking or any property of the company including stock-in-trade

(vii) A charge on calls made but not paid

(viii) A charge on a ship or any share in ship

(ix) A charge on goodwill, on a patent or a licence under a patent or a trade mark or on a copyright or a license under a copyright

Charges registered under the Companies Act is classified into (i) fixed charge and (ii) floating charge. Fixed charge is created on a specific property or properties of the company. This charge gives right to the creditor so secured, to sell the said property and claim the proceeds towards the dues payable by the company. Floating Charge is a charge that is general and not specific. The special features of floating charge are: 
(i) the charge floats over present and future property of the company

(ii) it does not restrict the company from assigning the property, subject to charge to third parties, whether by way of sale or security

Therefore, a floating charge is an equitable charge.

\section{Procedure for Registration of charge:}

As per Sec 125 and sub sections that all particulars of a charge created by the company should be filed with the Registrar of Companies, along with an instrument creating charge for registration within thirty days of the creation of charge. The time limit of thirty days may be extended by Registrar of companies by another thirty days.

(a) The company should file the prescribed details for creation, modification or satisfaction of the charge in the Form 8, or Form 13 or Form 17

(b) A copy of each instrument evidencing any charge or modification of charge is to be filed with the registrar duly verified and certified.

Registration of Charges is to be filed through electronic mode. Banks and other charge holders are required to file the particulars of charges created in their favour by the companies under electronic filing method.

\section{DOCUMENTATION}

One of the important requirements of the lending banker is to hold valid legal documents. The process of execution of required documents in the proper form and according to law is known as documentation. Proper documentation helps in recovery of loans and advances. Banks have their own standard forms for promissory notes and other documents and no deviations are normally permitted. The borrowers are expected to execute these documents as required by the bank. Banks also do not generally give copies of these documents to the borrower which sometimes creates difficulty when these documents become subject matter of a legal dispute. The following points must be kept in mind while executing the documents as required by the Bank.

\section{Precautions to be taken while executing loan documents}

The following are the precautions, in nutshell, which should be taken care of both by the borrower as well as banker, at the time of preparation, execution and registration of loan documents etc.:

(a) Person, executing the loan documents must be competent to enter into a contract i.e., he or she should have contractual capacity. Thus, minor, insolvent person, lunatic etc. are not competent persons to execute documents.

(b) The loan documents should bear proper type of stamps i.e. adhesive, embossed etc. Further value of stamp duty should be adequate, keeping in view the laws of the State in which the documents are executed. The Non Judicial Stamp papers, if used, should bear the date, prior to its execution and also the date should not be earlier than six months. The text of the agreement may be written on the Stamp papers itself and plain papers (additional sheets) may be used, if required in addition to Stamp papers.

(c) No column of the loan documents should be left blank. While executing the documents, the borrower must sign in full and in the same flow in which his signatures are available in the bank. The cuttings \& over writings must be avoided and if at all, they become unavoidable, they should be authenticated by the borrowers by signing in full.

(d) Sometimes the borrower does not understand the language of the loan documents. In such a case, a separate letter, in the language of the borrower should be taken from him stating that the contents of the loan documents have been explained to him and well understood by him, including the terms and conditions of the loan sanctioned. The letter should be got witnessed by another person. 
(e) In the case of an illiterate borrower who puts his thumb impression on the loan documents, the bank official in whose presence the documents are executed, should give a certificate on a separate paper that the contents have been fully explained to the borrower in a language which he speaks and understands. This certificate should be got witnessed by independent persons.

(f) Similarly, in case of a blind person, such a certificate should be obtained from lawyer or notary public in whose presence the borrower executes documents.

(g) In case the borrowers reside at different places, the loan documents should be got executed through the branches of the bank situated at those stations, after properly verifying the identity of the borrowers.

(h) As regards stamp duty, it should be according to the state which attracts highest value of stamp duty. The borrowers while signing the documents must put date and place of execution after their signatures.

(i) In the case of a partnership firm where a minor is admitted as partner to the benefits of partnership, he should not be allowed to execute any loan document. This is so because a creditor i.e. lending banker cannot proceed against the minor in person. However, minor's share in the firm can be proceeded against, as the major partners of the firm have executed loan documents, thereby binding each other by their act of execution. After the minor attains majority and elects to remain as partner in the firm, the bank should proceed to obtain an undertaking from him stating that he (minor attaining majority) stands fully liable for the dues of the bank against the partnership firm.

(j) Sometimes loan documents are executed by the holder of power of Attorney on behalf of a trading concern, partnership firm, Hindu undivided family (HUF), company, individual etc. In such a case, a notice should be sent to the principal, stating that the attorney has executed the documents on their behalf. A certified copy of Power of Attorney should be kept along with main loan documents. And also the letter/confirmation received from the principal in this regard, in response to the notice should be preserved.

(k) The borrowers must obtain a copy of the sanction and ensure that documents only for those facilities which are sanctioned in their favour are executed.

(I) All the documents must be completely filled in before their execution.

(m) The guarantee form should be executed if so agreed and stipulated as a term of sanction.

(n) Copies of all the documents executed must be obtained and kept on record for any future reference.

\section{Execution of Documents by Various Types of Borrowers}

\section{(a) Individual/Joint Borrowers :}

In the case of a single borrower, all documents must be signed by him in person. However, when more than one borrower has to avail the facility in the form of joint holder, it should be ensured that all the interested persons sign the application form and all of them must join in executing the security documents. Instructions should be obtained under the signature of all the joint account holders regarding withdrawal or delivery of securities in such accounts.

\section{(b) Execution of Document by Partnership Firm :}

In the case of a partnership carrying banking business, the number of partners should not exceed 10 in the case of partnership carrying on any other business with the object of making any gains, the number of partners should not exceed 20. According to Indian Partnership Act, 1932, every partner has implied authority to bind the firm by borrowing money, creating security on its moveable assets and executing documents therefore. It is, however, imperative that the partnership deed must be obtained and thoroughly scrutinized and studied at the time any proposal of advance is processed and when documents are being executed. If any doubt arises in the partnership deed about the authority of the partner(s) to borrow and thereby execute documents on its behalf, an authorization signed by all the partners in favour of the partner or partners, shall be obtained. 


\section{Partnership Firm as Guarantor :}

When a partnership firm is a guarantor for the obligation of another, the documents for guarantee must be signed either by all the partners or by a partner holding specific authority from the other partners for execution of the guarantee agreement. If there is no clause in the original partnership deed authorizing a partner to execute guarantee/counter guarantee/indemnity bond on behalf of the firm or unless one of the items of business of a firm is to give guarantee, the partner of a firm has no implied authority to do so. In such cases, the remaining partners shall execute a General Power of Authority in favour of the managing partner for the said purpose.

\section{Partnership Firm as Mortgagor :}

No partner has implied authority to bind the firm by a transaction involving immovable property and as such where a mortgage of the firm's properties is involved either all partners will have to join in the mortgage or the partner(s) signing the document must have specific letter of authority from the other partners.

\section{Partners' Individual Guarantee :}

In terms of Section 49 of the Indian Partnership Act, where there are joint debts from the firm, and also separate debts due from any partner, the property of the firm shall be applied in the first instance in payment of the debts of the firm and if there is any surplus, the share of each partner shall be applied first to the payment of his separate debts and then surplus, if any, in the payment of the debts of second creditors, in-so-far as the personal assets of the partner(s) are concerned for the debts of the first if he has other creditors. In order to ensure that the Bank would rank as first creditor even in respect of assets of the partner in the event of insolvency of the firm or its partners, the personal guarantee of the individual partner in respect of aggregate advances to partnership concern should be obtained.

\section{Reconstitution of Partnership Firm}

\section{(a) Working Capital Advance :}

Whenever the partnership firm is reconstituted on account of death, retirement, expulsion/admission etc. of partner(s) pending sanction of limits to the reconstituted firm, obtention of fresh documents and transfer of outstanding balances to the new account, a letter of continuity should be obtained from all the incoming and outgoing partners as an interim measure before allowing operations in the existing accounts. If advances to the dissolved firm are secured by way of third party guarantee as collateral security, a letter to confirmation must be obtained from the guarantor(s) before operations are allowed on the accounts of the reconstituted firm. Even in cases where a continuing guarantee with suitable modifications should be obtained. These formalities are required to be completed within a period of two months.

\section{(b) Medium Term Loan :}

In respect of outstanding term loans, there is no need to obtain fresh set of security documents. A supplementary stamped agreement should be obtained. It should be executed by the continuing partners, incoming partners and the guarantor(s), if any, at the time of obtaining fresh documents for working capital limits granted to the reconstituted firm.

\section{(c) Minor in a Partnership Firm :}

Section 30 of the Indian Partnership Act (Act No. IX of 1932) provides that where a minor is admitted to the benefits of partnership, the share of such minor is liable for the act of the firm, but the minor is not personally liable. A minor who has been admitted to the benefits of partnership may within 6 months of attaining his majority or obtaining knowledge that he has been admitted to the partnership give the public notice that he has elected to become a partner or that he has elected not to become a partner provided if he fails to give such notice, he shall on the expiration of the said 6 months become a partner in the firm, and where in such case he becomes a partner, he becomes personally liable to third parties for all acts of the firm done since he was admitted to the 
benefits of partnership. Where such ex-minor elects not to become a partner, his share shall not be liable for any acts of the firm done after the date of the notice aforesaid.

It is, therefore, essential to diarize the date on which the minor partner will come of age. The following fresh letters should be obtained after the minor partner attains majority to bind him for the liabilities of the firm :

(a) Partnership Letter;

(b) The ex-minor should sign the existing partnership letter in ratification of previous transactions; and

(c) Partner's Individual Guarantee.

\section{Execution of document by Joint Hindu Family}

There are a number of legal complications in making advances to a Joint Hindu Family concern. In law, the Karta of a Joint Hindu Family has an implied authority to borrow money, execute documents and give securities for the ordinary purposes of Joint Hindu Family letter signed by all the adult coparceners. Wherever operation on the account by coparceners other than the Karta are permitted in terms of the provisions of the aforesaid letter. Branch Manager will endeavour to obtain periodical ratification of the transactions from the Karta and record it at the branch. All important documents, such as Cash Credit Agreements, Demand Promissory Note etc. must as a rule be executed by the Karta on behalf of the family. In very exceptional cases, however, such as when the Karta is physically disabled or is likely to be absent from the station for the long period, the Branch Manager may permit, with the prior approval of controlling authority, the execution of documents by such other member(s) of the family as has/have been specifically authorized to sign on behalf of the family in terms of relative Joint Hindu Family letter. Before doing so, the Branch Manager will satisfy himself that Joint Hindu Family letter is on record duly signed by all the adult coparceners. The Joint Hindu Family letter stipulates notification to the Bank of any change in the constitution of the firm and also the coming of age of its minor members. The dates on which minor members come of age should be diarized and a fresh letter taken whenever a minor attains majority. He should also be asked to sign the existing Joint Hindu Family letter. While dealing with Joint Hindu Families, the Bank has to distinguish between an ancestral business conducted by the Karta of the family on behalf of the family as a whole and a new business undertaken by one or more of the adult members individually or in ordinary partnership. Although the later is often erroneously described as the family business, the family as such may not be liable for its debts. The Joint Hindu Family letter binds the signatories personally in the event of business undertaken by the firm proving to be outside the scope of the family's ancestral business. In such case, however, it must be realized that minor members may escape liability for business which is not ancestral; this must not be overlooked when accommodation is granted, particularly when the Karta is the only adult member of the family.

\section{Execution of document by Limited Liability Company}

Before an advance is granted to a limited liability company, copies (duly certified as true) of the company's memorandum and articles of association should be obtained and its certificate of incorporation must be registered at the Bank. Unless it is a private limited company, its certificate to commence business must also be similarly registered. From a scrutiny of the memorandum of association, the Branch Manager must satisfy himself that the purpose for which the advance is stated to be required is consistent with the object for which the company was formed, that the advance is within the borrowing powers of the company and normally that no prior charge exists over any of the assets offered as security. He must also be careful to see that the persons who sign the security documents and operate the account have been properly authorized. A company's borrowing powers are usually specifically stated in its articles of association but they are not always limited to a fixed amount. When no mention of borrowings is made, a trading company may generally be presumed to have powers to borrow for the purpose of its ordinary business, but no advance should be sanctioned in such circumstances without prior reference to the controlling authority. Under Section 292(1)(c) of the Companies Act, the powers of the company (Public or Private) to borrow may be exercised by its Board of Directors by means of resolutions passed at a meeting and not by circulation. All advances granted to a company must, therefore, be supported by resolutions so passed. 
Before granting an advance in any form to a limited company, a search should invariably be made in the office of the Registrar of Companies \{vide Section 130(3) of the Companies Act\} to ensure that no prior charge exists over the security offered. If a company has issued debentures, the Branch Manager must ascertain from the debenture trust deed that the assets of the company proposed to be charged to the Bank are not already mortgaged to the debenture trust deed holders. If there is any doubt on the point, a deed of release must be obtained from the debenture holders or their trustees in terms of the debenture trust deed. When debentures are being issued by a company whose stocks etc. are already pledged or hypothecated to the Bank, the Branch Manager must be careful to see that the Bank's interests are protected.

\section{Registration of Charge :}

The execution of documents by a company should be supported by a resolution. These documents should be executed on behalf of the company by the persons authorized by the resolutions of the Board. The common seal is required to be affixed to any instrument which requires prior authorization by a resolution of the Board of Directors or the Committee of the Board or if so required in terms of the provisions contained in the Articles of Association. Such affixation of seal is to be executed as per the provisions contained in the Articles of Association, which generally require it to be witnessed by any two of the directors and the Secretary.

\section{Execution of document by Co-Operative Societies}

Bye-laws of a society define the objects, area of operation and the limitations of the powers of the society. It contains the fundamental conditions under which the Society has been registered in accordance with the provisions of Cooperative Societies Act. It is important for the creditors who deal with the society to have full knowledge of such provisions of the bye-laws, which may, however be amended by a resolution of the general body, with the approval of the Registrar of Co-operative Societies. Detailed procedure is given in the Bye-laws of the Society. Maximum credit limit (which are the maximum borrowings that can be raised by a society) are determined in accordance with the clauses of the bye-laws of the society with or without the approval of Registrar of the Co-operative Societies.

Certified up to date True Copy of the Bye-laws should be obtained and kept with the account opening forms. Since annual audit of society(ies) account is conducted, copies of audited financial statements along with a copy of the auditor's report must be obtained.

\section{Execution of document by Clubs/Institutions/Schools}

Such bodies, if not incorporated, have not contracting powers as they have no legal entity. They can neither be used nor are the individual members of such institutions liable for any credit facilities, as long as the members signing the cheques do so in their representative capacity and not in their personal capacity. No limit should be sanctioned without prior approval of the controlling authorities. In such a situation, the bye-laws of the above institutions should be studies with a view to ascertaining their borrowing powers, the purpose for which a loan can be raised by it, the powers of the managing committee to charge the assets of institutions etc. A suitable resolution should be passed in this regard.

\section{Execution of document by Physically Handicapped}

Handicapped persons, without fingers, thumbs, toes, etc. are allowed to put simple marks or dots on the documents instead of signature. Such marks are invariably made on documents in the presence of the Branch Manager/ Manager of Division. The signatures of independent witnesses known to the Bank are obtained as attesting witnesses. If such witnesses are not available, then the Branch Manager/Manager of Division or any other employee should himself attest the impression. The document will then be treated as properly executed.

\section{Execution of document by Blind Persons}

Signature can be obtained in case where the blind person is able to sign consistently and uniformly. Where the person is not able to sign consistently, thumb impression should be obtained. A separate letter signed by two persons witnessing the execution of documents by blind person(s) may also be obtained. 


\section{Execution of document by Illiterate Borrowers}

In case of illiterate borrowers, the left hand thumb impression (right hand impression for ladies) of the illiterate borrower should be got affixed in the presence of the bank official and the wordings 'Left/Right hand thumb impression of Shri/Smt...............' Should be written just below the thumb impression. In case of illiterate borrowers a separate declaration should be taken from independent witnesses to the effect that the contents of the documents were explained to him/her and that he/she executed the documents of his/her own volition after understanding the implications thereof. If a document is signed in vernacular, the signature should be translated into English only at the end without attestation.

\section{Execution of document by Pardanashin Women}

In the case of pardanashin ladies, the law requires more care to be exercised in dealing with them. In case where loans are granted to, or guarantees are obtained from the pardanashin ladies, the Bank should have evidence to show that the documents were executed by such ladies out of their free will and without any undue influence or duress, after clearly understanding the nature of the transactions. If the documents are not in the mother tongue of the executants, the Bank must establish that the documents were explained to such ladies in their mother tongue, and that they understand the implications of the same. Wherever, documents are executed by pardanashin ladies, endorsements to the above effect should be made on the documents under the signature of some independent witness, after he has explained the implications of the contents of the documents to such ladies. Mere narration in the Document Execution Register to this effect which is an internal record is not enough.

\section{LESSON ROUND UP}

- One of the reasons why banks should hold valid collateral security is, banks lend against such security (movable/immovable assets, financial instruments, personal and corporate securities)

- Banks as lenders should be careful in accepting collateral security (primary/secondary) from borrowers.

- Different kinds of securities are obtained based on (i) type of finance (ii) nature of security (iii) type of borrowers, etc.,

- Collateral security if properly obtained with all collateral documents as appropriate would assist the banks to protect the interests of the banks in case the borrower defaults. These securities supported by correct and valid documents would assist the banks in recovery process as well.

- Banks loans and advances are secured to protect the banks against risks.

- Banks get a right to recover the loan amounts through a process called charging the securities in favour of the lender (banker). Such charges are created by means of appropriate legal documents.

- Banks should be careful while accepting various securities and ensure such securities are properly charged (like lien, hypothecation, pledge, assignment, set off and mortgages) in favour of the banks.

\section{SELF TEST QUESTIONS}

1. State whether the following statements are 'True' or 'False'

1. Assignment is a term associated with a loan against life insurance policy

2. Registration of charges with ROC is applicable to a registered partnership firm

3. Mark to market is a concept applicable in case valuation of pledged shares

4. Mortgage by deposit of title deeds is known as English mortgage 
5. Lien is the charge for book debt advances

6. Assignment is a not charge applicable to immovable property

7. The charge on an immovable property is called mortgage

8. The banker's lien is called implied pledge

2. Choose the correct alternative.

A. An automobile loan is secured by
(a) Assignment
(b) Pledge
(c) Mortgage
(d) Hypothecation

B. Bank XVM has granted working capital finance to a company against inventory. Identify the exception to Inventory
(a) Raw materials
(b) Goodwill
(c) Semi finished goods
(d) Closing Stock

C. In case of an advance to a Public Limited Company, which charge need not be registered with ROC
(a) Pledge
(b) Mortgage
(c) Hypothecation
(d) Assignment

D. Identify the exception to the documents of title to goods
(a) Railway receipt
(b) Bill of Exchange
(c) Lorry receipt
(d) Bill of lading

E. Which Act defines a Bill of Exchange?
(a) Bankers' Book Evidence Act
(b) Indian Contract Act
(c) Negotiable Instruments Act
(d) Indian Companies Act

F. Both ownership and possession is held by the borrower in case of
(a) Safe Deposit Locker
(b) Guarantee
(c) Hypothecation
(d) Safe Custody

3. What are the general principles of secured advances?

4. Explain different types of securities.

5. Explain the documentation process in registration of charge.

6. What do you mean by hypothecation? Differentiate between hypothecation and pledge.

7. What are the various charges available to a lending banker? With examples explain the importance of such charges

8. Why banks obtain various types of securities?

9. In case of loans against inventories and receivables what precautions banks should take?

10. Write short notes on:
(a) Right of lien
(b) Primary securities
(c) Loan against fixed deposits 
Lesson 7 ॥ Securities for Bank Loans 225 
226 PP-BL\&P 


\section{Lesson 8}

\section{Financial Analysis of Banks}

\section{LESSON OUTLINE}

- Principles of Lending

- Types of Analysis

- Financial Analysis

- Du Pont Model

- Bankers as Lender

- Bankers as Investor

- Lesson Round Up

- Self Test Questions

\section{LEARNING OBJECTIVES}

Banks accept deposits from their depositors which form the main source of funds for banks. Banks also raise funds in the domestic financial markets and international financial markets. These funds are deployed by banks as loans and advances and also as investments. Hence, the banker at the time of deploying his funds either as a lending banker or investing banker needs to be careful. Like any other lender and / or as an investor, a banker also needs to carry out many a type of analysis.

After reading this chapter the reader would be able to:

- Understand the types of financial statements and their role in financial analysis

- Appreciate the various aspects of financial analysis and their significance

- Know why financial analysis is an important tool for lending and investing bankers 


\section{TYPES OF ANALYSIS}

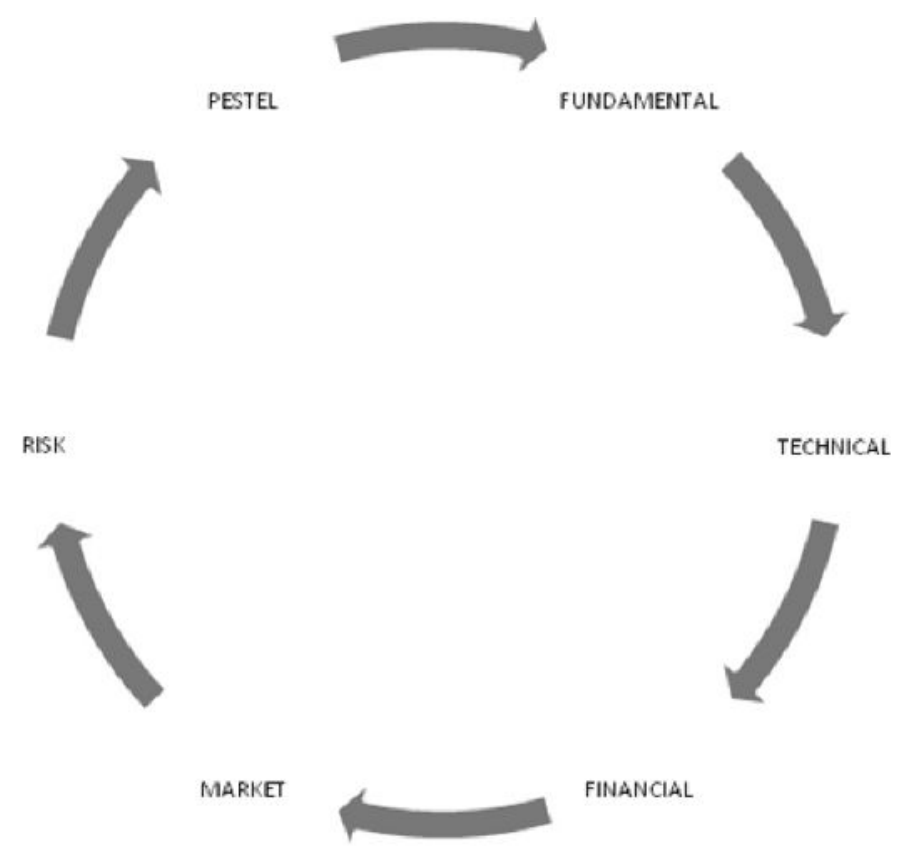

An analysis becomes an important aspect of decision making, hence analysis of different situations, scenarios and perceptions would assist banks to take appropriate decisions.

\section{FINANCIAL ANALYSIS}

The performance of a company or business enterprise can be measured by looking into the financial results of the company over a period of time. A comparative study of the financial statements would assist the analyst to assess the results. Two important financial statements commonly used for financial analysis are $P$ \& $L$ account, and balance sheet.

The financial statements are analyzed and interpreted by different classes of persons, such as individual investors, bankers, financial institutions, credit analysts, credit rating agencies, research and management students.

$P \& L$ and Balance sheet analysis:

(i) The balance sheet shows the financial position of the business as at the end of a particular period (month, quarter or year)

(ii) The profit and loss account shows the financial results of the working of an enterprise over a period of time. For example, $1^{\text {st }}$ of April 2012 to $31^{\text {st }}$ March 2013

(iii) When comparative analysis of these statements for a number of years is done, it would give a better view about the financial performance of the business unit.

(iv) Financial analysis and interpretation of financial statements have now become important decision making tools.

Advantages and limitations of analysis of financial statements:

(a) The financial results in the form of P\&L accounts and balance sheets are readily available. 
(b) These financial statements are drawn as per the accounting standards and as per the regulatory and legal frame work.

(c) Depending upon the requirement of the analyst (investors, bankers, credit rating agencies etc.,) the figures and data available on these statements can be easily grouped and interpreted.

(d) The financial statements can be used for ratio analysis, trend analysis etc

While using the financial statements, the limitations are:

(i) The balance sheet numbers are available as on a particular date hence may not reveal the correct position of the financial health for over a period of one year.

(ii) Since both profit and loss account and balance sheet are in the form of numerical statements, these statements would not reveal the overall picture about the performance of the concern or business unit.

(iii) The methods of valuation of assets, writing off depreciation, amortization of costs, large expenses etc. may vary from business unit to business unit. Therefore, a comparison of these numbers and ratios would not give desired results and calls for further detailed investigations.

(iv) Further, these financial statements depict the performance of the business enterprise. Therefore, any meaningful interpretation of these statements, will depend upon the projections of the future trend.

\section{Analysis of Balance Sheet}

The balance sheet is the most important financial statement prepared annually. It shows the assets and liabilities of a business concern as on a particular date (For example as on 31st March). The assets indicate what the company owns and its receivables, and the liabilities indicate what the company owes and its payables.

Assets:

Assets are classified into: (a) Current Assets (b) Fixed Assets (c) Intangible Assets

Please note that in the vertical form of balance sheet, most of these items are appearing as part of application of funds or deployment of funds

\section{Current Assets:}

Current assets are those assets which are to be liquidated into cash in the near future. These assets are also known as 'circulating assets'.

\section{Composition of Current Assets:}

Cash and bank balances, marketable securities, inventories, bills receivables and debtors (book debts) are examples of Current Assets. Debts and bills receivable which are outstanding for not more than 12 months are treated as current assets.

Inventories and Receivables are two important components of current assets. As already indicated while interpreting the financial statements, care should be taken to bifurcate these assets into two categories as current and noncurrent assets. A close review of the inventory and receivables would give better results of the efficiency of the management in managing these two assets, and clearly indicate the liquidity management skills of the business concern.

\section{Fixed Assets:}

The next important classification of assets is fixed assets. The fixed assets usually consist of Land and buildings, Plant and Machinery, fixtures and fittings, etc. These assets are used by the company for carrying on the business and are not meant for sale in the near future. While analyzing the fixed assets, care should be taken to verify the 
book value as well as market value (re-saleable value and necessary precautions to be taken to verify whether such assets are charged to any bank or financial institutions and the impact of the borrowings against such fixed assets). The depreciation and amortization policies should also be reviewed.

For example, the valuation of the fixed assets varies from type of assets. Land should be valued according to ownership pattern like free hold or lease hold, and the location of the land, etc., As regards valuation of building, the age of the building, location and other factors need to be given appropriate weightage.

\section{Intangible Assets:}

With the changing pattern of integration of global business environment, a lot of changes are taking place in the analysis of financial statements as well. Importance is being given to the intangible assets, and their valuation is an important part of financial analysis.

Generally, the following items are classified as intangible assets; goodwill, copy right, patents, trade mark, designs, brand value etc. These are also called as fictitious assets. These assets do not represent any tangible assets like land and building, raw materials, stocks etc; These intangible assets in a way represent the reputation earned by the company.

Apart from the above, certain other items which can also be classified as intangible assets are: preliminary expenses, debit balance in profit and loss account, which are either deferred revenue expenses or are actual losses to be written off over a period of time.

\section{Liabilities:}

The liabilities mainly represent sources of funds and can be broadly classified into: (i) Net Worth - Owned funds and share capital and free reserves (ii) Current liabilities and (iii) the term liabilities

Current liabilities: Those items which are repayable within one year are treated as current liabilities..

Borrowings from banks: Business units avail bank finance in the form of overdraft, / cash credit (working capital finance). An analyst should be interested to know the details of such bank borrowings like amount under different categories, security charged to the banks in the form of hypothecation and pledge of inventories and receivables etc.,

\section{Sundry or Trade Creditors:}

The review of trade creditors is crucial in determining the company's liquidity management. The review should be in detail relating to the nature of bills, the credit terms and other conditions. If the bills are drawn by other than trade creditors, then careful review is needed.

\section{Term Liabilities}

While the term liabilities are long term in nature, but the installments of term loans which are repayable or the maturity of debentures and other term liabilities which are due for payment within a period of one year, need to be classified as short term and treated like other current liabilities.

Apart from the above items, provision for taxes, interest on term loans and debentures and other charges, unpaid expenses, etc. are classified as other current liabilities

Term loans are classified into short term, medium term and long term.

While analyzing, care should be exercised to verify and satisfy to the various terms and conditions of the loans and term finance availed by the company. The details such as the rate of interest, the repayment period, and the security offered etc needs to be carefully reviewed. 


\section{Net Worth:}

The composition of 'net worth' is paid-up share capital, the retained profits held in the form of reserves and surpluses and the credit balance in the profit and loss account.

One of the important aspects of "net worth" is that the company's long term solvency depends on the strong capital base. The financial analyst should review to find out whether the long term needs of the business concern is financed by the owned funds or long term liabilities.

\section{Contingent Liabilities or Off Balance Sheet Items:}

Contingent liabilities are those liabilities which do not exist as on the date of balance sheet, however they may arise in future Unlike other items, which are classified as On balance sheet items, the contingent liabilities are classified as Off balance sheet items. On balance sheet items are part of the balance sheet as historical items, whereas the contingent liabilities are future items. In case these items become payable, it would distort the liquidity position of the company, hence a careful review as to the terms and conditions of such contingent liabilities, possible repayment amount and time etc., need to be given importance.

\section{Other important features:}

The balance sheet and the profit and loss account give the financial position of a company in numerical numbers. Apart from these, the auditors' report, explanatory schedules and notes on accounts, if applicable, provide useful information.

Funds flow and cash flow statements also provide useful information which show mathematical analysis of changes in the structure of two consecutive balance sheets. These financial statements are prepared as per the applicable Accounting Standards.

The financial statements should be prepared as per the legal frame work and the Accounting standards as applicable from time to time:

In case of banking companies, the formats of both balance sheet and P\&L account are prescribed by

The Banking Regulation Act. In case of other companies, they have to follow the Companies Act, 1956, as amended from time to time.

The Ministry of Corporate Affairs (MCA) has issued revised Schedule VI which lays down a new format for preparation and presentation of financial statements by Indian companies for financial years commencing on or after 1 April 2011.

The revised Schedule VI introduces some significant conceptual changes such as current/non-current distinction, primacy to the requirements of the accounting standards, etc. While the revised Schedule does not adopt the international standard on disclosures in financial statements fully, it brings corporate disclosures closer to international practices.

Some of the significant aspects of the revised Schedule are:

- Format of cash flow statement not prescribed - hence companies which are required to present this statement (i.e., other than small and medium sized companies) to continue to prepare it as per AS 3 , Cash Flow Statements

- Only vertical form of balance sheet is allowed - with significant changes vis-à-vis the structure of prerevised Schedule VI

- Shareholders' funds to be shown after deduction of debit balance of statement of profit and loss. 'Reserves and surplus' and 'shareholders' funds' (i.e., aggregate of Share Capital and Reserves and Surplus) could thus be negative figures. 
- Miscellaneous expenditure can no longer be shown as a separate broad heading under 'Assets'. It would be required to be reclassified depending on the nature of each such item.

- All assets and liabilities to be classified into current and non-current. This provides useful information by distinguishing assets/liabilities continuously circulating as working capital or expected to be settled/realized within 12 months from the balance sheet date from those used in long-term operations.

- Basic criteria for classifying an item (asset or liability) as current are:

- Basic criteria for classifying an item (asset or liability)

- Basic criteria for classifying an item (asset or liability) as current are:

- Current/non-current distinction will have major impact on classification of accounting information and account heads. Hence, changes would be required in accounting systems and procedures.

- Detailed disclosures required regarding defaults on borrowings.

- All liabilities to be classified into current and non-current on the basis of the same criteria of distinction as in the case of assets.

- Non-current liabilities include long-term borrowings, long-term maturities of finance lease obligations, long-term trade payables and long-term provisions. Current liabilities include current maturities of longterm debt and of finance lease obligations, short-term borrowings, and all borrowings repayable on demand, unpaid matured deposits/debentures, and short-term provisions.

- Intangible fixed assets to be disclosed separately.

- 'Investments' no longer a broad head - to be included under non-current and current assets categories; disclosures rationalised.

- Long-term loans and advances given not to be clubbed with current assets.

Cash and cash equivalents to be disclosed separately.

Statement of profit and loss

- Format of statement of profit and loss prescribed - classification of expenses by nature.

- Various computations relating to profits (losses) to be shown:

- Profit (loss) before exceptional and extraordinary items and tax

- Profit (loss) before extraordinary items and tax

- Profit (loss) before tax

- Profit (loss) from continuing operations

- Profit (loss) from discontinuing operations

- Profit (loss) for the period.

\section{Analysis of Profit and Loss account}

It is a statement of income and expenditure of an entity for the accounting period. Every P\&L account must indicate the accounting period for which it is prepared. The items of a P\&L account are:

Gross and Net sales 
Cost of goods sold

Gross profit

Operating expenses

Operating profit

Non-operating surplus/deficit

Profit before interest and tax

Interest

Profit before tax

Tax

Profit after tax (Net Profit)

\section{Gross and Net Sales:}

The total price of goods sold and services rendered by an enterprise, including excise duty paid on the goods sold, is called Gross sales. Net sales are gross sales minus excise duties.

\section{Cost of Goods Sold:}

This is the sum of costs incurred for manufacturing the goods sold during the accounting period. It consists of direct material cost, direct labour cost, and factory overheads. It is different from the cost of production, which represents the cost of goods produced in the accounting year, not the cost of goods sold during the same period.

\section{Gross Profit:}

This is the difference between net sales and cost of goods sold. Most companies show this amount as a separate item. Some companies, however, show all expenses at one place without making gross profit a separate item.

\section{Operating Expenses:}

These consist of general administrative expenses, selling and distribution expenses, and depreciation. Some companies include depreciation under cost of goods sold as a manufacturing overhead rather than under operating expenses.

\section{Operating Profit:}

This is the difference between gross profit and operating expenses. As a measure of profit, it reflects operating performance and is not affected by non-operating gains/losses, financial leverage, and tax factor.

\section{Operating Profit:}

This is the difference between gross profit and operating expenses. As ameasure of profit, it reflects operating performance and is not affected by non-operating gains/losses, financial leverage and the tax factor.

Non-operating Surplus: This represents gains arising from sources other than normal operations of the business. Its major components are income from investments and gains from disposal of assets. Likewise, non-operating deficit represents losses from activities unrelated to the normal operations of the firm.

\section{Profit before Interest and Taxes:}

This is the sum of operating profit and non-operating surplus/deficit. Referred to also as earnings before interest and taxes (EBIT), this represents a measure of profit which is not influenced by financial leverage and the tax factor. 


\section{Interest:}

This is the expenses incurred for borrowed funds, such as term loans, debentures, public deposits, and working capital advances etc.

\section{Profit before tax:}

This is obtained by deducting interest from profits before interest and taxes.

\section{Tax:}

This represents the income tax payable on the taxable profit of the year.

\section{Profit after tax:}

This is the difference between the profit before tax and tax for the year.

\section{Analysis of Funds flow/ cash flow statements}

Each item in the balance sheet represents either source of funds or use of funds. All items on the liabilities side represent the funds provided to the enterprise and all items on the assets side (except cash) represent use of these funds.

When we compare two balance sheets of different dates, change in each item (or introduction of a new item) in the balance sheet of later date, as compared to that item in the balance sheet of earlier date, will represent either addition of funds or additional use of funds in the intervening period. Any increase in any item on the liabilities side means additional funds available. Please note that additional funds are also available if there is decrease in any item on the assets side. Similarly, any increase in any item on the assets side or decrease in any item on the liabilities side means additional use of funds. A statement of these additional sources of funds and additional uses of funds is called Funds flow statement for the intervening period.

If we have to prepare the cash flow statement, we start with the cash in the first balance sheet as opening balance, add all the additional sources, excluding cash (cash is also a source of funds if it is at a reduced level in the subsequent balance sheet), and deduct all additional uses (excluding cash), thus arriving at the closing balance, which will be equal to the cash shown in the second balance sheet. In practice, the statement is prepared perceiving cash as a use or source of funds.

\section{TECHNIQUES USED IN ANALYSIS OF FINANCIAL STATEMENTS}

Three methods are used for analysis of financial statements:

\section{Funds Flow Analysis}

The total sources of funds are categorized as 'Long term' and 'Short term'. Similarly, the total uses are also categorized as 'Long term' and 'Short term'. If the short term sources are more than the short uses, it indicates diversion of working capital funds and needs to be probed further. Sometimes, it may be a desirable thing e.g., in case of companies with very high current ratio, it may be desirable to use the idle funds for creating additional capacity. The guiding principle is that this diversion should not affect the liquidity position of the company to unacceptable level.

\section{Trend Analysis}

Under trend analysis, methodology can be used:

(a) The items, for which trend is required to be seen, are arranged in horizontal form and percentage increase (decrease) from the previous year's fig is indicated below it. Generally, this is used to see the trends of 
sales, operating profit, PBT, PAT etc. from P\& $L$ account. Similarly, the balance sheets, arranged in horizontal order give the trends of increase or decrease of various items.

(b) Common size statements are prepared to express the relationship of various items to one item in percentage terms. For example, consumption of raw materials is expressed as a percentage of sales for different years and comparison of these figures gives indication of trend of operating efficiency.

The use of common size statements can make comparisons of business enterprises of different sizes much more meaningful since the numbers are brought to common base, i.e. per cent. Such statement allows an analyst to compare the operating and financing characteristics of two companies of different sizes in the same industry.

\section{Ratio Analysis}

This is the most commonly used tool for analysis of financial statements.

A ratio is comparison of two figures and can illustratively be expressed as:

Current Ratio

Debt Equity Ratio

Profitability Ratio
1.33

$1: 2$

$21.4 \%$

Both the figures, used in calculation of a ratio, can be from either $P \& L$ account, or balance sheet or one can be from $P \& L$ account and the other from balance sheet. Ratios help in comparison of the financial performance and financial position of an entity with other entities, as also for comparison with its own status over the years. While different users of financial statements are interested indifferent ratios, some of the important ratios are:

\section{Profitability Ratios:}

Operating profit margin (OPM) and Net profit margin (NPM) are calculated by dividing the figures of operating profit (EBIT which means earnings before interest and tax) and net profit respectively by the net sales. OPM is an indicator of the operating efficiency of the enterprise while NPM is an indication of ability to withstand the adverse business conditions.

\section{Liquidity Ratios:}

These are Current ratio $(C R)$ and quick ratio or acid test ratio. While $C R$ is a ratio of total current assets to total current liabilities, quick ratio is calculated by dividing current assets (excluding inventory) by total current liabilities. These ratios indicate the capacity of an enterprise to meet its short term obligations.

\section{Capital Structure Ratios:}

Debt Equity Ratio (DER) is a ratio of total outside long term liability to the Net worth of an enterprise. High debt equity ratios are an indication of high borrowings in relation to the owned funds but also affects the viability of the operation of the enterprise, as higher borrowings mean higher costs and lower operating margins. In case of those enterprises, which are not capital intensive (i.e. the requirement of fixed assets is low), this ratio may not indicate the correct picture as working capital borrowings, which are not indicated by DER, may be disproportionate to the capital. To get a better result, TOL/ TNW ratio i.e. the ratio of Total Outside Liabilities to Tangible Net Worth can be used.

\section{Coverage Ratios:}

Interest Coverage Ratio (ICR) and Debt Service Coverage Ratio (DSCR) are the important ratios under this category. ICR is calculated by dividing EBIT (earnings before interest and tax) by total interest on long term borrowings. DSCR is ratio of total cash flows before interest (net profit + depreciation + interest on long term borrowings) to total repayment obligation (installment + interest on long term borrowings). 


\section{Turnover Ratios:}

\section{Inventory Turnover Ratio:}

This is one of the important ratios to measure the skills of the management of the firm. This is an indicator of how fast or slow is the movement of inventory. It is calculated by dividing cost of goods sold by average inventory. A higher ratio indicates faster movement of inventory. This is also used for calculating average inventory holding period.

Debtors' Turnover Ratio: This is another important ratio to measure the efficiency of the receivables management of the firm. It is an indicator of how fast or slow the debtors are realized. It is calculated by dividing the net credit sales by average debtors outstanding during the year. A higher ratio indicates faster collection of debts. This is also used for calculating average collection period.

\section{DU PONT MODEL}

The Du Pont Company of US introduced a system of financial analysis considered as one of the important tool for financial analysis.

The Du Pont identifies that the earning power of a firm is represented by (Return on Capital Employed) ROCE. ROCE shows the combined effect of the profit margin and the capital turn over. A change in any of these ratios would change the company's earning power. These two ratios are affected by many factors. Any change in these factors would bring a change in these two ratios.

The usefulness of the Du Pont model is that it presents a picture of the overall performance of a company to enable the management to identify the factors relating to the company's profitability.

The two components of this ratio: profit margin and investment turnover ratio individually cannot give the overall view because the profit margin ratio ignores the profitability of investments and the investment turnover ratio ignores the profitability on sales.

ROCE $=$ Turn Over $x$ Profit Margin

Turn over $=$ Sales $/$ Capital Employed

Capital Employed $=$ Working Capital + Fixed Assets

Working Capital $=$ Stock + Bills Receivable + Debtors + Cash

Profit Margin: Net Profit/ Sales

Net Profit $=$ Sales $-($ Manufacturing costs + Selling costs + Administrative costs $)$

Du Pont Chart

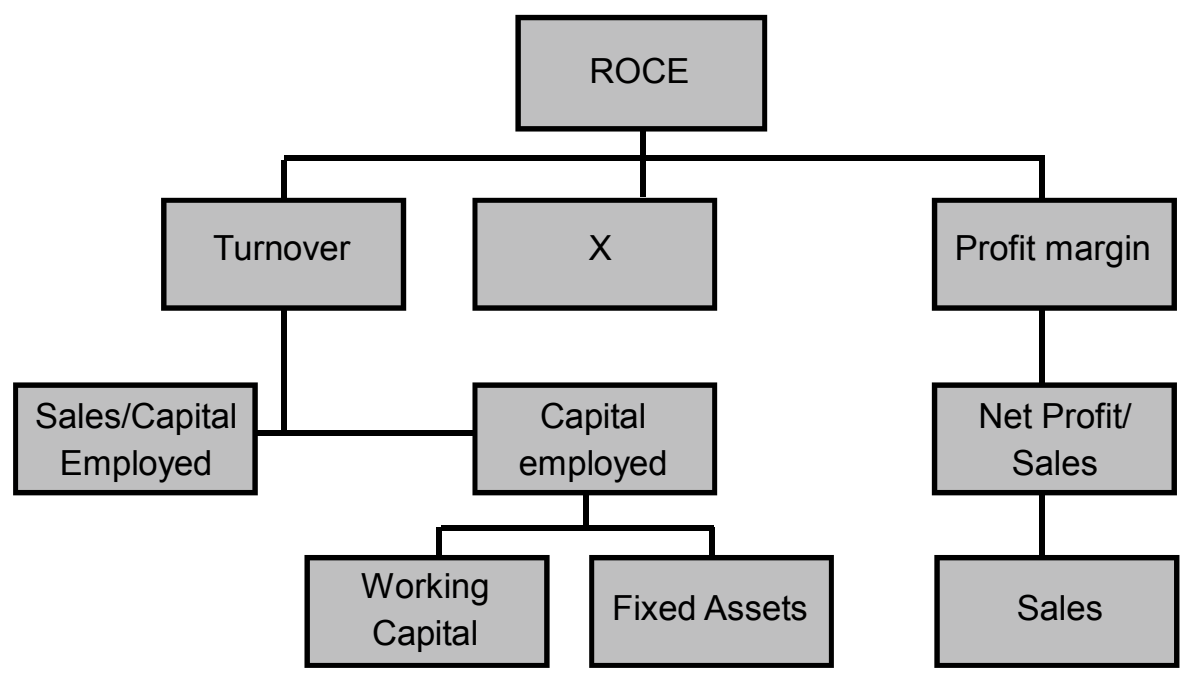




\section{Special issues in financial analysis - Banking Industry:}

Banks are financial intermediaries playing a crucial role in connecting the depositors (who save money) and the borrowers (who need money). Banks borrow money in the form of acceptance of deposits both from retail and wholesale customers (depositors) as well as banks and financial institutions. The funds are deployed as assets. Bank assets can be broadly classified into (i) Loan assets (ii) Investments and (iii) Other assets (fixed assets)

In both capacity as lending banker and investing banker, a banker needs to be careful. He needs to carry out as due diligence exercise for various reasons:

- Safety and security is the concern of a lending and investing banker, since he also acts as trustee for the depositor's money.

- While lending as well as investing, banks are exposed to many a risks.

- Banks needs to balance their assets and liabilities, and also ensure proper liquidity management.

- Banks should carefully handle their assets portfolio to ensure that their NPA levels remain at minimum possible levels.

In view of the above, a banker's financial analysis would be different from other category of persons and entities that use the financial statements for various purposes and reasons.

\section{FINANCIAL ANALYSIS BY BANK AS A LENDER}

While considering a loan proposal, apart from the borrower's integrity and KYC aspects, the banks are interested in knowing the financial details of the prospective borrower. The extent of these details depends upon the type of loan, type of borrower, purpose of the loan etc. In case of security based lending like loans against fixed deposits, etc, these financial details may be few or may not be required at all. However, in other cases of both fund based as well as non fund based limits, to secure the bank advances and also to manage the risks and recovery of loan amounts, banks would be ensuring collection of all relevant financial data, and other relevant information, to make a proper decision.

Some of the important areas are:

\section{(1) Net Worth of the borrower:}

For an individual, the excess of his assets over his liabilities is his net worth. The same thing applies to any business entity as well but, to consider various types of loans and advances, banks should be careful to evaluate the net worth.

\section{(2) Viability:}

Banks should assess the viability of the business unit, its operational capacity and its ability to increase it's production with the proposed bank loans. This is one of the important considerations for a bank in credit assessment (working capital finance and term finance). A scrutiny of the financial records of the existing activity helps bank in assessing whether the proposed bank loan will result in a significant increase in operations.

\section{(3) Repayment Capacity:}

Depending upon the type of borrower, the repayments of the loans would be determined. In case of an individual, the banks collects information like his income (salary, interest, dividend, etc.) as also his expenditure, including repayments of existing borrowings, if any, to assess the surplus available for repayment of installment and interest on bank's loan. However, in case of a business concern, banks obtain most of the required information from its financial statements and for other information banks collect information through their due diligence process. The banker's focus is normally on the following aspects: 


\section{(4) Assessment of Performance and Financial Position:}

An analysis of the financial statements reveals the trend of growth of its business and its profitability. The review of the financial statements reveal the composition of assets and liabilities of the company. By comparing these to the industry trend, opinion about the management and efficiency of the enterprise is formed.

\section{(5) Financial Health Indicators:}

Financial statement analysis is an important tool in identifying direction of business of the company. Also it assists the bank to determine the status of the financial health as well. The financial analysis helps the banker to detect any deterioration of its financial health. This signal would enable the bank to take preventive/ corrective measures to avoid/ minimize losses.

\section{(6) Assessment of Credit Requirements:}

Despite all best efforts, one of the difficulties banks face is to accurately assess the financial need of the borrower. Over-financing and under-financing both are risky for the borrower and the bank. Financial statement analysis is used by banks to assess the credit requirement to overcome this issue. Banks are also concerned with repayment of loan interest within a reasonable time. Analysis of the financial statements of the borrower helps in assessing the repayment schedule as also to assess credit risk, and deciding the terms and conditions of loan.

\section{(7) Cross Verification:}

The statements of stocks and book debts, as on the date of the balance sheet, submitted by the borrower, for calculation of drawing power in the cash credit account, are cross checked with the figures given in the balance sheet.

\section{BANKERS AS INVESTOR}

As per bank's investment policy and guidelines of the regulator, banks invest in securities under SLR and Non SLR investment categories.

These investments are made by banks for the following reasons:

(1) To comply with SLR requirements

(2) To optimally deploy surplus funds

(3) To manage the gap between assets and liabilities (mismatch)

(4) To diversify risks

While investing funds in Non-SLR securities, the following need to be taken into account:

1. They should adhere to exposure limits and counter-party limits.

2. The financial statements of banks and corporate clients, where the funds would be invested, need to be properly analyzed.

3. Like a lending banker, the investing banker also needs to verify all the important parameters to cover various risks.

4. If the investments are in market related instruments, banks also need to do a proper analysis of the market risks and their impact

5. Banks should ensure that all such investments are properly valued by practicing the mark-to-market concept.

6. Apart from trend ratio and other analysis, banks should also carry out PESTEL analysis (Political, Economic, Social, Technological, Environmental and Legal) and impact of the PESTEL factors on their investments. 
7. To protect the interests of the bank, while investing, careful assessment of the company's performance and stock markets, also needs to be carried out.

\section{LESSON ROUND UP}

- The main source of Financial analysis is the financial statements viz., the balance sheet, profit and loss account, cash flow and funds flow statements.

- The balance sheet depicts the position of its assets and liabilities as on a particular date, while P\&L account is prepared for an accounting period and states the position of income, expenses and the profit/loss.

- Different methods of analysis are used on the basis of comparison of two successive balance sheets.

- We can calculate the flow of funds in the intervening period.

- The credit and investment decisions are applicable for future needs of an enterprise, for which usually projected financial statements are also prepared and analyzed.

- These are based on actual statements for the past period and anticipated performance in the future.

- Analysis of financial statements helps banks in knowing the financial health, performance and viability of an enterprise, and in assessing its credit requirements.

- Some of the important methods used in analysis are trend and ratio analysis.

- The trend analysis shows how the business of an enterprise is growing while the ratio analysis depicts the most critical financial parameters at a glance. Thus, the key ratios like OPM, debt/equity ratio, current ratio, DSCR, debtors' turnover ratio assist an investor and a lender to get a reasonable understanding about the financial health and the performance of an enterprise. However, for a final decision, a more detailed analysis is necessary.

- While the format for balance sheet and P\&L account are prescribed, for meaningful analysis, rearrangement of these statements into various groups can be done according to the requirement of the analyst.

- Du Pont model highlights that the earning power of a firm is represented by Return on Capital Employed (ROCE). ROCE shows the combined effect of the profit margin and the capital turn over. Any change in any of the factors affects the company's earning power.

- Banks as lender and investor, carryout financial analysis. While analyzing the company's performance based on the financial statements, banks should also be careful to give due attention to other factors apart from the financial statements.

\section{SELF TEST QUESTIONS}

1. State whether the following statements are 'True' or 'False'

(a) Term loan installment due within one year, is classified under current assets.

(b) The motor cars ready for delivery of an automobile company, is classified as current assets.

(c) Off balance sheet items also needs to be included in the financial analysis of an enterprise.

(d) Debt: Equity ratio (DER) is a ratio of total outside liability to the net worth of an enterprise.

(e) Du Pont model is used by banks to assess a company's current ratio. 
(f) Banker can analyze the financial statements as a lender and an investor.

2. Select the correct alternative.

A. The financial statements of a company for financial analysis are used by:

(i) Bankers (ii) Investors (iii) Credit Rating Agencies (iv) Government

(a) i only (b) both i and iii (c) i, ii, iii, iv (d) ii, iii, iv

B. Identify the exception to the method of ratio analysis. ratios can be expressed as
(a) numbers
(b) percentage
(c) statements
(d) ratios

C. DuPont analysis include the following items, except one. Identify the exception
(a) ROCE
(b) Fixed Assets
(c) Sales (d)
(d) Goodwill

D. Which of the following statement is incorrect?

(a) Current ratio measures the short term solvency of a firm

(b) Trend Analysis is the best method to predict the future earnings of a firm

(c) PAT indicates the net profit of a company

(d) Working Capital finance can also include bills finance

3. How can an investor do the financial analysis of a bank? Explain in detail. What are the advantages and disadvantages of financial analysis?

4. Discuss the role of a banker as lender and as investor

5. Briefly highlight the features of working capital finance

6. Critically examine "Du Pont analysis" in banking companies.

7. Write a short note on

- Banker as a lender

- Banker as an investor

- Reserves and Surplus

- Off balance sheet items

- Trend Analysis

- Liquidity Ratios 
Lesson 8 - Financial Analysis of Banks 241 
242 PP-BL\&P 


\section{Lesson 9}

\section{Financial System Contemporary and Emerging Issue : An Overview}

\section{LESSON OUTLINE}

- Principles of Lending

- Role of Financial System

- Capital Market

- Mutual Funds

- Capital Market - Other Interesting Features

- Lesson Round Up

- Self Test Questions

\section{LEARNING OBJECTIVES}

To start a business, an entrepreneur depending upon the type and nature of business, requires large amount of investment in the form of capital. As discussed in some other chapters, the capital base of an enterprise should be strong to add stability to the business unit. Therefore, the capital is an important composition of a business unit in determining its financial status.

At the end of the chapter the reader would be able to:

- Appreciate the role played by Primary and Secondary Markets in the formation of capital

- Understand the significance of Intermediary Financial Institutional contribution for flow of capital

- Know the role of different Primary market facilitators 


\section{ROLE OF FINANCIAL SYSTEM}

A financial system consists of a structure in an economy, which mobilizes the capital from various surplus sources (investors) and distributes them to the needy segment of the economy. The financial system comprises of various intermediaries who play crucial roles in sourcing out the funds from one segment (surplus segment) and deploying such funds to another segment (needy segment). Some of the intermediaries are banks, financial institutions, mutual funds, etc.

Broadly financial market can be classified as under:

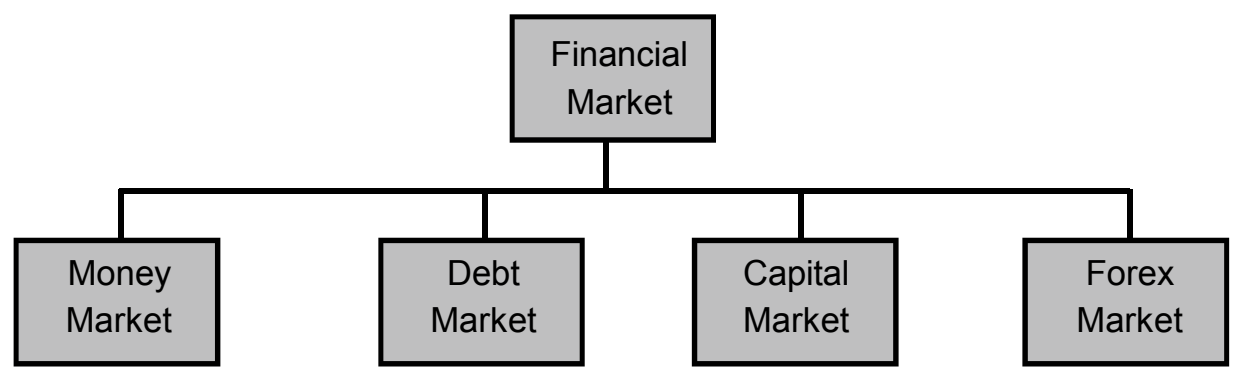

The promoters of a business can raise the funds for investing in business, through many ways like borrowing from banks and financial institutions, invest their own money and also raise funds by inviting public to invest in the form of shares, debentures etc.

\section{CAPITAL MARKET}

Capital Market is a market where investors/ buyers, and issuers of securities/ sellers engage in issue/subscription/ trade of financial securities like shares, bonds etc. This market helps in channelizing surplus funds from savers to the institutions in an organized manner, which then invests them into productive use. This market mostly deals in long term securities

It consists of two types viz., Primary market and Secondary market.
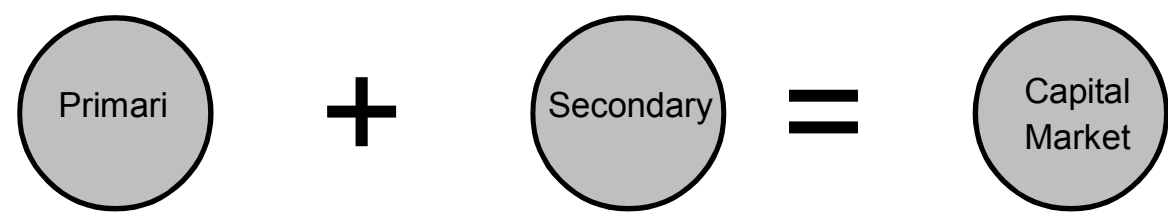

\section{Primary Market}

In this market, securities (shares, debentures, bonds etc) are offered to the public for subscription with a view to raise capital fund. The public issues are to be handled as per the guidelines of the regulator of Capital market, i.e., the Securities Exchange Board of India (SEBI) and applicable legal framework like the Companies Act. There are number of facilitators (intermediaries) in the primary market like merchant bankers and others, who through their services facilitate the public issue at different stages, to enable the investors to decide and invest in a company. 


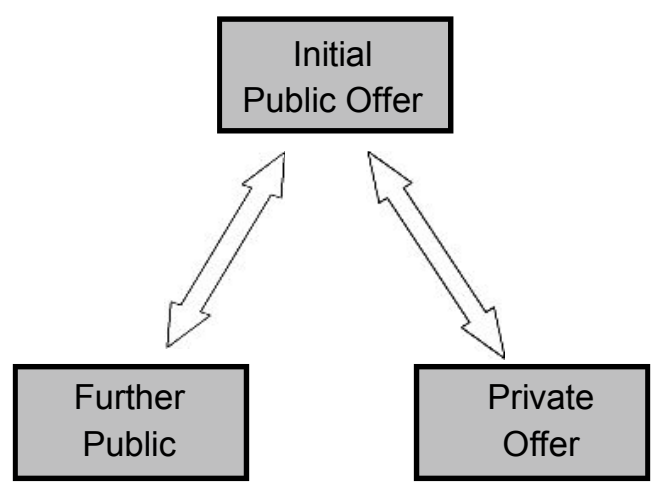

In the primary market, issues are classified into public, rights or preferential issues (also known as private placements). The public and rights issues involve a detailed procedure, whereas in case of private placements or preferential issues, the procedures are relatively simpler.

Public issues can be classified into Initial Public Offerings (IPOs) and Further/Follow-on Public Offerings (FPOs). When an unlisted company makes either a fresh issue of shares or an offer for sale of its existing shares or both for the first time to the public, it is called IPO. On the other hand, a company which is already a listed company, either makes a fresh issue of securities to the public or an offer for sale to the public through an offer document, it is known as FPO.

Rights Issue (RI) is one, when a listed company proposes to issue fresh securities to its existing shareholders as on a record date. The rights issue is normally offered in a particular ratio to the number of shares already held by the shareholders.

A private placement is an issue of shares or of convertible securities by a company, to a select group of persons under the provisions of Section 81 of Indian Companies Act, 1956, which is neither a public issue nor a rights issue. This is a faster way for a company to raise capital.

An example of private placements is a Qualified Institutional Placement (QIP). It is a private placement of equity shares or securities convertible into equity shares, by a listed company to Qualified Institutional Buyers (QIB) only.

SEBI has laid down eligibility norms for entities accessing the primary market through public issues. As per SEBl's guidelines, different facilitators provide service to ensure that the primary market issues are handled as per laid down laws and procedures.

\section{Various aspects of the Primary Market issues}

A merchant banker is the main facilitator for public issues. The issuer company makes detailed disclosures as per the SEBI Disclosure and Investor Protection (DIP) guidelines in its offer document while offering it for subscription. The merchant bankers are the specialized intermediaries who have to ensure after proper due diligence that all required disclosure and investor protection guidelines are complied with, at the time of submission of draft offer documents to SEBI. If a merchant banker fails to ensure compliance, the merchant banker would be penalized by SEBI in term of SEBI (Merchant Bankers) Regulations. The draft offer document filed by the merchant banker is also placed on the website for public comments. SEBl's officials at various levels check the details and ensure that all necessary material information is disclosed in the draft offer documents.

\section{Offer Document}

In case of public issue, an offer document is called as prospectus. It is called as offer for sale and Letter of Offer in case of a rights issue. These offer documents need to be filed with Registrar of Companies (ROC) another facilitator. These offer documents also need to be filed with the concerned stock exchanges. 


\section{Red Herring Prospectus (RHP):}

It is a prospectus which does not have details of share price or number of shares being offered or the amount of issue. If the price is not indicated, then the number of shares and the upper and lower price bands are disclosed. In the case of book building issues, it is a process of price discovery. In such a situation the price would not be determined until the bidding process is completed. Only on completion of the bidding process, the details of the final price are included in the offer document. Thereafter, the offer document is filed with ROC which is called a prospectus.

An offer document is an important document highlighting all the relevant information to assist an investor to make his/her investment decision about the company.

\section{Pricing of the Issue:}

As per SEBl's guidelines the price for an issue is to be determined by the issuing company in consultation with the lead merchant banker. Either of the two prices (a) fixed price or (b) floor price or a price band (final price is determined based on the market forces)

\section{Book Building:}

It is a process undertaken by the company based on the demand for the securities to be issued. The price for the proposed issue of securities is fixed based on the bids received for the number of securities (shares) offered for subscription by the issuing company. It is an opportunity for the market to discover the price for securities. As per the guidelines of SEBI, in the book building process, certain portion of issue are allocated for Retail Individual Investors, Non Institutional Investors and Qualified Institutional Buyers. Retail investor is an investor who applies or bids for securities (shares) of or for a value not more than Rs. 2,00,000.

Important facilitators in the primary market issues are:

(a) Merchant Bankers to the issue or Book Running Lead Managers (BRLM)

(b) Syndicate Members

(c) Registrars to the issue

(d) Bankers to the issue

(e) Underwriters to the issue

(f) Auditors to the company

(g) Solicitors

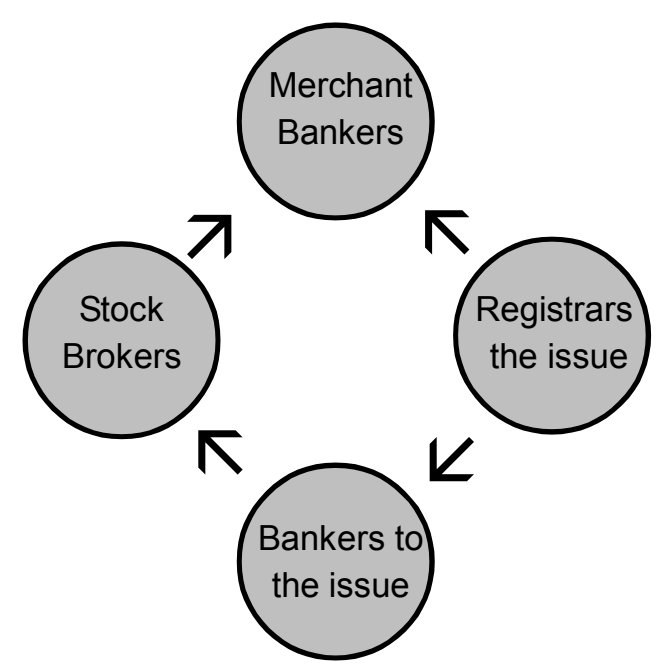




\section{Merchant Banker/Book Running Lead Manager (BRLM):}

A merchant banker needs to be registered with SEBI in accordance with the SEBI (Merchant Bankers) Regulations 1992 to act as a BRLM for an issue. In the pre-issue process, the Lead Manager (LM) takes up the due diligence of company's operations/ management/ business plans/ legal etc. Other activities of the LM include drafting and design of Offer documents, Prospectus, statutory advertisements and memorandum containing salient features of the Prospectus. The BRLMs ensure compliance with stipulated requirements and completion of prescribed formalities with the Stock Exchanges, RoC and SEBI including finalization of Prospectus and RoC filing. Appointment of other intermediaries viz., Registrar(s), Printers, Advertising Agency and Bankers to the Offer is also included in the pre-issue processes. The LM also draws up the various marketing strategies for the issue. The post issue activities including management of escrow accounts, coordinate non-institutional allocation, intimation of allocation and dispatch of refunds to bidders etc are performed by the LM. The post Offer activities for the Offer will involve essential follow-up steps, which include the finalization of trading and dealing of instruments and dispatch of certificates and demat of delivery of shares, with the various agencies connected with the work such as the Registrar(s) to the Offer and Bankers to the Offer and the bank handling refund business.

A merchant banker is required to do the necessary due diligence in case of QIP mechanism.

\section{Secondary Market}

Once the securities are issued in the primary market and/or listed in the Stock Exchange, these can be traded in a market called the Secondary Market. Secondary market is a platform for the investors to buy and sell the securities.

\section{Instruments - Capital Market}

\section{Equity Shares:}

The equity holder, popularly known as share holder is the part owner of the company. Depending upon the pattern of the share holding, the equity holder is entitled for dividends, and voting rights as members of the company. These shares can be obtained either through the Initial Public Offering (IPOs), Further/Follow-on Public Offering (FPOs) (primary markets) and can also be bought in the stock markets after the stocks are listed (Secondary markets)

\section{Rights issue (RIs):}

When a listed company wants to raise funds from the markets, one option available to the corporate is to arrange to issue additional/fresh stocks (shares/debentures) to the existing stock holders, known as Rights Issue. Rights Issues are offered to the existing shareholders whose names appear on a record date and in a particular ratio to the number of securities held by the shareholder.

\section{Preference Shares:}

The investors who hold the preference shares enjoy the following: (a) entitled for fixed dividend over other equity share holders. (b) In case of surplus, preference is given in distribution of income, over r equity share holders (c) In case of liquidation, their claims would rank above the equity share holders but only after the company's creditors, bond and debenture holders.. However, the preference share holders do not have the right to vote. .

\section{Debentures:}

One of the options available for an investor is to invest in a company's debentures. A debenture holder enjoys a fixed rate of interest payable every half year/year, on a fixed date. The principal amount is repayable on the date of redemption. Debenture holders are creditors of the company.

\section{Bonds:}

A bond is issued in the form of a negotiable certificate/ documents against indebtedness. 


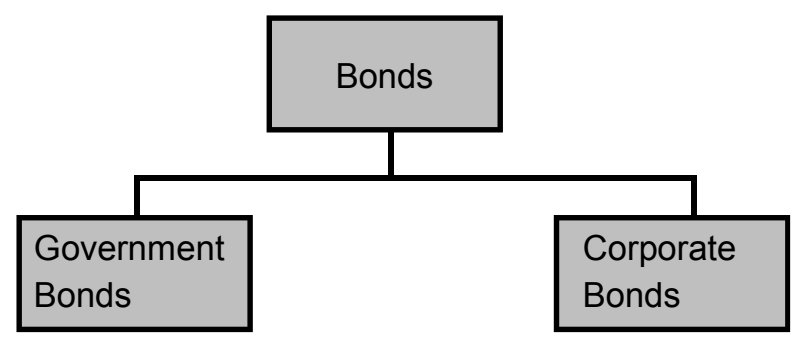

Bonds can be classified differently as per their characteristics, viz as coupon, zero coupon, and convertible and non-convertible etc.

\section{Coupon Bonds:}

When an investor invests in a bond, he gets his return on investment, based on the coupon rate (interest at a pre fixed rate).

\section{Zero Coupon Bonds:}

A bond which is issued at a discount and repaid at a face value is called a Zero Coupon Bond. No periodic interest is payable. The investor on the date of Redemption gets the face value of the bond and the difference between the face value and the issue price, is the return on investment for the investor.

\section{Convertible Bonds:}

The investor gets an option to convert the bond into equity at a fixed conversion price.

\section{Non-convertible Bonds:}

The investor does not have the option to convert the bond into equity.

\section{Commercial Paper (CP):}

Commercial papers are issued by companies with high credit ratings, in the form of promissory notes, at discount but repayable at par, to their holder at maturity. Commercial papers are money market instruments and issued as per the guidelines of the Reserve Bank of India.

\section{Certificate of Deposit (CD):}

A certificate of deposit (which is also a money market instrument) is issued by a bank. It is issued at discount to be redeemable at par on the maturity date. The minimum investment is Rs100,000. It is issued for a minimum period of 7 days up to a maximum period of one year. It is issued in the form of usance promissory note. The CDs can be traded in the market from the date of issue. The CDs are issued as per the guidelines of the Reserve Bank of India.

\section{MUTUAL FUNDS}

Mutual Funds play a key role as a financial intermediary in the financial services sector. A mutual fund pools money from investors and invests in Stocks, Debt and other financial securities. SEBI Regulations 1993 defines a mutual fund as: " a fund established in the form of a trust by a sponsor to raise monies by the trustees through the sale of units to the public, under one of more schemes, for investing in securities in accordance with these regulations"

\section{Role of Mutual Funds in the Capital Market:}

Mutual funds assist investors to have access to the capital markets through various schemes (as explained below). Mutual funds through their network across the country and also as financial advisors to their clients help the investors to invest in different schemes. To bring in uniformity as per SEBl's directives it is mandatory for any 
entity/person who markets/sells mutual fund products, to clear the required examinations conducted by the Association of Mutual Funds in India (AMFI)

Mutual Funds are classified into two broad categories based on the basis of execution. (i) Open ended and (ii) Close ended.

Apart from the above classification, mutual funds can also be classified into :

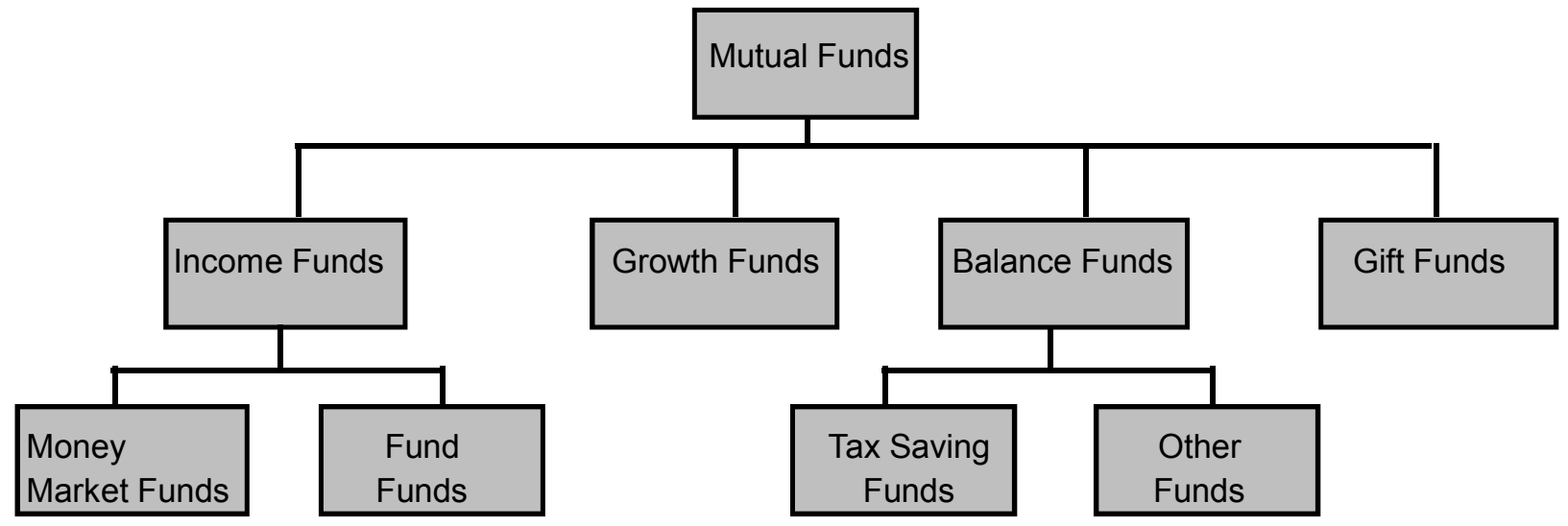

\section{Open ended funds:}

This is one of the popular mutual fund scheme. In this case, the size of the fund and the period of the fund is not pre fixed. The investors are free to buy and sell any number of units at any point of time.The main objective of the fund is income generation. The investors have the freedom of free entry and exit to/from an open ended fund. The units are not listed on the stock market, however the mutual fund would buy the units based on the Net Asset Value (NAV) of the units. Advantage to the investor is that the investor gets quick cash when he sells the units to the mutual fund on any working day.

\section{Close ended funds:}

Unlike the open ended funds, the corpus (total amount to be collected) and the duration are predetermined in this scheme. These are available for a parricular period, and the investors can buy the units at the face value.

Other important features are:

(i) The objective of the fund is capital appreication

(ii) The units under this scheme are traded in stock exchanges

(iii) At the time of redemption, the total funds collected under a close ended scheme would be liquidated and the proceeds are distributed among the unit holders.

\section{Income Funds:}

The objective of this fund scheme is to distribute income to the investors, regularly. The fund managers through their investment strategy, aim to provide a return better than the bank's fixed deposit interest .

\section{Growth Funds:}

For long term investors, one of the suitable option is growth funds. The fund managers aim to achieve capital appreciation through this fund. Regular income, is not distributed under this fund, like income funds.

\section{Balanced Funds:}

The features of the balanced funds are the combination of both income and growth funds. The special feature is that this fund aims at distribution of regular income and capital appreciation. The fund managers try to achieve 
this by balancing the investments between high growth equity shares as well as fixed income securities like debt instruments (T Bills, GOI Sec, etc.)

\section{Money Market Funds:}

An open ended scheme which exclusively invest in Money Market instruments like Certificate of Deposits, Commercial Papers, T.Bills and similar instruments, which are higly liquid and safe instruments. .

\section{Tax Savings Schemes:}

As part of tax planning, investors and income tax payers can invest in this fund. Depending upon the tax concession based on the provisions of the Income Tax Act, the investments under this fund attracts lot of investments especially during the period of January,February and March every year.

\section{Other Popular funds:}

\section{Index Funds:}

In view of the economic growth. the growing investment opportunities and to diversify risks, index funds are floated by mutual funds. Depending upon the market conditions, investment managers invest in specific index funds.

\section{Fund of Funds:}

When a mutual fund invests in their other funds or funds of other mutual funds, such investment is called fund of funds.

\section{Sectoral Funds:}

Investments are made in different sector wise industries like Pharma Companies, Banking, Automobile Companies etc., Depending upon the investment manager's investment strategy, the amounts are invested in different sectoral funds to gain the advantages of stock market movements.

\section{Net Asset Value (NAV):}

Mutual funds are required to declare the NAV for different schemes at regular intervals on their web sites. NAV is the net asset value of a particular fund, and the mutual funds calculate NAV on daily basis. The funds are bought and sold at the NAV, after the initial issue. NAV reflects the market conditions and may go up and down depending upon various factors. The redemption of units is based on the NAV of the particular scheme.

\section{Foreign Institutional Investors (FII):}

As per SEBI (FII) Regulations 1995, Foreign Institutional investor means an institution established or incorporated outside India which proposes to make investments in India in securities.

Foreign Institutional Investors need to be registered with SEBI to invest in the Indian equity and debt market..

\section{CAPITAL MARKET - OTHER INTERESTING FEATURES}

\section{Stock Exchange}

A stock exchange is a platform which provides services through stock brokers, to the investors/traders to buy/sell stocks, bonds and other securities. Trade on an exchange can be done only by its members, called stock brokers. The stock exchanges are regulated by the capital market regulator (SEBI).

The stock exchanges also provide clearing facilities for settlement of payments and delivery of securities.

Depository- Depository is an institution or a kind of organization which holds securities with it in which trading is done like shares, debentures, derivatives, commodities etc. There are two depositories in India: a) National Securities Depository Limited (NSDL) b) Central Depository Services Limited (CDSL) 
Depository Participant (DP) - A DP is an agent of the depository (NSDL/CDSL). It is an intermediary between the depository and the investor. ADP can offer depository related services only after obtaining a certificate of registration from SEBI.

\section{De-mat accounts:}

De-mat accounts are maintained in an electronic form. Dematerialization is the conversion of physical/ paper securities into the electronic form. The de-mat account is opened with a depository participant (e.g., a bank or a broker) who has an account with either Central Depository Services Limited (CDSL) or with National Securities Depository Limited (NSDL)

Stock brokers: These entities are members of stock exchange and are also required to be registered with the SEBI and be guided by the directives of SEBI. Stock brokers act as intermediaries between the buyer and the seller of stocks and other securities

\section{Qualified Institutional Buyers (QIBs)}

QIB are those institutional investors who are generally perceived to possess expertise and the financial muscle to evaluate and invest in the capital markets. They are covered by clause 2.2.2B (v) of SEBI (DIP) guidelines.. Some examples of QIBs are:

(i) Scheduled commercial banks ii. Mutual funds iii. Foreign institutional investors registered with SEBI iv. Venture capital funds registered with SEBI v. public financial institutions as defined under Indian Companies Act, 1956. vi. State Industrial Development Corporations vii Insurance Companies registered with Insurance Regulatory and Development Authority (IRDA)

\section{Foreign Direct Investment (FDI)}

It refers to Cross-border investment made by a resident in one economy with the objective of establishing a lasting interest in an enterprise.

According to IMF and OECD definitions, the acquisition of at least ten per cent of the ordinary shares or voting power in a public or private enterprise by non-resident investors makes it eligible to be categorized as FDI. However, in India there is no such official guideline for FDI, though FII is defined in SEBI regulations:

To support the economic growth of a nation, on account of inadequate domestic capital, flow of foreign capital is encouraged through the channel- Foreign Direct Investment. Apart from the capital funds, the FDI also brings with it, other benefits like technical knowhow, business expertise and knowledge and other advantages.

\section{FIPB: Functions:}

The main functions of Foreign Investment Promotion Board are:

(a) Expedite clearance process, (b) periodically review implementation of cleared proposals, (c) Review general and sectoral policy guidelines, (d) undertake investment promotion activities.

\section{LESSON ROUND UP}

- Capital market plays a crucial role in the economic development of the nation by assisting in the capital formation through primary and secondary market activities.

- Capital market which consist of many intermediaries (facilitators) like merchant bankers, bankers to the issue, stock brokers, and others, ensures that market participants are guided by the regulator SEBl's guidelines and directives.

- Many instruments (equity, debt, bonds) are traded in the secondary market. Mutual funds are very active through their net work, to attract investors to invest in their various schemes. 
- Apart from the domestic players, Flls also play an active role in the market movements. Foreign Direct Investment (FDI) is a window through which direct capital is flowing into the economy.

\section{SELF TEST QUESTIONS}

1. State whether the following statements are 'True' or 'False'

- SEBI is the regulator of Capital market as well as mutual funds

- Red Herring Prospectus (RHP) is issued by a mutual fund at the time of floating a new fund

- Bankers to the issues is an important facilitator in the secondary market

- Fund of funds is a scheme in which a mutual fund can invest in other mutual funds

- Foreign Institutional Investors can invest in capital markets

2. Choose the correct alternative:

A. Which of the following statement is correct?
(a) All Qualified Institutional Buyers are Flls
(b) Merchant Bankers need not register themselves with the SEBI
(c) Commercial Papers are issued by companies with high credit ratings.
(d) Certificate of deposit is not a short term investment

B. Identify the instrument which is not issued at discount.
(a) Commercial Paper
(b) Units of Mutual Fund
(c) Certificate of Deposit
(d) Zero coupon bonds

C. As regards capital market operations, who is not an intermediary?
(a) Merchant Bankers
(b) SEBI
(c) Mutual Funds
(d) Depositories

D. Which of the following statement is correct?
(a) Initial Public Offer is a term associated with the Capital Market
(b) NFO is a term not associated with Mutual Funds
(c) Commercial Paper is issued at Par
(d) A merchant banker should register with RBI

3. What role does financial system plays in an economy? Explain

4. Describe various types of bonds available in the financial market.

5. What do you mean by mutual funds? Explain the role of mutual funds in the financial market.

6. Discuss in brief about the different types of funds offered by mutual funds 
7. Highlight the features of primary and secondary markets.

8. Write short notes on following:
(a) Stock exchanges
(b) Qualified Institutional Buyers
(c) Treasury Bills
(d) Bonds
(e) Red Herring Prospectus 
254 PP-BL\&P 


\section{Lesson 10}

\section{International Banking Management}

\section{LESSON OUTLINE}

- International Banking - Overview

- Basel II

- Legal And Regulatory Frame Work

- Syndicated Credit - Important Features

- International Laws - Application In International Banking Scenario

- International Banking Operations Management

- Risk Management In International Banking

- Forex Markets - Features/ Issues

- Special Issues: Technology And International Banking

- Globalization And International Banking

- Financial Innovations In International Banking

- Lesson Round Up

- Self Test Questions

\section{LEARNING OBJECTIVES}

Banking activity crossing national borders is called as international banking. In today's ever changing competitive world, the growth of economies depends upon a country's linkage with different nations and the opportunities to create more international trade and financial activities. In this regard, the role played by banks across the globe with more and more international networking assumes importance.

After reading this unit the reader would be able to:

- Appreciate the important role of International Banking in Global Economic Development

- Analyze the various stages of evolution of International Banking

- Understand the implications of legal and regulatory framework

- Assess the risks associated with International Banking

- Understand the support of technology in international banking 


\section{INTERNATIONAL BANKING OVERVIEW}

International markets, offer opportunities to the traders and corporate and multinational companies, to expand their business, across different parts of the globe. International investors explore more investment avenues for their investments. The international markets in the financial sector offers a wide range of opportunities for expansion of trade and financial activities across the borders of nations.

"International Banking" can be defined as a sub-set of commercial banking transactions and activity having a cross-border and/or cross currency element. Multinational banking refers to the location and ownership of banking facilities in a large number of countries and geographic regions. International banking comprises a range of transactions that can be distinguished from purely domestic operations by (a) the currency of denomination of the transaction, (b) the residence of the bank customer and (c) the location of the booking office.

\section{International Banking - features:}

- Expansion: International Banking assists traders to expand their business and trade activities beyond the boundaries of a nation. Economic growth and conducive climate for carrying out the business activities in new nations are the factors because of which many enterprises are looking beyond the borders of their own nations for their business growth. Competitive advantages in respect of price, demand and supply factors, future growth opportunities, cost of production and operating costs, etc., are some of the other important factors for expansion of international trade and finance. In view of this, the presence of banks across the nations have led to the growth of international banking.

- Legal and Regulatory framework: Flexible legal and regulatory framework encourages traders and investors to enter into the international markets. Quick approval to set up business, less complicated compliance requirements and stable political situations help many new players to enter into a number of nations to expand their activities Also, due to lesser tax rates or no taxes to be payable, certain tax havens play important roles as off shore banking centers which encourages many international banking units to open their branches in such off shore centers.

- Cost of Capital: The operating efficiency of an enterprise depends upon the average cost of capital. Many companies enter into new emerging markets to take advantages of the lower cost of capital in such markets. Banks as a financial intermediary play an important role as source of funds.

Banks through their professional skills take advantage of the arbitrage opportunity in different international markets and increase their profits.

- Current account and Capital account transactions: Banks play crucial role in export and import trade. By providing different types of financial and non financial support, banks help enterprises, corporate customers and individuals doing business in different countries, by extending trade finance and investment opportunities. Banks also facilitate movement of funds (inward and outward remittances) through their network and correspondent banking arrangements.

- Risks: Different risks paved ways for diversification, thereby global investors look for alternative destinations to invest their savings with twin objectives of safety of funds and better returns. In view of their presence in different time zones, international banks also face various risks.

\section{Evolution of International Banking}

International monetary system has seen many changes over centuries. Initially the barter system was used as a medium of exchange to settle receipts and payments, on account of economic activities.. Different items like precious stones, gold, paper, etc., have been used as currency. Two important events which took place in 
international financial markets during the last century $\left(20^{\text {th }}\right.$ century) are: evolution of the Gold Standard System, Fixed and Floating exchange rate system.

\section{Gold Standard System:}

This system was used till the First World War. The gold standard system was based on the value of gold and subject to the value of gold held by the government/monetary authority. Over the years, different types of gold standards were practiced. There were gold specie, gold bullion standards and gold exchange system.

\section{Gold Specie Standard:}

Under this system actual gold coins and/or coins with fixed contents of gold were in circulation.

This system worked subject to certain conditions like: (i) the governments declare that the gold was the currency for exchange goods and services (ii) value of gold coin was same as value of gold content in it (iii) gold could be freely exported and imported

\section{Gold Bullion Standard:}

This system was introduced by USA. Under this system the monetary authorities held stock of gold. Currency in circulation was a paper currency. The currency was pegged to gold, and was unconditionally convertible to gold, on demand. The gold quantity per currency note was fixed by the issuing governments.

\section{Gold Exchange Standard:}

Under this system, as promised by the monetary authorities, currency was exchangeable for another currency at a particular ratio. Another currency, with which it was pegged, was called as reserve currency. In view of their dominance in the international markets, US Dollar or British Pound was used as reserve currency by many nations. These reserve currencies in turn, were convertible to real gold as in the case of gold bullion standard.

Gold Standard System - Important features:

- Monetary authority/Government was allowed to issue currency only against sufficient quantity of gold.

- Exchange rates were based on the ratios of gold quantity held against each currency; therefore gold parity was not subject to frequent changes. In view of the above, this system ensured fixed exchange rates.

- Limitations - The monetary authority/governments were to remain ready to convert unlimited amount of paper currency to gold at any time.

- The issuance of the currency was subject to the condition that the issuing authorities should hold exact quantity of gold in reserve, and in case the quantity decreases, the authorities should reduce the notes in circulation.

- Many nations faced difficulties in maintenance of gold parity (ratio) due to various reasons including political and unforeseen circumstance like war, natural calamities, etc.

- In view of the shortage of supply of gold, it became difficult to continue the system.

Gold Standard - Reasons for failure:

- On account of World War I, the United Kingdom stopped using the gold specie system and replaced it with the bullion standard.

- The bullion standard lasted until 1931. The United Kingdom stopped using the gold bullion standard also as it felt that large amounts of gold was being transferred to other nations. 
- On account of great depression nations like Australia, Canada etc had withdrawn from the gold standard due to monetary issues.

- In US, the gold standard came to an end in 1933, when President Roosevelt prohibited owning of gold privately, except for gold jewellery.

- World Wars led to the situation for more demand for financial support to meet war expenses. This led to a situation which forced monetary authorities/governments to print more currency notes without adequate support of gold available in the respective treasuries of monetary authorities/governments.

- Added to these issues, many countries faced problems of low GDP, higher inflationary pressures, and decline in the value of the currencies.

\section{Bretton Woods Conference}

The first half of the $20^{\text {th }}$ century witnessed many issues, such as, the First World War, 1929 Wall Street crash, the great depression, the Second World War and most importantly, the failure of the Gold Standard System. Many nations across the globe faced financial crisis, and this led to the policy makers to address these international financial issues. After the Second World War, in 1944, 44 Allied nations met at Bretton Woods, in New Hampshire of the USA. The Bretton Woods Conference has thus become an important milestone in the international banking system.

The main objectives of the new monetary order were:

- To establish an international monetary system with stable exchange rates

- To eliminate existing exchange controls

- To aim to bring convertibility of all currencies

The Bretton Woods Conference, created a new system popularly called as "Bretton Woods System"

Bretton Woods System paved the way for the formation of three important multilateral International institutions viz., -

- International Monetary Fund (IMF)

- International Bank for Reconstruction and Development (IBRD) - popularly known as "World Bank"

- International Trade Organization

\section{Bretton Woods Systems - Important Aspects:}

(i) The United States of America (USA) took the responsibility to convert the US Dollar into gold at a fixed parity of US $\$ 35$ per ounce of gold ( 1 troy ounce $=31.10$ grams) ii. Other member countries of IMF, agreed to maintain their currencies at specific parities (ratio) against US Dollar. There was a variance of $1 \%$ (plus or minus) allowed in the parity iii. In case the exchange rate of the member countries exceeds the $1 \%$ threshold limit, then the monetary authorities should take necessary steps to restore the situation. In case the market was buying dollars heavily, the authorities should arrange to sell dollars in order to maintain the parity.

(iv) To manage the parity level, member banks were allowed to borrow from IMF in the form of Special Drawing Rights (SDRs)

\section{International Monetary Fund (IMF)}

It was created in 1945 and presently has 188 members. Its Objectives are: 
(a) to promote international monetary cooperation,

(b) to strive for stable exchange rates

(c) to facilitate the balanced growth of international trade and creation of employment opportunities

(d) to assist in establishment of a multilateral payment system e. to assist member countries in case of balance of payments crisis

\section{Bank for International Settlement (BIS)}

BIS offers a wide range of financial services specifically designed to assist the central banks and the other official monetary institutions in management of their foreign exchange reserves. It is headquartered at Basel and has 140 customers including various international financial institutions who currently make use of these services. It provides Asset Management services in sovereign securities or high grade assets. It also extends short term credits to central banks, usually on a collateralized basis. It does not provide services to private individuals or private entities/corporate...

- Since 1930, the BIS have the legal form of a corporation. Its Board of Directors consists of 19 members out of which the Governors of central banks of Belgium, France, Germany, Italy, UK and US Fed chairman are the ex-officio members.

- The objective of BIS as per its Article :: 'The objects of the bank are to promote the cooperation of central banks and to provide additional facilities for international financial operations, and to act as trustee or an agent in regard to international financial settlements entrusted to it under agreements with the parties concerned'.

One of the important roles played by BIS was to create a Standing Committee of Bank Supervisors to address various international issues including international payment problems which arose on account of Herstatt crisis. Further, Banks across the globe have been advised by BIS to follow the systems and procedures in respect of capital adequacy norms, loan loss provisioning etc:

Herstatt Crisis: In the early stages of the floating exchange rate regime, the risk of default by the counter party in a spot foreign exchange transaction was highlighted by the Herstatt crisis. In this case, Deutsche (German) marks, were sold to Herstatt on $24^{\text {th }}$ June 1974 , by a number of banks on spot basis, the settlement of dollars was due on $26^{\text {th }}$ June1974. On the date of settlement the German marks were debited to the respective bank's account and the funds were deposited in Landes-Central Bank the clearing house of Bundesbank, and in turn credited to Herstatt. Before the settlement in dollars was made to the respective counterparty banks, Bankhaus Herstatt was officially declared bankrupt around $4.00 \mathrm{pm}$ on $26^{\text {th }}$ June, 1974 . This happened after the market closed in Germany but while foreign exchange was being traded in New York. By closing Herstatt before dollar settlements for the day, the Bundesbank exposed a risk (inter-bank credit risk) involved in spot foreign exchange transactions. This was one of the important cases in International Banking Scenario which highlighted the importance of the credit risk among banks.

Basle Concordat (1974) Highlighting the need for better supervision, guidelines were framed and approved by the Central Bank Governors of the Group of Ten in December 1975, and is called as "Basle Concordat". This is considered as an important milestone of international banks' supervisory cooperation'. The group of ten countries consist of Belgium, Canada, France, Germany, Italy, Japan, the Netherlands, Sweden, the United Kingdom and the United States, Switzerland was also included as part of the group.

\section{Basle Concordat (1974) - Important features:}

(a) The supervision of foreign banking establishments is the joint responsibility of parent and host authorities

(b) The supervision of liquidity is the primary responsibility of the host authorities 
(c) The supervision of solvency is essentially a matter for the parent authority in the case of foreign branches and in case of foreign subsidiaries the responsibility rest with the host authority

\section{Revised Basle Concordat (1983)}

In 1983, a revised version of the Basle Concordat was introduced. Effective cooperation between host and parent authorities is a central precondition for the supervision of banks' international operations. The supervision of banks' foreign establishments is considered from three aspects viz: solvency, liquidity and foreign exchange operations and position.

Solvency: The allocation of responsibilities for the supervision of solvency of banks foreign establishment between host and parent authorities will depend upon the type of establishment. For branches, their solvency is indistinguishable from that of the parent bank. For subsidiaries, thesupervision of solvency is a joint responsibility of both host and parent authorities. For joint ventures, the supervision of solvency should normally for practical reasons, be primarily the responsibility of the authorities in the country of incorporation.

Liquidity: The host authority is responsible for monitoring the liquidity of the foreign banks

Establishment in its country; the parent authority has responsibility for monitoring the liquidity of the banking group as a whole. For subsidiaries, primary responsibility for supervising liquidity should rest with the host authority.

Foreign Exchange Operations and Position: There should be a joint responsibility of parent and host authorities. Host authorities should be able to monitor the foreign exchange exposure of foreign establishments in their territories. They also need to be informed of the status of supervision undertaken by the parent authorities on these establishments.

Basle Capital Accord (1988): A committee of central banks of G10 countries was formed to stabilize the international banking system and regulate them as well. This is called as Basle Committee on Banking Supervision (BCBS). The Basle committee published a set of minimal capital requirements for Banks and this is called as the 1988 Basel Accord, which was enforced by law in G10 nations in 1992.

The main objective of the Basel Accord was to reinforce the capital base of the world's major banks, which were being eroded due to severe competition among the banks. This is also recognized as Basel I.

As per 1988 Accord, banks were advised to maintain capital equal to a minimum $8 \%$ of a basket of assets measured based on the basis of their risk. Banks were advised to maintain two tiers of capital viz., Tier I consisting of shareholders' equity and retained earnings, and Tier II covering additional internal and external resources available to the bank (example - Undisclosed reserves; Asset revaluation reserves, General provisions/general loan loss reserves, Hybrid (debt/equity) capital instruments and Subordinated debt.

The twin objectives of Basel I were:

(a) to ensure an adequate level of capital in the international banking system and

(b) to create a more level playing field in the competitive environment.

\section{BASEL II}

In January 2001, the Basel Committee on Banking Supervision issued a new proposal for a Basel Capital Accord to replace the 1988 Accord. The New Basel Capital Accord focused on, three pillars viz.

- Pillar I - Minimum capital requirement

- Pillar II - Supervisory review

- Pillar III - Market discipline 
Pillar I - Minimum capital requirement: The Committee on Banking Supervision recommended the target standard ratio of capital to Risk Weighted Assets should be at least $8 \%$ (of which the core capital element would be at least $4 \%$ ). The minimum capital adequacy ratio of $8 \%$ was prescribed taking into account the credit risk. However, in India the Reserve Bank of India has prescribed the minimum capital adequacy ratio of $9 \%$ of Risk Weighted Assets.

Pillar II - Supervisory review: The Supervisory review should be carried out in the following manner.

- Banks should have a process for assessing their overall capital adequacy

- Supervisors should review banks' assessments

- Banks are expected to operate above minimum

- Supervisor's intervention if capital is not sufficient

\section{Pillar III: Market Discipline}

1. Role of the market in evaluating the adequacy of bank capital

2. Streamlined catalogue of disclosure requirements

3. Close coordination with International Accounting Standards Board

4. in principle, disclosure of data on semiannual basis

\section{LEGAL AND REGULATORY FRAME WORK}

The legal framework that deals with various aspects of forex management in India is the Foreign Exchange Management Act, 1999 (FEMA 1999) which was implemented on $1^{\text {st }}$ of June, 2000. FEMA, 1999 replaced the Foreign Exchange Regulation Act, 1973 (FERA 1973)

FEMA, 1999 - salient features:

1. FEMA 1999 was enacted as part of liberalization process

2. The main objective of FEMA is to consolidate and amend the law relating to foreign exchange to facilitate external trade and payments and also to develop foreign exchange markets in India.

There are certain distinctions in the features of FERA and FEMA. They are:

\begin{tabular}{|l|l|}
\hline \multicolumn{1}{|c|}{ FOREIGN EXCHANGE REGULATION ACT 1973 } & \multicolumn{1}{c|}{ FOREIGN EXCHANGE MANAGEMENT ACT 1999 } \\
\hline $\begin{array}{l}\text { To conserve foreign exchange and to prevent its } \\
\text { misuse }\end{array}$ & $\begin{array}{l}\text { To facilitate external trade and payments and also to } \\
\text { develop foreign exchange markets in India }\end{array}$ \\
\hline Violation of FERA was a criminal offence & Violation of FEMA is a civil offence \\
\hline Offences under FERA were not compoundable & Offences under FEMA are compoundable \\
\hline $\begin{array}{l}\text { While many restrictions were part of FERA in respect } \\
\text { of transfer of funds }\end{array}$ & $\begin{array}{l}\text { Almost all current account transactions are free except } \\
\text { a few }\end{array}$ \\
\hline FERA was draconian criminal law & FEMA is a civil law \\
\hline
\end{tabular}

FEMA extends to whole of India. It also has some extra territorial jurisdiction i.e., it applies to all branches, offices and agencies outside India owned and controlled by a person resident in India. The provisions of FEMA are also applicable to any contravention committed outside India by any person.

Reserve Bank of India has overall control over the foreign exchange transactions; however, the enforcement of 
FEMA has been entrusted to the "Directorate of Enforcement' formed for this purpose

\section{FEMA - Important aspects:}

FEMA allows free flow of transactions on current account subject to certain reasonable restrictions

FEMA has control over realization of export proceeds

FEMA allows RBI to have control over capital account transactions

FEMA provides for dealing in foreign exchange through 'Authorised Persons' like authorized dealer/money changer/ off-shore banking unit;

\section{Legal Issues in International Banking Transactions}

Legal issues associated with international banking transactions arise due to involvement of more than one law/s of different countries. Due to various reasons, even in a simple two party loan agreement a number of different legal systems may be involved, for example an independent currency may be used for the transaction, but the loan is guaranteed by a third party based in another country. Under such circumstances, more than one law would be used.

In such a situation, the court would consider such cases, which contains a foreign element, principles of private international law, or conflict of laws, come into operation. The objects of private international law are:

1. to ascertain whether a court has jurisdiction to determine the case

2. to identify which system of law the court will apply to the determine fact of the case

3. to determine whether the court will recognize or enforce a judgment obtained in a foreign court

It is of the utmost importance that the legal aspects of any international banking transactions are made as predictable as possible. This question of predictability does not normally pose a significant problem in purely domestic banking transactions, since the rights and obligations of the various parties will normally be determined by the local systems of law under which they contract. However, this will not necessarily be the case in international banking and it will therefore be crucial to structure the transaction documentation within a competent legal framework. The most effective way in which this can be achieved is by selecting both (i) the system of law which governs the substantive aspects of the transaction, and (ii) the court which will have jurisdiction to resolve any dispute that may arise.

In view of the above, the international banks sometimes, face difficulties while handling the syndicated loans, depending upon the number of banks and countries involved.

\section{SYNDICATED CREDIT - IMPORTANT FEATURES}

The syndicated credit is a loan offered by a group of banks to a borrower. The lenders give loan/s against a common loan document specifying the terms and conditions as agreed to between the lenders (who have formed the syndicate) and the borrower. Usually, the syndicated credit is in the form of euro currency or denominated in US\$. Generally, these credits are designed based on the floating interest rates.

Parties to a syndicated loan agreement and their role:

(a) Following are generally, the parties to International Syndicated Loan (other than the borrower, guarantor and the group of lenders): i) Arranger or Mandated Lead Arranger ii) Book Runner iii) Agent iv) Security Trustee.

(b) (i) The arranger is responsible for advising the borrower as to the type of facilities required and then negotiating the broad terms and conditions for those facilities. ii) Book Runner invites Banks to join the 
syndicate and keep a record of how much debt each of the potential syndicate members wants to take. (iii) Agent: one bank from the syndicate is appointed as Agent of lenders and acts as- Point of contact (between the borrower and the lenders) - monitors compliance of terms of the facility by the borroweracts as a postman and record keeper- (borrower usually gives notice to the Agent) - the borrower makes all payments to the Agent who passes on these monies to syndicate members as per their share. iv) Security Trustee - He holds the security on trust for the benefit of all lenders.

In case of international loan agreements, banks and clients would incorporate an express choice of law clause within the terms of the contract documents. In case, if express choice is not mentioned, the contract would be governed by the system of law with which the transaction has its closest and most real connection. Another important aspect for the banks is to identify and determine

- the enforcement in the borrower's own jurisdiction, and/or

- in such jurisdictions where the borrower's assets are situated

The important aspects of the international loan agreement/s are:

- Clarity: The various terms and conditions are clearly mentioned. The borrower's status, incorporation, financial projections and other important aspects are clearly indicated

- Clearance/s: The loan agreement should specify the various clearances which are to be obtained by the borrower from government and regulatory authorities in the country, before any draw-down is allowed

- Condition/s: (i)The loan agreement should specify the procedure for the drawdown of the loan, the commitment period, method of draw down etc., (ii) Repayment schedule should be clearly indicated, and the pre payment option should also be clearly incorporated in the agreement

- Commitment fee/s: The loan agreement should clearly specify the commitment fees, front-end fees and interest payable (floating or fixed) indication of interest rate as LIBOR +75 basis points etc.,

- Confirmation: The loan agreement should confirm the methodology of the application of LIBOR. Generally the agent bank would find out the offered rates of a group of "reference banks" on a rollover day and the average is the applicable LIBOR.

- Cross-Default, Jurisdiction and Sovereign Immunity: Certain important clauses, if properly vetted would assist the lender in case of recovery.

Jurisdiction: The loan agreement should specify the place (jurisdiction) whose laws are applicable to the interpretation of the rights and obligations under it.

Cross-default: Cross-default clause allows the lenders the right to accelerate recovery of the loan in the event of default by the borrower or the guarantor/s under any other loan agreement

Sovereign immunity: An express waiver of sovereign immunity, is obtained from the borrower or guarantor as the case may be

\section{INTERNATIONAL LAWS - APPLICATION IN INTERNATIONAL BANKING SCENARIO}

- Choice of Laws: In case of cross border transactions, it is important to determine which law should govern the international banking transaction/s. Hence, it is imperative to choose a particular law which would protect the rights and obligations of the parties involved.

- Proper Law: The selection of choice of legal clause is very important to ensure that a proper law is selected, to protect the rights and obligations of the parties concerned. For example, the typical clause which would be incorporated in the agreements would be like this: 'This agreement shall be governed, continued and interpreted in accordance with the law of (the name of the country). 
This indicates that the parties concerned have agreed to a particular law, if there is any dispute in the future, to protect their rights and obligations.

- Recognition and enforcement of judgments: This is another important aspect which deals with enforcement of judgments rendered by foreign courts or awards of foreign arbitrations.

In view of the past experience London (English) and New York Laws are preferred since both have a well developed legal framework, covering the commercial jurisprudence which is very well integrated with the international banking system.

Language: An important factor which influences the selection of law is the language in which the International financial market deals and financial terms are used. English is preferred as an international language; therefore there is a preference for either English Law or New York Law.

The selection of the court which would have primary jurisdiction over any dispute is also influenced

By the following reasons:

(a) Speedy and effective judicial remedies in case of any breach of international agreements

(b) Recognition and enforcement of the judgments by the courts in other countries

\section{Legal Issues - Trade Disputes:}

The international trade and finance have certain peculiar aspects, some of which are given below:

- Buyers and sellers, investors, lenders, borrowers rarely meet each other

- On account of locations at different time zones, long distances(proximity), culture, political setup, languages, currency, systems and procedures, legal frame work, interpretations etc., invariably international commercial and financial markets face lot of differences and issues in dealing with different types of clients/ banks.

- The international trade takes place basically with the support of relevant documents and legal papers. Some of the important documents used are: Letters of Credit, Guarantees, Bills of Exchanges, Trade and loan agreements and other supporting commercial (Commercial Invoice) transportation (Bills of Lading), risk covering (Insurance Policy) and regulatory documents.

- The International Chamber of Commerce (ICC) Paris, publishes the UCPDC (Uniform Customs and Practices for Documentary Credits) and international trade related guidelines. In view of this, the honorable courts generally recognize these guidelines and refrain from giving verdicts in respect of trade disputes and the concerned parties are advised to be governed by ICC publications relevant to various transactions. International Chamber of Commerce (ICC) provides a conciliation/arbitration platform for settlement of international trade disputes. Besides this, Singapore International Arbitration Center has also of late, become a widely acceptable center for arbitration of disputes in international trade.

Derivative Transactions: Derivative is a financial instrument which derives its value from the value of underlying entities such as an asset, index or interest rate. It has no intrinsic value in itself. Derivative transactions include a variety of financial contracts including structured debt obligations and deposits, swaps, futures, options, caps, floors, collars, Forwards and various combinations of these...Different types of derivative instruments are used as risk management tools to hedge various risks like credit risk, interest rate risk, foreign exchange risk, etc.,

\section{Standardization of Legal Documents:}

As regards the derivative transactions, one of the important concerns for the international market players is the enforceability, which presents the greatest legal risk.

To mitigate the Legal Risk, some of the important standardized legal documents used in international banking 
system are:

- Master Agreements (Documentation)

- International Swap and Derivatives Association Master Agreement (ISDA)

- International Currency Options Master Agreement (ICOM)

- International Foreign Exchange Master Agreement (IFEMA)

ISDA Master Agreement is a comprehensive, omnibus document covering various derivatives Transactions/ deals.

\section{INTERNATIONAL BANKING OPERATIONS MANAGEMENT}

International banking is one of the important constituents of the international financial sector. Since 1973 it has acquired new characteristics and dimensions. The number of participants, which at the beginning of the period were mainly American banks, has considerably widened to include German, UK, Japanese, French, Italian and now Asian banks branches and subsidiaries. In view of the large scale expansion of international banking, with more cross border transactions, international banks have to face many issues like

- Cross border risks

- International legal and regulatory framework

- Money laundering activities

- Volatile international markets due to various factors including PESTEL factors

All these issues put more and more pressures on the operations of international banks across the nations. This has called for a collective effort to manage these issues, by strengthening the operational activities of international banks.

Some of the important features of Operations Management are:

Expansion of business: International banks are linked together in various ways;

(i) Correspondent banks

(ii) Foreign branches

(iii) Foreign subsidiaries and affiliates

(iv) Off shore Banking Units

(i) Correspondent banks: An informal linkage between banks in different countries is set up when banks maintain correspondent accounts with each other. Large banks have correspondent relationships with banks in almost every country in which they do not have an office of their own. The purpose of maintaining foreign correspondents is to facilitate international payments and collections for customers. Correspondent banking allows banks to help their clients in their business abroad. This relationship is primarily for settling customer payments, but it can also be extended to providing limited credit for each other's customers and to setting up contacts between local business people and the clients of the correspondent banks. Correspondent banking relationship is especially useful in issuing / confirming L/Cs, Guarantees, and Bid Bonds etc.

(ii) Foreign branches: When banks open their branches in another country/countries they are designated as "Foreign Branches". Foreign branches are subject to both Host country banking rules and the rules at home. The books of a foreign branch are incorporated in those of the parent bank, although the foreign branch will also maintain separate books for revealing separate performance, for tax purposes, for local authorities. Generally, these foreign branches are equipped with latest technology, and on account of competitive advantages they can offer better customer service, as well as innovative products to their clients. 
(iii) Foreign Subsidiaries and Affiliates: A foreign subsidiary is a locally incorporated bank that happens to be owned either completely or partially by a foreign parent. Foreign subsidiaries do all types of banking, and it may be very difficult to distinguish them from an ordinary locally owned bank.

Foreign subsidiaries are controlled by foreign owners, even if the foreign ownership is partial. Foreign affiliates are similar to subsidiaries in being locally incorporated, but they are joint ventures, and no individual foreign owner has control (even though a group of foreign owners might have control).

(iv) Off Shore Banking Unit (OBU): International banking handles its operations through many channels, as explained above. However off shore banking is having certain special features over others. An off shore bank is a bank located outside the country of residence of the depositor. These OBUs are generally located in a low tax jurisdiction or tax haven that provides tax and legal advantages.

Important features of offshore banks:

(a) Offshore banks provide access to politically and economically stable jurisdictions. This helps residents of many nations which are politically not very stable to make use of offshore banking units located in other centers, who can offer better avenues for their investments.

(b) Higher interest rates for deposits: In most of the offshore centers, banks have freedom to offer their own interest rates without any restrictions. In view of the lower cost of operations and other competitive advantages, off shore banks can offer higher rates to their depositors.

(c) Most of the offshore banks are located in tax havens, there by either lower taxes needs to be paid or no tax is applicable.

(d) In most off shore banking centers, banks get exemption from reserve requirements, hence costs are lower

(e) One of the issues faced by off shore banking units, in view of lesser regulatory controls, is that these units are used as a vehicle for money laundering activities Offshore Banking in India - salient features: In India offshore banking units have been permitted to be setup in Special Economic Zones (SEZs).

Article 10 of the Foreign Exchange Management Act, 1999 allows Reserve Bank of India to delegate powers to offshore banking units to deal in foreign exchange.

SEZs are treated as a foreign territory for the purpose of trade operations and duties/tariffs to encourage exports OBUs would be considered as foreign branches of Indian banks located in India.

These OBUs would be exempt from reserve requirements and provide access to SEZ units and SEZ developers to international finances at international rates.

\section{OBUs would be offering wholesale banking services}

By setting up different types of outlets and links like correspondent banks, foreign branches, foreign subsidiaries and affiliates, off shore banking units International banks manage their operations across various financial markets operating in different time zones. International banks operational efficiency would depend upon (i) effective international risk management system (ii) good corporate governance practices (iii) keeping pace with the changed environment by offering innovative cost effective products and services (iv) taking advantage of the technological revolutions.

\section{RISK MANAGEMENT IN INTERNATIONAL BANKING}

While risks are integral part of our lives, and are applicable to domestic trade and investment arena also, as far as international banking activities are concerned, these banks are exposed to additional risks on account of various factors. The important factors are: 
- Cross Border Risk: The cross border risks arise on account of trade and investment activities between two or more countries. This is one of the major risks the international banks face. This type of risk is also called as country risk

- Currency Risk: When an international trade and/or financial transaction take place, it would result in a currency deal. In view of the additional deal (involvement of foreign currency) a new risk arises called currency risk. Two or more than two currencies (in case of cross rates) are involved, and due to the market fluctuations the exchange rate (price) of the currencies results in a risk called "foreign exchange rate risk" as well

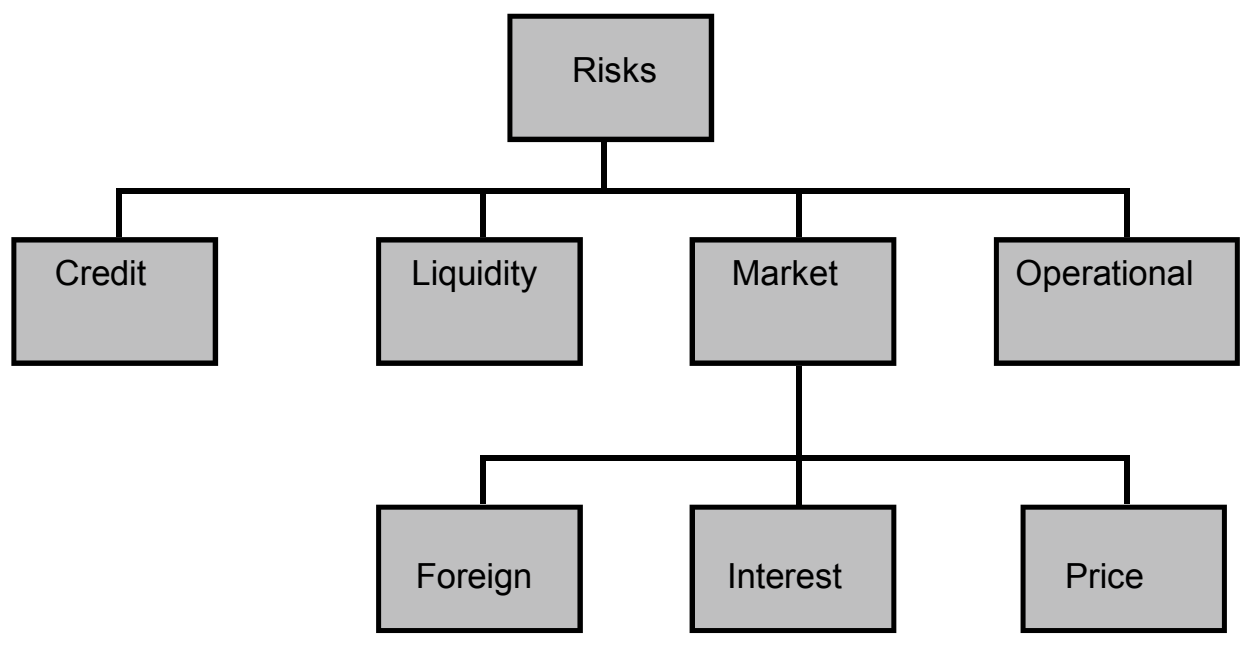

In addition to the above, the other risks associated with international banking are given below:

Credit Risk: In today's complicated international financial markets, the credit risk arises on account of nonperformance of obligations by counterparty in respect of On balance sheet items as well as off-balance sheet contracts such as forward contracts, interest rate swaps and currency swaps and counterparty risk in the interbank market. These have necessitated prescribing maximum exposure limits for individual counterparties for fund and non-fund exposures.

Mitigation of Credit Risk: To manage various risks, banks have formulated Risk Management policies duly approved by their board. Some of the risk mitigation practices are mentioned below:

- Banks have setup experienced credit management team to ensure better credit appraisal

- To restrict exposures, credit limits are setup both for at individual and group wise levels

- Investments are subject to bank's Investment Policy guidelines. Bank's investment policy is formulated as per the Regulator's directives

- In view of the uncertainties associated with the non performance in case of off balance sheet items like letters of credit, guarantees, derivative products like forward exchange contracts, futures, interest rate swaps, options, etc., a full credit appraisal needs to be carried out before limits for non funded credit lines are granted to the clients

- Adequate financial and/or physical assets should be obtained as collateral security. On an ongoing basis valuation of such collateral security should be carried out based on the market prices (this procedure is called as market to market practice) to assess the present value

- Exposure limits should be put in place covering counterparty, industry, country, and business group, currency for on and off balance sheet items. 


\section{Operational Risks:}

Operational risks can arise due to

- Non-compliance with laid-down procedures and authorizations for dealing, settlement and custody;

- Fraudulent practices involving deals and settlements;

- Legal risks due to inadequate definitions and coverage of covenants and responsibilities of the bank and counterparty in contracts and agreements.

- Information Technology, which drives the markets, should be given importance in managing the risks, especially the operational risks. The quality of software, hardware and the up gradation of IT support system are very crucial for ensuring quick and correct transfer of financial transactions and funds across the international markets. Hence importance needs to be given to handle this particular segment to ensure better control is exercised in disaster control management with an effective and tested backup system.

- Human Resource Management needs to be given proper attention to reduce the impact of operational risks through human errors and systems failure. Good and effective training would help the banks to have better results and lesser operational risks.

- Non compliance of legal and/or regulatory frame work, due to inadequate definitions and coverage of covenants and responsibilities of the bank and counterparty in contracts (especially in case of international loan agreements, derivative agreements, etc.).

- Frauds, insufficient internal control systems: Operational risks can be reduced if banks have a clear cut and effective internal control and audit systems. Banks Treasury functions should be demarcated clearly into (i) Front Office (ii) Mid Office (iii) Back Office, to have better control system. The internal control system should be effective in the sense quite a few activities should be subject to online (concurrent) audit, and risk evaluation should be an integral part of an effective internal control system.

- Money laundering: International banks main concern is to manage the money laundering activities. In view of the fast changing and increasing usage of technology, funds can be transferred from one end to the other part of the world quickly. Unless banks are geared up with a better control system to manage the money laundering it would create lot of operational risks for banks. To ensure better control system, banks should ensure that clear KYC policies are strictly followed at all levels, especially at the entry level of a financial transaction.

\section{Adherence to systems and procedures:}

Traders, dealers and other bank employees should strictly follow the guidelines, and ensure

(i) The limits (single borrower limit, group wise limit, counter party limit, country limits, overnight and day light limit, stop loss limit, gap limit etc.) are respected and they operate within the limits. (ii) All activities, operations are as per approved policies, systems and procedures and with proper approvals, authorizations. (iii) A proper reporting system should be in place for better management review and control and risk identification. To this end the Management Information System should not only be accurate, but also user friendly. (iv) There should be proper co-ordination between different divisions of the banks for a better result. ( $v$ ) A fair Performance Appraisal System is one of the key factors and this aspect needs to be given proper weights. (vi) Big ticket deals, transactions and legal documentation should be properly designed and vetted to protect the banks, especially in one-off transactions and structured deals. (vii) International banking is part of the international markets, which operate on $24 \times 7$ Basis, in different time zones covering various international centers. Hence banks should give importance to market volatility due to different reasons like PESTEL factors, technical and fundamental factors, and an ongoing 
review is very important in managing various risks by taking proper and pro active actions. (viii) With Basel III norms around the corner, banks in international markets need to put in place an effective and efficient risk management system, to identify various types of risks and manage them.

\section{FOREX MARKETS - FEATURESI ISSUES}

Foreign Exchange Markets (forex markets) play a very crucial role in international trade and financial sector. Salient features of Forex markets and their implications on international banking operations:

- Forex markets operate on $24 \times 7$ basis and therefore provide greater opportunity to the international banking system to handle the current account and capital account transactions

- These markets have become a driving force for vibrant global economies.

- In view of various PESTEL factors, forex markets are sensitive to the volatility, which results in the movements of exchange rates/ interest rates, and are also exposed to various kinds of risks

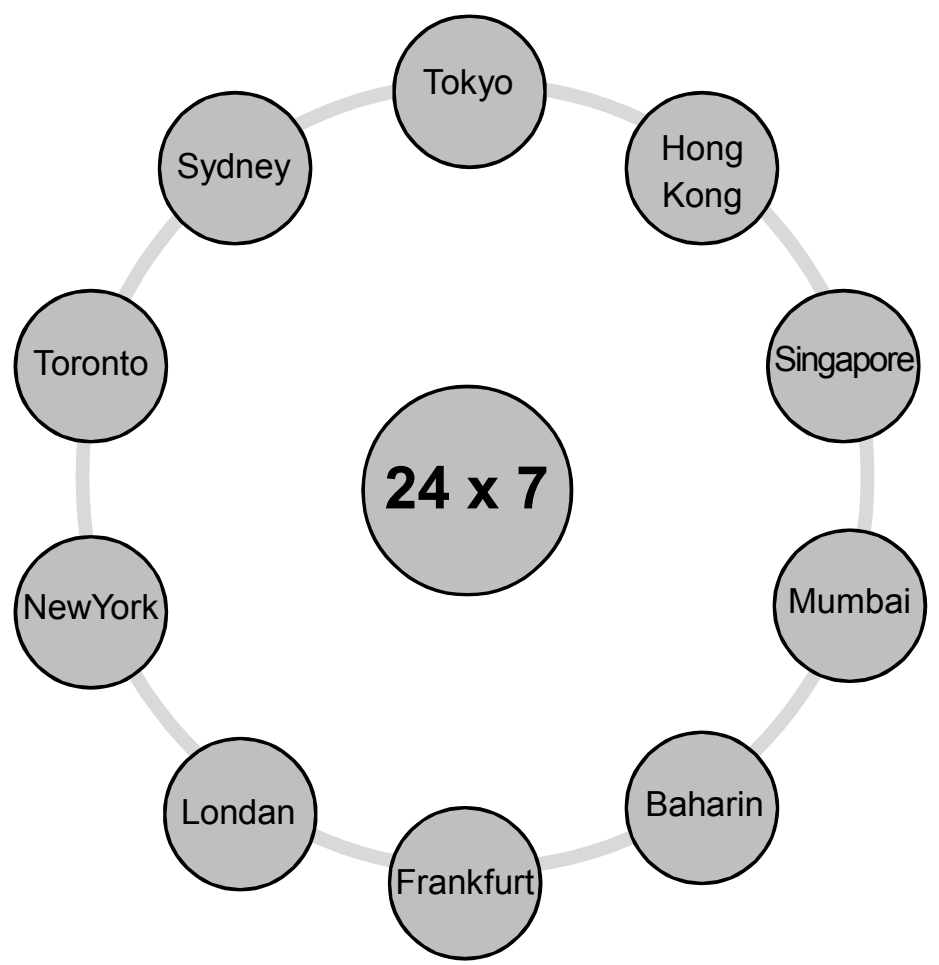

The forex markets invariably operate on $24 \times 7$ basis, in different time zones (as shown in the diagram)

However, it is not that all markets are active simultaneously. On account of geographical distribution of forex centers (as shown in the above diagram) starting with Japan (Tokyo), Hongkong, Singapore, India (Mumbai), Middle East (Baharin), Europe (Germany), UK (London), USA (Newyork) Canada (Toronto),Australia (Sydney), different markets operate in different time zones. In view of this peculiarity it is all the more difficult to perceive, predict and forecast about the market movements (exchange and interest rates as well as prices)

Some of the important factors that influence market movements are as below:

Foreign Exchange Rates - Fundamental Factors:

- Balance of Payments - Surplus leads to a stronger currency, while a deficit weakens a currency

- Economic Growth Rate - Rise in value of imports leads to fall in the currency 
- Fiscal Policy - Lower taxes can lead to higher economic growth rate.

- Monetary Policy - The way a central bank attempts to influence and control interest rates and money supply.

- Interest Rates - High interest rate attracts overseas capital and appreciates currency in the short term, in the longer term, however, high interest rates slows the economic growth, thus weakening the currency.

Foreign Exchange Rates - Technical Factors:

- Government Controls

- This can lead to an unrealistic value of currency resulting in violent exchange rate movements. Speculation:

- Speculative forces can have a major effect on exchange rates.

\section{Example:}

- There are expectations that a currency will be devalued.

- Speculator will start selling the currency in preparation for buying it back later at a cheaper rate, hence selling pressure from speculators extends to other market participants.

- This activity creates liquidity in the Foreign Exchange Market.

\section{SPECIAL ISSUES: TECHNOLOGY AND INTERNATIONAL BANKING}

Technological revolution has changed the style of functioning of many economies. New developments in communications technology are playing a key role in the international banking. Innovations in electronic equipment permitted the processing and transmission of information, the confirmation of transactions, and transfer of funds, in quick turnaround time. These innovations have assisted international banks to expand their operations and also offer value added services to their clients. In short, the technological revolutions have integrated the banks across the borders.

Financial institutions, and many international commercial banks, have been able to take advantage of the changed environment. These institutions and banks equipped with the latest technology have taken the lead to exploit the enhanced opportunities. They are quick in accessing higher-quality information about foreign financial systems. They are better placed to introduce new communications technologies, thereby reducing their costs of crossborder financial transactions.

Some of the technology support that has contributed significantly the growth of international banking are:

1. Clearing House Interbank Payment System (CHIPS): Introduction of CHIPS (Same Day Settlement by the has changed dramatically the clearing and settlement system in USA. Eventually international banking system started to make use of the technological development to introduce similar systems such as CHAPS,CHATS, RTGS,NEFT not only for quicker clearing of cheques but also for instant funds transfers. The revolution in communications technology that was taking place at the same time, enabled US banks to manage their liquidity position comfortably.

2. Technological innovations helped banks to setup effective clearing house interbank payment system wherein the Central Bank could play the role of an exchange to absorb credit risks. This assisted banks to mitigate credit risks subject to certain terms and conditions in interbank payment system on account of international payments arising out of Forex and Money Market operations.

3. SWIFT: Two networks collectively owned by the banks that use them dominate international payments. The Society for Worldwide Inter-bank Financial Telecommunications (SWIFT) provides the 
international lines used for such interbank advice, while the Clearing House Interbank Payment System (CHIPS) is the system in operation in New York. They are connected by a system called "Gateway". SWIFT a co-operative for a standardized automated international funds transfer information system between banks.

\section{GLOBALIZATION AND INTERNATIONAL BANKING: IMPORTANT ASPECTS}

1. Integration of global economies created more opportunities for expansion of trade and financial investments. In view of this, banks as an important segment of international banking system and financial markets started their expansion through different channels like correspondent banking, foreign branches, off shore banking units to play active role in today's globalized environment. Globalization of trade, commerce, deregulation and free movement of capital across borders has speeded up the growth of international banking.

2. International markets operate virtually on $24 \times 7$ basis, on account of their geographical locations. This special feature not only increases opportunities but also created cross border risks as well. Hence risks especially cross border risks, are unique features of international banking operations in a globalized environment.

3. International legal frame work and regulatory compliance is another important aspect which make the operations of international banks more complicated and difficult as well. Globalization and the advent of new technologies have changed the perception of managing business in international centers.

4. International Accounting Standards - On account of globalization, many economies have introduced deregulations and reforms. In view of these changes there is a requirement for the convergence of local financial reporting standards with International Accounting Standards (IAS) in order to have transparency in their operations. This would assist economies to attract investments from global investors. The business entities, especially banks are exposed to the changed globalized environment, and therefore required to comply with the International Financial Reporting Standards (IFRS). IFRS are standards and implementations adopted by the International Accounting Standards Board (IASB).

5. Bank for International Settlement (BIS) - Recognizing the importance of better controls and financial discipline among the international banks, the BIS, which acts as the world's central bank for central banks, has been playing a very active role in guiding and regulating the international banking system in the globalized environment. Basle norms have suggested measures for strengthening capital structure of banks by means of capital adequacy ratios and other measures like prudential norms. BIS addresses the issues relating to risk management and corporate governance practices of banks as well.

6. Technological innovations - Technological innovations have integrated many international financial centers and helps banks in their liquidity management and quick funds transfers. At the same time the technology revolutions have created room for operational risks as well. Banks, especially international banks face challenges to handle the money laundering activities and frauds on account of hacking into their technology.

7. International Financial Markets - Globalization has increased opportunities for international investors to tap different international markets, arbitrage deals, and diversification of their investments. In view of globalization international banks face many risks. International banks have launched many innovative financial instruments to handle these risks in the form of financial derivatives like forward exchange contracts, futures, options, swaps etc., International banks are able to have access to funds from different cross border centers, thereby they are able to offer External Commercial Borrowing facilities to their clients, as well as designing of loan syndications.

\section{FINANCIAL INNOVATIONS IN INTERNATIONAL BANKING}

Over the years and decades international banking has been part of many innovations. According to the changed environment on account of more and more cross border operations banks have to handle many risks. To mitigate 
such risks many innovative financial instruments and products have been introduced. Broadly such products can be termed as "derivatives".

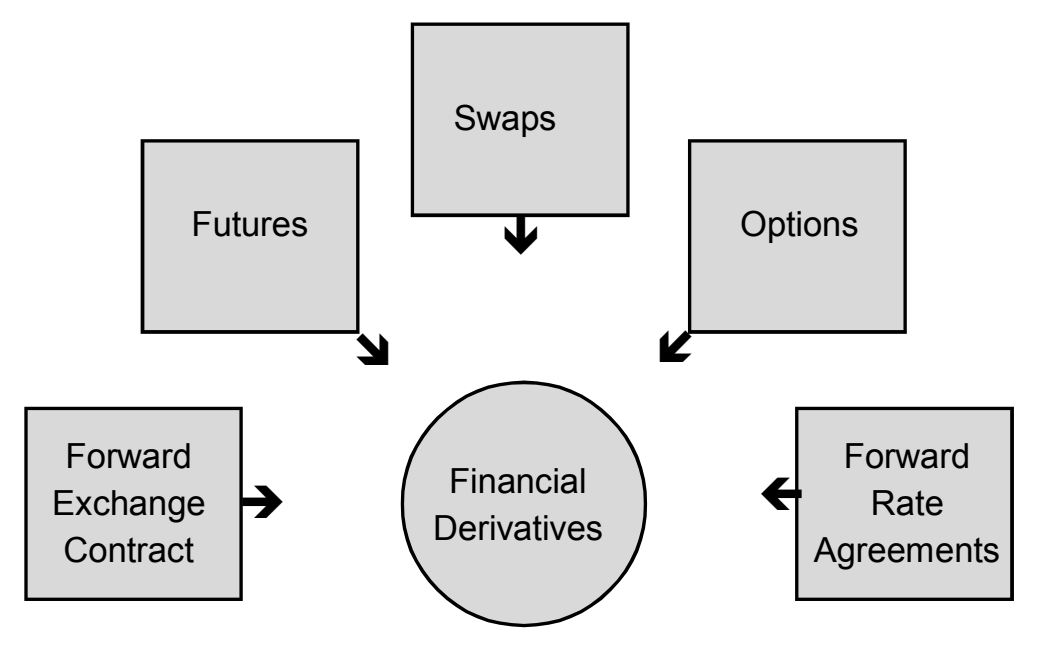

Forward Exchange Contract: Foreign Exchange Rate Risk: This arises due to market movements and on account of market forces (demand and supply). The foreign exchange rate risk can be mitigated by using a forward exchange contract. By predetermining the exchange rate well in advance, the counterparties peg the price (exchange rate) and thereby mitigate the exchange rate risk.

Forward Rate Agreement (FRA): An FRA is an agreement between the bank and a customer to pay or receive the difference (called settlement money) between an agreed fixed rate (FRA rate) and the interest rate which is expected to prevail on a stipulated future date (the fixing date) based on a notional amount for an agreed period (the contract period). In short, in this type of a contract the interest rate is fixed now for a future period. The basic purpose of the FRA is to hedge the interest rate risk. For example, if a borrower decides to avail of an External Commercial Borrowing (ECB) for a period of six months, at LIBOR rate, after 3 months, the borrower can buy an FRA whereby he can fix the interest rate for the loan.

Interest Rate Swap (IRS): An Interest Rate Swap is another example of a derivative, and is used to mitigate the interest rate risk. It is a financial transaction in which two counterparties agree to exchange streams of cash flows during the contract period. One party agrees to pay a fixed interest rate on a notional principal amount and the counter party agrees to pay a floating interest rate on the same notional amount. IRS is used as a hedging tool to mitigate the interest rate risks.

In International Banking System, Interest Rate Swaps are used to manage the asset liability mis-match as part of their Asset Liability Management. IRS is also helpful for the banks to structure their asset and liability to hedge the gap risk (mismatch) based on their respective cash flows.

Currency Swap: It is an agreement between two counter parties to exchange obligations in different currencies at various stages of the contract period- At the start, during the tenure and at the end of the transaction. At the beginning the initial principal amount is exchanged (it is not obligatory) periodic interest payments (either fixed or floating) are exchanged throughout the tenor of the contract. The principal amount is exchanged invariably at the end, at the exchange rate decided at the start of the transaction (contract). In view of the market volatility and to hedge exchange rate risks, the counterparties opt for currency swap, to enable them to reduce their funding costs in international markets.

Options: Another popular derivative instrument used in international banking arena, is a contract between the bank and its customers in which the customer has the right to buy/ sell a specified amount of an underlying asset at fixed price within a specific period of time, but has no obligation to actually buy or sell. In this type of contract, 
the customer has to pay specified amount upfront to the counterparty which is known as premium. This is in contrast of the forward contract in which both parties have as binding contract.

In international forex markets, this type of facility is generally offered to customers to enable them to book Forward Contracts in Cross Currencies at a target rate or price. This facility helps the customer to take advantage of the currency movements in late European market, New York market and early Asian market.

\section{Different Type of Credit Derivatives:}

The credit derivatives are designed to separate and then transfer the credit risk of non-payment or partial payment by a corporate or sovereign borrower, by transferring it to an entity other than the lender or debt holder. This synthetic securitization process has become increasingly popular over the last decade with the simpler version of these structures being known as synthetic collateralized debt obligations (CDOs), credit linked notes (CLNs), single tranche CDOs etc. which are funded credit derivative products. There are unfunded credit derivative products also like Total Return Swaps, Portfolio Credit default Swaps, Credit spread options etc.

Pricing of these products is not easy due to complexity in monitoring the market price of the underlying credit obligations. Risks involving credit derivatives are a concern among the regulators of financial markets.

\section{Concurrent Audit and Internal Control:}

As required by the $\mathrm{RBI}$, the banks operating in India have a concurrent audit of all forex transactions. Auditors are required to give daily and monthly reports covering:

- Compliance with approved open position limit

- Compliance with overnight exposure limits

- Compliance with aggregate and individual gap limits

- Compliance with value at risk norms

\section{LESSON ROUND UP}

- Post 1970s, the International banking has been dominated, by a number of trends. Global integration of financial markets is being driven by the worldwide opportunities, on one hand, for international investors to look into different lucrative international financial markets and on the other hand, for lower cost of funds for international banks.

- Meeting these objectives has been facilitated by improved communications, the erosion of barriers to capital flows, and the modernization of key national financial systems and the gradual liberalization of international trade in services.

- The effect of globalization is to give participants in financial markets a wide range of viable alternatives. The market places strict demands on participating financial institutions - staffing, facilities, market intelligence and research and changing regulatory requirements, all involving significant costs.

- Foremost among the global trends in the world's financial industry, are consolidation and convergence. These deals encompass financially driven mergers within domestic markets designed to cut costs, more strategic cross-border deals as banks with large shares in their own domestic markets, seek to expand across in other countries and a growing number of deals between banks and insurance companies. Banks want to merge to gain economic scale or enter new geographic markets.

- The Financial institutions are under increasing pressure to strategically reposition them in a marketplace 
where the competitive landscape has been redefined. Banks are forced to identify new ways, to increase efficiency, enter into developing markets, provide new products, shed unprofitable operations and capitalize on new opportunities.

\section{SELF TEST QUESTIONS}

1. State whether the following statements are 'True' or 'False'
(a) International markets operate on different time zones
(b) Credit risk is also called as settlement risk
(c) Bank for International Settlements is a banker for IMF
(d) Off shore banking unit is one of the international banking channels
(e) Basel Norms II specified 4 pillars for international banks
(f) Derivative is an example of on balance sheet item
(g) Interest rate risk can be mitigated by interest rate swap

2. Choose the correct alternative.

A. ICOM is term associated with
(a) International Business Management Course
(b) International Commercial Terms
(c) International Loan Agreements
(d) International Monetary Fund's Loan Scheme

B. Basle II recognized which of the following risks

(i) Credit risk

(ii) Operational risk

(iii) Market risk
(a) (i) only
(b) (i) and (iii)
(c) (i) (ii) and (iii)
(d) (ii) only

C. As regards international finance, identify the exception
(a) International Bank for Reconstruction and Development
(b) International Monetary Fund
(c) Bank for International Settlements
(d) International Chamber of Commerce
D. Identify the correct statement
(a) As regards floating exchange rate system, the exchange rates are based on market forces
(b) As regards fixed exchange rate system, the exchange rates are based on market forces 
(c) As regards forex markets $T+2$ settlement is a term associated with the forward deals

(d) As regards forex market exchange rate risk is not an example of market risk

3. Explain the evolution of International Banking system.

4. Write short note on:

(a) Bank for International Settlement (BIS)

(b) Bretton Woods Conference

(c) International Monetary Fund (IMF)

5. Explain the risk management in banking.

6. How has globalisation affected international banking. Explain critically.

7. Highlight the important aspects of FEMA,1999

8. Describe in brief the importance What are the three pillars advocated by Basel II norms

9. What are the reasons for volatility in international financial markets?

10. How would you define risk?

11. Briefly highlight the features of Credit and Operational risks.

12. Write short notes on:
(a) Interest Rate Swap
(b) Globalisation
(c) Forward Exchange Contract 
276 PP-BL\&P 


\section{Lesson 11}

\section{Electronic Banking and IT in Banks}

\section{LESSON OUTLINE}

- Principles of Lending

- IT Application in Banking

- Automated Clearing Systems

- Electronic Fund Management

- Real Time Gross Settlement (Rtgs)

- National Electronic Funds Transfer (Neft)

- Automated Teller Machines (Atms)

- Electronic Commerce And Banking

- International Payment Systems

- Cyber Crimes and Fraud Management

- LESSON ROUND UP

- SELF TEST QUESTIONS

\section{LEARNING OBJECTIVES}

The $20^{\text {th }}$ century witnessed many changes to the International Trade, Banking and Finance on account of new revolution in the Information and Communication Technology. Banks across nations have been moving to the e -commerce and e-banking environment. On account of these changes banks are able to provide more flexible banking options for their clients, by offering many innovative products and services through ATMs, Credit and Debit Cards, Internet Baking,Core Banking Solutions etc., While quicker and faster services like convenient banking, any where banking, $24 \times 7$ virtual banking are offered, coupled with quick remittance and funds transfers, on the other hand banks are also exposed to the cyber crimes, on account of more usage of computers and IT enabled services. Further, in view of cross border transactions, if proper control is not exercised, banks can be used as channels for money laundering as well.

At the end of the chapter the reader would be able to;

- Understand the significance of the $E$ banking in today's fast changing business environment

- Appreciate the innovations by banks, on account of revolutions in information and communication technology

- Be cautious in recognizing cyber crimes and frauds and can be pro active to handle such risks

- Look forward to the future scenario of $E$ commerce. E banking and other technological innovations 


\section{INTRODUCTION}

Over the years, especially in the later part of the $20^{\text {th }}$ century, the Indian Banking Sector has undergone fast growth and with the advent of technological changes, Indian banks are adopting to the new environment. The two successive Committees on Computerization (Rangarajan Committees) were responsible for bank computerization in India. Over the years led by the initiatives of the Reserve Bank of India, banks in India have witnessed lot of changes into their banking operations duly supported by IT and communication revolution.

Some important areas where the IT plays important roles are:

Funds Transfer mechanism: ECS, EFT, RTGS, NEFT

Clearing House operations: MICR, CTS

Innovative on line e- banking services: Tele banking, Mobile banking, SMS banking, Credit/ Debit Cards, ATMs, Internet banking, Core Banking Solutions, etc.

\section{IT and Communication Systems - Important features}

The integration of computers and communication techniques has opened opportunities for banks to provide various innovative and customer friendly products/services and also to redesign their internal control systems.

The data communication network systems play an important role in interface and interconnectivity of banks. With the fast changing technological supported world, banks in India have come a long way. Over the years different methods have been used to transmit data from computer to computer. The data is transmitted by means of data communication media like terrestrial cables, microwave and satellites.

\section{Communication Networks in Banking System}

As per the recommendations of the Saraf Committee, the Reserve Bank of India has set up a country wide data communication network for banks linking major centers of the country, known as INFINET (Indian Financial Network) and this network uses satellite communication with very small aperture terminals (VSATs) as earth stations.

VSAT network is a single closed user group network for the exclusive use of banks and other financial institutions. The VSATs are owned by individual banks and the RBI. The hub is owned by the RBI and the Institute for Development and Research in Banking Technology (IDRBT). Satellite services based on VSAT technology can establish reliable links to all sites. The central hub monitors and controls the flow of network traffic.

\section{Internet}

The internet is a global network of networks. Computers with internet links can allow users to exchange data, information, messages, files, etc, with other computers across the globe through internet connectivity.

\section{Internet Access Services}

Some of the important services available on internet are: E-mail: Most popular and widely used application. Messages can be sent and received to/from any place in very quick time. It is user friendly and cost effective as well.

\section{World Wide Web (WWW)}

This facility collates internet related resources and makes available the information. The access to this site assists user to source out a large variety of information.

Banks uses internet and web sites (banks' own web sites) to market their products and services. These platforms 
also allow banks to offer online banking facilities and can be used for posting their financial results and information to customers.

\section{SWIFT}

Society for Worldwide Inter-bank Financial Telecommunications (SWIFT) is a co-operative non-profit making organization established under Belgian law with its head quarters at Brussels. SWIFT is wholly owned by its member banks. SWIFT is a paperless message transmission system.

\section{SWIFT - important features:}

- Operates on $24 \times 7$ basis throughout the year

- All messages are transmitted to any part of the world immediately

- Message formats are standardized

- Information is confidential and is protected against unauthorized disclosure

- SWIFT assumes financial responsibility for the accuracy and timely delivery

\section{SWIFT and banks:}

- SWIFT has become an integral part of banking system. SWIFT assist member banks

- SWIFT transmit authenticated financial and non financial messages

- SWIFT with its well-standardized and structured message formats have been offering a reliable system of message transmission

- Banks use SWIFT platform to for transmission of financial and non financial messages covering international finance (settlement of forex deals), international trade (advising of LCs, amendments to LCs etc,)

\section{AUTOMATED CLEARING SYSTEMS}

\section{Clearing House Inter-bank Payment System (CHIPS)}

This is a clearing system run by New York clearing house. The financial transactions such as - foreign and domestic trade services, international loans, syndicated loans, foreign exchange trade settlements, are carried out through CHIPS. The CHIPS have a direct interface with the SWIFT system.

\section{Clearing House Automated Payment System (CHAPS)}

CHAPS is an automated system set up in UK which ensures immediate settlement of payments.

\section{Clearing House Automated Transfer System (CHATS)}

CHATS provide the inter-bank transfer facilities in Hong Kong. CHATS provide same day inter-bank settlement, instant order confirmation and enquiry facilities. The integrity of message transmission is carried out through authentication and encryption techniques.

\section{ELECTRONIC FUND MANAGEMENT}

Banking operations over the years and decades have witnessed many changes and have been adopting from time to time new innovations. The technological revolution especially in the Information and Technology front has changed the functioning of banks. In today's globalized competitive business environment banks are trying to have the competitive edge by using the latest technology to cut down turnaround time, cut costs and increase efficiency. "e Banking" through many innovative products and services has revolutionized banking operations. 


\section{Electronic Fund Management}

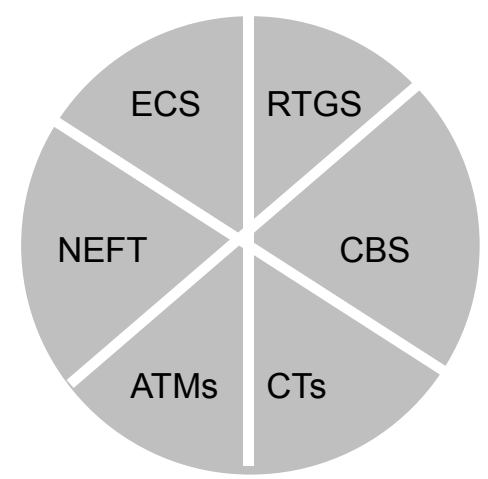

IT revolution has paved way for banks to implement different systems to handle funds management in banks. This methodology is collectively recognized as Electronic Fund Management.

\section{Electronic Clearing System (ECS)}

One of the earliest electronic forms of funds transfer is the Electronic Clearing System. ECS is a retail funds transfer system to effect payments (utility bills, dividends, interest, etc) ECS helps corporates, government departments, public sector undertakings, utility service providers to receive and/or pay bulk payments. ECS is divided into ECS (credit) and ECS (debit)

\section{ECS - important aspects/ features}

On receipt of the required mandate, the funds (payments/ receipts) can be handled by a bank through ECS. ECS (debit) is generally used by utility companies like electricity companies, telephone companies and other to receive the bill payments directly from bank accounts of their clients. Instead of payment of utility bills by means of cash or cheque payments, an individual or a company can make payment through ECS. In case the company has the facility of payment through ECS, the client can give a mandate to the company to receive the utility bill amount from his bank account directly. The utility company (service provider) based on the ECS mandate given by the client, would advise the client's bank to debit the bill amount to the client's account on the due date (or on a any date before the due date as per the client's request) and transfer the amount to the company's own bank account. Similarly, ECS (Credit) can facilitate payment to various clients like dividend warrants, maturity values of Annuities.

\section{Real Time Gross Settlement (RTGS)}

One of the important IT revolutions in Indian Banking Scenario was the implementation of the Real Time Gross Settlement (RTGS) system by the Reserve Bank of India. With the changing scenario from manual environment to electronic mode, banks started to use faster, safer and efficient methods to transfer funds.

In this regard, two important and popular electronic funds transfer systems are Real Time Gross System (RTGS) and National Electronic Funds Transfer System (NEFT)

RTGS is an electronic payment system, where payment instructions are processed on a 'continuous' or 'REAL TIME' basis and settled on a 'GROSS' or 'individual' basis without netting the debits against credits. In India, $\mathrm{RBI}$ introduced this system and the system is functioning well. The payments so effected are 'final' and 'irrevocable'. The settlement is done in the books of the central bank (RBI). The RTGS system allows transfer of funds across banks on a real time (immediate) basis. Each participant bank needs to open a dedicated settlement account for putting through its RTGS transactions. Not only does it allow transfer of funds, it also reduces the credit risk. Both customers and banks can transfer funds monies the same day at regular intervals within the banking hours. 
RTGS: Special features:

(a) Real Time Gross Settlement helps banks to settle interbank and forex settlements

(b) It also helps banks in handling big ticket funds transfers

(c) Since RTGS it is routed through RBI platform, the credit risk is minimized (this is one of the main advantages in settlement of funds)

(d) Unlike in case of cheque clearance, the drawer of the cheque cannot enjoy the float time (the date of issuance of cheque and the date on which it is received in inward clearing and debited by his banker) However, in the case of RTGS, the remitter's account is debited first and then only the funds are transferred

(e) If all relevant details such as the beneficiary's name, account number, IFSC code of the receiving branch, name of the beneficiary bank, etc., are correctly furnished it would assist the remitting bank to effect the transfer quickly

(f) As the name RTGS suggests, the transfer mechanism works on real time and, therefore, the beneficiary branch/bank should receive the funds immediately. The beneficiary's branch/bank should give credit to the beneficiary's account immediately or latest within 2 hours of receiving the funds transfer message.

However, in case the funds cannot be credited for any reason, such funds should be returned to the originating branch within two hours. In such a situation, as soon as the money is returned, the remitting bank should reverse the original debit entry in the client's (remitter's) account. This system is applicable between banks/branches who are on Core Banking Solutions (CBS)

\section{National Electronic Funds Transfer (NEFT)}

NEFT is a system similar to RTGS with certain differences. RTGS handles big ticket transactions, whereas NEFT handles smaller size transactions. Most branches are using this facility to transfer funds in an efficient manner. Once the applicant for the transfer of funds furnishes full and correct details (correct account details means correct name of the beneficiary, the correct account number, the branch and bank of the beneficiary, and the correct IFS code, etc.) funds can be transferred to the beneficiary's account by the remitting bank. Transfer of funds through NEFT is safe, quick. It reduces the paper work and is cost effective.

NEFT is an innovative electronic media for effecting transfer of funds. Special features of NEFT are:

1. NEFT is a funds transfer system which enables a customer of a bank to transfer funds to another customer of another bank having account with any participating bank

2. NEFT allows both intra and inter-bank funds transfer within a city and across cities

3. Since it is in the form of e transfer, without any physical movement of instruments, funds can be transferred quickly

4. The beneficiary customer gets funds in his account on the same day or at the earliest on the next day depending upon the time of settlement

5. Both the originating and destination bank branches should be on NEFT platform

6. The correct details of IFSC, beneficiary's name, account numbers, etc., should be furnished to the originating bank.

7. The originating bank branch can keep track of the status of the NEFT transaction.

8. In case for any reason the destination branch is not able to afford credit to the beneficiary's account, destination branch/bank have to return the funds to the originating bank within two hours of completion of the batch through which the transaction was processed 
9. It is not only easy method of transfer of funds, but also enables the remitters to have user friendly and cost effective transfer of funds

\section{Indian Financial System Code (IFSC)}

IFSC is an alpha-numeric code that identifies a bank-branch participating in the RTGS/NEFT system. IFSC has 11 digit code and the first four alpha characters represents the bank, the $5^{\text {th }}$ code is 0 (zero), which is reserved for future use and the last six digits are numeric characters represents the branch. Correct IFSC code is essential for identifying the beneficiary's branch and bank as destination for funds transfers. E.g. Syndicate Bank Cuffe Parade Branch, Mumbai- SYNB0005087

\section{Automated Teller Machines (ATMs)}

ATMs are used as a channel for cash management of individual customers. ATMs can be accessed by ATM card, debit or credit cards. To have access the customer (the card holder) needs to use his Personal Identification Number (PIN) issued by his/her banker and access password. ATMs generally used for cash deposit and withdrawals, they can also be used for payment of utility bills, funds transfer thereby ATMs serve as a channel for electronic funds management. Requests for new cheque book and statement of accounts can also be given through ATMs.

White Label ATMs- RBI has vide notifications dated $20^{\text {th }}$ June, 2012, permitted non-banking entities to set up or start ATMs which are called White Label ATMs (WLA). From such ATMs customers of any bank will be able to withdraw money, takeout statement, change PIN etc. These WLAs will not display logo of any bank. However, WLA operator has been permitted to display advertisements, and offer value added services as per regulations in force. While WLA operator is entitled to receive a fee from the banks for use of ATM resources by their customers, WLAs are not permitted to charge Bank customers directly for use of WLA.

\section{Internet Banking}

Internet banking one of the popular e-banking modes has changed the banking operations and offer virtual banking services to the clients on $24 \times 7$ basis. It is also called as convenient banking, since the customer (account holder) can have access to his bank account from anywhere at any time, through the bank's web site. The customer is allowed online access to account details and payment and funds transfer facilities. Net banking services of a bank can be accessed through a Personal Identification Number (PIN) and access password as in the case of ATMs. In net banking the advantage for the bank customer is that funds can be transferred from the client's bank account to another account with the same bank or another bank through NEFT/RTGS. Another method of funds transfer facility is online payment of taxes. Bank customer can pay various taxes like income tax, service tax, etc.; Net banking can be used as a channel by the customer to pay the utility bills (electricity bills, telephone bills, etc) on line. Customers can make use of net banking to pay the insurance premiums and similar other payments.

\section{Core Banking Solutions (CBS)}

Core Banking Solutions has helped banks to offer better customer service. It has also reduced the time and increased the efficiency. The Core Banking Solutions mainly work on the support of effective communication and good information technology. It is on account of merger of communication technology and information technology which enables the banks to offer core banking needs of the clients.

Core Banking Solutions are computer based banking applications (software) which works on a platform. The computer software handles the different functions of the bank like, recording of transactions, updating the balances in the accounts based on the type of transactions, calculate interests and application of interest, charges etc., The software is installed in the branches and the computer systems are interconnected with a main computer server though communication lines (telephones, satellite, internet, fibre optical) 
CBS is a back end system, and it processes daily banking transactions and updates the records accordingly. CBS helps the clients to operate their accounts from any CBS branch. CBS branch assist customers to handle their funds transfers in a quick turnaround time. It also assists the client to withdraw and deposit funds in other branches apart from the parent branch, where he maintains his account.

Data Warehousing- A Data Warehouse or Enterprise Data Warehouse (DWH/EDW) is a database used for reporting and data analysis. It is a central repository of data which is created by integrating data from one or more separate sources. DWH store current as well as historical data and are used for creating trending reports for use by senior management. The data stored in the warehouse are uploaded from the operation systems. The main source of data is cleaned, transformed, catalogued and made available for use by the managers for data mining, online analytical processing and decision support.

\section{Computerization of Clearing of Cheques}

Over the years Reserve Bank of India as a facilitator has been playing a vital role in the implementation of innovative systems, to enable banks not only to function effectively but also to offer better customer service. RBI is in charge of the clearing house and clearing operations. It has always taken lead to introduce new systems to speed up clearing process as well to reduce the turnaround time in clearance of funds. Computerization of clearing operations was the first major step initiated by RBI, over the years RBI has been upgrading the system with new changes. To overcome the increasing volume of cheques through the clearing mechanism, RBI has fully automated the clearing house operations. This is based on the Magnetic Ink Character Recognition technology; $\mathrm{RBI}$ upgraded the clearing functions with new set of MICR cheques. Under this new system, cheques should have MICR code consisting of 9 digits. Each cheque would have the unique 9 digit MICR code along with the cheque number.

MICR code consists of 9 digits as:

- First three digits indicates CITY \{identical to the first three digit of the postal pin code of the CITY (For example: in case of Mumbai, it would be 400)\}

- Next three digits represents the Bank and each bank has been given a three digit code called bank code

- Last three digits denote the branch code

Under this MICR system the computer program would read and sort out the cheques based on the codes, thereby, in quick turnaround time, the system is able to handle volume.

\section{Cheque Truncation System (CTS)}

Cheques are being used as a medium for exchange of funds, which play a key role in the funds management of customers and banks. The efficient cheque clearing system helps in settlement of receipts and payments. Cheque Truncation is a new system introduced in Indian Banking Scenario. It is a system of cheque clearance and settlement between banks based on electronic data and/or images without the need for exchange of physical cheques and negotiable instruments like demand drafts, pay orders, dividend warrants, etc.

Cheque truncation - Special features:

- Bank customers would get their cheques realized faster

- Quick realization helps in better cash management (receivables/payables)

- In the long run, it would reduce the administrative costs for bank

- Importantly this would assist banks' in reconciliation and also reduction in clearing frauds.

\section{ELECTRONIC COMMERCE AND BANKING}

The global e-commerce activities include the interaction of traders (buyers/importers and sellers/exporters) with 
banks and counterparties, manufacturers, service providers etc., Banks across the globe provide payments and settlements services thereby enable the rapid growth of global e-commerce.

"e marketing" or cyber marketing is an important segment of e commerce.

Salient features of internet (e) marketing are:
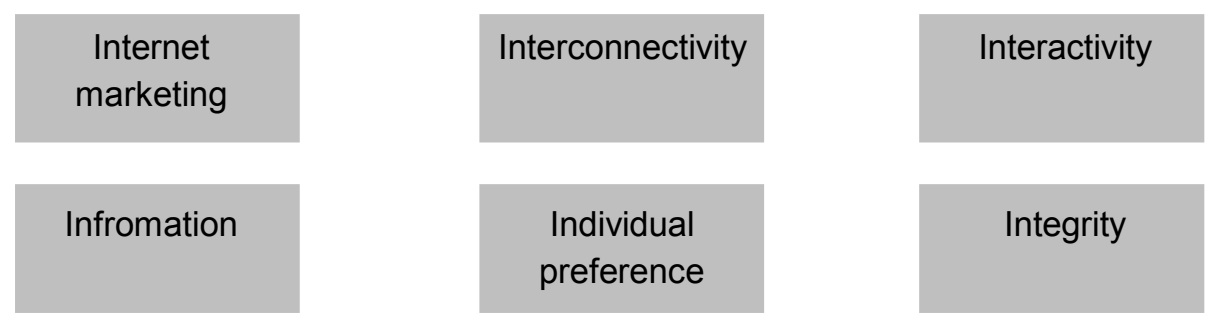

\section{Internet marketing:}

Internet based marketing is an important segment in e commerce. It plays a vital role in the supply chain process of exchange of goods between the producer and consumer.

Interconnectivity: Internet is recognized as a network of networks. The search engines assist the user of the internet to have access to required information. For customers, the interconnectivity offered by the internet helps him/her to have information/access to large number of diverse markets. One important feature is that it gives information and access about international markets as well.

\section{Interactivity:}

Internet not only allows access but also allows interface and interactivity among users. In view of this interface, it assists both the producer/manufacturer as well as customers to have better communication and choices. It allows the marketer to customize and focus even on individual customers in large markets. On the other hand the customers are also benefitted because of their interface with the marketer, peers and different web sites to make their selection.

\section{Information:}

The availability of large number of websites on the internet enables the customers to decide on price, choice of products, designs etc., On account of innovative methods of marketing the customers can have access to information covering wide range of areas.

\section{Individual preference:}

The interconnectivity, information and interface provided by the internet network assists the customer with wide choices. Based on his/her preference and capacity a customer can decide on his preference to choose and order.

\section{Integrity:}

With the changing time and requirements and on account of security issues and also to safe guard the users from cyber crimes, internet provides tools to check the authenticity of the data and its providers. In view of many fake offers \& advertisements, the internet users should be cautious. They should not provide any sensitive information like details of PIN, passwords and other information to any unauthorized sites, not only to safeguard their interests, but also not to allow cyber criminals to have access to this information.

\section{Internet and Supply Chain Management}

Internet also provides online distribution of digitalized products. This helps in quick turnaround reach to a large number of customers, and eliminates the lead time between the place of order and delivery. This also enables a better inventory management and quicker transaction processing. Many enterprises have started using the new 
concept called Enterprise Resource Planning (ERP) systems. e-distribution (cyber distribution) activities when linked to these ERP systems assist the companies to achieve a greater efficiency in their entire Supply Chain Management.

\section{Cyber Marketing: Limitations:}

Internet marketing is also exposed to quite a few problems. Some of them are in-built and others are external problems.

1. Digitization: For cyber marketing, the products should be in digitized format. This process requires manpower, skills and technical knowledge. The digitization is one of the issues faced by e marketing.

2. Shopping experience: Customers especially in India are more used to touch and feel experience as against click and view mode of shopping.

3. Cyber crimes: Despite the popularity of internet and e commerce and e-marketing, on account of different cyber crimes users are concerned about e marketing.

4. Security: While shopping on internet, customers are required to furnish sensitive personal data which are being shared by marketing companies and create inconvenience to the customers and also pose threats to their privacy.

While customers can have faster access to information and details about the range of products, customers are cautioned to be careful on account of various issues and risks associated with cyber marketing.

\section{INTERNATIONAL PAYMENT SYSTEMS}

In today's fast growing e commercial activities, banks' role is very important for the success of global e- commerce. e- commerce should be end to end covering various aspects like from the customer's end, the selection of on line products, placement of orders, and making and settling payments.

An effective global payment channel should be an integral part of global e commerce. Before setting up a global payment channel, an organization should consider certain aspects such as

1. Payment Type: Payments can be made through different modes like credit cards, debit cards, or online transfer. Customers should be allowed to choose any of the method to settle payments. Internal checking and balancing act should be embedded into the system

2. Legal frame work/Regulatory compliance: The system should satisfy the legal and regulatory requirements in the centers

3. Taxes: Taxation laws are different in different countries. The payment system should have the capability to calculate and compute the required taxes, duties as per the local tax laws

4. Banking relationship: Global e commerce involves cross border trade activities and to ensure prompt settlement of payments, the system should be supported by the banks to process these payments. As per the rules and procedures applicable at different centers, the payment system should be supported by well established banks.

5. Risk: Global e commerce is subject to risks. On-line payment risks can be classified into:

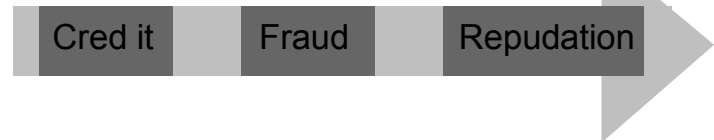

Credit Risk: The customer may not have sufficient funds to make payment

Fraud: Payments may be made on a misrepresented identify 
Repudiation: The customer may refuse to honour payment

Security: Global e commerce is exposed to various cross border nations, hence it is subject to different laws and regulations. Therefore, the payment system should be able to handle the country specific security regulations/guidelines.

An efficient global payment processing system should have the following features;

(i) A single system should enable national and internationa payments

(ii) It should be able to support multi=currency and multi=payment types

(iii) The processing facility should be active for $24 \times 7$

(iv) The system should be able to handle the high value transactions

(v) Interface facilities should be available in the system to enable the system in switching to one type of payment to another like (Real Time Gross Settlements (RTGS) Automated Clearing House (ACH)

(vi) Inter connectivity with message switching systems like SWIFT should be part of the system

(vii) It should also be able to handle current and future inflow/outflows

(viii) Importantly, it should have the feature and facility to comply with the regulatory requirements

Risks:

Some of the important risks associated with payment systems are:

Credit Risk: $\quad$ Failure by a party to meet the financial obligations

Liquidity Risk: $\quad$ A party in the system fails to pay on account of insufficient funds

Operational Risk: A risk can arise on account of human error, system failure, frauds etc.

Legal Risk: $\quad$ Non compliance of legal or regulatory framework can create a legal risk

Systemic Risk: It can have a chain effect into the system due to the default of one of the parties

\section{Legal frame work:}

The following Acts and Regulations handle the payment and settlement in India:

- The Payment and Settlement Systems Act 2007

- The Payment and Settlement Systems Regulation 2008

- Board for Regulation and Supervision of Payment and Settlement Systems Regulations 2008

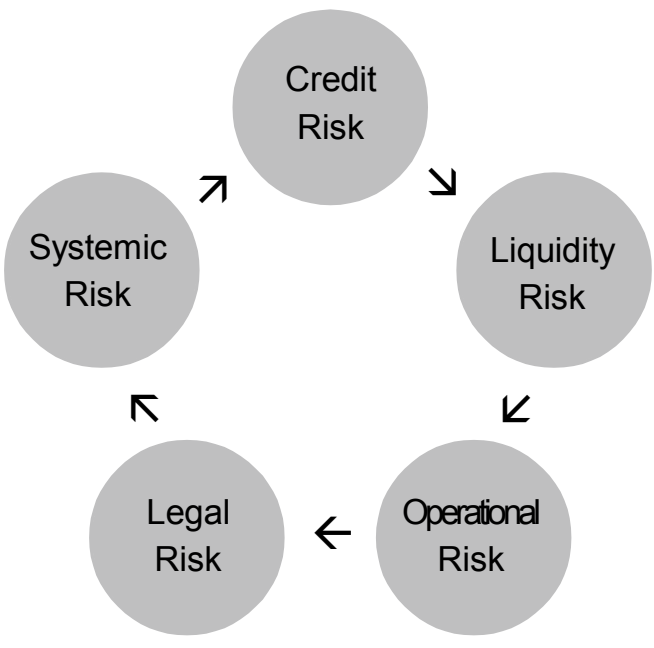


International Initiatives: Bank for International Settlements (Basel) has taken many international initiatives to ensure global financial stability. It is also taking actions to strengthen the global financial infrastructure. According to the Committee on Payments and Settlement Systems (CPSS), the core principles for a controlled payments and settlement systems are:

1. The system should be based on a clear legal framework under all relevant jurisdictions

2. All participants should be able to clearly understand the system's rules and procedures. There should be clarity regarding system's impact on each of the financial risks

3. Credit and liquidity risks are important risks in an e-commerce environment. Hence banks Payment systems should cover the area of credit and liquidity risk management

4. Liquidity management depends upon timely settlement of funds. In view of this, banks' settlement systems should ensure that settlements take place without fail on the value dates (during the day and/or definitely at the end of the day. In case of multilateral netting, at the minimum, the system should be able to complete daily settlements in case the participant of a single big ticket transaction is unable to make the settlement

5. The system should have an integrated high degree of security and operational reliability

6. The system should have a backup system to handle any contingency situations for timely completion of daily processing

\section{Role of Central Bank in Payment Mechanism}

The central bank of a country is responsible in applying the core principles for ensuring that an efficient and cost effective payments system is in place.

The central bank should:

- Clearly define the payment system's objectives and should publicly disclose the role and major policies in respect the payments system

- Ensure that the system is operating efficiently as per the core principles

- As supervisor and facilitator oversee that banks comply with the system's core principles.

- Co-ordinate and co-operate with other central banks for effective implementation of the payments system

\section{RBI - Payments and settlements System}

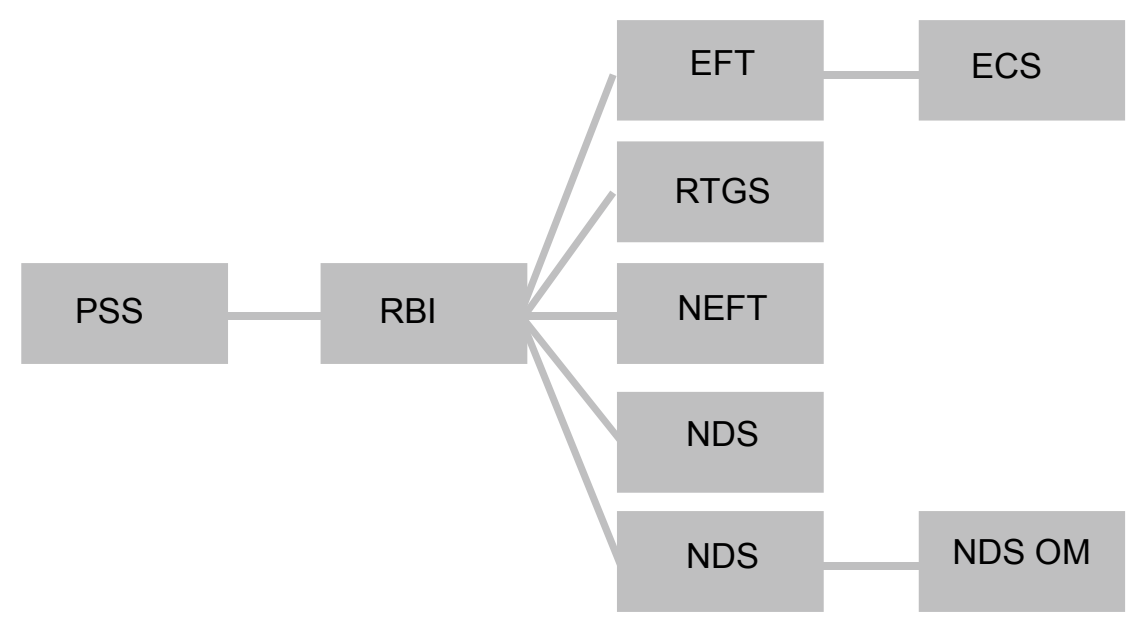


$\mathrm{RBI}$ as the central bank plays a pivotal role in ensuring that a payment and settlement system is established in conformity with the international standards. Some of the initiatives taken by RBI in introducing different models

$\mathrm{RBI}$ has been very active in introducing new systems to take care of changing environment and also to safe guard the interest of bank customers, banks, financial instiutions,traders, and others. RBI also ensures that the payment amd settlement systems opreating in India are safe, secure, efficient, accessible and authorised. In addition to the above, RBI played a key role in the establishment of the Clearing Corporation of India Ltd (CCIL), a central organisation that settles transactions relating to government securities and foreign exchange transactions.

Over the years, RBI has introduced the above mentioned payment and settlement systems to ensure that the e commerce participants are provided with world class system

The success of e-commerce depends upon the efficiency of the support system in timely settlement of funds (payments and receipts). In this regard, the Indian banks are enhancing their payment system to offer international standard service to support e commerce activities.

A simple payment processing model involves the following steps:

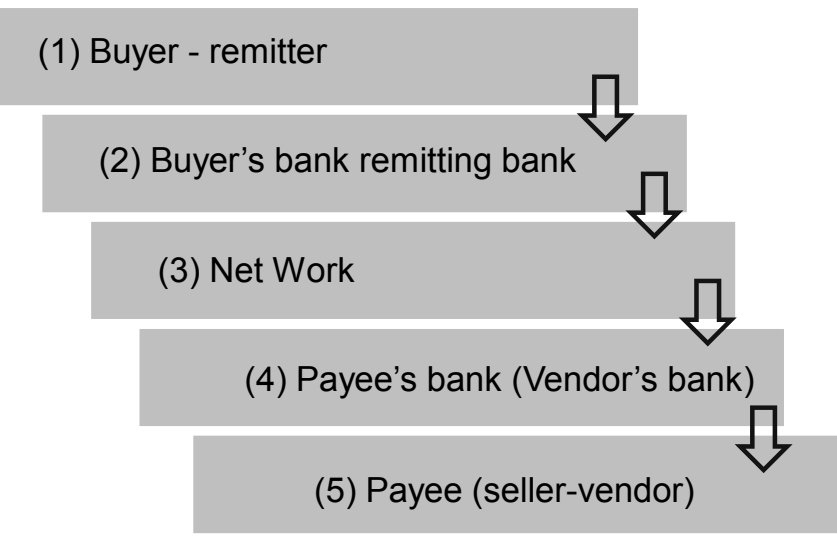

The buyer's bank receives money and instructions to remit the funds. Bank uses its payment and settlement network like RTGS, NEFT and remits the funds to the payee's (beneficiary - vendor - seller's account)

(INFINET) INdian FInancial NETwork- INFINET is the communication backbone for the Indian banking and the financial sectors. All banks in the public sector, private sector, co-operative etc. and the premier Fls in the country are eligible to become members of INFINET. It is a closed user group network for the exclusive use of the member banks and Fls and is the communication backbone for the National Payments System which caters to inter-bank applications like RTGS, Delivery vs. Payment, Automated clearing house, Government Transactions etc. With the availability of better and more reliable technology, INFINET backbone has now been to large extent migrated to multi protocol label switching (MPLS).

\section{Integrated Communication Network for Banks Security and Control Systems}

Banks in line with the IT and communication technology revolution and also to maintain better customer relationship management, offer core banking solutions, new on line payment systems like credit cards, debit cards, internet banking services, etc. While this technology based services offered by banks are better and quicker financial services/products, the banking operations are subject to many risks like cyber crimes. Cyber laws through the legal frame work, based on the Information Technology Act, 2000 aimed to setup a sound infrastructure guidelines and rules for e commerce activities through internet. The purpose of IT Act, 2000 is to promote the use of digital signatures for the growth of e-Commerce and e-Governance. It recognizes the digital signature in e-Commerce. The Act allows that any subscriber may authenticate an electronic record by affixing his/her digital signature. IT Act 2000 covers number of aspects relating to e-commerce and several cyber crimes like cyber terrorism, phishing and child pornography. 


\section{Digital Certificate and Digital Signature}

Digital certificate is an electronic identity provided to an entity by a competent authority or a certification authority. It is a unique public key provided to each entity for establishing the entity's authenticity

Digital signatures: As per Sec 2(1) (p) of the Act a digital signature means an authentication of any electronic record by a subscriber by means of an authentication of any electronic record by a subscriber by means of an electronic method or procedure in accordance with the other provisions of the Act

\section{CYBER CRIMES AND FRAUD MANAGEMENT}

Technological revolutions both in communication and information technology have changed the way of doing business. In today's changed and changing environment electronic commerce and electronic banking has become an integral part of customers as well as bankers. On account of e-commerce and e- banking distances of locations have reduced and many international financial markets have been linked. While it can be appreciated that the computers have become an integral part of one's life, it has also created space for cyber crimes. In view of the fast changing world on account of significant contribution of the IT sector, the cyber crimes pose a significant threat. Cyber crimes are usually carried out by the criminals with technical knowledge and can outstrip and think one step ahead to penetrate into the computers to carry out the crimes.

\section{Cyber Crimes}

A cyber crime can be defined as "criminal activity carried out by using computers and internet". A cyber crime can also be defined as "use of computers and/ or other electronic devices via information systems like computer network, internet to handle illegal activities like transfer of funds, withdrawal of funds through unauthorized access"

In cyber crimes, computers are either used as tools and/or targets. So the computer which is an electronic devise is used as a medium of cyber crimes.

\section{Effects of cyber crimes:}

1. Financial loss 2. Sabotage and theft to identifiable information 3. Exposed to reputation risks 4. Infringement of confidential information 5.Legal consequences 6. Operational risks

\section{Reasons for cyber crimes:}

Easy access to data:

If a cyber criminal is able to break into a computer's system, the access to the sensitive data including customer's confidential financial data, information can be copied into a small removable device. Since information technology drives the functioning of corporate, individuals, banks and government departments and other professionals, the storage of unprotected sensitive data and information in their computers pose a significant threat.

\section{Negligence on the part of the users:}

Individuals and the employees, officers, executives and other professionals who use the computer systems should be vigilant to protect their information and sensitive data stored in the computers. They should be very careful while using such devices by protecting the access to the system through proper usage of Personal Identification Number (PIN) and passwords. Any negligence on their part would make the cyber criminals' access to such devices and information easy

\section{Lack of internal control in organizations and banks:}

A computer system works based on instructions received from operating systems which are driven by a number of codes. An in-effective internal control and IT audit system would lead to lapses in the computerized environment on account of availability of inefficient hardware systems and software systems. Hence banks should ensure that ongoing internal control and IT audit systems are in place. All software used for operating systems should be pre- 
audited by an IT auditor and certified about their sensitivity, integrity and security. The operating systems should have clear demarcation of access by users at different levels. Since banks use many operating systems for their daily operations for transfer of funds, maintain customer deposit and loan and other accounts, preparation of regulatory returns, financial statements like balance sheets, P\&L accounts and other sensitive information and data, allows Core Banking Solutions, use RTGS,NEFT, ECS etc., there should be an effective control to avoid unauthorized access. Hence, the access to the operating systems should have dual control of access based on authorizations.

\section{Classification of Cyber Crimes}

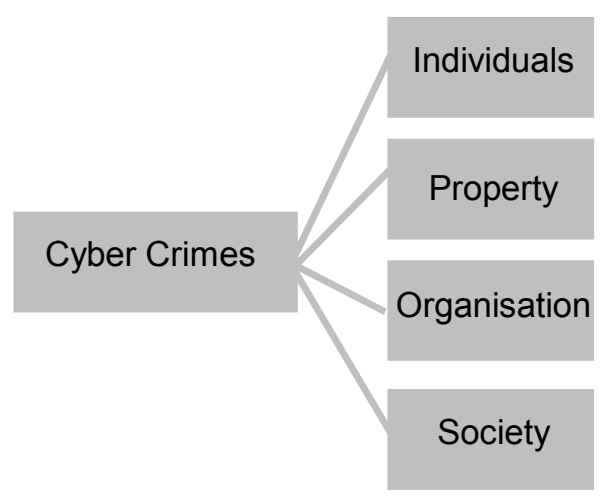

Cyber crimes which happen against individuals and others can be classified as under:

\section{Cyber crimes against individuals/ property:}

Crimes like cyber harassment, cyber stalking, child pornography, and e mail related crimes. if not controlled can leave undesirable impression on youngsters. The crimes against property (all types) include computer vandalism, IPR violations, Internet time thefts, etc., "Property" in this context not only include computers and/or its components but also refers to software, copyrights, patents, trade marks, and access codes as well. The criminals carrying out these types of crimes, invariably target organizations for various reasons and motives.

\section{Cyber crimes against Society:}

Society is one of the important stake holders along with the Government/s. Sensitive websites of governments and the military are subject to hacking. These sensitive web sites are interconnected and unless otherwise properly controlled and protected, it can pave way for cyber crimes. Crimes like money laundering, sale of illegal and prohibited articles, forgery, etc are examples of crimes against society and government/s.

Some examples of cyber crimes:

- Unauthorized access/control over computer system

- Intellectual Property crimes

- Internet time thefts

- Cyber terrorism against the government or organization

- Distribution of pirated software

- Trafficking

- Pornography (especially child pornography)

- Frauds

- Financial crimes 


\section{Financial Crimes}

Any crime committed for financial gains is called "financial crime". With the changed banking environment on account of IT and communication revolutions, banks are offering many services like internet and mobile banking, online trading and more of e commerce facilities. Examples of financial crimes are: cheating, credit card frauds, hacking into bank servers, etc.

\section{Fraud and Cheating:}

Fraud or cheating can be referred to any dishonest and intentional action to deprive or dupe a person of his or her money, assets or legal rights. As regards cyber crimes frauds and cheating can be classified into:

- On line cheating and/or fraud:-

This is the most popular cyber crime. Some examples are

(i) Offer jobs and require you to furnish sensitive information

(ii) Calls for sensitive information like bank account details, credit card details, pass words, user IDs. through the communications purported to have generated from the Income Tax authorities, Government Agencies, Reserve Bank of India and other Institutions

(iii) Informing about winning a lottery or identifying the person as the beneficiary of huge fortunes left by somebody. Such messages are usually circulated from foreign countries.

(iv) Encourage the customer to invest in schemes that offer unduly higher returns

(v) On line shopping may end up in the "buyer buys goods or services" when purchased articles are never delivered.

- Fraud committed on account of weakness in computer systems-

Input stage: data is falsified and entered in a manner that makes the data as genuine

Output stage: information is altered and/or destroyed to conceal un authorized transactions. Storage of data is altered or deleted

- On account of forgery: Forgeries are committed by using computers. Some examples are: printing of counterfeit currency notes, stamp papers, certificates. Modern printers and scanners photocopiers are used to carry out such frauds.

Information Theft: Information theft arises when confidential information is stolen for various reasons either by intruders to the IT system and /or by insiders. It can result in situations such as (i) the reputation of an entire organization is lost (ii) customer confidential information/data is damaged (iii) regulatory violations are exposed

\section{Other Important Issues}

Cyber extortion: A crime involving an attack or threat of attack against an enterprise. It is a crime through which a criminal gains access to a victim's email account by stealing his or her password. By this unauthorized access into the email account, the criminal sends malicious code to various persons in the victim's address book.

Intellectual Property Theft: Intellectual Property refers to the ownership of rights of a person, company with regard to software, copyright, patents, trademark and similar intangible assets. When the ownership rights as mentioned above are deprived partially or completely, it is called as an Intellectual Property Right (IPR) violation.

Computer Security: Computer system is very sensitive to security controls. In case of weak security control, computers are exposed to many risks. On account of carelessness by users, and organizations, the problems would be more including free access to cyber criminals which might lead to financial and reputational loss as well. 
Organizations including banks are subject to cyber attacks. Cyber criminals and hackers commit fraudulent acts involving stealing of credit card details of individual cardholders from a bank site. They can make use of the information to defraud the customer and bank to gain financially.

If a bank fails to protect or safeguard the sensitive information of the bank and or its customer/s, the bank would face losses which can be broadly classified into:

Financial Loss: Credit card/Debit card information hacked by criminals could result in huge financial loss.

Reputation Loss: On account of weak control system, a bank can face reputational loss

Legal Loss: A cyber attack on a bank can result in legal cases initiated by customer against the bank. The bank might end up paying huge amount of compensation and legal costs.

Banks as financial intermediaries play a crucial role in the financial markets. Banks also act as trustees depending upon situations. It is their responsibility to protect not only the funds of their clients but also the sensitive customer information/data as well. With increasing cyber crimes of different forms, banks should have a very good security control system to protect their customers, bank's assets and other information from cyber crimes.

\section{Integrated Communication Network for Banks Security and Control Systems}

Banks are exposed to many risks in their activities relating to management of funds on line banking services. credit card and other e- banking products/services are also facing risks which are associated with the use of IT tools, channels, platforms. Banks should have a good and effective control system to handle IT related issues and risks.

Control system can be classified as:

\begin{tabular}{|c|c|c|}
$\begin{array}{c}\text { Preventive } \\
\text { Controls }\end{array}$ & $\begin{array}{c}\text { Detective } \\
\text { Controls }\end{array}$ & $\begin{array}{c}\text { Computer } \\
\text { Controls }\end{array}$ \\
\hline $\begin{array}{c}\text { Detective } \\
\text { Controls }\end{array}$ & Internal & Information \\
\hline Controctive & Constem Audit \\
\hline Controls & Pysicla & \\
\hline
\end{tabular}

Preventive Controls: This type of control stops errors or irregularities. Good design/ screen lay out reduces or stops the errors at the time of coding data or entering data from source document.

Detective Controls: Identification of errors or irregularities happens after they occur. For example: An input validation program identifies data input errors.

Corrective Controls: These types of controls remove or reduce the effects of errors and irregularities after they have been identified. If any data is corrupted during transmission the communication software (with inbuilt control) may request for retransmission of information/data.

Physical Controls: In computerized environment, the control of access is very important in view of the confidential and sensitive information/data which are being processed/stored at the data processing center.

Access Control assist the organization and users in restricting entry to authorized persons only to the computer room and also allowing access to computer media, computer components, data, documentation etc. Unauthorized persons should not be allowed to undertake repairs/ maintenance of computer hardware. Access to the computer system should be protected through pass word protection mechanism. Access to the computer system can be 
allowed by means of PIN, biometric methodology. Access control should be very strict and only authorized users, officers should be allowed inside the data center, computer room and all others should be allowed to enter the data center and computer rooms after recording in the access log.

Output controls: Hard copies of all important reports generated should be preserved properly as per the bank's record maintenance policy.

As part of disaster management, the computer room, data centers need to be checked for proper functioning of fire extinguishers, smoke detectors and other devices. Backup tapes and other data should be stored in off sites. Regular checks should be carried out to ensure that such back up CDs and other tools/data can be used in case of an emergency/contingency.

Internal Controls: To ensure that the accounting data and other sensitive customer information are accurate and reliable and also to protect assets of the bank, a system of internal controls are built in the computerized systems. An effective and efficient internal control would assist the bank management to run the bank's operations in a better controlled environment.

Accounting Controls may be in the form of (a) dual controls and authorizations (b) validation checks on data (c) other controls on access to the software applications.

Some other controls include validation of each transaction against limits and balances, stop payments, post dated and stale dated cheques, etc.

Operational Controls: Operational controls are embedded in software whereas access controls can be enforced by the system software and an application software at different levels. The operational controls are usually provided in the application software to ensure data integrity and processing. To ensure operational controls, some tools like audit trail, checksum and data encryption are used. Audit trail maintains a record of processes that update the data and information. Checksum is a number calculated on the basis of certain key information in the system. Checksum is generated to ensure data integrity stored in a computer file. Data Encryption is the process of systematic encoding of data before transmission to protect the system from unauthorized access, and an unauthorized person cannot decipher it. End to end encryption protects the integrity of data passing between a sender and receiver. In the electronic funds transfer systems, a control mechanism which applies a message authentication code is used to identify changes to a message in transit.

Computer Audit covers, review of operations to ensure compliances of bank's systems and procedures and policies, standards.

It includes review of the system's integrity covering fraud detection/prevention, application program and operating system, user acceptance tests at the time of software program implementation and up gradation.

Audit around the computer: The auditor examines the internal control system of the computer installation and related input and output of the application system. 'Around the computer audit' needs to be carried out to ensure/ verify: (i) the systems are supported by well tested software (ii) a clear cut system generated audit trail is available (iii) proper physical controls are in place (iv) duties and responsibilities of various employees are well defined and segregated.

Audit through the computer: This is used to check whether logic and controls are available within the system and records produced by the system are in conformity with the input and expected level of output. Audit through the computers can be carried out by test checks, mock trial runs, and the tools like special audit modules embedded in the application systems to generate audit evidence. Auditors also use audit software consisting of computer program as audit tool. Computer Aided Audit Tools and Techniques (CAATTs) are used to audit computer generated files, records, data and documents. This tool also assists for evaluation of the internal controls of computerized environment in banks.

Information System Audit (IS): This audit is carried out through the IT systems with the assistance of CAATTs 
and CMITTs. These tools are used to carry out the information system audit. The information system audit covers various controls like preventive, detective and corrective controls and their effectiveness in protecting bank's information systems. Information System audit assesses the strengths and weaknesses of the bank's information system. It identifies the risks of exposure associated with the existing computerized environment. The audit findings can be used as a preventive tool by the banks to take appropriate action to mitigate such risks. IS of a bank can also highlight the following:

- integrity of the system to safeguard the assets of the bank

- reveals the status of the information system indicating any short comings as well

- assists banks to take a better decision on the management control system of the bank

\section{Off-site Audit}

Banks should setup proper offsite monitoring cell (OSM) in audit department or put in place suitable similar structure. Such cell should review the MIS on critical items and sensitize the controlling offices and the branches, for corrective action on daily basis. The OSM cell should also apprise the Top Management of serious irregularities, if any, immediately. The Banks should move to software based audit process.

\section{Information System Security (ISS)}

In today's complex and competitive changing business environment, the information technology assists banks across the globe to offer wide range of services and products and also give competitive edge to the players with well supported information system. However, banks are also exposed to many risks on account of growing opportunities on account of information system. This leads to the security concerns of the information system and calls for implementation of an effective control system as well. Since banks are important segment in the financial sector and also acts as trustees of funds. The information system security of banks should provide comfort levels both for the banks as well as customers and regulators.

\section{Objectives of banks' IS Security Policy:}

Confidentiality: The confidentiality of customer information and sensitive financial data should not be revealed to unauthorized persons. The IS security should ensure that the confidentiality is maintained

Integrity: Banks' IS security should protect banks information system from accidental or unauthorized and deliberate alteration or deletion of information

All the required controls should be in place to ensure availability of reliable and correct information to the authorized users and persons. These controls include access controls by PIN, pass words, proper approved authentication control, and effective internal controls.

E-banking allows on line banking services and as such the banks' should ensure high level of IS security as part of e banking.

Threats to IS Security: Banks are also offering Core Banking Solutions along with e banking or online banking. In view of these facilities, network security is a concern for banks.

E-mail viruses, Phishing attacks and other issues: Installation of updated antivirus software would assist banks to handle email viruses. The users should be cautioned not to open e mail from unknown sources and spam mails. Phishing is one form of cyber attack in which the attackers make the internet users to reveal sensitive information about the bank account details and personal information. Banks should use certain level of protection by installing fire walls for data integrity. Fire walls do not allow direct access between the internet and the banks' system. This facilitates a high level of control and monitoring. Necessary controls should be exercised in case of computer hardware and software to secure banks information system. 
Disaster Recovery Management Control for computer environment: Banks should have in place a disaster recovery policy as part of their management control system. Any incident which results in direct denial or stoppage of essential business functions of a bank for unreasonable period of time is called as a disaster. If this stoppage of business is going to affect the customers it should be treated as disaster. Disaster recovery plan of a bank should give importance to the security of bank's information system. Some examples which cause the disaster to a bank's operations are:

$\begin{array}{llll}\text { External Factors } & : & \text { Natural disasters like floods, fire and earthquake etc. } \\ \text { Internal Factors } & : & \text { Hardware and Software failures, } \\ \text { Other Factors } & : & \text { virus attack, acts of terrorism }\end{array}$

\section{Information Technology Act, 2000 \& other Relevant Acts}

Information Technology Act 2000 provides legal protection for transactions carried out by means of electronic communication. In view of the recognition given to electronic records, electronic signatures, and electronic documents, the banks are also required to follow the amendments of other Acts, such as,

(i) The Indian Penal Code 1860

(ii) The Indian Evidence Act 1872

(iii) The Indian Negotiable Instruments Act, 1881

(iv) The Banker's Books Evidence Act, 1891 and

(v) The Reserve Bank of India Act 1934

\section{LESSON ROUND UP}

- IT has revolutionized banking sector to a great extent.

- While the IT and communication technological revolutions have created good opportunities for banks in their business expansion, they have also exposed banks to risks associated with them.

- Banks have been able to offer virtual banking facilities to their clients and many innovations of making services available through $24 \times 7$ basis, internet banking and Core Banking Solutions, quicker transfer of funds through RTGS and NEFT.

- On the other side, banks are also subject to impact of Cyber Crimes, Money Laundering activities etc.,

- Recognizing the importance of risks in IT, the regulators, and banks' all over the world need to strengthen their risk management system.

- Banks are the main intermediaries in the financial sector, therefore, they should be very careful in handling the funds of their clients, with an effective and proactive IT related risk management controls in place to effectively handle the cyber crimes.

- With the fast growing e-banking and e-commercial activities, banks should endeavor to have innovative ways to handle the issues relating to the IT and Communications.

\section{SELF TEST QUESTIONS}

1. State whether the following statements are 'True' or 'False'

(a) RTGS offers real time transfer

(b) CTS is part of Core Banking Solution 
(c) Pre acceptance test of any new software program is an example of preventive control

(d) Public key and private key are terms associated with the digital signature

2. Choose the correct alternative

A. Which of the following statement is correct?

(a) Payment through RTGS reduces market risk

(b) Payment through RTGS reduces credit risk

(c) Payment through RTGS reduces cross border risk

(d) Payment through RTGS reduces liquidity risk

B. As regards Payment Systems identify the exception:
(a) CHAPS
(b) SWIFT
(c) CHATS
(d) CHIPS

C. Input validation program identifies data input errors is example of
(a) Preventive Control (b) Output controls
(c) Corrective Controls (d)
(d) Detective Controls

D. Which is not part of cyber crime?
(a) Intellectual Property crimes
(b) Internet time thefts
(c) Internet banking
(d) Distribution of pirated software

3. What do you mean by cyber crimes? Explain its types. What are the reasons for cyber crimes? How cyber crimes can be managed?

4. Discuss in brief the various aspects of electronic funds management

5. What are the various risks associated with the international payment systems?

6. As regards integrated communication network, identify an effective control system.

7. Write short notes on:
(a) Computer Audit
(b) Information System Security
(c) Financial loss
(d) Real Time Gross Settlement (RTGs):
(e) National Electronic Funds Transfer (NEFT)
(f) Automated Teller Machines (ATMs)
(g) RBI - Payments and settlements System 
Lesson 11 Electronic Banking and IT in Banks 297 
298 PP-BL\&P 


\section{Lesson 12}

\section{Risk Management in Banks}

\section{LESSON OUTLINE}

- Principles of Lending

- Risk Management - An Overview

- Risk Management - Important Features

- Credit Risk Management

- Liquidity And Market Risk Management

- Cross Border Risk

- Operational Risk

- Basel III

- Reporting of Banking Risk

- Risk Adjusted Performance Evaluation

- Lesson Round Up

- Self Test Questions

\section{LEARNING OBJECTIVES}

With the fast changing global business environment banks as part of the financial sector and as an important financial intermediary, handles different types of financial transactions. In view of the presence of the banks across globe, and their interconnectivity through branch net work and correspondent banking relations, banks are exposed to various types of risks. On account of their operations at different markets, banks are facing uncertainties in their operations, which are not only spread across different financial centers, but also more are less operative on $24 \times 7$ basis, and on different time zones. As such, the impact of various risks either directly or indirectly affects the banks' operations. In this chapter the different types of risks and the systems and procedures to manage the risks are covered.

After reviewing the chapter the reader would be able to;

- Understand the various types of risks associated with banking companies

- Appreciate the role of the Regulators in managing such risks

- Know the importance of risk management in banks and the guidelines of the Basel Committee

- Integrate the effectiveness of different types of risks and the reasons thereof and various methods to manage risks 


\section{RISK MANAGEMENT - AN OVERVIEW}

\section{Risks}

A risk arises on account of an uncertain event, which might result in a loss or gain to the parties associated with such risk. Even though the risk is an independent event, invariably risks are interlinked in the sense; one risk may lead to other risks as well.

Risks can be classified into various types. Few examples of risks are shown in the following diagram:
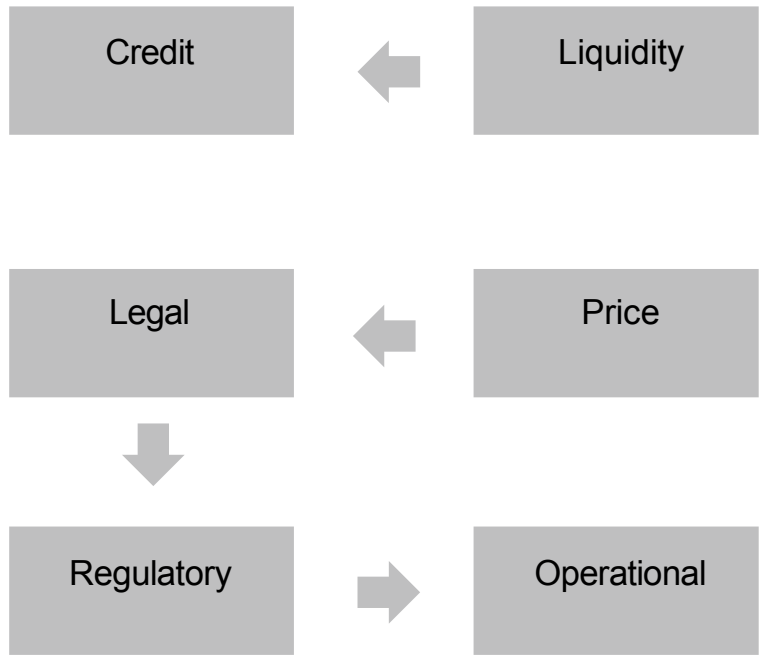

Interest

Rate

Foreign exchange

As per the Basel norms, these risks are broadly classified into three:

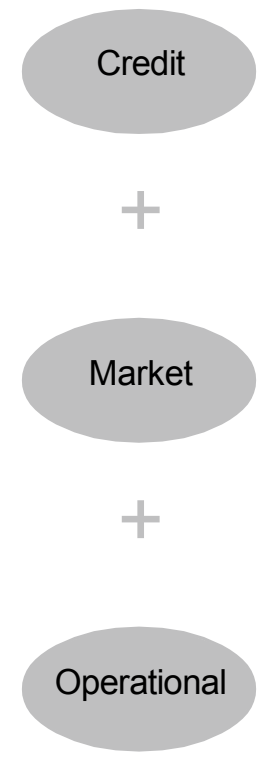

Riks

The first diagram indicates various risks and the second diagram shows three important classifications of the risks.

To illustrate how these risks are interlinked, let us take examples of two market situations.

(1) Bank A lends to B Rs.10,00,000.00 for a period of six months. On the due date (maturity of the loan) borrower B needs to repay to Bank A Rs. 10,00,000.00 + applicable interest. Assuming on the due date 
if $B$ fails to repay the amount, then it becomes a credit risk for bank $A$, on account of default in payment by the borrower. On account of the non receipt of the funds, Bank A would face another risk called liquidity risk. Not only that, it would lead to a situation of asset liability mismatch (gap risk) for bank A. In view of the shortage of funds, and also to manage the mismatch in its asset liability, bank A should arrange for funds from (a) accepting new deposits and/or approach the market to borrow at the markets interest rate. Hence bank A would be facing the market risk (and needs to pay the market interest rate). In the ordinary course, these transactions would not have arisen, if the borrower $B$ had repaid his loan on the original due date. Further, our assumptions are that after few days, if borrower $B$ repays the loan amount and interest thereof, once again the bank A would face asset liability mismatch on account of funds received. Such funds need to be deployed in the market subject to market interest rate. Assuming on the date of deployment if the market rates come down, the bank A would face a loss. A recap of this illustration would show case how; one risk is extended to series of risks. Credit risk - liquidity risk - mismatch (gap) risk - market risk (interest rate)

(2) Bank $X$ entered into a spot forex deal with Bank Y. Bank X agreed to sell US\$ 1 million to Bank $Y$ at a particular exchange rate. On the date of delivery Bank $Y$ settled the equivalent rupee funds to Bank $X$. However, Bank $X$ could not deliver the US $\$ 1$ million. So Bank $Y$ is facing a credit risk, also called settlement risk. This would lead to further risks for Bank $Y$. There would be shortage of funds in the Nostro account of Bank Y. Bank Y needs to fund the account and should (a) either arrange for a fresh deal and/or (b) borrow in US markets at the market's interest rate. The non receipt of US funds has created not only credit risk, but also liquidity as well as mismatch risk in the assets and liabilities of the bank Y. Further on account of approaching the forex markets as well as US market, to enter into a new forex deal and to borrow funds in the US market, bank Y would also face market risks (viz., Exchange Rate risk and Interest rate risk respectively).

Basel Norms categorized these risks broadly into three viz, (1) Credit Risk (2) Market Risk and (3) Operational Risk We have seen examples of Credit Risk and Market Risk and how these are interlinked.

Let us take another example i.e., Operational Risk: Apart from credit and market risks, other risks can be recognized as part of operational risk. Operational risk mainly arises out of non adherence to the regulatory directives, guidelines, non compliance of legal frame work, on account of human and system errors, natural disasters, and also on account of frauds, misappropriation of funds, weak internal control systems etc. Any risk which arises out of one or more factors mentioned above can be recognized as operational risk. Any of the operational risk would create a credit risk for the counter party, and as already explained above, there would be chain effect, like operational risk-credit risk-. liquidity risk - mismatch (gap) risk - market risk (interest rate).

In view of the above, banks should be very careful in their risk management.

\section{RISK MANAGEMENT - IMPORTANT FEATURES}

1. Risk management policies should be approved by the board. It should cover all the required guidelines and directives of the regulators and applicable legal frame work

2. There should be a good support from the Information Technology wing for creating an integrated system whereby an effective and efficient MIS would be an integral part of the risk management

3. There should be clear demarcation of functions and authority levels to ensure better internal control systems (ex: front office, mid office and back office of an integrated treasury)

4. An effective communication system coupled with the training programs

5. One of the risk mitigation measures is to setup appropriate limits for various aspects like counter party limit, country limit, currency limit, over night and intraday limits, stop loss limit, individual and group exposure limits etc. 
6. Inbuilt checking and balancing systems, such as input and output controls, access control to the computer systems, and sensitive areas of the banks

7. Apart from review by the ALCO members, a periodical review and evaluation system should be in place

Risk Management is a methodology that helps managers make best use of their available resources. The process consists of important steps like:

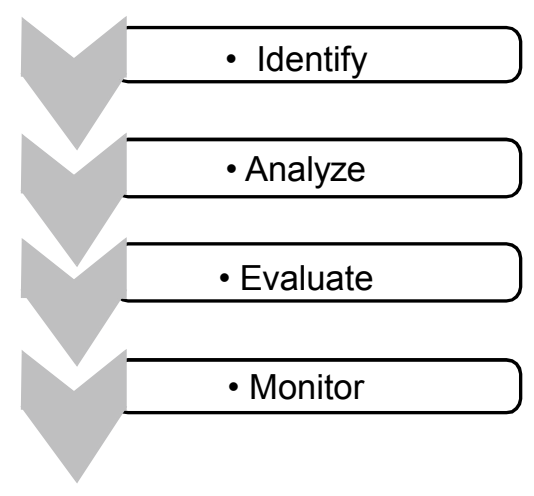

\section{Identification of risks:}

Identify the types of risks are associated with the banking business and operations. Define the types of risk, with special reference to the goals and objectives of the organization. Based on the past experience and future forecasts, risks can be identified and classified in to different levels like High, Medium and Low levels

\section{Analyzing the risks:}

Risks arise out of many factors like, PESTEL factors, Micro and Macroeconomic policies, ineffective internal control systems, speculation etc., Risks can be identified by means of using various analysis like financial, technical, trend and sensitivity analysis based on probability, trend, etc.,

\section{Evaluating the risks:}

The risk may be evaluated by following the Regulators guidelines and directives and also based on past experiences as well. At the time of evaluation, proper weightages needs to be assigned for different types of risks as per banks' risk management policies, such as, risk category, cost associated in managing such risks and also the impact of such risks.

\section{Monitor and review:}

Monitoring and review process is an important segment in risk management. An effective monitoring system would assist bank management to identify or forecast risks to enable it to strengthen risk management with more controls to manage the risks which might arise from their business models and their exposure to various markets, across borders. In identifying, prioritizing and treating risks, organizations make assumptions and decisions based on situations that are subject to change, (e.g., the business environment, trading patterns or government policies).

\section{Mitigation of risks:}

One of the main objectives of the Risk Management is to ensure that risks are either avoided or minimized. While it is agreed that not all risks can be avoided, good risk management practices should create an effective system of mitigation of risks.

\section{Risk Management Structure}

Banking companies should create an effective risk management structure to handle the risks associated with the 
bank's business models and operations. The risk management structure should cover the Credit, Market, Operational and other risks. The structure should be ably supported by the technology in identification and monitoring process of risks.

The Risk Management Committee should be formed at the Board level with the overall responsibility to monitor and manage the overall risks of the bank.

Asset-Liability Management Committee (ALCO) is a strategic decision making body, formulating and overseeing the function of asset liability management (ALM) of a bank.

ALCO is headed by the Managing Director or the Chief Executive Officer.

The functions of these risk management committees are to identify, assess, evaluate, monitor and measure the risk profile of the bank. The Risk Management Committee also develops the policies and procedures, reviews the pricing models, and also identifies new risks. The Risk Management Committee is assisted by other individual risk management sub-committees.

\section{Risk Management under Basel I}

The Basel Committee on Banking Supervision (BCBS) is a committee which was set up by the Central Bank Governors of a group of ten countries, to address international issues relating to the banking supervision. The Basel Committee on Banking Supervision in 1988 came out with a Capital Accord for banks, covering the areas of risks in respect of banks' assets and liabilities in the balance sheet and off balance sheet exposures. Under the Basel I Accord, only the credit risk factor was considered and the minimum requirement of capital funds was fixed at 8 per cent of the total risk weighted assets. In India, banks are required to maintain a minimum of 9 percent (Capital to Risk Weighted Asset Ratio - CRAR) on an ongoing basis.

\section{Risk Management under Basel II}

The Second Accord brought in significant changes in risk management in banks. The Basel II accord introduced a new approach based on the three pillars:

\section{Pillar I: Minimum Capital Requirements:}

The minimum capital requirement should be calculated based on three risks viz., (a) Credit Risk - (i) Standardized Approach (ii) Internal Ratings Based Approach (b) Operational Risk and (c) Market Risk

\section{Pillar II: Supervisory Review Process:}

This pillar addresses the issues like the key aspects of supervisory review, risk management guidance and transparency and accountability. It also covers the treatment of interest rate risk in the banking book, credit risk (stress testing, credit concentration risk etc) operational risk, enhanced cross border risks.

The committee had identified four key principles of supervisory review:

(i) Banks should have in place a process for assessing their overall capital adequacy in respect of their risk profile vs. maintenance of capital level

(ii) Supervisors should play a key role in reviewing and evaluating banks' internal capital adequacy assessments and strategies. Supervisors should also be satisfied with the banks' abilities in managing the capital adequacy ratios and comply with the regulators' guidelines. If not satisfied with the performance of banks in their compliance requirements, the supervisors should take appropriate

(iii) Supervisors should ensure that banks maintain and operate above the minimum regulatory capital ratios

(iv) Supervisors should intervene at an early stage, to prevent capital level from falling below the minimum levels required and take quick remedial measures 


\section{Pillar III - Market Discipline:}

As part of an effective risk management, banks are expected to disclose important information. Such market discipline can contribute to a safe and sound banking environment. These disclosures would assist various stakeholders to review and understand the status of the banks' operations and strategies in a competitive business environment. These disclosures would assist the investors to make their investment decisions

\section{CREDIT RISK MANAGEMENT}

Credit risk arises when one of the counter parties fails to fulfill the obligation to settle the payment or repay the borrowed amount. It is also called as default risk and/or settlement risk.

Identification of credit risk: Close monitoring of operations in operating loan account like working capital finance, cash credit and overdraft accounts would assist the bank to identify the risk based on the signals and warnings from the manner in which the account is being operated. Also non submission of stock statements, wrong information provided in stock statements, regular inspections of stocks, and review of market reports are essential tools to identify the credit risk.

\section{Mitigation of Credit Risk:}

Credit Risk can be mitigated if the banks follow certain norms like:

(a) Adherence to KYC norms: Clear identity of the borrower and the borrowing company, and the nature of business model

(b) Credit Appraisal: The loan proposals should be considered as per bank's loan policy and guidelines of the Reserve Bank of India and other directives. The credit limits (both fund based as well as non-fund based) should be fixed after due assessment of many risks associated with the type of borrower, nature of industry and other factors. Such limits should be subject to sufficient margin and appropriate collateral requirements to safe guard the banks' interests. Regular monitoring of the loan accounts should be an integral part of effective risk management system. Respecting the credit limits and allowing the clients to operate within the credit limits and ensuring other terms and conditions of the credit sanction, and adherence to the exposure norms as per regulators' guidelines would assist the banks to manage the credit risks. Risk based pricing of loans and advances and credit rating can be used as an effective tool as part of credit management.

\section{Credit Risk measurement - Basel II Norms}

The risk which arises on account of default is associated with almost any financial transaction. BASEL-II provides two options for measurement of capital charge for credit risk

1. Standardized Approach (SA) - Under the SA, the banks use a risk-weighting schedule for measuring the credit risk of its assets and off-balance sheet positions. A risk weight of $100 \%$ indicates that an exposure is included in calculation of assets for full value, by assigning risk weights based on the rating assigned by the external credit rating agencies.

2. Internal Rating Based Approach (IRB) - The IRB approach, on the other hand, allows banks to use their own internal ratings of counterparties and exposures, which permit a finer differentiation of risk for various exposures and hence delivers capital requirements that are better aligned to the degree of risks.

The IRB approaches are of two types:

(i) Foundation: Under this method banks estimate the risk of default or the probability of default associated with each borrower.

(ii) Advanced: Under this method banks are allowed to have additional internal capital to assess additional risk factors. 


\section{LIQUIDITY AND MARKET RISK MANAGEMENT}

As explained earlier, one of the important risks faced by banks is the liquidity risk. The banks' treasury handles the liquidity management through money market and forex market operations; hence a careful strategy needs to be in place for market related activities.

Identification of Liquidity Risk: Review of asset and liability mismatch is one of the eye openers. There should be close control on the utilization of short term funds for long term assets and vice versa, that would lead to maturity mismatches. An effective credit monitoring and operations of the banks can reduce the impact of the liquidity risk. A good internal control review and online monitoring system, identification of weakness in the systems and procedure etc, would also assist the bank to manage the inflow and outflow of funds effectively.

Internal limits for cash management including foreign funds and an effective reconciliation of nostro accounts are some of the measures to reduce the impact of the liquidity risk.

The role of the treasury in managing the liquidity position is very important. The treasury should closely watch the market movements and accordingly handle the situations. To effectively monitor the risk, banks should set up limits for currency, country and adhere to investment exposure norms as well. A close watch on the macro level factors at different markets and ensuring necessary control measures of revising exposure limits and other aspects would also assist to manage the liquidity risk. Review and understanding the various features of the monetary policy and quarterly review by the Central Bank (Reserve Bank of India) and appropriately adjust the strategies would assist the banks in effectively managing the liquidity position.

\section{Market Risk}

In a sense, the market risk arises on account of the external factors, i.e., market forces of demand and supply factors. Market risk arises from the adverse movements in market price. Market risk can also be defined as the risk of losses on account of on-balance sheet and off-balance sheet positions due to the movements in market prices.

The market risk can be broadly recognized as: (i) Interest Rate Risk (ii) Foreign Exchange Rate Risk (iii) Equity Price Risk (iv) Commodity Price Risk

\section{Interest Rate Risk:}

One of the important factors that affect the bottom line of any bank is the volatile movement of. Interest rate. .

The interest rates of deposits/loans are basically determined by the market forces (i.e., demand and supply for/ of funds). These are influenced by various factors like: (i) Government Policies (ii) Speculation (iii) Inflow and outflow of funds (iv) present and future commitments (v) Other factors such as opportunities to invest in other markets etc.

\section{Exchange Rate Risk:}

The price movement in terms of foreign exchange transactions (deals) is called the exchange rate risk. The exchange rate movement is mainly felt in case of the floating exchange rate system (price/exchange rate is decided by the demand and supply factors). As the markets are wide spread and the exchange rate movement is so quick and moves either way (up and down), it is difficult to assess the market movements when it is very volatile. The volatility in the exchange rates movement are due to various factors such as the Government and Regulators' policies, speculation, forecasting, markets operating in different time zones almost on $24 \times 7$ basis etc.

The market risk positions necessitate a bank to maintain the capital for calculation of capital adequacy ratio is:

(i) The risks associated with the interest related instruments and equities in the trading book of the banks and

(ii) Foreign exchange risk (including exposures in precious metals) throughout the bank, both in banking and trading book* 


\section{Banking book:}

The banking book comprises assets and liabilities, which are contracted basically on account of relationship or for steady income and statutory obligations and are generally held till maturity.

\section{Trading book:}

Investments held for generating profits on the short term differences in prices/yields, Held for trading (HFT) and Available for sale (AFS) category constitute trading book.

Market risk can be assessed/measured by various analysis such as scenario analysis, trend and stress analysis

\section{Scenario Analysis:}

A method in which the earnings or value impact is computed for different interest rate scenarios.

\section{Stress Analysis (testing):}

This is used to evaluate a bank's potential vulnerability to certain unlikely events or movements in financial variables. The vulnerability is usually measured with reference to the bank's profitability and /or capital adequacy

Duration Analysis, measures the price volatility of fixed income securities. It is often used in the comparison of interest rate risk between securities with different coupons and different maturities. It is defined as the weighted average time to cash flows of a bond where the weights are nothing but the present value of the cash flows themselves. It is expressed in years. The duration of a fixed income security is always shorter than its term to maturity, except in the case of zero coupon securities where they are the same.

\section{Market Risk - Basel II norms:}

Market risk is defined as the risk of loss arising from movements in market prices or rates away from the rates or prices set out in a transaction or agreement. The capital charge for market risk as per the Basel norms can be estimated by two methods viz., Standardized Measurement Method and internal risk management model.

\section{The Standardized Measurement Method:}

This method, currently implemented by the Reserve Bank, adopts a 'building block' approach for interest-rate related and equity instruments which differentiate capital requirements for 'specific risk' from those of 'general market risk'. The 'specific risk charge' is designed to protect against an adverse movement in the price of an individual security due to factors related to the individual issuer. The 'general market risk charge' is designed to protect against the interest rate risk in the portfolio. In the Standardized Approach, there are two ways to measure market risk i.e., duration method and maturity method. Under the duration method banks can calculate the interest rate risk, by calculating the price sensitivity, of each position separately. Further the measurement of capital charge for market risks should also include all interest rate derivatives and off-balance sheet instruments in the trading book.

Foreign exchange open positions and gold open positions are also to be considered for capital charge as per Basel norms and the Reserve Bank of India guidelines.

Banks should strictly follow the Reserve Bank of India's guidelines in classification of securities as Held for Trading, Available for Sale etc., and accordingly assign risk weights. Banks should also assess their trading books and assign risk weights as per the Reserve Bank guidelines

\section{Value at Risk:}

Market risk can be measured through this tool called "Value -at- Risk" (VaR). .VaR is a method for calculating and controlling exposure to Market Risk. It is a single number (currency amount) which estimates the maximum expected loss of a portfolio over a given time horizon (holding period) and at a given confidence level. It is measured in three variables: the amount of potential loss, the probability of that amount of loss and the time frame. 


\section{Other Important Risks:}

\section{Mismatch Risk (Gap Risk):}

Banks as important players in the financial sector acquire funds in the form of deposits from public (individuals/ corporates) and deploy them to (individuals/ corporates) as loans and advances. The funds accepted/borrowed are reflected as liabilities and the funds deployed/lent/invested appears as assets in the balance sheets. Depending upon the business model, the liabilities and assets will have a mismatch or gap between them. In case of Foreign Exchange Operations, the Foreign Exchange dealer's position (exposure) in various currencies arises due to the purchase and sale of foreign currencies in different markets, and for different maturities. The mismatch in maturities between purchases/sales creates a gap. These gaps can be classified based on the time period of maturity (due dates). Therefore, to cover these (exposures) open positions banks need to buy or sell/borrow or lend in the market, depending upon the price of currencies (exchange rates) and interest rates.

\section{Cross Border Risk}

Another risk which is exclusively applicable to foreign exchange transactions is the cross border risk. This type of risk is also known as country risk/sovereign risk. Foreign Exchange markets operate on 24X7 basis almost continuously. Obviously, all centers do not operate simultaneously and hence results in time zone difference and that leads to risks associated with various centers which is popularly called as cross border risk.

\section{Country Risk:}

It is a risk in which a foreign entity, private or sovereign may be unwilling or unable to fulfill its foreign obligations for reasons beyond the usual risks, in respect to all lending and investments.

\section{Country Risk Management System (CRMS)}

For an effective CRMS, as per the guidelines of the Reserve Bank of India, banks have to adopt the following. Some (a) Strict adherence to the "Know Your Customer" (KYC) principle in international transactions (b) Country risk factor should be given special attention while evaluating the counterparty risk (c) All exposures funded, non funded from domestic as well as international centers needs to be included while determining the country limits

The Statutory Auditors have to audit the country risk exposures of the bank as at the end of the year. In addition to the auditing being carried out by the Statutory Auditors, banks have to make necessary provisions for country risk exposures and should disclose them as part of the 'notes to account' of the balance sheet and report to the Reserve Bank of India as part of DBS return.

In respect of CRMS, the funded, non -funded and indirect exposures would include the following items: Some examples:

\section{Direct Exposure - funded:}

(i) Cash balances - Foreign currency, if any held by branches

(ii) Bank balances and deposit placements: Covers the bank balances and placements with banks incorporated outside India

(iii) Loans and Advances: Loans against NRI deposits exceeding the deposit amount, Travellers' cheques purchased

(iv) Overdrafts in Vostro accounts etc.

\section{Direct Exposure - non funded:}

(i) Letters of Credit: Exposures on account of Letters of credit issued by branches on behalf of constituents resident outside India 
(ii) Guarantees: Exposures on account of guarantees issued by branches on behalf of entities resident outside India iii Confirmed LCs issued by foreign banks etc.,

Short term country risk exposures are those exposures which have contractual maturity up to 179 days.

\section{OPERATIONAL RISK}

In banks, the risks which arise out of the failure in internal systems and procedures, internal control system and/or human and system errors, and other internal/ external factors like non compliance of regulatory and legal frame work, frauds, misappropriation etc., One or more of the above mentioned risks are collectively called as the "Operational Risk".

\section{Some Examples of Operational Risks}

\section{Information Technology Risk:}

Banks in India are well supported by the Information Technology to carry out their banking business and operations. This has increased the banks' operational risk. The risks associated with IT are: Error Risk, Fraud Risk, Interruption Risk etc., In case of weak IT controls and non adherence to the laid down policies and procedures, the computerized systems could be exposed to unauthorized access. Pre acceptance tests if not properly carried out can lead to issues which can be termed as operational risk on account of IT. If the computerized control (both around the computer system and through the computer system) is not properly ensured, it can lead to a situation of fraudulent activities. Failure on the part of the management to ensure regular testing of disaster management control, in case of emergency, might increase the risks. Hence importance should be given and care should also be exercised by having a proper operational risk management with special reference to the Information Technology.

\section{LEGAL RISK}

With the changing economic scenario, banks are not only exposed to risks associated with the domestic markets, but also to international markets as well. More and more banking activities across borders, banks have to comply with more than one regulatory authority and also a number of legal frame work of international importance. The cross border or country specific legal requirements needs to be properly interpreted and understood and applied in the case of international trade and finance. The money laundering has become an important international issue; banks have to be careful in its operations. Banks should appoint international legal firms to handle their legal compliance to avoid legal risks.

The Basel Committee defines this risk as "The risk of loss arising out of inadequate or failed internal processes, people and systems, or from external events". Banks have to make capital allocation for operational risks as well.

The revised BASEL II framework offers the following three approaches for estimating capital charges for operational risk:

(1) The Basic Indicator Approach (BIA): This approach sets a charge for operational risk as a fixed percentage ("alpha factor") of a single indicator, such as the banks' gross annual revenue.

(2) The Standardized Approach (SA): This approach requires that the bank separate its operations into eight standard business lines, such as trade finance, corporate banking and others. The capital charge for each business line is calculated by multiplying gross income of that business line by a factor ("beta") assigned to that business line.

(3) Advanced Measurement Approach (AMA): Under this approach, the regulatory capital requirement will equal the risk measure generated by the banks' internal operational risk measurement system.

As per the guidelines of the Reserve Bank of India, banks are required to integrate to the Basel II framework, with the Standardized Approach for Credit Risk and Basic Indicator Approach for Operational Risk. Banks are also 
required to upgrade their technology base to support implementation of Risk Assessment and Risk Management structure to meet the requirements of the Advanced Approaches under Basel II.

\section{RISK MANAGEMENT UNDER BASEL III}

As per Basel Committee on Banking Supervision (BCBS), Basel III reforms have been introduced to improve the banking sector's ability to absorb shocks arising from financial and economic stress, thus reducing the risk spillover from the financial sector to the real economy.

Basel III norms address the following:

(a) At micro level, through prudential regulation to strengthen the individual banking institution's ability to handle crisis in the period of stress

(b) At macro level, through prudential regulation to address system wide risks across banking sector as well as the pro-cyclical amplification of these risks over a period of time

(c) Raising the quality and level of capital to ensure that the banks are better equipped to absorb losses on both, a going concern basis and a gone concern basis

(d) Increase the level of risk coverage of the capital framework by introducing leverage ratio to serve as a backdrop to the risk-based capital

(e) Raise the standards for supervisory review (Pillar 2) and public disclosures(Pillar 3)

(f) The capital buffers- capital conservation buffer and the countercyclical buffer- are expected to protect the banking sector from the periods of excess credit growth.

The BASEL III capital regulations continue to be based on three-mutually reinforcing Pillars viz. minimum capital requirements, supervisory review of capital adequacy, and market discipline, of BASEL II.

In India guidelines on Basel III capital regulation have been implemented from April 1, 2013 in a phased manner. To ensure smooth transition to BASEL III, appropriate transitional arrangements have been made for meeting the minimum BASEL III capital Ratios, full regulatory adjustments to the components of capital, etc. Consequently, BASEL III capital regulations would be fully implemented as on March 31 , 2018.

Guidelines on Liquidity Coverage Ratio and Liquidity Risk Monitoring Tools under Basel III:

The Basel III Framework on Liquidity Standards includes Liquidity Coverage Ratio (LCR), Net Stable Funding Ratio (NSFR) and liquidity risk monitoring tools. RBl's guidelines included enhanced guidance on liquidity risk governance, and measurement, monitoring and reporting to the Reserve Bank on liquidity positions. The Basel III liquidity standards were subject to an observation period/revision by the Basel Committee with a view to addressing any unintended consequences that the standards may have for financial markets, credit extension and economic growth.

The Basel Committee has issued guidelines on the Liquidity Coverage Ratio and Liquidity Risk Monitoring Tools in January 2013 , and is in the process of finalizing the NSFR and disclosure requirements. The LCR is to be implemented from January 1, 2015 and the NSFR from January 1, 2018. The Reserve Bank will issue the final guidelines on Basel III liquidity standards and liquidity risk monitoring tools, taking into account the revisions by the Basel Committee.

\section{REPORTING OF BANKING RISK}

Accurate, complete and timely data is a foundation for effective risk management. However, data alone does not guarantee that the board and senior management will receive appropriate information to make effective decisions about risk. To manage risk effectively, the right information needs to be presented to the right people at the right 
time. Risk reports based on risk data should be accurate, clear and complete. They should contain the correct content and be presented to the appropriate decision-makers in a time that allows for an appropriate response. To effectively achieve their objectives, risk reports should comply with the following principles.

Accuracy - Risk management reports should accurately and precisely convey aggregated risk data and reflect risk in an exact manner. Reports should be reconciled and validated.

Comprehensiveness - Risk management reports should cover all material risk areas within the organization. The depth and scope of these reports should be consistent with the size and complexity of the bank's operations and risk profile, as well as the requirements of the recipients.

Clarity and usefulness - Risk management reports should communicate information in a clear and concise manner. Reports should be easy to understand yet comprehensive enough to facilitate informed decision-making. Reports should include meaningful information tailored to the needs of the recipients.

Frequency - The board and senior management (or other recipients as appropriate) should set the frequency of risk management report production and distribution. Frequency requirements should reflect the needs of the recipients, the nature of the risk reported, and the speed, at which the risk can change, as well as the importance of reports in contributing to sound risk management and effective and efficient decision-making across the bank. The frequency of reports should be increased during times of stress/crisis.

Distribution - Risk management reports should be distributed to the relevant parties while ensuring that confidentiality is maintained.

\section{RISK ADJUSTED PERFORMANCE EVALUATION: IMPORTANT ASPECTS}

Important aspects of Risk Adjusted Performance Evaluation are summarized below:

\section{Breaking down asset returns:}

Intuitively, we can consider the total return on an asset to be the sum of the risk free return, which is the reward for the time value of money, the beta return, which is the reward for the additional volatility of the asset, also called the market risk premium, and the alpha return, which is the superior performance attributable to the asset manager's security selection skill.

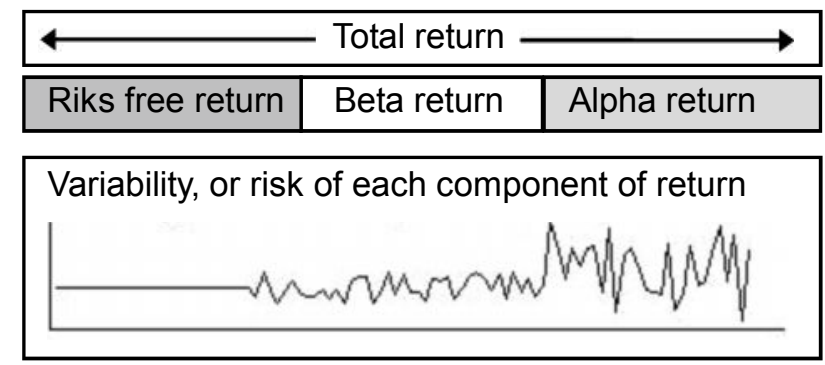

The risk free rate carries no volatility. The beta and alpha components of the return bring volatility to the asset's return stream, and the Sharpe ratio measures the excess return earned by the asset 'per unit of volatility'. It does so by dividing the excess return, i.e. assets return less risk free rate, by the standard deviation.

\section{The Sharpe ratio:}

The Sharpe Ratio reflects the ratio of all excess returns over the risk free rate to the total risk (or standard deviation) of the return stream. In other words, we strip out the risk free rate from the earned returns, and divide that by the total standard deviation of the returns. 
Sharpe ratio $=\frac{\mu-r_{f}}{\sigma}$

where $\mu$ is the expected return, $s$ is the standard deviation of returns, $r m$ is the return of the market portfolio and rf is the risk free rate:

\section{The Treynor ratio:}

The Treynor ratio is the ratio of the excess return to the beta of the portfolio. It is similar to the Sharpe ratio, but instead of using volatility in the denominator, it uses the portfolio's beta. Therefore the Treynor Ratio is calculated as [(Portfolio return - Risk free return)/Portfolio's beta].

Treynor ratio $=\frac{\mu-r_{f}}{\beta}$ where $\mu$ is the expected return, $s$ is the standard deviation of returns, $B$ the beta of the portfolio (or the security in question) measured against the market returns and rf is the risk free rate.

\section{Jensen's alpha:}

Jensen's alpha, often just referred to as alpha, is a measure of the returns that are attributable to the manager's skill, ie the returns remaining after deducting what would have been attributable to beta returns (which do not require skill) and the risk free rate. It is the difference between the return of the portfolio, and what the portfolio should theoretically have earned. Any portfolio can be expected to earn the risk free rate (rf), plus the market risk premium (which is given by [Beta $x$ (Market portfolio's return - Risk free rate)]. Anything remaining over and above is the result of the manager's security selection skill, and is alpha.

Jensen's alpha $=\mu-\mathrm{rf}-\beta(\mathrm{rm}-\mathrm{rf})$, where $\mu$ is the expected return, $\beta$ the beta of the portfolio (or the security in question) measured against the market returns, $\mathrm{rm}$ is the return of the market portfolio and $\mathrm{r}$ is the risk free rate

\section{Kappa indices}

One criticism of other risk adjusted performance measures is that they take both upside and downside risk into account, even though a portfolio manager or investor is only concerned with managing the downside. Kappa indices, which include the Sortino ratio and the Omega statistic, consider semi-variance, ie variance calculated only in respect of the downside risk instead of variance based on all returns. One problem with metrics based on semi-variances is that they are not mathematically tractable, ie it is difficult to do much more with them once they have been calculated.

\section{The Information Ratio:}

The Information Ratio, often used in the hedge fund world, is the ratio of the alpha component of total returns to the standard deviation of these excess alpha returns. The alpha component is the return that is attributable to the manager's skill (or luck;-), and is the residual after taking out the risk free return and the beta components from the total returns. Also note the difference in the denominator - while the Sharpe ratio considers the standard deviation of the total returns, the information ratio considers the variability of only the alpha component of the return (which also forms the numerator). In other words, the information ratio is merely Jensen's alpha divided by its standard deviation. The higher the information ratio, the greater the chances of the manager making money.

The information ratio only looks to compute the return per unit of risk undertaken for the alpha component. This is important because alpha returns are risky, as they represent a zero sum game for the market as a whole. In fact, average alpha for the market as a whole is in practice slightly less than zero because of transaction and other costs. Therefore it is easy for a manager to take on 'alpha risk' and lose money that will bite into the beta returns. 


\section{Interpreting the information ratio, or why is the information ratio important?}

The information ratio is very useful to understand how risky is dabbling with the alpha in question. If we were to assume that alpha returns will be normally distributed, then the information ratio allows us to model the alpha as being a distribution with mean $=I R$ and standard deviation $=1$. This is intuitive because $I R=$ (mean alpha return/ standard deviation of alpha returns). A ratio of say, 0.4 can be interpreted to imply a normal distribution with mean equal to 0.4 and a standard deviation of one. From this point, everything is easy because we can now estimate the probability of losing money, or the probability of meeting a benchmark.

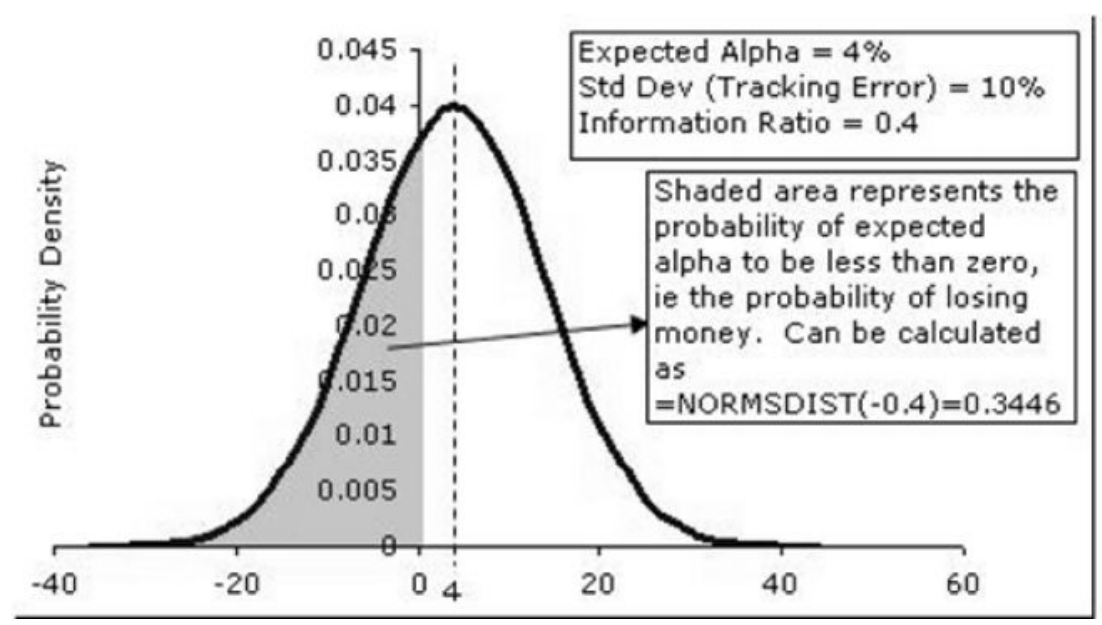

Note that just simply putting the formula =normsdist(-IR) gives us the probability of losing money in one year.

We can extend the analysis to multiple years - for example, consider a manager with an alpha of say, $3 \%$, and standard deviation of say $10 \%(\mathrm{IR}=0.3)$. The probability of him losing money over a one year period is $38 \%$. Now think of a three year horizon. The mean returns over a three year period will be $9 \%$, and the standard deviation will be $\left(3^{\wedge} 1 / 2\right)^{*} 10 \%$, or $17.3 \%$, and therefore a possibility of losing money over a three year period to be about $30 \%$.

\section{LESSON ROUND UP}

- Banks, being an important financial intermediary, are associated with many risks.

- It is obvious that despite best efforts banks cannot avoid or completely eliminate the risks.

- However through an effective risk management system, they can reduce the impact of risks if not avoid the risks.

- As per the Basel norms, banks can integrate the three pillar concepts with an effective management assessment and control, coupled with a very good supervision and market discipline banks can overcome the risks to a greater extent.

- Banks risk management system needs to address various aspects like identification, evaluation, monitoring and measuring the risks.

- Banks should ensure that their Risk Management System should be based on the Basel Norms and the Reserve Bank of India's guidelines. 


\section{SELF TEST QUESTIONS}

1. State whether the following statements are 'True' or 'False'

(a) Basel II norms identified three pillars, Pillar II deals with Supervisory Review

(b) VaR is a tool used for measuring the market risk

(c) Legal risk on account of an international trade is an example of market risk

(d) ALCO deals only with risk management issues

2. Choose the correct alternative.

A. As per the Reserve Bank of India the CRAR is
(a) 55 per cent
(b) 100 per cent
(c) 8 per cent
(d) 9 per cent

B. Interest Rate risk is an example of market risk. Identify the exception to market risk
(a) Exchange rate risk
(b) Default risk
(c) Equity price risk
(d) Commodity price risk

C. As regards "derivatives" identify the exception
(a) Forward Exchange Contract
(b) Futures Contract
(c) Fixed Deposit
(d) Forward Rate Agreement

3. What are the various types of risks associated with the banking system?

4. How is liquidity and credit risk managed in banks?

5. Explain the important aspects of Risk Adjusted Performance Evaluation.

6. How can you design a risk management system for a bank?

7. What is mitigation of a risk? (b) How different risks can be mitigated?

8. Write short notes on
(a) Cross border risks
(b) Market Risk
(c) Impact of risks 
314 PP-BL\&P 


\section{Lesson 13}

\section{Ethics and Corporate Governance in Banks}

\section{LESSON OUTLINE}

- Principles of Lending

- Ethics - An Overview

- Corporate Social Responsibility (CSR)

- Corporate Governance In Banks

- Auditors' Certificate On Corporate Governance

- Lesson Round Up

- Self Test Questions

\section{LEARNING OBJECTIVES}

In today's fast growing economies, the reputation of an organization is as much important as its market value. Added to the financial crisis, the organizations are facing governance issues which are creating reputational risks. To overcome these, the corporate sector is focusing on a new concept called "Corporate Governance". Corporate governance can be referred to the overall control of the activities of the corporation. In other words corporate governance refers to the problem arising from the separation of control and ownership. In this chapter we have addressed the issues relating to Ethics, Corporate Governance and Corporate Social Responsibility in banks.

After review the reader would be able to;

- know clearly about the importance of corporate governance

- Identify and appreciate the inter connectivity of

- Corporate ethics,

- Corporate Governance

- Corporate Social Responsibility 


\section{ETHICS - AN OVERVIEW}

The word "ethics" is derived from the Greek word "ethikos" which means character or custom. As per Chambers Dictionary "ethics" is a code of behavior considered correct. According to some other views, ethics is the science of moral, moral principles and practices. Ethics also deals with the distinction between different actions like 'good or bad'; 'correct or incorrect; 'moral or immoral'

\section{Understanding ethics:}

An individual or group of persons are influenced and guided by his/their religious faith. Religious teachings create values in individual or group of persons. Almost all religious practices are based on similar principles. Some of the important guidelines of religions:

(a) Be kind to all others including animals and natural resources

(b) Be humble, modest and simple and courteous

(c) Be truthful to one's self and others

(d) Avoid greed, lust, anger which are excesses of desire, love and annoyance respectively

(e) Be content in life

(f) Be happy with others' achievements/ performance

\section{Rights of people}

People have rights to (i) privacy (ii) information (iii) freedom-of faith, speech (iv) practice fair trade/ professional practices (v) safety (vi) equitable treatment.

An attempt by any person to violate any of these rights is considered unethical. Right to privacy is violated in many ways. For example: The personal data available with researchers have led to many junk/spam mails, tele-marketing calls, etc.

\section{Ethical and unethical issues}

In practical situations, it is not always easy to determine whether a particular issue is ethical or unethical. Based on certain perceptions and depending upon the situations, it can be referred to as ethical or unethical. Value is the factor that distinguishes an action as ethical or unethical.

\section{Value and ethics:}

Sincerity, trust, concern for others, keeping up the commitments, respect for others' rights, selflessness, are some examples of Values in an individual's life. Ethical meaning of certain terms is shown below:

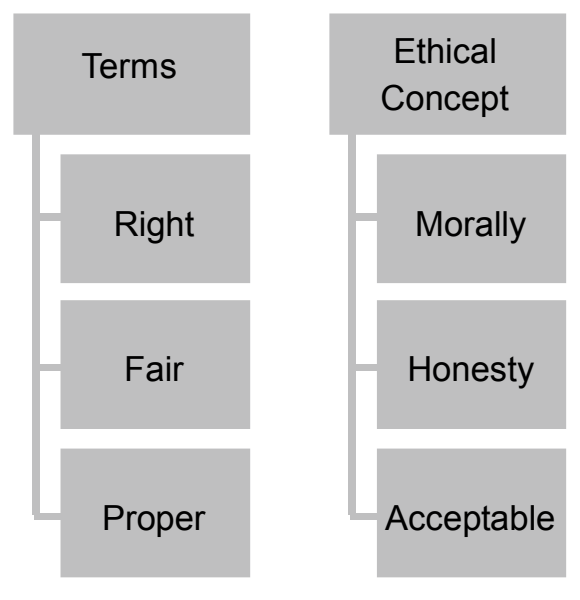




\section{BUSINESS ETHICS}

The study of moral values based on economic systems prevalent in different countries and across the globe is called as "Business Ethics". In today's changing environment this can also be recognized as corporate ethics.

\section{Ethics: Certain important concepts:}

Ethics involves a discipline that examines good or bad practices within the context of a moral duty. Moral conduct is the behavior that indicates which is right and wrong. Business ethics include practices and behaviors that are good or bad, in other words ethical or unethical.

There are many concepts of ethics and some of them are discussed below:

(1) Utilitarianism: Action is morally right. If, the total net benefit of the action exceeds the total net benefit of any other action. In other words, the result of the action is more favorable than unfavorable to everyone.

(2) Egoism: The theory which treats self-interest as the base of morality. Two forms of ethical egoism can be identified as individual and universal, which include other's interest only from the point of the assessors' self interest. It is mainly self-centered, and importance is given to self pleasure and gain and avoids pressure and pain

(3) Rights: A Right is considered as a person's just claim or entitlement.

1. Legal rights : defined by a system of laws

2. Moral rights : based on ethical standard - principles of right or wrong

3. Justice : Justice is the decision which could arise from the application of rules, policies, or laws that apply to a society or a group

\section{What is a Code of Ethics}

A code is a set of rules, which are accepted as guiding principles. A code is adopted by a Corporate, Professional bodies, and/or a nation. A Company's policy statements define the ethical code. Codes do not produce ethical behavior, unless the ethical practices are understood and practiced in both at individual and corporate levels.

\section{Ethical and Unethical Practices:}

There are many reasons for an individual or group of individuals or corporate and others to follow ethical or unethical practices. Some of the reasons are:

- Conflict of interest

- Incentives

- Unreasonable targets

- Decision making

- Weak control systems

- Unhealthy competition

- Discrimination

- Empathy

While ethical practices would ensure better and conducive climate in work place, many times, we come across unethical practices in the following areas: 


\section{Ethical aspects in Human Resource Management}

(i) Transparency: Transparency is one of the important ethical aspects in HRM. Lack of openness in interpretation, decision making and communication, performance appraisal, promotion process etc would de-motivate the employees.

(ii) Internal Stakeholders - Employees are important internal stakeholders and need to be dealt with highly ethical practices for all-round progress of the institution.

\section{Ethichal aspects in Marketing Management}

Marketing Mix is an important factor that determines the performance of the marketing team. There are " 4 Ps" of Marketing Mix viz., Place, Product, Price and Promotion. The unethical issues concerning these "4Ps" are:

\section{Place:}

"Place" is the link between the customer and producer, through appropriate delivery channels. Convenient location plays a crucial role in increasing the sale of the products. As regards banking, the term "place" represents their delivery channel i.e., branch net work, e banking channels like ATMs, Internet, Core Banking Solutions, etc. For the convenience of customers ATMs are also available at off site locations. The place acts as an important factor of the marketing mix, and ensures good customer relationship management.

Unethical practices on account of "Place" as part of marketing mix arises in the following situations: (a) If a branch of a bank is relocated to another area without sufficient notice and time (b) A customer who uses ATMs, Internet banking facility, is denied access to them on account of bank's failure to provide the services, and thereby the customer is facing inconvenience, loss of money and time.

\section{Product:}

"Product" is one of the important components of marketing mix. Product can be in the form of goods or an article or an instrument (in case of financial services), for which the consumer pays a value (price) and expects to get satisfaction/comfort.

If a bank offers a deposit product offering higher interest and suddenly stops offering such type of deposit products without any prior notice, then from the customers' point of view this could be viewed as unethical practice. Similarly when new loan products with certain value added features are launched, such value additions are offered only for the new loan customers but not for existing loan customers could be viewed as unethical by the existing customers.

\section{Price:}

"Price" is another important component of a marketing mix.

Price discrimination is labeled as unethical. For example, A bank, when there is change in the floating interest rates, immediately increases the interest rates for loan accounts for the existing borrowers, however, in case of rate cut, the bank does not reduce the interest rate immediately, is considered as unethical. Another example of unethical practice is, any increase in charges, fees are given immediate effect, however any reduction in charges, fees, etc which would benefit the customers, is not passed on to them immediately.

\section{Promotion:}

Reaching out to the customers through effective network and attractive communication is the major role of the marketing mix called "promotion".

Advertisement is the main component of promoting products. Unethical practices are:

(i) misleading advertisements to attract the clients

(ii) unsolicited telephone calls, e mails, and thereby inconveniencing the clients. 


\section{Ethical aspect in Financial Management}

A sound financial policy and effective management control, is very important for good corporate governance. Many unethical practices noticed in the area of financial management are putting pressures on the regulators and governments which affect both internal and external stakeholders.

Some of the noteworthy unethical issues in the financial activities and markets are:

\section{Concealment of facts:}

In case of Satyam's scam, for years the (real) financial position was concealed but unrealistic financial position was reflected in a systematic manner to appear as realistic numbers.

\section{Money Laundering activities:}

This is not only unethical but also criminal and illegal. These activities include conversion of illegal money into legal money, using the banks as channels to effect such activities.

\section{Misappropriation and diversion of funds:}

Many business enterprises including corporates avail of loans and do not use the funds for the purpose the loan was availed of, but divert the funds for other activities. For example: A manufacturing company avails of working capital finance for production purpose. The funds are raised against hypothecation of goods; however the funds are not used for production of the goods, but invested in real estate sector and/or capital markets to earn higher returns. Though the repayment of the loan is on schedule, these activities of the company are unethical on account of misappropriation of funds

\section{Lack of internal control:}

Due to weak internal controls at appropriate levels, sometimes loans become nonperforming assets. Unethical practices like corruption, diversion and misappropriation of funds, loans granted against collateral which are of inferior quality, lesser value, etc., not only affect the performance of the banks but also increases the levels of nonperforming assets.

\section{Non compliance of regulatory and legal frame work:}

Banks face many compliance issues, by not following the rules and regulations.. These non compliances have created avenues for conversion of black money to legal money through banking channels, and made banks not only to face embarrassment but also reputational risks.

\section{Desired Ethical Practices and Corporate Governance}

Some important factors of ethical issues as listed below, if not handled properly, would affect the corporate governance practices.

\section{(1) Conflict of interest:}

In case of mergers and acquisitions, (M\&As), an audit firm offers consultancy services through their consultancy division. The expertise of auditors' of the audit division, might be used by the consultancy division in valuations and this may be considered as an example of conflict of interest

\section{(2) Transparency:}

In financial statements and annual reports, "disclosures of actual facts to stakeholders" helps the investors and others to take decisions. Non transparent practice is window dressing of data and figures in the financial statements.

\section{(3) Insider Trading:}

The growth of the global economies depends (among other factors) upon the successful participation of financial and other competitive markets. Any changes in prices (interest rates, exchange rates and prices of commodities) 


\section{PP-BL\&P}

significantly affect the profitability of the companies; thereby affect the economic growth of a nation. There are many ways price of a product, and/or interest rate of an investment instrument, and/or exchange rate of a foreign exchange transaction can change or move upwards and/or downwards. Any person, who by virtue of his position in a corporate, can have access to sensitive information relating to the price. If such person makes use of this information to his advantage, which is unethical, it is called as insider trading.

\section{(4) Mergers \& Acquisitions (M\&As):}

In the competitive international business environment, mergers and acquisitions play a crucial role in business expansion across borders.Management Buyout is one type of takeover. In this case, the management decides to bid for the company. If successful, they can convert the company to a private company and at a later date depending upon the market conditions sell it in the market and make good profits. Unethical aspects relating to such take over, may be that during the buyout confidential information is leaked by employees/managers for their benefit and there will be a possibility of bringing down the share prices by the vested parties for buying them at a very cheaper rate

\section{(a) Golden parachute:}

Special incentives and benefits are offered to top executives to avoid a takeover situation. These benefits would include bonuses, stock options, etc., In view of the golden parachute; the top executives might not support the takeover of the company

\section{(b) Hostile Takeovers:}

When there is opposition from the board or employees or officers of the target company not to allow mergers and acquisitions, it is called as hostile takeovers. On account of vested interests, and to protect their own interests, managers may oppose the $M \& A$.

\section{(c) Green mail:}

It is a process through which the management of the target company sends green mails to prevent a shareholder or group of share holders to take over a company. There is a possibility of the buy back of the shares at a premium by the company at a later stage. Hence green mails are considered unethical.

In short, mergers and takeovers are considered unethical, if they ignore the interests of the shareholders.

\section{CORPORATE SOCIAL RESPONSIBILITY IN THE FINANCIAL SECTOR}

The institutions representing the financial sector like banks, mutual funds and other institutions. like other corporate sector players contribute significantly to the community development in many ways. International Financial Corporation (IFC) an affiliate of the World Bank, International Chamber of Commerce (ICC) and United Nations Organization (UNO) are participating in the various projects across the world. They are motivating banks and financial institutions to play an effective role in promoting environmental protection and social sustainability through these projects. In this respect, the financial institutions and banks are encouraged to follow certain principles in respect of CSR

(a) Commitment to sustainability: Fls should expand their mission of profit maximization to a vision of social and environmental sustainability. To achieve this Fls should integrate the consideration of ecological limits, social equity and economic justice into their corporate strategies and into their core business models.

(b) Commitment to 'Do No Harm': Fls should prevent or minimize harm to the environment

(c) Commitment to Responsibility: Fls should take full responsibility for the environmental and social impacts of their transaction

(d) Commitment to Transparency: Fls should have transparency in their policies and business dealings 
(e) Commitment to Accountability: Fls should be accountable to their stakeholders and the community where they operate. Fls should promote economic development through their CSR activities

(f) Commitment to good governance: Fls should frame good corporate governance policies and follow them in letter and spirit.

Quite often we come across many news pertaining to the CSR activities of banks and other players in the financial sector.

Some examples of CSR activities are:

Environment protection: Going Green is an eco friendly initiative not only to protect the environment but also to encourage younger generation to ensure such initiatives would lead to a better life around us. Some of the green initiatives include eco friendly e communication, banks and companies forwarding the annual reports by electronic mode (saving reams of papers for printing reports to the shareholders) Saving the globe from different kinds of pollution such as water, air, noise. etc.

Health Care: Many banks and other financial institutions including government organizations are keen in ensuring better health care facilities are provided for the needy persons. They organize regular blood donation drives, free medical checkups, donating ambulances, sponsoring free medical camps in remote villages.

Education: Educational services occupy an important position in CSR activities of organizations. Many organizations are promoting community schools, colleges. Scholarships are offered to many deserving students.

Social Causes: Many banks offer help and financial assistance through their CSR programs to assist weaker sections of the society for a better future.

Apart from the above many employees of the banks and other institutions, are very active in their contribution for the community development and these can very well be considered as part of Corporate Social Responsibility in view of the fact that each person is a stakeholder in one respect or another.

\section{CORPORATE GOVERNANCE IN BANKING SYSTEM}

Banks play an important role in the economic development of a nation. As intermediaries in the Financial Sector, banks also act as trustees of the funds of the depositors. As such for efficient functioning of banks an effective Corporate Governance practices should be an integral part of bank management.

Banks should have good Corporate Governance which should be much more than complying with legal and regulatory requirements. Good governance facilitates effective management and control of business, enables the Banks to maintain a high level of business ethics and to provide value additions to all their stakeholders.

The objectives of corporate governance would cover:

1. To protect and enhance shareholder value

2. To protect the interest of all other stakeholders such as customers, employees and society at large

3. To ensure transparency and integrity in communication and to make available full, accurate and clear information to all concerned

4. To ensure accountability for performance and customer service and to achieve excellence at all levels

\section{Role of the Board of Directors}

(i) The Bank's Board of Directors should meet regularly and to provide effective leadership and insights in business and functional areas. They also should monitor Bank's performance.

(ii) Setting up of a framework of strategic control and continuously reviewing its efficacy. 
(iii) Implementation, review and monitoring the integrity of its business and control mechanisms

(iv) Overseeing the risk profile of the Bank.

(v) Ensuring expert management and decision-making, internal control and reporting requirements.

(vi) Maximizing the interests of its stakeholders.

\section{Role of Chairman and/ or CEO}

The Chairman and/or CEO have the responsibility for all aspects of executive management and are accountable to the Board for the ultimate performance of the Bank and implementation of the policies laid down by the Board.

\section{COMPLIANCE OFFICER}

A senior executive is made responsible in respect of compliance issues with all applicable statutes, regulations and other procedures, policies as laid down by the GOI/RBI and other regulators and the Board, and reports deviations, if any.

\section{CLAUSE 49}

The Bank should ensure compliance with the provisions of Corporate Governance as per Clause 49 of the Listing Agreement with the Stock Exchanges as applicable.

Important board level committees are formed, to assist the Board of Directors to function effectively

These Committees provide effective professional support in the conduct of Board level business in key areas like Audit \& Accounts, Risk Management, resolution of Shareholders'/Investors' grievances, Fraud Review and Control, Review of customer service and redressal of customer grievances, Technology Management and Payment of Incentives to Executive Directors. The Remuneration Committee approves, once in a year, payment of incentives to whole-time Directors, based on Govt. of India guidelines,

\section{Audit Committee (AC)}

The Audit committee functions as per RBI guidelines and complies with the provisions of Clause 49 of the Listing Agreement to the extent that they do not violate the directives/guidelines issued by RBI.

Functions of Audit Committee:

(a) Audit Committee provides direction and also oversees the operation of the total audit function in the Bank.

(b) Audit Committee also appoints Statutory Auditors of the Bank and reviews their performance from time to time.

(c) Ensures transparency by reviewing bank's financials, Risk Management, IS Audit Policies and Accounting policies, systems and procedures.

(d) Audit Committee also reviews the internal inspection/audit plan and functions in the Bank - the system, its quality and effectiveness in terms of follow-up.

(e) Audit Committee focuses on the follow up of implementation:

- KYC-AML Guidelines;

- Major areas of housekeeping;

- Compliance of Clause 49 and other guidelines issued by SEBI from time to time;

(f) Audit Committee follows up on all the issues raised in RBI's Annual Financial Inspection Reports under Section 35 of Banking Regulation Act, 1949 and Long Form Audit Reports of the Statutory 


\section{Auditors and other Internal Audit Reports}

The meetings of Audit Committee are chaired by a Non-Executive Director. The constitution and quorum requirements, as per RBI guidelines, are to be complied with

Apart from Audit Committee other committees also assist the Board of Directors.

Shareholders'/Investors' Grievance Committee: As per Clause 49 of the Listing Agreement with the Stock Exchange, Shareholders'/ Investors' Grievance Committee of the Board looks into the redressal of shareholders' and investors' complaints regarding transfer of shares, non-receipt of annual report, non-receipt of interest on bonds/declared dividends, etc

\section{Customer Service Committee}

The Customer Service Committee reviews ongoing improvements on a continuous basis in the quality of customer service provided by the Bank.

\section{Special Committee for monitoring large value frauds}

This committee's functions are:

- to monitor and review all large value frauds with a view to identify systemic issues/risk, if any,

- to find out the reasons for delay in detection and reporting, if any

- to follow up on the status of progress of CBI/Police investigation, recovery position, etc.

- Action if any on staff involvement and their accountability and action thereof

- Also review the preventive measures to avoid similar frauds

\section{IT Strategy Committee}

This committee assists the Board to track the progress of the Bank's IT initiatives.

Some of the important functions of the committee are

(a) approving IT strategy and policy documents, ensuring that the management has put an effective strategic planning process in place;

(b) ensuring that the IT operational structure complements the business model and its direction;

(c) ensuring IT investments represent a balance of risks and benefits and those budgets are acceptable;

(d) evaluating effectiveness of management's monitoring of IT risks and overseeing the aggregate funding of IT at the Bank level; and

(e) reviewing IT performance matches with the bank's policy/plans

\section{Remuneration Committee}

This is one of the important committee in organization. This committee is set up for evaluating the performance of Whole Time Directors of the Bank in connection with the payment of incentives, as per the scheme advised by Government of India. The remuneration of the whole-time Directors and the Sitting Fees paid to the Non-Executive Directors for attending the meetings of the Board/Committees of the Board are as prescribed by GOI from time to time.

\section{Nomination Committee}

As per RBI guidelines, a Nomination Committee of independent Directors has been constituted. 


\section{PP-BL\&P}

This committee's function is to carry out necessary due diligence and arrive at the 'fit and proper' status of candidates filing nominations for election as Directors by shareholders.

Every financial year the Directors on the Bank's Board and Senior Management have to sign a declaration for compliance with the Bank's Code of Conduct for the financial year.

\section{DISCLOSURE NEW CLAUSE 41}

The Bank needs to disclose certain important information as per Clause 49 of the Listing Agreement with the Stock Exchanges, to the extent that the requirements of the Clause do not violate the provisions of the Rules and Regulations made there under and guidelines or directives issued by the Reserve Bank of India.

Mandatory requirements of Clause 49 as to the composition of the Board of Directors, composition and quorum of the Audit Committee, Non-executive Directors' compensation, the appointment, re-appointment of the Statutory Auditors and fixation of their fees etc needs to be disclosed.

In terms of Clause $49(\mathrm{~V})$ of the Listing Agreement, a certificate by the Managing Director \& Chief Financial Officer on the financial statements \& internal controls relating to financial reporting needs to be obtained.

The disclosure should cover all other required declarations as applicable.

The Bank should also declare that it has complied with applicable rules and regulations prescribed by stock exchanges or SEBI or any other statutory authority relating to the capital markets during the last three years. No penalties or strictures have been imposed by them on the Bank. The Whistle Blower Policy, approved by the Board of the Bank, is in place and has been uploaded on the Bank's intranet site for information of all the staff members.

Apart from the above mentioned details in the annual report, the bank should furnish the details of the corporate governance policies and relevant disclosures.

Since Annual Report is provided to every shareholder (either by post or by e mail), it would serve as a means of communication from the bank to reveal not only the financial performance of the bank but also other important aspects of the bank including the corporate governance practices.

\section{BASEL COMMITTEE RECOMENDATIONS}

The Basel Committee guidance provides a foundation for sound corporate governance practices for various banking system across countries. The guidance is divided into four major sections (i) overview of corporate governance in banks (ii) sound corporate governance principles (iii) role of supervisors and (iv) promotion of an environment to support sound corporate governance.

(i) Overview of Corporate Governance in Banks: The guidance stressed the importance of sound corporate governance practices as vital in gaining and maintaining public trust and confidence in the banking system and economy as a whole. The guidance suggested that the supervisors should take steps to ensure that the ownership structure does not affect the sound corporate governance practices in banks.

(ii) Sound corporate governance principles: The committee proposed eight principles which are considered important for an effective corporate governance process.

Principle 1: Board members should be qualified for their role in corporate governance and be able to exercise sound judgment in handling the affairs of the bank

Principle 2: The board of directors should approve and oversee the bank's strategic objective and corporate values that are communicated throughout the organization

Principle 3: The board of directors should set and enforce clear lines of responsibility and accountability throughout the organization 
Principle 4: The board should ensure that there is appropriate oversight by senior management consistent with board's policy

Principle 5: The board and senior management should effectively utilize the work conducted by the internal auditors, external auditors and internal control systems

Principle 6: The board should ensure that compensation policies and practices are in consistent with the bank's corporate culture, long tern objectives and strategy

Principle 7: The bank should be covered in a transparent manner

Principle 8: The board and senior management should understand the bank's operational structure and the jurisdiction

(iii) The Role of Supervisors: Supervisors play a key role to encourage and support strong corporate governance by analyzing and assessing a bank's implementation skills of the sound principles. Supervisors should

- Provide guidance to banks on sound corporate governance

- Consider corporate governance as one factor for depositor protection

- Assess the quality of banks' audit and control systems

- Evaluate the bank's performance in respect of effective implementation of corporate governance

(iv) Promotion of an environment to support sound corporate governance: As per the report the primary responsibility for good governance rests with board of directors and senior management of banks. Banks supervisors also play a key role in developing and assessing bank corporate governance practices. The guidance report also lists out role of others who can promote good corporate governance like shareholders, customers, depositors, auditors, Banking Industry associations, Governments, Credit rating agencies, Employees, stock exchanges etc;

According to the Basel guidance banks' good corporate governance practices would entail banks for better operational efficiency, greater opportunities to get low cost funds, and a good reputation and increased market value.

\section{AUDITORS' CERTIFICATE ON CORPORATE GOVERNANCE}

This certificate issued by Chartered Accountant, is to be furnished along with the Annual Report of the Bank. The certificate indicates the examination by the chartered accountant regarding compliance of conditions of Corporate Governance by the Bank for the financial year ending. This certificate is based on the clause 49 of the listing agreement of the bank with Stock Exchanges in India. The compliance of the conditions of Corporate Governance is the responsibility of the Management. The auditor's examination is being carried out in accordance with the Guidance Note on Certification of Corporate Governance, issued by the Institute of Chartered Accountants of India. It is regarding the compliance of corporate governance procedures and implementation thereof, adopted by the bank.

\section{LESSON ROUND UP}

- Business ethics, Corporate Governance and Corporate Social Responsibility have become not only an integral part of the present globalised business environment, but also have changed the business models of Banks.

- With stiff competition among themselves, to retain market share and also to ensure the Bank's reputation, banks' strategies are tuned to the need of the hour. 
- More and more Banks have started to reshape themselves to offer better customer services and also operate in more ethical manner, through their effective corporate governance practices.

\section{SELF TEST QUESTIONS}

1. State whether the following statements are 'True' or 'False'

(a) The term 'moral values' is associated with business ethics

(b) 'e communication' is an example of 'going green'

(c) Insider trading is not an example of business ethics

(d) Concealed liability is a type of accounting standards

(e) Phishing is an example of cyber crime

(f) Adoption of a school by a bank is part of bank's CSR

(g) The minimum capital for the new private sector banks would be Rs...500 crores

2. Choose the correct answer.

A. The audit committee meeting of a bank is chaired by
(a) Chief Executive Officer
(b) Chief Auditor
(c) Chief Finance Officer
(d) Non Executive Director

B. Over invoicing is an example of
(a) ethical practice
(b) market practice
(c) accounting practice
(d) unethical practice

C. Green mail means

(a) A management student is participating in a green environment seminar

(b) A NGO is celebrating an event for which the invitation is printed in green colour

(c) One of the green initiatives taken by a Corporate as part of their CSR to adopt a garden

(d) An unethical method of take over

D. ALCO is headed by
(a) Chief Operating Officer
(b) Chief Risk Officer
(c) Chief Finance Officer
(d) Chief Executive Officer

E. As regards unethical practices, identify the exception

(a) Discrimination in HR policies 
(b) Corrupt practices by an auditor

(c) Showing inflated profits in financial statements

(d) Appreciation for achievement of targets

3. What are the ethical and unethical practices associated with

(a) Human Resource Management

(b) Marketing Management

(c) Financial Management

4. (a) What is Corporate Social Responsibility?

(b) With examples explain the role of banks in their CSR activities.

5. (a) What are the important features of Corporate Governance practices in banking sector?

(b) Comment on the impact of different corporate governance committees on Indian Coporate Sector.

6. Write short notes on
(a) Transparency
(b) Insider trading
(c) Corporate Governance - Auditor's certificate 
328 PP-BL\&P 


\section{CUSTOMER SERVICE IN BANKS}

\section{GUIDELINES}

Banks are required to constitute a Customer Service Committee of the Board and include experts and representatives of customers as invitees. The role of the Committee includes:

- formulation of a Comprehensive Deposit Policy

- issues such as the treatment of death of a depositor for operations of his account

- product approval process with a view to suitability and appropriateness

- annual survey of depositor satisfaction

- Examination/review of the Awards being issued by Banking Ombudsman in respect of complaints relating to provision of banking services and address issues of systemic deficiencies existing in banks brought out by the Awards.

Banks are also required to set up Standing Committee to review the practice and procedures prevalent in the bank and take necessary corrective action on an ongoing basis. The committee would act as a bridge between the various departments of the bank and the Board / Customer Service Committee of the Board.

Banks are further required to establish Customer Service Committee at branch level to encourage a formal channel of communication between the customers and the bank at the branch level. Besides these, each bank is expected to have a nodal department/official for customer service at H.O. and each Controlling Office with whom customers with grievances can approach at first instance and with whom the Banking Ombudsman and RBI can liaise.

\section{Policies}

Along with profit, growth, and fulfillment of social obligations, customer service is treated as priority objective of banks. Accordingly, banks are required to have in place Board approved policies in respect of:-

(a) Comprehensive Deposit Policy - covering rights of the depositors in general and small depositors in particular and aspects of operation of deposit accounts, charges, and other related issues.

(b) Cheque collection policy - covering aspects viz. (i) immediate credit for local/outstation cheques, (ii) Timeframe for collection of local/outstation instruments, and (iii) Interest payment for delayed collection (Policy dealt separately)

(c) Customer Compensation Policy - covering (i) Erroneous Debits arising on fraudulent or other transactions, (ii) Payment of interest for Delays in collection, (iii) Payment of interest for delay in issue of duplicate draft, and (iv) Other unauthorised actions of the bank leading to a financial loss to customer

(d) Customer Grievance Redressal Policy - To be framed based on the broad principles

Banks should give adequate publicity of the policies by placing them prominently in their Websites and also the notice boards of the branches.

\section{Financial Inclusion- Role of Banks}

\section{"Basic Savings Bank Deposit Account"}

With a view to doing away with the stigma associated with the nomenclature 'no-frills' account and making the basic banking facilities available in a more uniform manner across banking system, RBI has modified the guidelines on opening of basic banking 'no-frills' accounts. Such accounts would be known as "Basic Savings Bank Deposit" Account which will offer the minimum common facilities as under:- 
- The account should be considered as a normal banking service available to all;

- No requirement of minimum balance;

- Facilitate deposit and withdrawal of cash at bank branch as well as ATMs;

- Receipt/credit of money through electronic payment channels or by means of cheques/ collection of cheques drawn by Central/State Government Agencies and departments;

- Account holders are permitted a maximum of four withdrawals in a month including ATM withdrawals;

- Facility of ATM card or ATM-cum Debit Card

- Facilities are free of charge and no charge would be levied for non-operation/activation of in-operative 'Basic Savings Bank Deposit Account';

- Holders of 'Basic Savings Bank Deposit Account' are not eligible for opening of any other savings bank accounts and existing such accounts should be closed down within a period of 30 days from the date of opening of 'Basic Savings Bank Deposit Account'.

- Existing 'no frills' accounts can be converted to 'Basic Savings Bank Deposit Account'

\section{I.T. enables Financial Inclusion}

Banks are required to increase their banking outreach to the remote corners of the country with affordable infrastructure and technology so as to lower the transaction costs to make small ticket transactions viable. Care should be taken to ensure that the solutions developed are highly secure, amenable to audit, and follow widely accepted open standards to allow inter-operability among different systems adopted by different banks.

\section{Printed material in trilingual form}

Banks are required to make available all printed material used by retail customers including account opening forms, pay-in-slips, pass books, etc. in trilingual form i.e. English, Hindi, and concerned Regional Language.

\section{Opening/operation of Deposit Accounts}

Banks are required to comply with the guidelines on KYC/AML for opening of accounts.

\section{(a) Savings bank rules}

- The Savings Bank Rules must be made available to account holders while opening the accounts.

- Photographs of all depositors/account holders whether resident or non-resident should be obtained in respect of all types of deposit accounts including fixed, recurring, cumulative, etc. except:-

(i) Banks, Local Authorities and Govt. Departments (excl. public sector undertakings or quasi Government bodies);

(ii) Accounts of Staff members (single/joint)

- Banks need not insist for the presence of account holder for making cash withdrawal of 'self' or bearer cheques unless circumstance so warrants.

- Photographs cannot be a substitute for specimen signatures.

- Only one set of photographs need be obtained and separate photographs need not be obtained for each category of deposit.

- Photographs of the 'Pardanishin' women need to be obtained

- For additional accounts, fresh photographs need not be insisted upon.

- While opening the accounts, the account holders should be informed in transparent manner the requirement 
of minimum balance and other charges, etc. Revision in charges also needs to be advised from to time.

- Banks may purchase cheques, drafts, etc. deposited in the account for clearing in case of suspension of clearing operations temporally or apprehension of prolonging the suspension. This facility is extended to customers upon examining the credit worthiness, integrity, past dealing, occupation, etc. so as to guard themselves from the possibilities of such instrument being dishonored subsequently.

- Savings Bank Pass Books must be provided invariably to all customers. In case of account statement, the same should be mailed to the customers regularly. These facilities should be provided at Bank's cost. Updating the pass book periodically should also be arranged by the banks.

- Banks may avoid the usage of inscrutable entries in pass books/statement of account and ensure that brief, intelligible particulars are invariably entered in pass books / statement of account with a view to avoiding inconvenience to depositors.

- Banks are required to ensure that full address / telephone number of the branch is invariably mentioned in the Pass Books / Statement of Accounts issued to account holders.

- All cheque forms should be printed in Hindi and English irrespective of the language the customer uses including regional language.

- Cheques bearing date in Hindi as per the National Calendar (Saka Samvat) can be accepted by banks for payment, if otherwise in order. Banks can, however, ascertain the Gregorian calendar date corresponding to the National Saka calendar in order to avoid payment of stale cheques.

- Banks are required to make available the Magnetic Ink Character Recognition (MICR) code and Indian Financial System Code (IFSC), besides cheque leaf, in all passbook/ statement of account holders

\section{(b) Term Deposit Account}

- Banks are required to issue term deposit receipt indicating therein full details, such as, date of issue, period of deposit, due date, applicable rate of interest, etc.

- Term Deposit Receipts can be freely transferable from one office of bank to another.

- In order to extend better service, banks should ensure sending of intimation of impending due date of maturity well in advance to their depositors. Change in rate of interest should be advised well in advance to the customers.

- Deposits repayable in less than three months or where the terminal quarter is incomplete, interest should be paid proportionately for the actual number of days reckoning the year at 365 days or 366 days in case of leap year.

- Banks may allow premature withdrawal of Term Deposits at the request of the depositor and interest on the deposit for the period that it has remained with the bank will be paid at the rate applicable Banks have the freedom to fix penal interest on such withdrawal. No interest need be paid where premature withdrawal takes place before completion of the minimum period prescribed.

- Bank can permit addition/deletion of name/s of joint account holders. However, the period and aggregate amount of the deposit should not undergo any change. Banks may also allow splitting of joint deposit, in the name of each of the joint account holders provided that the period and the aggregate amount of the deposit do not undergo any change.

- Banks may renew the frozen accounts upon obtaining suitable request letter for renewal. No renewal receipt be issued but suitable noting may be done in the deposit account. Renewal of the deposit may be advised to the concerned Enforcement Authority by registered post/Speed Post/Courier. Overdue interest may be paid as per the policy adopted by the banks. 
- Banks are required to ensure that their branches invariably accept cash over the counters from all their customers who desire to deposit cash at the counters. No product can be designed which is not in tune with the basic tenets of banking i.e. acceptance of cash.

- Notwithstanding the legal provisions, opening of fixed/recurring and savings bank accounts be permitted in the name of minor with mother as guardian provided bank take adequate safeguards in allowing operations in the accounts by ensuring that such accounts are not allowed to be overdrawn and that they always remain in credit.

\section{(c) Current Accounts}

- Banks while opening current account must obtain a declaration to the effect that the account holder is not enjoying any credit facilities with any other bank. Banks must scrupulously ensure that their branches do not open current accounts of entities which enjoy credit facilities (fund based or non-fund based) from the banking system without specifically obtaining a No-Objection Certificate from the lending bank(s).

- Bank may open account of prospective customer in case no response is received from its existing bankers upon waiting for a fortnight. The situation may be reviewed with reference to the information provided by the prospective customer as well as taking needed due diligence on the customer.

- For corporate entities enjoying credit facilities from more than one bank, the banks should exercise due diligence and inform the consortium leader, if under consortium, and the concerned banks, if under multiple banking arrangement.

\section{Reconciliation of transactions at ATMs failure}

- Banks are required to resolve complaints within 7 working days from the date of receipt of the complaint.

- Failure to recredit the amount with the timeframe shall entail payment of compensation to the customer @100/- per day by the issuing bank.

- For compensation, suitable application is to be made within 30 days of date of the transaction.

- All disputes regarding ATM failed transactions shall be settled by the issuing bank and the acquiring bank through the ATM System Provider only. No bilateral settlement arrangement outside the dispute resolution mechanism available with the system provider is permissible.

- Non-adherence to the provision attract penalty under the Payment and Settlement System Act 2007.

- Banks are required to display prominently at the ATM locations that complaints should be lodged at the branches where customers maintain accounts to which the ATM is linked along with telephone numbers of help desk/contact persons of ATM owning bank, etc.

- Each bank should ensure that the process flow is modified to provide for the pin validation for every transaction including balance enquiry facilitated through ATM. Failure to this attract penalty.

- Banks are required to have in place a system of online alerts for all types of transactions irrespective of the amount involving usage of cards at various channels.

\section{Levy of Service Charges}

Banks should ensure that the service charges fixed are reasonable and they are not out of line with the cost of providing such services. Customers with low volume of transactions are not penalized.

\section{Foreclosure charges/prepayment penalty - Home Loans}

Banks are not permitted to levy/charge prepayment charges/penalties on Home Loans on floating interest rates, with immediate effect 


\section{Banking hours/working hours/Operation}

- Banks are required to function for public transactions at least for 4 hours on week days and 2 hours on Saturdays in the larger interest of public and trading community. Extension counters, satellite offices, one man offices or other special class of branches may remain open for such shorter hours as may be considered necessary.

- Banks may fix, after due notice to customers, whatever business hours are convenient i.e. double shift, weekly holiday other than Sunday, or functioning Sundays also (7 days working) etc.

- The banks' branches in rural areas can fix the business hours (i.e., number of hours, as well as timings) and the weekly holidays to suit local requirements subject to the guidelines.

- Commencement of employees' working hours 15 minutes before commencement of business hours could be made operative by banks at branches in metropolitan and urban centres.

- Banks are required to extend business hours for banking transactions other than cash till one hour before close of working hours. Banks can have evening counters at the premises of existing branches in metropolitan/urban centres for providing facilities to the public beyond normal business hours to bring about improvement in customer service and the transactions should be merged with the main accounts of the branch where it is set up.

- All branches except very small branches should have "Enquiry" or "May I help You" counters either exclusively or combined with other duties located near the entry point of the banking hall. Time norms should also be displayed prominently in the banking hall.

- All Branch branches are required to display the various products and services they provide along with various key aspects such as service charges, interest rates, time norms for various banking transactions and grievance redressal mechanism, etc. grouped in 4 heads viz. "Customer Service Information", "Service Charges", "Grievance redressal" and "Others" as indicators in the Notice Boards as per the format provided by RBI. This would enhance the quality of customer service in banks and level of customer satisfaction.

- Further, in addition to the above Board, the banks should also display details such as 'Name of the bank I branch, Working Days, Working Hours and Weekly Off-days' outside the branch premises.

- Banks are further required to make available the detailed information in their Web-site in such a manner that customers are able to easily access the same from the Home Page of the site, besides in booklet form in the touch screen by placing them in the information kiosks or Scroll Bars, or Tag Boards. Website should contain the minimum information such as Policy/Guidelines, Complaints, Opening of accounts/ forms, Loans and Advances, Branches, etc.

\section{Sick/old/incapacitated account holders - Operational Procedure}

In case the old/sick/ incapacitated account holder can put his thumb or toe impression, the same may be accepted for withdrawal of money. It should be identified by two independent witnesses known to the bank, one of whom should be a responsible bank official.

- Where the customer cannot put even his/her thumb impression and also not able to present in the bank, a mark can be obtained on the cheque/withdrawal form which should be identified by two independent witnesses, one of whom should be a responsible bank official.

- Person to whom the payment is to be made may be indicated by the customer in both the above cases and he should be identified by two independent witnesses. The person should be asked to furnish his signature to the bank.

- As per the opinion obtained by IBA, a toe impression or any mark by a customer who lost both the hands can be taken for acceptance. 
- Banks are required to take necessary steps to provide all existing ATMs / future ATMs with ramps so that wheel chair users / persons with disabilities can easily access them and also make arrangements in such a way that the height of the ATM does not create an impediment in its use by a wheelchair user.

- Banks are required to ensure that all the banking facilities such as cheque book facility including third party cheques, ATM facility, Net banking facility, locker facility, retail loans, credit cards etc., are invariably offered to the visually challenged without any discrimination.

- Banks are required to make at least one third of new ATMs installed as talking ATMs with Braille keypads and place them strategically in consultation with other banks to ensure that at least one talking ATM with Braille keypad is generally available in each locality for catering to needs of visually impaired persons.

- In respect of disabled persons with autism, cerebral palsy, mental retardation and multiple disabilities Banks can rely upon the Guardianship Certificate issued either by the District Court under Mental Health Act or by the Local Level Committees under the above Act for the purposes of opening / operating bank accounts.

\section{Remittance}

- Remittance (DD/MT/TT, etc.) of ₹ 50000/- and above should be by debit to customer's account or against cheques only. DDs of ₹ 20,000/- and above are to be issued with "Account Payee” crossing only.

- ADD is uniformly valid for a period of three months and procedure for revalidation after three months should be simplified.

- Duplicate Draft in lieu of lost for amount upto and including $₹ \mathbf{5 0 0 0 / -}$ can be issued against suitable indemnity without waiting drawing advice within a fortnight from the date of receipt of the request. Delay beyond the period, penal provision to be invoked.

- Banks may ensure that both drop box facility and the facility for acknowledgement of cheques are made available at collection centres (branches) and no branch should refuse to give acknowledge of cheques if tendered at the counters. Banks should display on the drop box itself that "Customers can also tender the cheques at the counter and obtain acknowledgement on the pay-in-slips".

- Banks may place per transaction limits based on their risk perception in respect of Mobile transactions with the approval of their respective Boards.

- In order to assist migrant population who do not have access to formal banking channel for want of proof of identity/address, banks are permitted to put in place three schemes for person to person (P2P) fund transfers viz.

(a) Cash Pay-out scheme which facilitates transfer of funds from the accounts of their customers to beneficiaries not having bank accounts through the use of ATMs, BCs etc. upto ₹ 10,000 per transaction subject to a monthly cap of ' $₹ \mathbf{2 5 , 0 0 0}$ with full details of the beneficiary

(b) Cash Pay-in scheme where a walk-in / non-account holding customer can transfer funds to a bank account of a beneficiary etc. upto ' $₹ \mathbf{5 0 0 0 / - p e r}$ transaction with a monthly cap of ' $₹ \mathbf{2 5 , 0 0 0}$ with minimum details of the remitter.

(c) Card-to-Card transfers up to '₹ $\mathbf{5 0 0 0}$ per transactions subject to a monthly cap of ₹ $\mathbf{2 5 , 0 0 0 .}$

- Banks need not make payment of cheques/drafts/pay orders/banker's cheques bearing that date or any subsequent date, if they are presented beyond the period of three months from the date of such instrument (w.e.f. 01.04.12)

- For loss of cheque in transit or in clearing process or at the paying bank's branch, the banks are required to reimburse the accountholder related expenses for obtaining duplicate instruments and also interest for 
reasonable delays occurred in obtaining the same. The onus rests with the collecting banker and not the account holder.

\section{General}

\section{Complaints}

- Banks are required to provide Complaints/suggestion box at each office besides maintaining Complaint Book/Register with perforated copies in each set. A copy of the complaint is also to be forwarded to Controlling Office along with remark of the Branch Manager within a time frame.

- Complaint form along with name of the nodal officer for complaint redressal be provided in the Homepage of Website to facilitate submission by customers. Complaints received are to be reviewed by Board for taking corrective steps wherever required. The details are to be disclosed in the financial results giving the number of complaints received, redressed, Awards by Ombudsman, etc.

- Banks are also required to put in place a proper Grievance Redressal Mechanism and examine on an on-going basis whether it is found effective in achieving improvement in customer service in different areas.

\section{Erroneous Debits arising on fraudulent or other transactions}

- While opening and allowing operation in deposit accounts, banks should remain vigilant to avoid lapses to safeguard against unscrupulous persons opening accounts mainly to use them as conduit for fraudulently encashing payment instruments, etc.

- In such cases, banks should compensate the customer upon completion of departmental action or police interrogation as part of their approved Customer Relation Policy.

\section{Safe Deposit Locker/Safe Custody Article Facility}

- Banks have to refrain from restrictive practices such as linking the lockers facility with placement of fixed or any other deposit beyond what is specifically permitted. Banks may obtain Fixed Deposits to cover 3 years rent and charges of breaking open the locker to take care of an eventuality that the locker-hirer neither operates the locker nor pays rent.

- Bank branches are required to maintain a wait list for the purpose of allotment of lockers and ensure transparency in allotment of the lockers. A copy of the Agreement may be passed on to the locker-hirer at the time of allotment of the locker.

- Banks may carry out customer due diligence for both new and existing customers at least to the levels prescribed for customers classified as medium risk. If the customer is classified in a higher risk category, customer due diligence as per KYC norms applicable to such higher risk category should be carried out.

- Where the lockers have remained unoperated for more than three years for medium risk category or one year for a higher risk category, banks should immediately contact the locker-hirer and advise him to either operate the locker or surrender it. This exercise should be carried out even if the locker hirer is paying the rent regularly.

- Nomination facility is available to locker hirer which would provide for nomination and release of contents of safety lockers/safe custody article to the nominee and protection against notice of claim of other persons (Sec. $45 Z C$ to 45 ZF of B.R. Act 1949)

- Nomination facility can be made available in respect of deposits held in the name of individuals (single/ Joint accounts) including sole proprietorship concerns and Safe Deposit Locker/Safe Custody. Nomination shall be made only in favour of individuals and a nominee cannot be an Association, Trust, Society or any other Organisation or any office-bearer thereof in his official capacity 
- There cannot be more than one nominee in respect of a joint deposit account. In the case of a joint deposit account the nominee's right arises only after the death of all the depositors.

- Banks may allow variation/cancellation of a subsisting nomination by all the surviving depositor(s) acting together. This is also applicable to deposits having operating instructions "either or survivor".

- Banks are required to acknowledge in writing to the depositor(s)/ locker hirers (s) the filing of the relevant duly completed Form of nomination, cancellation and / or variation of the nomination.

- Banks may introduce the practice of recording on the face of the passbook the position regarding availment of nomination facility with the legend "Nomination Registered". This may be done in the case of term deposit receipts also.

\section{Deceased Depositors - Settlement of claims - Procedure thereof}

\section{Accounts with survivor/nominee clause}

In case there exists a valid nomination and the deposit account is opened with the survivorship clause ("either or survivor" or "anyone or survivor" or "former or survivor" or "latter or survivor"), bank can make payment of the balance in the deposit account to the survivor(s)/nominee of a deceased deposit account holder which is considered as a valid discharge of the bank's liability provided:-

(a) The bank has exercised due care and caution in establishing the identity of the survivor(s)/ nominee and fact of death of the account holder through appropriate documentary evidence; there is no order from the competent court restraining the bank from making the payment from the account of the deceased; and

(b) Survivor(s)/nominee has been advised in clear terms that he would be receiving the payment from the bank as a trustee of the legal heirs of the deceased depositor.

Banks may desist from insisting production of succession certificate, letter of administration or probate, etc., or obtain any bond of indemnity or surety from the survivor(s)/nominee, irrespective of the amount standing to the credit of the deceased account holder.

\section{Accounts without the survivor/nominee clause}

- In deceased deposit accounts without the survivor/nominee clause, banks may fix some minimum threshold limit for settlement of claim without insisting on production of any documents other than indemnity.

- Premature termination of Term deposit accounts would not attract any penalty and such clause may be incorporated in the opening form itself.

- Any claim on the balances lying in deceased depositors received from survivor(s) / nominee(s) should be settled within a period not exceeding 15 days from the date of receipt of the claim subject to the production of proof of death of the depositor and suitable identification of the claim(s), to the bank's satisfaction.

\section{Access to Safe Deposit Locker/Safe Custody articles (with survivor/nominee clause)}

- In the event of death of sole locker hirer, banks may give access to the locker with liberty to remove the contents of the locker to the nominee and in case of the locker hired jointly with operational instruction to operate under joint signatures and nomination exists, bank may give access to the locker with liberty to remove the articles jointly to the survivor(s)/nominee.

- In the case of the locker was hired jointly with survivorship clause and the hirers instructed that the access of the locker should be given over to "either or survivor", "anyone or survivor" or "former or survivor" or according to any other survivorship clause, banks may follow the mandate in the event of the death of one or more of the locker-hirers. 
- Banks are required to evolve a customer-friendly procedure drawn up in consultation with their legal advisers for giving access to legal heir(s) / legal representative of the deceased locker hirer. Similar procedure should be followed for the articles under safe custody of the bank.

- Banks are also required to prepare an inventory before returning articles left in safe custody/before permitting removal of the contents of the safe deposit locker. Banks are not required to open sealed/closed packets left with them in Safe Custody or found in locker while releasing them to the nominee and surviving locker heirs/depositor of safe custody article. Banks are required to put in their website the entire procedure for improvement in customer service.

\section{Settlement of claims in respect of missing persons}

Banks are required to formulate a policy which would enable them to settle the claims of a missing person after considering the legal opinion and taking into account the facts and circumstances of each case (claims are to be settled as per provisions u/s 107/108 of Indian Evidence Act 1872).

In order to avoid inconvenience and undue hardship to the common person, banks may, keeping in view their risk management systems, fix a threshold limit, up to which claims in respect of missing persons could be settled without insisting on production of any documentation other than (i) FIR and the non-traceable report issued by police authorities and (ii) letter of indemnity.

\section{Unclaimed deposits/Inoperative Accounts in banks}

- A savings as well as current account should be treated as inoperative / dormant if there are no transactions in the account for over a period of two years.

- If credits by way of interest on Fixed Deposit account is being received in the Savings Bank accounts as per the mandate of the customer, the same can be treated as a customer induced transaction and the account can be treated as an operative account. It will become inoperative only after 2 years from the date of the last credit entry of the interest on Fixed Deposit account.

- Banks need to ascertain the whereabouts of the account holder(s) by letters, telephone calls, or contacting legal heirs, or contacting the introducers or employers as available record or any other means suited to them in case of no operations (credits other than periodic interest or debiting service charges) for more than one year.

- Periodical interest should continue to be credited in the inoperative accounts and proceeds of FDR unpaid, the amount left unclaimed should attract Savings Bank rate of interest. Inoperative accounts should get audited periodically. There should not be any charge on activation of an inoperative account.

\section{Customer Confidentiality Obligations}

Banks are not supposed to divulge any information about the account to third parties except where:-

(a) disclosure is under compulsion of law

(b) there is duty to the public to disclose

(c) interest of bank requires disclosure and

(d) the disclosure is made with the express or implied consent of the customer.

The information collected from the customer for the purpose of opening of account is to be treated as confidential and not divulge any details thereof for cross selling or any other purposes.

\section{Transfer of account from one branch to another}

Instructions from customer for transfer of his account to another office should be carried out immediately by transferring the account opening form, specimen signature, standing instructions, etc. under advice to the customer. 


\section{Co-ordination with officers of Central Board of Direct Taxes}

Banks should maintain greater co-ordination between the Income-Tax department and extend necessary help/ co-ordination to tax officials whenever required.

\section{Declaration of Holiday under the Negotiable Instruments Act, 1881}

- In terms of Section 25 of the Negotiable Instruments Act, 1881, the expression "public holiday" includes Sunday and any other day declared by the Central Government by notification in the Official Gazette to be a public holiday.

- This power has been delegated to State Govt. by Central Govt. subject to the condition that the Central Government may itself exercise the said function, should it deem fit to do so and this implies that when Central Government itself has notified a day as "public holiday" under Section 25 of the Negotiable Instruments Act, 1881, there is no need for banks to wait for the State Government notification.

\section{Miscellaneous}

- In predominantly residential areas banks may keep their branches open for business on Sundays by suitably adjusting the holidays and banks should keep rural branches open on weekly market day.

- Banks are required to accept standing instructions in Savings and Current accounts and the same can be enlarged to include payments on account of taxes, bills, rents, school/college fees, etc.

- Branch Manger may be permitted to allow clean overdraft for small amounts to customers whose dealings have been satisfactory.

- All transactions, including payment of interest on deposits/charging of interest on advances, should be rounded off to the nearest rupee

- In order to keep a watch on the progress achieved by the bank in the implementation of the recommendations of various working groups/Committees on customer service, banks may examine the recommendations which have relevance in the present day banking and continue to implement them.

- Banks should follow various provisions of the Code of Bank's Commitment to Customers, implementation of which is monitored by the Banking Codes and Standards Board of India (BCSBI), etc. 
ANNEXURE II

CAPITAL ADEQUACY AND MARKET DISCIPLINE-NEW CAPITAL ADEQUACY FRAMEWORK (NCAF)

\section{BASEL II}

The Basel Capital Accord is an Agreement concluded among country representatives in 1988 to develop standardised risk-based capital requirements for banks across countries. The Accord was replaced with a new capital adequacy framework (Basel II), published in June 2004. The Revised Framework was updated in November 2005 followed by a comprehensive version of the framework was issued in June 2006.

Basel II is based on three mutually reinforcing Pillars that allow banks and supervisors to evaluate properly the various risks that banks face. The Pillars are:

(i) Minimum capital requirements, which seek to refine the present measurement framework

(ii) Supervisory review of an institution's capital adequacy and internal assessment process;

(iii) Market discipline through effective disclosure to encourage safe and sound banking practices

\section{(i) Minimum Capital Requirement (Pillar I)}

The New Capital Adequacy Framework (NCAF) provides three distinct options each for computing capital requirement for credit risk and operational risk as under:-

\section{Credit Risk}
(a) Standardised Approach
(b) Foundation Internal Rating Based Approach
(c) Advanced Internal Rating Based Approach

\section{Operational Risk}

(a) Basic Indicator Approach

(b) Standardised Approach

(c) Advanced Measurement Approach

All commercial banks (excluding Local Area Banks and Regional Rural Banks) are required to adopt Standardised Approach (SA) for Credit Risk and Basic Indicator Approach (BIA) for Operational Risk for computing capital to Risk Weighted Assets (CRAR) so as to fall in line with the International standards and reporting to their Boards on quarterly intervals.

With the up gradation of the risk management framework and likely accrual of capital efficiency thereto envisaged under Basel II as also the emerging international trend in this regard, it was considered desirable to lay down a timeframe for migration to the advanced approaches for credit risk and operational risk and accordingly a time frame has been drawn factoring the likely lead time for creating requisite technological and the risk management infrastructure etc. Banks were also advised to migrate to the approach, of course, with suitable approval from RBI.

\section{Capital Funds}

- Tier I CRAR is computed as under:-

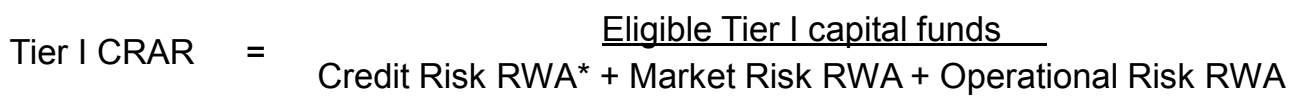

${ }^{*}$ RWA $=$ Risk weighted Assets 
- Banks are required to maintain a minimum Total CRAR of $9 \%$ on an ongoing basis. The RBI will take into account the relevant risk factors and the internal capital adequacy assessments of each bank to ensure that the capital held by a bank is commensurate with the bank's overall risk profile. Total CRAR is worked out as under:-

Total CRAR $=$ Credit Risk RWA + Market Risk RWA + Operational Risk RWA

- Capital funds are classified into Tier I and Tier II capital. Tier II capital will be reckoned to the extent of $100 \%$ of Tier I capital for the purpose of capital funds.

\section{Tier I capital}

It includes:-

(a) Paid-up equity capital, statutory reserves, and other disclosed free reserves, if any;

(b) Capital reserves representing surplus arising out of sale proceeds of assets;

(c) Innovative perpetual debt instruments (IPDI) eligible for inclusion in Tier I capital,

(d) Perpetual Non-Cumulative Preference Shares (PNCPS),

(e) Any other type of instrument generally notified by RBI from time to time for inclusion in Tier I capital.

\section{Limits on eligible Tier I Capital}

(a) IPDIs upto $15 \%$ of Tier I capital as on March 31of previous financial year;

(b) The outstanding amount of Tier I preference shares i.e. Perpetual Non-Cumulative Preference Shares (PNCPS) along with Innovative Tier I instruments shall not exceed 40 per cent of total Tier I capital at any point of time.

(c) Innovative instruments/PNCPS, in excess of the limit shall be eligible for inclusion under Tier II, subject to limits prescribed for Tier II capital.

\section{Tier II Capital}

(a) Revaluation Reserve;

(b) General Provisions and Loss Reserves;

(c) Hybrid debt capital instruments;

(d) Subordinated debts;

(e) IPDI in excess of $15 \%$ of Tier I capital and PNCPS in excess of overall ceiling of $40 \%$ of Tier I capital;

(f) Any other type of instrument generally notified by the Reserve Bank from time to time for inclusion in Tier Il capital.

\section{Limits on eligible Tier II capital}

(a) It shall not exceed $100 \%$ of Tier I capital net of goodwill, Deferred Tax Assets (DTA), and other intangible assets but before deduction of investments;

(b) Subordinated debt instruments are limited to $50 \%$ of Tier I capital after all deductions.

\section{Capital charge for Credit Risk}

\section{Claims on Domestic Sovereigns (standard Assets)}

(a) Both fund based and non fund based claims on the Central Government including Central Govt. guaranteed 
claims carry zero risk weight.

(b) Direct Loans/credit/overdraft exposure, if any, of banks to State Govt. and investment in State Govt. securities carry zero risk weight. State Government guaranteed claims will attract 20 per cent risk weight'.

(c) Risk weight applicable to Central Govt. exposure would also apply to claims on RBI, DI\&CGC and Credit Guarantee Fund Trust for Small Industries (CGTSI) and claim on ECGC would attract $20 \%$ risk weight.

(d) 'Amount Receivable from GOl' under Agricultural Debt Waiver Scheme 2008 is to be treated as claim on $\mathrm{GOI}$ and attract zero risk weight whereas the amount outstanding in the accounts covered by the Debt Relief Scheme shall be treated as a claim on the borrower and risk weighted as per the extant norms.

\section{Claims on Foreign Sovereigns}

Claims on Foreign Sovereigns in foreign currency would be as per the rating assigned as detailed in the RBI circular. In case of claims dominated in domestic currency of Foreign Sovereign met out of the resources in the same currency, the zero risk weight would be applicable.

\section{Claims on Public Sector Entities (PSE)}

Claims on domestic PSEs and Primary Dealers (PD) would be risk weighted in the same manner that of corporate and foreign PSEs as per the rating assigned by foreign rating agencies as detailed in the Circular.

\section{Other claims}

- Claims on IMF, Bank for International Settlements (BIS), Multilateral Development Banks (MDBs) evaluated by the BCBS will be treated similar to claims on scheduled banks at a uniform $20 \%$ risk weight.

- Claims on Banks incorporated in India and Foreign Banks' branches in India, the applicable risk weight is detailed in the RBI Master Circular.

- Claims on corporate Asset Finance Companies (AFCs) and Non-Banking Finance CompaniesInfrastructure Finance Companies (NBFC-IFC), shall be risk weighted as per the ratings assigned by the rating agencies registered with the SEBI and accredited by the RBI (Detailed in the Circular).

- The claims on non-resident corporate will be risk weighted as per the ratings assigned by international rating agencies.

- Regulatory Retail claims (both fund and non-fund based) which meet the Qualifying criteria, viz.

(a) Orientation Criterion: Exposure to individual person/s or to a small business (Average annual turnover less than ₹ 50 crore for last 3 years or projected turnover in case of new units);

(b) Product Criterion: Exposure (both fund-based and non fund-based) in form of revolving credits and lines of credit (incl. overdrafts), term loans \& leases (e.g. instalment loans and leases, student and educational loans) and small business facilities and commitments

(c) Granularity Criterion - Sufficient diversification to reduce the risk portfolio; and

(d) Low value of individual exposures - The maximum aggregated retail exposure to one counterpart should not exceed the absolute threshold limit of ₹ 5 crore.

Would attract risk weight of $75 \%$ except NPAs.

(e) Home loans to individuals upto ₹ 30 Lakh backed by mortgage on residential property, the risk weight would be $50 \%$; and above ₹ 30 Lakh but below ₹ 75 Lakh $75 \%$ provided the Loan to Value ratio (LTV) should not be more than $75 \%$ based on bank's approved valuation policy. LTV beyond $75 \%$ will attract a risk weight of $100 \%$.

(f) The risk weight for residential housing loans of ₹ 75 Lakh and above irrespective of the LTV ratio will be 
$125 \%$ and restructured accounts at $25 \%$.

(g) Commercial real estate exposure, the risk weight is to be taken at $100 \%$.

\section{Non-performing Assets (NPAs)}

- The risk weight in respect of the unsecured portion of NPA (other than a qualifying residential mortgage loan), net of specific provisions (including partial write-offs), shall be:-

$\begin{array}{ll}\text { Specific Provisions } & \text { Risk Weight \% } \\ \text { Less than } 20 \% \text { of outstanding } & 150 \\ \text { At least } 20 \% \text { of outstanding } & 100 \\ \text { At least } 50 \% \text { of outstanding } & 50\end{array}$

- The risk weight applicable for secured NPA is $100 \%$, net of provisions when provisions reach $15 \%$ of the outstanding amount.

- NPA Home Loan claims secured by residential property, the risk weight shall be $100 \%$ net of specific provisions. In case the specific provisions are at least $20 \%$ but less than $50 \%$ of the outstanding, the risk weight shall be $75 \%$ (net of specific provisions) and specific provisions are $50 \%$ or more the applicable risk weight is $50 \%$.

\section{Other specified categories}

\begin{tabular}{|c|c|c|}
\hline & Category & $\begin{array}{l}\text { Risk Weight } \\
(\%)\end{array}$ \\
\hline 01. & Venture capital & 150 or higher \\
\hline 02. & $\begin{array}{l}\text { Consumer credit including personal loans, credit card receivables, but excl. } \\
\text { educational loan }\end{array}$ & 125 \\
\hline 03. & Capital market exposure & 125 \\
\hline 04. & Investment in paid up capital of Non-financial entities & 125 \\
\hline 05. & $\begin{array}{l}\text { *Investment in paid up capital of financial entities (other than banks) where investment } \\
\text { is upto } 30 \% \text { of equity of investee entity. }{ }^{*} \text { Investment exempted from 'capital market } \\
\text { exposure' }\end{array}$ & 125100 \\
\hline 06. & Staff loans backed fully by superannuation benefits and/or mortgage of flat/house & 20 \\
\hline 07. & Other loans and advances to staff eligible for inclusion under retail portfolio & 75 \\
\hline 08. & All other assets & 100 \\
\hline 09. & Off balance sheet items (Market related and non-market related items) & $\begin{array}{l}\text { As detailed in } \\
\text { the RBI } \\
\text { Circular. }\end{array}$ \\
\hline 10. & 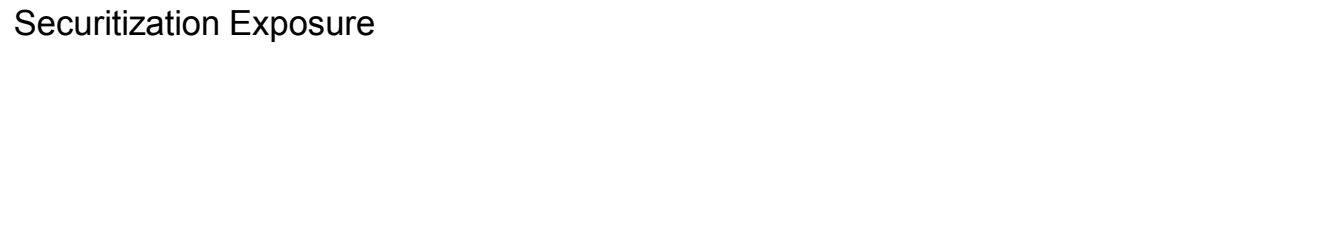 & $\begin{array}{l}\text { As per Cir. } \\
\text { Based on } \\
\text { rating by } \\
\text { external } \\
\text { credit agency }\end{array}$ \\
\hline 11. & Commercial real estate (MBS backed) & -do- \\
\hline
\end{tabular}




\section{External Credit Assessment}

- RBI has identified various credit agencies whose ratings may be used by banks for the purposes of risk weighting their claims for capital adequacy purposes as under:-

(a) Credit Analysis and Research Limited;

(b) CRISIL Limited;

(c) India Ratings \& Research Pvt. Ltd. (India Rating)

(d) ICRA Limited.

(e) Brickwork Ratings India Pvt. Ltd.

International Agencies (where specified)

(a) Fitch

(b) Moodys; and

(c) Standard \& Poor's

- Banks are required to use the chosen credit rating agencies and their ratings consistently for each type of claim, for both risk weighting and risk management purposes. The NCAF recommends development of a mapping process to assign the ratings issued by eligible credit rating agencies to the risk weights available under the Standardised risk weighting framework

- Under the Framework, ratings have been mapped for appropriate risk weights applicable as per Standardised approach. The risk weight mapping for Long Term and Short Term Ratings are given in the Circular.

\section{Credit Risk Mitigation Techniques}

\section{(a) Collateralized transactions}

- The credit exposure is hedged in whole or part by collaterals by a counterparty (party to whom a bank has an on-or off balance sheet credit exposure) or by a third party on behalf of the counterparty and banks have specific lien over the collaterals

- Under the Framework, banks are allowed to adopt either Simple Approach or Comprehensive Approach. The former approach substitutes the risk weighting of the collateral for the risk weighting of the counterparty for the collateraised portion of the exposure and under the latter approach which allows fuller offset of collaterals against exposures. Comprehensive approach is being adopted by banks in India.

- Cash, Gold, securities, KVP, NSC (no lock in period), LIC policies, Debt securities, Units of Mutual Funds, etc. are eligible financial instruments for recognition in the Comprehensive Approach.

\section{(b) Balance Sheet Netting}

Under this technique, banks have legally enforceable netting arrangements involving specific lien with proof of documentation. Capital requirement is reckoned on the basis of net credit exposure.

\section{(c) Guarantees}

Explicit, irrevocable, and unconditional guarantees may be taken as credit protection in calculating capital requirements. Guarantees issued by entities with lower risk weight as compared to the counterparty will lead to reduced capital charges.

\section{Capital charge for Market Risk}

Market Risk relates to risk of losses in on-balance sheet and off-balance sheet positions arising on account of 
movement in market prices. The market risk positions subject to capital charge requirement are risks pertaining to interest rate related instruments in trading books and equities and Foreign Exchange risk (including gold and other precious metals) in both trading and banking books.

Trading book for the purpose of capital adequacy will include:

(a) Securities included under the Held for Trading (HFT) category

(b) Securities included under the Available for Sale (AFS) category

(c) Open gold position limits

(d) Open foreign exchange position limits

(e) Trading positions in derivatives, and

(f) Derivatives entered into for hedging trading book exposures.

- Banks are required to manage the market risks in their books on an ongoing basis and ensure that the capital requirements for market risks are being maintained on a continuous basis, i.e. at the close of each business day. Banks are also required to maintain strict risk management systems to monitor and control intra-day exposures to market risks.

- Capital for market risk would not be relevant for securities which have already matured and remain unpaid. These securities will attract capital only for credit risk. On completion of 90 days delinquency, these will be treated on par with NPAs for deciding the appropriate risk weights for credit risk.

\section{Measurement of capital charge for Interest Rate Risk}

- The capital charge for interest rate related instruments would apply to current market value of the instruments in bank's trading book and banks are required to maintain capital for market risks on an ongoing basis by mark to market their trading positions on a daily basis.

- The minimum capital requirement is measured/ expressed in two ways viz. (i) Specific Risk charge and (ii) General Market Risk (dealt separately hereunder).

- In view of possible longer holding period and higher risk thereto in respect of debt securities held under AFS category, banks are required to hold capital charge for market risk equal to or greater of the Specific Risk Capital charge or Alternative Total Capital Charge.

\section{(i) Specific Market Risk}

The capital charge for specific risk is designed to protect against an adverse movement in the price of an individual security owing to factors related to the individual issuer both short (short position is not allowed in India except in derivatives) and long positions. The specific risk charges and Alternative Total Capital Charge for various kinds of exposures are detailed in Tabular Form in the RBI Circular.

\section{(ii) General Market Risk}

It relates to charge towards interest rate risk in the portfolio, where long and short position (which is not allowed in India except in derivatives) in different securities or instruments can be offset. The capital requirements for general market risk are designed to capture the risk of loss arising from changes in market interest rates.

General Market Risk is the sum of the following four components:-

(a) The net short (short position is not allowed in India except in derivatives) or long position in the whole trading book;

(b) a small proportion of the matched positions in each time-band (the "vertical disallowance"); 
(c) a larger proportion of the matched positions across different time-bands (the "horizontal disallowance"), and

(d) a net charge for positions in options, where appropriate.

- Two broad methodologies for computation of capital charge for market risks are suggested by the Basle Committee viz. Standardised Method and Internal Risk Management models method of which banks have been advised to adopt Standardised Method as banks have not yet developed their Internal Risk Management system.

- Under the standardised method there are two principal methods of measuring market risk viz. a "maturity" method and a "duration" method. It has been decided to adopt standardised "duration" method as the same is more accurate method to arrive the capital charge.

- The mechanics under the method, Time band and assumed changes in yield are detailed in the Circular for reference.

\section{Measurement for capital charge for Equity Risk}

- The capital charge for equities would apply on their current market value in bank's trading book. The Minimum capital requirement, to cover the risk of holding or taking positions in equities in the trading book is detailed in the Circular. The instruments covered include equity shares, whether voting or nonvoting, convertible securities that behave like equities, for example: units of mutual funds, and commitments to buy or sell equity.

- The capital charge for Specific Risk and General Market Risk, calculated on bank's gross equity position, would be $9 \%$ each and the Specific Risk capital charge on the banks investment in Security Receipts would be $13.5 \%$ (equivalent to $150 \%$ risk weight).

\section{Measurement of capital charge for Foreign Exchange Risk}

The bank's net open position in each currency shall be calculated by summing:

(a) The net spot position (i.e. all asset items less all liability items, including accrued interest, denominated in the currency in question);

(b) The net forward position (i.e. all amounts to be received less all amounts to be paid under forward foreign exchange transactions, including currency futures and the principal on currency swaps not included in the spot position);

(c) Guarantees (and similar instruments) that are certain to be called and are likely to be irrecoverable;

(d) Net future income/expenses not yet accrued but already fully hedged (at the discretion of the reporting bank);

(e) Depending on particular accounting conventions in different countries, any other item representing a profit or loss in foreign currencies;

The open positions both Foreign exchange and gold are at present risk-weighted at $100 \%$ and the capital charge for market risks in foreign exchange and gold open position is $9 \%$. These open positions, limits or actual whichever is higher, would continue to attract capital charge at $9 \%$. This capital charge is in addition to the capital charge for credit risk on the on-balance sheet and off-balance sheet items pertaining to foreign exchange and gold transactions.

For calculation of eligible capital for market risk, it will be necessary to ascertain the bank's minimum capital requirement for credit and operational risks so as to arrive the available Tier I and Tier II capital to support the market risk (Illustrated in the Circular).

\section{Capital charge for Operational Risk}


Operational risk is termed as the risk of loss resulting from inadequate or failed internal processes, people and systems or from external events. This includes legal risk, but excludes strategic and reputational risk. Legal risk includes, but is not limited to, exposure to fines, penalties, or punitive damages resulting from supervisory actions, as well as private settlements.

\section{Measurement Methodologies}

Three methods for calculating operational risk capital charges in continuum of increasing sophistication and risk sensitivity are provided under NCAF viz.

(i) The Basic Indicator Approach (BIA)

(ii) The Standardised Approach (TSA), and

(iii) Advanced Measurement Approach (AMA).

- Banks are advised, to begin with, to adopt the Basic Indicator Approach (BIA) and RBI would review the capital requirement under BIA for general credibility and in case it is found any laxity, appropriate Supervisory action under Pillar 2 will be considered.

- Under BIA, banks are required to hold capital for operational risk equal to the average positive annual gross income over the previous 3 years. In case the gross income for any year is negative or zero, the same should be excluded while calculating the average. RBI will initiate necessary supervisory action under Pillar 2 in case the negative gross income distorts banks Pillar I capital charge.

\section{(ii) Supervisory Review and Evaluation Process (SREP) - (Pillar 2)}

The objective of Supervisory Review Process (SRP) is to:-

(a) Ensure that banks have adequate capital to support all the risks in their business; and

(b) Encourage them to develop and use better risk management techniques for monitoring and managing their risks.

Key principles envisaged under the SRP are:-

(a) Banks are required to have a process for assessing their overall capital adequacy in relation to their risk profile and a strategy for maintaining their capital levels.

(b) Evaluation of banks' internal capital adequacy assessments and strategies as well as their ability to monitor and ensure their compliance with the regulatory capital ratios by Supervisors.

(c) Supervisors should expect banks to operate above the minimum regulatory capital ratios and should have the ability to require banks to hold capital in excess of the minimum.

(d) Supervisors should intervene at an early stage to prevent capital from falling below the minimum levels required to support the risk characteristics of a particular bank and should require rapid remedial action if capital is not maintained or restored.

- As regards SREP, banks should evolve an effective Internal Capital Adequacy Assessment Process (ICAAP) for assessing their capital adequacy based on the risk profiles as well as strategies for maintaining their capital levels.

- Pillar 2 also requires the Supervisory authorities to put in place an evaluation process known as Supervisory Review and Evaluation Process (SREP) and to initiate supervisory measures as may be necessary. This would also facilitate RBI to take suitable steps either to reduce exposure of the bank or augment/restore its capital. ICAAP is an important component of the SRP.

- Every bank (except LABs \& RRBs) should have an ICAAP both at solo and consolidated levels and 
the responsibility of designing and implementation of the ICAAP rests with the Board. Before embarking on new activities or introducing new products the senior management should identify and review the related risks arising from these potential new products or activities and ensure that the infrastructure and internal controls necessary to manage the related risks are in place.

- Banks are required to put in place a effective MIS which should provide the board and senior management a clear and concise manner with timely and relevant information concerning their institutions' risk profile including risk exposure. MIS should be capable of capturing limit breaches (concentrations) and same should be promptly reported to senior management, as well as to ensure that appropriate follow-up actions are taken. Risk management process should be frequently monitored and tested by independent control areas and internal and external auditors.

- The ICAAP should form an integral part of the management and decision-making culture of a bank. The implementation of ICAAP should be guided by the principle of proportionality and RBI expects degree of sophistication in the ICAAP in regard to risk measurement which should commensurate with the nature, scope, scale and the degree of complexity in the bank's business operations.

\section{Sound Stress Testing Practices}

- Stress testing that alerts bank management to adverse unexpected outcomes related to a broad variety of risks and provides an indication to banks of how much capital might be needed to absorb losses should large shocks occur. It is an important tool that is used by banks as part of their internal risk management. Moreover, stress testing supplements other risk management approaches and measures.

(iii) Market Discipline - (Pillar - 3)

- Market Discipline is termed as development of a set of disclosure requirements so that the market participants would be able to access key pieces of information on the scope of application, capital, risk exposures, risk assessment processes, and in turn the capital adequacy of the institution. It is considered as an effective means of informing the market about a bank's exposure to those risks and provides comparability. Non-compliance of the prescribed disclosure requirement attracts penalty including financial penalty.

- Banks are required provide as at the end of March each year all Pillar 3 disclosures both quantitative and qualitative along with annual financial statements. Banks with capital funds of $₹ 100$ crore or more are further required to make interim disclosures on the quantitative aspects on a standalone basis on their websites as at end of September each year.

- All banks with capital funds of ₹ 500 crore or more are required to disclose their Tier I capital, total capital, total required capital and Tier I ratio and total capital adequacy ratio, on a quarterly basis on their respective websites.

- The disclosure on the websites should be made in a web page titled "Basel II Disclosures" and the link to this page should be prominently provided on the home page of the bank's website. Each of these disclosures pertaining to a financial year should be available on the websites until disclosure of the third subsequent annual (March end) disclosure is made.

- Banks operating in India are required to make additional disclosures in respect of:-

(a) Securitisation exposures in the trading book;

(b) Sponsorship of off-balance sheet vehicles;

(c) Valuation with regard to securitisation exposures; and

(d) Pipeline and warehousing risks with regard to securitisation exposures 
- The disclosure requirements under Pillar 3 section wise along with narrations are outlined in Tabular Form in the RBI Master Circular on NCAF.

Detailed guidelines on issuance of various Debt Instruments viz. Innovative Perpetual Debt Instrument (IPDI), Perpetual Non-cumulative Preference Shares (PNCPS), Debt Capital Instruments, Perpetual Cumulative Preference Shares (PCPS), Redeemable Non-cumulative Preference Shares (RNPS), Redeemable Cumulative Preference Shares (RCPS), Subordinated Debts, Guidelines on Securitisation of Standard Assets, Credit Risk Mitigation - Illustrations, Illustrative Approach on Measurement of Capital Charge for Market Risks in respect of Interest Rate Risk and Derivatives, Illustrative Approach on Measurement Interest Rate Risk in Banking Books (IRRBB), etc. are given in the Master Circular RBI. 


\section{ANNEXURE III}

\section{BASEL III - CAPITAL REGLULATIONS}

\section{Introduction}

The main objective of the Basel III framework issued by the Basel Committee on Banking Supervision (BCBS) in Dec. 2010 is to improve the banking sector's ability to absorb shocks arising from financial and economic stress, whatever the source, thus reducing the risk of spillover from financial sector to real economy. The reform package will amend certain provisions existing under Basel II framework (NCAF) and introduce some new concepts and requirements. These new global regulatory and supervisory standards mainly seek to raise the quality and level of capital to ensure banks are better able to absorb losses on both a going concern and a gone concern basis, increase the risk coverage of the capital framework, introduce leverage ratio to serve as a backstop to the riskbased capital measure, raise the standards for the supervisory review process and public disclosures etc. The macro prudential aspects of Basel III are largely enshrined in the capital buffers. Both the buffers i.e. the capital conservation buffer and the countercyclical buffer are intended to protect the banking sector from periods of excess credit growth.

\section{A. Guidelines on Minimum Capital Requirement}

The Basel III capital regulations continue to be based on three-mutually reinforcing

Pillars, viz. minimum capital requirements (Pillar 1), supervisory review of capital adequacy (Pillar 2), and market discipline (Pillar 3) of the Basel II capital adequacy framework. Under Pillar 1, the Basel III framework will continue to offer the three distinct options for computing capital requirement for credit risk and three other options for computing capital requirement for operational risk, albeit with certain modifications / enhancements. These options for credit and operational risks are based on increasing risk sensitivity and allow banks to select an approach that is most appropriate to the stage of development of bank's operations. The options available for computing capital for credit risk are:-

(a) Standardised Approach,

(b) Foundation Internal Rating Based Approach; and

(c) Advanced Internal Rating Based Approach.

The options available for computing capital for operational risk are:-

(a) Basic Indicator Approach (BIA),

(b) The Standardised Approach (TSA); and

(c) Advanced Measurement Approach (AMA).

Keeping in view the Reserve Bank's goal to have consistency and harmony with international standards, as also capital efficiency likely to accrue to the banks by adoption of the advanced approaches, a time schedule was laid down in 2009 that all commercial banks in India (excluding Local Area Banks and Regional Rural Banks) may switch over to Internal Rating Based Approach (Both Foundation as well as Advanced Internal Rating Based Approach) for credit risk and Advanced Measurement Approach for operational risk by 31.03.2014. Accordingly, banks were advised to undertake an internal assessment of their preparedness for migration to advanced approaches and take a decision with the approval of their Boards/RBI, whether they would like to migrate to any of the advanced approaches. Banks may choose a suitable date to apply for implementation of advanced approach. The provisions of Basel III include:-

(a) The Basel III capital regulation has been implemented from April 1, 2013 in India in phases.

(b) To ensure smooth transition to Basel III, appropriate transitional arrangements have been provided for 
meeting the minimum Basel III capital ratios, full regulatory adjustments to the components of capital etc. Consequently, Basel III capital regulations would be fully implemented as on March 31, 2018.

(c) Banks are required to maintain a minimum Pillar 1 Capital to Risk-weighted Assets Ratio (CRAR) of 9\% on an on-going basis (other than capital conservation buffer and Countercyclical capital buffer etc.).

(d) Capital requirements for the implementation of Basel III guidelines are lower in the initial periods and higher in later years.

(e) Banks are required to disclose the capital ratios computed under Basel III capital adequacy framework from the quarter ending 30.06.2013.

(f) The RBI may consider prescribing a higher level of minimum capital ratio for each bank under Pillar 2 framework on the basis of their respective risk profiles and their risk management systems.

(g) Banks are required to comply with the capital adequacy ratio at two levels viz. consolidated (Group) and standalone (Solo) level. At consolidated level, the capital adequacy ratio requirements of a bank measure the capital adequacy of a bank based on its capital strength and risk profile after consolidating the assets and liabilities of its subsidiaries/joint ventures/associates, etc. except those engaged in insurance and any non-financial activities. The standalone level capital adequacy ratio requirements measure the capital adequacy of a bank based on its standalone capital strength and risk profile. The overseas operations of a bank through its branches will be covered in both the above scenarios. For the purpose of these guidelines, the subsidiary is an enterprise that is controlled by another enterprise (known as the parent), etc.

Under the Basel II framework, the total regulatory capital comprises of Tier I (core capital) and Tier 2 capital (supplementary capital). In order to improve the quality and quality of regulatory capital, capital will predominantly consist of Common Equity under Basel III. Non-equity Tier 1 and Tier 2 capital would continue to form part of regulatory capital subject to eligibility criteria as laid down in Basel III. Banks have to comply with the regulatory limits and minima as prescribed under Basel III capital regulations, on an ongoing basis. To ensure smooth transition to Basel III, appropriate transitional arrangements have been provided for meeting the minimum Basel III capital ratios, full regulatory adjustments to the components of capital etc. Consequently, Basel III capital regulations would be fully implemented as on March 31, 2018. In view of the gradual phase-in of regulatory adjustments to the Common Equity component of Tier 1 capital under Basel III, certain specific prescriptions of Basel II capital adequacy framework (e.g. rules relating to deductions from regulatory capital, risk weighting of investments in other financial entities etc.) will also continue to apply till March 31, 2017.

\section{Composition of Regulatory Capital}

Under Basel III, Banks are required to maintain a minimum Pillar 1 Capital to Risk-weighted Assets Ratio (CRAR) of $9 \%$ on an on-going basis (other than capital conservation buffer and countercyclical capital buffer etc.). The $\mathrm{RBI}$ will take into account the relevant risk factors and the internal capital adequacy assessments of each bank to ensure that the capital held by a bank is commensurate with the bank's overall risk profile. This would include, among others, the effectiveness of the bank's risk management systems in identifying, assessing / measuring, monitoring and managing various risks including interest rate risk in the banking book, liquidity risk, concentration risk and residual risk. Accordingly, RBI will consider prescribing a higher level of minimum capital ratio for each bank under the Pillar 2 framework on the basis of their respective risk profiles and their risk management systems. Further, in terms of the Pillar 2 requirements, banks are expected to operate at a level well above the minimum requirement.

The total regulatory capital fund will consist of the sum of the following categories:-

(i) Tier 1 Capital (going-concern capital*): comprises of:-

(a) Common Equity Tier 1 capital 
(b) Additional Tier 1 capital

(ii) Tier 2 Capital (gone-concern capital*)

( ${ }^{*}$ From regulatory capital perspective, going-concern capital is the capital which can absorb losses without triggering bankruptcy of the bank. Gone-concern capital is the capital which will absorb losses only in a situation of liquidation of the bank).

Banks are required to compute the Basel III capital ratios in the following manner:-

Common Equity Tier 1 Capital Ratio

Common Equity Tier 1 Capital

Credit Risk RWA* + Market Risk RWA + Operational Risk RWA

Tier 1 Capital Ratio

Eligible Tier 1 Capital

Credit Risk RWA* + Market Risk RWA + Operational Risk RWA

Total Capital (CRAR\#) Eligible Total Capital

Credit Risk RWA + Market Risk RWA + Operational Risk RWA

${ }^{*}$ RWA = Risk weighted Assets;

\# Capital to Risk Weighted Asset Ratio

\section{Elements of Capital funds - Indian Banks}

\section{(i) Common Equity Tier 1 capital}

(i) Common shares (All common shares should ideally be the voting shares as detailed in RBI M. Cir.)

(ii) Stock surplus (share premium)

(iii) Statutory reserves

(iv) Capital reserves representing surplus arising out of sale proceeds of assets

(v) Other disclosed free reserves, if any

(vi) Balance in Profit \& Loss Account at the end of previous year

(vii) Profit for current year calculated on quarterly basis as per the formula given in RBI Cir. (Less: Regulatory adjustments/ deductions)

(ii) Additional Tier 1 capital

(i) Perpetual Non-cumulative Preference shares (PNCPS)

(ii) Stock surplus (share premium)

(iii) Debt capital instruments

(iv) Any other type of instruments as notified by RBI from time to time.

(Less: Regulatory adjustments/ deductions)

(iii) Tier 2 Capital

(i) General Provisions and Loss Reserves

(ii) Debt capital instruments issued by banks

(iii) Preference share capital instruments (PCPS/RNCPS/RCPS)

(iv) Stock surpluses 
(v) Revaluation reserves at a discount of $55 \%$

(vi) Any other type of instruments generally notified by RBI for inclusion under Tier 2 capital (Less: Regulatory adjustments/deductions)

\section{Elements of Capital funds - Foreign Banks}

\section{Common Equity Tier I capital}

(i) Interest free funds from H.O.

(ii) Statutory reserves

(iii) Remittance surplus retained in Indian Books (non-repatriable)

(iv) Interest free funds remitted from abroad for acquisition of property

(v) Capital reserves arising out of sale of assets (non-repatriable), etc.

(Less: Regulatory adjustments/ deductions)

\section{Additional Tier 1 capital}

(i) H.O. borrowings for foreign currency

(ii) Any other item as allowed by RBI

(Less: Regulatory adjustments/ deductions)

\section{Tier 2 Capital}

(i) General Provisions and Loss Reserves

(ii) H.O. borrowings in foreign currency

(iii) Revaluation reserves at a discount of $55 \%$

(Less: Regulatory adjustments/deductions)

\section{Capital requirement}

(a) All scheduled commercial banks (excl. LABs \& RRBs) operating in India shall maintain a Minimum Total Capital (MTC) of $9 \%$ of total Risk Weighted Assets (RWA) i.e. capital to risk weighted assets (CRAR) as against $8 \%$ prescribed under Basel III rules.

(b) Out of the MTC of $9 \%$, Common Equity Tier I (CET1) capital shall be at least $5.5 \%$ of RWA (i.e. for credit risk + market risk + operational risk) on an ongoing basis (Basel III at least $4.5 \%$ of RWA).

(c) Tier 1 capital shall be at least $7 \%$ of RWA on an ongoing basis. In other words, within the Tier 1 capital, Additional Tier 1 capital shall be maximum 1.5\% of RWAs (Basel III 6\%).

(d) Total Capital (Tier 1 capital + Tier 2 capital) shall be at least $9 \%$ of RWAs on an ongoing basis i.e. within the minimum CRAR of $9 \%$, Tier 2 capital can be admitted maximum up to $2 \%$ (Basel III Tier $1+$ Tier 2 shall be $8 \%)$.

(e) If a bank has complied with Minimum Common Equity Tier 1 and Additional Tier 1 capital ratios, then the excess Additional Tier 1 capital can be admitted for compliance with the minimum CRAR of $9 \%$ of RWAs.

(f) In addition to the minimum Common Equity Tier 1 capital of $5.5 \%$ of RWAs, banks are also required to maintain a capital conservation buffer (CCB) of $2.5 \%$ of RWAs (dealt separately) in the form of Common Equity Tier 1 capital.

With the full implementation of capital ratios (For smooth migration to these capital ratios, transitional arrangements have been provided) and CCB the capital requirements would be as follows:- 


\begin{tabular}{clc}
\hline & Regulatory Capital & As \% to RWAs \\
\hline 1. & Minimum Common Equity Tier 1 Ratio & 5.50 \\
2. & Capital Conservation Buffer (comprised of Common Equity) & 2.50 \\
3. & MCE Tier 1 Ratio + CCB & 8.00 \\
4. & Additional Tier 1 Capital & 1.50 \\
5. & Minimum Tier 1 Capital Ratio $(1+4)$ & 7.00 \\
6. & Tier 2 Capital & 2.00 \\
7. & Minimum Total Capital Ratio (MTC) $\{5+6\}$ & 9.00 \\
8. & MTC + CCB (7 + 2) & 11.50 \\
\hline
\end{tabular}

(a) For prudential exposure limits linked to capital funds, the 'capital funds' will exclude the applicable capital conservation buffer and countercyclical capital buffer as and when activated, but include Additional Tier 1 capital and Tier 2 capital which are supported by proportionate amount of Common Equity Tier 1 capital. Accordingly, capital funds will be defined as the sum total of Common Equity Tier 1 capital, Additional Tier 1 capital, and Tier 2 capital eligible for computing and reporting CRAR of the bank. It may be noted that the term 'Common Equity Tier 1 capital' does not include capital conservation buffer and countercyclical capital buffer.

(b) For the purpose of reporting Tier 1 capital and CRAR, any excess Additional Tier 1 (AT1) capital and Tier 2 (T2) capital will be recognised in the same proportion as that applicable towards minimum capital requirements. In other words, to admit any excess AT1 and T2 capital, the bank should have excess CET1 over and above $8 \%(5.5 \%+2.5 \%)$.

(c) In cases where the a bank does not have minimum Common Equity Tier $1+$ capital conservation buffer of $2.5 \%$ of RWAs as required but, has excess Additional Tier 1 and / or Tier 2 capital, no such excess capital can be reckoned towards computation and reporting of Tier 1 capital and Total Capital.

(d) A countercyclical capital buffer of $0.205 \%$ of RWAs in the form of Common Equity or other fully loss absorbing capital is to be created to mitigate/protect the banking sector from periods of excess aggregate credit growth and resultant system-wide risk being an extension of CCB.

\section{Regulatory adjustments/deductions}

The regulatory adjustments / deductions which will be applied to regulatory capital both at solo and consolidated level are as under:-

(a) Goodwill and all other intangible assets are required to be deducted from the Common Equity component of Tier 1.

(b) Under Basel III, Deferred Tax Assets (DTA) which relies on future profitability of bank, only such DTAs are to be deducted from Common Equity. However, as per the RBI guidelines, banks in India will be required to deduct all DTAs irrespective of their origin from Common Equity Tier 1 capital as a prudent measure. Application of these rules at consolidated level would mean deduction of DTAs from the consolidated Common Equity which is attributed to the subsidiaries, in addition to deduction of DTAs which pertain to the solo bank.

(c) The amount of cash flow hedge reserve which relates to hedging of items that are not fair valued in the balance sheet (including projected cash flows) should be derecognized in the calculation of Common Equity Tier 1.

(d) Shortfall of stock of provisions to expected losses under the Internal Ratings Based (IRB) approach 
should be deducted in the calculation of Common Equity Tier 1 capital. The full shortfall amount is to be deducted and should not be reduced by any tax effects that could be expected to occur if provisions were to rise to the level of expected losses.

(e) Other areas such as Gain-on-Sale Related to Securitisation Transactions, defined benefit pension fund liabilities, Investment in a bank's own shares, etc. are to be deducted appropriately from Common Equity Tier 1 capital.

(f) The investment of banks in the regulatory capital instruments of other financial entities contributes to the inter-connectedness amongst the financial institutions and hence it should be deducted from the respective tiers of regulatory capital so as to avoid double counting of capital in the financial system.

(g) Reciprocal cross holdings of capital might result in artificially inflating the capital position of banks and hence such holdings of capital has to be fully deducted from component of capital (Common Equity, Additional Tier 1 and Tier 2 capital) for which the capital would qualify if it was issued by the bank itself,

(h) Capital instruments which no longer qualify as non-common equity Tier 1 capital or Tier 2 capital (e.g. IPDI and Tier 2 debt instruments with step-ups) are to be phased out beginning 01.01.2013, etc.

\section{Transitional Arrangements}

As per Basel III terms, in order to ensure smooth migration without any near stress, appropriate transitional arrangements for capital ratios have been made which commenced as on 01.04.2013. Capital ratios and deductions from Common Equity will be fully phased-in and implemented as on 31.03.2018 and accordingly the phase-in arrangements for SCBs operating in India are drawn as under:-

Transitional Arrangements (Excl. LABs and RRBs)

\begin{tabular}{l|r|r|r|r|r|r}
\hline Minimum capital ratios & 01.04 .13 & 31.03 .14 & 31.03 .15 & 31.03 .16 & 31.03 .17 & 31.03 .18 \\
\hline CET 1 & 4.50 & 5.00 & 5.50 & 5.50 & 5.50 & 5.50 \\
CCB & - & - & 0.625 & 1.25 & 1.875 & 2.50 \\
Minimum CET1 + CCB & 4.50 & 5.00 & 6.125 & 6.75 & 7.375 & 8.00 \\
Minimum Tier 1 capital & 6.00 & 6.50 & 7.00 & 7.00 & 7.00 & 7.00 \\
Minimum Total capital * & 9.00 & 9.00 & 9.00 & 9.00 & 9.00 & 9.00 \\
Minimum Total Capital + CCB & 9.00 & 9.00 & 9.625 & 10.25 & 10.875 & 11.50 \\
Phase-in of all deductions from & 20 & 40 & 60 & 80 & 100 & 100 \\
CET 1 (in \%) \# & & & & & \\
\hline
\end{tabular}

* The difference between the minimum total capital requirement of $9 \%$ and the Tier 1 requirement can be met with Tier 2 and higher forms of capital;

\# The same transition approach will apply to deductions from Additional Tier 1 and Tier 2 capital

The regulatory adjustments (i.e. deductions and prudential filters) would be fully deducted from Common Equity Tier 1 only by March 31, 2017. During this transition period, the remainder not deducted from Common Equity Tier 1 / Additional Tier 1 / Tier 2 capital will continue to be subject to treatments given under Basel II capital adequacy framework.

\section{Capital charge for Credit Risk}

$\mathrm{RBI}$ has identified external credit rating agencies that meet the eligibility criteria specified under the revised Framework. Banks are required to choose the external rating agencies identified by RBI for assigning risk weights for capital adequacy purposes as per the mapping furnished in the Basel III guidelines. 


\section{Claims on Domestic Sovereigns (standard Assets)}

(e) Both fund based and non fund based claims on the Central Government including Central Govt. guaranteed claims carry zero risk weight.

(f) Direct Loans/credit/overdraft exposure, if any, of banks to State Govt. and investment in State Govt. securities carry zero risk weight. State Government guaranteed claims will attract 20 per cent risk weight'.

(g) Risk weight applicable to Central Govt. exposure would also apply to claims on RBI, CGTMSE, and Credit Risk Guarantee Fund Trust for Low Income Housing (CRGFTLIH). The claims on ECGC will attract a risk weight of $20 \%$.

(h) 'Amount Receivable from GOI' under Agricultural Debt Waiver Scheme 2008 is to be treated as claim on $\mathrm{GOI}$ and attract zero risk weight whereas the amount outstanding in the accounts covered by the Debt Relief Scheme shall be treated as a claim on the borrower and risk weighted as per the extant norms.

\section{Claims on Foreign Sovereigns}

Claims on Foreign Sovereigns in foreign currency would be as per the rating assigned as detailed in the RBI circular. In case of claims dominated in domestic currency of Foreign Sovereign met out of the resources in the same currency, the zero risk weight would be applicable.

\section{Claims on Public Sector Entities (PSE)}

Claims on domestic PSEs and Primary Dealers (PD) would be risk weighted in the same manner that of corporate and foreign PSEs as per the rating assigned by foreign rating agencies as detailed in the Circular.

\section{Other claims}

- Claims on IMF, Bank for International Settlements (BIS), and eligible Multilateral Development Banks (MDBs) evaluated by the BCBS will be treated similar to claims on scheduled banks at a uniform $20 \%$ risk weight. Similarly, claims on the International Finance Facility for Immunization (IFFIm) will also attract a twenty per cent risk weight

- Claims on Banks incorporated in India and Foreign Banks' branches in India, the applicable risk weight is detailed in the RBI Master Circular.

- Banks' investment in capital instruments of other banks such investments would not be deducted, but would attract appropriate risk as detailed in the RBI M. Circular.

- Claims on corporate Asset Finance Companies (AFCs) and Non-Banking Finance CompaniesInfrastructure Finance Companies (NBFC-IFC), shall be risk weighted as per the ratings assigned by the rating agencies registered with the SEBI and accredited by the RBI (Detailed in the Circular).

- The claims on non-resident corporate will be risk weighted as per the ratings assigned by international rating agencies.

- Regulatory Retail claims (both fund and non-fund based) which meet the Qualifying criteria, viz.

(h) Orientation Criterion: Exposure to individual person/s or to a small business (Average annual turnover less than ₹ 50 crore for last 3 years in case of existing or projected turnover in case of new units);

(i) Product Criterion: Exposure (both fund-based and non fund-based) in form of revolving credits and lines of credit (incl. overdrafts), term loans \& leases (e.g. instalment loans and leases, student and educational loans) and small business facilities and commitments

(j) Granularity Criterion - Sufficient diversification to reduce the risk portfolio; and

(k) Low value of individual exposures - The maximum aggregated retail exposure to one counterpart should not exceed the absolute threshold limit of ₹ 5 crore. 
Would attract risk weight of $\mathbf{7 5 \%}$ except NPAs. As part of the supervisory review process, the RBI would also consider whether the credit quality of regulatory retail claims held by individual banks should warrant a standard risk weight higher than $75 \%$.

- The RWA on claims secured by mortgage of residential properties would be as under:-

\section{Category of Loan}

(a) Individual Housing Loans

(i) Up to ₹ 20 lakh

(ii) Above ₹ 20 lakh and up to ₹ 75 lakh

(iii) Above ₹75 lakh

(b) Commercial Real Estate - ResidentialHousing (CRE-RH)

(c) Commercial Real Estate (CRE)
LTV Ratio (\%)

Risk Weight (\%)

Note: 1 . The LTV ratio should not exceed the prescribed ceiling in all fresh cases of sanction. In case the LTV ratio is currently above the ceiling prescribed for any reasons, efforts shall be made to bring it within limits.

2. Banks' exposures to third dwelling unit onwards to an individual will also be treated as CRE exposures.

- Restructured housing loans should be risk weighted with an additional risk weight of $25 \%$ to the risk weights prescribed above.

- Loans / exposures to intermediaries for on-lending will not be eligible for inclusion under claims secured by residential property but will be treated as claims on corporate or claims included in the regulatory retail portfolio as the case may be.

- Investments in mortgage backed securities (MBS) backed by exposures will be governed by the guidelines pertaining to securitisation exposures (as detailed in the RBI Cir.)

\section{Non-performing Assets (NPAs)}

The risk weight in respect of the unsecured portion of NPA (other than a qualifying residential mortgage loan), net of specific provisions (including partial write-offs), shall be:-

\section{Specific Provisions}

Less than $20 \%$ of outstanding

At least $20 \%$ of outstanding

At least $50 \%$ of outstanding

\section{Risk Weight \%}

150

100

50

- The risk weight applicable for secured NPA is $100 \%$, net of provisions when provisions reach $15 \%$ of the outstanding amount.

- NPA Home Loan claims secured by residential property, the risk weight shall be $100 \%$ net of specific provisions. In case the specific provisions are at least $20 \%$ but less than $50 \%$ of the outstanding, the risk weight shall be $75 \%$ (net of specific provisions) and specific provisions are $50 \%$ or more the applicable risk weight is $50 \%$. 
Other specified categories

\begin{tabular}{c|l|l}
\hline & Category & $\begin{array}{l}\text { Risk Weight } \\
(\%)\end{array}$ \\
\hline 01. & Venture capital & 150 or higher \\
02. & $\begin{array}{l}\text { Consumer credit including personal loans, credit card receivables, but excl. } \\
\text { educational loan }\end{array}$ & 125 \\
03. & Capital market exposure & 125 \\
04. & Investment in capital instruments of NBFC & 125 \\
05. & The exposure to equity instruments issued by NBFCs & 250 \\
05. & Investment in paid up equity of non-financial entities (other than subsidiaries) where & 1251111 \\
06. & investment is below 10\% of equity of investee entity.Above 10\% & \\
07. & Other loans and advances to staff eligible for inclusion under retail portfolio & 20 \\
08. & All other assets & 75 \\
09. & Off balance sheet items (Market related and non-market related items) & 100 \\
& & $\begin{array}{l}\text { As detailed in } \\
\text { the RBI }\end{array}$ \\
10. & Securitization Exposure & $\begin{array}{l}\text { As per Cir. } \\
\text { Based on } \\
\text { rating by } \\
\text { external } \\
\text { credit agency }\end{array}$ \\
& & -do- \\
\hline
\end{tabular}

\section{Definitions and general terminology}

\section{Counterparty Credit Risk (CCR)}

CCR is the risk that the counterparty to a transaction could default before the final settlement of the transaction's cash flows.

\section{Securities Financing Transactions (SFTs)}

SFTs are transactions such as repurchase agreements, reverse repurchase agreements, security lending and borrowing, collateralised borrowing and lending (CBLO) and margin lending transactions, where the value of the transactions depends on market valuations and the transactions are often subject to margin agreements.

\section{Hedging Set}

Hedging Set is a group of risk positions from the transactions within a single netting set for which only their balance is relevant for determining the exposure amount or EAD under the CCR standardised method.

\section{Current Exposure}

Current Exposure is the larger of zero, or the market value of a transaction or portfolio of transactions within a netting set with a counterparty that would be lost upon the default of the counterparty, assuming no recovery on the value of those transactions in bankruptcy. Current exposure is often also called Replacement Cost. 


\section{Credit Valuation Adjustment}

It is an adjustment to the mid-market valuation of the portfolio of trades with counterparty. This adjustment reflects the market value of the credit risk due to any failure to perform on contractual agreements with counterparty. This adjustment may reflect the market value of the credit risk of the counterparty or the market value of the credit risk of both the bank and the counterparty.

\section{One-Sided Credit Valuation Adjustment}

It is a credit valuation adjustment that reflects the market value of the credit risk of the counterparty to the firm, but does not reflect the market value of the credit risk of the bank to the counterparty.

\section{Default Risk Capital Charge for CCR}

The exposure amount for the purpose of computing for default risk capital charge for counterparty credit risk will be calculated using the Current Exposure Method (CEM) as detailed in the Circular.

\section{Capitalization of mark-to-market counterparty risk losses (CVA capital charge)}

In addition to the default risk capital requirement for counterparty credit risk, banks are also required to compute an additional capital charge to cover the risk of mark-to-market losses on the expected counterparty risk (such losses being known as credit value adjustments, CVA) to OTC derivatives. The CVA capital charge will be calculated in the manner as indicated in the RBI Circular.

\section{Failed Transactions}

(a) With regard to unsettled securities and foreign exchange transactions, banks are exposed to counterparty credit risk from trade date, irrespective of the booking or the accounting of the transaction. Banks may develop and implement suitable systems for tracking and monitoring the credit risk exposure arising from unsettled transactions as appropriate for producing management information that facilitates action on a timely basis.

(b) Banks must closely monitor securities and foreign exchange transactions that have failed, starting from the day they fail for producing management information that facilitates action on a timely basis

(c) Failure of transactions settled through a delivery-versus-payment system (DvP), providing simultaneous exchanges of securities for cash, expose banks to a risk of loss on the difference between the transaction valued at the agreed settlement price and the transaction valued at current market price (i.e. positive current exposure).

(d) For DvP Transactions - If the payments have not yet taken place five business days after the settlement date, banks are required to calculate a capital charge by multiplying the positive current exposure of the transaction by the appropriate factor as given in the Circular. In order to capture the information, banks may upgrade their information systems in order to track the number of days after the agreed settlement date and calculate the corresponding capital charge.

(e) For non-DvP transactions (free deliveries) after the first contractual payment/ delivery leg, the bank that has made the payment will treat its exposure as a loan if the second leg has not been received by the end of the business day.

\section{External Credit Assessment}

$\mathrm{RBI}$ has identified various credit agencies whose ratings may be used by banks for the purposes of risk weighting their claims for capital adequacy purposes under the revised framework as under:-

(a) Brickwork Ratings India Pvt. Limited (Brickwork);

(b) Credit Analysis and Research Limited; 
(c) CRISIL Limited;

(d) ICRA Limited;

(e) India Ratings and Research Private Limited (India Ratings); and

(f) SME Rating Agency of India Ltd. (SMERA)

International Agencies (where specified)

(d) Fitch

(e) Moodys; and

(f) Standard \& Poor's

Banks are required to use the chosen credit rating agencies and their ratings consistently for each type of claim, for both risk weighting and risk management purposes. The revised framework recommends development of a mapping process to assign the ratings issued by eligible credit rating agencies to the risk weights available under the Standardised risk weighting framework. Under the Framework, ratings have been mapped for appropriate risk weights applicable as per Standardised approach. The risk weight mapping for Long Term and Short Term Ratings are given in the Circular.

\section{Credit Risk Mitigation Techniques}

Banks use a number of techniques to mitigate the credit risks to which they are exposed. For example, exposures may be collateralised in whole or in part by cash or securities, deposits from the same counterparty, guarantee of a third party, etc. In order for banks to obtain capital relief for any use of CRM techniques, certain minimum standards for legal documentation must be met. All documentation used in collateralised transactions and guarantees must be binding on all parties and legally enforceable in all relevant jurisdictions. Banks must have conducted sufficient legal review, which should be well documented, to verify this requirement. Such verification should have a well-founded legal basis for reaching the conclusion about the binding nature and enforceability of the documents

Few of such CRM techniques are given below:-

\section{(d) Collateralized transactions -}

- The credit exposure is hedged in whole or part by collaterals by a counterparty (party to whom a bank has an on-or off balance sheet credit exposure) or by a third party on behalf of the counterparty and banks have specific lien over the collaterals

- Under the Framework, banks are allowed to adopt either Simple Approach or Comprehensive Approach. The former approach substitutes the risk weighting of the collateral for the risk weighting of the counterparty for the collateraised portion of the exposure and under the latter approach which allows fuller offset of collaterals against exposures. Comprehensive approach is being adopted by banks in India.

- In the comprehensive approach, when taking collateral, banks will need to calculate their adjusted exposure to a counterparty for capital adequacy purposes in order to take account of the effects of that collateral.

\section{Hair Cut}

In the comprehensive approach, Banks are required to adjust both the amount of the exposure to the counterparty and the value of any collateral received in support of that counterparty to take account of possible future fluctuations in the value of either, occasioned by market movements. These adjustments are referred to as 'haircuts'. The application of haircuts will produce volatility adjusted amounts for both exposure and collateral. The volatility adjusted amount for the exposure will be higher than the exposure and the volatility adjusted amount for the collateral will be lower than the collateral, unless either side of the transaction is cash. In other words, the 'haircut' for the exposure will be a premium factor and the 'haircut' for the collateral will be a discount factor. 
It may be noted that the purpose underlying the application of haircut is to capture the market-related volatility inherent in the value of exposures as well as of the eligible financial collaterals. Where the volatility-adjusted exposure amount is greater than the volatility-adjusted collateral amount (including any further adjustment for foreign exchange risk), banks shall calculate their risk-weighted assets as the difference between the two multiplied by the risk weight of the counterparty.

Banks have two ways of calculating the haircuts viz. (i) Standard supervisory haircuts; using parameters set by the Basel Committee, and (ii) Own estimate haircuts, using banks' own internal estimates of market price volatility. Banks in India shall use only the standard supervisory haircuts for both the exposure as well as the collateral. The Standard Supervisory Haircuts (assuming daily mark-to-market, daily re-margining and a 10 business-day holding period), expressed as percentages, are given in detail in the RBI Circular.

\section{Eligible Financial Collateral in Comprehensive approach}

Cash, Gold, Securities issued by Central \& State Governments, KVP, NSC (no lock in period is operational), LIC policies, Debt securities (rated by a chosen rating agency), Debt Securities ( not rated by a chosen Credit Rating Agency in respect of which banks should be sufficiently confident about the market liquidity), Units of Mutual Funds, etc. are eligible financial instruments for recognition in the Comprehensive Approach.

\section{Calculation of capital requirement}

For a collateralised transaction, the exposure amount after risk mitigation is calculated as follows:

$E^{*}=\max \left\{0,\left[E \times\left(1+H_{e}\right)-C \times\left(1-H_{c}-H_{f x}\right)\right]\right\}$

Where:

$\mathrm{E}^{*}=$ the exposure value after risk mitigation

$E=$ current value of the exposure for which the collateral qualifies as a risk mitigant

$\mathrm{H}_{\mathrm{e}}=$ haircut appropriate to the exposure

$\mathrm{C}=$ the current value of the collateral received $\mathrm{H}_{\mathrm{c}}=$ haircut appropriate to the collateral

$\mathrm{H}_{\mathrm{fx}}=$ haircut appropriate for currency mismatch between the collateral and exposure

The exposure amount after risk mitigation (i.e., $E^{*}$ ) will be multiplied by the risk weight of the counterparty to obtain the risk-weighted asset amount for the collateralised transaction. (Illustrative examples calculating the effect of Credit Risk Mitigation is furnished in the RBI Circular).

\section{(e) On Balance Sheet Netting -}

On-balance sheet netting is confined to loans/advances and deposits. Under this technique, banks have legally enforceable netting arrangements involving specific lien with proof of documentation. Capital requirement is reckoned on the basis of net credit exposure. Banks may calculate capital requirements on the basis of net credit exposures subject to some conditions as listed in the Circular.

\section{(f) Guarantees -}

Explicit, irrevocable, and unconditional guarantees may be taken as credit protection in calculating capital requirements. Guarantees issued by entities with lower risk weight as compared to the counterparty will lead to reduced capital charges since the protected portion of the counterparty exposure is assigned the risk weight of the guarantor, whereas the uncovered portion retains the risk weight of the underlying counterparty. Detailed operational requirements for guarantees eligible for being treated as a CRM are given in the RBI Circular.

\section{Capital charge for Market Risk}

Market Risk relates to risk of losses in on-balance sheet and off-balance sheet positions arising on account of movement in market prices. The market risk positions subject to capital charge requirement are risks pertaining 
to interest rate related instruments in trading books and equities and Foreign Exchange risk (including gold and other precious metals) in both trading and banking books.

Trading book for the purpose of capital adequacy will include:

(g) Securities included under the Held for Trading (HFT) category

(h) Securities included under the Available for Sale (AFS) category

(i) Open gold position limits

(j) Open foreign exchange position limits

(k) Trading positions in derivatives, and

(I) Derivatives entered into for hedging trading book exposures.

Banks are required to manage the market risks in their books on an ongoing basis and ensure that the capital requirements for market risks are being maintained on a continuous basis, i.e. at the close of each business day. Banks are also required to maintain strict risk management systems to monitor and control intra-day exposures to market risks.

Capital for market risk would not be relevant for securities which have already matured and remain unpaid. These securities will attract capital only for credit risk. On completion of 90 days delinquency, these will be treated on par with NPAs for deciding the appropriate risk weights for credit risk.

\section{Measurement of capital charge for Interest Rate Risk}

The capital charge for interest rate related instruments would apply to current market value of the instruments in bank's trading book and banks are required to maintain capital for market risks on an ongoing basis by mark to market their trading positions on a daily basis.

The minimum capital requirement is measured/ expressed in two ways viz. (i) Specific Risk charge and (ii) General Market Risk (dealt separately).

In view of possible longer holding period and higher risk thereto in respect of debt securities held under AFS category, banks are required to hold capital charge for market risk equal to or greater of the Specific Risk Capital charge or Alternative Total Capital Charge.

\section{(i) Specific Market Risk}

The capital charge for specific risk is designed to protect against an adverse movement in the price of an individual security owing to factors related to the individual issuer both short (short position is not allowed in India except in derivatives) and long positions. The specific risk charges and Alternative Total Capital Charge for various kinds of exposures are detailed in Tabular Form in the RBI Circular.

\section{(ii) General Market Risk}

It relates to charge towards interest rate risk in the portfolio, where long and short position (which is not allowed in India except in derivatives \& Central Govt. securities) in different securities or instruments can be offset. The capital requirements for general market risk are designed to capture the risk of loss arising from changes in market interest rates.

General Market Risk is the sum of the following four components:-

(a) The net short (short position is not allowed in India except in derivatives) or long position in the whole trading book;

(b) a small proportion of the matched positions in each time-band (the "vertical disallowance");

(c) a larger proportion of the matched positions across different time-bands (the "horizontal disallowance"), and 
(d) a net charge for positions in options, where appropriate.

The Basel Committee has suggested two broad methodologies for computation of capital charge for market risks viz. Standardised Method and Internal Risk Management models method of which banks have been advised to adopt Standardised Method as banks have not yet developed their Internal Risk Management system.

Under the standardised method there are two principal methods of measuring market risk viz. a "maturity" method and a "duration" method. It has been decided to adopt standardised "duration" method as the same is more accurate method to arrive the capital charge. Accordingly, banks are required to measure the general market risk charge by calculating the price sensitivity (modified duration) of each position separately. The mechanics under the method - Time band and assumed changes in yield are detailed in the Circular for reference.

\section{Measurement for capital charge for Equity Risk}

The capital charge for equities would apply on their current market value in bank's trading book. The Minimum capital requirement, to cover the risk of holding or taking positions in equities in the trading book is detailed in the Circular. The instruments covered include equity shares, whether voting or non-voting, convertible securities that behave like equities, for example: units of mutual funds, and commitments to buy or sell equity.

Capital charge for specific risk (akin to credit risk) will be $11.25 \%$ or capital charge in accordance with the risk warranted by external rating of the counterparty, whichever is higher and specific risk is computed on banks' gross equity positions (i.e. the sum of all long and all short equity positions - short equity position is, however, not allowed for banks in India). In addition, the general market risk charge will also be $9 \%$ on the gross equity positions. These capital charges will also be applicable to all trading book exposures, which are exempted from capital market exposure ceilings for direct investments.

Specific Risk Capital Charge for banks' investment in Security Receipts will be 13.5\% (equivalent to 150 per cent risk weight). Since the Security Receipts are by and large illiquid and not traded in the secondary market, there will be no General Market Risk Capital Charge on them.

\section{Measurement of capital charge for Foreign Exchange Risk}

The bank's net open position in each currency shall be calculated by summing:

(f) The net spot position (i.e. all asset items less all liability items, including accrued interest, denominated in the currency in question);

(g) The net forward position (i.e. all amounts to be received less all amounts to be paid under forward foreign exchange transactions, including currency futures and the principal on currency swaps not included in the spot position);

(h) Guarantees (and similar instruments) that are certain to be called and are likely to be irrecoverable;

(i) Net future income/expenses not yet accrued but already fully hedged (at the discretion of the reporting bank);

(j) Depending on particular accounting conventions in different countries, any other item representing a profit or loss in foreign currencies;

(k) The net delta-based equivalent of the total book of foreign currency options.

The open positions both Foreign exchange and gold are at present risk-weighted at $100 \%$ and the capital charge for market risks in foreign exchange and gold open position is $9 \%$. These open positions, limits or actual whichever is higher, would continue to attract capital charge at $9 \%$. This capital charge is in addition to the capital charge for credit risk on the on-balance sheet and off-balance sheet items pertaining to foreign exchange and gold transactions.

Measurement of capital charge for Credit Default Swap (CDS) in the trading book, Capital charge for Counterparty Credit Risk, Capital charge for Counterparty Risk for Collaterised Transactions in CDS, Aggregation of the capital 
charge for Market Risks, Treatment for Illiquid Positions, Valuation Methodologies, etc. are detailed in the RBI Circular for reference.

\section{Capital charge for Operational Risk}

Operational risk is termed as the risk of loss resulting from inadequate or failed internal processes, people and systems or from external events. This includes legal risk, but excludes strategic and reputational risk. Legal risk includes, but is not limited to, exposure to fines, penalties, or punitive damages resulting from supervisory actions, as well as private settlements.

\section{Measurement Methodologies}

Three methods for calculating operational risk capital charges in continuum of increasing sophistication and risk sensitivity are provided under NCAF viz.

(iv) The Basic Indicator Approach (BIA)

(v) The Standardised Approach (TSA), and

(vi) Advanced Measurement Approach (AMA).

Banks are advised, to begin with, to adopt the Basic Indicator Approach (BIA) and RBI would review the capital requirement under BIA for general credibility and in case it is found any laxity, appropriate Supervisory action under Pillar 2 will be considered.

Under BIA, banks are required to hold capital for operational risk equal to the average positive annual gross income over the previous 3 years. In case the gross income for any year is negative or zero, the same should be excluded while calculating the average. RBI will initiate necessary supervisory action under Pillar 2 in case the negative gross income distorts banks Pillar I capital charge (the working is illustrated in the RBI Circular)

\section{B. Supervisory Review and Evaluation Process (SREP) - (Pillar 2)}

The objective of Supervisory Review Process (SRP) is to:-

(c) Ensure that banks have adequate capital to support all the risks in their business; and

(d) Encourage them to develop and use better risk management techniques for monitoring and managing their risks.

This in turn would require a well-defined internal assessment process within banks through which they assure the $\mathrm{RBI}$ that adequate capital is indeed held towards the various risks to which they are exposed. The process of assurance could also involve an active dialogue between the bank and the RBI so that, when warranted, appropriate intervention could be made to reduce the risk exposure of the bank or augment / restore its capital. Thus, Internal Capital Adequacy Assessment Process (ICAAP) is an important component of the SRP.

The main aspects to be addressed under SRP/ICAAP would include:-

(a) The risks that are not fully captured by the minimum capital ratio prescribed under Pillar 1 ;

(b) The risks that are not at all taken into account by the Pillar 1; and

(c) The factors external to the bank.

The capital adequacy ratio prescribed under Pillar 1 is only the minimum and addresses only the three risks viz. credit, market and operation risks, holding of additional capital might be necessary for banks to take care of the possible under-estimation of risks under the Pillar 1 and the actual risk exposure of a bank vis-à-vis the quality of its risk management architecture. Some of the risks which are generally exposed to but not fully captured in the regulatory CRAR include:-

(a) Interest rate risk in the banking book; 
(b) Credit concentration risk;

(c) Liquidity risk;

(d) Settlement risk;

(e) Reputational risk;

(f) Strategic risk;

(g) Risk of under-estimation of credit risk under the Standardised approach;

(h) Model risk i.e., the risk of under-estimation of credit risk under the IRB approaches;

(i) Risk of weakness in the credit-risk mitigants;

(j) Residual risk of securitisation, etc.

It is, therefore, only appropriate that the banks make their own assessment of their various risk exposures, through a well-defined internal process, and maintain an adequate capital cushion for such risks. Banks were advised to develop and put in place, with the approval of their Boards, an ICAA P, in addition to a bank's calculation of regulatory capital requirements under Pillar 1 , commensurate with their size, level of complexity, risk profile and scope of operations. The ICAAP was operationalised w.e.f. March 2008 by foreign banks and March 2009 by Indian Banks.

Based on the three mutually reinforcing Pillars i.e. Pillar 1, Pillar 2, and Pillar 3, the Basel Committee lays down four key principles under the SRP as under:-

(e) Banks are required to have a process for assessing their overall capital adequacy in relation to their risk profile and a strategy for maintaining their capital levels.

(f) Evaluation of banks' internal capital adequacy assessments and strategies as well as their ability to monitor and ensure their compliance with the regulatory capital ratios by Supervisors.

(g) Supervisors should expect banks to operate above the minimum regulatory capital ratios and should have the ability to require banks to hold capital in excess of the minimum.

(h) Supervisors should intervene at an early stage to prevent capital from falling below the minimum levels required to support the risk characteristics of a particular bank and should require rapid remedial action if capital is not maintained or restored.

The Principles a \& $\mathbf{c}$ relates to the supervisory expectations while others i.e. $\mathbf{b} \boldsymbol{\&} \mathbf{d}$ deals with the role of the supervisors under Pillar 2. This necessitates evolvement of an effective ICAAP for assessing their capital adequacy based on the risk profiles as well as strategies for maintaining their capital levels. Pillar 2 also requires the Supervisory authorities to put in place an evaluation process known as Supervisory Review and Evaluation Process (SREP) and to initiate supervisory measures as may be necessary. This would also facilitate RBI to take suitable steps either to reduce exposure of the bank or augment/restore its capital.

Based on the principles, responsibilities have been casted on banks and Supervisors under SREP and based on which banks are expected to operate above the minimum regulatory capital ratios commensurate with their individual risk profiles, etc. Under SREP, the RBI will assess the overall capital adequacy through comprehensive evaluation along with Annual Financial Inspection (AFI) based relevant data and ICAAP document being received from banks and available information. ICAAP and SREP are 2 important components of Pillar 2.

Every bank (except LABs \& RRBs) should have an ICAAP both at solo and consolidated levels and the responsibility of designing and implementation of the ICAAP rests with the Board. Before embarking on new activities or introducing new products the senior management should identify and review the related risks arising from these potential new products or activities and ensure that the infrastructure and internal controls necessary to manage the related risks are in place. 
Banks are required to put in place an effective MIS which should provide the board and senior management a clear and concise manner with timely and relevant information concerning their institutions' risk profile including risk exposure. MIS should be capable of capturing limit breaches (concentrations) and same should be promptly reported to senior management, as well as to ensure that appropriate follow-up actions are taken. Risk management process should be frequently monitored and tested by independent control areas and internal and external auditors.

The ICAAP should form an integral part of the management and decision-making culture of a bank. The implementation of ICAAP should be guided by the principle of proportionality and RBI expects degree of sophistication in the ICAAP in regard to risk measurement which should commensurate with the nature, scope, scale and the degree of complexity in the bank's business operations.

\section{Operational aspects of ICAAP}

The ICAAP of banks is expected normally to capture the risk universe, viz .Credit Risk, Market Risk, Operational Risk, interest rate risk in the banking book, credit concentration risk and liquidity risk. Other risks include reputational risk and or business or strategic risk, Off-balance sheet Exposure and Securitisation Risk etc. (Various risks are briefly outlined in the RBI Circular).

Bank's risk management process including the ICAAP should be consistent with the existing RBI guidelines on these risks. If banks adopt risk mitigation techniques, they should understand the risk to be mitigated and reckoning its enforceability and effectiveness on the risk profile of the bank.

\section{Sound Stress Testing Practices}

Stress testing that alerts bank management to adverse unexpected outcomes related to a broad variety of risks and provides an indication to banks of how much capital might be needed to absorb losses should large shocks occur. It is an important tool that is used by banks as part of their internal risk management. Moreover, stress testing supplements other risk management approaches and measures.

\section{Sound Compensation Practices}

Risk management must be embedded in the culture of a bank and should be under the critical focus of the Senior Management of the bank. For developing and maintaining a broad and deep risk management culture over time, compensation policies may be drawn which should be linked to longer-term capital preservation and the financial strength of the firm, and should consider risk-adjusted performance measures. In addition, a bank should provide adequate disclosure regarding its compensation policies to stakeholders.

\section{Market Discipline - (Pillar - 3)}

Market Discipline is termed as development of a set of disclosure requirements so that the market participants would be able to access key pieces of information on the scope of application, capital, risk exposures, risk assessment processes, and in turn the capital adequacy of the institution. It is considered as an effective means of informing the market about a bank's exposure to those risks and provides comparability. Non-compliance of the prescribed disclosure requirement attracts penalty including financial penalty.

Market discipline can contribute to a safe and sound banking environment. Hence, non-compliance with the prescribed disclosure requirements would attract a penalty, including financial penalty. It is recognized that the Pillar 3 disclosure framework does not conflict with the requirement under accounting standards which are broader in scope. RBI will consider future modifications to the Market Discipline disclosures as necessary in the light of its ongoing monitoring of this area and industry developments. Banks should have a formal disclosure policy approved by the Board of Directors that addresses the bank's approach for determining what disclosures it will make and the internal controls over the disclosure process.

The Pillar 3 disclosures as introduced under Basel III would become effective from 01.07.2013 and the first set of disclosures as required should be made by banks as on $\mathbf{3 0 . 0 9 . 2 0 1 3}$ (with exception of Post March 31, 2017 template (dealt separately). 
Pillar 3 applies at the top consolidated level of the banking group to which the Capital Adequacy Framework applies. Disclosures related to individual banks within the groups would not generally be required to be made by the parent bank. Banks are required to make Pillar 3 disclosures at least on a half yearly basis, irrespective of whether financial statements are audited, with the exception i.e. Capital Adequacy, Credit Risk: General Disclosure for all banks; and Credit Risk: Disclosures for Portfolios subject to the Standardised Approach. These are to be made at least on a quarterly basis by banks. All disclosures must either be included in a bank's published financial results/ statements or at a minimum, must be disclosed on bank's website.

Banks are required to make disclosures in the prescribed format by RBI. Banks are also required to maintain a 'Regulatory Disclosures Section' on their website where all information relating to disclosures will be made available to the market participants. The link should be prominently provided on the home page of the website so as to make it easily accessible. An archive for at least three years of all templates relating to prior reporting periods should be made available by banks on their websites.

\section{Post March 31, 2017 Disclosure Template}

A common template which will be used by banks to report the details of their regulatory capital after March 31 , 2017 i.e. after the transition period for the phasing-in of deductions is over. It is designed to meet the Basel III requirement to disclose all regulatory adjustments. The template enhances consistency and comparability in the disclosure of the elements of capital between banks and across jurisdictions.

\section{Template during the Transitional Period}

During the transition period of phasing-in of regulatory adjustments under Basel III in India i.e. from April 1, 2013 to March 31, 2017, banks will use a modified version of the post March 31, 2017 template. This template is designed to meet the Basel III requirement for banks to disclose the components of capital which will benefit from the transitional arrangements.

\section{Main Features Template}

A common template has been designed to capture the main features of all regulatory capital instruments issued by a bank at one place. This disclosure requirement is intended to meet the Basel III requirement to provide a description of the main features of capital instruments.

\section{Other Disclosure Requirements}

This disclosure enables banks in meeting the Basel III requirement to provide the full terms and conditions of capital instruments on their websites.

Banks operating in India are required to make additional disclosures in respect of:-

(e) Securitisation exposures in the trading book;

(f) Sponsorship of off-balance sheet vehicles;

(g) Valuation with regard to securitisation exposures; and

(h) Pipeline and warehousing risks with regard to securitisation exposures

\section{Capital Conservation Buffer Framework}

\section{Objective}

The capital conservation buffer (CCB) is designed to ensure that banks build up capital buffers during normal times (i.e. outside periods of stress) which can be drawn down as losses incurred during a stressed period. The requirement is based on simple capital conservation rules designed to avoid breaches of minimum capital requirements. Outside the period of stress, banks should hold buffers of capital above the regulatory minimum. When buffers have been drawn down, one way banks should look to rebuild them is through reducing discretionary 
distributions of earnings. This could include reducing dividend payments, share buybacks and staff bonus payments. Banks may also choose to raise new capital from the market as an alternative to conserving internally generated capital. In the absence of raising capital from the market, the share of earnings retained by banks for the purpose of rebuilding their capital buffers should increase the nearer their actual capital levels are to the minimum capital requirement.

The capital conservation buffer can be drawn down only when a bank faces a systemic or idiosyncratic stress. A bank should not choose in normal times to operate in the buffer range simply to compete with other banks and win market share. This aspect would be specifically looked into by RBI during the SREP. The banks which draw down their capital conservation buffer during a stressed period should also have a definite plan to replenish the buffer as part of its ICAAP and strive to bring the buffer to the desired level within a time limit agreed to with RBI during the SREP.

The framework of capital conservation buffer will enable the banks to:-

(a) Strengthen the ability of banks to withstand adverse economic environment conditions,

(b) Help increase banking sector resilience both going into a downturn; and

(c) Provide the mechanism for rebuilding capital during the early stages of economic recovery.

By retaining a greater proportion of earnings during a downturn, banks will be able to help ensure that capital remains available to support the ongoing business operations / lending activities during the period of stress. Therefore, this framework is expected to help reduce pro-cyclicality.

\section{Framework}

Banks are required to maintain a capital conservation buffer of $2.5 \%$ of RWA in the form of Common Equity Tier 1 capital above the regulatory minimum capital requirement of $9 \%$. CCB is to be phased-in over a period of 4 years in a uniform manner of $0.625 \%$ per year, commencing from 31.3.15. Banks should not distribute capital (i.e. pay dividends or bonuses in any form) in case capital level falls within this range. The constraints imposed are related to the distributions only and are not related to the operations of banks. The distribution constraints imposed on banks, when their capital levels fall into the range, increase as the banks' capital levels approach the minimum requirements. The minimum capital conservation ratios a bank must meet at various levels of the Common Equity Tier 1 capital ratios is shown as under:-

Minimum capital conservation standards for individual bank

\begin{tabular}{l|l}
\hline $\begin{array}{l}\text { CET 1 Ratio after including the current periods } \\
\text { of retained earnings }\end{array}$ & $\begin{array}{l}\text { Minimum Capital Conservation Ratios (in \% of } \\
\text { earnings) }\end{array}$ \\
\hline $5.5 \%-6.125 \%$ & $100 \%$ \\
$>6.125 \%-6.75 \%$ & $80 \%$ \\
$>6.75 \%-7.375 \%$ & $60 \%$ \\
$>7.375 \%-8.0 \%$ & $40 \%$ \\
$>8.0 \%$ & $0 \%$ \\
\hline
\end{tabular}

It may be observed from the above that a bank with a Common Equity Tier 1 capital ratio in the range of $6.125 \%$ to $6.75 \%$ is required to conserve $80 \%$ of its earnings in the subsequent financial year (i.e. payout not more than $20 \%$ in terms of dividends, share buybacks and discretionary bonus payments is allowed). Basel III minimum capital conservation standards apply with reference to the applicable minimum CET1 capital and applicable CCB. During the transition period, banks may refer to the level of ratios provided by RBI in the Circular for meeting the minimum capital conservation ratios at various levels of the CET 1 capital ratios. 
Capital conservation buffer is applicable both at the solo level (global position) as well as at the consolidated level, i.e. restrictions would be imposed on distributions at the level of both the solo bank and the consolidated group.

\section{E. Leverage Ratio Framework}

The leverage ratio provisions in the Basel III document are intended to serve as the basis for testing the leverage ratio during the parallel run period. The Basel Committee will test a minimum Tier 1 leverage ratio of $3 \%$ during the parallel run period from January 1, 2013 to January 1, 2017. The leverage ratio is calibrated to act as a credible supplementary measure to the risk based capital requirements. The main objective of the leverage ratio framework is:-

(a) constrain the build-up of leverage in the banking sector, helping avoid destabilising deleveraging processes which can damage the broader financial system and the economy; and

(b) reinforce the risk based requirements with a simple, non-risk based "backstop" measure

During the period of parallel run, banks should strive to maintain their existing level of leverage ratio but, in no case the leverage ratio should fall below $4.5 \%$. A bank whose leverage ratio is below $4.5 \%$ may endeavor to bring it above $4.5 \%$ as early as possible. Final leverage ratio requirement would be prescribed by RBI after the parallel run taking into account the prescriptions given by the Basel Committee.

The leverage ratio shall be maintained on a quarterly basis. The basis of calculation at the end of each quarter is "the average of the month end leverage ratio over the quarter based on the definitions of capital (i.e. the capital measure) and the total exposure (i.e. the exposure measure) respectively as detailed in the RBI Circular.

(The criteria for Classification as Common Shares (Paid up Equity Capital) for Regulatory Purposes for Indian Banks as well as Foreign Banks, Detailed guidelines on issuance of various Debt Instruments viz. Innovative Perpetual Debt Instrument (IPDI), Perpetual Non-cumulative Preference Shares (PNCPS), Debt Capital Instruments, Perpetual Cumulative Preference Shares (PCPS), Credit Default Swaps (CDS), Illustrations on Credit Risk Mitigation (Loan Exposures) - Calculation of Exposure Amount for Collateralised transactions, Illustrations on computation of capital charge for Counterparty Credit Risk (CCR) - Repo Transactions, Measurement of capital charge for Market Risks in respect of Interest Rate Derivatives and Options, An Illustrative Approach for Measurement of Interest Rate Risk in the Banking Book (IRRBB) under Pillar 2, Redeemable Noncumulative Preference Shares (RNPS), Redeemable Cumulative Preference Shares (RCPS), Subordinated Debts, Guidelines on Securitisation of Standard Assets, Illustrative Approach on Measurement of Capital Charge for Market Risks in respect of Interest Rate Risk and Derivatives, etc. are given in detail in the RBI Master Circular which also may be referred).

(Source: RBI M. Circular dt. 01.07.13) 
PROFESSIONAL PROGRAMME

\section{BANKING LAW AND PRACTICE}

\section{PP-BL\&P}

\section{Open Book Examination in Elective Subjects (Paper - 9) in Module-III of Professional Programme (New Syllabus) Examination}

Professional Programme (New Syllabus) offers five elective subjects in Module III, as mentioned herein below, out of which a student has to opt only one subject to study and qualify that suits his aptitude, interest, ability and career goal:

1. Banking Law and Practice

2. Capital, Commodity and Money Market

3. Insurance Law and Practice

4. Intellectual Property Rights-Law and Practice

5. International Business -Laws and Practices.

There is Open Book Examination (OBE) in all the above five elective subjects from June 2014 onwards. However, in all other subjects/modules of Professional Programme (New Syllabus), students would continue to be examined as per traditional pattern of examinations.

This is to inculcate and develop skills of creative thinking, problem solving and decision making amongst students of its Professional Programme and to assess their analytical ability, real understanding of facts and concepts and mastery to apply, rather than to simply recall replicate and reproduce concepts and principles in the examination.

In OBE, the candidates are allowed to consult their study material, class notes, textbooks, Bare Acts and other relevant papers, while attempting answers, as per the requirement of questions. The emphasis throughout is in assessing the students' understanding of the subject, applying their minds, rather than the ability to memorise large texts or rules or law.

Unlike a conventional/typical examination, which assesses how much information candiates have been able to store in their minds, the success in this type of examination depends on the candidate's ability to understand the question, identify inherent issues, application of various techniques, laws, principles, etc. while solving answers with the help of supporting reference material.

Broad pattern of Question Paper for OBE is as follows:

- Each question paper would contain Six questions carrying 100 marks

- Question No.1 will be of 50 marks based on case study ranging between 3000-4000 words.

- Question No.2 will be of 30 marks based on study of regulatory framework related to the subject.

- Question No.3-6 will be of 5 marks each covering important topics of the syllabus.

Candidates are not allowed to consult their fellow examinees or exchange their study material/notes, etc. with each other in the examination hall.

Candidates are prohibited to bring in any electronic devices, such as laptop, tab, I pad, palmtop, mobile phone, or any other electronic device/ gadget at the examination hall/room. However, they are permitted to use their own battery operated noiseless and cordless pocket calculator with not more than six functions, twelve digits and two memories. 


\section{PROFESSIONAL PROGRAMME EXAMINATION (NEW SYLLABUS) \\ ELECTIVE PAPER 9.1 - BANKING LAW AND PRACTICE}

PRACTICE TEST PAPER

OPEN BOOK EXAMINATION

Time allowed: 3 hours

Max Marks: 100

Attempt all questions. All questions are compulsory.

\section{Question No. 1}

Read the case study and answer all questions given at the end of the case:

\section{ABC ALUMINIUM COMPANY PVT. LTD.}

This case relates to $\mathrm{m} / \mathrm{s}$ ABC Aluminium Company Pvt. Ltd, a SSI unit located at Delhi Rohatak road, Haryana. The unit is in an area where cluster of industries have come up. It is located in an industrial area where all the infrastructure facilities are available.

The total capacity of the plant was 10 TPD which comes to 3000MT per annum. The company was provided medium term loan (MTL) of Rs 150.00 lacs and a cash credit (working capital) advance of Rs 160.00 lac. The loan was sanctioned by a nationalized bank at Patna and a sub limit was provided from one of the branches located at New Delhi for better control and supervision of account.

The promoters (directors) were from Patna (Bihar). They had a wooden ply industry at Patna, where they earned good money. Later on, during 1996 the pollution control board-department of government did not permit falling of the trees and transporting of local wooden logs and owner of the ply unit who promoted ABC Aluminium Company Pvt. Ltd deserted Patna and shifted to Rohtak for setting up this aluminium based plant.

Since the directors had contact with the bank at Patna during their plywood business at Patna they had a good and long relationship with the bank at Patna. The promoters approached the nationalized bank at Patna for creating the $\mathrm{ABC}$ Aluminium Company Pvt. Ltd for financial assistance. The bank asks for certain important information to satisfy them before appraisal of the loan proposal. The information asked was:

- Application form dully filled in.

- Memorandum and Article of Association of the Company.

- Allotment of land by Haryana Government- Industrial Area Development Authority.

- Project Report.

- Details of layout-land, building and detailed drawings of;

- Administrative building

- Factory shed

- Godowns

- Other civil constructions

- Quotations of machinery

- Estimate of civil construction duly signed by a civil engineer.

- Details of collateral securities of directors- land and building offered. 
- Details of land and building of the plant allotted by Government at Rohtak.

- Means of financial strength of promoters and total source of capital to be raised.

The bank appraised and sanctioned the loan. The raw material is locally available and import of scrap material is permitted at lower excise duty and found to be competitive.

The project performance was critically examined by the bank before sanction of the loan. The parameters covered were:

- Capacity of the project to perform.

- Projected level of working.

- The Break Even Point

- Sales at projected level

- Elements of cost of production

Based on the true value of expenses the projected performance at the time of sanction of loan was as under:

\begin{tabular}{|c|c|c|c|}
\hline \multicolumn{4}{|l|}{ Projected level of working $50 \%$} \\
\hline \multicolumn{4}{|c|}{ Sales quantity $=1500 \mathrm{MT}$ (Metric Tones) at $50 \%$ capacity } \\
\hline \multicolumn{4}{|c|}{ Sales Price (average) $=$ Rs 105,000 per MT } \\
\hline & $100 \%$ Level & $50 \%$ Level & (Rs in lacs) \\
\hline Yearly Sales & 3150 & 1575 & A \\
\hline \multicolumn{4}{|l|}{ Variable Cost } \\
\hline Cost of Raw Material & 2677 & 1340 & \\
\hline Fuel for Furnace & 112 & 56 & \\
\hline Fuel for DG set & 52 & 26 & \\
\hline Other Fuel & 26 & 13 & \\
\hline Cost of Tools \& Dies & 8 & 4 & \\
\hline Wages & 15 & 10 & \\
\hline Sub Total & 2896 & 1453 & B \\
\hline Contribution (A-B) & 254 & 122 & C \\
\hline \multicolumn{4}{|l|}{ Fixed Cost } \\
\hline Salary & 6 & 6 & \\
\hline $\begin{array}{l}\text { Selling General and } \\
\text { administrative expenses }\end{array}$ & 24 & 24 & \\
\hline Interest on Working Capital & 48 & 24 & \\
\hline Interest on Term Loan & 18 & 18 & \\
\hline Depreciation & 12 & 12 & \\
\hline
\end{tabular}




\begin{tabular}{|l|l|l|l|}
\hline Total Fixed Cost & $\mathbf{1 0 8}$ & $\mathbf{8 4}$ & $\mathbf{D}$ \\
\hline PBT (C-D) & 146 & 38 & \\
\hline Depreciation & 12 & 12 & \\
\hline Cash Accrual & 158 & 50 & \\
\hline Break Even Sales & 1339.37 & 1084.42 & \\
\hline Break Even \% & 42.51 & $68.85 \%$ of Operation & \\
\hline
\end{tabular}

Based on the performance the term loan against fixed assets amounting to Rs 150 lacs was Sanctioned to be repaid in seven years and was termed as medium term loan (MTL). Also using the Tandon committee norms a working capital of Rs 160 lacs was sanctioned.

After the sanctioned was made following securities were obtained:

- Hypothecation of stocks

- Pledge of land, buildings, plant and machinery and other assets of the company.

- Equitable mortgage of director's property (land and building) offered as collateral security.

- Liens on the shares hold by directors.

- A lien on NSC and PPF.

- Creating charge of assets of the company with Registrar of the Company, being a private limited company.

Later on during the year 2002 the company's performance declined which was a threat and an early warning signal for the bank and for the company. The symptoms noticed by the bank were:

- Sales proceeds were not fully rooted through bank account.

- The drawing power declined and account became irregular.

- The term loan instalments became overdue due to non-payment in time.

- The account was feared to be NPA.

The matter was reported to the head office of the bank and a detailed study was conducted by a team of experts the details of diagnostic study and its recommendations follows.

Technical feasibility and problem faced by the company were conducted, the details of which are:

\section{Process of manufacturing}

It was found to be a successful process and was accepted by the bank.

\section{Capacity of the plant}

The machines were found in sound state of operation and the capacity was arrived at 3000 MT per annum while working on three shifts.

During the study to minimise losses and improve the quality of product following recommendations were made:

- The scrap should be shorted out based on their quality.

- Small and lighter scraps should be bundled on bundling machines to give it a compact look. For each charge an input output record needs to be maintained to measure operational losses.

- The quality of raw material should be chemically examined before charging in to the furnace. For this a 
simple material testing equipment is needed. The charge to the furnace needs to be standardized.

- At furnace point there should be a temperature measuring device to exactly note the temperature.

\section{Land and building}

It was observed that land and building is adequate to accommodate the present facilities needed for production and there is a room for $100 \%$ expansion.

\section{Teething problems faced}

At the time of financing the proposal there was no room for tools and dies which is a large component of investment. The company created a die-shop by diverting funds without informing the bank. It was a necessary component of the project cost which was not taken in to account while sanctioning the project. The cost of dieshop and dies was about Rs 20lacsand this resulted in to short fall in working capital fund due to diversion in this case short term source was used for long term uses causing a setback in the current asset value. The project was found technically feasible and was in a perfect working order.

\section{Economic viability}

Following data were analysed and based on these current data the economic feasibility was determined:

- Work force strength planning and its cost.

- Cost of raw material- a material-mix was arrived at. The weighted average material cost was arrived at Rs 89,250 per MT including $5 \%$ losses during the process.

Revised working capital was assessed and the components of working capital were as under:

$\begin{array}{ll}\text { Raw materials } & 23 \text { days } \\ \text { Stock in process } & 7 \text { days } \\ \text { Finished goods } & 9 \text { days } \\ \text { Receivables } & 26 \text { days } \\ \text { Total working capital cycle } & 60 \text { days }\end{array}$

It was seen that the present working capital limit was adequate but there was a gap between the current asset needed and current asset available. Which needs to be bridged by the company?

The company was found to be economically viable and capable to serve its interest and instalments for medium term loan already granted to it.

\section{What went wrong?}

- The company did not record its sales fully and due to unrecorded sales it resulted in to wrong performance than actual.

- The company also followed the practice of under billing.

- Sells to some small petty traders were not recorded at all and such traders were twenty two in numbers.

- Company diverted about Rs 25lacs in creating a tool room and dies which resulted in to diversion of fund within the industry (diversion from short term sources to long term uses).

- The company opened an account in different bank and routed the sales and deposit through current account which was not proper.

- There was exemption of sales tax (vat) which the company did not avail fully which was due to their inclination towards cash dealing without billing. 
- The bank-customer relation was affected badly leading to strain relationship.

- Stock statements were not submitted in time and bank operation turned poorer day by day.

- The directors have created good asset in the form of self-owned building at Rohtak out of fund generated but diverted. Here this case was an example of healthy entrepreneur and sick industry.

The diversion of fund was traced and this amounted to about Rs 190 lacs during the past four years of operations which were as under:

Under billing

Dies and tool room

Construction of house

Total
Rs. 150 lacs

Rs. 25 lacs

Rs. 50 lacs

Rs. 190 lacs

This resulted into short fall in working capital and instalments payments to the bank resulting in to this bad shape.

Past four years of operation is an indicator of manipulation of facts which is detailed here under:

Year wise cash Accrual

$\begin{array}{lllll}\text { Year } & \text { Profit/Loss } & \text { Depreciation } & \text { Cash Accrual } & \begin{array}{l}\text { (Rs. in lacs) } \\ \text { Sales }\end{array} \\ 1998-99 & (-1.51) & 10.77 & 9.26 & 241.90 \\ 1999-2000 & (-2.20) & 10.64 & 8.44 & 175.45 \\ 2000-2001 & 0.36 & 11.00 & 11.36 & 324.86 \\ 2001-2002 & (-13.8) & 11.25 & (-2.55) & 240.01 \\ \text { Total Cash accrual } & & & 26.51 & \end{array}$

The sales do not correlate with profit or cash accrual and the diversion of fund is feared.

The increase in depreciation shows that there is a creation of fixed asset by diversion of fund. The fixed assets added were as under:

Year

1998-99

1999-00

2000-01

2001-02

Total
(Rs in lacs)

23.17

10.49

11.15

06.50

51.31

\section{Decision by the bank to take up the rehabilitation/ restructuring}

The account in the books of the bank has turned sticky and irregular and is classified as NPA but it has strength for rehabilitation and restructuring since the major diversion were within the business. It may be considered for rehabilitation and restructuring. Following were the terms and conditions of the bank for taking up this case for rehabilitation:

- Closing the account of another bank- CBI Paharganj, New Delhi as banking with other bank is not allowed mainly which is not lender to the company. 
- Providing additional working capital mainly coverage of Sundry Dr by clean bill limit.

- Restructuring the term loan and its repayment plan.

- Since it was a wilful default, no concession in interest should be permitted.

- The company should route the sales proceeds through bank account only and avail the bill limit by drawing bills through bank.

- The company must start working at least at $40 \%$ capacity utilisation which is higher than BEP and try to increase its level of operation subsequently.

- Additional security should be provided in the following manner.

- Pledge or mortgage of additional fixed assets created by diversion of fund.

- Equitable mortgage of land and building of directors created in personal or family name.

- Hypothecation of current assets covered under working capital and its renewal from time to time.

- Bringing fund in proportion to margin (own contribution) as required by the bank by raising the paid up capital.

Considering the facts and reasonable opportunity and probability to put the company on a proper track it is possible to rehabilitate the company by adopting honest practices and by creating a smooth bank-customer relationship. The care the bank should take is a stricter follow up, monitoring and control.

This decision will bring the company as a successful venture and will turn it in to a growing concern. This decision will add to the following advantages:

- The assets which may turn idle or scrap will be utilised.

- It will create better employment opportunity for the youth.

- The banks money will be realised and its NPA will be reduced. Also the bank will gain in long term in the form of interest earning which will keep on growing in relation to the growth of the company.

- The company directors and shareholders will be satisfied persons.

- By growth the company will expand providing more services to the nation.

\section{Questions: (related to case study)}

\section{Answer all questions}

a) What have you learnt from this case?

b) Why this industry faced this problem?

c) Is it the case of NPA or sickness?

d) How did the bank tackle this case?

e) What were wrong practices the company adopted?

f) What corrective measures do you suggest?

g) Conduct a SWOT analysis on this case?

h) What were the recommendations of the bank? Do you agree with the bank's decision?

i) For additional security of the loan what documents you should obtain as a branch manager?

j) It is very easy to call up the loan ending the bank-customer relationship but it is difficult to retain it for 
a longer period. In your opinion what would be the advantages to the company, its shareholders, bank and the nation if it is brought back to good health as a discipline entrepreneur?

(5 marks each)

\section{Question No. 2}

Answer all the following questions.

a) What are the important documents banks generally obtain for each liability (loan) created? Mention period of each type of documents before it is time barred. As a consultant to the bank what guide lines you should provide to the bank to prevent the document to become time barred?

(10 marks)

b) You are working as a bank manager and have received a loan proposal for a large industrial sector related to setting up a thermal power plant. The total loan requirement is Rs 10,000 Crores which for a single bank is not feasible. What step you will take to see that the requirement of Rs 10,000 Crores is met?

(10 marks)

c) What are the problems faced by India in implementing BASEL committee report?

(10 marks)

\section{Question No. 3}

For a quick and honest grievance redressal 'Banking Ombudsman' was created. Discuss the objectives of Ombudsman and type of grievances generally covered under it. Is it advantageous to the society and will it acts as a tool to create a healthier and an ethical customer relationship? Support your answer with suitable examples where help from 'Banking Ombudsman' can be taken.

(5 marks)

\section{Question No. 4}

Mechanisation and e-banking has provided speed and comfort for both the banks and the customers but at the same time it has generated risks. Discuss the risks associated with e- banking and your suggestions to minimise it. Give suitable examples of risks possible in e- banking system and its control mechanism.

(5 marks)

\section{Question No. 5}

In the year 1935 Reserve Bank of India Act was framed and after independence the Banking Regulation Act 1949 was created. Describe the reasons of this change and important provisions built in it. Explain how this Act is going to strengthen the banking system in India.

(5 marks)

\section{Question No.6}

a) What is Garnishee order and where is it applied? Narrate two situations where the Garnishee order will not be applicable.

b) What are the uses of Right of General Lien and Right of Set Off? Give an example of Right of Set Off. 